\title{
Het rechtsvergelijkende argument in de ontwikkeling van het Nederlandse vermogensrecht 1838-1940: aansprakelijkheid voor zaken, artikel 2014, publiek domein en de relativiteit van de onrechtmatige daad
}

Citation for published version (APA):

Milo, J. M. (1997). Het rechtsvergelijkende argument in de ontwikkeling van het Nederlandse vermogensrecht 1838-1940: aansprakelijkheid voor zaken, artikel 2014, publiek domein en de relativiteit van de onrechtmatige daad. [Doctoral Thesis, Maastricht University]. Intersentia. https://doi.org/10.26481/dis.19970516jm

Document status and date:

Published: 01/01/1997

DOI:

10.26481/dis.19970516jm

Document Version:

Publisher's PDF, also known as Version of record

Please check the document version of this publication:

- A submitted manuscript is the version of the article upon submission and before peer-review. There can be important differences between the submitted version and the official published version of record. People interested in the research are advised to contact the author for the final version of the publication, or visit the DOI to the publisher's website.

- The final author version and the galley proof are versions of the publication after peer review.

- The final published version features the final layout of the paper including the volume, issue and page numbers.

Link to publication

\footnotetext{
General rights rights.

- You may freely distribute the URL identifying the publication in the public portal. please follow below link for the End User Agreement:

www.umlib.nl/taverne-license

Take down policy

If you believe that this document breaches copyright please contact us at:

repository@maastrichtuniversity.nl

providing details and we will investigate your claim.
}

Copyright and moral rights for the publications made accessible in the public portal are retained by the authors and/or other copyright owners and it is a condition of accessing publications that users recognise and abide by the legal requirements associated with these

- Users may download and print one copy of any publication from the public portal for the purpose of private study or research.

- You may not further distribute the material or use it for any profit-making activity or commercial gain

If the publication is distributed under the terms of Article 25fa of the Dutch Copyright Act, indicated by the "Taverne" license above,

Download date: 26 Apr. 2023 
Het rechtsvergelijkende argument in de ontwikkeling van het Nederlandse vermogensrecht 1838-1940:

aansprakelijkheid voor zaken, artikel 2014, publiek domein en de relativiteit van de onrechtmatige daad 
Van dit proefschrift verschijnt een handelseditie in de Ius Commune Europaeum Reeks onder ISBN 90-5095-007-8 
HET RECHTSVERGELIJKENDE ARGUMENT IN DE ONTWKKELING VAN HET NEDERLANDSE VERMOGENSRECHT 1838-1940:

AANSPRAKELIJKHEID VOOR ZAKEN, ARTIKEL 2014, PUBLIEK DOMEIN EN DE RELATIVITEIT VAN DE ONRECHTMATIGE DAAD

\section{PROEFSCHRIFT}

ter verkrijging wan de graad van doctor aan de Universiteit Maastricht,

op gezag wan de Rector Magnificus, Prof. mr M.J. Cohen, volgens het besluit van het College van Decanen, in het openbaar to verdedigen op vrijdag 16 mei 1997 om 16.00 uur

door

J.M. Milo

geboren te Bussum 
Promotor:

Prof.mr G.E. van Maanen

Beoordelingscommissie: Prof.mr G.R. de Groot (voorzitter)

Prof.mr A. Fl. Gehlen

Prof.mr A.S. Hartkamp (Universiteit Utrecht)

Prof.mr J.H.A. Lokin (Rijksuniversiteit Groningen)

Prof.mr N.H.M. Roos 
Voorwoord

Graag noem ik een aantal mensen en instellingen naar wie mijn dank in het bijzonder uitgaat. Mijn promotor, prof mr. G.E. van Maanen vanwege zijn aangenaam inspirerende begeleiding en de leden van de beoordelingscommissie voor hun bereidheid het manuscript te beoordelen. Ine Corstjens droeg zorg voor de fraaie opmaak. Wies Rayar verzorgde de vertaling van de samenvatting. De vakgroep privaatrecht Maastricht bood de gelegenheid dit onderzoek aan te vangen en uit te voeren. Het Molengraaff Instituut Universiteit Utrecht, verschafte gelegenheid tot afronding.

Mevrouw M.H.R.N.Y. Cordewener, de heer L.M.I.A. Bregonje en de Mestreechter Geis stonden mij niet alleen in het Oud-Gouvernement terzijde, maar doen dat ook vandlaag. De twee eerstgenoemden ziet $U$ thans als paranimf in grote staat van paraatheid. 

\&2. Nadere invulling en afbakening van de vraagstelling

A. ARGUMENTEN UIT ANDERE RECHTSSTELSELS IN DE NEDERLANDSE DISCUSSIE

B. VERWIJZINGEN EN DE KWANTITATIEVE ONDERSTEUNING

C. DRie kwalitatieve maAtstaven

D. RECHTSVINDING ALS MAATSTAF

8

E. RECHTSVERGELIJKING ALS MAATSTAF

F. RECHTSVERGELUKING ALS TWEEDE OBJECT VAN ONDERZOEK

G. DE VIER MAATSTAVEN EN ENKELE ANDERE ASPECTEN

\$3. Een verantwoording van de onderwerpen

\$. Plan van behandeling

B. 1859: DE AMSTERdAMSCHE PuPGAZ-COMPAGNIE 
\$4. Publiek domein

85. De relativiteit van de onrechtmatige daad 24

A. INTRODUCTIE 24

B. DE ACCEPTATIE VAN DE RELATIVITEIT IN DE RECHTSPRAAK

86. Uitleiding 27

Hoofdstuk 3 De tekst van het BW als uitgangspunt: 1838

\$1. De totstandkoming van het Burgerlijk Wetboek 1838

\$2. Het BW van 1838 en het Romeinse recht 31

A. HET GEMENE RECHT EN DE NATIONALE CODIFICATIE 31

B. DE BETEKENIS VAN HET ROMEINSE RECHT VOOR HET BURGERLIJK RECHT

§ 3. Het Franse recht in Nederland

84. Een eerste interpretatie van de onderwerpen 37

A. AANSPRAKELIIKHEID VOOR ZAKEN 37

B. ARTIKEL 2014

C. Publiek DOMEIN

1. Publiekrecht of privaatrecht 45

2. Publiek domein 46

3. Zaken buiten de handel $\quad 50$

$\$ 5$. Conclusies 51

Hoofdstuk 4 Rechtsvergelijking als wetshistorie (1838-1850) 53

$\$ 1$. Inleiding

A. KENNISNAME VAN ANDERE RECHTSSTELSELS IN HET NEDERLANDSE PRIVAATRECHT

1. Kwantitatieve weergave

2. Romeins recht en Frans recht: terugtred en verandering 54

\$2. Aansprakelijkheid woor zaken

A. EEN EERSTE IMPLICIETE BETEKENIS IN DE LITERATUUR 
\& 3. Bezit geldt als volkomen titel: vele interpretaties van artikel 2014

A. LiteratuUr $\quad 58$

1. De Pinto 58

2. Goudsmit en Opzoomer $\quad 58$

3. Goudsmit en Philips 61

4. Diephuis 62

5. Coninck Liefsting en Faber 62

B. RECHTSPRAAK 64

§4. Publiek domein 65

A. IMPLICIETE ACCEPTATIE YAN EEN FRANSE BENADERING 65

B. DIEPHUIS 67

§5. Conclusies $\quad 69$

A. KWANTTTATIEvE ANALYSE 69

B. ONTLEENDE ASPECTEN $\quad 69$

C. RECHTSVINDING 70

D. RECHTSVERGELIJING

Hoofdstuk 5 Legisme: rechtsvergelijking voor wenselijk recht (1850-1880) 73

\$1. Inleiding 73

A. LEGISME

B. HET GENUANCEERDE LEGISME

C. DIEPHUIS EN OPZOOMER

1. Invloed van Diephuis en Opzoomer op de privaatrechiswetenschap 76

2. Interpretatiemethode van Diephuis en Opzoomer en de historische uitleg 77

3. Ongerijmdheden en onduidelijkheden in de wet 79

D. LEgISME In FRANKRUK, BELGIË EN DUITSLAND 82

1. Frankrijk en België $\quad 82$

2. Duitsland 83

E. ANDERE RECHTSSTELSELS IN HET NEDERLANDSE PRIVAATRECHT 84

1. De bekendheid met het Franse recht 85

2. Gebruik wan andere rechtsstelsels 85

\&2. Aansprakelijkheid voor zaken: enge en ruime opvattingen 87

A. DE AANZET: RUIME UITLEG VAN ARTIKEL 1403 BW IN RECHTSPRAAK 87

B. EEN ENGE UITLEG DOOR HET OPENBAAR MINISTERIE 
C. Het verschil vaN MENING tUSSEN DIEPHUIS EN OpZOOMER

1. Diephuis 91

2. Opzoomer 92

3. De Nederlandse Juristen-Vereniging: geen afwijking van het schuldbeginsel 93

D. DIEPHUIS' HEERSENDE LEER

E. CONCLUSIES AANSPRAKELUKHEID VOOR. ZAKEN ? 95

\&3. Artikel $2014 \quad 96$

A. DE GERMAANSRECHTELIJKE LEER 96

1. Diephuis 96

2. De Germaansrechtelijke leer nagevolgd in de literatuur 99

3. Bestendiging in de rechtspraak 100

B. De eErste terugtred VAN DE GermaAnse utTleg 101

1. Van Bemmelens Romeinsrechtelijk stelsel 101

2. Het nieuwe vraagpunt wan Molengraaff en Roelvink 102

C. CONCLUSIES ARTIKEL 2014 BW 104

\$4. Publiek domein 105

A. Proudhon en Thorbecke 105

B. THORBECKE'S LEERLINGEN EN HET ADMINISTRATIEFRECHT 107

C. THORBECKE EN WETGEVING 108

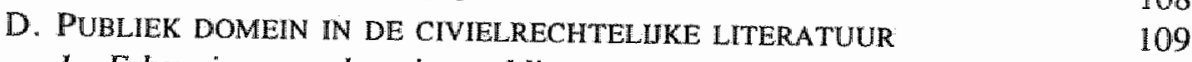

1. Erkenning van domaine public 109

2. Twijfel aan domaine public 111

E. CONCLUSIES PUBLIEK DOMEIN $\quad 114$

§5. Conclusies over de periode van het legisme (1850-1880) 115

A. DE HEERSENDE MENINGEN 115

B. KWANTTTATIEVE ANALYSE 115

C. ONTLEENDE ASPECTEN 116

D. RECHTSVINDING $\$ 116$

E. RECHTSVERGELIJKING

Hoofdstuk 6 Vrije rechtsvinding en rechtsvergelijking (1880-1910) 119

\$1. Inleiding: 'der menschen handel en wandel' 119

$\begin{array}{ll}\text { A. HET IUS CONSTITUENDUM EN DE VRIJE RECHTSVINDING } & 119 \\ \text {. WAT } & 119\end{array}$

B. 'WAT IS 'T VOORWERP DER RECHTSWETENSCHAP EN WAT IS HAAR ME-
THODE?' 
C. VRIJE RECHTSVINDING, LEGISME EN MAATSCHAPPELUKE ONTWIKKELINGEN

1. Maatschappelijke ontwikkelingen en een falende wetgever

2. Vrije rechtsvinding nader geduid als reactie op het legisme

a. Verzachting van het legisme enerzijds...

b. ....anderzijds profilering der vrije richting

D. VRIJE RECHTSVINDING IN ANDERE RECHTSSTELSELS 126

1. De Franse rechtswetenschap rond de eetwwisseling 126

2. De Duitse rechtswetenschap rond de eeuwwisseling 128

E. ANDERE RECHTSSTELSELS EN KENNISNAME DAARVAN IN NEDERLAND 129

1. Rechtsvergelijking als rechtsvinding 130

2. Rechrsvergelijking als afzonderlijke discipline 131

$\$ 2$. Aansprakellijkheid voor zaken: de ruime uitleg als een 'eisch des tijds' 131

A. AANVANG VAN EEN RUIME UITLEg IN HET LEGISME 131

B. DE DisCussie IN DE NEDERLANDSE JURISTEN-VERENIGING 132

C. DE YOORTZETTING VAN DE RUIME UITLEG DOOR EEN VRIJE RECHTSVINDING

1. De spoorwegen

2. Een ruime uitleg door een andere grondslag van aansprakelijkheid 134

3. De ruime Franse uitleg 135

4. De automobiel 137

D. DE HEERSENDE MENING EN DE RECHTSPRAAK 139

1. De heersende mening in handboeken... 139

2. ...en in rechtspraak 139

E. CONCLUSIES AANSPRAKELIJKHEID VOOR ZAKEN 140

$\S 3$. Artikel 2014: het verkeersbelang en de legitimatieleer 141

A. DE ONTWIKKELING VAN DE MODERNE LEER: DE LEGITIMATTE-THEORIE 142

1. De aanloop tot Scholtens legitimatieleer 142

2. De legitimatieleer van Scholten 142

B. DE HEERSENDE LEER EN DE VERANDERDE ONDERBOUWING 146

C. IN HET NIEUWE BURGERLIJK WETBOEK

D. CONCLUSIES ARTIKEL 2014

§4. Publiek domein, een privaatrechtelijke benadering 148

A. DE EERSTE OMSLAG NAAR EEN UNIFORM PRIVAATRECHTELUKE BENADERING

B. VON REEKEN EN ONMIDDELLUKE NAVOLGING 149

I. Von Reekens omslag 149

2. Onmiddellijke ondersteuning 150 
C. TWEe Franse schriuvers, eEN DUTTSE, EN VAN Gelein VITRINGA'S KRTTIEK

1. Berthélémy

2. Barckhausen en Hauriou

3. Otto Mayer

4. Van Gelein Vitringa's kritiek

D. DOCTRINE EN RECHTSPRAAK NA VON REEKENS ARTIKEL

E. CONCLUSIES PUBLIEK DOMEIN

\$5. De relativiteit der onrechtmatige daad

A. DE DUITSE RELATTVITEIT

B. DE KENNISNAME VAN \& 823 LID 2 IN NEDERLAND

C. ABSOLUTE ONRECHTMATIGHEID EN VAN GELEIN VITRINGA"S RELATTVERING

1. Slegten-Westenenk

2. De introductie door Van Gelein Vitringa (1919) 161

3. Een geheel nieuwe toevoeging?

D. De ZaAK Marchant et D'ANSEMbourg; Besier en Demogue 163

1. Marchant in het kort 163

2. Demogue (1924) en Besier (1928) 163

E. TELDERS: ONDERSTEUNING EN INVULLING AAN DE HAND VAN HET DUITSE RECHT (1929)

F. DE ONGESCHREVEN NORMEN VAN LANGEMEIJER (1934) 166

G. ACCEPTATIE IN RECHTSPRAAK, HANDBOEKEN, EN IN HET NIEUWE BW 166

H. CONCLUSIES RELATIVITEIT 168

\$6. Conclusies over de periode van de vrije rechtsvinding (1880-1910) 168

A. DE HEERSENDE MENINGEN 168

B. KWANTITATIEVE ANALYSE 169

C. ONTLEENDE ASPECTEN 169

D. RECHTSVINDING

$\begin{array}{ll}\text { E. RECHTSVERGELIJING } & 171\end{array}$

Hoofdstuk 7 Terugtocht van wrije interpretatie, bestendiging wan de rechtsvergelijking (1910-1940)

\$1. Inleiding

A. INLEIDING

B. KRITIEK OP DE VRIJE RECHTSVINDING: TWEE MOGELIJKHEDEN

C. HERZIENING VAN DE CODIFICATIE, EN EEN STERKERE BINDING AAN DE WET 
D. RECHT ALS OPEN SYSTEEM: SCHOLTENS METHODE 177

E. DE REACTIE OP VRuE INTERPRETATIE IN DUITSLAND EN FrankrIJK 178

1. Ontwikkelingen in Frankrijk 178

2. Ontwikkelingen in Duitsland $\quad 180$

F. ANDERE RECHTSSTELSELS EN KENNISNAME IN NEDERLAND 181

1. Rechtsvergelijking als afzonderlijke discipline 181

2. Rechtsvergelijkende argumenten 182

§2. Aansprakelijkheid voor zaken $\quad 183$

A. SCHULD ALS DOGMATISCH UITGANGSPUNT? 183

B. DE BESTAANDE WETGEVING RUIM UITGELEGD?

1. In het Nederlandse recht 185

a. De terughoudendheid in de ruime uitleg 185

b. Suijlings middenweg 186

2. In het Franse recht 187

C. EEN AFZONDERLUKE WETGEVING MET EEN VERLICHTING VAN HET $\begin{array}{ll}\text { SCHULDDBEGINSEL } & 189\end{array}$

1. De Nederlandse Juristen-Vereniging in $1913 \quad 189$

2. De Motor-en Rijwielwet en kritiek 191

3. Het nieuwe Burgerlijk Wetboek 192

D. CONCLUSIES AANSPRAKELIJKHEID VOOR ZAKEN 193

\$3. Artikel 2014, de legitimatieleer en de kritiek 194

A. DE ONZEKERHeid over de aANGehangen leER: Meuers en HoFMANN

B. DE ACCEPTATIE VAN DE LEGITIMATIELEER 197

C. CONCLUSIES $2014 \quad 198$

\$4. Publiek domein 198

A. DE VERANKERING VAN HET PUBLIEK DOMEIN IN HET PRIVAATRECHT $\mathbb{1 9 8}$

1. Goudekets uiteenzetting 198

2. Scholtens gemene rechtsleer 200

B. PUBLIEK DOMEIN IN FRANKRIJK EN DUITSLAND 201

I. Frankrijk 201

2. Duitsland 203

C. EEN TERUGTRED VAN DE PRIVAATRECHTELJKE WEG 205

1. Suijlings waarschuwing 205

2. Publiekrechtelijke beperkingen in het Burgerlijk Wetboek 206

3. Domaine public 207

D. CONCLUSIES PUBLIEK DOMEIN 208 
8. De relativiteit der onrechitmatige daad

A. DE ABSOLUTE ONRECHTMATIGHEID

1. Meijers' argumentatie

B. CaUSAAL Verband

1. Het dubbele causale verband van Besier

2. Andere voorstanders van het causale verband 212

C. SCHULD OF DE LEER VAN SMITS

D. CONCLUSIES RELATIVITEIT

86. Conclusies over de periode 1910-1940
A. DE HEERSENDE MENINGEN
B. ONTLEENDE ASPECTEN
C. KWANTITATIEVE ANALYSE
D. RECHTSVINDING
E. RECHTSVERGELIJKING

\section{Hoofdstuk 8 Conclusies}

\$1. Inleiding

\$5. De buitenlandse bron en rechtsvergelijking

A. HET GEBRUIK VAN EEN ANDER RECHTSSTELSEL ALS RECHTSVERGELIYKING

B. RECHTSVERGELUKING: EEN BUSSTELLING

$\S 1$. Inleidende opmerkingen
A. DE SELECTIE VAN HET TE ONDERZOEKEN MATERIAAL.
B. DE VERWUIZING
C. DE HERKOMST VAN DE VERWIJZING 
\$2. De getalsmatige weergave naar behandelde periode 228

A. TOELICHTING 228

B. DE EERSTE PERIODE $\mathbb{1 8 3 8 - 1 8 5 0} 228$

1. Verwijzingen 228

2. Inhoudsopgave Themis 229

C. DE TWEEDE PERIODE (1850 1880) 229

1. Verwijzingen 229

2. Inhoudsopgave Themis en Rechtsgeleerd Magazijn 230

D. DE DERDE PERTODE (1880-1910) 232

1. Verwijzingen 232

2. Inhoudsopgave Themis en Rechtsgeleerd Magazijn 232

E. DE VIERDE PERIODE (1910-1940) 233

1. Verwijzingen 233

2. Inhoudsopgave Themis en Rechtsgeleerd Magazijn 233

$\begin{array}{ll}\text { Samenvatting } & 235\end{array}$

$\begin{array}{ll}\text { Sunmary } & 241\end{array}$

$\begin{array}{ll}\text { Literatuur } & 247\end{array}$

$\begin{array}{ll}\text { Rechtspraakregister } & 263\end{array}$

$\begin{array}{ll}\text { Curriculum Vitae } & 267\end{array}$ 


Hoofdstuk 1

\section{Inleiding}

'Ons burgerlijk regt is geen in oorsprong en ontwikkeling zuiver Nederlandsch regt; dat altijd vrij is gebleven wan wreemden invloed en niets van elders heeft overgenomen. Vooral hebben het Romeinsche en het Fransche regt op het onze een gewigtigen invloed uitgeoefend, en men behoeft die vreemde imwerking niet to betreuren.' 1

\section{$\S 1$. Een nationale privaatrechtswetenschap?}

De derde privaatrechtelijke codificatie die op het grondgebied van de Nederlandse staat een exclusieve gelding had, het oude Burgerlijk Wetboek, verkreeg klokslag middernacht tussen 30 september en 1 oktober 1838 kracht van wet ${ }^{2}$. Vlak daarvoor had Voorduin deze Nederlandse privaatrechtelijke wetgeving als een nationale zegen aangeprezen:

'Sire! Naar eigene wetten te lewen, was reeds van ouds het kenmerk van de onafhankelijkheid der volken: door eene nationale wetgeving wordt de liefde tot het vaderland zelve, welke in Nederland ên is net de liefde tot den Koning, krachig aangekweekt; door haar wordt dies hechte band naauwer toegehaald en bevestigd, welke al den burgers van den Staat alls zoo vele kinderen van êen en hetzelfde huisgezin, moet verbinden; door haar worden bij het nagestach voorwaderijke zeden, woorvaderlijke deugden overgeplant.' 3

Dit citaat benadrukt zo kort na de afscheiding van België duidelijk een nationaal streven. Achtte Voorduin een dergelijke nationale benadering ook voor juristen noodzakelijk? In de inleiding van zijn werk laat hij daarover geen twijfel bestaan:

1. Diephuis, G., Het Nederlandsch Burgerlijk Regt deel $1(1869)$, p. 16.

2. Besluit van 13 april 1838 (Stb. 12). Overigens verkreeg het oude Burgerlijke Wetboek in de huidige provincie Limburg eerst op I januari $1842 \mathrm{kracht}$ wan wet. Wer wan 26 mei 1841 (Stb. 15), KB 10 oktober 1841. Zie hierover Luijten, E.A.A. (e.a.), 146 jaar Burgerlijk Wetboek (1989), p. 7.

3. Voorduin, J.C., Geschiedenis en beginselen der Nederlandsche wetboeken deel 1 (1838), wit de tekst. voorafgaand aan het voorwoord. 


\begin{abstract}
"Mogten zich dus, bij de beoefeming des Nederlandschen regts, twijffelingen voordoen nopens de hoofdbeginselen, door dery wetgever beoogd, de beradslagingen daarover gehouden, wijzen dezelve onfeilbaar aan onistater verschil over den zin der woorden - de wetgever heefi ze zelf verklaard; wil de spitsvindigheid den wetgever andere woorden in den mond leggen, dan hij gebezigd heeft of bedoelde - de geschiedenis der wetgeving leert de wijzigingen kennen, die de ontwerpen hebben ondergaam, en de redenen die daartoe geleid hebben; ontwouwt de gronden, waatron de wetgever juist zoo en riet anders gesproken heeft; laat omtrent zijne bedoelingen geenen twijfel over, 4
\end{abstract}

Uit beide citaten kan een eerste beeld worden gevormd van de betekenis van het Burgerlijk Wetboek voor de privaatrechtswetenschap van na 1838 . Deze betekenis vormt voor deze studie het uitgangspunt. In Voorduins citaat vallen twee punten op. In de eerste plaats wordt het eigen Nederlandse karakter van het Burgerlijke Wetboek onderstreept, in de tweede plaats wordt, bij twijfel omtrent de betekenis van een bepaling, de wil van de wetgever (zoals uit de wetsgeschiedenis blijkt) bij de uitleg gebruikt. Beide aspecten hangen nauw met elkaar samen. Door voor de uitleg van de wetsbepaling alleen de tekst van de bepaling en de wil van de wetgever toe te staan, wordt juist dit nationale karakter van het Burgerlijk Wetboek versterkt. Het recht wordt gevonden in het eigen Nederlandse wetboek. Men kan zich afvragen of dit beeld, zoals zich dat in Voorduins citaat opdringt, een correct beeld is. Voorduin zet één en ander bepaald sterk aan, zoals dat hoort in een aanprijzend voorwoord. Een veelheid aan schrijvers heeft dit verschijnsel, door Coing geduid als nationalisering van het privaatrecht, beschreven voor meerdere landen in continentaal Europa ${ }^{5}$. De negentiende-eeuwse codificaties veroorzaken in dat beeld een breuk met het verleden; een verleden, waarin de privaatrechtswetenschap met name was gericht op een aan alle continentale rechtsstelsels gemeenschappelijk Romeins recht; een heden waarin de nationale codificatie object van wetenschapsbeoefening is geworden.

Maar is de wetenschappelijke beoefening van het privaatrecht in de periode na de invoering van het Burgerlijk Wetboek in 1838 tot in de huidige tijd daadwerkelijk zo nationaal? Dit beeld lijkt op zijn minst bijgesteld te moeten worden: een dergelijke schets veronachtzaamt de inhoudelijke privaatrechtswetenschap. Slechts het werpen van een vluchtige blik in de literatuur volstaat om aan verwijzingen waar te nemen dat ook in dit nationale privaatrecht veelvuldig gebruik gemaakt wordt van andere rechtsstelsels.

4. Voorduin, J.C., dee 1 (1837), p. 3.

5. Coing, H. Europaisches Prwatrech II (1989), D. 2: Kop, P.C., Legisme en privaatrechtwetenschap (2e druk, 1992), p. 7: Schulze, R., Le droit privé conmun Européen, Revue Internationate de Droit Compars 1-1995, p. 8; Lokin, I.H.A., en W.J. Zwalve, Hoofdstukken ant de Europese codificaticheschiedewis (1992), p. 420; Van den Bergh, G.C.J.J. Geleerd recht (3e druk, 1994), p. 99; Lokin, 1.H.A., De nationale codificatie in hat verhouding tot het geschreven en ongeschreven subsidiaire recht, Nederlands Juristenblad 1988, p. 660-668, ook verschenen in Tekst en wäleg (1994), p. 39-62. passim; Zwalve, W.J., Hoofdrikken wit de geschiedenis van het Europese privaatrecht, deel 1 , Inteiding en zakenrecht (1993), p. 50: zie ook Roos, N.H.M., De Nederlandse privaatrechsteer in dramatisch perspectief, 1987, met name hoofdstuk 3 . 
Dat gebruik van andere rechtsstelsels in het Nederlandse privaatrecht is ook daarom interessant, omdat de huidige privaatrechtswetenschap (met de Europese Unie als krachtig katalysator) duidelijk gericht is op een Europees privaatrecht ${ }^{6}$. Een Europese privaatrechtelijke codificatie is volgens velen een vooralsnog onbereikbaar doel, zodat vooral de rechtswetenschap zich zal moeten wijden aan een Europese privaatrechtswetenschap. Zo bijwoorbeeld Zimmermann over een Europese codex van het privaatrecht:

$\therefore$...the time is by no means ripe for that. Without intensive scientific groundwork, a European codification of civil law is not realistically imaginable; nor is it desirable. First and foremost the juristic nationalisn which still to a large extent characterizes our consciousness will have to be overcome; in its place, a comprehensive 'Europeanization' of legal science has to be brought about. ${ }^{\text {? }}$

Het gebruik van buitenlandse bronnen in het Nederlandse privaatrecht is in dit verband interessant, omdat het licht kan werpen op dit 'juristic nationalism, ' en aldus dienstbaar kan zijn in deze gang naar een Europees privaatrecht. En als vanzelf vloeit dan voort uit de aanwezigheid van die verwijzingen de centrale vraagstelling in dit onderzoek. $\mathrm{Zij}$ zal zijn:

In welke mate en op welke wijze was er in de periode 1838 tot in recente tijd in de Nederlandse priwaatrechtswetenschap sprake van een internationale oriëntatie?

De vraag in deze algemene vorm beantwoorden is onmogelijk. Wel mogelijk is om op enkele concrete deelvragen een antwoord te vinden. Deze antwoorden tezamen geven een beeld van het veronderstelde nationale karakter van de Nederlandse privaatrechtswetenschap. In de volgende paragrafen $(\$ 2 \mathrm{ev}$.$) zal ik de vraagstelling toespitsen en$ werkbaar maken.

6. In dit verband is in de afgelopen jaren een groot anantal antikelen gepubliceerd (ik wolsta hier te verwijzen naar de door Hondius genoemde in: Harkamp, A.S. et al. (ed.). Towards a European Civil Code (1994), p. 13 ev.) en een antal nieuwe tijdschriften opgericht (European Review of Private Law: Zeitschrift far Europaisches Privatrecht, Maastrich Journal of European and Comparative Law).

7. Zimmermann, $\mathbb{R}$., Roman Law and European Legal Unity, in: Harkamp, A.S. et al (ed.), Towards a European Civil Code (1994), p. 67. In diezelfde zin reeds eerder Coing, H., Europäisienung aler Rechtswissenschaft, Neue Juristische Wochenschrift 1990, p. 937-941. En zo zijn er ook in de Nederlandse rechtswetenschap stemmen voor deze 'Europăisierung", bijvoorbeeld Zwalve: "Het is. dunkt mij. de taak van de Europese universiteitem (...) de grondslagen te leggen voor een Europeste rechtswetenschap..., zoals geciteerd en instemmend angehald door E.H. Hondius in diens preadwies voor de Vereniging voor Burgerlijk Recht: Naar een Europees burgerlijk recht (1993), p. 17. 


\section{\$2. Nadere invulling en afbakening van de vraagstelling}

\section{A. ARGUMENTEN UIT ANDERE RECHTSSTELSELS IN DE NEDERLANDSE DISCUSSIE}

Op verschillende wijzen kan invulling worden gegeven aan de beantwoording van de gestelde vraag ${ }^{3}$. In een onderzoek naar de invloed van de Duitse rechtswetenschap op de Nederlandse geeft Kop enkele maatstaven om die invloed nader te duiden. Zo noemt hij de vraag of er sprake was van bekendheid met de ontwikkeling van het privaatrecht in Duitsland; hij noemt de vraag of er sprake was van een discussie tussen Nederlandse en Duitse juristen; en voorts noemt hij de vraag of tussen Nederlandse juristen onderling mer behulp van de aan de Dwitse rechtswetenschap ontleende argumenten werd gediscussieerd $^{9}$. Deze laatste maatstaf voor invloed, thet gebruik van het aan een ander rechtsstelsel ontleend argument in de Nederlandse discussie, wordt ter beantwoording van de gestelde vraag in dit onderzoek gebruikt.

Als object van onderzoek worden vier verschillende onderwerpen uit het vermogensprivaatrecht onderzocht. De nadruk ligt daarbij op de vorming van standpunten in de wetenschap, zoals deze tot uiting komt in de literatuur: commentaren op het Burgerlijk Wetboek, boeken, publicaties in tijdschriften en annotaties. Geenszins is volledigheid beoogd in de weergave van de discussies. Alleen die standpunten worden beschouwd die een rol van betekenis hebben gespeeld. Daarbij was niet zozeer van belang of het standpunt werd aanvaard, maar juist of er in de discussie aan werd gerefereerd. Rechtspraak en wetgeving wordt onderzocht voor zover zij word behandeld in de gebruikte literatuur. De onderzochte periode vangt aan kort voor 1838 en eindigt rond 1940. Het huidige recht biedt de ingang tot de bespreking van de onderwerpen. Waar dit voor een

8. Mer zou zich bijvoorbeeld kunnen richten op internationale contacten van enkele thoogleraren warbij onderzoek wan gevoerde briefwisheling centraal stant Een woorbeeld is dar Jansen, C.J.H. Der Briefwechsel zwischen H.W. Tydeman (1778-1863) und F.C. Von Savigny (1779-1861): Streiflichter wuf die riederländische Rechiswissenschaft am Anfarig des 19. Jahrhunderts., in: Die Rechtswissenschaflichen Beziehungen zwischen den Niederlanden wnd Deatschland in historischer Sich (1991), $\mathrm{p}$ 71 -89. Zie ook in dezelfde bundel Kop, P.C. Bemerkungen zum EinfluB der Deutschen Rechtswissemschaft auf die Niederlandische Privatrechtswissenschaft des neunzehnten Jahriunderts (p. 91-107); verder Lokin, J.H.A. De irvloed wan de pandektistlek op het werk van Diephuis en Opzoomer, in: R. Pieterman e.a. (red.), Bijdragen for de rechtsgeschiedenis wan de negentrende eeww, (1994), p. 29; Kop, P.C., Savugny en de wettenschap van het privatrecht in Nederland in de negentiende eeuw, Tuidschrift voor Rechtsgeschiedenis 57 (1989) 117. Ook eerder wordt een dergelijke vraag gesteld maar de inwloed van de Franse en Duitse wetenschap en rechtsprak op de Nederlandse rechtspraak (en Wechtswetensohap) door Van Apeldoom in 1939 in een bespreking van bet Gedenkbok Burgerlijk Wetboek 1838-1939, in. Rechtsgeleerd Magazij. Themis 1939, p. 69.

Kop, P.C., (1991), p. 94. Het is dezelfde methode die Hondius hanteert bij zija onderzoek naar het gebruik wan an buitenlandse rechtsstelsels ontleende argumenten in (met name) de rechtspraak. Hondius, $\mathbb{B}$. $H$. Het Burgerlijk Wetboek in rechtswergelijkend perspectief, in: Recht vooruit. Opstellen werzameld ter gelegenheid wan 150 jaar BW (1988), p. 59-71. 
goed begrip van de gebruikte argumenten verduidelijkend is, wordt het standpunt uit het andere rechtsstelsel nader beschouwd.

\section{B. VERWUZINGEN EN DE KWANTTTATIEVE ONDERSTEUNING}

De onderwerpen worden aan de hand van de verschillende ingenomen standpunten en argumenten geanalyseerd. Venwijzingen maken duidelijk of een standpunt of argument afkomstig is uit een ander rechtsstelsel. De enkele aanwezigheid van een verwijzing zegt niet veel. Wel illustreert een relatieve verandering in het aantal gebruikte verwijzingen de gerichtheid van de rechtswetenschap op een ander rechtsstelsel. Daartoe worden verwijzingen geteld in geselecteerde literatuur en onderscheiden naar hun herkomst. $\llbracket k$ verwijs hiervoor naar de bijlage. Deze kwantitatieve benadering is het eerste criterium om de oriëntatie op andere rechtsstelsels te kunnen meten ${ }^{10}$. Verder worden drie andere kwalitatieve criteria gebruikt.

\section{DRIE KWALITATIEVE MAatSTAVEN}

Juist interessant is een kwalitatief onderzoek. Om meer over het gebruikte argument te weten te komen is een inhoudelijke toets noodzakelijk. Deze inhoudelijke toets vindt op drie niveaus plaats. Daarmee worden drie criteria voor de oriëntatie op andere stelsels gegeven. In de eerste plaats wordt de inhoudelijke ontwikkeling van het leerstuk geanalyseerd: duidelijk wordt aan de hand daarvan welke (delen van de) onderwerpen ontleend zijn aan andere rechtsstelsels. In de tweede plaats wordt het gebruikte argument gewaardeerd aan de hand van methoden van uitleg, van rechtsvinding. Deze methoden veranderen in de loop van de onderzochte periode. Sommige methoden werden wel, andere niet of veel minder geaccepteerd. Door het buitenlands argument als methode van uitleg te kwalificeren wordt de oriëntatie op het andlere stelsel duidelijker in die bekende ontwikkeling van het privaatrecht geplaatst. In de derde plaats wordt het aan het buitenlandse stelsel ontleende argument nader beschouwd door meningen van civillisten over rechtsvergelijking erbij te betrekken. Veel civilisten hebben zich uitgelaten over het gebruik van ander recht bij de uitleg van de Nederlandse bepalingen. Over de eerste inhoudelijke toets hoeft op dit moment niet veel meer te worden gezegd. Overnames van

10. Eenzelffe benadering: Hondius, E.H., (1988), p. 67 met betrekking tot rechrspraak van de Hoge Ratad, en met interessante voorbeelden van een rechtswergelijkende argumentatie in andere landen, de 'rechisswergelijking in het kwadraat"; werder bijwoorbeeld Lokin, J.H.A., (1994), p. 33, die spreekt over: "Welke schrijvers haalt Diephuis nu het meest aan? Veel meer dan de naant wan Von Savigny valt één maam op en dat is die van Joseph Unger."; zie ook: Brahn, O.K., in: Luijten E.A.A., (e.a.), 146 joadr Burgerlyjk Werboek. (1989), p. 51. Zie ook Smits, I.M., "A brooding ominipresence in the sky": over rechtsontwikkeling en buitenlandse rechtsliteratuur, WPNR 6207 (1996), p. 45; voor een kwartitatieve aralyse van de gebruikte argumenten in de rechtspraak wan de Hoge Raad en gerechtshoven: Snijders. H.J., Rechtsvinding door de burgerlijke rechter (1978), die overigens in de onderzochte rechtspralk geen beroep op buttenlands recht is tegengekomen dan in verband met international privatrecht, $\mathrm{p}$. 34-36. 
leerstukken zoals de relativiteit of publiek domein zijn bekend. Er blijkt echter veel meet ontleend te zijn aan andere rechtsstelsels. Op rechtsvinding en rechtsvergelijking als matstaven voor orientatie op andere rechtsstelsels wordt in de volgende twee paragrafen ingegaan.

\section{RECHTSVINDING ALS MAATSTAF}

Standpunten over de uitleg of interpretatie van een artikel komen tot stand na argumentatie; deze argumentatie betreft eigenlijk de interpretatie of de rechtsvinding. In beschouwingen over de beoefening van het privaattecht in de negentiende en twintigste eeuw nemen de methoden van rechtsvinding een belangrijke positie in. Bekend is met name de wijze waarop de negentiende-eeuwse privaatrechtswetenschap wordt beschreven: als exegetisch of legistisch. De grammaticale en systematische wetsuitleg wordt als het belangrijkste kenmerk van die periode beschouwd. Bekend is eveneens de volgende periode waarbij het recht ook buiten de wet mocht worden gevonden: de periode van de vrije rechtsvinding ". Dit onderzoek plaatst het gebruik van andere rechtsstelsels in die methoden van interpretatie. Het onderzoek wordt ingedeeld in perioden, naar de heersende ideeën over rechtswinding in de Nederlandse privaatrechtswetenschap. Onderscheiden worden achtereenvolgens een korte periode na 1838 , de periode van het legisme, de periode van de vrije rechtsvinding en de periode van de terugtred van de vrije rechtsvinding. Elk hoofdstuk wordt ingeleid door een beschouwing over de gevolgde methoden van interpretatie.

\section{E. RECHTSVERGELIJKING ALS MAATSTAF}

Rechtsvergelijking biedt een derde kwalitatieve maatstaf voor gebruik van ander recht. Veel civilisten hebben zich sinds de invoering van het BW in 1838 uitgelaten over het gebruik van andere rechtsstelsels voor de interpretatie van de Nederlandse bepalingen. Het Romeinse recht en het Franse recht staan vlak na 1838 in de belangstelling en gewezen wordt op de herkomst van het Nederlandse recht uit het Franse of het Romeinse recht. Veel later wordt de aandacht gevestigd op de noodzaak van kennisname van andere rechisstelsels in verband met het internationaal privaatrecht ${ }^{12}$, soms zelfs

11. Zie bijwoorbeld Scholten, P., Algeneen Deel (1931), passim; Vranken, J.B.M., Agemeen Deel (1995), passim; Pito. A., Het systeem wan het Nederlandse prinatrecht (1958), p. 33; Gilissen, J., Wistorische inleiding tot het rechr (1981), met name p. 480-486; Jaspers, A.Ph.C.M., Rechtspreken in de maarschappij (1980); Lokin, J.H.A. Tekst en witleg (1994), passim; Kop, P.C. Legisme en Priwatrechtswetenschap (2e dnk, 1992), passim; Van der Bergl, G.C.J.J., Geleerd recht (3e druk, 1994), p. 117 ev, Voor Belgiè en Nederland: Van Dievoet, E., Het burgerlijk rechr in België en Nederland 1800-1940, (1943), met name p. $83-228$. Zie woor Duitsland onder meer Wieacker, F.
Privarechusgeschiche der Neuzeir (1967), p. $430 \mathrm{ev}$.

12. Daarover Steenhoff, G.J.W., De Wet
periade tussen 1862 en 1962 (1994). 
om eenmaking van privaatrecht te bewerkstelligen in verband met het internationale handelsverkeer.

\section{F. RECHTSVERGELUKING ALS TWEEDE OBJECT VAN ONDERZOEK.}

Is er sprake van rechtsvergelijking wanneer verwezen wordt naar andere rechtsstelsels? In beschouwingen over rechtsvergelijking wordt nauwelijks ingegaan op het gebruik van buitenlandse rechtsstelsels in het privaatrecht zelf. Beschouwingen van comparatisten geven een geheel ander beeld dan uit het privaatrecht zelf kan volgen. In de eerste plaats wordt door comparatisten meestal een beperkte omschrijving van rechtsvergelijking gehanteerd. Van wetenschappelijke rechtsvergelijking zou eerst dan sprake zijn wanneer de historische wording en sociologische aspecten bij de vergelijking worden betrokken ${ }^{13}$. Samenhangend daarmee wordt de geschiedenis van de rechtsvergelijking beschreven als de geschiedenis van een afzonderlijke wetenschappelijke discipline. Gesteld wordt bijvoorbeeld dat het begin van rechtsvergelijking gevonden kan worden bij de oprichting van een rechtsvergelijkend tijdschrift, of bij het eerste rechtsvergelijkende congres in Parijs in $1900^{14}$. Daarmee blijft een belangrijk deel van rechtsvergelijkende arbeid onbeschreven. Wanneer een ruime definitie van rechtsvergelijking wordt gebruikt, dan laat zich ook het buitenlandse argument, zelfs de enkele verwijzing, in de Nederlandse discussie daaronder vatten, en aldus verschaft dit onderzoek inzicht in de ontwikkeling van rechtsvergelijking binnen het Nederlandse privaatrecht ${ }^{15}$. In de tweede plaats wordt de oorsprong van de rechtsvergelijking gelegd in de nationale codificatie van het privaatrecht ${ }^{16}$. Daarmee wordt versluierd dat de wetenschappelijke beofening

13. Zie Kokkini-Iatridou, D., Een inleiding tot het rechtsvergelijkende onderzoek (1988), p. 6; De Boer. Th. M., Uitgangspanten van een rechisvergelijkende theorie: een paradigma voor de lage landen, in: Ars Alequi 43 (1994) 5. p. 39; anders De Groot, G.1R., Vergelijkr alles en behoud het goede (1989). p. 2-3;

14. Zo bijvoorbeeld Constantinesco, L.J., Rechtsvergleichung 1, 1971, p. 69, over de zelfstandige beoffening van rechtsvergelijking sinds het laatst van de negentiende eeuw als: 'Denkprozeß der systematischen Gegenuberstellung"; verder dezelfde, p. $115 \mathrm{ev}$; Hug. W., The history of comparative law, Harward law review 1932, p. 1031 ; Gutteridge, H.C., Comparative law (1971), p. 25; Coing, H., (1989), p. 58-63; De Boer. Th. M. (1994), p. 39. Een geheel andere benadering hanteert Watson: rechtsvergelijking als de studie naar de werbanden tussen rechtssystemen. waarbij juist wordt gekeken naar aan andere rechtssystemen ontleende onderdelen, "legal transplants'. Een interessatate benadering waaronder ook dit onderzoek gebracht kan worden. Zie Watson, A., Legal transplants. An approach to comparafive law (1993), p. 19.

15. Eenzelfde benadering van rechswergelijking: Hondius, E.H., (1988), p. 61; een aanzet tot clergelijk onderzoek naar rechtswergelijking, en een frataie schematisering woor wal de eigentijdse rechtspraak in burgerlijke zaken wan de Hoge Raad betreft is gedaan door Strikwerda L., en I.R. de Jong, Rechtskergelijking en rechtsvinding in burgerlijke zaken, Ars Aequil 43 (1994) 5 , p. 20.25. Ook Smits heeft in een tweetal recente artikelen in het WPNR de nadruk gelegd op de rechtswergelijking als methode van rechtsvinding: zie Smits, J.M., De noodzaak en de mogelijkheid wan rechisvergelijking in her civiele recht, WPNR 6154 (1994), p. 728-730; dezelfide, "A brooding omnipresence in the sky": over rechtsontwikkeling en buitenlandse rechtsliteratuur, WPNR $6207(1996), \mathrm{p}, 44-47$.

16. Coing, H., (1989), p. 56 ev. 
van het privaatrecht in Nederland kort na de codificatie door de oorsprong uit de Franse Code civil nawwelijks 'nationaal' becefend kon worden.

\section{G. DE VIER MAATSTAVEN EN ENKELE ANDERE ASPECTEN}

Het onderzoek biedt antwoord op de vraag of in de ontwikkeling van de onderwerpen zelf duidelijk aanwijsbare aspecten aanwezig zijn van buitenlandse herkomst. Daarnaast wordt inzicht geboden op twee andere niveaus. Het buitenlands argument wordt geplaatst in de methoden van rechtsvinding. Voorts wordt het buitenlands argument geduid in verband met de waarde die aan andere rechtsstelsels werd toegekend bij de uitleg van het Nederlandse recht (rechtsvergelijking). Met behulp van een kwantitatieve analyse wordt ondersteuning geboden. Met het nodige voorbehoud worden de gevonden resultaten geëxtrapoleerd naar het vermogensrecht in het algemeen, en kunnen enige conclusies worden getrokken met betrekking tot de oriëntatie van het Nederlandse vermogensrecht op andere rechtsstelsels. Teneinde aldus te kunnen veralgemenen wordt elk afzonderlijk hoofdstuk ingeleid met een behandeling van de (heersende) ideeën over rechtsvinding en over rechtsvergelijking. Bovendien wordt aandlacht besteed aan de wetenschap van het privaatrecht in Frankrijk, Duitsland, België en incidenteel aan enkele andere Europese landen. Verder wordt tevens inzicht geboden in de wijze waarop binnen het privaatrecht rechtswergelijking werd bedreven.

\section{\$3. Een verantwoording van de onderwerpen}

Enkele leerswukken en artikelen uit het Burgerlijk Wetboek worden onderzocht op de oriëntatie op andere rechtsstelsels: de in artikel 1403 lid $1 \mathrm{BW}$ weergegeven aansprakelijkheid voor zaken, publiek domein, artikel 2014 BW en de relativiteit van de onrechtmatige daad. Deze onderwerpen vormen tezamen slechts een kleine uitsnede uit het Nederlandse vermogensrecht. Zij zijn uitgekozen om twee redenen. Elk van de leerstukken heeft een duidelijk herkenbaar ijkpunt in een buitenlands rechtsstelsel. Voor aansprakelijkheid voor zaken betreft dit de ruime Franse en Belgische uitleg van artikel $1384 \mathrm{Cc}$ aan het einde van de negentiende eeuw; voor publiek domein betreft dit de duidelijke introductie door Thorbecke van de Franse theorie inzake 'domaine public' van de vroegnegentiendeẻeuwse jurist Proudhon; artikel 2014 is een letterlijke vertaling van een in het Franse recht al onbegrijpelijke zinsnede; de relativiteit van de onrechimatige daad kan herleid worden tot een bepaling uit het Duitse BGB. Voordeel van deze benadering is dat in de discussie aan andere rechtsstelsels ontleende argumenten een belangrijke rol zullen spelen. Duidelijker wordt dan hoe er in de loop van de onderzochte periode veranderingen optraden in het gebruik van het aan een ander rechtsstelsel ontleende argument. Nadeel van deze methode is vanzelfsprekend dat leerstukken die een dergelijk in een ander rechrsstelsel gelegen ijkpunt missen, niet worden onderzocht. De tweede reden waarom juist deze leerstukken werden geselecteerd, ligt in de intensiteit van de gevoerde discussie. Alle leerstukken laten een levendig debat zien, en de hoeveelheid van de standpunten en gebruikte argumenten maken dat meer gezegd kan 
worden over de ontwikkeling van de leerstukken, het gebruik van het aan een ander rechtsstelsel ontleende argument, de wijze van rechtsvinding en de rechtsvergelijking. Deze twee redenen zijn niet de enige; dat zou een benadering zijn die ten onrechte een exactwetenschappelijke benadering zou pretenderen. Minstens evenzeer is de keuze veroorzaakt door een interesse in de leerstukken, en door aan die interesse voorafgaand toeval.

\section{\$ 4. Plan van behandeling}

In het eerstvolgende hoofdstuk 2 worden de leerstukken geïntroduceerd. De hoofdstukken 3-7 betreffen elk een afzonderlijk te onderscheiden periode in de Nederlandse beoefening van het privaatrechtswetenschap. In hoofdstuk 3 wordt de privaatrechtswetenschap voorafgaande aan 1838 belicht. Ingegaan wordt op het aan het BW voorafgaande gemene Romeinse recht, het Franse recht, en de betekenis van beide voor het BW van 1838. Deze beide rechtsstelsels worden gebruikt om de eerste betekenis van de onderzochte onderwerpen te bepalen. Hoofdstuk 4 vervolgt met de eerste periode (18381850) kort na de codificatie van 1838 . In hoofdstuk 5 wordt de periode van het legisme behandeld (1850-1880). In hoofdstuk 6 wordt de periode van reactie op deze tekstexegese belicht, een periode waarin een vrije wetsuitleg opvallend op de voorgrond treedt (1880-1910). Hoofdstuk 7 behandelt de periode waarbij zowel kenmerken van het legisme, als kenmerken van de vrije rechtsvinding zijn aan te treffen (1910-1940). Grenzen tussen de perioden kunnen niet scherp worden getrokken. Zij dienen voor een eerste houvast. In de afzonderlijke hoofdstukken worden de vier genoemde maatstaven teikens voor die periode behandeld in de volgorde: (1) een kwantitatieve analyse van verwijzingen naar andere rechtsstelsels, (2) een identificatie van de aan andere stelsels ontleende inhoudelijke aspecten van de onderwerpen, (3) het gebruik van buitenlandse bronnen in de methoden van rechtsvinding, (4) het gebruik van buitenlandse bronnen in verband met visies op rechtsvergelijking. Hoofdstuk 8 ten slotte besluit het onderzoek met een conclusie, waarin dezelfde volgorde als in de afzonderlijke conclusies wordt aangehouden, en tevens de vraag naar de rechtsvergelijking binnen het privaatrecht wordt besproken. Bovendien wordt ingegaan op de betekenis van dit onderzoek voor een Europees privaatrecht. In een bijlage zijn de getalsmatige gegevens weergegeven en is een uiteenzetting van de gevolgde methode voor de kwantitatieve ondersteuning opgenomen. 


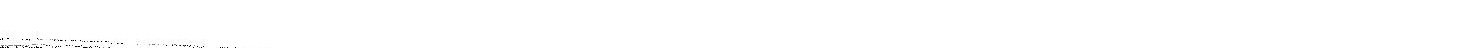


Hoofdstuk 2

\section{Introductie van de onderwerpen}

\section{§1. Inleiding}

In dit hoofdstuk worden de onderwerpen gepresenteerd vanuit het huidige recht. Achtereenvolgens zijn dat de aansprakelijkheid voor zaken, artikel 2014 BW, publiek domein en de relativiteit van de onrechtmatige daad. Een korte beschrijving van het onderwerp wordt gegeven. In het bijzonder gaat de aandacht uit naar die momenten in de ontwikkeling sinds 1838 waarbij een belangrijke toon voor de discussie is gezet. Dit kan zijn een duidelijk twistpunt in de discussie, een omstreden rechtelijke beslissing of een introductie van een buitenlands standpunt. Deze momenten komen in het verloop van dit onderzoek weer aan de orde.

\section{\$2. Aansprakelijkheid voor zaken}

\section{A. ONTSTAAN VAN EEN APARTE AANSPRAKELIKKHEID VOOR ZAKEN}

In het nieuwe Burgerlijk Wetboek bevindt zich een aparte aansprakelijkheid yoor roerende zaken. Artikel 6:173 vestigt die aansprakelijkheid voor de bezitter van een roerende zaak. Deze roerende zaak moet gebrekkig zijn en voorts een bijzonder gevaar voor personen of zaken opleveren ${ }^{17}$. Te bewijzen door de gelaedeerde is hier (onder andere) dat de zaak een gebrek had, maar niet dat de bezitter onrechtmatig heeft gehandeld of schuld treft aan de schadeveroorzakende gebeurtenis. Een gunstige bewijspositie wordt zo bewerkstelligd; schuld behoeft niet te worden bewezen en vaak kan uit de gestelde en bewezen feiten worden afgeleid dat sprake was van een gebrek van de zaak:

17. Artikel 6: 173 lid 1. De bezitter van een roerende zaak waarvan bekend is dat zij, zo zij niet voldoet aan de eisen die men in de gegeven omstandigheden aan de zaak mag stellen, een bijzonder gevaur voor personen of zaken oplewert, is, wanneer dit gevaar zich verwezenlijkt, aansprakelijk, tenzij aansprakelijkheid op grond van de vorige afdeling zou hebben ontbroken indien hij het gevaar op het vijdstip van ontstaan daarvan zou hebben gekend. 
'res ipsa loquitur". ${ }^{18}$ Naast deze algemene bepaling is ook sprake van afzonderlijke wetgeving over specifieke zaken: in de Wegenverkeerswet 1994 is in artikel 185 een ruime aansprakelijkheid gevestigd voor schade, veroorzaakt door motorrijtuigen.

Van cen dergelijke afzonderlijke aansprakelijkheid voor zaken was na de codificatie van 1838 nog geen sprake. Geheel anders laat zich dan ook de positie van de gelaedeerde aanzien. De sleutel tot de aansprakelijkheid voor door zaken veroorzaakte schade wordt dan geboden door het criterium 'schuld' in artikel $1401 \mathrm{BW}$, door de criteria "nalatigheid of onvoorzigtigheid' in artikel $1402 \mathrm{BW}$. Dit ontbreken van een aansprakelijkheid voor zaken is ten tijde van invoering van de codificatie niet zeer vreemd. Ook al was bij een schadeveroorzakende gebeurtenis een 'schadeveroorzakende' zaak betrokken, vaak was sprake van rechtstreeks menselijk doen of nalaten. De zaak zelf speelt in de juridisch-dogmatische constructie ter vaststelling van de aansprakelijkheid dan geen rol. Tot ver in de negentiende eeuw kan dit beeld worden volgehouden. Indien door een dergelijke zaak schade wordt toegebracht dan is de gebruiker van de zaak veelal direct aansprakelijk uit 1401 en 1402 . De betekenis van "schuld" kon na 1838 nogal variëren. Een ruime betekenis, aansprakelijkheid uit 1401 en 1402 in het algemeen, lijkt de eerste betekenis geweest te zijn. De betekenis van verwijtbaarheid verkrijgt het begrip pas later ${ }^{19}$. Welke juridische betekenis schuld ook werd toegekend, onder de geschetste omstandigheden ligt een aparte aansprakelijkheid voor zaken, naast de aansprakelijkheid voor eigen doen of nalaten, niet voor de hand. De bepalingen met betrekking tot de onrechtmatige daad zijn voldoende. Slechts voor dieren en gebouwen waren afwijkende regels geschreven ${ }^{20}$. In het oude Burgerlijk Wetboek wordt de aansprakelijkheid voor onrechtmatige daad met betrekking tot eigen handelen of nalaten, en daarnaast die voor zaken, beheerst door de volgende bepalingen:

Artikel 1401 . Eike onregtmatige daad, waardoor aan een ander schade wordt toegebragt, steli dengenen door wiens schuld die schade veroorzakt is in de verpligting on dezelve te vergoeden.

Arikel 1402. Een ieder is vefantwoondelijk, nier allesen woor de schade welke hij door zinne datu, watr ook voor die welke hij door zijne nalatigheid of onvoorzigtigheid veroorzakt heeft.

18. Zie Asser-Harkamp IIL (1994), n匹 176; evemzo: conchusie AG Harkamp voor HR 24 december 1993 , Ne 1904, 214 (Leebeek/ Numona). Zie ook TdC (Lankhors), aam. 5 bij ant. 173 boek 6 BW, waar
wordt gesproken over een risiso-aansprakelijkheid.

19. Zie Van Matnen, G.E., Onrechmange dacd (1986), p. 38, 104 en 192; dezelfde in: '..om te doen

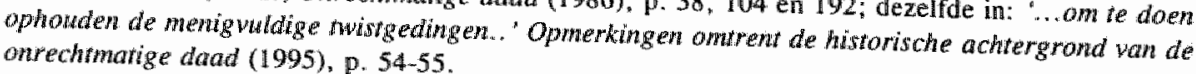
Het betreft hier overigens bepalingen die reeds in het Romeinse recht voorkwamen. Zie bijwoorbeeld: Instituten (1993). 
Artikel 1403 lid 1 . Men is niet alleen verantwoordelijk woor de schade, welke men door züne eigene daad weroorzaakt, maar ook voor die welke veroorzakt is door de daad van personen woor welke men aansprakelijk is, of door zaken welke men onder zijn opzigt heeft.

Artikel $1404 \mathrm{BW}$. De eigenaar yan een dier, of degene die zich van hetzelve bedient, is, zoo lang hetzelve tot zijn gebruik verstrekt, aansprakelijk wegens de schade welke het dier heef weroorzaakt, thet zij hetzelve onder zijn toezigt en bewaring. dan wel werdwaald of ontsnapt zij.

Artikel 1405 BW. De eigenaar van een gebouw is verantwoordelijk voor de schade door deszelfs geheele of gedeeltelijke instorting veroorzaakt, indien deze door verzuim van onderhoud, of door een gebrek in de bouwing of inriguing, is te weeg gebracht.

Vestiging van aansprakelijkheid op basis van deze artikelen is lastig, wanneer de schade niet direct door handelen of nalaten van de gebruiker van de zaak is veroorzaakt. Aan wat voor soort gevallen moet gedacht worden? Een verscheidenheid doet zich voor. Opvallend in de jurisprudentie zijn met name ongelukken met spoorwegen en met auto's. Eveneens veel voorkomend in rechterlijke uitspraken zijn gevallen waarbij schepen in aanvaring komen met objecten in het water. Waarom is vaststelling van aansprakelijkheid lastiger? De benadeelde dient in die gevallen het onrechtmatig handelen of nalaten aan te tonen van diegene die de zaak gebruikte, die de onrechtmatige daad (indirect) pleegde ${ }^{21}$.

In de loop van de negentiende eeuw doen zich deze gevallen met een zelfstandig schadeveroorzakende zaak steeds vaker voor. Op een tweetal ontwikkelingen moet worden gewezen: in de eerste plaats is er sprake van een flinke toename in het aantal machines. In de tweede plaats neemt de diversiteit van in het verkeer gebrachte goederen toe, de intensiteit van het verkeer en, in het verlengde daarvan, de gevaren waaraan mensen zijn blootgesteld ${ }^{22}$. Met name in bedrijfsmatige situaties en bij het (gemotoriseerd)

21. Zie Zimmemann, Law of Obligations, Roman foundations of the ciwilian tradition, (1990) p. 1034 : 'In the course of the 19th century, the principle that liability is based on fault acquired the status of an unquestionable, axiomatic truth.' Even verdler: 'it fitted the prevailing economic liberalism and served the interests of expanding industry and of the rising middle class;" Jhering "s stelling "nicht der Schaden verpflichtet zum Schadenersatz, sondern die Schuld" wordt veelvuldig in de Nederlandse literatur rond de eeuwwisseling aangehaald. Jhering, $R$. von "Das Schuldmonent im römischen Priwatrecht, Vermischte Schriften juristischen Inholts (1879), p. 199.

22. Zie voor een beschrijving van de ontwikkeling van een aansprakelijkheid voor zaken: Zimmermann, R. The Law of Obligations. Roman foundations of the civilian tradition (1990), p. 1034-1035; Knijf, D., Gebrekkige zaken (1973), p. 6-7; Schwitters, R.J.S., Riskante aansprakelijkheid, Recht en Kritiek 17 (1991) $1_{\text {" }}$ p. 5; en van dezelfide auteur: De risico's wan de arbeid. Het onitstan van de ongevallenwet in sociologisch perspectief (1991). Zie ook de recensie in Recht en Kritiek 18 (1992) p. 79; Braams, W. Th, Buiten-controcuele aansprakelijkheid woor gevaarlijke stoffen (1989), pass im. Scholten brengt de ontwikkeling natar een bijzondere aandacht woor schade, veroorzaakt donr zaken, in werband met de verschuiwing naar meer vrijere vormen van rechtsvinding, waarover meer in hoofdstuk 6. Zie ook Scholten, P.. Atgemeen Deel (1931) 25. Evenzo Valkhoff, die deze ontwikkeling als een voor" beeld gebrukt voor de wermaatschappelijking van thet privalutrecht. Valkhoff, J., Een eeuw rechtsontwikkeling (2e druk, 1949), p. 172-173. 
vervoer is hiervan sprake. In Nederland doet deze ontwikkeling zich juist sinds het laatste kwart van de negentiende eeuw voor, later dan in bijvoorbeeld België en Duitsland. Duitse wetgeving met betrekking tot aansprakelijkheid, eerder tot stand gebracht door de industriële voorsprong, $\mathrm{kreeg}$ in de Nederlandse rechtswetenschap veel aandacht ${ }^{23}$. Een andere mogelijke weg voor vestiging van aansprakelijkheid is artikel 1403 lid 1. In dat artikel wordt gewag gemaakt van een aansprakelijkheid voor zaken, terwijl schuld niet wordt genoemd. Deze bepaling zou een mogelijkheid bieden om een aansprakelijkheid voor zaken te vestigen. De Hoge Raad zelf vestigt daarop de aandacht, in een in 1859 gewezen arrest. Wij keren terug naar 1859 en zien in het arrest reeds ontvouwd de discussie die later over de uitleg van artikel 1403 lid 1 laatste zinsnede zou ontbranden.

\section{B. 1859: DE AMSTERDAMSCHE PUPGAZ-COMPAGNIE}

Op 28 januari 1859 wijst de Hoge Raad een merkwaardig arrest, waarin aan artikel 1403 lid 1 BW een bijzondere uitleg wordt gegeven. Het volgende had zich voorgedaan. Trautwein, hoofdrolspeler in deze zaak, heeft in Amsterdam een winkel, aangesloten op een gasleidingnet van de zogeheten "Amsterdamsche pijpgaz-compagnie." In de leidingen van deze maatschappij ontstaat een lek, gas ontsnapt en hoopt zich op onder de winkel. Een ontploffing volgt en schade aan de winkel is het gevolg. Deze schade wenst Trautwein op de gasmaatschappij te verhalen. Hij begint een gerechtelijke prom cedure, waarin hij een beroep doet op artikel 1403 lid 1 BW. De Rechtbank Amsterdam wijst de vordering af: Trautwein slaagt er niet in aan te tonen dat er sprake was van schuld, nalatigheid of onvoorzichtigheid aan de zijde van de gasmaatschappij. De rechtbank doelt hier op vereisten uit 1401 en $1402 \mathrm{BW}$; vereisten die echter in artikel 1403

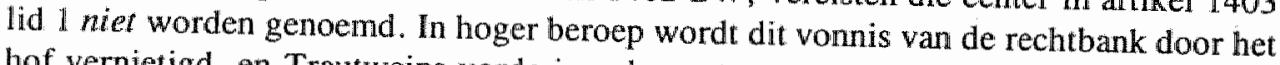
hof vernietigd, en Trautweins vordering alsnog toegewezen, omdat:

\footnotetext{
'de pijpen der toen geint, mer het diarin bevatte gaz zijn zaken, die zij onder haar opzigt heeft, en zij derhalve in het algemeen is verantwoordelijk voor de datrdoor veroorzakk te schade, met name ook voor de ontploffingen van het ten gevolge van gebreken aan de pijpen ontsnapte gaz:"
}

De gasmaatschappij is volgens deze uitspraak in het algemeen verantwoordelijk voor de door haar gaspijpen veroorzaakte schade omdat zij deze onder haar opzicht had. Zij stelt beroep in cassatie in. Als cassatiemiddel stelt zij dat het Hof artikel $1403 \mathrm{BW}$ verkeerd toegepast heeft. Volgens de gasmaatschappij had het Hof de vordering niet op grond van artikel $1403 \mathrm{BW}$ kunnen toewijzen 'zonder in facto het bestaan van verzuim bij de eischeresse aan te nemen. ' Van belang is dus of de vereisten van 1401 (schuld) of 1402 (verzuim) ook gelden bij aansprakelijkheid op grond van 1403 lid $1 \mathrm{BW}$. De Hoge Raad onderzoekt dan eerst voor welke zaken artikel 1403 lid $1 \mathrm{BW}$ is bedoeld en 
komt tot twee mogelijke interpretaties: of artikel 1403 ॥id 1 BW heeft een algemene betekenis en is van toepassing op alle zaken of het is slechts beperkt van toepassing en verwijst in dat geval naar de in 1404 en 1405 BW genoemde dieren en gebouwen. De Hoge Raad kiest met een a-contrario argument voor de eerste mogelijkheid: artikel 1403 BW wijst in de volgende leden wel enige personen aan waarvoor men aansprakelijk kan zijn, maar geeft géén nadere concretisering van het begrip zaken. Vervolgens stelt de Hoge Raad de vraag aan de orde of schuld een vereiste is bij aansprakelijkheid op grond wan 1403 lid I BW, en overweegt dan met een geheel op de tekst van artikel $1403 \mathrm{BW}$ gebaseerde uitleg: ". dat ter toepassing van art.1403 geen bewijs van schuld wordt gevorderd." ${ }^{24}$ Twee vragen keren in de komende discussie telkens terug: is artikel 1403 van toepassing op alle zaken (of verwijst het slechts naar de dieren en gebouwen als in de (wee volgende artikelen)? als eerste vraag; en: is 'schuld' een vereiste voor aansprakelijkheid? als tweede vraag. Het 'onder opzigt hebben' van welke zaak dan ook, en het veroorzaken van schade is in de lijn van deze uitspraak voldoende om voor schade aansprakelijk te zijn.

De uitspraak wordt in de discussie over een aansprakelijkheid voor zaken vaak aangehaald: zij is de eerste waarbij de twee wijzen van uitleg van artikel 1403 lid 1 duidelijk werden omschreven en wordt als voorbeeld gebruikt voor een aansprakelijkheid, waarbij de grondslag niet door schuld wordt gevormd. Toch heeft deze uitleg van 1403 in de rechtspraak niet echt kunnen beklijven. In latere uitspraken wordt wel een aansprakelijkheid aangenomen op grond van 1403 lid $1 \mathrm{BW}$, schuld wordt dan wel vereist. Onlangs is nog door de Hoge Raad deze uitleg aan artikel 1403 gegeven in een zaak waarin een op een boot vervoerde lading hout was gaan schuiven en was terechtgekomen op een trekker en tankoplegger, die daardoor schade hadden opgelopen. Eiser stelde dal van door zaken veroorzaakte schade sprake was, dat gedaagde het hout onder opzicht had in de zin van artikel 1403, en dat van een vermoeden van schuld uitgegaan moest worden. Vergeefs: 'Uitgangspunt moet zijn dat art. 1403 lid 1 zelfstandige betekenis mist, zowell voor wat betreft "de daad wan personen voor welke men aansprakelijk is" als voor wat betreft "zaken, welke men onder zijn opzigt heeft". Dat brengt mee dat voor aansprakelijkheid van degene die de zaak waardoor de schade is veroorzaakt, onder zijn opzicht had, tevens onrechtmatigheid en schuld moeten vaststaan (...).'25 Deze laatste, enge uitleg van 1403 staat nogal in contrast met de ontwikkeling die het overeenkomstige Franse artikel $1384 \mathrm{Cc}$ sinds 1896 te zien heeft gegeven. Dat artikel speelde een hoofdrol bij de ontwikkeling van een aansprakelijkheid voor zaken in

24. HR 28 ja nuari 1859, W2031; ook gepubliceerd in Nederlandsche regtspraak, deel 61, 20, p. 92-105

25. Zie HR 19 februari 1993, $N J 1996,318$; voor de feiten, zie de conclusie van AG Harkamp. De lagere rechtsprak wijkt soms van dit standpunt af. Zie Asser-Hartkamp III (1994), nr. 160. Harkamp meent dat in gelijksoortige gevallen min of meer willekeurig een beroep gedatan werd op 1401 of 1403 lid $1 \mathrm{BW}$. De rechter zou geneigd zijn de bewijslast wat lichter te stellen wanneer artikel 1403 lid I BW aan de vordering ten grondslag gelegd werd. Zie hoofdstuk $62,2.2$. 
Frankrijk. In de Nederlandse discussie is dit opgemerkt en zodoende komt artikel 1403 lid 1 alsnog sterk in de belangstelling te staan. Naast deze aansprakelijkheid voor zaken in een algemene bepaling heeft bijzondere wetgeving uit met name Duitsland een grote rol in de Nederlandse doctrine gespeeld.

\title{
\$3. Artikel 2014
}

Wanneer een beschikkingsonbevoegde een roerende niet-registerzaak overdraagt, dan stelt artikel 3: 86 een duidelijke regel ower de verkrijging van de eigendom. De feitelijke macht die de beschikkingsonbevoegde over de zaak uitoefende legitimeert hem in dat geval tegenover de derde-verkrijger als beschikkingsbevoegd. De derde-verkrijger wordt, als aan de andere voorwaarden van het artikel is voldaan, tegenover de oorspronkelijke eigenaar beschermd indien deze de betreffende zaak wenst te revindiceren: de derde is eigenaar geworden. Lid 3 maakt een uitzondering in geval van diefstal.

\begin{abstract}
Ant. 3:86 lid 1. Ondanks onbevoegd heid van de verweender is een overdracht overeenkonstig artike 90,91 of 93 van een roerende zaak, niet-registergoed, of een recht aan toonder of order geldig, indien de overdracht anders dan om niet geschiedt en de verkrijger te goeder trouw is. Lid 3. Nietremin kan de eigenaar van een roerende zaak, die het bezit daarvan door diefstal heeft verloren, deze gedurende drie jaren, te rekenen wan de dag wan de diefstal af, als zijn eigendom opeisen, tenzij:

a. de ztak cloof een naluurlijke persoon die miet in de uitoefening van een beroep of een bedrijf handelde, is verkregen van een vervreemder die van het werthandelen aan het publiek van soontgelijke zaken anders dan alss veilinghouder zijn bedriji makt in een daaroe bestende bedrijfsruinte, zijnde een gebouwde onroerende zaak of een gedeelte daarvan met de bij het een en ander behorende grond, en in de normale uitoefening van dat bedrijf handelde; of

b. het geld dan wel toonder- of orderpapier betreft.
\end{abstract}

Hoeveel onduidelijker was de voorganger van artikel 3:86 in het oude BW, artikel 2014 geredigeerd:

Lid 1. Met berrekking tot roerende goederen die noch in renten bestaun, noch in insehulden welke niet ain toonder betalbaar zijn, geldt het bezit als wolkomen tinel.

Lid 2. Niettemin kan degene die iets verloren heeft of aan wien iets ontvreend is, gedurende drie jaren, we rekenen wan den dag warop het verlies of de ontyremding heeft plaatsgehad, het werlorene of ontwreemde als zijn eigendom terug vorderen wan dengenen in wiens handen hij hetzelve vind, behoudens her verhalal wan den laatstgemelde op dengenen wan wien hij het bezit bekonen heeft, en onverminderd de bepaling van artikel 637 .

Met name het zeer onduidelijke eerste lid heeft aanleiding gegeven tot een omvangrijke literatuur, en lijnrecht tegenover elkaar staande standpunten: wat moet verstaan worden onder "bezit geldt als volkomen titel"? De uiteindelijke lezing van artikel 2014 komt 
grotendeels overeen met de in artikel 3:86 neergelegde legitimatieleer ${ }^{26}$. Er zijn enkele opvallende verschillen tussen artikel 2014 uit het oude BW en 3: 86 uit het thans geldende. Verdwenen is in de latste bepaling de bescherming die aan vinders werd geboden. Voor deze categorie verkrijgers is een aparte regeling in de tweede titel van boek $5 \mathrm{BW}$ neergelegd. Een ander opmerkelijk verschil ligt in de in artikel 3:86 toegevoegde bescherming van de consument-koper in het derde lid onder $\mathrm{a}$.

De tekst van artikel 2014 'geldt het bezit als volkomen titel' is in 1950 door de Hoge Raad uitgelegd op de wijze van de met name door Scholten voorgestane legitimatieleer ${ }^{27}$. Dit gebeurt in één enkele overweging, waarbij op eenvoudige wijze een eind wordt gemaakt aan jarenlange controversen. Een knoop wordt doorgehakt:

\begin{abstract}
'O. dat de bepaling van het eerste lid wan art. 2014 B.W. op de algemene regelen betreffende de eigendomsverkrijging van roerend goed door middel van levering slechts in zover een uitzondering makkt, dat de beschikkingsonbevoegdheid van dengeen, die overdrage, den verkrijger te goeder trotw niet kan worden tegengeworpen;"
\end{abstract}

Wat was de onderliggende casus? Damhoff had in 1944 van een Duitse vennootschap een partij meubelen gekocht, en vervolgens longa manu geleverd gekregen. Na de bevrijding werden de goederen in beslag genomen door de overheid, en vervolgens verkocht. De eigendomsoverdracht van de Duitse vennootschap aan Damhoff, zo stelde de staat in de daarop volgende procedure, berustte op een nietige koopovereenkomst. De nietigheid vloeide voort uit een besluit van 7 juni 1940. Alle overeenkomsten die waren aangegaan met, onder meer, een 'vijandelijken onderdaan' werden met deze sanctie bedreigd. Damhoff had met een Duitse vennootschap gehandeld, zodat Damhoff volgens de staat nimmer eigenaar geworden was, de Duitse vennootschap echter die kwaliteit had behouden. Deze goederen nu werden, als vijandelijk vermogen, van rechtswege eigendom van de staat ${ }^{28}$. Damhoff beriep zich erop dat hij wel de eigendom verkregen had. Hij was immers, zo stelde hij, te goeder trouw geweest, want had van dit, in Londen uirgevaardigde besluit geen weet gehad "en zijn enkele bezit gold mitsdien als 'volkomen titel'. Neen, aldus de Hoge Raad, die als boven geciteerd overwoog. Alleen de beschikkingsbevoegdheid van de vervreemder mag ontbreken, een geldige titel en de goede trouw van de verkrijger zijn vereist. Alleen bezitter te goeder trouw zijn, zoals Damhoff had gesteld, is onvoldoende. Met dezelfde korte uitspraak decreteerde de Hoge Raad tevens het causale stelsel van eigendomsoverdracht: een

26. Zie bijwoorbeeld: Pitlo-Brahn, Het Nederlands Burgerlijk Wetboek, deef 2, Het Zakenrecht (1987), p. $175 \mathrm{ev}$, Brahn, O.K., Levering, Beschikkingsonbewoegdheid (1992), p. $55 \mathrm{ew}$, Z Watlve W.J., Hoofdstukken wir de geschiedenis wan het Elaropese privaatrecht, deel 1, Inleiding en zakenrecht, (1993), hoofdstukken 2 en 3, passirn; Snijders, H.J., Rank-Berenschot, E.B., Goederenrecht (1994), p. 327 ev.

27. HR 5 mei $1950, N J 1951,1$ (Damhoff-Staat).

28. Besluit van 7 jumi 1940, Statsblad A 6, en besluat 20 oktober 1944, Sib. E 133, arrikel 3, in: Lem. P.D.M., Nieuw recht (1945). 
geldige titel is ten minste noodzakelijk voor overdracht van eigendom. De in Damhoffstaat naar voren komende tweespalt geeft de kern van de discussie zoals in de halve eeuw van 1910 tot 1950 in Nederland gevoerd, goed weer. Aan de ene zijde Scholten, met de nieuwe legitimatieleer; aan de andere zijde Meijers, met het ook door Damhoff voorgestane standpunt. Het is met name de zinsnede '...geldt het bezit als volkomen titel.' die in het onderzoek belicht zal worden. De andere delen van de bepaling komen af en toe zijdelings aan de orde.

Voor 1900 werd deze bepaling echter op vele andere wijzen uitgelegd. Zo werd door Meijers in navolging van Diephuis verdedigd dat bezit van een derde te goeder trouw, als eigendom zou gelden ${ }^{29}$. In dat geval zou Damhoff, mits deze zijn goede trouw bewezen zou hebben, eigenaar geworden zijn, en aanspraak hebben kunnen maken op een schadevergoeding. Meijers nam niettemin de uitleg van de Hoge Raad, Scholtens legitimatieleer, over in zijn ontwerp Nieuw Burgerlijk Wetboek ${ }^{30}$. Met name tot aan de eerste introductie van de legitimatieleer aan het begin van deze eeuw zijn er vele, soms sterk uiteenlopende, standpunten verdedigd. Deze veelheid aan mogelijke interpretaties bracht Modderman tegen het einde van de negentiende eeuw tot de constatering dat artikel 2014 een van de centrale problemen vormde van het verouderd Burgerlijk Wetboek ${ }^{31}$. Ten grondslag aan deze grote onduidelijkheid lagen dezelfde bewoordingen in de Franse Code civil. Vrijwel vruchteloos is gedurende meer dan een eeuw gepoogd aan verschillende interpretaties een aan het Franse recht ontleende rechtshistorische onderbouwing te verlenen. Voor de onderbouwing van aspecten van de legitimatieleer werden meerdere rechtsstelsels gebruikt.

\section{\$ 4. Publiek domein}

Een overheid die privaatrechtelijke bevoegdheden gebruikt teneinde éen van de haar toebedeelde taken uit te oefenen. Ziehier in het kort een sedert tijden controversiële kwestie, in Nederland, maar ook in Frankrijk en Duitsland. Het is precies dlatgene dat ook bij publiek domein het thema van discussie uitmaakt, een discussie die sinds de codificatie van 1838 wordt gevoerd, en die eveneens zeer actueel is. Het arrest Staat/ Windmill ${ }^{32}$ heeft de discussie over publiek domein flink aangewakkerd ${ }^{33}$.

29 .

30 .

32.

33.
Zie hoofdsruk 6 \& 3.C en met name hoofdstuk 7 \$ $3 . \mathrm{A}$.

Artikel 3.4.3 Ontwerp Meijers.

In: Weekblad van het Recht $4470(1880)$, als geciteerd bij Meijers, E.M. Wijzigingen en aanvullingen van het Burgerlijk Wetboek na 1838, Gedenkboek Burgertijk Wetboek 1838-1938 (1938), p. 59. Zie voor een overzicht van de discussie over artikel 2014: Salomons, A.F., De interpretatiegeschiedenis wen artikel 2014 BW (1838-1945) (1990), en: Brahn, O.K., De ontwikkeling wan wee zakenrechtelijke bepalingen tussen 1842 en 1988, in: 146 jaar Burgerlijk Wetboek (1989), p. 49-60.

HR 26 januari 1990, $A B$ 1990, m. 408; RvdW 1990, 36; NJ 1991, 393.

Ik wijs hier op de volgende publicaties: Konijnenbelt, W., Publiek domein en privaatrecht, in: $Q u i$ bene distinguit bene docet, privaatrechtelijke opstellen aan S. Gerbrandy (1991); Tak, Publiek domein, 
Een producent van meststoffen, Windmill Holland BV, loost afvalstoffen op de Nieuwe Waterweg. Windmill is in het bezit van de vereiste vergunningen krachtens (onder andere) de Wet Verontreiniging Oppervlaktewateren (WVO). Voor Windmills lozingen kan een heffing worden opgelegd op grond van een publiekrechtelijke regeling, de WVO. Niettemin eist de overheid als eigenaar van de Nieuwe Waterweg, op grond van een aan Windmill verstrekte privaatrechtelijke vergunning, een vergoeding. Laatstgenoemde vergunning wordt met ingang van 1 januari 1980 ingetrokken en de staat is slechts bereid een nieuwe 'privaatrechtelijke vergunning' af te geven indien Windmill voor de lozingen een veel hogere vergoeding zal betalen. Windmill weigert dit, de staat vordert voor de rechtbank een verbod tot lozing zolang geen nieuwe overeenkomst tot stand is gekomen. Zowel rechtbank als, in hoger beroep, hof wijzen deze vordering af. De staat gaat in cassatie en de Hoge Raad overweegt dan dat een overheid

\begin{abstract}
"ingevall haar bij een publiekrechtelijke regeling ter behartiging van zekere belangen bepaalde bevoegdheden zijn toegekend, die belangen ook mag behartigen door gebruilk te maken wan haar in beginsel krachtens het privaatrecht toekomende bevoegdheden "zoals aan het eigendomsrecht ontleende bevoegdheden, de bevoegdheid overeenkomsten naar burgerlijk recht te sluiter of de bevoegdheid een vordering op grond van een jegens haar gepleegde onrechtmatige daad bij de burgerlijke rechter in te stellen. Wanneer de betrokken publiekrechtelijke regeling daatrin niet voorziet, is voor de beantwoording van deze vraag beslissend of gebruik wan de privaatrechtelijke bevoegdheden die regeling op onaanvaardbare wijze doorkruist.'
\end{abstract}

De Hoge Raad gaat er dus vanuit dat gebruik van het privaatrecht door de overheid in beginsel mogelijk is, zelfs indien zij gebruik kan maken van een publiekrechtelijke regeling. In het bovenstaand arrest werd door de overheid een beroep op haar eigendomsrecht gedaan. Zij zou eigenaar zijn van de Nieuwe Waterweg, en zich kunnen beroepen op rechten, ontleend aan dit privaatrechtelijk eigendomsrecht. Voor een bepaalde categorie zaken die aan de overheid toebehoren, valt over toekenning van dit eigendomsrecht aan de overheidl wel één en ander te zeggen. Die categorie zaken betreft het zogenaamde publiek domein, zaken met een openbare, een publieke bestemming, zoals (water)wegen en markten, maar ook kunstvoorwerpen of defensiewerken ${ }^{34}$. Het

overheidscontract en rechterlijke wetshandhaving, Nederlonds Tijdschrift voor Bessus rstecht 90/9, p. 265; Van Maamen, G.E. Publiek domein en twee-wegenleer, Recht en kritiek 16 (1990) 3. p. 198: dezelfde, Van de vogelen des hemels en de strarden der zee. WPNR 6074 (1992), p. 970-977, die een meer publiekrechtelijk eigendomsconcept construeert op publiek domein. Voorts Teunissen, J.M.H.F. en A.Q.C. Tak, Recht ist was der Umwell nutat, Nederlands Juristenblad 1994, 18, p. 605-617, en een reactie daarop van Van der Veen. Nederlands Jaristenblad 1994, 29, p. 1008-1010; Tak. A.Q.C., en J.M.H.F. Teunissen, 'Een ieder neemt voldoende zorg voor het milieu in acht'. Wie zorgt er voor de rechtsstaat? Een voortgezet debat. Recht en Kriviek 20 (1994) 4, p. 340-354. Zie teverns het fraaie proefschrift van Teunissen, J.M.H.F., Het burgerlijk kleed van de Stact (1996), met name hoofdstuk 3, die een fundamenteel bezwar heeft tegen gebruik van priwatrecht door de overheid." zie p. $317 \mathrm{ev}$.

34. Zie voor een overzicht van de indeling van de typen wan eigendom en voorbeelden dabaij Van Maanen, G.E., Publiek domein en twee-wegenleer, Recht en kritiek 16 (1990) 3, p. 202, en Van Maanen, 
is het privaatrechtelijk eigendomsbegrip dat zich minder goed verdraagt met die openbare bestemming. Wat houdt dit privaatrechtelijk eigendomsbegrip in?

De karakteristieken van privaatrechtelijke eigendom zijn bekend: vit artikel 5 lid 1 van het nieuwe Burgerlijk Wetboek is duidelijk dat sprake is van het meest omvattende recht ${ }^{35}$. Tevens wordt in het tweede lid een gebruiksrecht omschreven, terwijl een ieder van dat gebruik uitgesloten kan worden ${ }^{36}$. Voor die zaken die een openbare bestemming ${ }^{37}$ hebben en aan de overheid behoren (publiek domein), spreekt deze toekenning van privaatrechtelijke eigendom wat minder voor zich. De algemene kenmerken die aan privaatrechtelijke eigendom worden gegeven, en dan met name de mogelijkheid van uitsluiting van gebruik, zijn in geval van een openbare bestemming nauwelijks meer van toepassing. De meningsverschillen werden, en worden nog immer, veroorzaakt door de lastige samen te voegen begrippen "private eigendom" en 'openbare bestemming.' Kortheidshalve kunnen in de discussie twee standpunten onderscheiden worden; een standpunt waarbij publiek domein vanuit een publiekrechtelijk uitgangspunt wordt beschouwd en een standpunt waarbij publiek domein uiteindelijk op een privaatrechtelijke wijze wordt bezien. In het eerstgenoemde standpunt zou er sprake zijn van twee soorten eigendom, een privaatrechtelijk eigendom dat ook aan de overheid kan toekomen wanneer geen sprake is van publiek domein ${ }^{38}$ en een publiekrechtelijke eigendom in ieder geval bij publiek domein. In het laatstgenoemde, privaatrechtelijk standpunt, zoals bijvoorbeeld door de Hoge Raad in het besproken Windmill-arrest werd

G.E., (1992) p. 972. Brahn merke tevecht op dat het hebben van een "openbare bestemming" nog nict wil zeggen "openstasn tot algemeen gebruik. Dit kan zo zijn, bjjoorbeeld bij een operbare weg, doch houft zeker nist by boorbeeld bij defensilewerken. Pillo-Brahn, 1987, p. 45.

35. Artikel 5:1 lid 1. Eigendom is het mest omvatiende rech dat een persoon op een zaak kan hebben. 2. Het staat lle eigenatr mer uitsluitug van een ieder vrij van de zak gebruik te maken, mits dit gebrukt met strijd met rechten van anderen en de op wetrel hike voorschriften en regets van ongeschreven: rocht gegronde beperkingen databij in acth worden genomen.

36. Zie onder meer Van Den Bergh, G.C.J.J., Etgendom. Grepen wit de geschiedenis wan een anwtreden begrip (2e dnuk 1988). 13. 34, die spreekt over totaliteit (een soort aigendom), abstractheid (begrip is niet concreet te omschrijen) en absolumheid (bimnen grenzen wan de wat onbeparkte beschikking

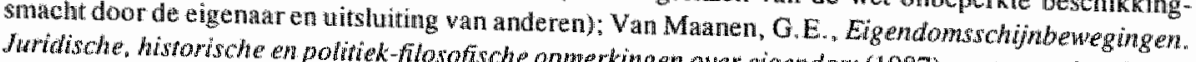
3 s. B.

37. Verschillende termen vor d ive openbare bestemming worder gebruikt: niet alleen openbare bestenwitgigdnikt.

38. Anders Teunissen, J.H.M.F., (1996), p. 323: onderscheid tussen publiekrecht en privaatrecht zou alle zin varliezen als a anw and zow worden dat de overheid "bij haar optreden in burgerrechtelijke hoedanigalgemene belangen wordt angewend." 
verwoord, zou slechts van én soort eigendom sprake zijn: de privaatrechtelijke zoals in het $\mathrm{BW}$ is verwoord ${ }^{34}$.

Aldus weergegeven lijkt de kwestie overzichtelijk, maar met de wetteksten uit het oude BW ernaast treden complicaties op. In het Burgerlijk Wetboek van 1838 is sprake van drie soorten bepalingen die voor de discussie van belang zijn. In de eerste plats is daar de bepaling over de privaatrechtelijke eigendom.

Art.625. Eigendom is het regt om wan eene zaak het wrij genot te hebben en daarover op de volstrektste wijze te beschikken, mits men er geen gebruik wan make strijdende tegen de werten of de openbare verordeningen, dargesteld door zoodanige nagt, die daartoe, volgens de Grond wer, de bevoegdheid heef, en mits men an de regten van anderen geen hinder toebrenge; alles behoudens onteigening ten algemeenen nutte tegen behoorlijke schadeloosstelling \# ingevolge de Grondwet.

Dan zijn er in de tweede plaats bepalingen die handelen over "zaken", te weten enkele algemene bepalingen en bepalingen die concretiseren aan wie die zaken toebehoren.

Art.555. De wet verstaat door zaken alle goederen elu regten welke het voorwerp van eigendom kumen zijn.

Art.575. Er zijn zaken die aan miemand toebelooren; de overige zijn het eigendorn of wan den staat, of van gemeenschappen, of van bajzondere personen.

An. 576. Gronderwen en andere onroerende zaken die onbetherd zijn en genen eigenar hebben, gelijk mede de zaken van dengenen die zonder eigenaar overleden is, behoorefn aan den staat.

Art.577. Insgelijks behooren aan den staat de wegen en straten welke te zijnen laste zijn, de stranden der zee, de bevaarbare en vlobbre stroomen en rivieren met humen oevers, de groote en kleine eilanden en de platen welke in die wateren opkomen. geljk ook de havens en rewlen; onverminderd de door titel of bezit verkregen regten wan bijzondere personen of gemeenswap. pen.

In de derde plaats is er een categorie bepalingen over 'zaken buiten de handel."

Art.593. Zaken welke niet in den handel zijn, kumen geen voonwerp van bezit opleveren.

Art 1210 . Voor hypothee zijn alleen vatbar: $1^{\circ}$. Onroerende goederen welke in den handel zijn, met derzelver toebehoren, voor zover dat lattste als onroerend goed beschouwd wordt. $(\ldots+)$

Art. 1368 . Zaken welke in den handel zijn kunnen alleenlijk het onderwerp wan owsteenkomsten uitmaken.

39. Zie ook Milo, M. Publiek domein in de negentiende eeuw. Een discusste in gescheiden circuits, Rech en Kritiek 21 (1995) 2, met mame p. 168-172. 
Art. 1480. In geval de zekere en bepaalde zaak, welke het onderwerp der overeenkomst uitmaakte. vergaat, buiten den handel der menschen geraakt, $(\ldots)$ vervalt de verbindtenis $(\ldots)$.

Art.1481. Indien de verschuldigde zak zonder toedoen wan den schuldenaar (..) buiten den handel der menschen geraakt (..) is, is de schuldenaar gehouden, ingeval hij eenige regten of vorderingen tot schadevergoeding betrekkelijk deze zaak heeft, die aan zijnen schuldeischer af te stakn.

Art.1779. Al hetgeen tot den handel der menschen behoont, en niet door het gebruik verloren

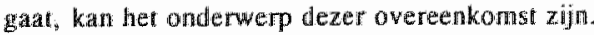

Ant.1990. Men kan door verjaring den eigendom niet verkrijgen van zaken die buiten den handel zijn.

In artikel 577 zijn enkele zaken met een openbare bestemming weergegeven die aan de staat behoren: publiek domein. De opsomming in dit artikel van zaken met een openbare bestemming is niet limitatief. Wat moeten we nu aan met de bepalingen over zaken buiten de handel, welke zaken vallen er onder? In Pitlo-Brahn wordt gesteld dat de vraag, of ons recht twee soorten van eigendom erkent, een publiekrechtelijke en een privaatrechtelijke, gewoonlijk tot uiting komt in de vraag, of ons recht zaken buiten de handel kent ${ }^{40}$. Met deze stelling wordt vooralsnog de verhouding tussen publiek domein en de bepalingen over zaken buiten de handel voldoende geschetst. Pitlo/Brahn geefl slechts één van de gangbare meningen, een mening waarbij beide begrippen, 'publiekrechtelijke eigendom' en 'zaken buiten de handel, ' als synoniem worden voorgesteld. De genoemde categorieën bepalingen spelen bij elk ingenomen standpunt een rol. De theorie van de Franse jurist Proudhon over "domaine public" werd bij ons te lande rond 1850 geïntroduceerd, en zette de toon voor de discussie.

\section{$\S 5$. De relativiteit van de onrechtmatige daad}

\section{A. INTRODUCTIE}

In het Burgerlijk Wetboek wordt in artikel 6:163 het vereiste van de relativiteit van de onrechtmatige daad weergegeven. Niet in alle gevallen van normschending zal de pleger van een onrechtmatige daad gehouden zijn tot schadevergoeding, want, stelt dit artikel:

Geen verplichting tot schadevergoeding bestabt, wanneer de geschonden norm niet strekt tot bescherming tegen de schade zoals de benadeelde die theeft geleden.

Er dient dus een zeker verband te bestaan tussen de onrechtmatige daad en de schade door de benadeelde geleden. Het vereiste van de relativiteit kent, behalve de genoemde "schade" nog een andere component: ook dient sprake te zijn van een onrechtmatige daad jegens een ander. Dit 'persoonlijke' deel van de relativiteitsleer treffen we aan in 
het eerste lid van artikel 6:162. Met de opname van dit relativiteitsbeginsel in de nieuwe wetgeving is de rech spraak van de Hoge Raad gevolgd. Sinds de late jaren twintig heeft de Hoge Raad steeds de eis gesteld dat een onrechtmatige daad óók onrechtmatig dient te zijn jegens de benadeelde, en dat het geschade belang ook door de geschonden norm moet worden beschermd ${ }^{41}$. Aldus wordt een beperking aangebracht op de aansprakelijkheid voor de toegebrachte schade ${ }^{42}$. Van Gelein Vitringa heeft dit vereiste in $\mathrm{Ne}-$ derland geîntroduceerd: niet alleen als raadsheer in de Hoge Raad in het aanstonds te bespreken arrest uit 1928 Marchant et 'd Ansembourg, maar reeds negen jaren eerder, terloops, in een artikel in het Rechtsgeleerd Magazijn, waarbij hij de aandacht vestigde op een bepaling in het Duitse BGB ${ }^{43}$.

De eis van de relativiteit heeft met name concrete betekenis gekregen door de recente toepassingen bij aansprakelijkheid voor milieuverontreiniging. In het arrest StaatAmersfoort ${ }^{44}$, dat handelde over het kostenverhaal van bodemsanering door de overheid op de vervuiler, stonden voor de overheid twee mogelijkheden open om de ge-maakte kosten te verhalen. In de eerste plaats was daar voor de overheid de weg van de onrechtmatige daad uit het Burgerlijk Wetboek. Wil deze vordering toegewezen kunnen worden, dan zal ook aan het vereiste van de relariviteit voldaan moeten zijn. Met andere woorden: de verontreiniging moet dan onrechtmatig geweest zijn jegens de overheid. In de tweede plaats bestond een op bodemverontreiniging toegesneden regeling. In die regeling (art. 21 Interimwet Bodemsanering, later art. 75 Wet Bodembescherming), zo was het standpunt van de overheid, zou dit relativiteitsvereiste voor onrechtmatige verontreiniging niet worden gesteld. Deze opvatting werd door de Hoge Raad weersproken, waarmee aangesloten werd bij de geldende vereisten voor onrechtmatige daad, waronder de relativiteit:

\footnotetext{
"Nu de wetsgeschiedenis (...) geen ondubbelzinnige aanwijzingen geeft voor de door de Staat verdedigde opvatting dat art. 21 erioe strekt mede ter zake van dergelijke bodenverontreiniging aansprakelijkheid te vestigen zonder dat aan alle, destijds voor aansprakelijkheid op grond wan anikel $140 \mathrm{lBW}$ geldende vereisten is woldaan en nu ook in de tekst van ant. 21 daarvoor geen steun is te vinden, moet die opwatring van de hand worden gewezen, "4.5
}

41. HR 25 mei $1928, N J 1928,1688$ m.n. E.M.M.

42. Zie Asser-Flartkanp III (1994), nr. 95.

43. Van Gelein Vitringa, J., Openbatrheid wan den weg en burgendijk recht, Rechtsgeleerd Magazijn 1919. p. 29. Zhe hoofdstak 6 \&.A voor $\$ 823$. Zie voorts Lank horst, G.H., De relativiteit wan de onrechmarige daad (1992), p. 11

44. HR 9 februari 1990, NJ 1991, 462.

45. HR 9 februari 1990, NJ 1991, 462; onder r.0. 3.1.4. Om aan dit vereiste te woldoen dient de qverheid "ten tijde van het weroorzaken wan de verontreiniging zich dat sane ringsbelang reeds aantrok, dan wel voor de veroorzaker voldoende duidelijk was of behoorde te zijn dat zij zich dat belang zou gaan aantrekken. (r.o. 3.2.). Zie hierover de noot van Brunner onder het arrest. Een nadere invulling vant dit criterium heeft is gegeven bij arrest van de Hoge Raad van 24 april 1992. NJ 1993, 643 (Staat/Van Wijngaarden). De Staat zou zich het saneringsbelang wan bed riffsterreinen zijn gatan aantrekken vanaf 1 januari 1975; zie ook de in A.sser-Harkamp III (1994), onder nr. 98 genotnde literafuur. 


\title{
B. DE ACCEPTATIE VAN DE RELATIVITEIT IN DE RECHTSPRAAK
}

Het arrest Marchant et d' Ansembourg uit 1928 wordt als begin gezien van het relativiteitsvereiste in het Nederlandse recht ${ }^{46}$. In dit arrest werd dit vereiste nog niet echt expliciet onder woorden gebracht. De Hoge Raad bereikte een vergelijkbare uitkomst op een dogmatisch jets afwijkende wijze. Blijkbaar kan ook op andere wijzen een oplossing worden geboden voor het door dit relativiteitsvereiste aangesproken probleem.

Enkele percelen land van de eisende partij, de graaf de Marchant et d"Ansembourg, waren door de staat aangewezen ter onteigening, in verband met een mogelijke exploitatie van steenkoolmijnen. Aan die aanwijzing mankeerde echter een formeel vereiste. Een aantal jaren na die aanwijzing bleken de exploitatieplannen niet door te gaan. Door de aanwijzing was d"Ansembourgs land in waarde gedaald en door de graaf nog slechts tegen lage prijzen te verhuren. D'Ansembourg stelde daardoor een schade geleden te hebben van $f 450.000,-$, en spreekt de staat aan met een vordering uit onrechtmatige daad. De onrechtmatigheid was volgens d'Ansembourg gelegen in de boven reeds kort aangeduide formele onregelmatigheid: de ter inzagelegging van de onteigeningsplannen had in strijd met artikel 12 Onteigeningswet niet plaatsgevonden. Over dit standpunt zegt de Hoge Raad:

\begin{abstract}
'dat eischers echter ten onrechte in aanwijzing ter onteigening, zonder voorafgaande naleving wan art. 12 der Onteigeningswet een onrechtmatige daad in den zin van art. $1401 \mathrm{BW}$ zien: dat toch de strekking van ant. 12 der Onteigeningswet niet is om den eigenaar te beschemen tegen nadeelen, die mochten voortvloeien uit de aanwijzing wan zijn goed ter onteigening, doch de bij dat artikel voorgeschreven ter inzagelegging slechts is een van de waarborgen, waamede de wet de uitoefening wan het recht tot onteigenen heeft omkleed, teneinde de eigenaar te beschermen tegen ongerechtvaardigde ontzetting uit zijn eigendom, wat medebrengt dat de werking wan dit voorschrift zich beperkt tot die bescherming, zoodat niet-naleving daarvan geen ander rechtsgevolg, kan hebben dan dar mu aan den eigenaar zijn goed niet kan worden ontnomen:"
\end{abstract}

Wordt hier nu het vereiste van de relativiteit gesteld? Daarover kunnen de meningen verschillen ${ }^{47}$. De bewoordingen die de Hoge Raad gebruikt lijken sterk op de bewoordingen die in artikel 6:163 $\mathrm{BW}$ worden gebruikt. Met evenveel recht zou echter verdedigd kunnen worden dat de uitspraak een enge interpretatie van artikel 12 Onteigeningswet geeft. Deze beperkte uitleg heeft dan hetzelfde uiteindelijke gevolg als een toepassing van een relativiteitsvereiste gehad zou hebben: geen verplichting tot schadevergoeding ontstaat. Hoe dit alles ook zij, in een reeks latere arresten zal de

46. HR 25 mel 1928, NJ 1928, 1688; zie bjwoorbeald Lankhorst, G.H., (1992), p. 20; Want Maanen, Q.E., Onrechmatige doad (1986), p. 196; Asser. Hartkamp WI (1994), nr. 95.

47. Zle Asser-Harkamp HI (1994), nr. 95; meer terughoudend: Hartlief, T. en G. E. wan Manen, Hoe:

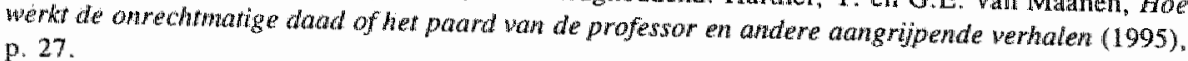


Hoge Raad steeds kiezen voor de toepassing van het relativiteitsvereiste als afzonderlijk criterium ${ }^{48}$.

In het arrest volgt de Hoge Raad niet de conclusie van de AG Besier, die in de traditionele vereisten (onrechtmatigheid, schuld, schade en causaal verband) de oplossing voor de gestelde casus zag ${ }^{49}$. De Hoge Raad blijft in zijn uitspraken deze rellativiteitsleer voorstaan, ondanks gezaghebbende tegenstanders in de literatuur van de jaren dertig. In die literatuur kunnen verschillende stromingen worden onderscheiden. Allereerst zijn daar de voorstanders van de nieuwe theorie, waarvan met name Van Gelein Vitringa, Telders, en Langemeijer genoemd moeten worden ${ }^{50}$. Daarnaast is er een omvangrijke groep tegenstanders van het nieuwe vereiste. Zij kunnen in drie groepen ingedeeld worden. In de eerste plaats diegenen die om principiële redenen de absolute onrechtmatigheid voorstaan: Meijers en Scholten. Een tweede stroming ziet een mogelijk alternatief in de causaliteit: Wolfsbergen, Wertheim, Fruin, van Nispen tot Sevenaer, en de Haan. Een derde groep, Vigelius, Kist en Smits, meent dat met gebruikmaking van het schuldvereiste hetzelfde resultaat bereikt zal kunnen worden ${ }^{51}$. Zoals gezegd, zijn er meer constructies dan de relativiteitsleer om de onrechtmatigheid te relativeren zodat geen aansprakelijkheid ontstaat ${ }^{52}$.

\section{§6. Uitleiding}

Vier onderwerpen zijn aan de orde geweest. De achtergrond van de relativiteit van de onrechtmatige daad is een andere dan die van de overige behandelde onderwerpen. In de eerste plaats is de herkomst van het leerstuk niet terug te voeren naar de Code civil, maar naar de Duitse wetgeving en in de tweede plaats is de aanvang van dit onderwerp in de Nederlandse privaatrechtswetenschap veel later dan die van de andere behandelde onderwerpen. Dat maakt dat dit onderwerp eerst vanaf hoofdstuk 6 zal worden behandeld. In het volgende hoofdstuk vangen wij aan met de vaststelling van de betekenissen van de onderwerpen en de wettelijke bepalingen in 1838 als uitgangspunt voor de komende discussie. Bij die vaststelling zall een bestudering van het Romeinse, maar vooral het Franse recht noodzakelijk blijken. Nu de vier onderwerpen en tevens de wetsartikelen waarop zij zijn gegrond in kaart gebracht zijn, kan wordlen vervolgd met

48. Voor een overzicht van rechispraak, Onrechematige daad I (Van Maanen), artikel 6: 163, aantekewing 8 ev. (juni 1996).

49. Zie onder hoofdstuk 6 \& 5.D.2.

50. Zie Van Mamnen, G.E., (1986), p. 197 en Lankhorst, G.H., (1992), p. 23

51. Zie ook: Van Maanen, G.E., (1986), p. 196-199. Ook iets afwijkende kwallificaties zijn gebruikt. Zo spreekt Lankhorst over de relativiteit van de schuld, en de relativiteit van de causaliteit. Lankhorgh, G.H., (1992), p. 49-74.

52. Zie Lankhorst, G.H., (1992), p. 49; Hartief, T., en Van Maranen, G.E., (1995), p. 21, die spreken over een madere foetsing: indien een norm is geschonden moet nog geconcludeerd kunnen worden dat het gedrag van degene die de norm owertrad laakbaar geweest is. 
het eigenlijke onderzoek. Daarvoor keren wij terug in de tijd en hervinden ons in 1838 ten tijde van de invoering van het Burgerlijk Wetboek. 


\section{Hoofdstuk 3}

\section{De tekst van het BW als uitgangspunt: 1838}

In dit hoofdstuk moet de eerste betekenis (in 1838) van de behandelde onderwerpen worden vastgesteld. Om dat met vrucht te kunnen doen, ga ik in op de behandeling door de wetgever van de verschillende onderwerpen, maar tevens op het Franse en het Romeinse recht. Achtereenvolgens behandel ik de totstandkoming van het Burgerlijk Wetboek 1838 ( $\$ 1$ ) en de gevolgen van deze codificatie voor het gebruik van Frans en Romeins recht in de Nederlandse rechtswetenschap ( $\$ 2$ en $\$ 3$ ). \& 4 geeft een eerste interpretatic van de onderwerpen.

\section{$\S 1$. De totstandkoming van het Burgerlijk Wetboek 1838}

De totstandkoming van het Burgerlijk Wetboek 1838 heeft nogal wat voeten in de aarde gehad. Nadat in 1813 de Nederlandse soevereiniteit was hersteld, werd besloten tot een nieuwe Nederlandse privaatrechtelijke wetgeving. Onder meer in de Grondwet 1814 werd dit met zoveel woorden vastgelegd ${ }^{53}$. De Code civil, van kracht sedert 1811 , zou dus slechts zo lang behouden worden als voor de vervaardiging van die nieuwe privaatrechtelijke wetgeving noodzakelijk was. De gedachte was een Nederlandse wetgeving te vervaardigen, gebaseerd op het oude Nederlandse recht ${ }^{54}$, en wlot volgde in 1816 het eerste ontwerp van Kemper ${ }^{55}$. Nadat dit ontwerp geen genade bleek te kunnen vinden in de ogen van Belgische juristen aan wie dit ter beoordeling werd voorgelegd ${ }^{56}$, zette Kemper zich aan een volgend ontwerp. Een van de voorstellen van de Belgische juristen was echter geweest dat juist de Code civil als basis voor een nieuw

53. Voorduin, J.C., deel 1 (1837), p. 10, zie voor een beschrijving ook: Scholten, P., Algerneen Deel (2e druk 1934), p. 231; Florijn, E.O.H.P., Ontstaan en onrwikkeling wan het nieuwe Butrgerlijk wetbrek (1994), p. 9; zie ook Pillo, A., (1990), p. 48.

54. Voorduin, J.C., deel $1(1837)$, p. 11 .

55. Voorduin, J.C., deel 1 (1837) p. 40.

56. Voorduin, J.C., deel 1 (1837), p. 72 ev.; zie daarover ook Van Caenegem, R.C., Geschiedkundige inleiding tot het privatrecht (1981), p. 132. 
wetboek genomen zou behoren te worden ${ }^{57}$. Als uitgangspunt voor het Ontwerp 1820 was het Ontwerp 1816 genomen. Kempers inspanningen bleken vruchteloos: ook het Ontwerp 1820 zou geen wet worden. Het werd door het parlement niet aangenomen ${ }^{\text {s8 }}$. 'Noodelooze omslag, herhalingen en langwijligheid' lagen aan die afwijzing onder meer ten grondslag ${ }^{59}$. Ten slotte zou het Burgerlijk Wetboek totstandkomen in de jaren 1822-1826, waarbij vooral de Franse Code civil werd gevolgd ${ }^{6}$. De bijdragen van dezelfde Belgische juristen-kamerleden die de voorgaande ontwerpen hadden werworpen waren het meest invloedrijk. De invoering van het in 1829 afgeronde wetboek zou plaatsvinden in 1831, doch de afscheiding van België maakte uitstel noodzakelijk ${ }^{61}$. Dit betekende nu echter geen afstel, want na het aanbrengen van enkele slechts geringe wijzigingen werd in 1838 ons Nederlandse Burgerlijk Wetboek ingęverd.

Wat was de betekenis van de invoering van het Burgerlijk Wetboek voor het gebruik van het Franse en het Romeinse recht? Moet het jaar 1838 voor de Nederlandse privaatrechtswetenschap als een scheiding worden gezien zoals in hoofdstuk $1 \S 1$ aan de orde is gesteld? De vraag kan slechts ten dele bevestigend worden beantwoord. Voor 1838 waren immers reeds andere, nationaal geldende, privaatrechtelijke codificaties van kracht geweest, te weten het Wetboek Napoléon, ingerigt voor het Koningrijk Holland, en de Code civil. Aan de gelding van het Romeinse recht was reeds in 1809 bij wet een einde gemaakt. Had het Romeinse recht in het geheel geen betekenis meer in de beoefening van het Nederlandse privaatrecht sinds 1809 ? Daarvan was geen sprake ( 82 ). De Franse Code civil had in 1838 nog een grote betekenis in de Nederlandse privaatrechtswetenschap (\$3). Zowel het Franse als het Romeinse recht blijkt noodzakelijk voor de eerste interpretatie van de onderwerpen $(\$ 4)$.

57. Voonduin, J.C., deel $1(1837), \mathrm{p} .82$.

58. Voordum, J.C. deel $1(1837)$, p. 250-251 en 266-267.

59. Zie Florijn, E. O.H.P., (1994), P. 18.

60. Voorduiti, J.C., ded $1(1837), 9.277-278$

61. Zie Lokin, J.H.A., en W.J. Zwalve, (1992), p. 287; zie ook Lokin, J.,H.A., De invoering wan het BW in het Hertogdon Limburg op 1 januari 1842, in: 146 jar Burgerlijk Wetbok . Het jublewn van her 150-jakig Weboek en zijn invoering in her Hertogdom Limburg op I janwari 1842, p. 1528; 0ok verschethen in Lokin, J.H.A. Tehst en Uitleg (1994), p. 99-110. Over de visie van de Noond-NederIandse parlementarièrs vlak na de afscheiding van Belgie, op de bijdragen van de voormalige Belgisehe leden van het partement verdient anabeveling het veel angehaalde citaat van Asser in diens Het Nederlandsch burgerlijh Wetboek vergeleken met her Wetboek Napoleon (2e druk, 1838), inleuding, p. 3; 20 ook sen vergelijkbare passage uit de behandeling in het parlement als weergegeven bij Voorduin, J.C., (1837), p. $366 \mathrm{ew}$, ook weergegewen bij Lokin, M. H.A., en W.J. Zwalwe, (1992), p. 288. 


\section{§. Het BW van 1838 en het Romeinse recht}

\section{A. HET GEMENE RECHT EN DE NATIONALE CODIFICATIE}

Sinds de Pandekten van het Corpus Juris Civilis in de twaalfde eeuw opnieuw waren ontsloten, kon het Romeinse recht het recht worden waarmee juristen in geheel Europa werkten ${ }^{62}$. Over geheel Europa ontstond een juristenstand, geschoold in eigentijds ${ }^{63}$ Romeins recht, die bovendien in staat was tot een onderlinge discussie door middel van een begrippenapparaat in een gemeenschappelijke taal ${ }^{64}$. Met name aan de universiteiten was de positie van het Romeinse recht zeer overheersend. In de juridische praktijk was het van plaats tot plaats verschillende gewoonterecht echter evenzeer van belang, en de grote verscheidenheid daarvan was de in de praktijk werkzame jurist een doom in het oog. Romeins recht bleef wel een subsidiaire werking houden: als gewoonterecht geen oplossing geeft, dan bevindt zich het Romeins recht als een vangnet daaronder ${ }^{65}$. In de $17 \mathrm{e}$ en $18 \mathrm{e}$ eeuw verschijnt als Europees verschijnsel, naast het Romeinse recht, het natuurrecht ${ }^{66}$. Onder invloed van de in die tijd heersende wetenschapsopvatting werd in de rechtswetenschap uitgegaan van de gedachte dat de rede, net zoals in de natuurwetenschappen, van tijd en plaats onafhankelijke, algemeen geldende rechtsregels zou kumen vinden. Nimmer heeft het natuurrecht echter zo een positie kunnen verwerven als het Romeinse recht ${ }^{67}$. Toch had het natuurrecht een beslissende betekenis in de jaren die zouden volgen. Wat was er aan de hand?

In de $18 \mathrm{e}$ eeuwse verlichting stond deze natuurrechtsgedachte aan de basis van de nationale codificaties van de vroege negentiende eeuw, de Code Civil, en ons Burgerlijk Wetboek. Een van de vruchten van het natuurrecht is de gedachte dat elk volk gebaat is bij een begrijpelijke, en dus in de eigen taal geschreven wetgeving ${ }^{68}$. Deze gedachte

62. Men zie voor een uitgebreide beschrijuing van de ontwikkeling van het Romeinse rectut in Europa: Van den Bergh, G.C.J.J., (1994), p. 2I ev."Koschaker, P. Europa und das Romirche recht (1966), en chan met name p. 55 ev; Lokin, J.H.A., (1994), p. 40 ev; Wieacker, F., (1967), p. 97 ev.; Lokin, J.H.A., en W.J. Zwalwe, (1992), p. 80 ev.

63. Het gemene recht moet dus nief gelijkgesteld worden an Romeins recht, maar is het voor de eigen tijd door interpretatie geschikt gentakte recht. Men zie hierover Van Den Bergh, G.C.J.J., Etgendom. Grepen wit de geschiedenis van een onstreden begrip (1988), $\mathrm{p} .36$.

64. Volgens Koschaker was dit tevens mogelijk ond at de ideeënwereld destijds biet een nationale, doch een universele was. Kosehaker, P. (1966), p. 84 en p. 350-351.

65. Zie voor een beschrijving Lokin, J.H.A. en W.I. Zwalve, (1992), met name p. $255 \mathrm{ev}$. De natte warin op het Romeinse recht een beroep gedaan werd verschilde in Nederland nogal van provinche tot provincie: waar in Friesland het Romeinse recht de boventoon woerde, werd in Drenthe veel minder vlot een beroep op het Roneinse recht gedarin. Zie Spruir, J.E., (1993), p. ix.

66. Van den Bergh, G.C.J.J., (1994), p. 72; Koschaker, P., (1966) p. 252. Over de vraag naar de verhowding massen Romeins recht en natuurrecht aan de universiteit, zie: Jansen, C.M.H., Natuastecht of Romeins recht (1987).

67. Van den Bergh, G.C.J.J., (1994), P. 74.

68. Van den Bergh, G.C.J.J., (1994), p. 86-91; Lokin, J.H.A., en W.J. Zwalve, (1992), p. 34 ev. 
vond in de grote verscheidenheid aan gewoonterechten een vruchtbare bodem. De in de eigen taal geschreven codificaties betekenden het einde van een Europese rechtswetenschap, het Europese gemene recht. De codificaties worden door de nationale overheden uitgevaardigd en hebben exclusieve kracht, hetgeen zoveel wil zeggen dat een beroep op ander recht, buiten de codificaties niet vrijstaat. Het recht wordt in deze codificaties gevonden en zo dan wordt de jurist gebonden aan een nationale wetgeving. Het gemene recht, grotendeels Romeins recht, deels natuurrecht, zou daarmee een einde gevonden hebben. Voor Nederland kreeg deze afschaffing voor de eerste maal zijn beslag in 1809, en dit jaartal markeert dan ook het beginpunt van een rechtsstelsel dat formeel begrensd werd door de eigen nationale codificatie. Het recht wordt dan in het wetboek gevonden, een beroep op het subsidiaire Romeinse recht staat niet meer vrij. Niettemin betekent het jaar 1809 voor de wetenschap van het privaatrecht nu ook niet zo'n grote overgang. Met recht kan gezegd worden dat als er al een caesuur in de beoefening van de Nederlandse wetenschap van het privaatrecht is te onderkennen, dat deze dichter bij 1838 te vinden zal zijn dan bij 1809, en deze stelling wordt in het navolgende onderbouwd. De rol van het Romeinse recht was na 1838 nog niet uitgespeeld. Voor de uitleg van verschillende bepalingen is kennisname van dit recht vooralsnog onontbeerlijk.

\section{B. DE BETEKENIS VAN HET ROMEINSE RECHT VOOR HET BURGERLUKK RECHT}

In Nederland was het Burgerlijk Wetboek van 1838 niet de eerste nationale privaatrechtelijke codificatie. Immers, in de periode voor 1838 was de Code Civil van kracht. Dit wetboek gold vanaf 1811 , en daarvoor was er nog het Wetboek Napoleon ingerigt voor het Koningrijk Holland dat in 1809 voor het eerst de band verbrak met de voorgaande tijd, waarin een beroep op het Romeinse recht gedaan kon worden omdat het gelding had. Niet minder dan drie keer is het Romeinse recht bij wet expliciet afgeschaft: de eerste maal in 1809 , de tweede maal in 1811 , en door een wet uit 1829 , bij de invoering van het burgerlijk wetboek in $1838^{69}$. Deze afschaffing was belangrijk voor de toepassing van rechtsregels in de praktijk; een beroep op Romeins recht als geldend recht was immers niet meer mogelijk. Dat was ook bij de grootste voorstanders van het Romeinse recht wel duidelijk. Maar dezelfde afschaffing bracht niet direct een ommekeer teweeg in de rechtswetenschap. Daarvoor was de positie van het Romeinse recht in de Nederlandse rechtswetenschap veel te belangrijk. Zo nam de studie van Romeins recht aan de Nederlandse universiteiten in de twintiger jaren van de negentiende eeuw nog meer tijd in beslag dan het onderwijs in het geldende recht, dat sinds 1811 was neergelegd in de Code civil ${ }^{70}$. En ook de wetenschap, zo wordt duidelijk, hield zich in die tijd, waarin de Code civil in Nederland gold, meer bezig met het Romeinse rechit, dan met het

Zle Kooiker. H., De overlevingskanalen van thet romeinse recht na de codificatie, in: Jansen, C.I.H., E, Poortings. T.J. Veen (red), Twaalf bijalragen tot de sfudie wan de rechtsgeschiedenis wan de megentiende eeww (1993), p. $118 \mathrm{ev;}$, Kooiker, $\mathrm{H}$, Lex scripra abrogata. De derde renaissance van het Romeinse recht (1996).

70. Kop. P.C., Legisme en privaatrechtswetenschap (2e druk 1992) p. 23. 
eigentijdse recht. Daarbij zal de verwachting dat Nederland binnen afzienbare tijd over een eigen, Nederlandse wetgeving beschikken zou, zeker een belangrijke rol meegespeeld hebben ${ }^{71}$. Zeker, het Romeinse recht was afgeschaft en een moderne wetgeving was van kracht geworden. Dit realiseerde zich ook de vertaler en bewerker van een werk van de Duitse hoogleraar Hufeland ${ }^{72}$, Warmolts. Het gebruik van het Romeinse recht moest dlaarom aangepast worden; overbodig was het zeker niet geworden.

Moderne codificaties, aldus Hufeland, bestaan uit twee soorten bepalingen: in de eerste plaats de 'stellige voorschriften des wetgevers', en hier kan de taak van de rechtsgeleerde niet een andere zijn dan het 'zuiver redekundig' afleiden van de verdere gevolgen van de regel. Het Romeinse recht kan bij dit soort bepalingen geen andere taak vervullen dan het lenigen van een strikt rechtshistorische belangstelling. Van veel groter belang is het grootste deel van thet burgerlijke recht dat niet deze stellige voorschriften omvat, maar

"meer eigenlijk tot de wetenschap behoort. In dat gedeelte stelt het Romeinsche regt, hoezeer: het, onder geen woorwendsel. daar waar het als wet is afgeschaft als wet moge opgedrongen worden, zich echter den Regrggeleerden van beroep alls model en voorbedd ter navolging voor. 73

Aldus wordt door Hufeland, en in navolging van deze door zijn vertaler Warmolts, een tweedeling geschapen in het privaatrecht: aan de ene kant de stellige voorschriften, na een logische behandeling rijp om in een concreet geval toegepast te worden, aan de andere kant het wetenschappelijke deel van het privaatrecht. En juist in dat laatstgenoemde, en meest belangrijke deel biijft het gebruik van het Romeinse recht op de woorgrond aanwezig: in de rechtswetenschap. Hufeland:

'Daarom zijn het verlichte, in alle takken wan menschelijke kennis goed onderleide, door ondervinding opgeslepene Regtsgeleerden, die, in dit opzigt, de hoogste weldatad voor ieder land uimaken: zonder deze, en waar hunne opleiding wordt verwarloosd, bliff de beste wetgeving zielloos liggen, of wordt aan onkundigen toebetrouwd, een mes in kinderhanden! Ongelukkig die Staat, waar het achterdochtig despotisme Jetterknechten en formulierk ramers schept, die, gelijk het alle werlichting vreezende Bestuar zulks wenschat, zich owe ral bek lemd en in tret mauw gevoelen; maar heil der Regering, onder welke de Regtsgeleerde zich, natr alle zijden, mag vormen en beschaven, om op den duur, in de maatschappij, een" wrijen blik rondom zich te slaan, en niet tot dat getal te behooren, warwan een groout wijsgeer zeide; dat ze gewoon zijn zich in boeijen en banden te bewegen. De keus tusschen dit en dat, is geen oogenblik atan

71. Kop, P.C., (1992), p. 23-24.

72. Zie over Gotlieb Hufeland (1760-1817): Kleinheyer, G. en Schroder, Deatsche juristen aus fawf Jahthunderten (1989), p. 344.

73. Hufeland, G., Verhandeling over den eigenaardigen geest van het Romeinsche regt in het algemeen. en wet betrekking tot de hedendaagre wetgewing en regtsgeleerdheid, door C.C.C. Warmolis (Leeuwarden, 1827 ), p. 44.45 . 
bedenking onderhevig; en wij, en ons nageslach kunnen alleen dezer weldadige Regering en hare inrigtingen en goed tharte toedragen." 74

Warmolts voegt na dit slot aan Hufelands betoog nog een geheel op Nederland toegesneden voetnoot toe. Ook hem, zo blijkt daaruit, is het juist te doen om de rechtsgeleerdheid en pas in de tweede plaats om de wetgeving. Teneinde deze keuze te legitimeren pleit hij voor een samensmelting van 'Wet en Regtsgeleerdheid':

'Gelukkig die Staat, warar wet en regtsgeleerdheid tot een geheel wersmelten! waar de, eens uit een hoog wetenschappelijk standpunt bewerkte, Wetgeving aan hare zijde eene verlichte Regtskennis ziet gevestigd, die met de matschappelijke beschaving gelijken tred houdt." 75

Wanneer Warmolts de enige geweest was die een dergelijke benadering proclameerde, dan was dit een wat smalle basis geweest om de vooraanstaande positie in de rechtswetenschap te kunnen concluderen. Er zijn echter meer, en meer bekende juristen die in deze periode ecnzelfde mening voorstaan, zoals Den Tex, in diens Encyclopaedia Jurisprudentiae: het Romeinse recht was weliswaar afgeschaft, de modeme codificaties Waren wel gebaseerd op dat Romeinse recht, dat daarom nog steeds het hoogste gezag had, rationis auctoritate, uit kracht van de rede ${ }^{7 \%}$.

Het Romeinse recht had ook tijdens cle periode van de Code civil een vooraanstaande positie in de rechtswetenschap tussen 1811 en 1838 . Was het daadwerkelijke gebruik van het Romeinse recht in de wetenschap nu zo hoogstaand? Dat vonden sommigen wat later in de negentiende eeuw in ieder geval niet. Zo wordt over de bestudering van dit Romeinse recht in die periode later in de negentiende eeuw, in het volgende citaat een vernietigend oordeel geveld:

"En inniddeis heerste aan onze Academien schier volslagen duisternis. Terwijl in Frankrijk het practische regt met liefde, helderheid en verstandige scherpzinnigheid werd beoefend en in Duitsland de studie van her klassieke regt eene ongekende vlugt nam, werd bij ons het extste zoo goed als geheel werwarloosd en bleef men, wat het laatste betreft, bijna zonder uitzonde-

74. Hufeland, G. (1827), P. 62 .

75. Wammolts, C.C.C., in: Hufeland, G., (1827), noot 41, p. 103.

76. Den Tex, C.A., Encyclopedia Iwrispradentiae (1839), p. 91: "Ius Romanum hodieque in foris et Judiciis summa vatet aucioritate, non quidem vi legis, sed rationis auctoritate. "Zie ook: Nedertandsche Janobeken voor Rechtsgeleerdheid en Wergeving uit 1839 , voorwoord, warin enkelc redenen voor en woortgande 3 tudie varu Romeins recht geschetst worden. Romelns recht is een hulpmiddel woor witleg wan het Nederlandse recht; het is cen bron wan nieuwe Rechtsbegrippen en Wetsbepalingen, maar

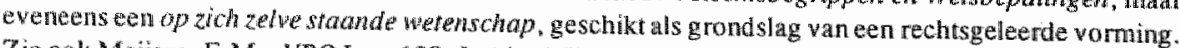
Zie ook Meijers, E.M. VPO I, p. 138; Lokin. J.H.A. De plats van Meijers in de legistische traditie. in: Tehst en witeg (1994), p. $147 \mathrm{ew}$. : Zonder vael ophef wijzigde de status van her Roneinse reche zich van lex soripta tor ratio scripta." 
ring bij Heineccius en Westenberg staan of vermalkte zich met te snuffelen in het corpus juris. gelijk kinderen schelpen zamelende aan het strand." 7

De wetenschap richt zich in die periode onder het Franse recht blijkbaar voornamelijk op het oude ius commune. Met een formele afschaffing van het Romeinse recht werden geen wonderen verricht. Zo eenvoudig kon het Romeinse recht, sedert eeuwen ten grondslag liggend aan de beoefening van het privaatrecht, geen halt worden toegeroepen. Daarvoor was wat meer nodig dan de formele ontkrachting en een Code civil: een flink deel van dat meerdere werd in 1838 door een eigen, Nederlandse codificatie geboden. Tezamen met de redenen die in de navolgende paragraaf $2 . \mathrm{C}$ worden gegeven voor de geringe wetenschappelijke atandacht in de periode 1811-1838 voor de Code civil, lijkt het aannemelijk dat de wetenschappelijke belangstelling voor het Romeinse recht eerst daadwerkelijk kon afnemen nadat het Burgerlijk Wetboek van 1838 kracht van wet verkreeg. Lang na 1838 heeft het Romeinse recht niet meer deze betekenis gehouden. Daarvan kon geen sprake zijn in een periode waarin steeds meer aan de tekst van de eigen, Nederlandse wetgeving werd gehecht. Veel stelliger zou een beroep op het Romeinse recht worden afgewezen om de formele reden, dat het was afgeschaft ${ }^{78}$. Nog is de beoefening van het Romeinse recht op de voorgrond aanwezig, allengs zal het meer naar de achtergrond worden gedrongen. Wanneer het aantal verwijzingen naar Romeins recht in het tijdschrift Themis wordt beschouwd, dan blijkt dat dit aantal rond 1840 nog een kwart betreft van het totaal aantal verwijzingen, terwijl tegen het einde van de negentiende eeuw de verwijzingen naar Romeins recht nog slechts één-tiende bedragen van het totaal ${ }^{79}$. Met bovenstaande is een caesuur geschetst rond 1838 met betrekking tot het gemene recht, een caesuur die echter bepaald niet zeer scherp te duiden valt. Van doorwerking van het Romeinse recht is zeker sprake.

\section{\$ 3. Het Franse recht in Nederland}

Frankrijk exporteerde in 1811 zijn privaatrechtelijke wetgeving naar Nederland. Nederland werd immers, na een kortstondig bestaan als koninkrijk onder Lodewijk Napoleon,

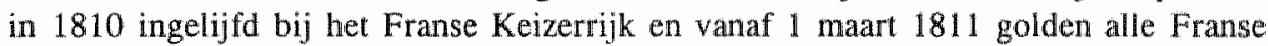
wetten ook op het Nederlandse grondgebied. De Code civil was een van die wetten. En daarmee werd de basis gelegd voor het gebruik dat in de Nederlandse rechtswetenschap van de Code civil gemaakt is ${ }^{80}$, de basis voor de eerste hernieuwde internationale oriëntatie van de Nederlandse jurist na 1838.

77. Kappey ne van de Coppello, bespreking van Goudsmit, J.E., Pandekten-Systeem (1866), Themis 1867, p. 467. Overigens werd deze situatie eveneens gesignaleerd door Van Apeldoorn in zijn bespreking van het Gedenkboek Burgerlijh Wetboek in Kechtggeleerd Magazijn Themig 1939, p. 77. Juist na de 170 en begin 18 e eeuw is het peil van de rechtswetenschap in Nederland volgens hem belangrijk gedaald.

78. Zie hoofdstuk 4 \&.B.

79. Zie bijlage I, en hoofdstuk 4 \& 1.B.1. en hoofdstuk $4 \$ 5$.

80. Zie bijwoorbeeld Scholten, P., (1934), p. 233. 
Met de inwerkingtreding van de Code Civil verviel de rechtskracht van het Wetboek Napoleon, ingerigt voor het Koningrijk Holland. Met deze eerste exclusief geldende Nederlandse codificatie is in de twee jaar dat zij van kracht is geweest in de praktijk weinig gewerkt ${ }^{81}$. Dat lijkt niet het geval geweest te zijn met de Code civil: de praktijk moest zich van deze wetgeving bedienen, daar dit immers de van kracht zijnde wetgeving was. Aan de universiteiten, in de rechtswetenschap lijkt de Franse wetgeving veel minder onderwerp van onderzoek geweest te zijn; het citaat van Kappeyne van de Coppello in $\$ 2$. B wees al in die richting. De geringe wetenschappelijke belangstelling voor de Nederlandse Code civil is vaker geconstateerd. Voor deze geringe belangstelling zijn een aantal verklaringen gegeven: in de eerste plaats nam de studie wan het Romeinse recht nog een belangrijke plaats in; in de tweede plaats was er de verwachting dat Nederland binnen niet al te lange tijd een eigen codificatie zou hebben en in de derde plaats tenslotte, waren er door Franse juristen all omvangrijke commentaren geschreven op de Code civil, die in Nederland veel gebruikt werden ${ }^{82}$. Nederlandse juristen grepen veelvuldig terug op de voor het Franise recht geschreven commentaren $^{83}$. Hoe belangrijk werd het Franse recht voor de beoefening van het Nederlandse privaatrecht geacht ten tijde van de codificatie van 1838 ? Van dit belang wordt blijk gegeven in vele werken. Zo blijkt wan de kennis die Nederlandse juristen hadden van de cormmentaren op de Franse Code in het voorwoord van De Pinto in zijn handboek, waarin deze stelt dat die betreffende werken in een ieders bezit behoren te zijn ${ }^{\$ 4}$. En zo spreekt Asser de verwachting uit dat het gezag van het Franse recht na invoering van het BW in 1838 nog zeker een halve eeuw zal voortduren:

\footnotetext{
"Intusschen zoude het als een verregand dwaalbegrip moeten aragemerkt worden, indien men vermeende, dat in het vervolg de Fransche wetgeving, alsmede de werken der schrijvers en de werzamelingen wan gewijsden, welke tot uitlegging en opheldering van dezelve verstrekken, dadelijk buiten gebruik zullen geraken; want, gelijk wij zoo even aanvoerden, alle handelingen en angelegenheden stan in een zoo naauw werband met de wetten, waaronder wij tot dus verre geleefid hebben, en zijn van derzelver geest als het ware zoodanig doordrongen , dat nog gedurende eenen geruime tijd die wetten steds zullen voortgan wan eenen dagelijksche toepassing
}

81. Zie bijroorbeeld Florijn, E.O.H.P. (1994), D. 14; z.te ook Asser, C., (1838), p. II

82. Deze conmentaren werden ook in Brussel uigegeven. Zie Kop, P.C. (1992), p. 24. De aandacht van

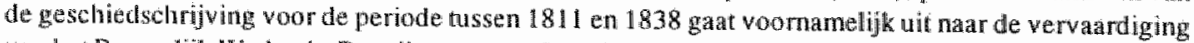
wan het Burgerlijk Wetboek. De wijze warop door de Nederlandse rechitswetenschap met de Code civil is gewerkt, ontsnapt an de aandacht.

83. Bijwootbeeld: Tomllier (1752-1835), hoogleraar te Rennes, wiens Droit Civil Frangais wan 1808 tot aan. 1838 in 20 deleil verscheen, een commentar dat nog de geest ademt van de voorgande naturrechtelijke periode; Duranton (1783-1866). Cours de Dront Frangais; Troplong (1795-1869) Le Droir Civil expligue suivam les: artictes du Code schreef; Aubry (1803-1883) en Rat (1803-1877), wie en op het

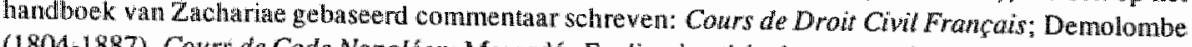
(1804-1887), Cours de Code Napoleon; Marcade, Explication théorique el pratique du Code Napoléon. bekend gebleven om zijn polemische hand van schrijuen; Laurent (1810-1887), Principes de droit civil. Bouckaen geefi een korte hiografie van enkele van de genoemde juristen. Bonckaert, B., De exegeti sche school (1981), P. 51.63; zie ook Coing, H., (1989), p. 30 en Van Diewoet, (1943), p. 92 ev.

84. De Pinto, A. Handleiding rot het Burgenlik Wetboek deel 2 (1838), p. 5 . 
te zijn op de meeste geschillen, ja dat er wel cene halve eeuw en meer zal verloopen, eer dezelve hare kracht zullen verloren hebben.. 85

Ook door anderen wordt het belang van het Franse recht onderstreept. Aldus door Den Tex en Van Hall, die de Nederlandsche zeden, behoefien en regt wel woorop stellen bij de beoefening wan het Nederlandse recht, maar tevens vermelden dat van de Franse wetgeving, van Merlin en Toullier evenzeer door de 'jongelingschap' kennis genomen moet worden ${ }^{86}$. Bovendien worden de Franse commentaren als voorbeeld gebruikt bij de redactie van Nederlandse commentaren. Zo is het handboek van Lipman opgezet naar voorbeeld van de uitgave van de Franse wetboeken door Rogron ${ }^{87}$. En De Martini hanteert in zijn De Nederlandsche wetgeving een vergelijking met het Franse recht die, zo zal blijken, exemplarisch is voor de omgang met het Franse recht vlak na $1838^{\text {g8 }}$. Door deze bekendheid van de Nederlandse jurist met het Franse recht, wordt in de allereerste beschouwingen over de Nederlandse bepalingen vaak aangenomen dat de verschillende (vaak uiteenlopende) standpunten wel duidelijk zullen zijn. Deze worden dan niet vermeld, of er wordt slechts terloops naar verwezen. De behandeling bij Voorduin geeft dit goed weer: weinig wordt naar de verschillende Franse standpunten verwezen, in hoofdzaak wordt vermeld wat de twistpunten in een Nederlandse vertaling kunnen zijn; ook in De Pinto's handboek valt op dat zelden verschil van mening over de uitleg van Franse bepalingen in de Franse privaatrechtswetenschap wordt geëxpliciteerd. Onder deze omstandigheden is het Franse privaatrecht, de Code civil des te meer onmisbaar om een uitleg van de Nederlandse bepalingen te kunnen geven.

\section{\$4. Een cerste interpretatie van de onderwerpen}

\section{A. AANSPRAKELIJKHEID VOOR ZAKEN}

Het oude Burgerlijk. Wetboek kende in 1838 een artikel dat een aansprakelijkheid voor zaken lijkt te omvatten: "Men is niet alleen verantwoordelijk voor de schade, welke men door zijne eigene daad veroorzaakt, maar ook voor die welke veroorzaakt is (....) door zaken welke men onder zijn opzigt heeft,' luidt artikel 1403 eerste lid, voor zover van toepassing. Aansprakelijkheid voor schade door zaken was echter, zo was in hoofdstuk $2 \& 2$. A uiteengezet, een ontwikkeling die in Nederland eerst sinds de tweede helft van de negentiende eeuw heeft plaatsgevonden. Toch wordt er over een 'verantwoordelijkheid voor schade door zaken' gesproken. Enige betekenis moet het dus hebben gehad. Maar welke betekenis was dat? Daarvoor gaan wij te rade bij de volgende bronnen: de

85. Asser, C., (1.838), p. I-II.

86. Den Tex, C.A., en J. wan Hall, Nedertandsche jaarboeken woor regtsgeleerdheid en suergeving (1839), p. vi.

87. Van Hasselt, W.J.C., De Nederlandsche wetboeken met aanteekeningen (1843), p. v; Rogron, Code Civil explique par ses motifs et par des exemples, avec la solution, sous chaque artiche (6e druk. 1833).

88. De Martini. G.J. De Nederlandsche wergeving (1840), p. 5-6. Zie ook hoofdstuk 4 \& 1. 
parlementaire geschiedenis, zoals weergegeven bij Voorduin; bij enige eerdere Nederlandse wetgeving of wetsontwerpen, en Franse commentaren op het Franse artikel 1384 uil de Code civil. Van enige controverse over de uitleg blijkt niet.

Voorduin wijdt aan de zinsnede geen woord ${ }^{39}$. Blijkbaar sprak dit deel van het artikel voor de Nederlandse juristen voor zich. Welke betekenis lag dan zo voor de hand? Werd gedacht aan een aansprakelijkheid voor zaken in het algemeen, en aan een aansprakelijkheid waarvoor schuld hetzij niet vereist zou zijn, hetzij vermoed werd aanwezig te zijn? Van een zo verstrekkende benadering kan geen sprake zijn wanneer geen woord aan de uitleg van het artikel wordt gewijd. Een bepaling uit een voorafgaande wetgeving, het Wetboek Napoleon ingericht voor het Koningrijk Holland maakt op een vrijwel identieke wijze melding van een aansprakelijkheid voor zaken.

Artikel 1315. Men is niet alleen verantwoordelijk voor de schade, welke men door zijn eigen däd veroorzaakt, maar ook voor die, welke veroorzaakt wordt door de daad van personen, woor welke men atansprakelijk is, of door zaken, welke men onder zijn opzigt of beheering theeft.

Vergroot het woord beheering de kring van aansprakelijkheid? Dat is niet zo. Er is niets anders mee bedoeld dan aan te geven of de zaak krachtens een persoonlijk recht of een zakelijk recht bij de verantwoordelijke berust. Zowel in de indeling van De Groot, maar ook in die van het Ontwerp van het Burgerlijk Wetboek 1820 zijn dezelfde bewoordingen aan te treffen in juist die betekenis ${ }^{50}$. Het zegt niets over de zaken waarover de bepaling zich uitstrekt (algemeen of slechts enkele) of over een vereiste van schuld, in welke betekenis dan ook. Asser vergeleek de bepalingen van het Burgerlijk Wetboek met de overeenkomstige in de Code civil. In dit verband is zijn voorwoord interessant, waarbij hij de lezer voor een behandeling van niet door hem genoemde artikelen (zoals 1403), die blijkbaar niet (voldoende) afwijken van het Franse recht, verwijst naar de Franse discussie. Deze werkwijze wordt rond 1838 vaker aangetroffen in de Nederlandse rechtswetenschap. Ze maakt het zeer lastig om de standpunten van de artikelen te kunnen bepalen. Ze zal het in hoofdstuk 4 ook zeer lastig maken om de standpunten van de Nederlandse commentaren in de eerste periode na 1838 te achterhalen. Wetsgeschiedenis brengt ons niet verder. We zullen thans rechtstreeks de Franse commentaren op de Code civil raadplegen en aldus doen zoals Den Tex en Van Hall het de 'jongelingschap" van 1.838 hadden aangeraden.

Het artikel uit de Code civil dat overeenkomt met ons oude artikel 1403 is 1384 :

89. Voorduin, J.C., deel $5(1838)$, p. 83.

90. De Groot, H. Inleidinge tot de Hollandsche rechts-geleerdheid, door F. Doving, H.F.W.D. Fischer en E. M. Meijers (1952), 1.1.8; Onwwerp van het Burgerlijk Wetboek voor het Koningrijk der Nederlanden $(1820)$. 
On est responsable non-seulement du dommage que l'on cause par son propre fait, mais encore de celui qui est causé par le fait des personnes dont on doit repondre, ou des choses que l'on a sous sa garde.

Deze bewoordingen verschijnen letterlijk vertaald in het Nederlandse artikel. Toullier schrijft over de in dit artikel genoemde "choses" het volgende. Het verbod om onrechtmatige daden jegens anderen te plegen heeft niet alleen betrekking op door de pleger zelf in persoon begane daden, doch verplicht ook:

\begin{abstract}
'de tenir toutes les choses qu'ils possedent en tel êtat que personne n'en reçoive aucun dommage. C'est sous la condition de remplir ce devoir que la loi protège nos propriétés. On n'est done pas seulement responsable du dommage causé par son propre fait, ou par celü des personnes dont on doit répondre, mais encore par les choses que l"on a sous sa garde."
\end{abstract}

Zoveel word duidelijk: volgens Toullier omvat artikel $1384 \mathrm{Cc}$ een aansprakelijkheid voor zaken in het algemeen (toutes les choses), en bovendien is schuld wel degelijk een vereiste, als het ware besloten in het opzicht, garde: 'de tenir les choses qu'il possèdent en tel état..' In dit standpunt is er in de toepassing geen verschil met een aansprakelijkheid voor zaken die rechtstreeks onder een onreclitmatige handelen (1401 BW, 1382 $\mathrm{Cc}$ ), of nalaten $(1402 \mathrm{BW}, 1383 \mathrm{Cc})$ wordt gebracht, en de zinsnede is dan strikt genomen een overbodige zinsnede. $\mathrm{Zij}$ bevestigt slechts, wat op grond wan de algemene artikelen over de onrechtmatige daad al aangenomen mocht worden ${ }^{92}$. Daarover spreekt ook Toullier niet. In Toulliers uitleg, zo hebben we gezien, staan twee kwesties centraal. In de eerste plaats of 'zaken' (choses) betrekking heeft op alle zaken. In de tweede plaats of schuld (net als bij $1384 \mathrm{Cc}$ en $1401 \mathrm{BW}$ ) een vereiste is. Deze twee kwesties, die door Toullier beide bevestigend beantwoord worden, kwamen al in hoofdstuk 2 \&2.A aan bod; de discussie zal in Nederland over beide kwesties worden gevoerd. Ook voor een eerste uitleg van artikel 1403 lijkt deze uitleg van Toullier het meest aannemelijk.

Is een ruime aansprakelijkheid voor zaken, gebaseerd op artikel 1403 een zeer onwaarschijnlijke uitleg? Nee. Aanzetten naar een aansprakelijkheid buiten schuld waren al bekend, zo was geconstateerd. Een in het verloop van de negentiende eeuw ontwikkelde

91. Toullier, C.B.M., Le droit civil Français, suivant lordre du code, deel I1 (3e druk, 1824), nr. 296. p. 348 .

92. In de Franse Code civil luiden deze als volgt: Arrikel $1382 \mathrm{Cc}$. Tout fait quelconque de I"lhomme, qui cause à autrui un dontmage, oblige celui par la faute duquell il est arrivé, à le réparert.

Arrikel $1383 \mathrm{Cc}$. Chacun est responsable du dommage qu'il a causé non seullement par son fait, mais encore par sa négligence ou son umprudence.

Waarom zou niet gesproken worden over een eventuele overbodigheid van de zinsnede over zaken in artikell $1384 \mathrm{Cc}$ ? Bij Toullier zou daaroor als verklaring kunnen dienen dat deze de zinsnede niet als overbodig beschouwde. Toullier stond nog gterk in een natuurtechtelijke traditie. Een codificatie moest in de landstaal geschreven zijn en voor ieder begrijpelijk zijn. Om die reden mag wen codifictatie wel wat langer van stof zijon. 
aansprakelijkheid voor zaken komt dan ook niet uit de lucht vallen. Welke aanzetten kunnen er worden gevonden? Allereerst een enkele in het Romeinse recht. Dat stelsel kent cen aansprakelijkheid van de bewoner van een gebouw voor uit dat gebouw geworpen objecten. Feenstra kenschetst deze Romeinsrechtelijke aansprakelijkheid als een belangrijk historisch aanknopingspunt voor ristcoaansprakelijkheid ${ }^{93}$. Daarnaast zijn er zowel in het Burgerlijk Wetboek, als in de Code civil enkele bepalingen die een aansprakelijkheid vestigen terwijl schuld niet expliciet als vereiste is gesteld. Te noemen zijn de aansprakelijkheid voor bijzondere categorieën zaken, gebouwen en dieren ${ }^{94}$, en bovendien artikel 1403 zelf, waaruit een aansprakelijkheid kan ontstaan voor andere personen. Maar ook voor zaken in het algemeen was een mogelijkheid aangereikt. Dat was de mogelijke uitleg waarbij aan artikel 1403/1384 een, wat later genoemd zal worden, zelf fstandige betekenis toekomt, waarbij het niet alleen verwijst naar de in de volgende artikelen genoemde dieren en gebouwen, maar naar zaken in het algemeen. Deze mogelijkheid wordt gegeven door Toullier, en ze zal ook in het Nederlandse recht worden gebruikt ${ }^{95}$.

Daarmee is de stand van zaken in 1838 vormgegeven. Aan een aansprakelijkheid voor zaken was gedacht. Deze was immers in artikel 1403 lid 1 weergegeven. Daarbij ging het echter niet om een afwijkende aansprakelijkheid, waar bijwoorbeeld het louter onder 'opzigt' hebben voldoende zou zijn om aansprakelijkheid te vestigen. Daarvoor was meer nodig, zoals Toullier duidelijk maakte: eveneens moest aangetoond worden dat de opzichter onvoldoende had gezorgd dat de zaak verkeerde 'en tel état que personne n'en reçoive aucun dommage". Tevens is nu duidelijk dat een aansprakelijkheid voor zaken 'buiten schuld' of een aansprakelijkheid voor zaken waarbij met een vermoeden van schuld wordt gewerkt geen heel grote stap hoeft te zijn. Er waren immers al voorbeelden bekend van kwalitatieve aansprakelijkheid (de eigenaar van een dier), en de tekst van de bepalingen over aansprakelijkheid voor zaken laat genoeg ruimte voor een dergelijke verandering van standpunt. Zowel het ontbreken van het woord 'schuld' als de aanwezigheid van het begrip 'opzigt,' laten die ruimte. Het ontbreken van schuld is aanleiding tot een interessante controverse tussen Diephuis en Opzoomer ${ }^{\%}$. Het tweede punt, het begrip 'opzigt' laat ruimte om schuld daarin reeds besloten te achten en zo eenvoudiger tot aansprakelijkheid te kunnen concluderen.

93. Feenstra, R. Romeinsrechrelihte grondslagen van het Nederlands privaatrecht (1990), p. 166. Zie ook Spruit, J.E. en K.E.M. Bongenaar, deel 1, Instituten (1993), 4, 5.

94. De Franse attikelen luiden als wolgt: Artikel $1385 \mathrm{Cc}$. Le propriétaire d'un animal, ou celui qui s'en sert, pendant qu'il est à son usage, est responsable du dommage que l'animal a causé, soit que l'animal fût sous sa garde, soit qu'il fût égaré ou échappé. Artikel $1386 \mathrm{Ce}$. Le propriétaire d'un bâtiment est responsable du dommage causé par sá ruine, lorsqu'elle est arrivêe par suite du défaut d'entretien ou par le vice de sa construction. Zie voor de Nederlandse bepalingen hoofdstuk $2 \$ 2$. A.

95. Zie de uitspraak inzake de Amsterdamse gasmaatschappij, hoofdstuk 2 \$2.B.

96. Zie hoofdstuk 6 . 


\section{B. ARTIKEL 2014}

'Bezit geldt als volkomen titel' is een parafrase van een zinsnede uit artikel 2014 $B W^{97}$ :

Hoe wordt dit artikell uitgelegd? Het is een buitengewoon lastige opgave de betekenis die het artikel destijds had, te achterhalen. Het Wetboek Napoléon, ingerigt voor het Koningrijk Holland sprak in vrijwel gelijke bewoordingen als het BW van 1838, en ook van de bewoordingen van artikel $2279 \mathrm{Cc}$ was in vertaling niet afgeweken:

Artikel 1906 WNH. Met betrekking tot roerende goederen, geldt bezit voor een" volkomen titel: Niettemin kan de geen, die eene zak verloren heeft, of ata wien dezelve onfreemd is, die zaak gedurende drie jaren, ungaande met den dag van bet verlies of de ontvreending, als zijne eigendom reclameren, bij when hij dezelve ook vinderu moge; behoudens het verhasal van den houder tegen den geen", wan wien hij dezelve zaak bekoment heeft.

Art. $2279 \mathrm{Cc}$. En fait de meubles, la possession vaut titre.

Néanmoins, celui qui a perdu ou auquel i) a ếté volé une chose, peut la tevendiquer pendant trois ans, à compter du jour de la perte ou du vol, contre celui dans les mains duquel il la trouwe; sauf à celui-ci son recours contre celui duquel il ta rient.

Kempers Ontwerp 1820 sprak van de mogelijkheid van een driejarige verjaringsperiode. teneinde de eigendom van een roerende zaak te verkrijgen.

Artikel 1040 Ontwerp 1820 lid 1. De eigendom van tilbaar of roerend goed wordt bekomen door een bezit van drie jaren, mits niet kunne bewezen worden, dat de bezitter in dat tijdsverloop immer geweten hebbe, dat hij door het bezitten wan de zaak ienands regt verkorte.

Maar dit ontwerp werd nu juist met kracht van tafel geveegd. Voorduin is uitermate kort over de geschiedenis van artikel 2014 BW. Alleen enkele kleine tekstuele wijzigingen in vergelijking tot de aan het Burgerlijk Wetboek van 1838 voorafgaande ontwerpen worden door hem vermeld ${ }^{98}$. Asser merkt alleen op: 'De voorschriften van art. 2005 2014 van het Nederlandsch Burgerlijk Wetboek stemmen grootendeels overeen met de bepalingen van art. 2271 - 2280 van het Wetboek Napoleon. Men behoeft ten deze alleen op te merken (...). ${ }^{99}$ En vervolgens makı hij enkele opmerkingen waarvan

97. In 1838 luidde het artikel wat anders dan de latere redactie. De wijziging is niet zeer van belang voor het betoog. De redactie van dit artikel is in 1884 veranderd, om dit artikel in overeenstemming te brengen met het Wetboek van Strafrecht. Het begrip "diefstal" is daarbij verwangen door "ontvreemding". Zie Veegens, J.D., en Oppenheim, A.S., Schets wan het Nederlandsch Burgerlijk Recht, deal 2 (3e druk, 1925), p. 33.

98. De toevoeging van de lastste woorden van het tweede lid "en onverminderd de bepaling van artikel 637. ter wervanging van een afzonderlijk artikel in een eerder ontwerp. Voorduin, J C., deel 5 (1838), p. $575-576$.

99. Asser, C. (1838), p. 621-622. 
geen enkele betrekking heeft op artikel 2014. Het Franse artikel $2279 \mathrm{Cc}$ en de commentaren daarop, zijn onmisbaar voor de uitleg.

Welke betekenis werd aan dit Franse artikel $2279 \mathrm{Cc}$ gehecht? 'Sans doute, ce principe est ridiculement formulé," aldus Marcadé, die daarmee duidelijk maakt dat ook in de Franse rechtswetenschap sprake was van een grote onduidelijkheid ${ }^{100}$. Die onduidelijkheid zou zijn ontstaan doordat een uitleg van die bewoordingen "possession vaut titre" in de juridische werken waarvan de makers van de Code civil gebruik hadden gemaakt, ontbrak. De zinsnede zou voor zich spreken, aldus Planiol ${ }^{10 !}$. Verduidelijking kan worden geboden door de oorsprong van de bepaling na te gaan. Zij is afkomstig, zo blijkt uit diverse bronnen, van de achttiende-eeuwse jurist Bourjon ${ }^{102}$. Deze stelde dat de regel 'possession vaut titre' vaste rechtspraak van het Châtelet van Parijs was ${ }^{103}$. Met deze tekstuele overeenkomst is nog niets gezegd over de betekenis. Met het bezit, zo wil Bourjon, wordt tevens de eigendom verkregen ${ }^{104}$, en niet slechts de mogelijkheid ofm een revindicatie af te weren. Aldus Toullier en Marcadé, die over de uitleg zoals die door Bourjon werd gegeven eensgezind zijn. Toullier in 1831:

"Il est done évident que Bourjon attribue à la simple possession des choses mobilières, tous les effets de l'occupation proprement dite, qui donne immédiatement la propriété des choses dès le monent même où s"en est saisi, dès le moment où l"on en ä appréhendé la possession.' 105

Marcadé over de rechtspraak van het Châtelet, zoals đie door Bourjon overgenomen is in de regel 'en fait de meubles la possession vaut titre': '(..) et d'admettre ainsi que ce

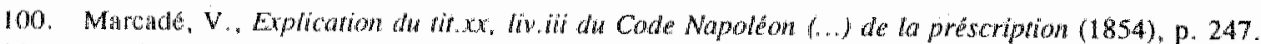

101. "Lo Code civil a conserve presque sans changenent les solutions achuses à la fin du XVMe siecta.

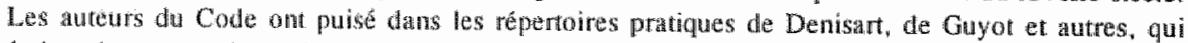

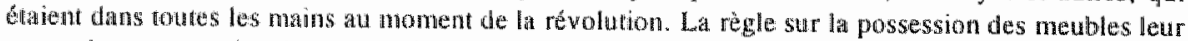

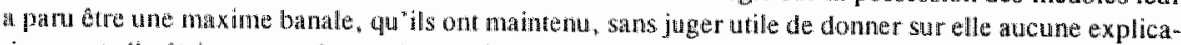

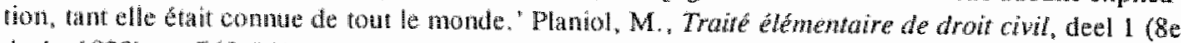
druk, 1920), p. 760-761.

102. Ziv bijwoorbeeld Marcadé. V. (1854). P. 246 ev.; Toullier, C.B.M. deel 14 (1831), nr. 109; Goud-

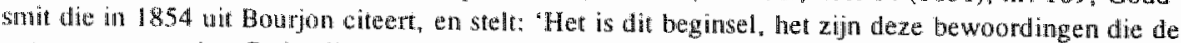
ontwenpers van den Code bij de zamenstelling van a. 2279 voor oogen hadden en onze wergewer op nieuw in a. 2014 B. W. heeft bekrachtigd. " Goudsmit, J. Ez, over de werking en den aard van het bezt van foenende goederen, nar analeiding wan art. 201 . B.W., Themis 1854 , p. 476. Zie ook Pitlo-Bralun (1987). p. 178-179, watrin getmpliceerd lijkt te worden, doch geheel ten onrechte, dat de in mavolging Van Sctholten geacepteerde legitinatie leer (zic hoofdstuk 2 \&) reeds door Bowrjon werd bedoeld.

103. Buiten twijfel is dit niet: zie bijoorbeeld Marcade, V, (1854), p. 246. Zie ook: Salomons. A.F., $(1990)$, p. 11 .

104. Anders echter: Zwalve, W.J., (1993), p. 94-96, die stelt dat alleen voor beziters die te goeder trouw żjin, deze gelijkstelling wan bezit met eigendom opgat.

105. Toullier, C.B.M., deel 14, (1831), nur. 114. Een andere uitleg van Bourjon geeft Salomons, A.F., (1990), p. 13, die stelt dat Bourjon de bezitter niet tot eigenar laat worden. 
tiersacquêreur en devenait propriétaire par l'effet instantané de sa possession.' 106 Waar Toullier en Marcadé het eens waren over de door Bourjon gegeven uitleg, hebben beiden een geheel ander standpunt over de uitleg van artikel $2279 \mathrm{Cc}$.

Terwijl Marcadé in de voetsporen van Bourjon blijft zoals die hierboven werden gevormd, en de derde-verkrijger de eigendom toekent, na een prescription instantanée (een verjaring zonder enig tijdsverloop), heeft Toullier een andere mening ("une grave hérésie,' kwallificeert Marcadé Toullier's standpunt), en leest in artikel 2279 geen eigendom voor de derde-verkrijger, doch slechts een vermoeden van eigendom (een processuele functie van het artikel): '. .la possession fait présumer le possesseur propriétaire..." deren, waarvoor slechts de goede trouw een vereiste is, en geeft aldus ook een materiële betekenis aan 2279 .

\begin{abstract}
"De quoi s"agitili dans la chapitre oü est placée cette disposition? Des prescriptions dont les unes n'exigent thi titre, ni bonne foi, conme les prescriptions trentenaires; les autres exigent et titre at bonne foi, conme les prescriptions d'immeubles par dix ou vingt ans; d'autres, enfin, seulement la bonne foi de celui qui prétend prescrire.

Enfin, l"art.2279 vient à la préscription des meubles, pour laquelle tous les auteurs tenaient, avant le Code, qu'il fallait et titre et bonne foi, quoique Pothier convint qu'il était difficile de présenter un titre écrit, la translation de propriété de meubles se faisant verbalement dans l"usage. Le Code a donc très-saggement retranché la nécessité d"un titre écrit pour la prescription des meubles, en statuant, dans l'art.2279, qu'en fait de meubles la possession vaut titre; et voilà le vrai serws de cet anticle." 108
\end{abstract}

\title{
Marcadé hierover:
}

"C"est donc une grave hérésie que la doctrine par laquelle Toullier (..) soutient que notre art. 2279 n'entend donner à la possession, tout d'abord, qu'une simple presomption de propriécé cédant à la preuve contraire $() .$.

Dat was nogal sterk aangezet, want wellicht bedoelde Toullier alleen de processuele functie te schetsen, terwijl hij op een geheel andere plaats in zijn commentaar wel degelijk de eigendom toekende aan de bezitter ${ }^{110}$. Dat stond Marcadé ook voor, zo

106. Marcadé, V., (1854), p. 246. Anders ower de mening wan Bourjon: Salomons, A.F., (1990), p. 11-14. die de teksten bij Bourjon zelf heeft geanalyseerd, de vegentiende-eeuwse uitleg in de Franse rechtswerenschap er niet bij betrekt.

107. Toullier, C.B.M., deel $14(1831)$, nr. 112.

108. Toullier, C.B.M., deel 14 (1831), nr 116.

109. Marcadé, V.. (1854), p. 247. Marcadé's opmerking "une grave hérésie", (zware ketterij of een grove afvallighteid $)$, doet nogal bruwsk aan. Het was anderen op gaan vallen. Zo Planiol over het werk van Marcadé: 'Ouvrage remarquable à centains égards, malheureusement écriu sous une forme agressive, dans la partie due à Marcadé", deel 1 (8e druk 1920), nr. 130, p. 148.

110. Toullier. C.B.M., deel 9 (1821), nr. 94, p. 141 . 
had ik reeds opgemerkt. Door de onmiddellijke verjaring zou de bezitter te goeder trouw de eigendom verkrijgen:

\begin{abstract}
'Ainsi, bonne foi et juste titre, telles sont les deux conditions exigées ici, pour la prescription d'un meuble par la possession instantanée, comme elles sont dans l'art. 2265, pour la preseripcion d'un inmeuble, par la possession de dix à vingt ans. ACQUISITION D'UN MEUBLE FAITE A NON DOMINO. MAIS AVEC JUSTE TITRE ET DE BONNE FOI, tel est le cas d"application, et le seul cas d'application de notre art. 2279, comme le cas analogue est, quant aux immeubles, te seul pour lequetle l"article 2265 édicte sa prescription décennale. " 111
\end{abstract}

Met een 'juste titre' wil Marcadé aangeven dat degene die zich op artikel 2279 beroept, zijn bezit verworven moet hebben op een wijze, die normaal gesproken in het Franse rechtssysteem tevens de eigendom doet overgaan:

\begin{abstract}
'd'achvat, d'Échange, de donation, de succession, de legs, de dation en paiement. Car s'il n'a pas ainsi acquis, de fait, par l'un des modles légaux de transmission de propriété, il ne peut donc pals se croire propriétaire, il ne peut pas posséder de bonne foi animo domini, et dès lors la prescription de notre article ne fui est pas applicable. 112
\end{abstract}

Vergelijkbaar met Toullier's standpunt is het standpunt zoals dat door Rogron in 1833 wordt weergegeven: '..le possesseur est réputé tellement propriétaire, que celui qui a une titre, ou qui pourrait prouver sa propriété.(..) Mais ont pourrait prouver que le possesseur l'est devenu de mauvaise foi." 113 Hier wordt uitgegaan van een vermoeden van eigendom: de processuele regel zoals ook door Toullier werd verwoord. De werkelijke eigenaar heeft in deze betekenis nog de mogelijkheid te bewijzen dat hij eigenaar is, of dat de bezitter te kwader trouw is. Aan de artikelen $2014 \mathrm{BW}$ en $2279 \mathrm{Cc}$ worden in veel recenter jaren twee duidelijk verschillende functies gehecht. Op die twee functies, de procesrechtelijke en de materiële, wordt uitgebreid ingegaan in hoofdstuk $6^{114}$. Echter nu reeds is het onderscheid interessant. Duidelijk is dat beide aspecten op onduidelijke wijze bij Toullier aan bod komen, terwijl alleen de processuele door Rogron wordt vermeld, en bij Marcadé de processuele functie, zoals geschetst door Toullier, op zoveel weerstand stuit. De oorsprong van de regel 'bezit geldt als volkomen titel' ligt in haar processuele functie, zoals uit het Romeinse recht kan blijken, en door Zwalve duidelijk is uiteengezet ${ }^{\prime 15}$. De materiële zou later aan deze regel zijn gehecht. Hoe deze ontwilkkeling ook geweest mag zijn, duidelijk is dat beide betekenissen nogal door elkaar gebruikt worden, en dat er flinke meningsverschillen aanwezig zijn in het

111. Marcadé, V., (1854), p. 250

112. Marcade, $V_{\text {., }}(1854)$, p. 249. De eigendom wordt in het Franse recht overged ragen door de owereenkonnst, "par l'effet des obligations' (zie art. $711,1138,1583,938 \mathrm{Cc}$ ). Planiol, M., deell $I_{\text {. }}(1920)$, nr. 2589 , p. 798 : 'Le droit français a abandonne l'antique principe qui rendait la tradition nécessaite pour le unansfert (...)': zie ook Zwalve, W.J., (1993), p. 180-185.

113. Rogron, (1833), p. 432 .

114. Hoofustuk 6 \$ 3. A.2.

115. Zwalve. W.J., (1993), p. 94. 
Franse recht. Wordt de eigendom aan de bezitter gegeven, of betekent de zinsnede slechts een bewijsvermoeden? Welke vereisten zijn bovendien nodig voor een geslaagd beroep: een titel en goede troww, zoals Marcadé vereist, of alleen de goede trouw, zoals door Rogron wordt gesteld? Is sprake van een onmiddellijke verjaring, vanwege de plaats in de titel over verjaring, of heeft het artikel daar niet zoveel mee te maken? Deze vragen komen in de volgende perioden aan de orde.

Wanneer we deze Franse meningen als hulpmiddel gebruiken voor de uitleg van artikel 2014, dan wordt duidelijk dat het beginsel, waarvan door Voorduin geen duiding noodzakelijk werd geacht, tot zeer uiteenlopende interpretaties kan leiden, in Frankrijk, en in navolging eveneens in Nederland. Een verscheidenheid aan interpretaties verschijnt na 1838 ook in de Nederlandse rechtswetenschap. Een eenduidige heersende uitleg kan voor de Nederlandse rechtswetenschap, door het ontbreken van enige stellingname, maar evenzeer door de uiteenlopende interpretaties in Frankrijk, niet worden gegeven.

\section{PUBLIEK DOMEIN}

\section{Publiekrecht of privaatrecht}

Naar de juridische herkomst van publiek domein is al uitgebreid onderzoek verricht ${ }^{116}$. Twee visies zijin verdedigd met betrekking tot de dogmatische plaats van publiek domein rond 1838. In de eerste plats is dat de visie die door Von Reeken in 1893, en door Vegting een halve eeuw later wordt voorgestaan. Publiek domein moet in beginsel worden gezien als onderworpen aan privaatrechtelijke eigendom, en, zo stellen zij, dit standpunt was ook van oudsher, ook rond 1838 , de heersende mening. Wat is het meest zwaarwegende argument voor hun standpunt? Een grammaticaal argument: de bronnen ${ }^{117}$, de diverse schrijvers, spreken over eigendom. Daarmee kan niets anders dan privaatrechtelijke eigendom worden aangeduid, en daarom moet de overheid beschouwd worden als privaatrechtelijk eigenaar van publiek domein. De andere visie wordt door recent historisch onderzoek naar voren gebracht, en schijnt mij meer aannemelijk toe. De rechten van de overheid op publiek domein zijn daarin tot regalia of hoogheidsrechten, publiekrechtelijke constructies, te herleiden, en daarmee is een publiekrechtelijke herkomst gegeven. Hardenberg en in navolging van deze, Van

116. Zie voor de publiekrechtelijke visie met name hoofdstuk $7 \& 4 . \mathrm{C}$, warin ook enkele eigentijdse sclurijwers aan de orde homen; voor de privaatrechtelijke visie in hoofdstuk $6,4, C .4$.

117. Vegting, W.G., Publiek domein en zaken buiten de handel (1946), passim. De door Vegting gebruikte bronnen zijn zeer diwers. Zo gebruikt hij uiteenzeningen van glos Satoren, commentatoren, juristen uir de Hollandse elegante school, en alan de modeme codificaties voorafgaande ontwerpen voor een civielrechtelijke codificatie. Von Reeken, C.G., Uitoefening van private rechten op zaken met eene publieke bestemming. Themis 1893 , p. 1-67. 
Maanen, kunnen onder deze laatste richting worden geschaard ${ }^{18}$. Maar wat werd rond 1838 over het samenstel van bepalingen, zoals in hoofdstuk $2 \& 4$ werd genoemd, geschreven? Daarvoor beschouwen we met name de bepalingen over publiek domein (art. 575 ev BW, 4.C.2) en de bepalingen over zaken buiten de handel (\$4.C.3).

\section{Publiek domein}

Uit de privaatrechtelijke wetgeving en de wetsontwerpen die het Burgerlijk Wetboek voorafgaan is niet of nauwelijks af te leiden of publiek domein mi door privaatrechtelijke regels wordt bestreken, of door andere, publiekrechtelijke regels. In het Wetboek Napoleon ingerigt woor het koningrijk Holland wordt plaats ingeruimd voor publieke domeinen, en gesteld, dat zij 'voor geenen uitsluitenden eigendom vatbaar zijn':

Art. 433. De wegen, rij-en gangpader, die tot laste van het rijk zijn, de bevaarbare stroomen wn rivieren , de stranden van de zee, de havens en redeh, en in het algemeen alle gedeelten van Hollands grond, wetke voor geenen uitsluitenden eigendom vatbaar zijn, worden onderhoorig geach an de publieke dome:linen.

Twee mogelijke intedpretaties zijn denkbaar: de aangehaalde zinsnede kan er op wijzen dat er geen rechten van particulieren op kunnen rusten enerzijds, anderzijds zou ze kunnen wijzen op de onvatbaarheid van die zaken voor eigendom, ook voor de staat. Cras en Kemper lijken in hun ontwerpen voor een Burgerlijk Wetboek eerder een publiekrechtelijke, dan een privaatrechtelijke constructie neergelegd te hebben ${ }^{119}$. Twijfel blijft op grond van de tekst zeer wel mogelijk. In het ontwerp Kemper (1816) luidt artikel 1056:

\footnotetext{
Zaken welke den Stat toebehooren, worden onder land gemeene zaken of landszaken genoemd, gelijk in het algemeen Staatsbezittingen onder den naam van domeinen of Staats domeinen begrepen worden. En heeft daarop de Staat dezelfde regten, welke aan particulieren op humne zaken toekomen. De grondwet van den Stat on de staatkundige inrigtingen, bepalen de administratie wan, en de beschikking over dezelve 20
}

Hierin lijkt weergegeven dal publiek domein geregeerd wordt door publiekrechtelijke regels, immers: 'De grondwet van den Staat en de staatkundige inrigtingen bepalen de administratie van, en de beschikking over dezelve.' Maar de bepaling vervolgt met de toekenning aan de staat van dezelfde rechten als aan particulieren zouden kunnen toeko. men. Het vervolg lijkt weer wat van die toekenning van private rechten weg te nemen.

118. Ha ruenberg, L., De "eigendom' van de stant, in: Ter recognitie. Opstellen aangeboden aan prof, mr. H. wan der Linden bij zin afscheid als hooglenar in de Nederiandse rechssgeschiedenis aan de Vrye Cmiversiteit (1987), p. 341-371, Van Manen, G.E., (1992), p. 973.

119. Zie ook Van Mannen, G.E., (1992).

120. Un: Van Gessel-De Roo Bmowen wan de Nederlandse codificatie sinds 1798.2 akewrech 1798.1820 (1991), p. 176.177. 
Alleen op grond van de tekst wordt geen duidelijkheid gebracht. Het ontwerp 1820 werpt lets meer licht op de kwestie, en stelt in artikel 951:

Er kan door bijzondere personen geen regt tegen den stat op zaken verkregen worden, welke klaarblijkelijk ten algemeenen nute bestend zijn, en dien ten gevolge onverv reemdbare landgemeene zinn.

'Onvervreemdbare landgemeene" geeft aan dat de zaken 'ten algemeenen nutte' aan de staat behoren ${ }^{12 !}$ en onvervreemdbaar zijn. Een aantal van de zaken die in het $\mathbb{B W}$ 1838 in artikel 577 genoemd worden, werden in dit wetsontwerp onder deze 'zaken ten algemeenen nutte' gebracht. Wat zijn de standpunten tijdens de parlementaire behandeling van het BW 1838 ?

Voorduin is niet expliciet over de rechtstoestand van publiek domein. Slechts uit enkele zinsneden kan blijken van de bijzondere positie van deze zaken. Zo vermeldt hij bij artikel $555 \mathrm{BW}^{122}$ het volgende. In een voorgaande redactie van deze bepaling werd gesproken over 'openbaren of afzonderlijken eigendom:'

Men verstaat door zaken, al hetgeen het onderwerp kan uitmaken van openbaren of alzonderlijken eigendom.

Een voorstel was geweest om de twee woorden 'openbaren of afzonderlijken' weg te laten. Daar was de regering tegen, en haar argument daarvoor is in dit verband interessant. "Men achtte het aan de zijde der Regeering van belang 'om deze woorden te behouden, ten einde te doen zien, dat ook voorwerpen van openbaren eigendom, door de burgerlijke wet geregeerd worden ${ }^{123}$. Daarnaast is een punt van discussie geweest of het woord zaken, in de Franse tekst (de behandeling speelt in 1823 , België maakte immers nog deel uit van Nederland) door "biens" (goederen) vertaald moest worden. Nicolaï, 'Belgisch' kamerlid merkte hierover het volgende op:

'Dans le langage des jurisconsultes le mot: biens, ne s'applique qu' aux choses qui peuvem erre l'object d"une propriété publique ou particulière; ainsi l'on ne comprend pas sous cette dénomination les choses qui sont utiles à tous, et qui n'appartient a personne: comme l"air, la mer, le vent, les animaux sawages, ete." 124

Uit beide discussiepunten en de korte behandeling kan wel het een en ander geconcludeerd worden. Het Burgerlijk Wetboek werd gedacht om zaken van 'openbaren eigen" dom' (publiek domein) te regeren. Duidt het ook op toekenning van privaatrechtelijke eigendom, zoals particulieren zou kunnen toekomen? Dat hoeft daar nog niet uit te

121. Aldus artikel 949: Zaken, welke aan den Stat toebehooren, worden land gemeene of lands zaken genoend (...).

1.22. Zie hoofdsruk 2 .

123. Voorduin, J.C., deel 3 (1838), p. 303-305.

124. Voorduin, J.C. deel 3 (1838), p. 304 . 
volgen, het hangt er maar van af wat precies de inhoud was van het begrip 'openbare eigendom," en wat de betekenis was van 'burgerlijke wet." 125 Nicolai maakt duidelijk dat hij in ieder gevall 'les choses qui sont utiles à tous' als een afzonderlijke categorie beschouwt. Maar welke zaken worden daar onder begrepen? Ook publiek domein, of valt publiek domein onder "propriété publique"? Nicolail's criterium, "utiles à tous," komt aan de orde bij de behandeling van 'zaken buiten de handel.' Eerst zullen we echter naar de Franse bepalingen kijken, en naar de "jurisconsultes," de juristen, waarnaar Nicolail verwees. Dit Franse recht is iets duidelijker over het rechtskarakter van publiek domein.

De Code civil biedt meer aanknopingspunten, maar de betreffende bepalingen vergen dan een nogal bijzondere interpretatie. In Code civil zou volgens Franse schrijvers publiek domein worden beheerst door regels van publiekrechtelijke aard. De artikelen luiden als volgt:

\begin{abstract}
Art. 538 . Les chemins, routes et rues la charge de l'État, les fleuves et rivières navigables ou fottables, les riwages, lais et relais de la mer, les ports, les havres, les rades, er généralement toutes les portions du territoure frangais qui ne sont pas susceptibles d'une propriété priwée, sont consätérés comme des dépendances du domaine publis.
\end{abstract}

Art.539. Tous les biens vacants et sans maître, ef ceux des personnes qui decedent sans héritiers, ou dont les successions sont abandionmes, appartiennent au domaine public.

Art.540. Lés portes murs, fossés, remparts des places de guerre et des forteresses, font aussi partie di domatine public.

In artikel $539 \mathrm{Cc}$, zou bij wijze van vergissing sprake zijn van de woorden "domaine public". In 1807 werden de oorspronkelijke woorden "à la nation' vervangen door "au domaine public." Met deze verandering was geen inhoudelijke wijziging beoogd ${ }^{126}$. Vooral vroege Franse schrijvers (voor 1838 ) kwalificeerden deze wijziging als een vergissing, omdat zij zeer expliciet een onderscheid maakten tussen 'domaine public' en "domaine prive". ${ }^{127}$ Dat onderscheid lazen zij ook in de Code civil, en daarin schuilt de aanvang van een lange discussie. Want wanneer de zaken worden beschouwd van artikel 539 , dan valt op dat genoemde goederen geen openbare bestemming hebben,

125. Detkent "openbare eigendom" thiet meer dan publiek domein in onze betekens.? Omvat burgerlijke wet, het Murgertijk Wetboek, meer dan alleen priwarrechtelijke regels? Als dat zo zou zjin dan zou het een fratie illustratie wan de stelling dat het Burgerlijk Weboek ook regells bevat, die als algemeen recint te duiden zijn, en ean weergave zijn van beginselen die aan het privaat maar ook her publiekrecht ergen zijn. Zie darover Teunissen, J.H.M.F., (1996), p. 324

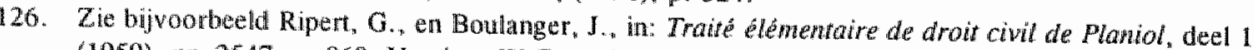
(1950), nir. 2547, p. 860; Vegting, W.G., (1946), p. 158-159.

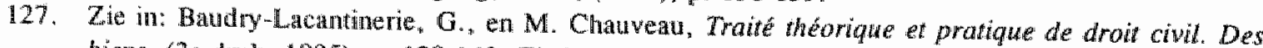
biens. (3e druk, 1905), p. 139-140. Zie Proudhon, J.B. . . Traúé du domaine de propriêté, (1842), p. 308, onder nr. 816; Toullier, C.B.M., deel 3 (1820), nr. 32; Marcadé, V., Explication théorique el pravique du Code Napoleon, deel 2 (5e druk, 1852), p. 382; zie hoofdstuk 5 , 4.A. 
de in 538 en 540 echter wel. Alle genoemde zaken maken volgens de wettekst onderdeel uit van het domaine public. Het is in het genoemde criterium, "openbare bestemming;" waarin een onderscheid gezien wordt tussen de in 538-540 Cc genoemde zaken. Ripert en Boulanger merken het op: "l'affectation d"une chose à l"usage de tous." verdeling in privaat en publiek domein zou ook kunnen blijken uil de parlementaire behandeling van de Code civil ${ }^{129}$.

In de Nederlandse bepalingen wordt niet over 'domaine public' gesproken, doch over 'behooren aan den staat.' Over de verandering van de redactie van artikel $577 \mathrm{BW}$ ten opzichte van artikel $538 \mathrm{Cc}$ wordt echter slechts iets opgemerkt over de toevoeging van de laatste zinsnede aan het artikel: "welke de strekking had, om de uitgebreidste betekenis aan de aanspraak der Domeinen te geven, doch de nauwste beperking aan de op titels of prescriptie gegronde regten van bijzondere personen ${ }^{130}$. Over de redactie van de Franse bepalingen wordt niets vermeld. De in artikel 577 BW genoende zaken zijn "van dien aard, dat zij onmiskenbaar tot 's lands eigendom behooren, terwijl het schier niet denkbaar is dat anderen daarop eenig regt kunnen bezitten.' De in dat artikel genoemde zaken kunnen in deze visie slechts aan de staat toebehoren ${ }^{131}$. In het Franse artikel $538 \mathrm{Cc}$ worden genoemd de aanwassen, gorsingen en schorren ("lais et relais de la mer') en, zo merkt Asser op, 'deze toch kunnen, naar den regel niet worden gelijk gesteld en op dezelfde lijn geplaatst' met de in artikel 577 BW opgesomde zaken. De 'aanwassingen, gorsingen en schorren,' gelegen aan rivieroevers, behoren in Nederland vaak aan particulieren, maken aldus deel uit van hun eigendom, en worden daarom (in artikel 651 en $652 \mathrm{BW}$ ) bij eigendom behandeld ${ }^{132}$. Met dit standpunt (de staat als enig mogelijke eigenaar van de in 577 BW genoemde zaken) is een weg geopend voor de opvatting dat dit recht van de staat een ander recht betreft dan een privaatrechtelijk. eigendomsrecht. Uit Assers woorden is een dergelijk 'ander recht' echter nog niet af te leiden ${ }^{133}$. Dat is merkwaardig, daar deze bewoordingen uitdrukking waren van een

128. Ripert, G., en J. Boulanger, (1950), nr, 2549, p. 861

129. Zie Code Napoléon, saivi de l'exposé des motifs, sur chaqué loi (..) deel 4 (1808). p. 9 (Treillard); p. 17-18 (Goupil-Préfeln); p. $24-25$ (Savoye-Rollin).

130. Voorduin, J.C., deel $3(1838)$, p. 342, bij de behatndeling van artikel 577 BW.

131. Vergelijkbaar met deze uitleg is de oplossing die in het nieuwe Burgerlijke Weboek is te vinden: in de artiketen $25-28$ boek 5 BW wordt aan de Stat de eigendom toegekend van de bodem van do territoriale zee en de waddenzee en wordt een eigendomsvermoeden aan de Staat gegeven van bijvoorbeeld (artikel 5: 28) onroerende zaken die openbaar zijn.

132. Voor zover van belang: artikel 651 lid 2. De anspoeling kont ten voordele wan de eigenaars wan den oever, zonder anderscheid of in den titel van eigendom al of niet melding worde gemaakt wan de hoegrootheid der landen; behouders de wetten en werordeningen opzigtelijk voet- en jaagpaden.

Artikel 652 lid 1 . De bij het tweede lid van het vorige artikel gemaakte bepaling is ook toepasselijk op aanspoelingen, welke aan de oevers van bevaarbare meeren plats hebben. Lid 2. Dezelfide bepaling is eindelijk ook toepasselijk op aamwassen, gorsingen en schorren, door de zee aan de stranden en aan de oevers der rivieren, alwaar ebbe en wloed gaat, angespoeld, het zij de oever an den staat, of wel aan bijzondere personen of gemeenschappen, toebehoort.

133. Asser, C., (1838), p. 239. 
in de Franse rechiswetenschap reeds voor 1838 gangbaar onderscheid tussen publiek domein (zaken met openbare bestemming) en privaat domein (zaken zonder openbare bestemming); een onderscheid dat met aanzienlijke moeite in het Burgerlijk Wetboek. met minder problemen in de Code civil te lezen was.

\section{Zaken buiten de handel}

De 'zaken buiten de handel' vormen een categorie bepalingen die, zo zagen wij, door Pitlo-Brahn als synoniem voor publiek domein worden gezien: een aan de overheid toebehorende zaak met een openbare bestemming (publiek domein), is tevens een zaak buiten de handel ${ }^{134}$. Het verband tussen beide bepalingen wordt duidelijk, wanneer het Romeinse recht wordt beschouwd. Het begrip 'zaken buiten de handel' is een begrip dat direct te herleiden is tot romeinsrechtelijke categorieën. Een latijnse benaming, die veelal wordt gebruiki, het begrip 'res extra commercium' is echter een begrip dat niet in de Romeinse bronnen voorkomt, doch later ingang heeft gevonden ${ }^{135}$. Wel wordt in Romeinse bronnen gesproken over zaken die 'extra patrimonium' zijn, en één daartoe behorende categorie betreft de "res publicae," waaronder weer de zaken met een openbare bestemming worden gebracht. Omdat, aldus Wubbe, de 'res publicae' behoren aan de staat, en de staat niet onder het privaatrecht valt, zijn deze zaken geen voorwerp van

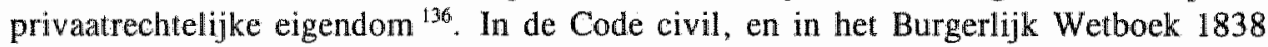
heeft dit Romeinsrechtelik concept een plaats gekregen. In voorgaande paragraaf werd duidelijk dat in het Franse recht uit de tekst van de artikelen $538-540 \mathrm{Cc}$ geen onderscheid kon blijken, maar dat dit onderscheid werd gezien in '1'affectation d'une chose à l'usage de tous."

Voorduin vermeldt het volgende over zaken buiten de handel. In de eerste plaats de tijdens de parlementaire behandeling gemaakte opmerking dat zaken buiten de handel niet onder zaken in de zin van artike 555 BW kunnen vallen. Artikel 593 bepaalt dat zaken buiten de handel geen voorwerp van bezit kunnen zijn, waardoor zij eveneens geen voorwerp van eigendom zouden kuninen zijn ${ }^{137}$. Daamaast wordt bij de behandeling van (de voorlopers van) artikel 593 BW opgemerkt dat de in een eender ontwerp voorkomende zinsnede 'Zaken aan den staat behoorende, welke niet in den handel zijn (..)' verkort werd tot 'Zaken welke niet in den handel zijn (..). ' Dit was juist gedaan om aan te geven dat zaken buiten de handel ook aan andere overheidslichamen kunnen

134. Pito-Brahn (1987), p: 45; zie ook hoofdsak 2 \&

135. Aldus Kaser, M., Rumems privaatrecht, bewarke door F.B.J. Wubbe (2e druk, 1971), p. 93 en p. 2.

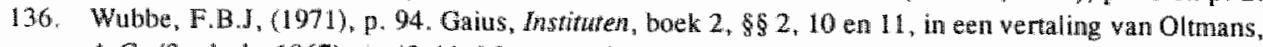
A.C. (3e druk, 1967), p. 43.4.4. Met name 11: Quae publicae sumt, nullius videntur in bonis esse; ipsius eninu unikersitatis esse creduntur. Die, welke publiek zijn, worden geacht niemands eigendom te zijn; want zij worden beschouwd van en gemeenschap of corporatie zeif te zijn. Zie voor de romeinsrechelike achtergrond eveneens: Van de Vijwer, The Etatisation of public property, in: D.P. Visser (ed.), Essays on the histary of law (1989), p. 216-300.

137. Voorduin.,$C$. deel $3(1838)$, p. 305 . 
toebehoren. Hiermee wordt duidelijk dat de wetgever destijds een verband legde tussen zaken met een openbare bestemming die aan de staat behoren $(577 \mathrm{BW})$ en zaken buiten de handel (onder andere artikel $593 \mathrm{BW}$ ) ${ }^{138}$. Vervolgens wordt in de parlementaire behandeling een criterium geformuleerd om aan te geven welke zaken als zaken buiten de handel aangemerkt moeten worden: 'de bestemming der goederen ad utilitatem publicam, zoo lang zij die bestemming blijven behouden." "39 De regering waagde zich niet aan een beschrijving wat nu precies onder 'zaken buiten de handel' begrepen zou moeten worden, omdat, zo meende zij, het onmogelijk zou zijn bij algemene definitie dit begrip te omschrijven. De rechter zou dit moeten uitmaken ${ }^{140}$. Ook Asser neemt in navolging van die parlementaire behandeling dit standpunt in:

\footnotetext{
'Men beschouwde het als ongeraden, ja als ten eenenmale onuitvoerlijk, om bij eenen algemeenen regel aan te duiden, welke het kenmerkend ondersclyeid zij usschen de zaken, welke in of buiten de handel zün. Wel is war zoude men onder de laatstgemelde kunnen rangschikk en de zoodanige, die ten algemeenen mutte strekken, doch mern ware daarmede weing gevorderd, omdat alsdan sleeds de vraag zoude zijn onbeanrwoord gebleven, wat met door alge meen nut te verstaan hebbe.'
}

De wetgever noemt daarom geen criterium, maar wat heeft nu de rechter te doen, wanneer zich een vraag aan hem voordoet. Die moet in dat concrete geval beslissen, of de zaak in kwestie een zaak buiten de handel is, en daarbij het genoemd criterium moeten aanwenden. Aldus worden de bepalingen over zaken buiten de handel, door dit niet in de wet genoemd criterium in verband gebracht met de zaken die in artikel 577 aan de staat behoren ${ }^{|c|}$. Deze onduidelijkheid over het criterium zou nog lang in de discussie van invloed blijven.

\section{$\S 5$. Conclusies}

De betekenissen konden alleen met veel moeite uit de Nederlandse parlementaire geschiedenis en uit de voorgaande ontwerpen van wetgeving worden afgeleid. Er was meer nodig dan deze Nederlandse bronnen. De Franse wetgeving en de commentaren waren onontbeerlijk. Soms moest van Romeins recht gebruik worden gemaakt. De mogelijkheid van een aansprakelijkheid voor zaken in het algemeen was aangereiki door Franse commentaren: op alle zaken kon $1384 \mathrm{Cc}$ van toepassing zijn. De vraag of schuld was vereist, kon bevestigend worden beantwoord. De betekenis van artikel 2014 werd in Nederland als bekend verondersteld en er werden weinig woorden door de wetgever aan besteed. In de Franse commentaren blijkt van een groot aantal onduidelijkheden. Dezelfde onduidelijkheden zullen zich voortplanten in de Nederlandse discussie:

138. Voorduin, J.C, deel 3 (1838), p. 353.

139. Voorduin, J.C., deel $3(1838)$ p. 354.

140. Voorduin, J.C., deel 3 (1838), p. 355; en deel 4 (1838), p. 495 .

141. Asser, C., (1838), p. 243. Zie over dit argument ook Opzoomer, die meent dat met dit critertum juist wel een nadere bepaling van de zaken buiten de handel wordt gegeven (hoofdstuk $5 \$ 4 . D, 2$ ). 
is sprake van eigendom bij de bezitter of slechts een vermoeden van eigendom; is een titel vereist, of goede trouw; gaat het om een verjaring? Over de rechtstoestand van publiek domein bleef ook een sluier hangen. Was in de wetgeving een aparte plaats ingeruimd voor publiek domein? Uit de Code civil kon zulks met meer kracht worden beweerd dan uit de Nederlandse wetgeving. De Romeinsrechtelijke 'res extra commercium' waren als zaken buiten de handel teruggekeerd in de nieuwe Franse en Nederlandse wetgeving, maar wat moest onder deze bepalingen worden gebracht? Zaken die tot allgemeen nut strekken? Dat criterium was niet in de wet genoemd. En was publiek domein buiten de handel? Het zijn vragen die zo expliciet nog niet werden gesteld, maar in de volgende perioden aan de orde gesteld zullen worden. Wat wij in dit hoofdstuk zèlf gedaan hebben, vaststelling van betekenissen van de onderwerpen en artikelen, zullen wij in de komende hoofdstukken overlaten aan de Nederlandse juristen van na 1838. 
Hoofdstuk 4

\section{Rechtsvergelijking als wetshistorie (1838-1850)}

\section{\$. Inleiding}

De interpretatie van de onderwerpen voor 1838 was lastig. De wetgever blijkt een duidelijk begrip van de artikelen bij de Nederlandse juristen als aanwezig verondersteld te hebben. Meerduidigheid in het Franse recht werd doorgegeven in het Nederlandse recht, en lag besloten in de Nederlandse bepalingen. Vanwege de vaak vrijwel letterlijke vertalingen lag kennisname van de Franse literatuur voor de hand. Zo stelt De Pinto in zijn voorwoord in 1838 dat de Franse commentaren in ieders handen behoren te zijn. Illustratief voor het belang van het Franse recht is ook dat Diephuis in zijn vroegere werk Het Nederlandsch burgerlijk regt, naar de volgorde van het Burgerlijk wetboek in opmerkelijk veel gevallen eerst verwijst naar de Franse auteurs, dan pas naar de Nederlandse. Kennisname van het Romeinse recht werd, ondanks de formele afschaffing, evenzeer dringend aanbevolen, 'rationis auctoritate.' In de Duitse rechtswetenschap werd het Romeinse recht als eigentijds recht beofend, en ook via de Duitse rechtswetenschap werd verwezen naar Romeins recht. Deze opvattingen over Frans en Romeins recht zijn voor de beschouwingen voor de eerste periode na 1838 nog van grote betekenis.

\section{A. KENNISNAME VAN ANDERE RECHTSSTELSELS IN HET NEDERLANDSE PRIVAATRECHT}

\section{Kwantitatieve weergave}

Van het totale antal verwijzingen (1503) in het handboek van De Pinto (1838) is $42 \%$ naar Nederlandse bronmen en $41 \%$ naar Franse. In $2 \%$ wordt naar Duitse bronnen verwezen, terwijl slechts twee maal naar Belgisch recht word verwezen. Een percentage van $15 \%$ is naar Romeins recht. Uit zes jaargangen van Themis tussen 1838 en 1850 is een percentage van $49 \%$ naar Nederlandse bronnen, $21 \%$ naar Franse bronnen, $22 \%$ naar Romeins recht en $6 \%$ naar Duitse bronnen. In de tweede druk wan Diephuis' commentaar wordt in $60 \%$ van het totaal aantal verwijzingen verwezen naar Franse bronnen, in $36 \%$ naar Nederlandse bronnen, in $4 \%$ naar Duitse, en in $1 \%$ van de 
gevallen werd naar Romeins recht verwezen. De inhoudsopgave van twee jaargangen Themis laat slechts 1 artikel met Duits recht als onderwerp zien van de 31 artikelen. Van de 30 besproken of aangekondigde boeken zijn er 3 op het Franse recht gericht, en is er I Spaans werk.

\section{Romeins recht en Frans recht: terugtred en verandering}

Ook vanaf de codificatie van 1838 wordt gewezen op het belang dat voor de rechtswetenschap in het Franse en het Romeinse recht is gelegen als hulpmiddel bij de uitleg van de Nederlandse bepalingen. Carel Asser had de verwachting uitgesproken dat het gezag van het Franse recht na invoering van het $B W$ in 1838 nog zeker een halve eeuw zou voortduren ${ }^{142}$. Den Tex en Van Hall stellen, net als De Pinto, dat van de van de Franse wetgeving, van Merlin en van Toullier, door onze jongelingschap kennis genomen moet worden ${ }^{843}$. Veel schrijvers halen bij de bespreking van de Nederlandse bepalingen de overeenkomstige artikelen uit de Code Civil aan en wijzen kort op overeenkomsten en verschillen in de redactie. Soms gebeurt dit min of meer uitgebreid, zoals door Carel Asser, soms beknopter, zoals in De Pinto's handboek. De Martini heeft in zijn De Nederlandsche wergeving uit 1840 een zeer abstractanalytische benadering. De sleutel tot de betekenis van de Nederlandse bepalingen is bij hem als volgr: "eene eenvoudige aanhaling' betekent dat 'hetzelven van gelijken inhoud is;' 'indien voor het Fransche artikel geplaatst is $\mathrm{Vg}_{\mathrm{g}}$,' betekent dit dat 'hetzelve in het Nederlandsche artikel is gewijzigd;" als 'geene aanhaling hoegenaamd van een Fransch artikel" plaatsvindt, dan betekent dit, dat er in de Franse codificatie geen bepaling van gelijke strekking voorkomt als de Nederlandse bepaling ${ }^{144}$. De benadering die bij de totstandkoming van de Nederlandse wetgeving werd gekozen, het niet expliciteren van de discussie over de Franse bepalingen zet zich voort. Pas later wordt het Franse recht uitgebreider behandeld.

Behalve deze vooranstaande positie van het Franse recht werd ook het Romeinse recht door de juristen van kort na 1838 een functie toebedacht. Duidelijk daarover was Den Tex. In navolging van dit standpunt kan de mening van Goudsmit en Opzoomer geplaatst worden. Ook zij stellen zich achter het gebruik van Romeins recht als hulpmiddel voor de uitleg van het Nederlandse burgerlijke wetgeving; zij spreken echter over Romeins recht als een nationaal recht, omdat het in het Nederlandse recht geïncorporeerd is, en bestudeerd moet worden in verband met de Nederlandse codificatie ${ }^{145}$. Daarbij zal de beoefening van Romeins recht als eigentijds recht in Duitsland een rol

142. Zie hoofalstuk 3 \& 3, Asser, C. (1838), p. i-ii.

143. Den Tex, C.A., en J. vin Hail, (1839), p. vi. De Pinto, A. (1838), p. 5. Het handboek van Lipman is opgezet naar voorbeeld van Rogron. Zie Van Hasselt, W.J.C., (1843), p. V.

1.44. De Martini, G.J., (1840), p. 5-6.

145. Zie hoofdstuk 3. 2. Goudsmie, J.E. en C.W. Opzoomer, Beschouwing wan artikel 881 en 619 B.W., Themis 1844, p. 251. 
gespeeld hebben ${ }^{146}$. Zowel Opzoomer als Goudsmit maken in de analyse van de bepalingen in het Burgerlijk Wetboek gebruik van Duits en Oostenrijks recht. Tegelijk wordt reeds een terugtred zichtbaar van het Romeinse recht. Waaraan ligt dat? Opzoomer en Goudsmit stellen vast dat in het Nederlandse privaatrecht een gewoonte is ontstaan veel naar het Romeinse recht te verwijzen. Lang niet alle verwijzingen naar Romeins recht worden door hen als even zinvol beschouwd. De privaatrechtswetenschap maakt zich vaak schuldig aan nutteloze aanhalingen van bepalingen uit het Corpus Juris. Op veel plaatsen heeft 'ons eigen wetboek beslist, "en kan het 'uit zich zelve worden verklaard'. En zo krijgt het Romeinse recht al spoedig een minder prominente positie bij de uitleg van de Nederlandse bepalingen. Opzoomer zet met behulp van een handigheid ${ }^{147}$ het Romeinse recht op een zijspoor. Diephuis, die in zijn eerste werk het Romeinse recht in dit geval zonder voorbehoud gebruikt, verwerpt in zijn latere werk het gebruik expliciet ${ }^{148}$.

\section{§2. Aansprakelijkheid voor zaken}

\section{A. EEN EERSTE IMPLICIETE BETEKENIS IN DE LITERATUUR}

De meest waarschijnlijke betekenis in 1838 van de zinsnede in artikel 1403 is die waarbij een schuldaansprakelijkheid kan bestaan voor elke zaak. Schuld (of nalatigheid) is vereist. Dit ligt dan besloten in een gebrek in het uit te oefenen opzicht. De eerste Nederlandse commentaren laten zich echter nog nauwelijks uit over de betekenis van deze zinsnede. Zo is De Pinto's bespreking uiterst summier. Wat daaruit naar voren komt is dat zijn uitleg voor een groot deel overeenstemt met de uitleg die bij Toullier aangetroffen werd. De zinsnede wijst bij De Pinto op een algemene aansprakelijkheid voor zaken die iemand onder zijn opzicht heeft:

"Men is veranwoordelijk voor de schade, veroorzaakt: $1^{\text {" }}$. door zijne eigene daad. ...4". door eene zaak, welke men onder zijn opzigt heef, of een gebouw, waarvan men eigenar is, indien dezelve door verzuim wan onderhoud, of door een gebrek in de bouwing of inrigting is te weeg gebrache." 149

146. Modderman, W., De receptie van het Romeinsche regt (1874), p. 8.

147. Waarbij hij aan de ene kant een sterk aan tekst gekoppelde uitleg geeft van een bepaling om de betekenis zoals die in zijh ogen is (ius constitutum) te achterhalen, aan de andere kant een veel yrijere uitleg gebruikt on de betekenis zoals die zou moeten zijn (hus constitusendum) te kunnen vaststellen. Zie verder hierover hoofdstuk 5 1.C.3.

148. Zie \& 4.B en hoofdstuk 5 4.D.2. Over deze verwerping Lokin , J.H.A., De taak van de rechtswetenschap volgens Diephuis en Opzoomer, In: G. Diephuis, C.W. Opzaomer $1892-1992$ (Een utgave van de stichting "Het Groningsch Rechtshistorisch fonds, 1992). Verder is Diephuis zeer karig met het gebruik wan Romeins recht, ook in zijn eerdere werk.

149. De Pinto, A., deel 1 (1838), p. 201-202. 
Toullier wordt door De Pinto vaak gebruikt, onder andere bij de aansprakelijkheid voor personen die ook in artikel $1403 \mathrm{BW}$ is weergegeven. Uit dit standpunt kan een uitleg voor de aansprakelijkheid voor zaken volgen. De Pinto verwijst naar Toullier en deelt diens standpunt. Die aansprakelijkheid voor personen zou slechts gelden met betrekking tot de in dat artikel genoemde personen ${ }^{150}$. Tot andere personen mag de aansprakelijkheid niet worden uitgebreid. Waarom niet? Een 'algemeen beginsel' ligt daaraan volgens De Pinto ten grondslag. Artikel $1403 \mathrm{BW}$ is bedoeld als een uitzondering op de regel dat iemand slechts aansprakelijk is voor eigen doen of nalaten ${ }^{151}$. De Pinto verwerpt het tegenover Toullier staande standpunt van Delvincourt, die juist wel een uitbreiding tot andere personen voorstaat ${ }^{152}$. Deze argumentatie laat zich denken voor de aansprakelijkheid voor zaken, die zich dan niet verder kan uitstrekken dan de zaken als genoemd in de artikelen 1404 en 1405. Dit argument wordt gebruikt in de conclusie voor het arrest inzake de Amsterdamsche Pijpgaz-compagnie ${ }^{153}$. Over het vereiste van schuld wordt door De Pinto niet gesproken. De reden voor dit ontbreken ligt besloten in het bovenstaande argument. De aansprakeliikheid voor andere personen is een uitzondering op de normale aansprakelijkheid voor eigen doen of nalaten. Die uitzonderingen zijn in de wet weergegeven. Een aansprakelijkheid voor zaken in het algemeen zou ook een uitzondering zijn, en dan is volgens. De Pinto wetgeving noodzakelijk. Daarvan is geen sprake, en schuld is een noodzakelijk vereiste.

De twee commentaren van Toullier en Delvincourt illustreren dat meerdere visies verdedigbaar waren met betrekking tot de uitleg van artikel $1384 \mathrm{Cc} / 1403 \mathrm{BW}$. Een enge uitleg, waarbij de opsomming van de personen en de zaken (in 1404 en 1405) als limitatief moet worden aangemerkt; en een ruime, waarbij dat niet het geval is. De Pinto lijkt een aanhanger van de enge opvatting. In andere kort na de codificatie verschenen werken zijn minder aanknopingspunten aan te treffen. Zo wordt door Asser niet gesproken over aansprakelijkheid voor zaken, terwijl hij in het algemeen voor niet door hem behandelde artikelen (die niet zouden afwijken van de Franse bepalingen) verwijst

150. Artakel 1403 lid 1. Men is niet alleen verantwourdelijk voor de schade, welke men door zijne eigene dand veroorzatkt, naar ook voor die welke veromzatkr is door de daad van personen voor welke men a ansprakelijk is, of door zaken wetke men onder zijn opzigt heeft. 2. De vader, en bij gebreke van dien, de moeder zijn veranwwoordelijk voor de schade, veroorzakkt door humne minderjarige kinderen, die bij hen inwonem. 3. De meesters en degenen die anderen aamstellen tot de waarneming hunner zaken zijn verantwoordelijk voor de schade, door humen dienstboden en ondergesch ikten veroorzaakt. in de werkzamheden waartoe zij dezelve gebruikt hebben. 4. De schoolonderwijzers en werkmeesters. zijn verantwoordelijk voor de schade door hunnen leerlingen en knechts veroorzaakt, gedurende den tijd dat dezelwe onder hun toezicht staan. 5. De hier-boven wermelde verantwoordelijkheid houdt op. indien de vater en de noeder, de schoolonderwijzers en werkmeesters bewijzen dat de daad "voor welke zij aansprakelijk zouden zijn, niet hebben kunnen beletten.

151. De Pinto, A., deel 2 (1838), p. 370. Toultier, C.B.M., deel 11 (1824), p. 279-280.

152. Zie hoofdstuk 3 4.A. De Pinto. A., deel 2 (1838), p. 370. Toullier, C. B.M., deel 11 (1824), nr. 279-281: Delwincourt, deel 8, ur, 454 en 455 .

153. Weekblad wan het Recht 2031 (1859), p. 4; zie ook hoofdstuk 5 \& 2.B. 
naar de Franse discussie ${ }^{154}$. Ook andere werken, van De Martini, van Van Hasselt en van Lipman gaan niet in op een aansprakelijkheid voor zaken ${ }^{155}$. Ook in Opzoomers eerste (driedelige) commentaar ontbreekt een stellingname ${ }^{156}$. Uit de commentaren kan worden afgeleid dat, zo men al aan een aansprakelijkheid woor zaken dacht, die aansprakelijkheid niet afweek van de artikelen 1401-1402. Indien een afwijking van het schuldvereiste was bedoeld, dan zou dit expliciet in de wetgeving uitgedrukt moeten zijn.

\section{B. 1850: BEVESTIGING IN RECHTSPRAAK}

Het impliciete standpunt, dat er een aansprakelijkheid voor alle zaken in artikel 1403 ligt besloten, maar dat voor het bereiken van die aansprakelijkheid wel schuld is vereist, wordt in de rechtspraak bevestigd. Een arrest uit $1850^{157}$ wordt in latere negentiende eeuwse commentaren vaak aangehaald als illustratie. Sprake was van een in de Rotterdamse haven lekgestoten schip. De schipper sprak de gemeente Rotterdam aan ter vergoeding van de schade, en baseerde zijn vordering op artikel 1403. De rechtbank wees de vordering af omdat de schipper er niet in slaagde te bewijzen dat het ongeluk te wijten was aan de schuld of de nalatigheid van de gemeente Rotterdam. Het ZuidHollandse Provinciaal Gerechtshof daarentegen stelde dat schuld besloten lag in de feitelijke omstandigheden, te weten de plaats van het gebeurde en het gegeven dat de gemeente eigenaresse van de haven was en het beheer daarover had. Dit kon niet volgens de Hoge Raad. Met deze door het Hof aangenomen omkering van cle bewijslast zou volgens de raad artikel 1902 geschonden zijn ${ }^{i 58}$. Daarmee is door de Hoge Raad uitgegaan van aanwezigheid van een schuldvereiste in artikel 1403. Volgens de Hoge Raad zijn afwijkingen van deze regel, zoals een omkering van de bewijslast, alleen dan toegestaan wanneer dit in wetgeving uitdrukkelijk is bepaald ${ }^{159}$. Opvallend is de uitspraak van het Provinciaal Gerechtshof. Het Hof bewerkstelligt op deze wijze een matiging van het schuldvereiste. Slechts weinig jaren na deze uitspraak zal de in de inleiding al behandelde uitspraak over de Amsterdamse gasmatschappij volgen. De summiere uitleg die de Hoge Raad daarin gebruikt, is de aanzet to een uitgebreide discussie in de لliteratuur.

154. Asser, C., (1838), p. ix.

155. De Martini, G.J. (1840): Lipman, S.P. Het Burgerljk Wetboek voorafgegaan door de wet, houdende algemeene bepalingen der weggeving wan het koningrijk, wergeleken met her Romeinsche en het Fransche regt (1839): Van Hasselt, W.J.C., (1843).

156. Zie Opzoomer, C. W., Het Burgerijke Werboek. Awneekening op de artikelens die thans nog verktaring behoeven, deel $3(1852)$.

157. HR 7 november 1850 , Weekblad van her Recht 1218 (1851). p. 2.

158. Arrikel 1902. Een tegelijk die beween eenig regt te hebben, of zidh op cenig fët tot staving wan zijn regt, of tot tegenspraak wan eens anders regt, beroept, mot hei bestalan wan dat regt, of van dat feit, bewijzen.

159. Bij de uitleg wan de aansprakelijkheid in de Spoorwegwet tegen het einde van de negentiende eeuw zal dit artikel een belangrijk argument zijn om de grenzen van aansprakelijkheid niet al te veel op te rekken. Zie hoofdsruk $6 \$ 2.3$. 


\section{§ 3. Bezit geldt als volkomen titel: vele interpretaties van artikel 2014}

De behandeling van het artikel 2014 in de commentaren na de codificatie wordt gekenmerkt door een grote verscheidenheild van ver uit elkaar lopende standpunten. In deze baaierd van interpretaties valt geen rode lijn te ontdekken, maar wel kunnen de standpunten die later, sinds 1870 tot de heersende werden reeds worden onderscheiden. Wel is sprake van een rode lijn in de wijze waarop de verschillende standpunten worden gevormd: het is de rechtshistorie die met name van belang is voor de interpretatie.

\section{A. LITERATUUR}

\section{De Pinto}

In 1838 stelt De Pinto dat artikel 2014 BW een noodzakelijke bepaling is, omdat roerende goederen van hand tot hand worden overgegeven, zonder dat enig schriftelijk stuk de overgave hoeft te staven. Zonder de bepaling zou handel onmogelijk worden, want 'niemand zou zich meer een roerend goed van enige waarde willen aanschaffen, indien hij ieder ogenblik aan het gevaar door uitwinning derzelve blootgesteld was.' De regel 'en fait de meubles possession vaut titre' is volgens De Pinto alleen van toepassing 'indien men cene roerende zaak voor zich-zelven als eigenaar bezit (..).' Geen toepassing vindt het artikel wanneer voor een ander gehouden wordt ${ }^{60}$. Dit schept alleen duidelijkheid over de betekenis van 'bezit."

\section{Goudsmit en Opzoomer}

Goudsmit stelt, onder verwijzing naar Bourjon zoals deze wordt vermeld bij Troplong, dat de in 2014 genoemdle zaken niet vatbaar zijn voor verjaring: "lla possession d'un meuble, ne füt-elle que d'un jour." "Artikel 2014 stelt alleen de noodzaak van bezit, ten einde tegen de revindicatie van de eigenaar te worden beschermd. Goede trouw van de bezitter is niet vereist. Dat zou niet stroken met de plaats van artikel 2014:

\footnotetext{
alle deze vereiselhten betreffen de usucapio, terwijl de plats waar onze regel voorkomt, een duidelijk blijk is dat het bezin op zich zelve beschouwd, onafhankelijk van elke hoedanigheid" ik zoude bijna zeggen het ongequalificeerd bezit, het middel is waardoor de reivindicatio wordt kracheloos gemakn." 161
}

Bezit, uitgelegd conform artikel $585 \mathrm{BW}^{162}$, wordt door Goudsmit eigenlijk gelijkgesteld met eigendom. Iedere eigenaar kan revindiceren, 'zoo lang hij eigenaar is, maar

160. De Pinto, A., deel 2 (1838), p. 507.

161. Gondsmit, J.E. Bespreking van: Van Boneval Faure, Specimen inawgurale continens obserwationum ad tit. WI, Lib. IV Codicis Civils Capina IV. Groningae 1848, in: Themis 1848, p. 675-690.

162. Artikel 585. Door bezit wotd verstan het houden of genieten eener zaak, welke iemand, of in persoon, of door wen ander, in zijne magt heeft, als of zil hem toebehoonde. 
nu gaat de eigendom door verlies van het feitelijk bezit verloren." ${ }^{163}$ Opzoomer over $2014^{1644:}$

\begin{abstract}
"De zin van onze bepaling is derhalwe van dezen inhoud: ieder, die een roerend goed onder zich heeff, op welken grond en op welken wijze ook, heeft een titel, niet on zich als eigenaar to beschouwen, maar om de revindicatie van dat goed, even krachig als ware hij eigenaar, af te slaan." 165
\end{abstract}

Bij deze uitleg maakt Opzoomer, naar hij expliciet opmerkt, gebruik van de woorden der wet en de plaats van artikel 2014 in het BW. Opzoomer brengt artikel 2014 in verband met de bevrijdende verjaring (prescriptio), de afdeling waarin het artikel zowel in de Franse, als in de Nederlandse wetgeving is geplaatst. Het artikel geeft dan aan dat er sprake is van een verjaring van de revindicatie zonder het geringste tijdsverloop ${ }^{166}$. Van verkrijgende verjaring (usucapio), zonder tijdsverloop (zoals door Goudsmit wordt voorgestaan) kan op systematische grond geen sprake zijn. Goudsmit reageert op Opzoomer en bespreekt onduidelijkheden in het Franse recht, waarbij hij de standpunten van Toullier, Troplong en Marcadé behandeldt ${ }^{167}$. Goudsmit stelt de bezitter aan de eigenaar gelijk. Opzoomer kende de bezitter slechts een verweer tegen de eigenaar toe. Goudsmit gebruikt wetssystematische, grammaticale en historische argumenten.

Was slechts een afweren van de revindicatie bedoeld, zoals Opzoomer meende, dan zou een plaats bij de revindicatie ${ }^{168}$ meer voor de hand hebben gelegen. Daarnaast stelt Goudsmit zich tegen Opzoomers argument dat 2014 niet bij de verkrijgende verjaring is geplaatst, de tweede afdeling van titel 7 . Waarom? In de Franse Code civil is artikel $2279 \mathrm{Cc}$ in de afdeling. 'De quelques préscriptions particulières' geplaatst, niet om het artikel van verkrijgende verjaring af te zonderen, maar om een onderscheid te maken met de in de Code civil voorgaande afdelingen betreffende "De la préscription trentenaire' en 'De la préscription par dix et vingt ans." Dit laat de mogelijkheid open artikel $2279 \mathrm{Cc} / 2014 \mathrm{BW}$ als een verkrijgende verjaring te beschouwen ${ }^{169}$.

Goudsmits grammaticale argument houdt in dat de uitdrukking 'bezit geldt als volkomen titel' zeer ongelukkig gekozen was, wanneer de wetgever Opzoomers standpunt, afwering van revindicatie, ermee bedoeld had uit te drukken ${ }^{170}$. Dit laatste argument is niet sterk, omdat het artikel nu juist geen enkel standpunt heider vertolkt. Wel een

164. Opzomer, C.W., deel 3 (1852), p. 316-324.

165. Opzoomer, C.W. deel 3 (1852), p. 321.

166. Opzoomer, C.W. deel 3 (1852), p. 317 .

167. Goudsmi, J.E., Over de werking en den aard van het bezil van roerende goederen, naar aanleiding van art 2014 BW. Themis 1854 , p. 473.

168. Artikel 629. De eigenaar heeft het regt om de aan hem toebehoorende zatik wan iederen houder terug te vorderen, in den staat waarin zij zich bevindt.

169. Goudsmit, J.E., (1854), p. 477; rie ook Toullier in hoofdstuk $3 \& 4, B$.

170. Goudsmit, J.E., (1854), p. 479. 
krachtig argument heeft Goudsmit met zijn constatering dat in zijn uitleg de eigendom wordt verkregen ${ }^{171}$. Goudsmit verwijst naar een identiek verschil van mening in de Franse doctrine tussen Toullier en Troplong. De laatste huldigde hetzelfde standpunt als Goudsmit, en gebruikt daarvoor hetzelfde argument. Wetshistorische argumenten haalt Goudsmit tevens uit de geschiedenis wan de totstandkoming van de Code civil. Dat Bourjon"s standpunt in de Code civil opgenomen is blijkt voor Goudsmit uit enkele zinsneden van Bigot-Préameneu en Goupil-Préfell ${ }^{172}$. Vervolgens behandelt Goudsmit enkele concrete vragen: wat onder 'bezit' in artikel 2014 BW wordt verstaan; of de goede trouw een vereiste is en of voor de toepassing van artikel 2014 een geldige titel is vereist. Achtereenwolgens zullen we deze punten in Goudsmits betoog behandelen.

Wat wordt in artikel 2014 verstaan onder "bezit"? Wordt daarmee houderschap bedoeld, of het engere houden voor zichzelf ("animo domini")? Goudsmit meent het laatste, en plaats zijn standpunt tegenover het standpunt van Opzoomer, waarbij Goudsmit de Duitse rechtswetenschap betrekt ${ }^{173}$. De term 'bezit' in artikel 2014 moet gelezen worden in de zin van artikel 585 , en betekent dan het houden van een zaak voor zich zelf, het 'burgerlijk bezit.' Moet bezit in artikel 2014 BW te goeder trouw zijn? Goudsmit: 'Deze vraag wordt bevestigend beantwoord behalve door vroegere autheurs over het Fransche regt door Marcadé (..), en zulks in strijd met de in Frankrijk nagenoeg algemeen gevestigde jurisprudentie.' Ook Delvincourt, Merlin en Troplong stelden goede trouw als vereiste, onder meer in navolging van Bourjon. Niettemin werd in de Franse rechtspraak de goede trouw echter niet vereist, zoals Marcadé met enige ontzetting vermeld ${ }^{174}$. Goudsmit verwerpt het goede trouw-vereiste eveneens, stelt bij Bourjon dit vereiste niet te kunnen lezen, en stelt verder dat het beroep van de Franse juristen op artikel $1141 \mathrm{Cc}^{175}$, waar de eis van de goede trouw wel gesteld wordt, op wetssystematische grond volstrekt onjuist is. In artikel 1141 wordt de goede trouw terecht als eis gesteld ter voorkoming van dubbele verkoop. De goede trouw, door Troplong en Marcadé gesteld op grond van de 'eerlijkheid in de handel' is volgens Goudsmit nu

171. Onder het oude recht (voor 1992) was dit bij de heersende uitleg een probleem: bezit en eigendom waren durzaam geseheiden. Beekhus, J.H, in: Asser-Beekhuis I, zakenrecht (10e druk, 1975), p. 268 ev.

172. Goudsmir, J.E., (1854), p. 476 ev,

173. Goudsmir, J.E. (1854). p. 484 ew.

174. Marcadé, V., (1854), p. 248 en 250: "La première condition requise, c'est que la possession soit de bonne foi. L"idéte de la loi ast d'excuser l'erreur, et nullement de favoriser la fraude (...) Or, chose incroyable, si claires et si simples que soient ces idées elles paraissent n"avoir jamais été comprises jusqu'a ce jour dans le monde judiciaire (...)" Merlin, M. Répertoire de jurisprudence, deell 29, (5e $\mathrm{druk}_{\mathrm{k}}$ 1828), Revendication, p. 411: (. . ) le proprietaire d'un effet mobilier ne peut le revendiquer sur le tiers possesseur qui l'a acquis de bonne foi du non propriétaire, que dans deux cas: dlans celui ou cet effet a été perdu par le propriétaire, et dans celui ou il a été volé."

175. Artikell $1141 \mathrm{Cc}$. Si la chose qu"on s'est obligé de donner ou de livrer à deux personnes successivement, est purement mobilière, celle des deux qui en a té mise en possession réelle est préféréte et en demeure propriétaire, encore que son titre soit postérieur en date, pourvu toutefois que la pössession soir de bonne foi. 
juist een belemmerende factor (procedures), en dit is onderkend bij de totstandkoming van de Code civil ${ }^{176}$. Ook een geldige titel is volgens Goudsmit niet vereist. De tekst van de wet spreekt dit tegen: waar bij verjaring de vereisten bezit, goede trouw en een geldige titel vereist, en in artikel 2014 spreekt over "geldt als ...titel," 'mogen wij dan behalve het bezit een titel eischen?' ${ }^{m}$ Goudsmit verwerpt Marcadé's interpretatie: de vereisten voor verjaring, goede trouw en een geldige titel, worden niet in het eerste hoofơstuk van de twintigste titel van de Code civil, "Dispositions générales" besproken, doch alleen bij de concrete tien- en twintigjarige verjaring. Uitbreiding bij wijze van analogie naar artikel $2279 \mathrm{Cc}$ is daarom niet toegestaan ${ }^{17 \%}$. Opzoomer blijft vier jaar later in een reactie op Goudsmit's artikel bij de interpretatie die hij in 1852 gaf: "Mijn vriend $\mathrm{G}$. heeft de kracht van dit betoog volkomen gevat, zonder er echter door overtuigd te worden.' 179 Opzoomer verwijst kort naar Marcadé, met wiens standpunt het zijne grote overeenkomst vertoont ${ }^{180}$.

\title{
3. Goudsmit en Philips
}

Philips staat een ruim begrip van het in artikel 2014 genoemde bezit voor en begrijpt daaronder ook de houder. Hij neemt daarmee hetzelfde standpunt in als Opzoomer.

\begin{abstract}
'Enkel van verloren of gestolen goed kan eene vindicatie plats hebben; geene andere roerende zaken kunnen het woorwerp van die actie zijn. Hij die eene, niet gestolen of verloren, roerende zaak in zijne magt heeft is daarvan steeds de eigenaar, onverschillig of hij houder, bezitter ad interdicta of bezitner ad usucapionem zij. Die derhalve eene roerende zaak wrijwillig uit zijne magt geeft verliest de vindicatie; die eene zaak tegen zijnen wil ontbeert kan ze terugvorderen. Waanut volgt dat de eigendom eener roerende zatak verkregen wordt door iedere overgave der zaak " uit welke oorzaak ook geschied. Met het wegvallen der vindicatie verwalt immers ook het eigendom, daar het juist het toekennen van beschemende regtsmiddelen is wat een toestand tot eern regt maakt." "81
\end{abstract}

Maar anders dan bij Opzoomer, kent Philips de eigendom toe, zoals ook Goudsmit deed. Philips is de eerste die de gelijkstelling van bezit met eigendom als Germaansrechtelijk betiteld ${ }^{182}$. Juist de onderbouwing van dit standpunt zal door Goudsmit met

176. Goudsmit, J.E., (1854), p. 491

177. Goudmit, J.E., (1854), p. 493 .

178. Marcade, V., (1854), p. 250; hoofdstuk $3 \$ 4 . B$.

179. Opzoomer, $\mathrm{C}$.W., Over den aard en de werking van het bezit wan roerende goederen, naar analeiding van art. 2014 BW, Themis 1856, p. 96.

180. Opzoomer, C.W., (1856), p. 108.

181. Phillips, Ang. (1849), p. 41-42

182. Philips, Aug., (1849), p. 43. Van éên Germaansrectrelijk stelsel is in het geheel geen sprake. Zie daarower Scholten, P., Mr. C. Asser's Handleiding tot de beoefening wan het Nederlandsch burgerlijk recht, deel 2, zakenrecht (5e druk, 1913), p. 73. Karakteristiek voor dit "Germanase recht" is dat bescherming wordt werleend aan ieder die bezit, die een 'gewere" heeft over een zaak. Wordt een zaak vrijwillig uit handen gegeven, dan ontbeert degene die de zaak wit handen gaf de mogelijkheid om de 
kracht worden bestreden. Philips beroept zich vooral op de Duitse rechtswetenschap, met name Hugo, Puchta, Mittermaier, Phillips en Bethman-Hollweg. 'Ontijdige romanisering!' reageert Goudsmit in 1854, onder verwijzing naar Savigny: houders, rechthebbenden op andere zakelijke rechten, zoals de vruchtgebruiker, hebben eigen rechtsmiddelen tegen een stoornis in de uitoefening van hun recht en hebben de bescherming van 2014 niet nodig ${ }^{183}$.

\title{
4. Diephuis
}

Diephuis is in tegenstelling tot Opzoomer niet van mening dat artikel $2014 \mathrm{BW}$ iets met verjaring te maken zou hebben:

\begin{abstract}
"Welke nu ook de zin mag zijin, dien men aan deze bepaling meent te moeten geven, in allen gewalle komu met opzigr tot die goederen geene verjaring te pas. (..) De bezitter heeft door zijn bezit alles wat hij noodig heeff; werjaring komt hier dus niet te pas; zij zou hem niet meer geven dan hij reeds zonder haar heeft." 184
\end{abstract}

Wat betekent artikel 2014 voor Diephuis wel? Diephuis: '(..) het komt mij voor, dat onze wetgever daardoor het bezit heeft willen doen gelden als het volkomen bewijs van eigendom, en alzoo den bezitter als eigenaar behandeld wil hebben.' bezit op zich zelf het volkomen bewijs van eigendom, zoo is ook de bezitter daardoor in het oog der wet volkomen eigenaar." Bezit vat Diephuis op in enge zin (houden voor zichzelf), omdat dit in het algemeen de zin is waarin de wet van bezit spreekt ${ }^{186}$. Van verjaring is in het geheel geen sprake, en hij verwerpt dan ook de opvatting van Toullier, die een verjaring voor roerende goederen in artikel $2279 \mathrm{Cc}$ had gelezen, waarvoor titel noch goede trouw een vereiste was ${ }^{187}$.

\section{Coninck Liefsting en Faber}

De gelijkstelling van bezit aan eigendom (het Germaanse beginsel) is voor Coninck Liefsting net als voor Philips en voor Diephuis, het leidende beginsel:

$182 . \rightarrow$

Zatak teng te vorderen van een derde (die dan een gewere heefo). Romeins recht verdringt door receptie deze inheemse opvatting, en het recht on de zaak onder een derde op te vorderen, werschijnt. Zo bijwoorbeeld bij Hugo de Groot, die stelt dat 'den eygendom bestaet in dat regt on weeder te bekomen het verloren bezit." Zelfs zou de eigenaar dat hebben tegen een bezitter te goeder trouw, zo voegt hij daaraan toe. De Groot, H., (1952), II.3.4 en II.3.5.

183. Goudsmit, J.E. (1854), p. 484 ev.

184. Diephuis, G. Het Nederlandsch Burgerlijk Regt naar de valgorde van het burgerlijk wetboek (18561859), deel 9. nr. 626 en deel 3 , nr. 205 ew. en 294 ev.

185. Diephuis, G., (1856-1859) deel 3, p. 87-88.

186. Zie boven \$ 3.A.2 en \$ 3.A.3.

187. Zie hoofdstuk 3 \&.B. 


\begin{abstract}
"Het Romeinsche recht onderscheidde ook bij roerende zaken eigendom en bezit; ons recht daarentegen vereenigt beide rechten met betrekking tot roerende zaken. Eenwoudig bezil geldt wolgens art. $2014 \mathrm{~B}$. W. als volkomen titel van eigendom. Dit is het Oud Gemaansche beghsel, dat geen bezit van eigendom onderscheidde. (...) De rechthebbende op de zak (eigenaar en bezitter tegelijk), die zijn goed aan een ander toewertrouwt en dar in zijn feitalijk bezit overbrengt, verliest volgens Germaansche beginselen zijn zakelijk recht, dat is, het recht om dat goed van elken houder terug te vorderen "om daarvoor terag te bekomen eene persoonlijke vordering regen hem aản wien hij her toeventouwt, zoolang her in her vermogen van dezen is, en recht op schadevergoeding, indien thij thet uit nalatigheid of ter kwader trouw an anderen mocht overdragen." 188
\end{abstract}

Het zou juist dit Germaanse beginsel zijn dat in de Code civil in artikel 2279 werd opgenomen en zoals dat eveneens door Bourjon werd verwoord. 'Bezit alleen,' zegt Coninck Liefsting, 'bevat in zich den meest volkomen titel van zakelijk recht op roerend goed." 189 Hij verwijst naar Delvincourt, Aubry en Rau, Duranton, Marcadé, Troplong en Merlin, en citeert uit de geschiedenis van de totstandkoming van de Code civil. Merlin identificeert lang niet zo stellig bezit met eigendom, en ziet beide begrippen wel degelijk gescheiden: '(..) le propriétaire d'un effet mobilier ne peut le revendiquer sur le tiers possesseur qui l'a acquis de bonne foi du non propriétaire (..)." 190 Liefsting zet zich sterk af tegen Toullier, wiens 'vermoeden van eigendom' volgens hem geheel onjuist is ${ }^{191}$. In het Nederlandse Burgerlijk Wetboek is deze Germaansrechtelijke betekenis overgenomen. Ook systematische argumenten legt hij ten grondslag aan zijn standpunt: 'De artikelen uit den titel over het bezit, die op roerende goederen betrekking hebben, zijn voor het meerendeel in overeenstemming gebracht met het beginsel van art. 2014 B.W.' 192

Faber bespreekt Coninck Liefstings Bezitrecht. Faber legt 2014 uit op een manier die modern aandoet. Zijn standpunt lijkt veel op de later door Scholten aangehangen, en nog later door de Hoge Raad geaccepteerde legitimatieleer. 'Ach, wat had hij er weinig succes mee in die dagen!' verzuchtte Van Oven in $1908^{197 .}$. En zo was het: de meeste interpretaties gingen uit van een gelijkstelling van bezit met eigendom, en in deze Germaansrechtelijke overheersing werd Faber's afwijkende mening nauwelijks opgemerkt. Het is het stelsel van de wet als geheel dat zich tegen een gelijkstelling van eigendom met bezit verzet, aldus Faber. Daartoe wijst hij op een aantal artikelen uit het Burgerlijk Wetboek, her Wetboek van Burgerlijke Rechtsvordering en het Wetboek van Koophandel. Artikel $230 \mathrm{~K}$, waarin een reclamereclat is neergelegd; artikel $638 \mathrm{BW}$,

188. Coninck Liefsting, F.B., De algemeene beginselen van het bezitrecht en de Nederlandsche bezitaciën (1869), p. $486-487$.

189. Coninck Liefsting, F.B., (1869), p. 536-537.

190. Merlin, M., Répertoire whiversei et raisonné de jurisprudence (5e drulk, 1828), deel 29, Revendication \$1, v, P. 411 .

191. Coninck Liefsting, F.B., (1869), p. 552; zie bowen onder hoofdstuk 3 \& 4.B.

192. Coninck Liefsting, F.B., (1869), p. 543.

193. Van Oven, J.C., Artikel 2014 en de bezitsbescherming van roerend goed "WPNR 2016 (1908), p. 419. 
waarin aan de eigenaar het recht wordt gegeven 'in zee geworpene en door de zee opgeworpene" goedleren terug te vorderen; de artikelen 1652 en $1766 \mathrm{BW}$ met een recht van retentie; artikel $1778 \mathrm{BW}$ dat de uitlener eigenaar laat blijven, en voorts de artikelen over het pandrecht (1198 BW ev.) maken alle dat er volgens Faber wel degelijk sprake is van een van het bezit onafhankelijk recht van eigendom met betrekking tot roerende goederen ${ }^{194}$. Faber legt de regel 'possession vaut titre” als volgt uit:

'dat hij, die cen roerende zaak als eigenaar verkrijgt, den tiel van dengene, die hem in het bezit stelt, niet behoeft te onderzoeken, zoodat diens bezil geldt voor titel." 195

Bezit geldt woor titel betekent echter niet hetzelfde als eigendom:

"De eigenaar blijft dit, al draagt hij het bezil aan een ander over. Misbruikt deze het vertrouwen, door den eigenaar in hem gesteld, en ged ragt hij zich tegenover een derde als eigenaar, hem het bezit overdragende, dan geld de regel mobilia non habent sequelam. Hand musz Hand wahren, possession vaut sitre, of hoe zij verder luiden. " 196

De verkrijger wordt dan in Fabers standpunt eigenaar. Faber's standpunt vond in die jaren geen bijval, het is de Germaansrechtelijke uitleg die in de 'leer van Diephuis' de heersende zal worden. Maar vooralsnog niet meer dan een heersende leer in de literatuur. De (weinige) rechtspraak van de Hoge Raad wijst in die jaren minder op die Germaansrechtelijke uilleg.

\section{B. RECHTSPRAAK}

Twee maal in de besproken periode laat de Hoge Raad zich uit over artikel $2014^{197}$. In de eerste van die twee arresten, in $1846^{198}$ "wordt een uitleg gegeven aan het begrip 'bezit.' De Hoge Raad stelt zich op het standpunt dat onder bezit slechts het houden voor zichzelf alls eigenaar wordt begrepen. In een arrest uit $1855^{199}$ bevestigt de Hoge Raad deze opvatting, doch voegt daarnaast nog de eis van de goede trouw toe. Dat vereiste werd door De Pinto niet genoemd, door Goudsmit ten stelligste verworpen, maar door de Franse schrijvers eensluidend geaccepteerd. De uitleg van artikel 2014 in het arrest van de Hoge Raad doet sterk denken aan Marcadé's uitleg, die een voorstander was van een prescription instantanée, een onmiddellijke verjaring:

194. Faber. J.G.A., Vier opmerkingen ower bezit. Naar aanieiding van Mr. Coninck Liefsting's Bezitrecht, Themis 1871, p. 6.

195. Faber, J.G.A., (1871), p. 1.

196. Paber, J.G.A., (1871), p. 8.

197. Zie daarover Salomons, A.F., De interpretatiegeschiedenis van art. 2014BW (1838-1945), (1990), p. 31-33: reeds eerder door: E.M. Mejjers, De rechtsprak wan den Hoogen Raad omtrent "bezit geldt als volkomen vitel" in: WPNR 3026-3027 (1927), en in: Verzamelde Privatrechtelijke Opstellen $I_{*} \mathrm{p}$. $138-151$.

198. HR 3 april 184, W. 707 .

199. HR 29 juni 1855, in: Van den Honert, Burgerlijk Recht, deel 19. p. 337. 
'O. mu, dat bezit ter goeder trouw animo domini als eigenaar, met betrekking tot roerende goedleren, die noch in renten, noch in inschulden bestaan, welke niet aan toonder betaalbar zijn, niet slechts geeft een vernoeden van eigendom maar dat zoodanig bezit, ingevolge de uiturukkelijke bepaling wan art. 2014, al. 1 BW geldt als volkomen titel, die elke terug vordering. tegen den beziter uitshit, van het oogenblik, waarop deze het roerend goed, als eigenara, ter goeder trouw bezit, ondat door dit bezit eene onmiddellijke verjaring plaats vindt, waardoor de eigendom verkregen wordt."

Geen vermoeden van eigendom (zoals door Toullier werd voorgestaan) maar méér dan dat: een onmiddellijke verkrijging door verjaring. De meningen in de literatuur sluiten zich nauwelijks aan bij de uitleg van de Hoge Raad.

\section{$\S$ 4. Publiek domein}

\section{A. IMPLICIETE ACCEPTATIE YAN EEN FRANSE BENADERING}

In de eerste commentaren na 1838 wordt geen onderscheid gemaakt tussen een privaatrechtelijke en een publiekrechtelijke benadering van publiek domein. Wel worden de afzonderijke artikelen besproken. Daarbij wordt dan door de schrijvers meestal teruggegrepen op dezelfde punten die ook bij Voorduin aan de orde kwamen. Soms wordt er echter in het geheel niet op de arikelen ingegaan, zoals bij Van Hasselt ${ }^{200}$, terwijl De Martini slechts een korte opmerking maakt over de laatste zin van artikel $577 \mathrm{BW}$ in vergelijking met het Franse artikel $538 \mathrm{Cc}^{201}$. De Pinto komt door middel van een enge definitie van het begrip zaken in artikel $555 \mathrm{BW}$ tot twee vormen van toebehoren: eigendom, en cen 'overheidseigendom,' zo althans komt dit in De Pinto's omschrijving naar voren. Onder zaken als bedoeld in artikel 555 worden volgens De Pinto alle goederen verstaan, die het voorwerp van eigendom kunnen zijn. Daaronder vallen volgens hem niet die zaken waarop mensen geen recht, en dus ook niet dat van eigendom kunnen uitoefenen. Als woorbeeld van een dergelijke zaak noemt de Pinto de zaken die buiten de handel zijn:

\footnotetext{
'Maar onder zaken verstaat de wet niet die zaken of regten, warop de menschen geen regt en das ook niet dat van eigendom kunnen uitoefenen; zoo als de zaker, welke niet in den handel zijon. welke men niet bezitten (art. 593), en waarvan men nog veel minder eigentaitr zijn kan, b. x. de zon, de maan, de zee, enz.; wartoe almede behooren de zaken, warvan de eigendom aan den Staat of sommige mindere zedelijke ligchamen toebehoort, en welke tot aller gebnuik dienen, bij de Romeinen res publicae genoemd; deze zijn dus in deri regtskundigen zin geene zaken." 202
}

De Pinto gebruike de term eigendom in dit citaat in twee betekenissen. Een privaatrechtelijke eigendom, en een overheidseigendom (van de in het citaat genoemde res

200. Van Hasselt, W.J.C., (1843), p. 99-101.

201. De Martini, G.1. (1840), p. 375-376, en p. 5-6. Zie ook $\$ 1$.

202. De Pinto, A., deel $2(1838)$, p. 162 . 
publicae). Dit standpunt wordt bevestigd in De Pinto's analyse van de artikelen 577-581 BW. Daarin vergelijkt hij de in zijn ogen betere redactie van het artikel 577 BW met het Franse artikel $538 \mathrm{Cc}$. Ook Asser was reeds ingegaan op dit verschil. In het Franse artikel worden 'de aanwassen, gorsingen en de schorren, door de zee aan de stranden en aan de oevers der rivieren, alwaar ebbe en vloed gaat, aangespoeld' (in artikel 652 jo $651 \mathrm{BW}$ ) vermeld. Deze zaken worden behandeld bij 'Eigendom', zijn 'dus thans aan het gemeene regt onderworpen." 203 Aannemelijk is dat ook De Pinto twee wormen van toebehoren ziet: eigendom, de privaatrechtelijke vorm van toebehoren ("het gemeene regt') en een publiekrechtelijke vorm van toebehoren, waarbij de staat de enig mogelijke rechthebbende is.

Over zaken buiten de handel verschilt De Pinto met Asser van mening. Zag Asser nog geen direct nut in het criterium 'openbare bestemming' (hij noemde het wel), De Pinto onderschrijft dit criterium wel, maar laat aan de rechter over om in elk concreet geval uit te maken welke zaak buiten de handel is ${ }^{204}$. Voor de vraag welke zaken dan buiten de handel zijn, verwijst De Pinto naar Toullier ${ }^{205}$. Toullier legt daar de verbinding tussen zaken buiten de handel en de zaken die opgesomd worden in artikel 538 en $540 \mathrm{Cc}$, de Franse equivalenten van de Nederlandse artikelen, respectievelijk 577 en $579 \mathrm{BW}$.

\footnotetext{
Les biens hors du conmtherce sont ceux qui ne sont pas susceptible d'une propriété privée, et ceux qui, quoiqu ils sont susceptibles, sont maturellement consacrés a des usages publics incompatibles avec une propriété privée, mais qui rentrent dans le commerce aussitôt que cesse leur destination.

Tels sont lles chenins, moutes et rues les édifices publics, les eglises, les portes, murs fossés ef rempants des places de guerre et des forteresses."
}

De in artikel 577 en 579 genoemde en aan de staat behorende zaken zijn buiten de handel. Dat is niet in de tekst van de wet te vinden. Deze kwalificatie kan pas worden gemaakt als het criterium 'openbare bestemming' wordt toegepast. Toullier doet dat met zoveel woorden.

Met deze analyses van standpunten na de codificatie is het volgende duidelijk geworden: uit de samenhang tussen de besprekingen van zaken buiten de handel enerzijds, en zaken die aan de staat behoren anderzijds, volgt dat er aan twee vormen van toebehoren werd gedacht. Door de verwijzingen naar de Franse Code civil en het commentaar van Toullier wordt deze tweedeling expliciet. Wat echter in de Nederlandse commentaren ontbreekt is een expliciete directe verbinding tussen zaken die aan de staat behoren (artikel $577 \mathrm{BW}$ ) en zaken buiten de handel (diverse bepalingen). Toullier was over het verband

203. De Pinto, A., deel 1 (1838), p. 113; deel 2 (1838), p. 165-166.

204. De Pinto, A. deel 2 (1838), p. 170.

205. De Pintio, A. deel 2 (1838), p. 359. Toullier, C.B.M., deel 3 (1820), nr. 39. 
duidelijk. Door Diephuis zal kort nadien, in 1846, en in 1856 het onderscheid tussen de twee vormen van toebehoren zeer vervagen.

\title{
B. DIEPHUIS
}

Diephuis gebruikt een ruimere definitie van het begrip 'zaak' in artikel 555 BW dan De Pinto en Asser in navolging van Voorduin ${ }^{206}$. Diephuis stelt dat 'zaken buiten de handel' ook zaken zijn in de zin van artikel $555 \mathrm{BW}$. Het gevolg daarvan is dat ook die zaken die aan de staat behoren, onderworpen kunnen zijn aan privaatrechtelijke eigendom:

\begin{abstract}
"Maar hetgeen de Romeinen res communes noemden, waarvan wel is warar allen genot hadden, maar niemand eigendom kon verkrijgen, als: de lucht, de zon, de maan, de zee enz., kan naar onze wet niet onder de zaken gerekend worden, juist ondat het geen voorwerp van eigendom zijn kan. De Pino neemi dit ook aan van zaken, walarvan de eigendom aan den Staat of sommige mindere zedelijke ligchamen toebehoon, en welke rot aller gebruik dienen, bij de Romeinen res publicae genoend. Maar ofschoon het ontwerp van 1823 en het Wetboek van 1830 spraken van zaken, die het woorwerp konden uitraken van openba ren of atzonderlijken eigendorn, en deze redactie later bekort is, zoo is het toch wel ontegenzeggelijk, dat zaken, warvan de eigendom aan den Stat behoort, een woorwerp van eigendom zijn." 207
\end{abstract}

Twee punten in dit citaat zijn belangrijk. In de eerste plaats dat Diephuis' ruimere definitie van het begrip 'zaak' de zaken buiten de handel onder de reikwijdte van het eigendomsbegrip uit het Burgerlijk Wetboek brengt. In de tweede plaats dat Diephuis gebruik maakt van het in oorsprong Romeinsrechtelijk criterium "tot aller gebruik dienen.' Zaken die tot publiek domein behoren, waaronder de in artikel 577 BW genoemde zaken, zijn volgens Diephuis buiten de handel.

Twee soorten zaken kunnen aan de staat behoren: zaken waarvan de staat eigenaar is geworden, en, ten tweede zaken waarvan "derzelver aard of toestand haar tot eigendom van den staat maakt, doordien alle zoodanige zaken, volgens de wet, aan den staat moeten toebehooren. ${ }^{308}$ Het is de laatste soort zaken die door Diephuis weer wordt onderverdeeld in voor ons interessante categorieën: zaken 'die wegens haren toestand eigendom van den staat worden, schoon zij daarna niets eigenaardigs hebben, dat haar aan den staat verbindt, zoodat zij ook in den handel blijven, en het eigendom van bijzondere personen worden kunnen" (Diephuis verwijst naar de in artikel 576 BW genoemde zaken), en, in de tweede plaats zaken die 'het eigendom van den staat zijn, en blijven zullen zoo lang zij niet van aard veranderen.' (Diephuis verwijst hier naar de in artikel $577 \mathrm{BW}$ genoemde zaken) ${ }^{209}$. Het is die laatste categorie zaken, publiek do-

206. Zie hoofdstulk $3 \$ 4$.

207. Diephuis, G., deel 3 (1846), p. 5; evenzo in de tweede druk (1856-1859), p. 8-9.

208. Diephuis, G., deel 3 (1846), p. 40 . Aldus word door Diephuis dezelfde constructie voorgestatan als in het nicuwe Burgerlajk Wetboek in de artikelen 25 tot en met 28 boek 5.

209. Diephuis, G. deel 3. (1846), p. 40-41. 
mein, die door Diephuis als 'buiten de handel' aangemerkt wordt. Diephuis verwijst naar Toullier en Duranton. Toullier gebruikt een wat andere indelling voor zaken die aan de staat behoren. Zijn eerste onderscheidend criterium voor publiek domein is de vatbaarheid woor eigendom van private personen ('propriété privée') ${ }^{210}$. De in artikel $538 \mathrm{Cc}$ genoemde zaken zijn daarvan een voorbeeld: zij behoren 'au souverain de la nation, moins à tittre de propriétế qu'à titre de souveraineté.' 211 Diephuis gaat minder ver dan Toullier, wanneer hij de privaatrechtelijke eigendom wan de in artikel $577 \mathrm{BW}$ genoemde zaken, die iets 'eigenaardigs' hebben, mogelijk acht.

In zijn analyse van de categorie 'zaken buiten de handel' verwijst Diephuis naar Voorduin, en zet zich af tegen De Pinto en Königswarter ${ }^{2 / 2}$. De laatste had zaken buiten de handel buiten het privaatrecht geplaatst (zoals ook De Pinto had gedaan): 'choses qui sont (..) hors le commerce, (..) ne peuvent être l'objet de droit civil.' In artikel 555 BW, stelt Diephuis, wordt over voorwerp van eigendom, en niet over bezit (zoals in artikel $593 \mathrm{BW}$ ) gesproken. Een ander grammaticaal en systematisch argument is artikel 593 BW. Als onmogelijkheid van bezit impliceert dat eveneens geen zakelijke rechten kunnen bestaan, dan zou het tweede lid van artikel $593 \mathrm{BW}$, waarin de mogelijkheid van erfdienstbaarheid wordt geboden ${ }^{213}$, met het eerste in strijd zijn. Volgens Diephuis kunnen zaken die niet in de handel zijn weliswaar niet verkocht of overgedragen worden, maar daaruit volgt dan nog niet dat zij geen voorwerp van eigendom kunnen zijn: zij zijn 'juist een voorwerp van eigendom en als zoodanig niet in den handel.' 214

Maar waarom zijn de in artikel $577 \mathrm{BW}$ genoemde zaken buiten de handel? Het is door het gebruik van het criterium 'openbare bestemming' dat Diephuis nog een scherp onderscheid kan maken tussen publiek en privaat domein. Ontbreekt de openbare bestemming, dan gelden de beperkingen van de zaken buiten de handel niet. De in artikel 577 BW genoemde zaken behoren dan niet aan de staat als "buiten de handel, "maar in gewone privaatrechtelijke eigendom. Een en ander komt fraai tot uitdrukking in volgende, wat uitgebreide citaat.

Belalve eene stellige wetsbepaling kan ook de bestemming der zaken haar buiten den handel stellew. Hierin heef men dan ook vooral bij de beraadslagingen het kenmerk gezocht, en wel in that bestemming tot algemeen gebruik of de openbare dienst. Te weten, miet alle zaken, den sthat of eenig ander zedelijk ligcham toebehoorende, zijn buiten den handel, maar die, welke de wer wegens hare bestemming tor het eigendom van den stat of eenig ander zedelijk لligcham verklaart; zoo zij, zijnde hetgeen zij zijn, aan geen* ander kunnen toebehooren. Al wat aan den stat behoort krachtens een gewoon regt van eigendom, is even goed in den handel als wanneer een particutier daa rwam eigenaar is. Gronderven en andere onroerende zaken, die onbeheerd zijn

210. Touller. C.B.M., deel 3, (1820), nr. $30-36$.

211. Toulliter, C.B.M., deel $3(1820)$, nr. 37, p. 22-23.

212. Die overigens in Nede rhand heeft gestudeerd en lid van de Ansterdamse balie was. Zie Themis 1852 , p. 609,

213. Zie hoafdstuk $2 \& 4$.

214. Diephuis, G., deel $3(1856-1859)$, p. 6. 
en geen eigenaar hebben, behooren, volgens ant. 576 R. W., aan den statt, maar zijn niet buiten den handel, ondat zij eenvoudig aan den staat zijn toegekend, dewijl zij aan geen" ander toebehooren, maar mu dan ook in den staat een eigenaar hebben zonder door hunne toestemming. daaraan werbonden te zijn. Maar volgens art. 577 B.W. behooren insgelijks aan den stant de wegen en de straten, welke te zijnen laste zijn, de stranden der zee, enz. Deze behooren als zoodlanig aan den stalat, omdat zij zijn wegen, straten, stranden. Niet die weg. dat strand heeft den staat tot eigenagr, maar al wat weg is ten laste van den statat, al wat strand is behoort aan den staat, kam dus geen anderen eigenaar hebben, en moet alzoo noodwendig als zoodanig onverv reemdbatar en buiten den handel zijn.

Daar zoodanige zaken buiten den handel zijn, als behoorende noodwendig aan den staat enz.. omdat zij, zijnde hetgeen ze zijn, aan geen" ander kumnen twebehooren, zoo wolg tevers, dat zij alleen buiten den handel zijn zoolang ze dien aard of die bestemming behouden. Houdt een weg op weg te zijn, zoo boudt hij tevens op als zoodanig nowdwendig atan den statat toe te behooren, wordt eene eenwoudige bezitting van den staat, maar kan ook een anderen eigenaar hebben, en is alzoo in den handel. ${ }^{215}$

Hoewel Diephuis later expliciet afstand zal nemen van het gebruik van Romeins recht bij de uitleg van Nederlandse bepalingen en ook in zijn eerdere werk weinig van dat recht gebruik maakt, past hij het in dit geval toe ${ }^{216}$.

\section{\$. Conclusies}

\section{A. KWANTITATIEVE ANALYSE}

Veel wordt verwezen naar Frans recht: door De Pinto evenveel als naar Nederlandse bronnen, door Diephuis zelfs met $60 \%$. Een gemiddelde over de eerste 12 jaar na de codificatie in Themis geeft voor het Franse recht een percentage van $21 \%$. Dat geeft aan dat de mate van gerichtheid op het Franse recht aanzienlijk was. Datzelfde geldt voor het Romeinse recht (in Themis 22\%; De Pinto 15\%). Diephuis maakt weinig gebruik van het Romeinse recht. Ook in de inhoudsopgaven van Themis is sprake van een (lichte) gerichtheid op het Franse recht. De oriëntatie op het Franse recht is het meest opvallend.

\section{B. ONTLEENDE ASPECTEN}

Kort samengevat zijn de standpunten van de drie onderzochte leerstukken als volgt: een aansprakelijkheid voor zaken heeft zich nog niet gevormd, een enge uitleg lijkt het meest waarschijnlijk; artikel 2014 wordt in een aantal richtingen uitgelegd; zichtbaar wordt in de eerste commentaren dat er bij publiek domein van een anderssoortig eigendomsconcept sprake kan zijn. Hoe konden deze standpunten gevormd worden? De restrictieve uitleg van artikel 1403 (alleen bij wijze van expliciet genoemde uitzondering zou een aansprakelijkheid kunnen ontstaan buiten eigen toedoen of nalaten) wordt

216. Zie hoofdstuk $5 \& 1 . C .2$. 
zichtbaar met behulp van een onder het Franse recht gevoerde discussie over de aansprakelijkheid voor personen. De verscheidene Franse interpretaties van artikel $2279 \mathrm{Cc}$ verschijnen na de codificatie in evenzovele interpretaties van het Nederlandse artikel 2014 in de literatuur. Bij publiek domein wordt eerst de redactie van de Nederlandse bepalingen vergeleken met die van de Franse artikelen, waarin een onderscheid. tussen publiek domein en privaat domein wordt gemaakt. Dat onderscheid lijkt overgenomen in het Nederlandse recht; door Diephuis wordt dit onderscheid echter veel minder gemaakt, maar wel past hij nog een aan het Romeins recht ontleend criterium toe (openbaar nut) om de bepalingen over 'zaken buiten de handel' een betekenis te kunnen geven.

\section{RECHTSVINDING}

In de methoden van rechtsvinding zijn twee chronologische perioden te onderscheiden. Er is cen eerste fase waarin nog sterk wordt geleund op de gedachte dat een bepaling alleen uitgelegd hoeft te worden indien sprake is van een afwijking van de overeenkomstige Franse bepaling (De Martini, Asser, De Pinto). Een tweede fase volgt, waarin ook de meerduidigheid van niet van de Franse tekst afwijkende bepalingen kon blijken (Diephuis, en meerdere auteurs over artikel 2014). De betekenis van het Nederlandse artikel kan slechts worden gegeven door stelling te nemen in een voordien door Franse juristen gevoerde discussie. Doordat dit Franse recht miet in de voorgaande periode is geëxpliciteerd, is een 'herhaling' van de Franse discussie in Nederland onvermijdelijk. Dat is de reden dat er zo veelvuldig expliciet van Franse commentaren gebruik is gemaakt. Dat het Burgerlijk Wetboek een vertaling is van de Franse Code civil speelt natuurlijk een belangrijke rol, maar maakt op zich zelf verwijzen niet noodzakelijk. De wetgever heeft slechis vertaald, zonder zich rekenschap te geven van de betekenissen die zogenaamd eenduidige bepalingen konden hebben. Alleen met behulp van de Franse rechtswetenschap kan de betekenis van de Nederlandse bepalingen worden achterhaald. Het Romeinse recht is voor uitleg van het Nederlandse recht van vergelijkbaar bellang (maar in mindere mate).

\section{RECHTSVERGELIJKING}

Gebruik van andere rechtsstelsels is noodzakelijk om tot een uitleg van Nederlandse bepalingen te kunnen komen. Er is sprake van rechtsvergelijking om de betekenis van een Nederlandse bepaling te achterhalen: rechtsvergelijking als historische interpretatiemethode ${ }^{21 \%}$. In het geval van artikel 2014 is deze rechtshistorische interpretatiemethode zelfs een voorwaarde om een zinnige betekenis aan het artikel te kunnen geven. Van een nationalle wetenschapsbeoefening was eigenlijk nauwelijks sprake, zo blijkt uit de verwevenheid van de Nederlandse uitleg met het Franse, en in mindere mate het

217. Zie: Hartkamp. A.S., Wersuitleg en rechtwoepassing na de invoering van het nieuw Burgerlijk Wetboek, oratie Utrecht (1992), nr. 11 
Romeinse recht. Van een nationale rechtswetenschap kan eerst in de volgende periode worden gesproken. 
Hoofdstuk 5

\section{Legisme: rechtsvergelijking voor wenselijk recht}

\section{$(1850-1880)$}

\section{$\S 1$. Inleiding}

\section{A. LEGISME}

In de periode van 1850 tot 1880 vallen de hoogtijdagen van het legisme ${ }^{24:}$. Met een citaat kan dit legisme worden geillustreerd. Aan het woord zijn Thorbecke en een van zijn studenten tijdens éen van de eerste colleges administratief recht.

\footnotetext{
'Eens gebeurde het, dat een gewraggde, op een strijd tusschen twee wetsbepalingen gewezen. antwoordde, dat zij niet met elkander waren overeen te brengerı. "indien gij gelijk hebt, "zeide $T$., "dan heeft de wetgever in ëen van de twee artikelen eene ongerijndheid gezegd." - "Ik geloof, dat de wetgever dit ook gedaan heeft, "antwordde de ondervragagde. $\mathbb{T}$. hield een oogeriblik op, zag hem strak aan, als on hem de gelegenheid te geven eene zoo stoute stelling terug te nemen, doch toen dit niet gebeurde, herwatte hij: "Ik geloof het ook." 218
}

Dit citaat uit een werk van W.C.D. Olivier, een leerling van Thorbecke, geeft de ambivalentie weer van de rechtswetenschap in deze periode. $\mathrm{Zij}$ illustreert aan de ene kant de sterk op de autoriteit van de wetgever en op de tekst en systematiek van de wet gerichte rechtsvinding ${ }^{226}$. Zij brengt aan de andere kant naar voren dat in de wettekst

218. Kap, P.C., (1992), p. 2.

219. Olivier, W.C.D., Herinneringen aan Mr. J.R. Thorbecke (1872), p. 24. Zie voorts \& 3.

220. Zie bijwoorbeeld Pitlo, A., (1958), p. 19: 'Men spreekt van legisme als men zich bij de interpretatie van de wet strak aan de tekst houdr." Scholten, P., (1931), p. 49, p. 8: "de rustige verzekerdheid van velen in de $19 \mathrm{e}$ eeuw, dat rechtsvinding is wetstoepassing"; Van Dievoet, E., (1943), P. 111: "alle privaatrecht (berusti) op de wet; Van Heijnsbergen, P. Geschiedenis der rechtswetenschap in NederLand (1925), p. 193: "dat woor hen de wet de allesbeheersende grootheid is'; Coing, H., (1989), p. 31 : 'Wer interpretiert, ist der Sklave des Gesetzes.'; veel genuanceeruer Van den Bergh, G.C.J.J. (1994). 
"ongerijmdheden" kunnen voorkomen. Wat moet de uitlegger doen in geval van een onduidelijke wettekst of een onduidelijke systematiek? De wetgever kan de redactie wan het artikel of het samenstel van de artikelen verbeteren al dan niet op aangeven van de rechtswetenschap. In dat geval constateert de rechtswetenschap de onduidelijkheid, en laat de wetswijziging aan de wetgever. Een ruime interpretatie door de rechtswetenschap is onmogelijk omdat tekst en systeem van de wet zich daarmee niet verdragen. Gebruik van andere rechtsstelsels in de argumentatie lijk lastig omdat tekst en systeem van de eigen wetgeving bovenal de witleg bepalen.

Toch blijkt de priwatrechtswetenschap ook in deze periode mogelijkheden te bieden om andere rechtsstelsels te gebruiken. De rechtswetenschap kan twee doelen dienen. In de eerste plats kan zij door interpretatie beredeneren wat het geldende recht is (ius constitutum); in cle tweede plaats kan zij (indien bijwoorbeeld sprake was van een onduidelijkheid) het wenselijke recht beredeneren (ius constituendum) ${ }^{21}$. Tekst en systeem staan minder op de voorgrond in de beredenering van dit wenselijke recht. Het is daarom eenvoudiger om andere rechtsstelsels in de argumentatie te gebruiken. Voorts is de strikte interpretatie met tekst en systeem van het BW (uiteraard) minder sterk aanwezig in het nieuwe administratiefrecht. Bij publiek domein wordt een sterk op tekst en systeem gebaseerde uitleg van civilisten overschaduwd door een uitleg uit het administratiefrecht. De laatste uitleg is de heersende uitleg die zeer sterk leunt op het Franse recht. Naast deze twee mogelijkheden om van ander recht gebruik te maken, blift de historische uitlegmethode in gebruik.

Voor wij de analyse van de leerstukken voortzetten $(\$ 2 \mathrm{ev}$.$) , vervolgen we eerst met$ een korte tour d'horizon in een aantal gebieden. In de eerste plaats moet meer duidelijkheid geboden worden over het legisme (\$ 1.B). In de tweede plaats behandel ik de methoden van interpretatie van Diephuis en Opzoomer (\$1.C). In de derde plaats ga ik in op de rechtswetenschap in Frankrijk, België en Duitsland (8 1.D). In de laatste inleidende paragraaf $(\$ \mathbb{1}$. E) komt het gebruik van andere rechtsstelsels aan de orde.

\section{B. HET GENUANCEERDE LEGISIME}

Uitgangspunt is de (heersende) opvatting over de beoefening van het privaatrecht in de periode 1850-1880. De meest gehoorde opvatting daarover is die waarbij de nadruk wordi gelegd op de aan tekst en systeem van de wet gebonden uitlegmethoden. Deze omschrijving doet geen recht aan de werkelijk gehanteerde witlegmethoden, en lijkt

5.5, met name p. 119, en Kop, P.C., (1992); zo ook Coing: 'Die vorherrschende Meinung ist wohl doch durch die kritische Wende an Ende des 19. Jahrhunderts noch zu stark beeinfluBt." p. 31. Zie ook voor en beschrijving vande legistische periode: Jaspers, T. Rechtspreken in de maatschappij (1980), p. $67 \mathrm{ew}$.

221. Zie Kop, P.C., (1992), p. 42 . 
eerder de latere 'vrije rechtsvinding' tegen het legisme af te willen zetten ${ }^{222}$. Op beide kanten van het legisme, gebondenheid aan tekst en systeem enerzijds en de werkelijk gehanteerde uitlegmethoden anderzijds, wordt in het navolgende ingegaan.

De Nederlandse privaatrechtswetenschap in de tweede helft van de negentiende eeuw wordt gekarakteriseerd als gericht op tekst en systeem van de wet ${ }^{223}$. De gedachte is dat in die wettekst zelf de positieve verschijnselen besloten liggen, die door wetenschappelijk onderzoek geanalyseerd kunnen worden. Deze wijze van beoefening van wetenschap staat bekend als legisme of wetspositivisme. Zij komt niet uit het niets: enerzijds sluit zij aan bij een wetenschapsopvatting die bekend staat als het positivisme, anderzijds dwingt de exclusieve gelding van de privaatrechtelijke codificaties de rechtswetenschap zich op die nieuwe wettekst te richten ${ }^{224}$. Wij zagen een aanzet hiertoe in de artikelsgewijze benadering van de eerste commentaren van kort na 1838 . Het verband met de verschillende methoden van rechtsvinding is duidelijk. Met name de dicht bij de tekst van de wet liggende uitlegmethoden, de grammaticale, de systematische, soms de wetshistorische, zullen voorop staan. Andere methoden van rechtsvinding die verder van tekst en systeem van de wet zijn gelegen (zoals een analoge toepassing van een wetsbepaling, of een teleologische uitleg) worden vooralsnog niet geaccepteerd. Zo lezen wij in 1885 bij Teixeira, bewerker van het handboek van De Pinto, over de uitleg van het begrip 'gebouw' in artikel $1405 \mathrm{BW}$ :

'Men kan immers met Dalloz niet aannemen, dat by een boom moet worden gelijk gesteld met een gebouw, al ware het maar alleen ondat de wet van het tweede wel, maar van het eerste niet spreekt." 225

Tekst en systeem prevaleren ook in de manier van becommentariëren van het Burgerlijk Wetboek door Opzoomer, in zijn Aanteekening op de artikelen die thans nog verklaring behoeven uit 1849. De titel spreekt bijna voor zich. In zijn voorwoord lezen we: 'De meeste bepalingen der wet zijn reeds toegelicht; ik zou eenvoudig moeten overnemen wat door onze uitleggers reeds oniwikkeld is en zich in ieders handen bevindt." ${ }^{226}$ In eenzelfde richting voert een bespreking van het eerste commentaar van Diephuis Het Nederlandsch burgerlijk regi, naar de volgorde van het Burgerlijk Wetboek door Olivier in 1844. Diephuis heeft naar Oliviers mening veel te veel getracht de artikelen uit het

222. Zie bijwoorbeeld over deze tegenstelling tussen het legisme en de latere, opvolgende methode: Scholten, P., (1931), p. 242; voor de owergang van de periode van het legisme mar de volgende periode, waarin de rechtsvinding losser van de wet kwam te staan, Kop, P.C., (1992), p. 11, met name over de vergelijkbare overgang in Frankrijk. Daar waren het Geny en Saleilles die het legisme zo schril portretteerden. Zo ook: Coing. H., (1989), p. 35. Zite hoofdstuk 6.

223. Zie over het legisme de in de woetnoten van \$1.A aangehaalde literatuur, en met name: Kop. P.C. (1992)

224. Zie Kop, P.C., (1992), p. 1-2.

225. De Pinto, A., Handleiding tot het burgerlijk wetboek (6e druk, 1886), bewerkt door Teixeira de Mattos, p. 574.

226. Opzoomer, C.W., deel 1 (1849), voorrede. 
BW 'te" wenden en te wringen tot hetgeen de wetgever naar zijn oordeel heeft willen zeggen, ook wanneer zij eenvoudig, in hunne ware beteekenis genomen, dien zin niet hebben kunnen. Ik zou bijna kunnen zeggen dat de $S$. te veel eerbied woor de wet heeft en haar, haars ondanks, altijd voor verstandig houdt. "227 Volgens Olivier had Diephuis zich meer met de gebreken in de wetgewing moeten bezighouden. Diephuis geeft in zijn voorwoord al aan dat hij zich met wetsuitleg zal bezighouden: "Ik heb mij vooral eene exegetische en dogmatische behandeling van het Burgerlijk Wetboek voorgesteld; en mij daartoe, in de eerste plaats, toegelegd op een naauwgezet onderzoek der wet zelve, (..). ${ }^{228}$ Aan Oliviers commentaar is te zien dat een aan tekst en systeem vasthoudende uitleg niet zonder meer hoog aangeslagen werd. Op het beeld van de legistische beoefening van het privaatrecht zijn nuances aan te brengen. Dat zijn de volgende.

Ook woor de legistische jurist zijn de woorden van de wet nooit zonder meer duidelijk. Zij behoeven interpretatie. Van eenvoudige wetstoepassing is zelden sprake. In de volgende paragraf zullen wij dit zien aan de belangrijkste vertegenwoordigers uit die periode, Diephuis en Opzoomer ${ }^{229}$. Beiden trachten altijd een zinvolle betekenis te geven aan wettelijke bepalingen en binnen tekst en systeem van de wet komen zij soms met zeer ruime interpretaties. Elk van de onderzochte onderwerpen toont deze ruime uitleg. Daarnaast is er een andere karakteristiek van het legisme waarop niet zo vaak wordt gewezen: de scheiding tussen het ius constitutum en het ius constituendum. Wanneer de wetenschap zich met de beredenering van het wenselijke recht bezig houdt, zijn tekst en systeem veel minder belangrijk. Tenslotte is er sprake van andere rechtsgebieden zoals het administratiefrecht die van invloed kunnen zijn op de privaatrechtswetenschap en een minder aan tekst en systeem van de wet gebonden uitleg kunnen laten prevaleren. Een voorbeeld is de acceptatie van Thorbecke's theorie van domaine public ${ }^{230}$. Aan de hand van een korte uiteenzetting over Diephuis en Opzoomer wordt eén en ander geïllustreerd.

\section{DIEPHUIS EN OPZOOMER}

\section{Invloed van Diephuis en Opzoomer op de privaatrechtswetenschap}

Diephuis en Opzoomer zijn in clie periode de meest invloedrijke Nederlandse juristen ${ }^{231}$. Diephuis' Het Nederlandsch Burgerlijk Regt naar de volgorde van het Bur-

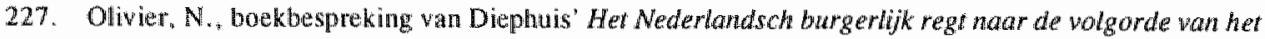
Burgerlijk Wetboek deel 1 (1844), in: Themis 1844, p. 355-360.

228. Diephuis, G., deel $1(1844)$, voorwoord p. iii.

229. Zie ook Kop, P.C., (1992), p. 4.

230. Zo bijwoorbeeld Thorbecke in zijn behandeling van publiek domein; $\$ 4$

231. Zie over beide juristen: G. Diephuis. C.W. Opzoomer. 1892-1992. Een uitgave van de Stichting "Het Groningsch Rechtshistorisch Fonds", Groningen, 1992, waarin: Lokin, J.H.A. . De taak van de rechtswetenschap volgens Diephuis en Opzoomer; Brunner, C.J.H., Was Diephuis een legist? Een herwaar- 
gerlijk Wetboek krijgt van De Pinto in Themis een zeer lovende recensie. De Pinto merkt op: 'Onze wetgeving heeft meer dan één werk in het licht doen komen; de meeste van gering allooi. De Heer Diephuis heeft een beteren weg ingeslagen.' ${ }^{232}$ Olivier, zo bleek reeds uit zijn recensie van Diephuis' werk uit 1844, heeft wel enig commentaar op het exegetische karakter van Diephuis' handboek ${ }^{233}$. De ontvangst van Opzoomers eersteling was veel slechter. Recensent Kappeyne van de Coppello besluit met de wens dat Opzoomer zich blijft wijden aan het burgerlijk recht, maar dan zo dat 'de mindere hoeveelheid van den oogst door zijne betere hoedanigheid wordt vergoed." 234 Waaraan schortte het? Kappeyne: 'Historische studie ontbreekt. Van de beide bronnen der Fransche, zoowel als van onze burgerlijke wetgeving, het Germaansche en het Romeinsche regt, legt de schrijver met het eerste geene bekendheid aan den dag, en past het laatste toe op eene wijze, die bezwaarlijk oordeelkundig mag heeten, of op de hoogte der wetenschap." ${ }^{235}$ Het verschil in waardering tussen Opzoomer en Diephuis verdwijnt later. Opzoomer, zo schrijft Scholten in 1931, "in zijn tijd achite men hem zeker den eersten - wij zouden wellicht anders oordeelen. ${ }^{236}$ Wat was het verschil tussen Diephuis en Opzoomer met betrekking tot hun invloed op het privaatrecht? Van den Bergh stelde deze vraag ${ }^{237}$. Aan de hand van de onderzochte onderwerpen blijkt het steeds Diephuis' mening te zijn die wordt geaccepteerd.

\section{Interpretatiemethode van Diephuis en Opzoomer en de historische uitleg}

Zowel Opzoomer als Diephuis laten er geen twijfel over bestaan dat alle burgerlijk recht in de wet gevonden moet worden. 'Het burgerlijk regt wordt bij ons geopenbaard en bepaald door en gekend uit de wet' vangt Diephuis zijn verhandeling over de rechtsbronnen van het Nederlandse burgerlijk recht aan ${ }^{238}$. Rechtspraak is geen zelfstandige bron: rechterlijke uitspraken hebben alleen tussen partijen gezag van gewijsde, 'het strekt zich niet verder uit, en is ten eenen male vreemd aan de wetenschappelijke waar-

dering na 100 jar, p. 1-23; en Zwalve, W.J., Over oorzaak en titel bij Diephuis en Opzoomer, p. 4559: zie ook Kop, P.C., (1992), p. 33 ev.: Veen, T.J.en P.C. Kop, Zestig juristen (1987), p. 215 (Diephuis) en p. 218 (Opzoomer).

232. De Pinto, A., bespreking wan Diephuis, G., Het Nederlandsch Burgerlijk Regt, naar de volgurde van het Burgerlijk Wetboek deel 1 (2e druk 1856), Themis 1857, p. 471-479.

233. Oliwier, N., (1844). p. 356. Met een systematisch handboek zou volgens Olivier de wetenschap volgens hem meer gebaat zijn: "een organisch geheel, waarin ieder deel zijne bepalde plaats heeft, het eene in noodwendige orde op het andere volgt.'

234. Kappeyne van de Coppello, J , bespreking van Opzoomer, C.W., Het Burgerlijk Wetboek. Aariteekening op de artikelen die thans nog werklaring behoeven (1849). Themis $1849 . \mathrm{p} .627$.

235. Kappeyne van de Coppello, J., bespreking van Opzoomer, C.W., Het Burgerlijk Wetboek, Aanteekening op de artikelen, die thans nog verklaring behoeven deel 2 (1850). Themis 1850 , p. 597

236. Scholten, P., (1931), p. 239. Zie woorts over Opzoomer: Kop, P.C., (1992), hoofdstuk 4 2: Zestig juristen (1987), p 218-224;

237. Van den Bergh, G.C.J.J., (1994), p. 123; hierower ook Brunner, C.J.H., (1992), passim.

238. Diephuis, G., deel 1 (1869), p. 19. 
de van hetgeen de regter als zijne opvatting van de wet of het regt heeft voorgedragen. Ook dat iets meermalen en telkens op dezelfde wijze door den regter is aangenomen, zet daaraan geen gezag bij.. ${ }^{239}$ Ook de gewoonte "geldt bij ons niet als rechtsbron ${ }^{240}$. Over de vraag welke methoden van witleg zijn toegestaan, spreken beiden zich uit. Rechtsvinding is wolgens Diephuis bij uitstek de taak van de rechtswetenschap. 'Het regt wordt bepaald door de wet, en om het te kennen moet in de eerste plaats de wet gekend worden. Hiertoe is het niet genoeg dat men hare woorden kent, men moet haren zin verstaan, de gedachte kennen die de wetgever in haar heeft uitgedrukt." 241 Hoe kan de betekenis van de bepaling dan worden gekend? Een grammaticale, een logische en een historische wetsuitlegging komen Diephuis daarbij te hulp: 'de eerste heeft plaats voor zover men de gedachte des wetgevers uit de woorden eener wetsbepaling, de andere voor zoo ver men haar van elders, en in het bijzonder de historische, voor zoo ver men haar uit de rechtsgeschiedenis afleidt. "242

Interessant is hier met name dat het Diephuis te doen is om de 'gedachte des wetgevers' te achterhalen. Daarin schuilt met name het verschil in (historische) interpretatie tussen Diephuis en Opzoomer. Bij Diephuis gaat het meer om de gedachte van de wetgever ten tijde van het vaststellen van de bepaling, bij Opzoomer echter om een andere historische interpretatie. In Opzoomers historische interpretatie speelt de wil van de wetgever geen rol. Laten wij nog even Opzoomer aan het woord over zijn interpretatiemethoden. Die benoemt Opzoomer iets anders dan Diephuis, maar zij dekken dezelfde lading. Opzoomer vermeldt de volgende, in navolging van Savigny: de grammaticale, de logische, de systematische en de historische methode.

\footnotetext{
"Nooit is de titlegging iets anders dan "die Reconstruction des den Gesetzen inwohnenden Gedankens." En altijd moeten er in haar, wil zij volledig zijn, wier elementen woorkomen, wier natuur door Savigny net juistheid is ontvouwd. Het is het grammaticale element, waarbij de woorden naar de wetten der taal worden verklaard; het logische, dat in de analyse der gedachten bestalit, in het aanwijzen van de betrekkingen tussehen thare deelen; het systematische, dat den samenhang aller rechtsregels, de eentreid van het rechtsstelsel doet uitkomen; ent eindelijk het historische element $(\ldots) .^{243}$
}

Wat verstaat Opzoomer onder het historische element? Het is 'den zin der wet te verstaan in verband met het recht dat in de historie aan haar vooraf ging "om den omvang te leeren kennen der verandering die zij daarin teweeg bracht.' Maar hieronder wordt

239. Diephuis, G., deel 1 (1869), p. 119. Zie voor een illustratie van deze betekenis van rechterlijke beslissingen: $\$ 2$.C.1. Overigens neemt het belang van de rechtspraak naar het einde van de negentiende eenw wel degelijk toe.

240. Diephuis, G. deel 1 (1869), p. 96.

241. Diephuis, G. deel $1(1869)$, p. 109.

242. Diephuis, G. deel $1(1869)$, p. $\| 10$.

243. Opzoomer, C.W., Aantekening op de wet, houdende algemeene bepalingen der wetgeving van het koningrijk (viende anuk, 1884), p. 215, Zells kan Opzoomer nog de redelijkheid en de billijkheid gebruiken. Zie Opzoomer, C.W., (1884), p. 230 ev; zie daarover ook: Lokin, J.H.A., (1992), p. 34. 
door de meesten, zo zegt Opzoomer, ook het 'oogmerk dat de wetgever zocht te bereiken' verstaan, een will van de wetgever ten tijde van de totstandkoming van de wet. Dat kan niet. Wanneer de wil van de wetgever wordt afgeleid uit bijvoorbeeld de parlementaire behandeling, dan gaat het naar Opzoomers mening om rechtsvinding buiten de wet ${ }^{244}$. De wil van de wetgever kan van belang zijn, maar slechts zoals die blijkt uit de woorden der wet:

'Men mag geen letterknecht zijn; dat wil zeggen: men moet niet bij de letters, die men woor" zich heeft, blijven staan, alsof er in de wet niet nog meer letters te vinden waren. Men moet al de letters van al de wetten met elkander in verband brengen: wat dan het resultaat is, dat is de wil des wetgevers. Het is zijn geesr, zijn meening, bedoeling of hoe men het noemeas wil; mar het is een geest, uit de woorden zelve der geheele wet opgenaakt, geen wil dien men slechts buiten de wet om heeft leeren kennen. ${ }^{245}$

Diephuis stelde nu juist wel expliciet dat van die bedoeling van de wetgever kan blijken uil andere bronnen dan de woorden der wet alleen.

\footnotetext{
'(.) daar ieder de beste uitlegger is van zijner eigene woorden, kan, hetgeen door de Regeering of in de Kamers der Staten-Generaal tot toetichting, tor vendediging of tot bestrijding is gezegd, over de bedoeling van den wetgever en alzoo over de beteekenis zijner bepaling een belang rijk licht verspreiden; $(\ldots) \cdot 246$
}

Het verschil in gebruik van de historische methode heeft gevolgen voor het gebruik van andere rechtsstelsels. De historische uitlegmethode is immers een belangrijke wijze waarop de rechtswetenschap van andere rechtsstelsels gebruik kan maken. Bij Opzoomer is daarvoor wat meer plaats ingeruimd. Hij interpreteert 'in verband met het recht dat in de historie (...) vooraf ging," zoals het Romeinse en Franse recht. Diephuis gaat vooral te rade bij de wil van de wetgever ${ }^{247}$. Die wil van de wetgever blijkt uit de parlementaire geschiedenis en daarin is veel van Frans techt gebruik gemaakt. Zo komt het eens te meer bij Diephuis aan de orde. De historische interpretatie komt tegen het einde van de megentiende eeuw meer in de belangstelling te staan onder invloed van de Duitse rechtswetenschap. Met name Lands interpretatie is sterk gericht op een historische vitleg ${ }^{248}$.

\section{Ongerijmdheden en onduidelijkheden in de wet}

De wetsbepalingen vormen zowel voor Opzoomer als Diephuis altijd de latste toets bij de uitleg. Maar soms zwijgt de wet of heeft de wetgever zijn will niet, of niet duidelijk

244. Zie Lokin, J.H.A., De invloed van de pandektistiek op het werk van Diephuis en Opzoomer, in: Pieterman, R., e.a., Bijdragen fot de rechrgeschiedenis wan de negentiende eeww (1993), p. 35-36.

245. Opzoomer, C.W. (1884), p. 212.

246. Diephuis, G., deel 1 (1869), p. 112.

247. In deze laatste zin: Lokin, J.H.A., (1992), p. 34-36.

248. Zie \& 3.A. 
genoeg uitgedrukt. Ook de invulling van deze onduidelijkheid behoort tot de taak van de rechtswetenschap. Bij Diephuis komt de uitlegger meer vrijheid toe naarmate de wet meer open heeft gelaten. Een regel kan in de eerste plaats uit de wet worden afgeleid, bij voorbeeld door analogie, of door tegenstelling. Toch mag dit bij Diephuis niet zomaar: noodzakelijk is dan dat er een rechtsbeginsel aanwezig is, dat zowel geldt voor de well aanwezige, maar onduidelijke wetsbepaling, als voor datgene waarover de bepaling zwijgt. Dat beginsel is bij Diephuis niet snel aanwezig: want nodig is in dat geval:

'dat de bepaling, die men wil toepassen, werkelijk de uitdrukking is van een voor mimere toepassing varbaar beginsel, en niet eene bijzondere beschikking, waarin voor een bepaald onderwerp, om redenen van doelmatigheid, van een anders geldend beginsell is afgeweken; $(\ldots) .^{249}$

Diephuis is voorzichtig met het toepassen van deze constructie ${ }^{250}$. Dat is hij ook bij de a-contrario redenering: 'men zal in het algemeen vooral in de gevolgtrekking bij tegenstelling zeer voorzigtig moeten zijn. Die alleen van eene zaak iets zegt, zegt het niet van eene andere, maar geeft daardoor nog niet te kennen, dat hiervoor het tegendeel, althans niet hetzelfde geldt. ${ }^{251}$ Wat doet Diephuis als de wet geheel zwijgt en door afleiding geen regel te vinden is? Het volgende: onderzoek van aard en doel van de handeling, van het wezen en de werking der rechtsbetrekking; onderzoek met behulp van de gewoonte als deze aanwezig is, en eventueel bijgewerkt aan de hand van de in het recht aanwezige beginselen. Ook als die gewoonte ontbreekt kan door de rechtswetenschap de geldende regel worden gevonden: 'Zoo is de rechtswetenschap voor de kennis van het regt werkzaam door uitlegging van, door afleiding uit en door opsporing buiten de wet.' Lijkt deze vrijheid op het eerste gezicht nogal groot, veel van die vrijheid wordt onmiddellijk terug genomen. De rechtswetenschap kan 'in zekeren zin' een bron van recht worden genoemd, 'zij is het echter niet in den zin, waarin de wet het is.' De rechtswetenschap openbaart of ontdekt het recht, maar de wet heeft het recht gemaakt. Deze ondergeschikte positie van de rechtswetenschap werkt beperkend op Diephuis ${ }^{7}$ vrijheid bij interpretatie van wetgeving ${ }^{252}$. Diephuis" "afleiding uit" en "opsporing buiten de wet' hebben gelijkenis met Opzoomers "rechtsontwikkeling." Toch is er verschil. Diephuis spreekt nog steeds over de vaststelling van het geldende positieve

Diephuis, G., deel 1 (1869), p. 114

250. Zie bijwoorbeeld zijn behandeling van de aansprakelijkheid woor zaken, $\$ 2 . C .1$.

251. Diephuis, G., deel $1(1869)$, p. 114.

252. Diephuis, G., deel 1 (1869), p. 116-117. Volgens Kop kent Diephuis an de wetenschap een groter gewicht toe, en de door de wetenschap bijwoorbeeld natar analogie vastgestelde uitkomst zou als bron rechistreeks door de rechter mogen worden toegepast; en zo niet door Opzoomer. Bij hem zou de weterischap als zelfstandige bron van het recht niet denkbaar zijn. Kop, P.C., (1992), p. 38. Ik wraag mij zeer af of dit verschil tussen beide wel juist wordt weergegeven. Zoals uit de hoofdtekst volgt ziet Diephuis de rechiswetenschap als een rechtsbron 'in zekeren zin', met andere woorden, niet zoals de wet rechtsbron is. De wetenschap kan thet recht niet scheppen, maar het uit de wet doen kernen. Opzoomer heeft voor de wetenschap nog de takk van de rechtsontwikkeling. 
recht terwijl Opzoomer bij zijn "rechtsontwikkeling" spreekt over het wenselijke recht. Laten wij eerst kijken hoe Opzoomer met onduidelijkheden omgaat. Het lijki dat Opzoomer een grotere vrijheid heeft dan Diephuis. Wanneer de wet zwijgt neemt Opzoomer volgens eigen zeggen zijn toevlucht tot de redelijkheid en de billijkheid, teneinde tot het geldend recht te kunnen geraken ${ }^{253}$. Niet vaak past hij dit toe en overigens zal ook deze vrijheid in interpretatie uiteindelijk moeten betreffen: "die Reconstruction des dem Gesetzen inwohnenden Gedankens.' Ook Opzoomer laat zijn uitleg uiteindelijk op de woorden van de wet berusten. Wel blijkt aan zijn interpretatie van artikel 1403 dat zijn uitleg zeer ruim kan zijn ${ }^{254}$.

Behalve deze grotere vrijheid van uitleg kende Opzoomer aan de rechtswetenschap twee gescheiden taken toe. Opzoomer vergelijkt de rechtswetenschap van zijn tijd met de Romeinse rechtswetenschap. Romeinse juristen hielden zich niet alleen bezig met uitleg. Bij hen

\footnotetext{
'gat de uitlegging de grenzen eener ware interpretatie vaak zeer ver te buiten, en neent het karalkter eener ontwikkeling des rechts aan. (...) Onze juristen daarentegen zijn tot de uitlegging, in den strengen zis des woords, beperkt. Op de rechtsontwikkeling kunnen zij slechts middellijk, door middel van de organen der wetgeving hun invloed oefenen, die dan een zeer krachige, en waar zij door wetenschap uitmunten een zeer heilzame kan zijn.' 255
}

Aldus scheidt Opzoomer uitleg van de wet, van ontwikkeling van het recht. Het eerste geeft aan wat recht is (ius constitutum). Het tweede geeft aan hoe het recht bij voorkeur zou moeten luiden (ius constituendum). In het ius constituendum is de gebondenheid aan tekst en systeem minder dan in het ius constitutum. Bij de behandeling van de onderwerpen treffen we deze genuanceercle legistische benadering ${ }^{256}$. Ook anderen gebruiken dit onderscheid, zoals Land, juristen tijdens de discussies van de Nederlandse Juristen-Vereniging en Diephuis ${ }^{257}$. Diephuis doet dat minder nadrukkelijk dan Opzoomer. Ook hij omschrijft de taak van de rechtswetenschap als een tweeledige: enerzijds als 'verklaren, aanvullen en heipen toepassen' van de wetgeving, anderzijds als het meewerken aan wetgeving 'door een onpartijdig oordeel over de wetgeving, tot derzelver volmaking.'

253. Opzoomer, C.W., (1884), p. 230. Niet alleen wanneer de wet zwijgt: ook is redelijkheid en billijklyeid voor Opzoomer richingge vend bij de uitleg van artikel $1403 \mathrm{BW}$. Zijn uitleg kornt vrijer ower dan die van Diephuis. Zie $2 . \mathrm{C}$.

254. Zie 2. C.2.

255. Opzoomer, C.W.. (1884), p. 220-221.

256. Zo Opzoomer bij de behandeling van publiek domein ( 8 4) en in zign beschouwing over artikel 1403 $B W(\& 2)$.

257. Diephuis, G., deel $1(1856)$, p. *. 


\title{
D. LEGISME IN FRANKRIJ, BELGIË EN DUITSLAND
}

\section{Frankrijk en België}

In Frankrijk is een groot aantal commentaren geschreven op de Code civil van 1804 . De eerste commentaren zijn nog sterk georiënteerd op het natuurrecht, en maken veel gebruik van Romeins recht (Toullier), de latere (zoals van Marcadé of de Belg François Laurent) hanteren een methode die meer op tekst en systeem de nadruk legt ${ }^{258}$. Net als in Nederland kende het legisme in Frankrijk ('l'école de l'exégèse') en België (de exegetische school) hoogtijdagen. Bouckaert plaatst deze exegetische school in de jaren 1830-1880 ${ }^{259}$. De beoefening van het privaatrecht in die tijd wordt aldus omschreven:

\begin{abstract}
'Le droit se confond totalement avec la loi écrite. Particulièrement le droit civil est entièrement contenu dans le Code civil. Une fois les faits établis il suffit de formuler le syllogisme judiciaire dont la majeure est constituée par la règle écrite appropriée, et la mineure par la constatation que les conditions prévues dans cette règle sont ré̉alisées.' 260
\end{abstract}

Het is de heersende methode van het privaatrecht in Frankrijk en België ${ }^{261}$. De bronnen van het positieve privaatrecht zijn volgens Marcadé de Code civil en andere wetten ${ }^{262}$. Maar is de uitleg nu ook zo strikt aan de tekst van die wetgevingen gebonden? Dat is (net als voor het Nederlandse privaatrecht) te overdreven gesteld ${ }^{263}$. Marcadé over artikel $4 \mathrm{Cc}$ : 'La loi ne pouvant pas tout prévoir ni s'expliquer toujours assez clairement, et la justice, néanmoins, devant toujours être rendue, il est enjoint aux juges de toujours prononcer, en ce décident, en cas d'insuffusance ou d'obscurité de la loi, d'après les lumières de leur raison et de l'équité (...)." ${ }^{264}$ De Gentse hoogleraar Laurent wordt als de meest duidelijke vertegenwoordiger van het legisme beschouwd. Laurent in zijn voorwoord uit 1878 voor zijn Principes de droit civil: 'Les codes ne laissent rien à l'arbitraire de l'interprête, celui-ci n'a plus pour mission de faire le droit, le droit est fait. Plus d'inceritude: le droit est écrit dans les textes authentiques.' Voor het wenselijke recht keek Laurent veel verder. In een omvangrijk rechtsvergelijkend werk beschouwde hij de rechtsstelsels van een groot aantal landen.

258. Zie hoofdstuk 3 woor een konte beschrijving van de verschillende commentaren en verdere verwijzingen.

259. Bouckaert, B., (1981), p. 49.

260. Ghesin, J., en Goubeaux, G., Traité de droit civil, untroduction générale (Ge druk, 1990\%, nr. 143, p. 102.

261. Zie Van Dievoet, E. (1943), p. 85; G. Ripert en J. Boulanger, deel 1 (1950), nr. 150, p. 66; in het kort ook Van Caenegem, R.C., Geschiedkundige inleiding tot het privaatrecht, (1981), p. $128 \mathrm{ev}$.

262. Marcadé, $V$., deel 1 (5e druk, 1852), p. 24.

263. Zie boven $\$ 1 . B$.

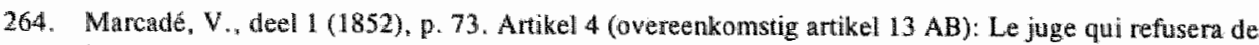
juger, sous prétexte du silence, de l'obscurité ou de l'insuffisance de la loi, pourra être poursuivi comme coupable de déni de justice. 


\section{Duitsland}

Duitsland kent een geheel andere rechtswetenschappelijke school. Het is daar juist de eigentijdse systematische beoefening van het Romeinse recht die bewondering bij de Nederlandse jurist afdwingt. De Duitse rechtswetenschap in de negentiende eeuw kan het beste begrepen worden door terug te gaan naar de pennestrijd die in het begin van de negentiende eeuw gevoerd is tussen Thibaut en Savigny over de vraag of er al dan niet een nationale codificatie komen moest ${ }^{265}$. De tegenstander van codificatie Savigny wint het pleit. Waarop baseert hij zich? Alle recente codificaties (het Allgemeine Bürgerliches Gesetzbuch, de Code civil, en het Allgemeine Landrecht für die Preussischen Staaten) zijn ontstaan vanuit een onzinnige rechtstheorie: het natuurrech. De genoemde codificaties ontberen daarom elk wetenschappelijk karakter. Wat moet er dan gebeuren om een codificatie dat predikaat 'wetenschappelijk' te kunnen geven ${ }^{26}$ 's? De wetenschap heeft als taak om de leidende rechtsbeginselen op te sporen. Deze rechtsbeginselen liggen verscholen in de samenleving en ontwikkelen zich daarin op een 'organische' wijze. In een meer ontwikkelde samenleving zorgt de juristenstand voor die rechtsontwikkeling. Juristen kunnen dat echter alleen doen door gebruik te maken van het Romeinse recht. Dat rechtsstelsel is immers bij uitstek historisch gegroeid: 'Erneuerung des wissenschaftlichen Characters des geltenden Rechts durch das Medium der geschichtlich gewachsenen Stoffmassen des gemeinen Rechts. ${ }^{267}$

Deze historische methode werd toegepast in een systematische ordening van het eigentijdse recht. Eerst door Savigny zelf, later door anderen, met als doel: 'auf der Grundlagen der Quelien des Corpus luris Civilis ein in sich dogmatisch widerspruchsfreies, neues Rechtssystem zu formen. ' Deze systematische privaatrechtswetenschap is bekend geworden als de pandektistiek. ${ }^{268}$. In Oostenrijk kende de pandektistiek ook enkele representanten, van wie met name Unger genoemd moet worden ${ }^{269^{\circ}}$. Het is deze Oostenrijkse jurist die via Goudsmit in het werk van Opzoomer is te vinden. Een tweede belangrijke stroming (de Germanistische) binnen de historische school legt juist de

265. Zie Schlosser, H., Grundzuge der neueren Privatrechtsgeschichte (1985), \& 4, p. 97 ew.

266. Lokin, J.H.A., en W.J. Zwalwe, (1992), p. 213 ev.

267. Schlosser, H., (1985), p. 100.

268. Bekende vertegenwoordigers wan deze wetenschapsbeoefening zijn Puchta, Wangerow, Dernburg en Windscheid. Schlosser, H., (1985), p. 101-102.

269. Joseph Unger (1828-1913) was hoogleraar te Wenen, en wordt gezien als éćn van de meest invloedrijke Oostenrijkse juristen wan de negentiende eeuw: "gilt als erneuerer der ôsterreichischen Rechtswissenschaft im Sinne der Historischen Rechtsschule und Uberwinder der "exegetischen Schulle" " aldus Kleinheyer en Schroder, (1989), p. 308-310. 
nadruk op de Duitse rechtsbronnen ${ }^{270}$. Duidelijke sporen van de Historische School en deze Germanistische stroming zijn in het Nederlandse privaatrecht te herkennen.

Aan de rechtswetenschappelijke methode van de Historische School zou het volgens Constantinesco hebben gelegen dat rechtsvergelijking in Duitsland destijds niet tot ontwikkeling gekomen is (ondanks enkele aansprekende aarhangers van de rechtsvergelijking als Feuerbach, Thibaut, Zachariae en Mittermaier) ${ }^{27 !}$ : '(...) alle im Rahmen der historischen Schule hervorgetretenen Auffassungen ausdrücklich oder jedenfalls implicite zur Nutzlosigkeit rechtsvergleichender Untersuchungen geführt haben. Das Recht is jedes Volk so spezifisch und so sehr mit ihm verbunden, das es für ein anderes nicht passen kann.' 272 Op een dergelijk standpunt voor de Nederlandse rechtswetenschap zou wel wat af te dingen zijn. Discussies in de Nederlandse Juristen-Vereniging werden gevoerd naar aanleiding van omvangrijke vergelijkende studies, omdat juist het belang van internationale regelingen hoog werd ingeschat ${ }^{273}$. In 1900 komt het dan toch tot de invoering van een Duitse codificatie van het burgerlijk recht.

\section{E. ANDERE RECHTSSTELSELS IN HET NEDERLANDSE PRIVAATRECHT}

Van de buitenlandse rechtsstelsels wordt in de volgende percentages gebruik gemaakt ${ }^{274}$ "In een deel van Diephuis' systeem wordt in $49 \%$ verwezen naar Franse bronnen. In $11 \%$ van de gevallen wordt naar Belgische bronnen (Laurent) verwezen. Naar Duits en Romeins recht wordt in $1 \%$ van de gevallen verwezen, terwijl naar Oostenrijks en Zwitsers recht incidenteel wordt verwezen. In 38\% van de gevallen wordt naar Nederlands recht verwezen. In Themis wordt in $48 \%$ naar een Nederlandse bron werwezen, naar Romeins recht in 19\%, naar Frans recht in $22 \%$ en naar Duits recht in $10 \%$. Incidentele verwijzingen betreffen Oostenrijk (3) en België (1). De inhoudsopgaven van Themis en (sinds 1882) het Rechtsgeleerd Magazijn bieden het volgende beeld. In Themis zijn alle artikelen in de vier onderzochte jaargangen gericht op het Nederlandse recht. Één artikel heeft een Romeinsrechtelijke oriëntatie. Van de 43 besproken boeken zijn er vier gericht op het Duitse recht, zes op het Franse, twee op het Italiaanse recht en 1 op het Spaanse. Het Rechisgeleerd Magazijn (opgericht als rijdschrift voor binnen- en buitenlandsche rechisstudie) is veel meer gericht op andere rechtsstelsels. In de cerste twee jaargangen zijn van de 41 artikelen 19 op een ander rechtsstelsel georiënteerd. Van de 86 besproken en aangekondigde boeken zijn er 41

270. Vertegenwoordigers van deze stroming zijn Jacob Grimm, Beseler, Von Gierke, en de Zwitser Bluntschli. Over Grimm (1785-1863). Beseler (1809-1888), Gierke (1841-1921) en Bluntschli (1808-1881) zie Kleinheyer, G, en J. Schröder, (1989); Schlosser, H. (1985), p. 108-109. Zie voor een beschrijwing vala het Duitse priwatrecht in de negentiende eeww ook: Lokin, J.H.A., en W.J. Zwalve, (1992), p. 213 ev. Zie cok: Kop, P.C., (1991) en Jansen. C.J.H. (1991), passim.

271. Constantinesco, L.J., deel 1 (1971), p, 99. Koschaker, P., (1966), p. 253 -254.

272. Constantinesco, L.J., deel 1 (1971), p. 96; zo ook Koschaker, P., (1966), p. 254.

273. Zie \& $2 . C .3$ en $\$ 3 . C$.

274 . Zie bijlage $\$ 2.2$. 
gericht op een ander rechtsstelsel: 35 op het Duitse, 5 op het Franse, 5 op het Italiaanse, $_{2}$ op het Engelse en é̉n ten slotte heeft een Romeinsrechtelijke strekking.

\section{De bekendheid met het Franse recht}

De Franse commentaren op de Code civil worden allemaal in Nederland gebruikt. De eerste commentaren (zoals Toullier) worden gebruikt omdat de Code civil hier te lande tot 1838 heeft gegolden, de latere (Marcadé, Laurent, Aubry en Rau) vanwege een historische uitleg van de Nederlandse bepalingen. De gewoonte om met die Franse commentaren te werken zal het gebruik ervan thebben vereenvoudigd. Bovendien waren er geen uitgebreide Nederlandse commentaren in de eerste jaren na de codificatie. Veelvuldig wordt in die tijd in de Nederlandse literatuur melding gemaakt van publicatie van in andere landen verschenen werken, vaak worden privaatrechtelijke werken uit andere rechtsstelsels in de Nederlandse literatuur besproken ${ }^{275}$. Maar wat vonden Nederlandse juristen van gebruik van andere rechtsstelsels in het Nederlandse privaatrechi?

\section{Gebruik van andere rechisstelsels}

Het gebruik van tekst, systematiek en de historie van wetsbepalingen als belangrijkste interpretatiemethoden heeft betekenis voor het gebruik van andere rechtsstelsels. Alleen in verband met de wetshistorie kan aan een ander rechtsstelsel betekenis toekomen in de uitleg. Dat onderkennen zowel Diephuis als Opzoomer in hun methodologische uiteenzettingen.

Zo stelt Diephuis reeds in 1844 'dat eene blinde aanneming der resultaten, waartoe de Franse Regtsgeleerden, bij de behandeling van menige regtsvraag, geraakten, onder onze wetgeving geheel onjuist zou zijn." ${ }^{276}$ Maar wel gebruikt hij het Franse recht, namelijk daar waar het voor de uitleg dienstig kan zijn. Wanneer is dit nu het geval? In Diephuis' boven besproken methode alleen dan wanneer het als wets- of rechtshistorische uitleg kan dienen: voor de uitleg van de Nederlandse artikelen heeft het Nederlandse recht 'de ondervinding van dat regt voor zich." 277 Tevens heeft Diephuis nauwgezet kennis genomen van 'eenige meest geachte werken over den Code Civil, welke laatste mij voorall tot de behandeling van menige regtsvraag heeft aanleiding gegeven.' Diephuis' kennis wan de Franse commentaren bieden hem soms een uitleg, woor zover het de historie van de Nederlandse bepaling kan verduidelijken. Daarnaast dienen zij als

275. Zo bijyoorbeeld door Kappeyne wan de Coppello, J., bespreking van Larombière, M.L.. The erie et pratique des obligations ou commentaire des Tutres III el IV, liwre IV du Codte Napoléon in: Themis 1857, p. 312. Larombière, aldus Kappeyne van de Copello, 'handhaft overal de wrijheid zijner overtuiging en verdedigt niet zelden de warheid, zelfs waar zij de meerderheid en het gezag der stemmen niet aan hare zijde heeft, met krachtige en wetenschappelijke gronden."

276. Diephuis, $\mathrm{G}_{\text {., deel }} 1$ (1844), p. i-ii.

277. Diephuis, $G$., deel 1 (1844), p. wi. 
een bron wan rechtswragen. Het Romeinse recht vindt in Diephuis' benadering nog een (zeer) geringe plaats. Het komt soms betekenis toe bij de (historische) uitleg van een enkel artikel. Over het algemeen heeft het Romeinse recht 'minder dadelijk belang' bij de uitleg van het geldende recht ${ }^{278}$. Later neemt Diephuis afstand van het Romeinse recht. Het is afgeschaft en voor uitleg van artikelen uit het Burgerlijk Wetboek kan aan dit recht geen warde worden toegekend. Ook in de door ons onderzochte leerstukken komt deze argumentatic van Diephuis voor ${ }^{279}$. Over de toepassing van andere rechtsstel sels laat Diephuis zich niet expliciet uit. De autoriteit van de wet lijkt in de weg te staan van een uitgebreidere toepassing van andere rechtsstelsels, ook wanneer de wet onduidelijk is of zwijgt. Maar in zijn uiteenzettingen wordt toch meer gebruik gemaakt van andere rechtsstelsels dan verklaard kan worden met de historische interpretatiemethode alleen. Vaak verwijst Diephuis naar eigentijdse Franse bronnen. Dat heeft waarschijnlijk te maken met het opdoen van inspiratie voor de behandeling van rechtsvragen (zoals Diephuis stelde), maar ook met de gewoonte om naar Franse bronnen te verwijzen. Dit verwijzen naar eigentijds recht betekent dat het gebruik van andere stelsels als historische interpretatie verschuift naar een rechtsvergelijkende methode.

Ook bij Opzoomer heeft de aan tekst en systeem van de wet gebonden uitleg consequenties voor het gebruik van andere rechtsstelsels. Het Franse recht gebruikt Opzoomer als historische interpretatie. Anders dan Diephuis, verwerpt Opzoomer het Romeinse recht niet. In zijn uitleg is dan ook voor dat recht plaats ingeruimd. Wel moet volgens Opzoomer de jurist zeer voorzichtig zijn met aanneming van in het Romeinse recht gegewen regels, omdat het meestal onterecht zal zijn een argument uit dat stelsel te ontlenen voor de uitleg van het Nederlandse recht. Waarom? De positie van de Romeinse jurist was een geheel andere, bij hen was immers lang geen sprake meer van uitleg, maar van "rechtsontwikkeling."

Opzoomer en Diephuis laten zich niet uit over toepassing van andere stelsels dan de genoemde. Die andere stelsels (met name het Duitse) spelen vaak een rol. Een aantal voorbeelden is al genoemd, zoals de aan Savigny ontleende nitlegmethoden van Opzoomer. Olivier sprak in zijn bespreking van Diephuis' werk van een voorkeur voor een 'organische" behandeling van het Nederlandse recht. Daarmee leunt hij sterk aan tegen een van de ideeen van de Historische School van Von Savigny. Levy, die sterk door de Historische School is geînspireerd, stelt zich in zijn werk Het ideele in recht en staat wit 1877 op het standpunt dat het recht 'boven en buiten den natie geplaatst' niet bestaat, want '[i]eder rechtsstelsel is de vrucht en het getuigenis tevens der nationale rechtsover-

278. Diephuis, G., deel $\mathbb{\text { l }}$ (1844), p. vii. Een "doorgaande vergelijking" met het Romeinse (en het oudvaderlandse) fecht had Diephuis voor ogen gestan, "vrees voor al te groote vitvoerigheid, gevoegd bij het minder dadelijk belang voor de kennis van her hedendagsche regt" heeft hem daarvan weerhouden. Z ire hoofdstuk $3 \$ 2.8$ ower het belang dat nog aan het Romeinse recht werd gehecht, zo whak nat de codificatie, en hoofdstuk 4 4.B voor Diephüs' mening over publiek domein.

279. Lokin, J.H.A., (1993), P. 35 en 36. Zie woorts 4 . 
tuiging en vindt zijn steumpunt in het volk als organisme. 'Levy zelf maakt juist veel gebruik van andere rechtsstelsels ${ }^{230}$. Ook in de behandelde onderwerpen wordt daarvan gebruik gemaakt.

Een aantal manieren waarop gebruik van andere rechtsstelsels in de legistische periode mogelijk was, passeerde de revue. In de eerste plaats kan van ander recht gebruik worden gemaakt in verband met een historische interpretatie. In de tweede plaats kan van andere rechtsstelsels gebruik worden gemaakt door de invloed van andere (Nederlandse) rechtsgebieden op het privaatrecht. In de derde plaats kan in de argumentatie naar het wenselijke recht eenvoudiger een beroep op andere rechtsstelsels gedaan worden. In de vierde plaats tenslotte wordt steeds vaker verwezen naar het eigentijdse buitenlandse recht. Van deze mogelijkheden wordt zeker gebriik gemaakt. Want ondertussen zag de Nederlandse jurist wat er in andere rechtsstelsels gebeurde. Kappeyne van de Coppello zien wij schrijven over de beoefening van het Franse recht 'met liefde, helderheid en verstandige scherpzinnigheid, ' en over de 'ongekende vlugt' van beoefening van het klassieke recht in Duitsland. De Nederlandse civilist bevindt zich in een lastig parket. Aan de ene kant de prille, eigen Nederlandse rechtswetenschap in gebondenheid aan de toegestane methoden van uitleg van de Nederlandse wettekst, aan de andere kant de lofuitingen aan het adres van het andere recht.

\section{§ 2. Aansprakelijkheid voor zaken: enge en ruime opvattingen}

\section{A. DE AANZET: RUMME UITLEG VAN ARTIKEL 1403 BW IN RECHTSPRAAK}

De rechtspraak biedt in 1857 de aanzet tot de discussie over de uitleg van artikel 1403 . Deze discussie kenmerkt zich door de sterk tegen over elkaar staande standpunten van Opzoomer en Diephuis ${ }^{281}$. Het Hof Amsterdam wijst in 1857 en 1858 twee arresten en geeft daarin aan artikel 1403 lid $1 \mathrm{BW}$ een ruime uitleg. Een van die twee uitspraken mondt uit in het arrest van de Hoge Raad betreffende de Amsterdamse gasmaatschap$\mathrm{pij}^{282}$. In het kort zal het eerste arrest uit 1857 hier worden geschetst ${ }^{283}$. In deze uitspraak speelt de Hollandsche IJzeren Spoorwegmaatschappij de hoofdrol. Wat was

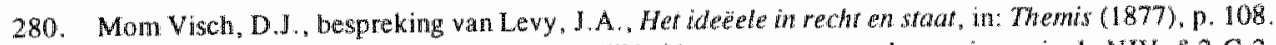
Zie Levy in de discussic ower oe arnsprakelijkeid van spoorwegondernemingen in de NJV, $2,2.3$.

281. Zie voot het voorafgande loofdstuk $3 \$ 4$. A ery loofdltak 4 \& 2 .A.

282. Beide zaken zijn gewezen door het Prownciall Geregtshof van Woord-Molland, 1 oknober 1857 , Rechtsgeleend Biblad, behoorende hot de Nieuwe Dijdragen voor Reglsgeteerdheid en Wergewh (1858), p. 151-156 ea, in dezelfde verzameling. 8 februari 1858, (1858), p. 438-440. Bij de laatste uitsprak handelt het ower de Amsterdamse gasmaatschappij. Zie hoofdstuk 2 2.B. Dieptuis, G., det $6(1856-1859), p .275-276$.

283. Vakholf wijst bij een bespreking van dit arrest op een werk van Paignon, die in 1853 raeds voor eet ruime uitleg van artikel $1384 \mathrm{Cc}$ had geple th. Een verband tussen Paignons publicatie en de Nederlandse rume utleg is mogelijk maar blikt niet uit verwijzingen. Zie Valkhoff, J., De invloed van de Spoorwegen op enkele gebieden wan het Nederlandse priwatrecht, RM Themis $1939 ., 399$. 
er gebeurd? Op 10 augustus 1856 rijdt een locale spoortrein, op weg van 's Gravenhage naar Rotterdam, achterop een andere trein. Een van de inzittenden van de laatste trein raakt zwaargewond. Voor deze schade spreekt passagier de maatschappij aan op grond van artikel 1403 lid $1 \mathrm{BW}$. Het Hof overweegt dat de spoorweg waarop het ongeluk plaatsvond uitsluitend door de gedaagde spoorwegmaatschappij werd geexxploiteerd, en dat daaruit reeds volgt dat het ongeluk door haar schuld was teweeggebracht:

\begin{abstract}
'Dat, indien aan de gegrondheid dier praesumptie eenige twijfel bestond, zij door den Wetgever bij art. 1403 lid 1 Burg. Wetb., tot eene wettelijke praesumptie is werheven; Dat het woond zaken, in dat artikel, van algeneture beteekenis is, (..) dat immers uit de omstandigheid, dat bij het Romeinse Regt bijzonderlijk voorzien was in het geval van door dieren toegebrachte schade (..) geenszins volgt, đat de Nederlandse Wetgever, die het woord zaken gebezigd heeft, allến van dieren heeft willen spreken; dat het evenmin opgaat de kracht der aangehaalde alinea, als eener inteiding tot de, in de volgende artikelen, vermelde gevallen te beperken., (...) en het woorzeker niet geoorloofd is, de overbodigheid van eenig Wetsartikel aan te nemen, welks heilzame bedoeling in thet oog valt;"
\end{abstract}

Het Hof construeert hier op grond van artikel 1403 lid $1 \mathrm{BW}$ een gunstige bewijspositie woor de gelaedeerde. Omdat de spoorwegmaatschappij het 'opzigt' had over de spoorweg wordt tot aanwezigheid van schuld geconcludeerd. De spoorwegmaatschappij zou het tegendeel nog kunmen aantonen, dat was haar blijkbaar niet gelukt. Een van de redenen van het Hof doet aan de argumentatie van Toullier denken. Die spreekt immers van een algemene betekenis; het artikel is van toepassing op alle zaken, 'toutes les choses." Van een vermoeden wan schuld blijkt niet bij Toullier ${ }^{284}$. De omkering van de bewijslast, zoals door het Hof verwoord, is een nieuwe uitleg. De Hoge Raad casseert: wel is sprake van een omkering van de bewijslast, doch die volgt niet uit artikel 1403, maar uit artikel $1959 \mathrm{BW}$. De rechter kan op grond van de feiten uitgaan van een schuldvermoeden ${ }^{285}$. Op deze manier kan eenzelfde resultaat bereikt worden als door middel van $1403 \mathrm{BW}$ met een omkering van de bewijslast. De toepassing van dit feitelijke vermoeden van artikel 1959 BW blijft echter an de rechter.

Minder dan een jaar na deze uitspraak doet de Hoge Raad uitspraak in de zaak van de Amsterdamse gasmaatschappij en geeft dan een ruime uitleg aan 1403 lid 1. Een risicoaansprakelijkheid wordt gevestigd door het louter onder "opzigt" hebben. De Hoge Raad gebruikt een buitengewoon summiere grammaticale interpretatie. Wel worden enkele personen genoemd waarvoor men aansprakelijk kan zijn, die opsomming ontbreekt echter voor zaken, zodat dit artikel een algemene betekenis heeft. Van schuld wordt in

284. Zie hoofdstak 3 \$ 4.A.

285. HR 11 juni 1858,W. 1967. Art. 1959. Vermoedens welke niet op de wet zelve gegrond zijn worden overgelaten aan het oordeel en aan de voorzigigheid van den regter, die echter op geene andere letten mag dan op die welke gewigtig, naawwkeurig, bepaald en met elkander in overeenstemming zijn. Zoodanige vermoedens kunnen alleenlijk in aanmerking komen in de gevallen waarin de wet het bewijs door getuigen todat, en ook bijaldien, wit hoofde van kwade trouw of bedrog, tegen eene handeling of akte wordt opgekomen. 
het artikel niet gesproken. Deze uitspraak van de Hoge Raad gaat in tegen de conclusie van het Openbaar Ministerie, die eenzelfde onderbouwing voor zijn standpunt heeft als Diephuis ${ }^{236}$. Deze uitspraak wordt gebruikt in het parlement bij de vervaardiging van spoorwegwetgeving. Tweede kamerlid Wintgens pleit voor een aanknoping bij de ruime uitleg van artikel 1403 lid $1 \mathrm{BW}$. In bijzondere, op spoorwegmaatschappijen toegesneden wetgeving behoort 'afwijking van het gemeene regt (..) niet te worden toegelaten. De Franse regtsgeleerde schrijvers leeren dat men aansprakelijk is voor de benadeeling, door zaken, waarop men toezicht heeft, ook zonder schuld.' ${ }^{287}$ Zo stellig als Wintgens die ruime Franse uitleg schetst, is de uitleg in Frankrijk zeker niet. Bij Toullier was een dergelijk standpunt niet aanwezig ${ }^{288}$, bij latere schrijvers, zoals Marcadé, blijkt eerder van een vermoeden van schuld, dan van een aansprakelijkheid zonder schuld ${ }^{289}$. Afzonderlijke wetgeving is wel de weg waarvoor gekozen wordt, niet voor een ruime uitleg van artikel 1403 . Vooralsnog zijn de meningsverschillen over de uitleg groot, tussen het Openbaar Ministerie en de Hoge Raad, maar tevens in de literatuur.

\section{B. EEN ENGE UITLEg DOOR het OPENBAAR Ministerie}

Het Openbaar Ministerie geeft in een aantal zaken een enge uitleg aan artikel 1403. Het OM doet dat in de zaak van de gasmaatschappij in 1859, maar ook in een zaak in $1869^{290}$. AG Karseboom stelt dan over de ruime uitleg van 1403 dat

'omtrent deze wets-opvatting eenig verschil van gevoelen heeft bestaan tusschen den Hoogen Raad en het Openb. Min., zoo bij monde van den heer proc.gen. als van den heer adv.gen. Gregory, die bij hunne conclusiën de zaak zoodanig in het breede hebben behandeld, dat ik mij ontslagen mag achten die gronden opnieuw aan te voeren.(...) Ook naar het mij voorkomt is de bepaling van art. 1403 all. $1 \mathrm{BW}$, op het voetspoor van art. 1384 al.1 C.N., meer doctrinatis, dan de gevallen aanduidende, terwijl de ontwikkeling der gestelde leer der verantwoordelijkheid

286. Zie hoofdstuk 2 \& 2.B, voor zowel de overweging van het Hof, als de uitspraak van de Hoge Raad. Zie de AG Gregory woor het arrest van de Amsterdamse gasmatschappij, W. 2022 (1859), en tien jaut later een conclusie van de $\mathrm{AG}$ Karseboom, watrin nog eens axpliciet het verschil van mening tussen de Hoge Raad en het Openbaar Ministerie wordt verwoord, W. 3084.

287. Bijblad wan de Nederlandsche Staats-couran II, 1858-1859. p. 1203. In die wet wordt ten aansprakelijkheid met onkering van de bewijslast voor de spoorwegondernerning gevestigd, in navolging van de spoorwegwetgeving in Pruisen. Zie hierover ook Van Maanen, G.E., Stoomtreinen en alansprakelijkheid, WPNR 5742-5743 (1985). Van de door Wintgens voorgestelde regelgeving zonder schuld komt het niet. Wel wordt op voorstel van Thorbecke een omkering wan bewijslast aangenomen. Zie verder onder hoofdstuk 6 2. Tichelaar, P.A., Artikel 1 der wet van 9 april $1875(S .67)$, tof regeling van de dienst en het gebruik der spoorwegen, Rechtsgeleerd Magazijn 1891 . p. 9; ook in: W. 5856 (1890). conclusie PG voot HR 3 april 1890 , p. 1.

288. Zie hoofdstuk 3 \&.A.

289. Marcadé, $\mathrm{V}$, deel 8 (7e druk, 1867), p. 283.

290. W. 3084 (1869). De Hoge Raad laat zich niet uit over de uitleg van artikell 1403 in deze laatste zatak uit 1869, want de vordering van de eiser was naar de feitelijke beslissing van hett Hof een vordering. op grond van artikel 1402 , zodat "de bewering van schending of verkeerde toepassing van art. 1403 van dat wetboek hier in geene aannerking kan komen." 
ten ăanzien van personen in de wolgende alinea's, ten aanzien van zaken in de beide volgende artikelen speciarl wordt arangegeven."

Het OM verwijst naar Diephuis ${ }^{291}$, die in de tweede druk van zijn werk Het Nederlandsch Burgerlijk Regt naar de volgorde van het Burgerlijk Wetboek ingegaan was op de bovengenoemde uitspraken van het provinciaal Hof van Noord-Holland. Voorts haalt het $O M$ Toullier en Zachariae aan. Uit Zachariae betrekt het $O M$ de wetsgeschiedenis van artikel $1384 \mathrm{Cc}$. Toullier stelt schuld van de opzichter als vereiste wanneer schade door een zaak is veroorzaakt. Artikel $1384 \mathrm{Cc}$ mag niet 'par analogie' worden uitgelegd, '[c]ar cette responsabilité étant contraire à la raison, on ne peut, en cette matière, raisonner par analogie." Bij De Pinto ${ }^{292}$ en Diephuis komt dit analogieverbod aan de orde, en in de methodologische uiteenzettingen van Opzoomer en Diephuis wordt ook over deze uitlegmethode gesproken ${ }^{293}$. Daarnaast wordt Marcadé aangehaald, over wiens standpunt een verschil van uitleg bestaat. Eisers in deze zaak hadden Marcadé voor ondersteuning van een ruime uitleg gebruikt. Ten onrechte, aldus de AG, en hij lijkt het bij het rechte eind te hebben. Marcadé is, net als Toullier, tegen een toepassing van artikel $1384 \mathrm{Cc}$ "par analogie" en ziet een limitatieve opsomming in de artikelen 1384-1386 Cc. Marcadé spreekt over: "Les cas dans lesquels cet article et les deux suivants imposent à une personne la responsabilitế du dommage causé, soit par (..) des choses lui appartenant ou confiées à sa garde, sont des cas de quasi-délits. "Verder, over 1386: 'Un dernier cas de responsabilité légale est indiqué par l'article 1386.' 294 Alleen voor de genoemde personen en zaken geldt een vermoeden van schuld. De interpretatie door Nederlandse juristen van het Franse recht kan nogal uiteenlopen. Latere Franse schrijvers, zoals Mazeaud, zijn van mening dat de Gentse hoogleraar Laurent (in 1878) als eerste een ruime uitleg heeft voorgestaan ${ }^{295}$.

In 1870 komt de Hoge Raad terug op zijn eerdere ruime uitleg ${ }^{296}$. 'Is men alleen dan verantwoordelijk voor de schade veroorzaakt door zaken, die men onder zijn opzigt heeft, wanneer zij het gevolg was van verzuim of nalatigheid? Ja." stelt het kopje boven de uitspraak. In deze zaak handelt het on twee oude bomen die waren omgewaaid en schade teweeg hadden gebracht. De eigenaar van de bomen werd aangesproken, op grond van artikell 1403 lid 1 BW. Van aansprakelijkheid zou sprake zijn, 'afgescheiden van de vraag, of er schuld of nalatigheid hebbe bestaan bij den eigenaar of opzigter der boomen.' Zowel AG (onder verwijzing naar Toullier) als Hoge Raad komen echter tot de conclusie dat de kwaliteit van eigenaar of opzichter alleen niet tot aansprakelijkheid

291. Zie $8 . C$.

292. Zie hoofdstuk $4 \$ 2$.A.

293. Toullier, C.B.M., deel 11 (1824), nr. 258. Zie boven hooldstuk 3 \& 4.A, hoofdstuk 4 \& 2.A en $\$ 1 . \mathrm{C} .2$.

294. Marcadé, V., deel 5 (Se ànk, 1852), p. 269 en 273 .

295. Zie hoofdstuk 6 2.C.2.

296. HR 4 maart 1870. Van den Honert, Verzameling wan arresten wan den Hoogen Raad der Nedertanden, burgerlijk regt, regt van koophandel en burgerlijke regtsvordering, deel 34 (1871), nr. 1162. 
kan leiden, doch dat tevens nalatigheid of verzuim is vereist ${ }^{297}$. In een vrij constante jurisprudentie is verder deze uitleg aan artikel 1403 gegeven ${ }^{298}$.

\section{Het verschil van mening tussen Diephuis en Opzoomer}

\section{Diephuis}

De ruime uitleg in de jaren vijftig van het Provinciaal Hof brengt Diephuis tot een stellingname. Hij stelt dat de zinsnede 'zaken, welke men onder zijn opzigt heeft,' niet meer is dan een inleiding op de navolgende bepalingen 1404 en $1405 \mathrm{BW}$. Iemand kan wel aansprakelijk zijn voor zaken, maar alleen indien de schade veroorzaakt is "door eene onregtmatige daad, of door nalatigheid of onvoorzichtigheid en dus art 1401 of 1402 toepasselijk mogt zijn. ${ }^{209}$ Een systematisch argument is de plaatsing van artikel 1403 voor de artikelen 1404 en 1405 BW. Een systematisch argument betrekt hij uit artikel $534 \mathrm{~K}$. In dat artikel wordt voor schade toegebracht door een schip, schuld als grondslag genomen ${ }^{300}$. Diephuis stelt als eerste met zoveel woorden dat schuld een vereiste is voor aansprakelijkheid voor schade door zaken. Impliciet hebben wij bij Toullier dit vereiste voor aansprakelijkheid gezien. Bij het analogieverbod van artikel 1403 haalt hij Toullier, Duranton en Zachariae aan: 'Gelijk de verantwoordelijkheid voor de daden van anderen bepaald is tot art. $1403 \mathrm{~b}$-d, is ook die wegens zaken bepaald tot de gevallen van art. 1404 en v..' ${ }^{301}$

In zijn latere werk geeft Diephuis dezelfde interpretatie en gaat dan in op het standpunt van Opzoomer ${ }^{302}$ :

'En artikel 1403 a zelf heeft niet het voorkomen eener uitdrukking van den regtsgrond dier bepalingen, maar zou toch ook wanneer dat het was medebrengen, dat deze, en zij allieen geldende zijn. De voorstelling van een algemene bepaling, met bijzondere bepalingen dararevens latat zich wel is waar denken, maar is toch ook vrij onatmemelijk, daar door de vereniging van beiden ten aanzien van het een niets, ten aanzien van her ander alles aan "s rectiters oordteel overgelaten, maar daardoor dan ook de regtszekerheid kwalijk gediend zou zijn.." 393

297. Zie de conclusie van de advocaat-generaal voor HR 22 januari 1869 , in W. 3084 (1869).

298. Zie hoofdstuk 6 2.D.2.

299. Diephuis, G., deel $6(1856-1859)$, nr. 700 a.

300. Artikel 534. Indien een schip, door schuld van den schipper of van zijn scheepswolk, een ander schip overzeilt, of tegen hetzelve aanzeilt, aanvaart of aandrijft, en alzoo beschadigt, moet de gehele schade, aan het schip en aan de goederen toegebracht, worden vergoed door den schipper wiens schip de schade heeft veroorzaakt.

301. Zie hoofdstuk 4 \& 2.A. Zo word Diephuis' terughoudendheid met de meer extensieve interpretatie, analogie en a-contrario redenering gellustreerd. Zie $\$ 1 . \mathrm{C}$.

302. Diephuis, G, deel 11 (1888), p. $90 \mathrm{ev}, 106,113 \mathrm{ev}$. Dat Diephuis zich niet oveti de rechtspraak uiflat windr zijing grond in de door Diephuis gevolgde methoden wan rechtswinding. Zie boven 1 1.C.2.

303. Diephuis, G., deel $11(1888)$, p. $92-93$. 
Zo nemen in Diephuis" visie alleen de aansprakelijkheid voor dieren en gebouwen (artt. 1404 en 1405) een bijzondere positie in. Bij een andere zaak volgt alleen aansprakelijkheid indien aan de vereisten van artikel 1401 of $1402 \mathrm{BW}$ voldaan is. Diephuis keert zich expliciet tegen de in het Franse recht gemaakte analoge interpretatie. Toullier, Larombière en Demolombe geven een ruime uitleg aan artikel 1386 en brengen de 'omgevallen boom' onder de werking van het artikell: 'Ce que nous avons dit du dommage causể par la chûte d'un bấtiment, peut s'appliquer au dommage causế par la chûte d'une arbre. Le principe est le même, si c'est par la faute ou la négligence du propriétaire qu'il est tombé; tout dépend des circonstances." ${ }^{304}$ Nee, aldus Diephuis, analogie is niet geoorloofd:

\begin{abstract}
'Wat artikel 1404 zegt van een dier, en art. 1405 van een gebouw, is niet eene toepassing, of nadere bepaling of ontwikkeling wan een regel of algemeen beginsel, in art. 1403 a uitgedrukt, unaar om en in verband met die bepalingen is daar in de inleiding sprake van zaken die men onder zijn opzigt heeft. En is dit zoo, dan mag noch hieruit, noch bij analogie uit die arti. iets worden afgeleid, omtrent ansprakelijkheid voor schade, ten gevolge van eenig woorwerp geleden. Zoo zal b.v. de schade verporzaakt door den val wan een boom, naar mijn oordeel eenvoudig gedragen moeten worden door hem wien zij getroffen heeft, omdat geen ander daarvoor jegens hem aansprakelijk is gesteld. En deze voorstelling komt mij des te meer aannenelijk voor, omdat ik niet zie, hoe en waarom de wetgever, die met betrekking tot dieren en gebouwen nadere bepalingen noodig achtte, heeft kumen meenen ten aanzien van boomen en andere voorwerpen alles onbepaald te moeten of te kunnen laten; $(.$.$) of te kunnen volstaan met$ die [aanduiding] welke het slot van art. 1403 a bevat $(.),.{ }^{305}$
\end{abstract}

\title{
2. Opzoomer
}

Opzoomer geeft een ruime uitleg aan artikel 1403. Dat kan hij doen mits die -interpretatie maar leidt tot de reconstructie van de 'inwohnende Gedanke." ${ }^{306}$ In 1403 wordt in het algemeen van zaken gesproken, en dus is er een algemene regel gegeven:

\footnotetext{
¿.dat $\$ 1$ van ons artikel exu algemeenen regel bevat, die zonder eenige uitzondering woor alle gevallen getdt" waarop zijn woorden van toepassing zijn.(..) En nast dien algemeenen regel komen dan, maar met een geheel eigen karakter, zoodat ze daardoor een recht op een zelfstandig bestaan hebben, veel meer dan enkel voorbeelden zijn, de bijzondere bepatingen," 307
}

Hierin verschilt hij volledig met Diephuis van mening. Welke redenen heeft Opzoomer voor zijn standpunt? Ondanks het beeld van Opzoomer als strikt aan de woorden van de wet vasthoudende jurist blijkt hij niet alleen in theorie, maar ook bij inhoudelijke

304. Toullier, C.B.M., deel 11 (3e druk, 1824), nr. 317; zo ook Demolonbe die aansprakellikheid laat volgen indien sprake is 'd'une faute, $d$ 'une imprudence ou d"une négligence imputable au propriétaire." Demolómbe, C., Cours de Code Napoléon. Traité des engagements qui se forment sans convention, deel 8, ne. 664: Larombière, op art. 1386, n. 10.

305. Diephuis, G. deel $11(1888)$, p. 113.

306. Zie boven, 1. C. 2 .

307. Opzoomer, C.W. Het burgerlijk wetboek verklaard, deel 6 (1879), p. 324-325. 
onderwerpen de maatschappelijke wenselijkheid en de redelijkheid en de billijkheid mee te wegen bij de interpretatie ${ }^{308}$. Opzoomer:

\begin{abstract}
'Is deze voorstelling mogelijk, ze is bovendien noodzakelijk. (...) Immers, de zaken, in die twere artikelen genoemd, dieren en in zeer bijzonderen toestand zich bevindende gebouwen, zal men toch wel niet geneigd zijn te beschouwen of als de eenige voorbeelden ter opheldering van een gestelden regel gekozen, of als de eenige voorwerpen, voor wier schadelijke werking ienand aansprakelijk zou kunnen zijn. Veeleer zal men moeten en willen toegeven, dat terwijl wolgens onze $\$ 1$ de rechter in ieder voorkomend geval, waarin iemand wordt aangesproken voor schade. door een zaak (niet door een persoon) veroorzakt, met volle vrijheid zal moeten beslissen, of die zaak heeten mag onder het 'opzigt' van den gedaagde te zijn, en hem in dat gewal tor schadevergoeding te veroordeelen, die vrijheid daar, waar de zaak een dier of een gebouw is, door de bepalingen van art. 1404 en 1405 is beperkt." $30 \%$
\end{abstract}

De redactie van de artikelen 1403-1405 BW laat volgens Opzoomer nogal te wensen over. De wetgever heeft zich er met een jantje-van-leiden van afgemaakt, want:

"In plats van bij dit en de twee volgende artikelen de ogen te openen voor al de vragen, waartoe de drie overeenkomstige artikelen warn het Fransche wetboek aanleiding hadden gegeven, heeft men, als waren die nooit gedaan of als misten ze alle grond, zich maar weer eenvoudig aan het vertalen gezet." 310

De onduidelijkheid vloeit voornamelijk daaruit voort dat er een algemene regel is gegeven náást bijzondere bepalingen. Over de verhouding tussen beide heeft de wetgever zich niet uitgelaten. Van andere rechtsstelsels maakt Opzoomer geen gebruik bij de behandeling van dit artikel. Dat was ook niet nodig. Binnen de woorden van de wet kon hij tot een acceptabele uitleg komen. Maar Diephuis standpunt wordt de heersende leer ${ }^{31 !}$.

\title{
3. De Nederlandse Juristen-Vereniging: geen afwijking van het schuldbeginsel ${ }^{312}$
}

In 1874 discussieert de Nederlandse Juristen-Vereniging over de aansprakelijkheid van spoorwegondernemingen. Moest er een van het gewone burgerlijk recht, van het schuld-

308. Zie \& 1.C.2.

309. Opzoomer, C.W., deel 6 (1879), p. 326. Bij wan Dievoet wordt Opzoomer gekarakteriseerd als cen hets strengere wetsuillegger dan Diephuis. De grammaticale uilleg zou meer de boventioon woeren, en de wil van de wetgever, zoals die blijkt uit parlementaire stukken mag voor Opzoomer bij wetsuitleg. ging geen rol spelen. Zie Van Dievoet, E., (1943), p. 111. Zo ook Lokin, J.H.A. "(1993), p. 29. Met de uitheg wan artikel 1403 blijkt echter toch dat Opzoomer door juist dicht bij de tekst van de wet te blijwen een ruime uitieg kan bewerkstelligen.

310. Opzoomer, C.W., deel 6 (1879), p. 323.

311. Af en toe wordt Opzoomers standpunt nog verdedigd. Zo had ook Land een uitleg, waarbij schuld niet vereist was. Land, N.K.F., Beschouwingen over de verbintenis uit ontrechtmatige dadad (1896), p. 164 ev. Zo bijvoorbeeld ook door Tichelaar, Scholten en Bruins. Zie hoofdistuk 6 \& $2 . \mathrm{C}$.

312. Zie over de Nederlandse Juristen-Vereniging uitgebreid Lokin, J.H.A., en C.J.H. Jansen, Tussen droom en daad (1996), passim: zie ook hoofdstuk 6. 
beginsel afwijkende regeling komen? In 1859 en 1874 had de Spoorwegwet een aansprakelijkheid met omkering van de bewijslast gevestigd, maar die betrof slechts de door verwoerde personen en an vervoerde goederen geleden schade. Moest er voor nietreizigers iets vergelijkbaars worden geregeld ${ }^{3 / 3}$ ? Sommigen staan dit voor, met een beroep op de wenselijkheid van een gunstiger positie voor de gelaedeerde. Deze voorstanders verwijzen naar de wetgevingen in Duitse landen. Wetsvergelijking voor het ius constituendum wordt met kracht voorgestaan. Wetgeving uit andere landen biedt "voor het ius constituendum niet onbelangrijke bijdragen, en zoo hel nog lang eene onmogelijkheid zal blijven een Europeesch regt te verkrijgen, zal het toch altijd zaak zijn, om bij de herziening van eigen regt op dat van naburige staten het oog te houden. 314 Met grote meerderheid, met 27 tegen 14 stemmen, wordt een dergelijke verandering van het gewone burgerlijk recht afgewezen ${ }^{315}$. Eenheid van recht (geen afwijking van het gewone recht voor bijzondere gevallen) en het schuldbeginsel als onwrikbaar systematisch uitgangspunt zijn de belangrijkste beweegredenen voor afwijzing. Dat geeft een fraai beeld van het legisme enerzijds en illustreert de grote waarde van het wetssystematische argument. Anderzijds biedt het een blik op de reeds aanwezige kracht van het aan de maatschappij ontleende argument ${ }^{316}$.

\section{DIEPHUIS' HEERSENDE LEER}

In andere handboeken wordt de mening van Diephuis nagevolgd. De ruime uitleg van 1403 zoals door de Hoge Raad gegeven is volgens De Pinto weinig aannemelijk. De Pinto vermeldt in 1860 dat artikel 1403 lid $1 \mathrm{BW}$

\footnotetext{
"is alzoo geen voorbeeld, matar het regelt of expliceert de uitzondering op dien regel, waardoor de verantwoordelijkheid ook wordt uitgestrekt tot die schade, die veroorzaakt is door zaken, welke men onder zijn opzicht heeft, art 1403; en deze bepaling mag daarom ook niet worden uitgestrekt tot andere gelijksoortige gevallen, tenzij het blijke, dat de schadle door de zaak weroorzagkt te wijten zij atin schuld of nalatigheid van den eigenat, bezitter of gebruiker.: 317
}

Uitzonderingen op de regel dat aansprakelijkheid slechts volgt op eigen daad of verzuim moeten strikt geïnterpreteerd worden, volgens zowel De Pinto, als Teixeira de Mattos in een bewerking van De Pinto's handboek uit $1885^{318}$. Zowel het Répertoire van

313. Handelingen 1874, p. 178.

314. Handelingen 1874, p. 182.

315. Handelingen 1874, p. 219.

316. Zie hoofdstuk $6 \$ 2$.E.

317. De Pinto, A., (4e druk, 1860), p. 532.

318. De Pinto verwijst eveneens nat het hierboven weergegeven arrest van 7 november 1850 . De Pinto, A. (1860), p. 532. De beide door De Pinto ter ondersteuning aangehaalde arresten zijn de volgende: HR 7 november $1850, W .1218$ (boven vermeld en weergegeven) en bovendien HR 30 oktober 1857 . W. 1908. Dalloz, Répertoire, no. 749. Marcadé, V., deel 5 (5e druk, 1852), p. 269. Teixeira de Mattos, A., (1885), p. 571. 
Dalloz als Marcadé biedt ondersteuning voor de strikte interpretatie. De voorbeelden van artikel 1385 en $1386 \mathrm{Cc}$, citeert De Pinto uit Dalloz: 'n'ont rien de limitatif.'

\section{E. CONCLUSIES AANSPRAKELUKKHEID VOOR ZAKEN}

De enge uitleg van artikel 1403 lid 1 wordt geaccepteerd in de literatuur, en niet de ruime uitleg van Opzoomer. Wat zou daarvan de reden kunnen zijn? De grammaticale, systematische en de historische uitlegmethoden hebben de meeste argumentatieve kracht. Dat is ook bij Opzoomer het geval. Ook hij laat zijn uitleg altijd berusten op 'de woorden zelve der geheele wet.' Die woorden kunnen echter veel omvatten alls zij ook met behulp van redelijkheid en billijkheid uitgelegd worden. Dat doet Opzoomer bij artikell 1403, en dat was een extensieve interpretatie die voor de meeste juristen toch onacceptabel was.

Veel verwijzingen naar het Franse recht worden gebruikt. Is deze interpretatie met behulp van het Franse recht nog een historische interpretatie te noemen? Voor een groot deel zeker. Maar vaak blijkt het om een verwijzing naar het eigentijdse Franse recht te gaan. Naast de grammaticale, de systematische en de historische interpretatie verschijnt een nieuwe wijze van interpretatie, de rechtsvergelijkende. Wat is het belang van deze nieuwe rechtswergelijkende methode bij de vorming van de heersende leer over artikel 1403? De Franse commentaren geven van het overeenkomstige artikel in de Code civil, 1384, een enge uitleg. Zij bieden zo een ondersteunende parallel voor de enge uitleg van 1403 in de Nederlandse rechtswetenschap: bij Diephuis, in zijn gebruik van het werk van Toullier, Demolombe en Larombière; bij De Pinto en Teixeira, waar deze gebruik maken van Marcadé. Waarom waren die rechtsvergelijkende argumenten nodig? Het heeft waarschijnlijk te maken met de gewoonte om Franse commentaren te gebruiken. Een gebruik vanwege een historische interpretatie verkeert langzaam in een gebruik van de eigentijdse Franse interpretaties. Deze vergelijking heeft misschien geen formele kracht van uitleg, maar in de discussie wordt zij wel gebruikt.

Naast deze rechtsvergelijkende argumenten uit het Franse recht is er sprake van gebruik van andere rechtsstelsels in de Nederlandse juristenvereniging. Ingegaan wordt op het wenselijke recht, het ius constituendum. Vooral wetgeving uit Duitse landen inzake aansprakelijkheid komt aan de orde. Wel worden al deze afwijkingen verworpen, omdat de eeriheid van het burgerlijke recht in het BW, en het beginsel van 'schuld' vooropstaan. Dat geeft aan dat een verandering van het recht naar aanleiding van een buitenlandse opvatting in de periode van het legisme niet cenvoudig is. 


\title{
\$ 3. Artikel 2014
}

\section{A. DE GERMAANSRECHTELIJKE LEER}

Uit de vele interpretaties van 2014 in de periode na $1838 \mathrm{krijgt}$ de interpretatie waarbij bezit gelijk gesteld word aan eigendom (Goudsmit, Coninck Liefsting en Diephuis) de overhand. Deze uitleg wordt de 'Germaansrechtelijke' genoemd ${ }^{319}$. Deze interpretatie wijkt sterk af van de Romeinsrechtelijke, waarbij juist een scherp juridisch-dogmatisch verschil tussen bezit en eigendom wordt aangenomen ${ }^{320}$.

\section{Diephuis}

Veel uitgebreider dan twintig jaar voordien behandelt Diephuis in de jaren tachtig artikel 2014. Nog steeds 'wordt over de betekenis dier bepaling (..) verschillend gedacht.' Maar toch neigt de uitleg van deze bepaling veel sterker naar een gelijkstelling van bezit met eigendom:

\begin{abstract}
"Het bezil geldt als tirel, als volkomen tirel. De nanurlijke betekenis dier bepaling is deze, dat het bezit zich zelf wettigt, dat hij, die het heeft, daaron reeds als de rechthebbende beschouwd moet worden. De bezitner heeft het niet noodig zijn regt van bezit te staven. In het algemeen, in behalve in het geval wan ant. 2014b komt de vraag niet te pas, hoe hij het bezit heefit gekregen en van wien, of hoe lang hij het gehad heeft; hij heeft het, en dat is voor hem genoeg. Geen ander kan als eigenaar, en op grond van zijn eigendomsrecht, de zak van den bezitter opvorderen; het beweerde regt. dat zoo ienand zou willen doen gelden, stuit af op het bexit wan dezen. De bezilter wordt om zijn bezit zelf als de eigenatar beschouwd, zoodat geen ander tegenover hem een hooger regt kan hebben. Of liever, de onderscheiding wan eigendom en bezit, die ten aanzien van andere zaken gemaakt en ook door de wet erkend worden, zoodat men eigenatr kan wezen zonder bezitter, en bezitter zonder eigenaar te zujn, en eigenaar kan worden doordien men een tijd lang bezitter is geweest, die onderscheiding valt voor de roerende goederen, watrvan art. 2014a spteekt, weg, zoodat eigendom en bezit ten aanzien van die zaken én zijn. Tegenover den bezitter kan geen eigenaar staan; bezit is eigendom, de bezitter eligenaar; de zaak is de zijne, en het is onverschillig of men hem bezitter of eigenaar gelieft te noemen. ${ }^{\prime 2}$
\end{abstract}

Dat is duidelijk: bezit is eigendom, de zaak is de zijne, een wolkomen gelijkstelling (behalve bij verlies of diefstal). Diephuis voert rechtshistorische argumenten aan voor zijn uitleg, en gebruikt daarvoor Bourjon, de geschiedenis van de Code civil, Toullier, Delvincourt, Aubry en Rau, Laurent en Marcadé. Naast deze rechtshistorische uitleg, gebruikt Diephuis grammaticale en systematische interpretatiewijzen: '.. de bepaling, die zegt dat bezit als volkomen titel geldt, geeft ook door haren inhoud geen aanleiding, om aan een titel tegen de revindicatie te denken. Trouwens, van zoo iets spreekt de wet nergens..,' en over het tweede lid van 2014: 'de bepaling staat kennelijk in het naauwste

319. Zie hoofdstuk 43 .

320. Zie daarover. Zwalve, W.J., (1992), p. 94, p. 109, p. 190.,

321. Diephuis, G., deel $6(1880)$, p. 379. 
verband met die van het eerste lid, waarmede zij éến art. uitmaakt, en waarmede zij door het woord niettemin verbonden is (...)." Ten slotte: bezit moet worden opgevat als het bezitten voor zichzelf, als eigenaar, omdat dit volgt uit de betekenis die de term bezit heeft gekregen in het Burgerlijk Wetboek, in de artikelen 604 en 605 . Diephuis: 'Bij art. 604 sub 1 en 605 sub 1 hebben wij alleen aan een bezit in dien bepaalden zin te denken, en wij zouden bij eene bepaling van gelijksoortige, maar veel krachtiger strekking, dat woord in de meest algemeene beteekenis moeten opvatten?' ${ }^{322}$ De goede trouw is volgens Diephuis niet vereist: 'behalve in het geval van art. 2014b, komt de vraag niet te pas, hoe hij het bezit heeft gekregen en van wien (..) hij heeft het, en dat is voor hem genoeg."

$\mathrm{Nu}$ is het interessante dat in de argumentatie van Diepluis vrij veel te herkennen valt van de argumentatie van Laurent ${ }^{324}$. Diephuis behandelt uitgebreid verschillende standpunten in het Franse recht. Hij vermeldt Toullier, Delvincourt, Zachariae (Aubry et $\mathrm{Rau}$ ) en de Gentse hoogleraar Laurent. Opvattingen over $2279 \mathrm{Cc}$ van Toullier (vermoeden van eigendom) en van Marcadé ('préscription instantanée') verwerpt Diephuis met kracht ${ }^{325}$. In het commentaar van Toullier zijn een tweetal opvattingen aan te treffen. Hij blijkt, naast het vermoeden van eigendom als uitleg, op een andere plaats uit te gaan van een gelijkstelling van bezit met eigendom. Zo verschillen de interpretavies niet alleen tussen de schrijvers, maar zelfs bij één en dezelfde schrijver:

\footnotetext{
"A défaut de l'une de ces deux preuves, celui qui revendiquerait le meuble contre le possesseur. prouverait inutilement qu'il en était propriétaire. Le possesseur lui répondail avec succès: Ma possession vaut titre; il est possible que vous fussiez propriétaire de ce meuble, mais wous ne l"êtes plus; vous l'avez aliéné de manière ou d'autre, puisque vous ne prouvez ni que vous l'avez perdu, ni qu'on vous l'a volé, et que cependant vous en êtes dessaisi. J'en suis atjourd'hui propriêtraire puisque je le possède: vous n’avez rien à me demander." 326
}

Er is in Diephuis' weergave van de Franse commentaren meer eenstemmigheid waar te nemen in de Franse literatuur. Wanneer we de standpunten van Aubry en Rau, en Laurent (wier werken door Diephuis als voorstanders van zijn standpunt worden aangehaald) beschouwen, dan valt ook in die Franse literatuur een verandering op ten gunste van de "Germaansrechtelijke" interpretatie. Aubry en Rau vermelden een vermoeden van eigendom, zodat de bezitter in staat is een revindicatie van de eigenaar af te slaan. Dit standpunt gaat minder ver dan dat van Diephuis. Toch geeft hun standpunt de bezitter een zeer sterke positie. Waarom? Het vermoeden van Aubry en Rau is een vermoeden

322. Diephuis, G., deel $6(1880)$, p. 382 .

323. De goede trouw is alleen van belang yoor de teruggave yan de koopprijs op grond wan arikel $637 \mathrm{BW}$, warop de bezitter die op grond van artikel 2014 lid 2 zijn bezit kwijt ragkt aan de oorspronkelijke eigenaar recht zou kunnen hebben. Zie Brunner, C.J.H., (1992), p. 2, over (onder meer) her wereiste van de goede trouw bij Diephuis.

324. Diephuis, G., deel $6(1880)$, p. 376-379.

325. Zie hoofdstuk 3 \& $4 . \mathrm{B}$.

326. Touller, C.B.M. deel $9(1821)$, n. 94. 
van eigendom "absolue et irréfragable." Waarom deze veel stelliger uitleg? Dat hangt samen met de redactie van artikel $2279 \mathrm{Cc}$, want omdat het tweede lid een uitzondering bevat op de regel uit het eerste lid, en spreekt over de mogelijkheid te revindiceren in de twee genoemde gevallen, diefstal en verlies, moet het eerste lid noodzakelijkerwijs wel in de zin wan de uitzondering worden uitgelegd, en de mogelijkheid van de revindicatie dus in het algemeen dienen uit te sluiten:

\footnotetext{
'En fait des meubles, la possession vaut titre. Art. 2279, al 1 . En d'autre termes, la possession engendre instantanérnent, et par elle-mềme, en faveur du possesseur d'une chose mobilière, une pressomption de proprieté, a l'aide de laquelle ill peut repousser toute action en revendication, ell qui est, en général, absolue et irréfragable.

Il suit de lă que l'action en revendication na'est point, en rềglè, recevable en fait de meubles. Toutelois, el par exception ă cette règlè, celui qui a perdu une chose mobilière, ou auquel une pareille chose a été volée, est autorisé à la revendiquer entre les mains de tout tiers possesseur. méme de boune foi." 327
}

Nog verder gaat Laurent, en het is eerst met recht dat Diephuis diens standpunt aanhaalt als gelijk aan zijn eigen mening. Ook Laurent legt "la maxime de l'article $2279^{\text {" in de }}$ eerste plaats uit met behulp van de in het tweede lid geformuleerde uitzondering:

'Le deuxiène alinéa de l'article 2279 précise le sens dủ premier; il est ainsi conçu: "neanmoins celui qui a perdu ou auquel il a été volé vine chose peut la revendiquer pendant trois ans contre celui dans les mains duquel il la trouve." Ainsi c'est par exception, dans les cas de perte ou de vol, que les choses mobilières peuvent être revendiquées contre le possesseur; la règle est danc que les neubies ne peuwent pas être revendiqués. ${ }^{28}$

Vervolgens neemt Laurent een volgende stap. Want waarom is die revindicatie van roerende goederen in het algemeen onmogelijk? Dat komt omdat er meer is dan slechts een vermoeden van eigendorn, zoals door Toullier (tegenbewijs is mogelijk) en Aubry en Rau (een vermoeden 'absolue et irréfragable') wordt voorgestaan. De tekst van de wet sprekt nergens over een vermoeden, en de geschiedenis van de wetsbepaling leert Laurent dat door het bezit alleen, de eigendom aanwezig is. Bourjon sprak over "la simple possession produit tout l'effet d'une titre parfait.' Wat is een titre parfait, een volkomen titel, anders dan de eigendom? Want een volkomen titel (in het Franse recht) is een titel die de eigendom doet overgaan, 'comme la vente, la donation," zoals de koop, of de schenking:

'Or, on ne dira certes pas d'un vitre de vente que c'est une présomption; c'est phus que cella, e'est l'acquisition de la propriétét; le possesseur n'est pas présumé propriétaire, il est propriétaire. (..) Le possesseur est propriétaire par cela seul qu'il possedde; la possession est son titre; et il serait absurde de permettre une preuve contraire au fait de la possession, car ce fait doit

327. Aubry, C. . en Rau, C. Cours de droin civil Francais, deel 2 (4e druk, 1869), \$183, p. 107-108.

328. Laurent, F., principes de droin civil, deel $32(1878), \$ 540$, p. 552 
être établi pour que le possesseur puisse invoquer la maxime de l'arricle 2279, et quand le fant est établi, il ne peut plus s'agir de faire la preuve contraire." 329

Diephuis formuleert zijn standpunt met de wetenschap van de argumentatie in de door hem genoemde commentaren van Aubry en Rau, en Laurent. Diezelfde argumentatie is bij Diephuis zelf herkenbaar. Naast grammaticale, systematische en rechtshistorische uitlegmethoden zijn in de argumentatie van Diephuis de vergelijkende beschouwingen over het eigentijdse Franse recht nadrukkelijk aanwezig ${ }^{330}$.

\section{De Germaansrechtelijke leer nagevolgd in de literatuur}

De uitleg van Diephuis is in de laatste decennia van de negentiende eeuw de heersende leer. Zo stelt bijwoorbeeld Asser, in navolging van de met name genoemdle Diephuis dat de bezitter van een roerende zaak het 'eenige en tevens het hoogste recht, d.i. het eigendomsrecht heeft," en dat dezelfde uitleg in Frankrijk de heersende uitleg is. Aldus wordt Diephuis' uitleg vaster ingebed in de literatuur ${ }^{33 !}$. Is er daadwerkelijk sprake van eenzelfde uitleg in Frankrijk? Uit de Jurisprudence Gënérale Dalloz blijkt dat er rond 1900 in Frankrijk een veelheid aan interpretaties is en dat de rechtspraak een vermoeden van eigendom voorstaat ${ }^{332}$. De historische interpretatie brengt Land tot een vergelijkbaar standpunt als dat van Diepluis. Omdat in de Code civil het Germaansrechtelijke beginsel in artikel $2279 \mathrm{Cc}$ is bedoeld weer te geven, moet dit ook zo zijn voor artikel $2014^{333}$. Land toont zich een voorstander van een historisch-continue uitleg:

'De continuiteit wan het recht wordt nooit zonder groor gevaar miskend. Zooals het recht wan heden nooit wolledig verklaard wordt, tenzij wij ook zijne hisiorische wording nagaan (...), zall ook woor de toekomst weinig heil zijn te wachten van het breken met het bestaande recht, waarin toch ook veelal een gezonder kern en meer stof tor ontwikkeling ligt, dan sommigen in hun ongeduld well meenen. De richting warin het recht zich voortbewoog, verder te vervolgen,

329. Laurent, F., deel $32(1878), \$ 542$, p. 557 .

330. Zie hoofdstuk 4 \$.A.3. Overigens wordt in de Franse rechtspratk in die tijd wel de theorie van het vermoeden van eigendom aangehangen, zo vermeldt ook Laurent. Daarmee wijkt de doctrine af van de heersende rechtspraak in Frankrijk. Laurent, F., deel $32(1878), \$ 542, p .558$. Zie voor eerizelfde afwijking tussen theorie en rechthpraak $\$ 2$.

331. Asser, C., Handleiding tot de beoefening wath het Nederlandsch burgerlijk rechr deel 2 (2e druk, 1890), p. 38.42 .

332. Jurisprudence gếnérale Dalloz, Nouveau Code Civil, annoté et expliqué d’apres La jurisprudencé êt la doctrine deel 4 (1907), ant. 2279 , nr. 18., p. 1973 .

333. Land, N.K.F., Ons recht op roerend goed, Rechtsgeleerd magazijn 1889, p. 283 , en dezelfde auteur: Burgerlijk regt en regtswordering - Aanteekeningen op artikelen vam het burgerlijk wetboek, $V$, Themis 1873. p. 485-486; Zie (kort) \& 1.C. 2.; over Lands historische interpretatiemethode zie ook Kop, P.C. (1992) p. 40. 
wijst ons in den regel den meest betrouwbaren weg; die weg is meestal langer dan wij wen-

schen, doch de ervaring wan eeuwen dwingt ons toch tot een bedachtzamen tred.' 33A

Onder invloed van Savigny staat deze historische interpretatie aan her einde van de negentiende eeuw sterk in de belangstelling. Het lijkt mij dat deze opwaardering van de historische argumentatie het gebruik van eigentijdse buitenlandse bronnen, de rechtsvergelijkende methode heeft gekatalyseerd.

\section{Bestendiging in de rechtspraak}

De rechtspraak volgt Diephuis' Germaansrechtelijke uilleg. Met name de uitspraken van de Hoge Raad rond 1900 waaraan Coninck Liefsting als raadsheer heeft meegewerkt, vallen op door hun overeenkomst met Diephuis' uitleg ${ }^{335}$. Reeds in 1883 , later in 1895, 1900 en 1906 spreekt de Hoge Raad zich uit in de zin van Diephuis' mening. Ook de AG Gregory concludeert in 1900 in overeenstemming met de mening van Diephuis. Over welke kwestie ging het in die zaak uit 1900? Zij speelt in Nederlands-Indië, waar de heer Voûte koffie had laten inzamelen van landen die hij harl gehuurd, doch waarvan de huurtermijn ten tijde van de inzameling reeds was verstreken:

\footnotetext{
'Nu is het volkomen waar dat de app. op koffie die, zooals de geïnt. beweent, na 1 jan. 1894 werd ingezameld, gelijk wit het zoo straks besprokene volgt, wit het contract geen recht kon ontleenen, maar dit neent niet weg dat de app. juist door die inzameling al geschiedde ze te kwader trouw, bexitter werd en dus t.a. van die koffie, krachtens art. 1977 1e al. I.B.W., geheel owereenkomende met art. 2014 le al. val ons B.W. en huldigende den regel "en fait de meubles possession vaut titre", als eigenat moet worden beschouwd. En zoo zegt dan ook Diephuis, Syst. VI bl. 380-381: "de wet beschermd hem (den bezitter) tevens, waar hij de zaak tegen, althans zonder zijnen wil is kwijtgeraakt." 336
}

De Hoge Raad, met Coninck Liefsting als raadsheer, gaat mee in deze conclusie: '(...) omdat de app. door de inzameling krachtens art. 1977 I.B.W. eigenaar was geworden (..).' Geen sprake is echter van een vereiste van goede trouw. Over dat vereiste bestond ook geen duidelijkheid. In de Nederlandse Juristen-Vereniging wordt het in 1890 wel als vereiste voorgesteld. Dan wordt echter ook een nieuwe interpretatie van 2014 verdedigd.

334. Land, N.K.F., Verklaring van her burgerlijk wetboek, deell 1 (1889), p. viii-ix. De wet staat bij Land centraal, en valak wordt hij afgeschilderd als de meest illustratieve vertegenwoordiger van het legisme. Maar meer nog dan als 'legist', zou Land geschetst kumen worden als een aanhanger van deze 'historische methode'. Zie verder Kop, P.C., (1992), p. 42; Salomons, A.F., (1990) p. 43.

335. In een arrest wit 1855 word al een wergelijkbare uitleg gegeven. Artikel 2014 matkt de bezitter eigenant door onmiddellijke verjaring, mits deze te goeder trouw is. Zie hoofdstuk 4 \& 3.B

336. HR 14 december 1900, Weekblad wan het Recht 7536, 25 jan. 1901, De andere uitspraken zijn te vinden in: Weekblad wan het Recht 4929, Weekblad van het Recht 6616 en Weekblad wan het Recht 8390 


\section{B. DE EERSTE TERUGTRED VAN DE GERMAANSE UITLEG}

\section{Van Bermmelens Romeinsrechtelijk stelsel}

De vergadering van de NJV uit 1890 is om twee punten interessant. In de eerste plaats vanwege een uitleg van Van Bemmelen, die een zeer afwijkende historische interpretatie hanteerde voor een afwijkend standpunt. In de tweede plaats (zie \$ 3.B.2) ondat een nieuwe uitleg van 2014 verschijnt waarbij met meer vrijheid wordt geïnterpreteerd. De heersende leer is nog sterk vertegenwoordigd. Dat wordt met nane veroorzaakt doom een reactie op Van Bemmelens preadvies. Daarin toont hij zich een voorstander van een vrijwel onbeperkte revindicatie ${ }^{337}$. Zijn argumenten daarvoor zijn de volgende. In het Franse artikel 2279, met de woorden 'possession vaut titre,' en het Nederlandse artikel 2014 wordt in het geheel geen Germaansrechtelijk stelsel uitgedrukt, maar juist een Romeinsrechtelijk, met een onderscheid tussen bezit en eigendom, en met een (onbeperkte) mogelijkheid van revindicatie. Van Bemmelen makt gebruik van een bont palet van verschillende rechtsstelsels: van dicht bij huis, van 'zuiver germaansche rechten (het scandinavische en het engelsche)' ${ }^{338}$, via het Griekse recht naar Indiase rechtsstelsels, waar "uit Brahmaansche scholen voortgesproten heilige boeken (..) geen spoor van beperking der revindicatie" laten blijken ${ }^{339}$. Zowel de (afwijkende) historische interpretatie als de afwijkende uitleg overtuigt niemand in de vergadering. Levy merkt het op tijdens de vergadering: 'Sedert Von Savigny is het de hoogste eerelitel van den jurist, indien hij bij zijne rechtshanteering de historische continuiteit niet uit het oog verliest, en eene aanbeveeling voor den wetgever, indien hij zich inprent dat het recht niet sprongen maakt, zoomin als de natuur dat doet.' ${ }^{340}$ Deze zonde tegen de historische continuïteit begaat Van Bemmelen juist wel. Van Bemmelens, woorkeur ging uit naar het volgende systeem:

\footnotetext{
"Ik meen nog, dat het ronneinse stelsel van onbeperkte revindicatie, ook zonder eenige moderathën, geen enstig bezwaar oplever. De eignendon worde gehandhat fd omdat hij eigendon is, wan noerend goed gelijth van on roerend goed. Wie het goed eens derden bona fide gekocht heeft, troostte zich in dit zijn ongeluk; hetgeen hem gemakkelijker zall vallen dan den eigenaar, die zich behalve over zijn ongeluk ook over zijn geschonden recht zal hebben te troosten. ${ }^{34}$
}

337. Tegen deze vereenwoudigde weergave van het Romeinse stelsell zal Coninck Liefsting bezwar maken. Zie Handelingen II (1890), p. 31 .

338. Van Bemmelen, P., in: Handelingen I (1890), p. 8.

339. Handelingen I (1890), p. 10\%11. De door Van Bemmelen aangebaalde schrijvers zijn onder meer: Muller, The sacred books of the east (1879-1886): Kohler, Indische Gewohnheissrechten, in: Zeitschrift für vergleichende Rechsswissenschaft, Band 8 (1888); Thallheim, Th. Die Griechischen Rechtsalterthümer (1884); Leist, B.W., Graco-Halische Rechsgeschichte (1884); Leist, G.A., Der atrische Eigenthumsstreit im System der Diadikasien, (1886): Bücheler, F. en Zitelmann. E., Das Rech von Gorny (1885); Bernhöft, Das Gesetz von Gortyn, in: Zeitschrifi fur vergleichende Rechtswissevaschafi 1886 , p. 291.

340. Handelingen II (1890), p. 20.

341. Handelingen $\llbracket(1890), p, 32$. 
'Volkomen vicieus' was een van de oordelen in de vergadering: 'Van Bemmelen spreekt van het wezen van het recht en ik kan mij nu geen ander wezen van het recht denken dan thetgeen ontstaan is als gevolg van de maatschappelijke behoefte en van de billijkheid." 3422 Een andere interpretatie zou door de vergadering worden aanvaard. Een interpretatie die weel minder uitgaat van een gelijkstelling van bezit met eigendom, maar niet zo ver gaat als die van Van Bemmelen ${ }^{343}$.

\section{Het nieuwe vraagpunt van Molengraaff en Roelvink}

Onder anderen Molengraaff en Roelvink stellen een anders geformuleerd vraagpunt voor. Dat nieuwe vraagpunt biedt op twee manieren een blik op de periode die op het legisme volgt. De eerste manier heeft te maken met de opzet van de NJV. Er wordt gediscussieerd over het wenselijke recht (ius constituendum). Ook Van Bemmelen laat zich daar over uit:

'De J. V. houdi zich bezig, noch met wetsinterpretatie, noch met rechisgeschiedenis, maar met het jus consituendum. Zij vraigt wiet wat recht is of geweest is, maar alleen wat recht behoort te zijn. Het moet haar dus volkomen onverschillig zijn, of een stelsel romeinsch of gernaansch is. Zij vraagt stechts: wat is nuttig, heilzaam, goed, en zulks niet in abstracto, maar bij ons te landie en heden ten dage." 94 th

Het wenselijke recht van Van Bemmelen met betrekking tot 2014 is echter een ander dan dat van de meeste andere aanwezigen. Van Bemmelen houdt vast aan systeem van de wet: eigendom als Romeins rechtsbegrip moest worden gehandhaafd, en een onbeperkte revindicatie was daarvan het gevolg. Maatschappelijke behoefte en billijkheid spelen voor Roelvink en Molengrafff een grotere rol, bij de beoordeling van de wenselijke interpretatie. Dat is karakteristiek voor de in het volgende hoofdstuk te bespreken periode van cle vrije rechtsvinding waarbij de witlegger een grotere wrijheid ten opzichte van de wet nemen mag. Ook in de discussie over de aansprakelijkheid bij spoorwegvervoer is deze argumentatie duidelijk aanwezig (1874), maar legt een aan de maatschappij ontleende argumentatie (bescherming van gelaedeerden) het nog af tegen tekst en systematiek van de wetgeving ${ }^{345}$.

342. Handelingen II (1890), p. 55 .

343. Juist in Frankrijk wordt aan de uitleg van Van Benmelen weel aandacht geschonken, naar aanleiding van zijn Le' système de la propriêté mobilière (1886). Baudry-Lacantinerie schrift daarover: '(..)la propriêté mobilière ne donnait lieu à un droit de suite qu'au cas de perte ou de vol. Il faut ajouter que cette théorie n'est pas admise par tous lés auteurs. Elle a été combattue récemment dans un fort intéressant ouvrage de $M$. van Bemmelen. $D$ 'apres lui les prétendus principes germaniques $n^{\prime \prime o n t ~ p a s ~}$ existê et ce n'est que depuis le siècle dernier que la législation allemande et surtout la législation Française ont porté atteinte la revendication mobilière: in: Baudry-Lacantinerie, G., en Tissier, A., Trate theorique et pratique de droit civil, de la prescription (3e editie, 1905), nr 818, p. 644.

344. Handelinget 1 (1890), p. 2.

345. Zie \& $2 . \mathrm{C} .3$. 
De tweede manier waarop de volgende periode zichtbaar wordt ligt in de uitkomst van de discussie. De nieuwe uitleg van 2014 wordt ontleend aan het Duitse recht. Het is de aanzet tot de 'moderne' theorie of legitimatietheorie, waaraan vooral de naam van Paul Scholten verbonden is. De vergadering stemt in met preadviseur Roelvink. Zijn voorkeur gaat, na een rondgang langs wetgevingen van verschillende landen, uit naar een uitleg overeenkomstig artikel 877 eerste ontwerp BGB:

\begin{abstract}
"Wenn der Veräusserer nicht Eigenthümer der Sache war, der Erwerber aber diesen Umstiand bei dem sich wollziehenden Erwerbe nicht gekannt, seine Unkentnisz anch nichit auf grober Fahrlässigkeit beruht hat, so erlangt der Erwerber üsch den im $\$ 874$ bezeichneten Vertrag das Eigenthum. ${ }^{346}$
\end{abstract}

Roelvink acht deze bepaling voor het Nederlandse recht de juiste, met toevoeging van de goede trouw. Indien er enige reden bestaat voor de verkrijger om te twijfelen aan de eigendom van de vervreemder, behoort de laatste geen eigendom te verkrijgen. In de uiteindelijke versie van het $\mathrm{BGB}$, in $\$ 932$, wordt die goede trouw expliciet ingebracht ${ }^{347}$. Wat is de belangrijkste grond voor Roelvinks standpunt? Die vinden wij samengevat in de volgende zinnen:

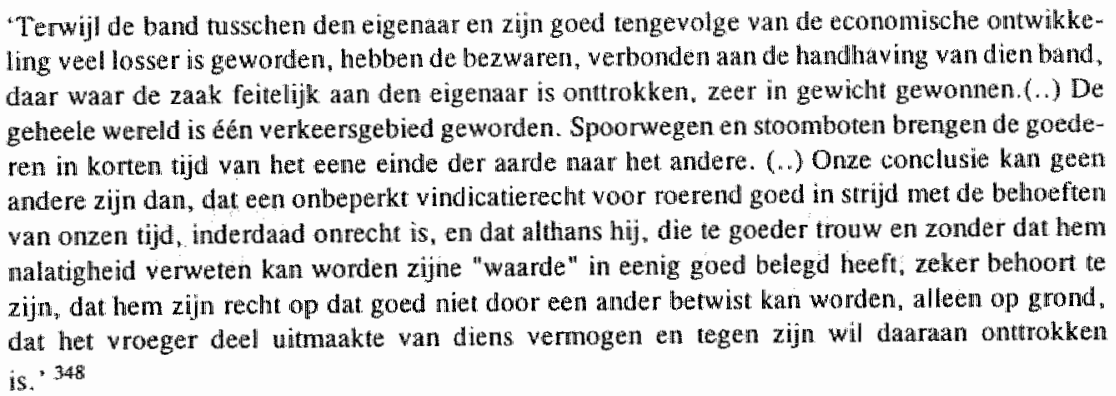

Tijdens de discussie stellen Roelvink en Molengraaff tezamen met andere aanwezigen het vraagpunt voor:

"Behoon de wetgever uir te gaan van thet beginsel, dat hij, die roerend goed in zijne persoonlijke macht heeft, daarop - of schoon onbevoegd hiertoe, tocli zakelijke rechten kan verschaffen aan derden, zoo dikwijls van hen niet kan worden aangetoond, dat zij met diens onbevoegdheid bekend waren of behoorden te zijn?"

346. Handelingen I (1890), p. 205-206. In het BGB is deze bepaling uiteindelijk terecht gekomen in \$ 932 . Zie hoofdstuk 6 3.A.2.

347. De meningsverschillen over de noodzaak van goede trouw duren woont. Zie de voorgande paragraat met de uitspraak wan de Hoge Raad uit 1900; zie tevens \$ 6.3.1.2 over de weranderde opvatting wan Scholten tussen 1905 en 1911.

348. Handelingen I (1890). p. 203-205. 
Ondanks de onbevoegdheid van een bezitter/niet-eigenaar om de eigendom over te dragen, zal deze "tegenover derden [optreden] als de persoon, die wèl bevoegd is om over het goed te beschikken." ${ }^{349}$ Dit vraagpunt wordt door de vergadering in stemming gebracht en aangenomen ${ }^{350}$. De vraagstelling is zeer toegesnedien op de wijze walrop het Duitse artikel uit het ontwerp is geredigeerd.

De argumenten hebben in die vergadering een geheel ander aanzien gekregen. In de eerste plaats staat als wenselijke uitleg de behoefte van de maatschappij voorop, in de tweede plaats hebben rechtsvergelijkende argumenten een meer nadrukkelijke positie verkregen. In het bijzonder daarom, omdat het handelsverkeer zich over de grenzen van de nationale rechtsstelsels heen uitstrekt. Duidelijk wordt zichtbaar dat met Opzoomers rechtsontwikkeling, met het ius constituendum zoals dat door Van Bemmelen was verwoord, een ruime mogelijkheid is geboden om oplossingen uit andere rechtsstelsels nadrukkelijk in de discussie een rol te kunnen laten spelen. Dat is juist het geval als ook tekst en systeem minder belangrijk worden als middelen van uitleg. Maar wellicht is tevens van belang geweest dat het handelsrecht juist gediend is met een minder star aan tekst en systeem van het $B W$ vasthoudende interpretatie en dat Molengraaff zich vooral met het handelsrecht heeft bezig gehouden.

\section{CONClusies ARTIKEL 2014 BW}

Ook in de discussie over artikel 2014 blijkt het vooralsnog de mening van Diephuis te zijn die de boventoon voert. Het zijn wooral grammaticale, systematische en historische argumenten die voor de onderbouwing zorgen. Dezelfde soort onderbouwing kiest Van Bemmelen voor zijn afwijkende mening. Uit de vergadering van de Nederlandse juristenvereniging blijkt dat de heersende uitleg aan het veranderen is. De interpretatie van Roelvink en Molengraaff krijgt daar de voorkeur. Voor die acceptatie is het belangrijkste argument het maatschappelijk belang. Voor de onderbouwing wordt gebruik gemaakt van andere rechtsstelsels.

De heersende mening wordt onderbouwd met aan het Franse recht ontleende historische argumenten. Zo ontleent Diephuis veel aan de Franse wetsgeschiedenis, zoals vermeld bij verschillende Franse schrijvers. Zo ook Van Bemmelen, die zich meer van andere 'Germaansrechtelijke' bronnen bedient. Het rechtshistorisch argument wordt belangrijker. Verschillende schrijvers (Land, Levy) wijzen in navolging van de Duitse rechtswetenschap op de continuiteit van de rechtsontwikkeling. Ook wordt, met name door Diephuis, gebruik gemaakt van eigentijdse standpunten uit het Franse recht. Dat heeft voor Diephuis door de gedetailleerdheid waarmee hij die discussie behandelt, waarde voor de uitleg. Het is een rechtsvergelijkende exercitie die net als bij de aansprakelijkheid voor zaken, ook hier duidelijk gestalte krijgt. De nieuwe uitleg wordt beargumen- 
teerd door te wijzen op de maatschappelijke wenselijkheid. In dat verband wordt juist gewezen op het Duitse recht. In de vergadering van de NJV wordt een bepaling uit het ontwerp voor een Duits burgerlijk wetboek onderschreven. Ook aan ket handelsrecht en aan Molengraaff kan de onderschrijving van een uitleg als in het Duitse artikel te danken zijn.

\section{§ 4. Publiek domein}

In de late jaren veertig van de negentiende eeuw kiest Thorbecke duidelijk positie in zijn colleges over het administratiefrecht. Daarin spreekt Thorbecke een sterke voorkeur uit voor een Franse theorie van het domaine public, een theorie die afkomstig is van de Franse hoogleraar Proudhon. In een handgeschreven collegedictaat van één van zijn leerlingen komen passages voor die overduidelijk wijzen op een publiekrechtelijk uitgangspunt voor overheden bij publiek domein ${ }^{351}$. De theorie van het domaine public is gedurende een halve eeuw de heersende leer. Zo schrijft in 1885 Teixeira de Mattos:

'De waarheid is deze: er moet onderscheid genaakt worden tusschen de zaken, die de staat bezit jure publico, zoo als b.v. de rivieren en stroomen; daarop zijn geene regten van particulieren denkbaar, en die welke hij bezit jure privato, zoo als b.v. de eilanden en platen(..), 352

Het lijkt zo stellig. Er is echter iets merkwaardigs aan de hand. De heersende leer van het domaine public blijkt, anders dan veelvuldig is aangenomen, met name een heersende leer in het nieuwe vakgebied van het administratieve recht. Het privaatrecht lijkt de theorie van 'domaine public' te accepteren, maar onder de oppervlakte is meer aan de hand. In de onderbouwing blijken problemen te schuilen ${ }^{353}$.

\section{A. PROUdHon EN ThORBECKe}

In een college administratiefrecht in het studiejaar 1846-1847 behandelt Thorbecke de wetgevende macht van het gemeentebestuur, met betrekking tot de "tot gemeene dienst van allen bestemd[e]" platsen. Op deze zaken

\footnotetext{
'windt het gewoon begrip van eigendom I. I geene of althans eene zeer beperkte toepassing. want eigendom is de uirsluitende verbintenis wan eene zak met eenen persoon, en bij de zaken valt die uitsluiting [.] het eerste vereiste van eygendom, weg, data zij dienen tot het bereiken wan de verwulling der behoeften of luet gebruik van allen. 354
}

351. Thorbecke, J.R., Collegedictaat adninistratief regt (1846-1847). Dit manuscript bevindt zich in de universiteitsbibliotheek Maastricht onder nummer MU EAG 661

352. Teixeira de Mattos, A., (1885), p. 256-257.

353. Zie hierover Milo, J.M., (1995), p. 166-187.

354. Thorbecke, J.R., Collegedicraar (1846-1847), p. 63-64 
Overheidseigendom komt ook aan de orde in het college dat handelt over 'het bestuur van den Staat of de Rijksgemeente.' De staat oefent over sommige zaken een in het publiekrecht wortelende macht uit: "Hetgeen de Staat iure publico bezit is op eenen anderen grond dan hetgeen hij iure privato bezil, het is meestal tot een ander einde bestemd en wordt volgens andere regels dan het domein bestuurd." 355 Thorbecke"s argumentatie is als volgt: wanneer de karakteristieken van privaatrechtelijke eigendom worden bezien, dan blijkı dat één daarvan de zogenaamde exclusiviteit betreft, het recht van de eigenaar om met uitsluiting van een ieder van de zaak gebruik te kunnen maken ${ }^{356}$. Het is deze karakteristiek die zich niet goed verdraagt met publiek domein. De zaken die tot publiek domein horen 'dienen tot het bereiken van de vervulling der behoeften of het gebruik van allen.' Deze gedachtengang vindt veel weerklank bij leerlingen van Thorbecke, zoals De Bieberstein en Olivier ${ }^{357}$. De Franse hoogleraar Proudhon was degene die 'domaine public' met kracht introduceerde. Proudhon:

'Ce domaine a'est pas en tout soumis aux règles qui gouvernent le droit ou le domaine de propriétéc, puisqu'il ne peut être la propriété de personne; mais il est soumis aux lois et règlements de police, et à l'administration exercée par le gouvernement ou an son nom." 358

Zo wordt publiek domein door hem niet onderworpen geacht aan privaatrechtelijke rechtsregels, maar aan publiekrechtelijke: 'aux lois et règlements de police, et à l'administration exercée par le gouvernement ou en son nom.' Proudhon heeft ook een onderbouwing uit de artikelen $538-540 \mathrm{Cc}^{359}$. In de drie Franse artikelen wordt gesproken over bepaalde zaken die behoren tot het 'domaine public.' Maar eigenlijk is bedoeld, zo zou wolgen uit de Franse wetsgeschiedenis, een onderscheild weer te geven tussen de zaken genoemd in 539 enerzijds en de artikelen 538 en 540 anderzijds. In de laatstgenoemde artikelen worden zaken vermeld met een openbare bestemming. Deze openbare bestemming ontbreekt bij de zaken in het eerste artikel. De genoemde zaken met een openbare bestemming 'ne sont pas susceptible d'une propriété privée' (art 538 en 540 Cc). Proudhon begrijpt dit als 'ne peut être la propriêté de personne.' De zaken kunnen niemands eigendom zijn, óók niet van de overheid ${ }^{360}$.

355. Zie verder bij Thorbecke in zijn Alanteekening op de Grondwet deel 2 (1843), p. 136-137. Met betrekking tot publite zaken win de gemeente merkt hij op dat daarover 'riet door het thans regerend bestuhur, als particulieren over de hunne, [mag] worden beschikt. Want zij behooren aan de allen overtevende universitas, watrin de tegenwoordige leden niet meer regt hebben, dan hunnen opvolgers. " Verder merkt Thorlbecke op in Over plaatselijke begrooting (1847), p.64-67, dat "markten of hallen (..) uit haren aard publieke verkoopplatatsen, in deze hoedanigheid zoo min, als weg of strat "privaateigendom der gemeente" zijn. Zie ook Thorbecke in De Gids 1843, p. 446-451.

356. Zie voor artikel $625 \mathrm{BW}$ hoofdstuk $2 \& 4$.

357. Zie ook Poortinga. E., De scheiding hussen publiek en privatrecht bij Johan Rudolph Thorbecke (1987), p. 207-252. Vegting, W.G., (1946), p. 214.

358. Proudhon, J.B.V., Traité du domaine de propriêté (1842), p. 308 onder nr. 816.

359. Zie hoofdsouk 3 4.C.3.

360. Zie daarover ook hoofdstuk $6,4 . C_{n}$ war met deze opvatting wordt afgerekend door Barckhausen $(1884)$. 


\section{B. THORBECKE'S LEERLINGEN EN HET ADMINISTRATIEFRECHT}

Proudhons 'domaine public' wordt de heersende leer in het Franse administratiefrecht. In het Nederlandse recht vindt deze theorie ingang đoor Thorbecke. Leerlingen van Thorbecke en handboeken administratiefrecht hangen deze leer van het 'domaine public' aan ${ }^{361}$. Zo bijvoorbeeld twee promovendi van Thorbecke, Olivier en De Bieberstein. Olivier maakt een onderscheid tussen zaken die een overheid 'als domein, jure privato' bezit, en zaken die een overheid op een publiekrechtelijke wijze, "krachtens zijne regeringsbevoegdheid,' kunnen toebehoren. En zo behoort 'De straat (..) aan het publiek; (..) eenen grond die door zijne besternming zelfs onvatbaar is voor bijzonderen eigendom." ${ }^{362}$ Olivier verwijst maar Proudhon, en onderschrijft diens argumentatie ${ }^{363}$. Ook het privaatrecht verschaft Olivier argumenten. In art. $538 \mathrm{Cc}$ wordt gesteld dat de in dat artikel genoemde zaken 'ne sont pas susceptibles d'une propriété privée,' niet vatbaar zijn voor eigendom. Het overeenkomstige Nederlandse artikel, artikel $577 \mathrm{BW}$ wil hetzelfde zeggen. 'Het beginsel evenwel,' zegt Olivier,

"is bij ons even als in Frankrijk, dat de bevaarhare en vlotbare stroomen behooren aan den Staat. Behooren, dat is niet, dat zij deel uitmaken van de domeinen van den Staat en dat deze er regt wan beschikking over heeft; maar dat zij (.) nier aan de publieke dienst kunnen ontrokken worden. Van beperking van het regt van eigendom $(.$.$) kan dus geene sprake zijn, want er$ is geen eigendom wan een vlotbaar en bevaarbaar water., 364

Proudhon en Thorbecke klinken door in dit citaat. Olivier gaat ervan uit dat er in de Franse artikelen $538-540 \mathrm{Cc}$ een onderscheid beoogd is tussen de zaken die als domaine public aan de staat behoren en die zaken die als domaine privé behoren aan de staat. Weliswaar staat in de beide artikelen 538 en $539 \mathrm{Cc}$ 'domaine public,' in artikel 539 had moeten staan: 'appartiennent à l'État,' om aldus tot uitdrukking te brengen het verschil tussen de zaken bestemd voor openbaae nut in artikel 538, en de zaken die dat openbare nut niet hebben, in artikel $539 \mathrm{Cc}$. Aldus argumenteren bijvoorbeeld ook de door De Bieberstein en door De Bosch Kemper aangehaalde Franse administratiefrechtelijk jurist La Ferrière, maar ook de civilist Marcadé ${ }^{365}$.

361. Veel ondersteuning putten de Nederlandse voorstanders van domaine public uit de Franse administratiefrechtelijke literatuur. Zoals La Ferrière, zoals Cormenin, die, zo blijkt uit citaten wan Olivier, over publick domein dezelfde mening hebben als Proudhon: 'De se qui sert à l'usage public et conmun, et ne peut etre dès lors, la propritete exclusive de personne, lels que les chemins ce sens, le domaine public est inaliénable; dans ce sens le domane public est impréscriptible." Zie Olivier, W.C.D., Proeve over de beperkingen wan den eigendon door her polineregt, (1.847) p. 210 . noot 2.

362. Olivier, W.C.D. (1847), p. 15, 134, en 209.

363. Olivier, W.C.D.. (1847), p. 67.

364. Olivier, W.C.D., (1847), p. 208-211.

365. Zie over dit onderscheid \$3.4.3.2. 
De Bieberstein brengt publiek domein onder de vigeur van de artikelen die handelen over 'zaken buiten de handel." 366 Daarvoor gebruikt hij het volgende criterium:

\begin{abstract}
"die goederen welke tot gebruik van het publiek, ofwel voor eene publieke dienst bestemd zijn; warvan eenige voor altijd, andere daarentegen slechts zoolang het gebruik of de bestemming duurt, buiten den handel blijen. En waarin bestaat, deze bestemming tot publiek gebruik? Wanneer die zaken bestaan woor het algemeene belang, nut of verdediging, of door de natur zelve tot gebruik vain iedereen dargesteld zijn. Deze goederen zijn buiten den handel, immers kunnen zij, zoolang zij deze bestemming liebben, geen voorwerp van eigendom zijn." 367
\end{abstract}

\begin{abstract}
Aldus wordt op eenvoudige wijze gebruik gemaakt van bepalingen in het Burgerlijk Wetboek on het leerstuk wan domaine public in het Burgerlijk Wetboek te verankeren. De Bieberstein:

${ }^{2}[\mathrm{~g} J$ eheel kunnen wij ons wereenigen met Proudhon, Traité du domaine public. Le Domaine Public embrasse généralement tous les fonds, qui sans apparttenir propriétairement à personne, ont été civillement consacrés au service de la sociétê. Niemand kan daarvan eigenaar zijn, zoolang die goederen hume bestemming behouden; immers eigendom brengt mede, (..), het denkbeeld van uitsluiting van het gebruik. 3698
\end{abstract}

De mening zoals die door Olivier en De Bieberstein in navolging van Thorbecke en Proudhon wordt verwoord, treffen we tevens aan bij menig ander werk over het administratiefrecht ${ }^{369}$. Deze onderbouwing uit het Burgerlijk Wetboek met behulp van de artikelen 576-581 en het criterium om te bepalen wanneer zaken 'buiten de handel' zijn, kan echter nauwelijks door civilisten verwezenlijkt worden.

\title{
C. THORBECKE EN WETGEVING
}

Thorbecke heeft de van Proudhon overgenomen theorie in de Gemeentewet 1851 tot uitdrukking gebracht ${ }^{370}$. In twee artikelen is het onderscheid tussen openbare gemeente-

366. De Biaberstain, P.G.E.H., Prove over zaken buten den handel (1849), voorrede p. wii.

367. De Bieberstein, P.C.E.H., (1849), P. 9.

368. De Bieberstein, P.G.E.H., (1849), p. 19

369. Van Hengst, C.I.W.N., Eemige opmerkingen over het engendomsregt der gemeentew (1863), p. 34-35; Jotdens, H.G., Beschowwingen over zaken buiren den hawdel (1869), p. 97. Pekelharing, G., Opmerkingw over den onderhoudsplich vam bijondere personen ten opziche van wegen en andere ten openbaren dienste bestende werken $(1880)$, p. 11; Boissevain. „H. G., De Gemeentewer, opgeheldera' door ene aantekwing, adngevuld met ene geschiedenis harer toepassing door G. Van Oosterwik (1864): De Bosch Kemper, I. Handleiding tot de Kennis van het Nederlandse staatsregt en staatsbestwar (1865), D. 716, De La Bassecour Can, J.J. Hawdleiding tot de kennis wan het administratiene regt in Nederland, deel 1 (1865), p. 127; ook de redictie van De Gemeentestem was voorstander van een lesertuk van donaine public: Onderhoudsplicht, art. 231 en 239 gem. wet, De Gemetriestem 1242 (1875). De redactie zal in de thchtiger jaren van de vorige eeuw hatr standpunt wijzigen. en dit zall mede van belang blijken wor de omslag naar privaatrechtelijke eigendom die door Von Reeken in 1893 kon worden voorbereid. Zie daarover hoofdstuk 6 en Milo, J.M., (1995), p. 182.

370. Wet van 29 juli 1851 , Sitb 85 . 
zaken en andere gemeentezaken uitgedrukt. Deze wetgeving geeft de voorstanders van domaine public een argument meer om het onderscheid te kunnen maken. Hoe luiden deze artikelen?

Art. 229. De gemeentebesturen zorgen, dat een nawwkeurige staat opgemakit en bijgehouden worde van hetgeen, naar her burgerlijk regt, eigendom der gemeente is. (..)

Art 230 . De and de gemeste behoorende wegen, straten, pleinen, grachten, varten kanalen, bruggen, hawens, kader, wallen wn openbare gebouwen mogen miet wouden werwreend, bezward of verpand, dan nadat zij door een besluit van den Rad werklaard zijn, ten openbare dienste niet meer bestend te wezen.

Het onderscheid van Thorbecke komt hier fraai tot uitdrukking. Artikel 229 privaatrechtelijke eigendom, artikel 230 'domaine public' yoor bepaalde zaken, bestemd voor openbare dienst.

\section{Publiek domein in de civielrechtelijke literatuur}

\section{Erkenning van domaine public}

Als 'de waarheid,' zo omschrijft Teixeira de heersende leer van het domaine public. Anderen zijn minder stellig. Zo maakt Asser een onderscheid tussen zaken die de staat (of de gemeente) 'als zoodanig' toebehoren, en die zaken, waarvan de staat privaatrechtelijk eigenaar is: 'zaken die in publico usu en die in pecunia populi zijn.' ${ }^{371}$ Het Burgerlijk Wetboek is niet erg duidelijk in dit onderscheid maar het kan er wel in worden gelezen, en bovendien is het onderscheid in de Gemeentewet 1851 aanwezig. Tevens zijn zaken met een openbare bestemming 'buiten de handel. " ${ }^{372}$ Ook Land erkent de aanwezigheid van 'domaine public': 'Van een geheel anderen aard is het recht van den staat op de goederen, die in art. 577 worden genoemd. De wegen en de straten en wat daar nog verder volgt, zijn voor de publieke dienst bestemd en in zoover aan het privaatrecht onttrokken. ${ }^{373}$ Evenzeer vinden wij eenzelfde visie in Schüllers handboek, waarin wordt gesteld dat de staat 'een eigendomsregt iure publico [heeft] op die zaken welke voor de openbare dienst en voor het algemeen bestemd zijn, en welke zoolang zij die bestemming behouden, buiten den handel zijn, hetgeen medebrengt dat een dominium iure publico eigenaardige daaruit voortvloeiende verplichtingen oplegt, wartoe een eigenaar iure privato niet gehouden is." ${ }^{374}$ In De Pinto heeft de theorie van het domaine public een voorspreker van format:

371. Asser, C. Van Heusde, P.W., Handleiding fot de beoefening won het Nederlandsch burgerlik recht deel $2(1890)$, p. 14-16.

372. Asser, C., deel 2(1890), p. 16.

373. Land, N.K.F., Verklaring wan het Burgerlijk Wetboek deel 2 (1889), p. 43-44.

374. Schüller, C.L.. (1867). p. 138. 
"Zal men nu zeggen dat de woorden wan art. 577 dat onderscheid niet uitd rukkelijk maken? Wij zijn geene voorstanders van de letterknechterij, die niets anders voor regt houdt, dan hetgeen zij meent in de woorden der wet, all leidt dat nog tot zoo grooten onzin, te lezen. De wet kan dan ook niet mogelijk maken, wat onmogelijk is: en onmogelijk is her, dar dat wat bestemd is en gebezigd word tof algemeen gebruik wan allen, tegelijkertijd het eigendom kan zijn van hen, die daarover, met uitsluiting van allte anderen, op de volstektste wijze kan beschikken (art. 625 . 375

De voorstanders van domaine public ontlenen ook aan de rechtspraak ondersteuning. De Hoge Raad heeft zich vaak onomwonden uitgelaten ten faveure van de Franse theorie. Zo bijvoorbeeld een uitspraak uit 1863 :

"dat de regten van dien Staat op zaken zijn tweeledig, die van den Staat als zoodanig, en die van den Staat als gelijkstaande met elk bijzonder persoon. Tot de eerste soon behooren de zoodanige, welke voor de openbare dienst en voor het algemeen besiemd zijn en, zoolange zij die bestemming behouden, zijn buiten den handel, $(.$.$) ; dat dexe onderscheiding reeds met juistheid$ is in acht genomen in het Romeinsche regt $(\ldots)$; dat eveneens her Fransche regt onderscheid de verschillende aan den Staat behoorende zaken, die namelijk welke uitmaken het domaine public en het domaine privế van de Staat; dat eindelijk dexelfde onderscheiding , hoewel niet met name vermeldt in het Burgerlijk Wetboek $(, \ldots .$, noodzakelijk volgt uit de artt.577 tot 581 van dat wethoek (..). . 376

Andere uitspraken hebben een stelligheid die met deze is te vergelijken ${ }^{377}$. Eveneens. kunnen echter andersluidende uitspraken worden gevonden ${ }^{378}$, en wij moeten ons dan ook afvragen, hoe sterk de worteling van 'domaine public' is in het privaatrecht.

375. De Pinto, A., Ast. 577 BW - Openbaar stats-domein, W. 3404 (1872).

376. Ook de AG Gregory neem in deze zaak stelling woor dit onderscheid op basis van de wetsartikelen uit het Burgerlijk Weboek. HR 22 mei en 26 juni $1863, W .2499$ (1863).

377. HR 29 jum 1871, W. 3399 (1871). HR 30 juni 1879, W. 4406 (1879). De conclusie van de AG Polis strekt eveneens tot aanname van een onderscheid tussen een publiek en een privaat domein. HR 17 december 1883, W. 5000 (1884). HE 6 oktober 1885, W. 5086 (1885).

378. Bijwoorbeeld HR 31 ok ober 1895,W. 6732 (1895). waarin weliswaar een principieel onderscheid tussen openbare en niet-openbare zaken aangenomen wordt doch tevens wordt gesteld dat de openbaarheid niet betekent dat de overheid geen privalrechelijke eigenaar kan zijn. Andere uitspraken, waarvain vele door Von Reuken als ondersteuning voor zijn standpunt aangehaald: HR 6 juni $1854, \mathrm{~W}$. 1510; HR 1 februari 1867. NR deel 85; HR 26 juni 1867, W. 2929 (1867); HR 24 april 1868, W.3004 (1868); Provinciaal geregtshof Gelderland 23 december 1874, W. 3882 (1875)); HR 30 mei 1881, NR deel $128, \mathrm{p} .163$; Rb 's Gravenhage 21 november $1883, W .5006$ (1884); veel overeenstemning met de visie van Von Reekten ventoont de volgende uitspraak: $O .(.$.$) dat toch de onttrekking eener zaak$ aan het verkeer eeniglijk haren grond kan hebben in haren bestemning ten openbaren nutte en derhalve ook niet verder reikt dan zoodanige bestemming noodzakelijk maakt; dat daarom nteer in het bijzonder aen strook gronds, bezwaard net den last van openbaren weg, door zoodanigen last nief wordt eene zak buiten den handel onvatbarar voor privaateigendom, bezit of andere zakelijke rechten van bijzondere personen of gemeenschappen, naar het zeer wel mogelijk is, dat daarop zoodanige rechten worden uigeoefend, alrijd behoudens en onwerkort de openbare bestemming." (HR 17 november 1892, W. 6271 (1892); HR II december 1899, W. 7374 (1900). 


\section{Twijfel aan domaine public}

Wanneer we wat meer nawwgezet naar de standpunten kijken die door de civilisten van destijds worden ingenomen dan volgt een genuanceerder beeld van de acceptatie van domaine public in civielrechtelijke kring. Met name Opzoomer en Diephuis hebben hun twijfels $^{379}$. Zowel Opzoomer alls Diephuis onderschrijven de gedachte dat er voor de zaken die bestemd zijn voor openbare dienst een ander rechtsregime zou moeten zijn dan de privaatrechtelijke eigendom, maar tegelijkertijd hebben zij (in tegenstelling tot de administratiefrechtelijke juristen) problemen met de onderbouwing aan de hand van het BW. Diephuis stelt dat de zaken in artikel 577 BW 'iets eigenaardigs' hebben. Opzoomer:

\footnotetext{
'Bij zaken, die tot algemeen gebruik dienen, wie er ook eigenarar van zij, ja zelfs is er uit haren aard in het geheel geen eigendon wan mogelijk, blijft het recht wan den staat, om ter regeling van bet gebruik zijn publiek gezag te doen gelden, onbetwistbaar. Eigetndomsrecht en publiek gezag (souvereiniteit, hoogheidsrecint) zijn hier scherp te onderselneiden. Zelfs. warar de staat eigenaar is, regelt hij het gebruik niet uit kracht van zijn eigendomsrecht, maar alleen uit kracht van zijn publiek gezag, en dit bljift bij hem onverlet, al verloor bij den eigendom aan anderen, ja al kon die noch bij hem noch bij lemand anders bestaan.. 380
}

Ten onrechte, aldus Opzoomer, wordt daarom in het Burgerlijk Wetboek geen verschil gemaakt tussen de zaken genoemd in de artikelen 576-579. Dit verschil had er wel behoren te zijn. In navolging van Goudsmit, haalt Opzoomer de Oostenrijkse wetgeving aan, waar een dergelijk onderscheid wel wordt uitgedrukt: 'Het verschil van zaken welke in usu publico en in pecunia populi zijn, wordt in het Oostenrijkse wetboek $\$ 287$ uitgedrukt door öffentliche of allgemeine Güter en Staatsvermögen. ' Ook in het ontwerp 1820 komt, naar Opzoomers mening, het onderscheid nog naar voren ${ }^{381 .}$

Van een dergelijk verschil is echter volgens. Opzoomer geen sprake in het Nederlandse Burgerlijk Wetboek van 1838. Een van de onderbouwingen van domaine public was gelegen in de rechtshistorische uitleg van de Nederlandse artikelen 576-579 BW met behulp van de Franse artikelen $538-540 \mathrm{Cc}$. In de betreffende Franse artikelen wordt gesproken over 'domaine public' ${ }^{382}$. In artikel $539 \mathrm{Cc}$, het equivalent van artikel 576 BW, had moeten staan 'appartiennent à l'État.' Dit is voor Opzoomer onvoldoende om aan te nemen dat er ook een dergelijk onderscheid in de Franse artikelen 538-540 Cc is uitgedrukt. Het onderscheid kan alleen aanwezig zijn als er ook daadwerkelijk zou

379. In zijn dissertatie wit 1869 had Cort wan der Linder reeds een lans gebroken woor een uniform privaatrechtel hike be nadering. Zijn argumenten ontleende hij aan de wettekst: "Inderdaad het is bijna onbegrijpelijk hoe men zulk een groot en diep ingrijpend beginsel heeft durven invoeren, heeft kunnen lezen in een wet, waarin geen woord er wat geschreven staat.' Con van der Linderi, P. W.A., Beschouringen over het strand (1869), p. 35-50.

380. Opzoomer, C.W. deel 3 (2e druk 1876), p. 18.

381. Datarower hoofdstuk $3 \$ 4 . C .2$.

382. Zie hoofdstuk 3 \$.C.2. 
staan 'à l'état' in plaats van 'au domaine public' ${ }^{383}$. Het staat er niet, en dus kan het onderscheid niet in de Franse wetgeving worden gelezen. Wel wordt dit onderscheid in de Franse rechtswetenschap gemaakt, en daaruit citeert hij Cormenin, Droit Administratif: 'Il faut distinguer le domaine public du domaine de l'état. Le domaine public est celui qui (...) n'est pas susceptible d'une propriété privée.' Verder haalt hij Aubry en Rau, en Marcadé aan. Genoemde Franse schrijvers baseren hun onderscheid in de verschillende zaken die aan de staat behoren tevens op een in de Codle civil gemaakt onderscheid. Marcadé spreekt er zijn verwondering over uit dat de Code niet in woord een onderscheid maakt tussen de zaken "genoemd in art. 538, en die, genoemd in 539:

'On voit, du reste, que le Code emploie les expressions l'Etat ou le domaine public, comme synonymes; il eût été plus logique de leur attribuer à chacune un sens propre."

Niettemin maakt Marcadé zèlf het onderscheid tussen publiek en privaat domein wel degelijk, want de zaken, genoemd in artikel 539

'(...) entrent dans le domaine prive de l'Etat (...). Ils sont dans le commerce ee susceptibles de prescription et d'aliénation.' 3⿶凵

Een dergelijke uitleg wijst Opzoomer van de hand. Elke uitleg moet immers te herleiden zijn tot de woorden van de wet en de woorden van de Franse wet nemen geen onderscheid aan. Een rechtshistorische interpretatie van de Nederlandse bepalingen met behulp van de overeenkomende Franse bepalingen wijst volgens Opzoomer niet in de richting van een onderscheid tussen publiek en privaat domein in het Burgerlijk Wetboek. Omdat het geldende Franse recht een onderscheid aanneemt, dat niet door de woorden der wet wordt omvat kan aan het Franse recht geen betekenis toekomen voor de uitleg van de Nederlandse bepalingen. Hier is de grens bereikt van Opzoomers interpretatievrijheid ${ }^{385}$.

In Opzoomers uitleg is daarmee de kous nog niet af. Want Opzoomer kent wel betekenis toe aan de bepalingen met betrekking tot zaken buiten de handel: "[W]at men door zaken, die niet in den handel zijn, te verstaan heeft, vernemen wij niet. Men zal er wel niets anders toe mogen brengen dan hetgeen tot algemeen nut of gebruik bestemd is." ${ }^{386}$ Bovendien: "Men heeft alleen te denken aan hetgeen, ofschoon het een voorwerp van eigendom wel degelijk kan zijn en zelfs is, aan den eigendom van privaatpersonen en het handelsverkeer is onttrokken.' ${ }^{387}$ Anders dan Diephuis, die geen criterium heeft voor de nadere bepaling van zaken buiten de handel, heeft Opzoomer

383. Opzoomer, C.W., deel 3 (1876), p. 17, noot 1.

384. Marcade, V., deel 2 (1852), nr. 396, p. 382.

385. Zie $\$ 1 . C .2$ en 1.C.3.

386. Opzoomer, C.W., deel 3 (1876), p. 118-119, en in de voetnoot.

387. Opzoomer, C.W., deel 3 (1876), p. 119. 
dat wel: "algemeen nut of gebruik." Opzoomer verwijst instemmend naar Goudsmits uiteenzetting ${ }^{388}$. Goudsmit neemt met een uitvoerig betoog en onder vele verwijzingen naar de Duitse en Oostenrijkse rechtswetenschap, naar Kierulff, Puchta, Windscheid, Wächter en Unger, een onderscheid aan tussen zaken in, en zaken buiten de handel ${ }^{389}$. Deze verwijzingen vinden we niet terug bij Opzoomer, wel is hij sterk door Goudsmits onderbouwing beînvloed. Het onderscheid tussen zaken in, en zaken buiten de handel kan Opzoomer nog net maken voor het ius constitutum, het onderscheid tussen publiek en privaat domein kan hij niet maken, maar het zou er behoren te zijn. In dat verband hebben andere stelsels betekenis voor Opzoomers 'ontwikkeling" van het Nederlandse recht. We kunnen hier een parallel trekken tussen Thorbecke en Goudsmit: beiden stonden met hun standpunt bepaald niet midden in de civielrechtelijke discussie, maar die standpunten werken daarin wel door. Dat van Thorbecke op duidelijke wijze, dat van Goudsmit bescheiden, via Opzoomers 'rechtsontwikkeling.' Bij Opzoomers acceptatie van het criterium 'algemeen nut of gebruik' hebben de via Goudsmit genoemde andere stelsels zelfs betekenis voor het geldende recht.

Diephuis' bezwaar tegen 'domaine public" is fundamenteler. Eerst gaat Diephuis uit wan een tweedeling in de zaken die de overheid kunnen toebehoren ${ }^{300}$ Zaken die vanwege de openbare bestemming aan de overheid behoren hebben 'iets eigenaardigs.' Weliswaar, aldus Diephuis, zijn zij een voorwerp van eigendom, zijn de in artikel $577 \mathrm{BW}$ genoemde zaken eigendom van de staat, 'doordien alle zoodanige zaken, volgens de wet, aan den staat moeten toebehooren," 391 tevens zijn zij door hun aard, hun openbare bestemming, buiten de handel. Ook hier was Diephuis niet expliciet voor de leer van het domaine public. Maar wel was hij nog in staat om de zaken die werden genoemd in artikel $577 \mathrm{BW}$ te onderwerpen aan het regime van de bepalingen met betrekking tot zaken buiten de handel. Dat verandert in zijn latere werk. Want daarin stelt Diephuis dat zaken buiten de handel, of de zaken genoemd in artikel 577 BW een voorwerp van privaatrechtelijke eigendom zijn:

'De in artikel. 577 en 579 aangeduide zaken worden verklaard an den stat te behooren, onverminderd de door titel of bezit verkregen regten van bijzondere personen of gemeenschappem.(...) De zaken die aldus aan den staat behooren, worden als zijn publiek eigendon woorgesteld, in tegenstelling van hetgeen hij anders heeft en als privaat of particulier eigendom bezit." 392

En: 'De wet zegt dan ook in art. 577-581 van de stranden der zee, de bevaarbare en vlotbare stroomen en rivieren met hunne oevers, "s lands vestingwerken enz., dat ze aan

388. Opzoomer, C.W., deel $3(1876)$, p. 179-180.

389. Goudsmit, J.E., Pandecten-Syrteem (1866), p. 98 ev.

390. Zie hoordstuk 4 \&.B.

391. Hoofdstuk 4 4.B.

392. Diephuis, G., deel 1 (1869). p. 494-495. 
den staat behooren. ${ }^{393}$ Aldus maakt Diephuis duidelijk dat de in artikel 577 en volgende genoemde zaken eigendom zijn van de staat. Hij werwijst naar Olivier, De Bieberstein, Opzoomer en de Duitse jurist Wappäus. Het is voor Diephuis onmogelijk geworden om te bepalen welke zaken nu 'buiten de handel' zijn. In de wet kan hij daarvoor geen criterium vinden. In het criterium 'openbare bestemming' is 'geen grond gelegen om ze als zaken buiten de handel te beschouwen.' Waarom niet? Het is niet in de wet genoemd, en bovendien spreekt de wet over 'behooren' aan de staat. Diephuis kon dit criterium niet langer gebruiken. Wel wordt het genoemd bij de totstandkoming van het Burgerlijk Wetboek, het is een Romeinsrechtelijk criterium, een rechtsstelsel dat reeds drie maal bij wet was afgeschaft, en dat om die reden geen betekenis toekomt bij de uitleg van de Nederlandse bepalingen ${ }^{394}$. Diephuis neemt dan ook afstand van zijn eerdere werk en verwerpt de standpunten van Opzoomer, Toullier en Aubry en Rau, die allen dit criterium wel aannemen ${ }^{395}$. Diephuis' benadering heeft iets ambivalents over zich gekregen: enerzijds is er iets bijzonders aan de hand met de zaken uit artikel 577 , zij hebben een openbare bestemming, maar niets slaat thans voor Diephuis nog de brug naar de bepalingen over zaken buiten de handel. In de Gemeentewet is door Thorbecke wel een duidelijk onderscheid gemaakt tussen privaat- en publiek domein. Diephuis kan daaraan geen argument ontlenen: de bepaling in de Gemeentewet is immers alleen bedoeld voor zaken die aan de gemeente behoren; voor de zaken die aan de staat behoren, ontbreekt in de wetgeving een dergelijke bepaling. Diephuis:

\footnotetext{
"Heeft onze wetgever zoodanige uitzondering niet gemaakt voor zaken, waarvoor men haar wenschelijk zou achten en hij zelf haar misschien bedoeld en werondersteld heeft, en zal daardoor onder den regel vallen wat wel in de uitzondering had mogen begrepen zijn, men kan dit den wetgever wijten, maar mag op grond daarvan geene uitzondering erkennen, die geen grond windt in de wet. ${ }^{396}$
}

\section{E. CONCLUSIES PUBLIEK DOMEIN}

De heersende leer is die van de publiekrechtelijke eigendorn. De argumentatie is in het administratiefrecht makkelijker dan in het burgerlijk recht. Juist in het burgerlijk recht is sprake van lastige clogmatische problemen. Door Thorbecke wordt de Franse theorie van het 'domaine public' in de Nederlandse rechtswetenschap geïntroduceerd. Het wordt op eenvoudige wijze, door de invloed van Thorbecke zo lijkt mij, de heersende leer. Grammaticale, systematische en historische argumenten, met enige vrijheid gewaar-

393. Diephuis, G., deel 1 (1869), p. 499.

394. Zie voor deze verwerping van het Romeinse recht door Diephuis: Lokin, J.H.A., (1992), p. 29. Zeer duidelijk is dezelfde argumentatie gepresenteerd in het Tijdschrift voor het Nederlandsche regt, Nog iets over zaken buiten den handel, p. 305-316, in 1876, in een artikel van een niet met name genoemde auteur. Op grond van de gebruikte argumentatie, en het gegeven dat Diephuis de redactie voerde, zal Diephuis zelf hoogstwarschijnlijk de auteur geweest zijn.

395. Diephuis, G., deel $₫(1869)$, p. 499.

396. Dieplusis, G. deel $1(1869)$, p. 501 . 
deerd, waren voor die acceptatie voldoende. Uit het Franse recht wordien historische argumenten geleverd; daarnaast worden uit het Franse administratiefrecht ook rechtsvergelijkende argumenten gebruikt. De Pinto (1872) verklaart dat het onderscheid tussen privaat en publiek domein niet eens uitdrukkelijk hoeft te worden gemaakt om toch te worden aangenomen, en zo ook de Hoge Raad (1863). De tekst van de wet vermeldt het niet, toch volgt het noodzakelijk uit de artikelen. Maar Diephuis en Opzoomer wegen de argumenten wat meer met behulp van tekst en systeem van het Burgerlijk Wetboek. Dan blijken ze niet meer voldoende te zijn om het onderscheid aan te nemen. Het Burgeriijk Wetboek kent het onderscheid niet. Diephuis verwerpt de leer van Thotbecke met de meeste kracht. Daarvoor heeft hij genoeg aan tekst en systeem van het Burgerlijk Wetboek, maar juist ondat zoveel argumenten voor domaine public zijn ontleend aan het Franse recht, besteedt hij ook daaraan aandacht. Ook Opzoomer ontkent het onderscheid in het BW, maar stelt onder inbreng van andere rechtsstelsels ${ }_{\text {, }}$ dat het er wel zou behoren te zijn: een onderscheid zoals in de Oostenrijkse wetgeving, en door Duitse schrijvers wordt gemaakt. Anders dan Diephuis aanneemt, kent Opzoomer wel betekenis toe aan de bepalingen over 'zaken buiten de handel.' De rechtshistorie of het Romeinse recht kon hem dai criterium bieden; beide waren voor Diephuis minder bereikbaar.

\section{$\S 5$. Conclusies over de periode van het legisme (1850-1880)}

\section{A. DE HEERSENDE MENINGEN}

Aan artikel 1403 lid 1 wordt in de jurisprudentie voor het eerst een zelfstandige betekenis toegekend: een ruime opvatting, aansprakelijkheid buiten schuld, en toepasselijkheid op alle zaken. In de literatuur echter is deze uitleg omstreden, en daar krijgt de enge opvatting, de opvatting van Diephuis, de overhand. Artikel 2014 wordt hoe langer hoe stelliger uitgelegd als een Germaansrechtelijk beginsel: bezit van een roerende zaak moet worden gelijkgesteld aan de eigendom. Publiek domein krijgt eerst cen bijzondere juridische status door Thorbecke. Zaken van de overheid dienen niet onderworpen te zijn aan het eigendomsrecht, maar aan een geheel voor die zaken zelf bedoeld rechtsregime. Het is een status die uit het privaatrecht niet zonder meer is af te leiden. Sommige handboeken zijn wel stellig in de acceptatie maar Opzoomer en Diephuis leggen de problemen bloot bij de civielrechtelijke onderbouwing.

\section{B. KWANTTTATIEVE ANALYSE}

Diephuis verwijst nog steeds veel naar het Franse recht (50\%). In Themis is $20 \%$ van de verwijzingen naar Frans recht. De toename in verwijzingen naar het Belgische recht (Laurent) is opmerkelijk. Verwijzingen naar het Duitse recht zijn in aantal afgenomen. De verwijzingen in Themis geven een ander beeld: daar wordt slechts een enkele maal verwezen naar Belgisch recht. Het percentage verwijzingen in Themis naar Duitse bronnen is toegenomen ten opzichte van de vorige periode. In Themis zijn de artikelen 
vrijwel volledig op het Nederlandse recht georiënteerd. In het Rechtsgeleerd Magazijn is bijna de helft van de artikelen gericht op een ander rechtsstelsel. Datzelfde beeld komt uit de boekbesprekingen en aankondigingen naar voren. Met name de belangstelling voor het Duitse recht valt op.

\section{ONTLEENDE ASPECTEN}

De heersende, enge uitleg van artikel 1403 met het verbod van een analoge toepassing wordt ook door Franse schrijvers, door Toullier en Marcadé (art. $1384 \mathrm{Cc}$ ), voorgestaan. Waar het Franse recht soms een analoge interpretatie toestaat, is Diephuis resoluut. Van analogie mag bij de uitleg van artikel 1403 geen gebruik worden gemaakt. De Germaansrechtelijke uitleg van artikel 2014, met name zoals die door Diephuis werd verdedigd, lijkt sterk op de uitleg van Laurent: revindicatie door de oorspronkelijke eigenaar is als uitzondering toegestaan in artikel 2014 \id 2, en daarom moet lid 1 een algemene regel geven die revindicatie uitsluit. Wat betekent dan deze onmogelijkheid van revindicatie anders dan de eigendom voor de bezitter? Het wetsontwerp voor het BGB wijst op een andere uitleg dan de germaansrechtelijke: de overdracht van eigendom door een beschikkingsonbevoegde. Tussen bezit en eigendom bestaat verschil. Soms kan een beschikkingsonbevoegde bezitter toch de eigendom overdragen. In de NJV wordt deze uitleg als wenselijk recht geaccepteerd. Publiek domein wordt begrepen als de Franse theorie van domaine public, met dezelfde argumentatie als in Frankrijk werd gebruikt. Het criterium 'algemeen nut' werd aan het romeinse recht ontleend.

\section{RECHTSVINDING}

In de eerste plaats dienen andere rechtsstelsels als historische interpretatie. In alle leerstukken is daarvan sprake, en met name het Franse recht wordt daarvoor gebruikt. Bij de aansprakelijkheid voor zaken wordt de verhouding tussen de artikelen 1382 $1386 \mathrm{Cc}$ gebruikt. Bij de uitleg van 2014 is de gehelle Franse geschiedenis van het adagium 'possession vaut titre' vanaf Bourjon van belang. Voorts wordt het Romeinse recht en wat later het Germaanse recht beschouwd. Bij publiek domein wordt gebruik gemaakt van Frans en Romeins recht als historische onderbouwing.

In de tweede plaats is sprake van een vergelijkende weergave van een ander rechtsstelsel. Ook deze interpretatie wordt bij elk onderwerp aangetroffen, en dat meer naarmate 1838 verder in het verleden ligt. Bij de aansprakelijkheid voor zaken wordt op eenzelfde interpretatie in het Franse recht gewezen (De Pinto, 1860); bij artikel 2014 wordt op verschillende interpretaties in het Franse, en Belgische recht gewezen: Aubry en Rau, Laurent, Marcadé worden aangehaald. Diephuis' uitleg vertoont grote overeenkomst met die van Laurent. Bij publiek domein worden Franse administratiefrechtelijke en civielrechtelijke commentaren gebruikt ter onderbouwing van de publiekrechtelijke eigendom. Opzoomer verwerpt de interpretatie van Franse civielrechtelijke commentaren. 
In de derde plaats is er sprake van andere rechtsstelsels in de argumentatie voor het wenselijke recht. Dat komt voor de aansprakelijkheid voor zaken aan de orde in de NJV, waar van Duitse wetgeving gebruik wordt gemaakt. Enkelen staan een met Duitse regelingen vergelijkbare regeling voor in het Nederlandse recht, maar de meerderheid verwerpt die mogelijkheid. In de discussie over 2014 wordt (in de NJV) met grote instemming een artikel uit het Duitse ontwerp BGB als uitleg van 2014 gezien. Een opvallend verschil met de NJV discussie in 1874 valt op: het wenselijke recht wordt in die eerdere vergadering vormgegeven in hoofdzaak met het systeem, de eenheid van de wetgeving, in de vergadering van 1890 is vooral het matschappelijk belang richtsnoer. Bij publiek domein komt het wenselijke recht bij Opzoomer aan de orde. In dat verband verwijst hij naar Oostenrijkse wetgeving, en betrekt via Goudsmit ook het Duitse, Oostenrijkse en Romeinse recht bij zijn interpretatie.

In de vierde plaats is sprake van een invloed van andere Nederlandse rechtsgebieden op het Nederlandse privaatrecht. Drie maal zijn andere rechtsstelsels doorgedrongen in het Nederlandse privaatrecht doordat andere Nederlandse rechtsgebieden of schrijvers een zekere invloed hadden: Thorbecke en zijn navolgers introduceren en onderbouwen 'domaine public' uit Frankrijk; Goudsmit maakt gebruik van de Duitse rechtswetenschap voor 'domaine public' en heeft via verwijzingen van Opzoomer invloed; Molengraaff pleit vanuit het handelsrecht voor een door het Duitse recht geïnspireerde uitleg van 2014.

\section{E. RECHTSVERGELIJKING}

Summierlijk laten schrijvers zich wit over rechtsvergelijking. Enkele opmerkingen geven aan dat ze het Franse recht eigenlijk als onderdeel van de interpretatie zien als rechtshistorische interpretatie. Diephuis ziet het Franse recht als aanleiding voor de behandeling van rechtsvragen. Van die eigentijdse Franse bronnen maakt Diephuis gebruik, maar het blijkt meer in te houden dan een aanleiding voor rechtsvragen. Vaak betreft het een rechtsvergelijkende weergave van een ander rechtsstelsel. In de behandeling van de onderwerpen blijkt een enkele keer van expliciete aandacht voor de positie van het buitenlandse rechtsstelsel in het Nederlandse recht. Zo wordt gewezen op de noodzaak van een internationale regeling voor spoorwegvervoer (NJV 1874). Zo word gesteld dat bij de uitleg van artikel 2014 rekening gehouden moet worden met andere rechtsstelsels met het oog op het handelsverkeer (NIV 1890). 



\section{Vrije rechtsvinding en rechtsvergelijking (1880-1910)}

\section{$\S 1$. Inleiding: 'der menschen handel en wandel'}

De periode van de 'vrije rechtsvinding' verschilt in methoden van rechtsvinding sterk met de periode van het legisme ${ }^{397}$. In de inleidende paragrafen komen achtereenvolgens aan de orde: in de eerste plaats het ius constituendum uit het legisme, waarin de overgang naar de vrije rechtsvinding is te herkennen ( $\$ 1 . A$ ); in de tweede plaats de vrije rechtsvinding in samenhang met de voorgaande legistische rechtsvinding en enkele maatschappelijke ontwikkelingen $(\$ 1 . C)$; in de derde plaats de rechtsstelsels van Frankrijk en Duitsland rond de eeuwwisseling ( $\$ 1 . D$ ); in de vierde plaats de kennisname van de andere rechisstelsels in de Nederlandse privaatrechtswetenschap en de opkomst van de rechtsvergelijking ( $\& 1 . E)$.

\section{A. HET IUS CONSTITUENDUM EN DE VRIJE RECHTSVINDING}

In de privaatrechtswetenschap tijdens het legisme wordt voor het ius constituendum uitdrukkeiijk plaats ingeruimd. In de argumentatie naar het wenselijke recht is plaats voor gebruik van andere rechtsstelsels. Zo bijwoorbeeld door de Nederlandse JuristenVereniging. Van Bemmelen verwoordt in 1890 de doelstelling van de vereniging als volgt:

De J. V V. houdt zich bezig, noch met wetsinterpretatie, noch met rechtsgeschiedenis, maar met het jus constituendum. 2 ij w raggt niet wat recht is of geweest is, matar alleen wat recht behoont

397. Scholten, P., (1934), p. 245 ew, Jaspers, T. (1980), passim; Kop, P.C.. (1992), p. 45; Van den Bergh, G.C.JJ, (1994), p. 140; De Bentity, N., Proeve tot verzoening van de dogmatische en sociologische richtingen in de rechtswetenschap, Rechisgeteerd Magazijn Themis 1939, p. 139; Bouckaert, B., (1982), p. 49. 
te zijn (...) Zij vraagt slechts: wat is nutug, heizaam, goed en zulks niet in abstracto, maar bij ons te lande en heden ten dage." 398

De grens tussen ius constituendum en ius constitutum vervaagt. Tijdens het legisme ligt het laatste woord over het ius constitutum bij de wetgever. Die is gelegitimeerd om in wetgeving het wenselijke recht weer te geven, en het aldus tot geldend recht te maken. De rechtswetenschap kon slechts dit wenselijke recht aanbevelen. Dit blijkt ook uit de doelstelling van de NJV:

'De Nederlandsche Juristen-Vereeniging stelt zich ten doel aan de Nederlandsche rechtsgeleerden de gelegenheid te geven anderling te beraadslagen over onderwerpen wan wetgeving betreffende het burgerlijk-, handes-, straf-en procesrecht en daarmede samenhangende onderwerpen, daardoor onder hen over die onderwerpen evene gemeenschappelijke overtuiging te doen ontstaan, door den zedelijken invloed dier overtuiging mede te werken tot de hervorming van het Nederlandsch rechtswezen.'

Dat een verandering van het recht slechts door een verandering van wetgeving (door de wetgever) mogelijk wordt geacht, kan volgen uit het eerste aan de vergadering voorgelegde preadvies over een onderwerp dat "zoo zeer alles beheerscht en beheerschen moet', herziening van de wetgeving:

\begin{abstract}
"Welke hoofdbezwaren staan aan de herziening onzer wetboeken in den weg, en hoe die op te lossen, ten einde te bevorderen, dat die wetboeken steeds beantwoorden aan de veranderende eischen der samenleving en ten allen tijde de juiste uiturukking zijn der meest algemeene apvatting van het recht door de bevoegde beoordelaars in ons vaderland? ${ }^{399}$
\end{abstract}

Zou een vrije rechtspraak door een vrije interpretatie mogelijk zijn? De vereniging kiest voor een voortdurende aanpassing van de wetgeving, aldus Jansen en Lokin, en met geen woord wordt gerept over de mogelijkheid van een vrije interpretatie van de wettekst. Rond de eeuwwisseling wordt een vrije rechtspraak, door middel van een vrije rechtsvinding bepleit. Het wenselijke recht gaat een rol spelen bij de interpretatie. Zo zien we dat bijvoorbeeld bij de Amsterdanse hoogleraar Hamaker. De grens tussen het 'ius constitutum' en het 'ius constituendum' 'werd wel eens vaag', zo schetst Van Oven de door hem bij de Amsterdamse hoogleraar Houwing gevolgde colleges ${ }^{400}$. Een nieuwe stroming verschijnt: de vrije rechtsvinding. De interpretatie van het Nederlandse recht kan met grotere vrijheid geschieden.

398. Van Bemmelen, P., in: Handelingen I (1890), p. 2; zie ook hoofdstuk 5 3. Zie over dit kenmerkende aspect voor de legistigche rechtswetenschap Kop. P.C., (1992), p. 42.

399. Als aangehaald door Lokin, J.H.A., en C.J.H. Jansen, (1995), p. 3 en p. 31.

400. Van Oven, als geciteerd in Zestig juristen (1987), p. 58. 


\section{B. "WAT IS "T VOORWERP DER RECHTSWETENSCHAP EN WAT IS HAAR METHODE?"}

"Wat is "t voorwerp der rechtswetenschap en wat is haar methode?" Hamaker stelt zich deze vraag als aanvang van zijn colleges burgerlijk recht in het studiejaar 1888-1889. De student Vlamingh Kiebêrt noteert het college vlijtig en verschaft ons Hamakers antwoorden. Het contrast met de methoden van de periode van het legisme kan niet groter zijn:

\footnotetext{
'Het object voor ons moet de maatschappij zijn. Wij moeten deze en hare inrichting bestudeeren. Wij zullen ons moeten (bezighouden en) tevredenstellen met kennis uir de $2 \mathrm{e}$ hand. Met beschrijving van het maatschappelijk leven moeten wij ons behelpen. Wij vinden deze in onze wetboeken, zeer betrouwbare beschrijying, daar zij producten van de arbeid van talrijke gestachten zijn. (...) Interpretatie is onze taak, mas die is wrij, daar de wet niet ons doel is, maar een middel om tot het doel te geraken. De recintsliteratuur en de jurisprudentie moeten wij als twee hulpmiddelen gebruiken bij wetsgebruik. ${ }^{40 !}$
}

De interpretatie is vrij. Met de in het vorige hoofdstuk beschreven rechtsvindingsmethoden van Opzoomer en Diephuis staan zij in schril contrast. Binnen de methoden van interpretatie die hen ten dienste staan, kunnen ook zij (en vooral Opzoomer) soms tot ruime en maatschappelijk zeer aanvaardbare interpretaties komen. Maar nooit is de 'afleiding uit' (Diephuis), de maatschappelijk 'noodzakelijke" uitleg (Opzoomer), de laatste toets: die blijft voorbehouden aan de woorden der wet en de artikelen in onderlinge samenhang. Een grotere vrijheid kan de legistische jurist zich permitteren door te argumenteren hoe het recht zou behoren te luiden. Nu dan is er onder meer bij Hamaker een geheel ander geluid. Het wenselijke recht is meer geworden dan een aanbeveling aan de wetgever. Het is een methode van uitleg geworden. In de door Hamaker voorgestane methode is de vrijheid niet totaal: de wet is immers een zeer betrouwbare beschrijving van het maatschappelijke leven, en bij de uitleg dient de wet dan ook betrokken te worden. Hamaker plaatst zijn interpretatie tegen de methoden van het legisme. Het legisme vat hij samen onder de opvatting die recht aan wet gelijkstelt: 'Lang heeft dit denkbeeld geheerscht. Telkens vindt men het nog uitgesproken.' ${ }^{402}$

\section{VRUIJE RECHTSVINDING, LEGISME EN MAATSCHAPPELIJKE ONTWIKKELINGEN}

Wij bekijken nader welke methoden van rechtsvinding in de periode van vrije rechtsvinding worden gebruikt. Daarvoor is het noodzakelijk twee kwesties te belichten waarmee de vrije rechtsvinding verband houdt. In de eerste plaats is sprake van maatschappelijke

401. Hamaker, H.J. Burgerlijk Recht, (1888-1889), p. 1-5. Collegedictuar vân F.J. Vlamingh Kiebêrt. Bibliotheek FdR, UU, B $1 \mathrm{~d}-1$.

402. Andere gangbare opvattingen over de privaatrechtelijke rechtswinding zijn er volgens Hamaker eveneens. Zo plaatst hij zijn eigen methoden in een verzameling van drie theorieèn die alle uitgaan van een verschil tussen trecht en wet ("dualisme"): daamaast noem Hamaker als prominemte, doch achterhaalde ('Wat is echter die volksgeest? Men hect gevarar van willekeur') theorie die van de Historische School van Savigny, 
ontwikkelingen in het laatst van de negentiende eeuw die op de rechtswetenschap een sterke invloed hebben. Aan de maatschappij ontleende argumenten zijn vaak richtinggevend voor de uitleg. In de tweede plaats is de vrije rechtsvinding ontstaan als reactie tegen het legisme.

\title{
1. Maatschappelijke ontwikkelingen en een falende wetgever
}

Enkele maatschappelijke ontwikkelingen hebben een sterke invloed uitgeoefend op het privaatrecht. Valkhoff schetst er vier: bevolkingsaanwas, de urbanisatie, het verkeer en de industrialisatie ${ }^{403}$. Veranderingen vinden plaats in de wetgeving. Maar ook de rechter heeft een grotere vrijheid genomen bij de uitleg van wetsbepalingen ${ }^{404}$. Voornamelijk de industrialisatie en de toename in het (handels)verkeer zijn in de rechtswetenschappelijke discussie te herkennen. De toename van de industrialisatie maakte een andere mening over aansprakelijkheid uit onrechtmatige daad mogelijk. Het handelsverkeer speelt een rol in de discussie over artikel $2014 \mathrm{BW}$. Ook Molengraaff kent deze maatschappelijke omstandigheden een belangrijke rol toe:

\begin{abstract}
'(...) de sociale quaestie [is] ook wel degelijk eene rechtsquaestie. (...) Voor iederen jurist, en voor den civilist, den beoefenaar van het werkeersrecht, even goed als voor den beoefenaar van het statsrecht, moet dus de sociale quaestie een voorwerp van studie en onderzoek uitmaken. (...)

De rechtswetenschap, het behoeft wel geen nader betoog, is een deel van de wetenschap der samenleving. Vandaar ook het innig verband, waarin zij staat tot de economie en de sociologie. Vandaar dat het werkelijk leven, der menschen handel en wandel, de basis moet zijn, waarop de jurist zijne wetenschappelijke stelsels doet rusten. Missen zij die basis, dan kunnen de kumstigste "aprioristische denkoperaties" niet voorkomen, dat zij in de lucht blijven hangen. 405
\end{abstract}

Vaak wordt 'der menschen handel en wandel' vermeld ${ }^{406}$ "ook in de onderzochte onderwerpen. Zo veroorzaken de ontwikkelingen in het (handels)verkeer en de industrialisatie een bijzondere belangstelling van de rechtsgeleerde wereld voor maatschappelijke kwesties. Het geldende recht kan worden beredeneerd door te wijzen op de maatschappelijk noodzakelijke uitleg. Belangstelling voor die maatschappelijke onderwerpen is er al in de periode van het legisme. Opzoomer gebruikte het bijvoorbeeld voor een redelijke uitleg. In ieder geval kan een wenselijke uitleg dienen als aanbeveling voor de

403. Valkhoff, J. Eest euw rechtsontwikkeling. De vermaatschappelijking wan her Nederlandse privalrechr sinds de codificatie (1838). (2e druk, 1949), p. 185.

404. Zo bijvoorbeeld Valkhoff, J., (1938); Schwitters, R., De risico's war de arbeid. Her ontstaan van de ongewallenwet in sociologisch perspectief (1991); Zie ook Van den Bergh, G.C.J.J., (1994), p. 94; Kop, P.C.. (1992), p. 46.

405. Molengratf, W.L.P.A., Het werkeersecht in wetgeving en wetenschap (1885), p. 24-27; opgenomen in: Molengraatf bundel. Kenze uit de geschriften wan Mr. W.L.P.A. Molengraaff met levensbeschrijwing en biografie (1978), p. 48-51.

406. Zo bijvoorbeeld wordt in 1886 in Themis melding genaakt van economische recessies in de zeventiger en tachiger jaren. Zie Thenis 1886, p. 74 . 
herziening van de wetgeving. Van herziening komt het echter niet vaak genoeg. Minister van Justitie Modderman somt in 1880 een aantal onderwerpen waarvan de wettelijke regeling niet meer voldoet: onder (veel) meer onderwerpen treffen we aan 'eigendommen van den Staat' (publiek domein) en artikel 2014 lid $1^{407}$. Eerst in 1899 is een deel van het ontwerp (de boeken 1 en 2) gereed, maar van invoering komt het niet. De wetgever was te traag? Aan enkele reacties af te lezen werd daar wel zo over gedacht: 'geheel en al onvoldoende' spreekt Bruins over de bepalingen inzake de aansprakelijkheid uit onrechtmatige daad, en, wat later over dezelfde kwestie, Star Busman: 'wie zich op de wetgever verlaat, bouwt op zandgrond." 408 Molengraaff en Drucker: "Het is een bedenkelijk, maar tevens onloochenbaar verschijnsel, dat de staatkundige toestand, de zoogenaamde hooge politiek, meer en meer als een hinderpaal in den weg staat aan de bevrediging van zoovele nooden en behoeften der maatschappij." 4004 Fockema Andreae spreekt over 'eene zeer langzaam, omslachtig en onvoldoende functionneerende wetgevende machine." 410 Met deze laatste bezwaren wordt een van de hoekstenen van de legistische interpretatie geraakt: altijd was immers de wetgever de aangewezene om het recht vast te stellen. Maatschappelijke ontwikkelingen als toename van het verkeer, industrialisatie, economische recessie, en een falende wetgever; het ontstaan van de vrije rechtsvinding is door deze combinatie van factoren bespoedigd.

\section{Vrije rechtsvinding nader geduid als reactie op het legisme}

\section{a. Verzachting van het legisme enerzijds...}

Uit Hamakers beschrijving wordt duidelijk dat geen sprake is wan een scherpe scheiding tussen de periode van het legisme en de vrije rechtsvinding, maar meer van een vloeiende overgang. Beide methoden doen zich naast elkaar voor. Hamaker vindt de gelijkstelling van recht aan wet nog telkens uitgesproken. De vrije rechtsvinding ontstaat niet plotseling; de kiem van een meer los van de wet staande uitlegmethode was reeds aanwezig in het legisme. De rechtswetenschap moest immers onjuistheden of onwenselijkheden in tekst en systeem van de wetgeving signaleren en verbetering suggereren aan de wetgever. Bij latere representanten van het legisme neemt de nadruk op dit ius constituendum toe. Zo geschiedt bijwoorbeeld in de methoden van Land, in zijn Verklaring van het Burgerlijk Wetboek ${ }^{41}$. Hoewel Land door Kop wordt beschreven als de auteur die zich in zijn methoden van rechtswinding het meest legistisch opstelt ${ }^{412}$,

407. Bij de instelling van een staatscommissie voor herziening wan het burgerlijk recht. Zie ook Kop, P.C.. (1992), p. 48.

408. Zie hoofdstuk 6 de $\$ \$ 2 . C .2$ en 2.C.3.

409. Rechtsgeleerd Magazijn 1885, p. 369. Zie over de Commissie Meerbeke eveneens: E. O.H.P. Florijn. (1994), p. 56.

410. Fockema Andreae, J.P., Moderne Praetuur? Beschouwingen over het jangste verleden en de naaste coekomst wan wetstoepassing en rechtshervorning (1907). p. 138.

411. Zie over Land en zijn methode: Kop. P.C., (1992), p. 39 ev.

412. Kop, P.C., (1992), p. $39-40$. 
wordt uit een bespreking van de tweede druk van Lands Verklaring, en uit de daarin verwerkte citaten wan Land zelf, duidelijk dat een enkele kwalificatie "legistisch" onterecht zou zijn:

'De houding, welke de heer $L$. tegenover den tekst der wet aanneemt, is mijns inziens eene zeer gelukkige eerbied voor den duidelijk uitgesproken wil des wetgevers, werbonden met zooveel zelfstandigheid, dat nooit wordt uit het oog verloren, hoe de wet slechts eene uiting (soms eene gebrekkige uiting) is yan het recht. Reeds in de Voorrede wordt dit punt met nadruk op den voorgrond gesteld; $(\ldots)^{4} 413$

Zowel bespreker als besprokene menen, dat de wet slechts een weergave is van het recht. De methodologie van Land heeft bepaald meer te bieden. Zij verenigt in zich een nadrukkelijker behandeling van het wenselijke recht, en onderstreept tevens het (aan de Duitse Historische School ontleende) belang van een historische interpretatie. De wet is niet alleen het enige, of uiterste object van de rechtsvinding, maar wordt door Land geschetst als slechts een mogelijke weergave van het recht, en soms zelfs een gebrekkige weergave. Wat is daarvan de consequentie? Land laat zijn verklaring van de wet met kritiek op die wet gepaard gaan. Die verklaring van wetsbepalingen

\begin{abstract}
( ...) moet in de eerste plaats leiden tot volledige kemnis van het bestaande, maar bovendien kunnen wij alleen doot ons kalm rekenschap te geven van de gebreken, inzien, war verbetering behoort te worden aangebracht. Zulk een verbetering is alleen te bereiken door ontwikkeling van het bestaande recht; ook in dit opzicht is nawwkeurige kennis van de wet gewenscht. De continuiteit van het recht wordt nimmer zonder groot gevar miskend. Zooals het recht van heden nooit volledig verklaard wordt, tenzij wij ook zijne historische wording nagaan, zal ook voor de toekomst weinig heil zijn te wachten van bet breken mer het bestaande recht, waarin toch ook veelal een gezonder kern, en meer stof tot ontwikkeling ligt, dan sommigen in hun ongeduld wel meenen. De richting, warin het recht zich voortbewoog, verder te verwolgen, wijst ons in den regel den meest betrouwbaren weg; die wege is meestal langer dan wij wenschen, doch de ervaring van eeuwen dwingt ons tot een bedachtzamen tred." 414
\end{abstract}

De nadruk ligt in dit citaat op de gebreken van de wet en de historische wording wan het recht. Deze gebreken kunnen door de rechtswetenschap door 'ontwikkeling" van het recht worden bestreden. De wetenschap wijst de weg, die de wetgever zal moeten gaan. Opvallend in dit verband is Lands stellingname inzake aansprakelijkheid buiten schuld. Een uitspraak van de rechter te verlangen waar de wet zwijgt, alleen op grond van 'zijne rechtsovertuiging, naar hetgeen hij vermeent, misschien slechts gevoeld, recht te moeten zijn,' is veel te bezwaarlijk: 'men zal moeten erkennen dat wij hier hoogstens wenschen hebben omtrent hetgeen hier positief recht behoort te zijn. " 15 Bij Land heeft de taak van de rechtswetenschap, te beredeneren hoe de wetgeving zou behoren

413. Feith, P.R., bespreking wan Land, N.K.F., Verklaring van het Burgerlijk Wetboek deel 2 en 3 (2e druk, 1901, 1902), en Land, N.K.F., Rechten op Zaken, naar het Ontwerp Tweede Boek B.W. 1901 , in: Themis 1904, p. 170.

414. Land, N.K.F. in zijn voorrede, als geciteerd door Feith, P.R., (1904), p. 171.

415. Land, N.K.F., Inteiding tor de verklaring van het burgerlijk wetboek, (1910), p. 34-35. 
te luiden, een prominente positie verworven. De historische ontwikkeling van het recht is eveneens een opvallend aspect in de methode van Land: 'Voor het juiste begrip van het bestaande recht is de kennis van zijne geschiedenis van het hoogste gewicht." 416 $\mathrm{Zij}$ is aanwezig bij Lands argumentatie inzake artikel $2014^{417}$. Met name in Lands grotere aandacht voor de vraag hoe het recht zou behoren te luiden kan de nieuwe richting, de vrije rechtswinding worden gehoord.

\section{b. ... anderzijds profilering der vrije richting}

Een aantal juristen heeft een voortrekkersrol voor de vrije rechtsvinding gespeeld. Hamaker is uitgebreid aan het woord geweest. Genoemd moeten verder worden Drucker, Molengraaff, Levy, en wat later, Scholten ${ }^{418}$. Zij allen spelen in de onderzochte onderwerpen een rol van betekenis. Waar zij hun methoden van rechtsvinding verantwoorden, laat dit aan duidelijkheid niets te wensen over. Zo spreekt Drucker in zijn oratie over 'De grootste kanker van ons rechtsleven ligt evenwel in de vervreemding, de klove tussen theorie en practijk der rechtswetenschap.' Deze kloof kan door een vrije interpretatie worden gedicht:

'bij de uitlegging der wet eische men met klem voor wetenschap en practijk uitgebreider macht dan hun thans toekomt. Het stelsel van codificatie heeft uit het oogpunt van rechiseenheid en rechtszekerheid te heilzame vruchten opgeleverd, dan dat wij er aan zouden denken, het te bestrijden. Maar de wetgever behoort zich te beperken: de wetgever kan nu eenmaal niet alles regelen; sommige onderwerpen zijn nog niet rijp woor wettelijke ordening, andere zijn over het geheel te ingewikkeld of te weinig belangrijk; tal van bijzondere gevallen ontsnappen aam wettelijke formuleering. Daarom slechts de beginselen in de wet neergelegd, de wrije toepassing aan den rechter overgelaten. ${ }^{*} 419$

Omdat, volgens Molengraaff, de wetgever een meer beperkte rol krijgt toebedeeld, wordt de taak van de rechter, en van de rechtswetenschap groter. Ook Molengraaff is een voorstander van een grotere interpretatievrijheid. In zijn oratie uit 1885 geeft hij een catalogus van verschillende rechtsvindingsmethoden, die de jurist ten dienste staan. In de eerste plaats het recht, zoals dat in de wetgeving is uitgedrukt. Maar, "De wet, daaromtrent is geen twijfel meer mogelijk, mag dus niet het eenig kompas zijn, waarop

416. Land, N.K.F., (1910), p. 143.

417. Zie over de historische methode hoofdstuk 5 1.D. 1; over Opzomers 'rechtsontwikkeling' hoofdstuk 5\& 1.C. 3; over Lands historische methode in zijn standpuntbepaling in de discussie over arikel 2014 thoofdstuk 5 3.A.2, waarin deells hetzelfide citaat is opgenomen. Zie ook hoofdstuk 5 3.B. watrin de historische nethode door Levy wordt verdedigd in zijn kritiek op Van Bemmetens standpunt over de historische ontwikkeling van artikel 2014

418. Zie ower Scholten ook hoofdstuk 7 \&.D.

419. Drucker, H.L.. Rechtswetenschap en wetgeving (1882), in: Rechisgeleerd Magazijn 1882, p. 542 . Z ie over de kloof tussen praktijk en recht ook: C.J.H. Jansen. Popularisering van het recht in Nederland. Enige beschouwingen over de kloof tussen recht en wolk in het laatste kwart wan de $19 \mathrm{e}$ en het begin van de 20 eeuw, Tijdschriff woor rechtsgeschiedenis nr. 63 (1995), p. 119 ev; Land, N.K.F., (1910), p. $42-56$. 
de leeraar zeilt." Exegese van de wet gaat tezamen met de praktijk van het recht, naar 'datgene wat in het verkeer als recht wordt geobserveerd, onverschillig of het al dan niet officieel recht is'. Verder zijn er enige ander hulpmiddelen om tot een uitleg te komen: de rechtsgeschiedenis, het recht is immers "het resultaat van eeuwenlange ervaring en moeitevollen strijd"; en "eindelijk maakt het cosmopolitisch karakter van het verkeersrecht de rechtsvergelijking tot een onmisbaren factor, die bij het onderwijs te minder verwaarloosd mag worden, daar zij bij oordeelkundig gebruik zeer veel kan bijdragen tot betere waardering van het eigen recht." 420 Molengraaff maakt als een noodzakelijk onderdeel van zijn interpretatie gebruik van andere rechtsstelsels. Ook anderen houden rekening met andere rechtsstelsels bij de uitleg van Nederlandse bepalingen.

\section{VRIJE RECHTSVINDING IN ANDERE RECHTSSTELSELS}

\section{De Franse rechrswetenschap rond de eeuwwisseling}

De École de l'exégèse ${ }^{421}$ krijgt aan het einde van de negentiende eeuw met kritiek te maken. Het zijn met name Geny en Saleilles die zich afzetten tegen de strikt aan de tekst en systeem van de wet vasthoudende interpretatiemethoden in de doctrine:

\footnotetext{
'Dominés et conme éblouis par les resultwats de la codification, les commentateurs français modernes onu accepté, au moins implicitement, à titre de postulat, cette idęe, "que la législation formelle, - j'entends dire l'ensemble des actes legislatifs promulgués, et encore en vigueur en France, - doit suffire à nous révéler toutes les règles juridiques, nécessaires au besoins de la vie sociale "en matière de droit privé', 422
}

Met wetgeving kan niet alles worden geregeld. Onduidelijkheden en onvoorziene kwesties moeten door de wetenschap worden verduidelijkt en ingevuld. De rechter moet met een vrije interpretatie in het concrete geval beslissen. Alleen op deze wijze kan zorggedragen worden voor een constante aanpassing van wetgeving aan de behoeften van de maatschappij. Die taak kan door de rechtswetenschap slechts worden vervuld wanneer zij zich vrijer van de wet opstelt. 'La libre recherche scientifique' zo noemt Geny deze vrije rechtsvinding in 1899 en hij propageert die vrije rechtsvinding met name voor de rechtswetenschap: de Franse rechtspraak heeft zich naar zijn mening al redelijk wrij ten

420. Molengraaff, W.L.P.A., Het verkeersecht in wetgeving en wetenschap (1885), p. 34-36; Molengraaff bundel (1978), p. 58-60. Zie voorts Molengraaff, W.L.P.A., De "oneerlijke concurrentie" voor thet forum van den Nederlandschen rechter, Rechtsgeleerd Magazjin 1887, met name p. 384 ev.; ook in: Molengroaff bandel (1978), p. $113 \mathrm{ev}$.

421. Zie hoofdsuk 5 \&; Ghestin, J., en Goubeaux, G., Trairé de droit civil, introduction générale (1990), ar $14.7 \mathrm{ev}, \mathrm{p}, 107 \mathrm{ev}$.

422. Geny. $\mathbb{F}_{\text {. }}$, Méthode d'interpretations et sources en droit privé positif, deel $1(1899,1954)$, nr. 12. 
opzichte van de wet betoond ${ }^{423}$. Wanneer een verandering noodzakelijk is, en de wetgever zorgt voor wetgeving, '(...) rien de mieux. Mais, vraiment, on ne peut se fier àlui, pour suffire à tout. Son intervention doit rester rélativement rare, en matière de droit privé.' Dat maakt de noodzaak duidelijk,

"à coté de la force proprentent législative, d"un organe plus souple, formam le droit en appliquant, tout au noins pour remédier aux insuffisances de la lo $(.$.

De rechtspraak heeft zich die rol al aangemeten: "Aussi bien, notre jurisprudence contemporaine n'a jamais absolument méconnue son rôle, ni son pouvoir en ce sens. Plus que jamais aujourd hui, elle se sent appellée (...) à compléter le droit existant, suivant les besoins sociaux (...). Ce faisant, non seulement elle n'exède pas son droit, mais elle satisfait simplement à sa mission. "Wat moet de rechtswetenschap met dit voorbeeld doen? Het volgende:

"Loin dono de décourager, par ces exigences surannées, cetze jurisprudence progressive, la doctrine ne peut mieux faige que l'appuyer, en cherchant à éclairer ses procédés, et à imprégner d'avantage d'un veritable esprit scientifique ceux qui les mettent en oevre."

Ook Saleilles spreekt zich uit voor een vrijere interpretatie. Zo onder meer in zijn voorwoord voor Geny's werk, waarbij duidelijk wordt dat de Franse vrije rechtsvinding schatplichtig is aan de Duitse rechtswetenschappelijke methoden:

\begin{abstract}
"Aussi je ne saurais mieux finir que par cette forte devise, inspirée d'un mot analogique d" Jhering. et autour de laquelle converge (...) tout le livre de M. Geny: Par le Code ciwill, mais audelà du Code ciwil"

Je serais de ceux peut-être qui en eussent volontiers retourne les termes: Au-delà du Code civil. mais par le Code civil! Je reconnais que ce serait manquer un peu de hardiesse et wouloir conserver une part de fiction. Aussi je n'insiste pas, trop heureux de me laisser convaincre,

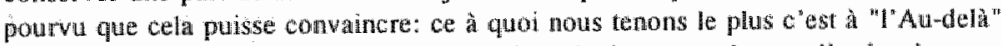

II sera difficile dếsormais que cet "Au-delà" ne devienne pas le mot d'ordle de tous les juristes. 42 . 4 年
\end{abstract}

In het gehele werk maakt Geny veel gebruik van Duitse (Jhering) en Oostenrijkse juristen (Menger). Ook in de Duitse rechtswetenschap was voor de eeuwwisseling een vergelijkbare discussie over de rechtsvinding gevoerd. Moest deze zich strikt baseren op de systematische juridische dogmatiek, of was de praktijk ook van belang?

423. Geny, F., deel 2 (1899, 1954), p. 229; Coing. H., (1989), p. 36-37. Zie Bouckatrt, B., De exegethsche school (1981), p. 48; Lokin, J.H.A., en W.J. Zwalve, (1992), p. 182. Zie ook Kelly, J.M. A Shon History of Western Legal Theory (1992), p. 362.

424. Geny, $\mathbb{F}_{\text {., }}(1899,1954)$ woorwoord, p. xxv. 


\section{De Duitse rechtswetenschap rond de eeuwwisseling}

In Duitsland is het niet een gebondenheid aan de wet die een 'vrije rechtsvinding' teweeg brengt, maar de systematische beoefening van het Romeinse recht: de 'Begriffsjuristische Pandektenwissenschaft.' ${ }^{425}$ De Pandektistiek na Savigny heeft zich, onder invloed van met name Puchta, ontwikkeld tot een wetenschap die zich met een abstractdogmatisch begrippensysteem bezig hiell. 'Puchta's abstrakt-begriffliches System hat die Dogmatik der Folgezeit am nachhaltigsten bestimmt. Es wies der Rechtswissenschaft aber auch ganz deutlich ihre Grenzen. Die steigende Vergeistung der Rechtsbegriffe hatte zur Folge, daß sich zwischen Rechtssystem und Lebenswirklichkeit eine tiefe Kluft auftat, " ${ }^{426}$ Tegen deze kloof stelt Jhering zich te weer. Tegenover de Begriffsjurisprudenz stelde Jhering de Interessenjurisprudenz: 'Der Grundgedanke des gegenwärtigen Werkes besteht darin, dass der Zweck der Schöpfer des gesammten Rechts ist, dass es keinen Rechtssatz gibt, der nicht einem Zweck, dli. einem praktischen Motiv, seinen Ursprung verdankt." ${ }^{27}$ Ook bij andere juristen is sprake van een vergelijkbare wending van de systematische dogmatiek naar een meer praktisch georiënteerde wetenschapsbeoefening. Zo pleit Gierke voor een socialer privaatrecht ${ }^{428}$ en Oostenrijkse juristen nemen het voortouw met hun socialistische kritiek op het privaatrecht ${ }^{429}$. Onder hen treffen wij Menger en Mataja, die ook in Nederland, bijvoorbeeld door Scholten (instemmend) en Eyssell (afwijzend), worden aangehaald. De maatschappij is voor deze juristen cen van de belangrijkste bronnen van het recht ${ }^{430}$. Deze wending in de Duitse rechtswetenschap naar de maatschappij wordt tot in een uiterste voortgezet door aanhangers van de Freirechtschule ${ }^{431}$. Uitgangspunt van deze beweging was dat 'die konkrete Fallenentscheidung des Richters in Wahrheit nicht auf logisch-verstandesmäßiger Ordnung, sondern auf dem Rechtsgefühl beruhe. Der Richter dürfe und müsse vom Gesetz abweichen, sobald es zu unrichtigen Ergebnisse führen würde." ${ }^{432}$

Behalve deze wending naar de maatschappij is er nog een ander aspect van de Duitse rechtswetenschap dat de aandacht in Nederland trekt: de totstandkoming van het BGB. De Duitse codificatie wan het privaatrecht komt in 1896 tot stand en verkrijgt op 1 januari $1900 \mathrm{kracht}$ van wet. Het is bepaald niet de eerste algemene Duitse codificatie. Het handelsrecht is het BGB in 1870 als codificatie voorgegaan, op enkele deelgebieden

425. Zie hoofilstuk 5 \& 1.D.1; Schlosser.H., (1985), p. 105.

426. Schlosser, H., (1985), p. 106.

427. Von Jhering, R., als geciteend in Lokin, J.H.A., en W.J. Zwalve, (1992), p. 232.

428. Zie Wieacker, F., (1967), p. 453; Gierke, O., (1889), als aangehald door Kop, P.C., (1992), p. 46; Van Diewoet, E., (1943) p. 67; Kobler, G., Deutsche Rechssgeschichte (1996), p. 183.

429. Wieacker, $\mathrm{F}_{\ldots},(1967)$, p. 457.

430. Zie Schlosser, H. (1985), p. 116 ev.; Coing, H., (1989), p. 52.53; Wieacker, F., (1967), p. 449.

431. Kantorowicz. H., Ars der Vorgeschichte der Freirechrslehre (1925), p. 39; Ehrlich, E., Freie Rechtsfind wh whd freie Rechtswissenschaft $(1906,1987)$, passim. De stroming is door de toepassing wan vrije interpretatie van de wetgeving ten tijde van het nationaal-socialisme in Duitsland volstrekt verdwenen. Köbler, G., (1996), p. 189. Zie ook: Muscheler, K., Relativismus wad Freirecht (1984), p. 85 ev. 
waren reeds codificaties tot stand gebrach,, en (ontwerpen voor) privaatrechtelijke codificaties hadden in enkele delen van het Duitse gebied eerder het licht gezien. Aan het begin van de negentiende eeuw was in de rechtswetenschap door Von Savigny nog krachtig en met succes gepleit tegen een privaatrechtelijke codificatie. Met de totstandkoming van een eenheid in het handelsrecht, en met andere privaatrechtelijke codifica ties die op het Duitse grondgebied gelding hadden, is voor een algemene privaatrechtelijke codificatie de weg deels geëffend ${ }^{433}$. Tegenover deze codificatie als zodanig staan aanhangers van een vrije rechtsvinding niet negatief. Juist de strikt technische, op tekst en systeem gebaseerde uitleg staat hen tegen. Ehrlich:

'Die Kodification des geltenden Rechtes ist, wenn das Juristenrecht einen gewissen Umfang erreicht hat, nicht zu vermeiden und düfte neben niclat wegzuleugnenden Nachteilen überwiegend günstige Folgen haben. "Der Gegensatz der freien Rechtsfindung und der technischen liegt daher nicht darin, dass die erste über das Gesetz hinaus ggehen würde, er liegt eher in dem Wege, der eingeschlagen wird. 434

Kantorowicz omschrijft de stroming juist als een strijd met het 'Werkzeugdogma”; '..es genügt also nich die "Auslegung"; vielmehr bedarf es eines eigenen Verfahrens, der ihrer selber voll bewußten und ehrlich als solcher auftretenden "freien Rechtsfindung " 435 . Als gunstige gevolgen van een codificatie noemt Ehrlich ordening in 'den Wust des Juristenrechts' en eenvormigheid van het recht. Als nadeel noemt hij de barrière van nationale juridische grenzen voor een internationale 'Wechselwirkung der wissenschaftlichen Arbeit', een barrière die hij overigens op termijn geslecht ziet door rechtsvergelijking.

\section{E. ANDERE RECHTSSTELSELS EN KENNISNAME DAARVAN IN NEDERLAND}

De verwijzingen in Themis geven het volgende beeld. Naar Nederlandse bronnen wordt verwezen in $69 \%$ van de gevallen, naar Franse bronnen in $16 \%$, naar Duits rech in $7 \%$, Romeins recht in $6 \%$ en naar Belgische bronnen maar in $1 \%$ van de gevallen. De inhoudsopgaven van Themis en het Rechtsgeleerd Magazijn bieden het volgende beeld: alle 20 artikelen uit twee jaargangen (1904 en 1905) Themis zijn gericht op bet Nederlandse recht. Van de eveneens twintig besprekingen en aankondigingen hadden een tweetal betrekking op Duits recht. Het Rechtsgeleerd Magazijn plaatst in dezelfde jaren 18 artikelen, waarvan een zevental betrekking heeft op een ander stelsel. Van de 79 aangekondigde of besproken boeken hebben er 11 betrekking op een ander rechtsstelsel: op het Duitse recht 7 , het Franse recht 2, het Engelse en het Italiaanse elk 1.

433. Schlosser, H., (1985), p. $120 \mathrm{ev.}$

434. Ehrtich, E., (1906), p. 18 .

435. Kantorowicz, H., (1925), p, 6. 


\section{Rechtsvergelijking als rechtsvinding}

De in $\$ 1 . C .1$ geschetste ontwikkelingen in de maatschappij, de economische recessie en de toename van het (handels)verkeer, zijn Europese ontwikkelingen ${ }^{436}$. Door verschillende Nederlandse civilisten wordt gewezen op de noodzaak van kennisname van andere rechtsstelsels bij de uitleg van het Nederlandse recht. Zo is rechtsvergelijking voor Molengraaff vanwege het internationale verkeer een 'onmisbaren factor' bij de uitleg. Hij is niet de enige die pleit voor rechtsvergelijking als methode van beoefening van het Nederlandse privaatrecht. Anderen doen dat evenzeer, om uiteenlopende redenen. Op een meer algemeen rechtswetenschappelijk niveau spreekt Drucker zich uit voor een herwaardering van het Romeinse recht als lingua franca voor een Europese rechtswetenschap. 'De gemeenschap der Latijnse taal is lang verbroken; de tijd, toen men onze werken allerwege citeerde, is voorbij. De wiskundige formule, het natuurkundig onderzoek, vinden hun weg door alle landen; verschil van taal en wetgeving beperkt den gezichtseinder van den jurist.' Rechtseenheid is volgens hem een lofwaardig streven, maar weimig realistisch:

\footnotetext{
'Men verlangt internationale rechtseenheid, internationale rechtsbeoefening. Lof waardig streven voorwaar! Maar onvruchtbar tevens trots alle congressen en gloeiende redevoeringen, zoolang men essentieel verschillende methoden volgr; zoolang de Engelschman zich alleen bezighoudt met concrete beslissingen, zonder te vragen naar de beginselen die daaraan ten grondslag liggen: zoolang de Franschman geene andere rechtswetenschap kent dan uitlegging zijner wetboeken, vaak tegen de gesclureven letter in, volgens de rede en de billijkheid; zoolang eindelijk de Duitscher zich verdiept in bespiegelingen, waarwan het practisch nut hem zelf walk niet duidelijk is."
}

Die internationale rechtsorde kan dichterbij worden gebracht door gebruik te maken van het Romeinse recht, "de gelukkige samensmelting van theorie en practijk" ${ }^{437}$. De Savornin Lohman maakt gebruik van het Duitse recht (het BGB) om een zeer praktische reden: 'Ik meende intusschen mij daarbij niet altijd te kunnen beperken tot onze Nederlandsche auteurs, maar met name gebruik te moeten maken van het met den aanvang dezer eeuw ingevoerde Duitsche burgerlijk wetboek en van een enkele zijner commentatoren, daar waar ik meende dat zulks kon bevorderlijk zijn tot klaarder inzicht in onze eigen wetgeving; ${ }^{\circ} 38$ Wetsvergelijking was een vorm van rechtsvergelijking die al eerder werd gepropageerd, als onderdeel van de bepaling hoe het wenselijke recht zou moeten luiden ${ }^{439}$. Nu wordt steeds meer expliciet gewezen op de noodzaak van rechtsvergelijking bij de uitleg van Nederlandse bepalingen.

436. Zie Wieacker, F., (1967), p. 453 ev; Coing, H., (1989), p. 2-3.

437. Drucker, H. L.. (1882), p. 546-547.

438. De Savornin Lohman, W.H. Verklaring van her burgerlijk wetboek door Mr. N.K.F. Land. deel 4, (2e druk, 1907), p. vii-viii.

439. Zie hoofdstuk 5 \& $2 . C .3$. 


\section{Rechtsvergelijking als afzonderlijke discipline}

Overzichten van de geschiedenis van de rechtsvergelijking schetsen een beeld waarin rechtsvergelijking eerst wordt gekenmerkt door incidentele en afzonderlijke beoefening. Gewezen wordt in de eerste plaats op het ontstaan van de nationale codificatie, vervolgens worden enkele afzonderlijke rechtsvergelijkende activiteiten genoemd. Zo bijvoorbeeld Coing, die aanhaalt hoe de "législation comparée", de wetsvergelijking in Frankrijk als afzonderlijke discipline ontstond naar aanleiding van de nationale codificaties. Daarbij wijst hij op een aantal tijdschriften die in verschillende landen worden opgericht met wetswergelijking als onderwerp. In bijzondere rechtsgebieden zoals het handelsrecht is wel aandacht voor andere rechtsstelsels, maar over de vraag hoe het nu in de privaatrechtelijke literatuur is gesteld met rechtsvergelijking is hij kort. Hij noemt enig werk van Saleilles over het BGB en voorts enkele verzamelingen van wetgevingen uit verschillende landen. Ook anderen schetsen een dergelijk beeld ${ }^{440}$. Tevens in opkomst is de beoefening van het internationaal privaatrecht, en in dat verband wordt ook rechtsvergelijking gepropageerd, en zelfs unificatie van materieel privaatrecht. Dat laatste wordt wegens de politieke onhaalbaarheid terzijde gesteld. In Nederland zijn het Asser (T.M.C.) en Josephus Jitta, en in mindere mate Hamaker die de wetenschap van het internationaal privaatrecht in Nederland laten aanvangen ${ }^{44}$. Een beschrijving wan rechtsvergelijking als een afzonderlijke discipline, of als een incidentele, uitwendige belangstelling voor andere rechtsstelsels, doet te kort aan de werkelijkheid. Onderdeel van de vrije rechtsvinding is de toepassing van rechtsvergelijking als rechtsvindingsmethode binnen het privaatrecht. De aanloop naar een inhoudelijk gebruik is ook al in de legistische periode waarneembaar.

\section{§ 2. Aansprakelijkheid voor zaken: de ruime uitleg als een 'eisch des tijds"}

\section{A. AANVANG VAN EEN RUMME UTLEG IN HET LEGISME}

Opzoomer geeft artikel 1403 in de periode van het legisme een goed onderbouwde ruime uitleg ${ }^{442}$. Naast de ruime uitleg van Opzoomer is er de nauwelijks gemotiveerde ruime uitleg van de Hoge Raad uit 1859. Op cleze standpunten wordt voortgebouwd. Een eerste voortzetting is te vinden in de discussie die in de Nederlandse Juristen-Vereniging wordt gevoerd over de aansprakelijkheid van spoorwegondernemingen in $1874^{443}$.

440. Coing, H., (1989), p. 56 ev: Sauveplarme, J.G., Van buitenlands recht tot rechtsvergelijking, ün: Kokkini-latridou, D., e.a. (1988), p. 45-48. Sauveplanne, J.G., Rechtsstetsels in vogelwheht (1981), p. 22.

441. Zie daarover Steenhoff, G.J.W., (1994), p. 53 ev.

442. Opzoomer, C.W., deel 6 (1879), p. 326.

443. Zie hoofdstuk $5,2, \mathrm{C} .3$. 


\section{B. DE DISCUSSIE IN DE NEDERLANDSE JURISTEN-VERENIGING}

De Nederlandse Juristen-Vereniging spreekt over preadviezen van Bolhuis en Pijnappel met betrekking tot de vraag: "Hoe behoort de aansprakelijkheid der spoorwegondernemingen bij het vervoer van goederen en personen, in verband met het Nederlandsche burgerlijk- en handelsrecht te worden geregeld?' ${ }^{444}$ Bij de totstandkoming van de Nederlandse spoorwegwet wordt de mogelijkheid van een ruime uitleg van artikel 1403 lid 1 weliswaar betrokken, maar niet overgenomen. Artikel 1 van de Spoorwegwet van 1859 (1875) vestigt een aansprakelijkheid met omkering van de bewijslast van schuld, maar het artikel wordt eng uitgelegd ${ }^{445}$. Aansprakelijkheid ontstaat alleen voor schade geleden door vervoerde personen of aan vervoerde goederen ${ }^{446}$. Vanwege het internationale karakter van spoorwegvervoer prefereert Pijnappel een internationale regeling. Hij vreest echter:

'dat de tijd daarvoor nog niet rijp is. De wreesselijke oorlog, woor korte jaren in Europa gewoerd, en de wrok als gevolg daarvan achtergebleven, zijn er niet gunstig voor. Duitsland schijnt bowendien meer geneigd anderen in zich op te nemen dan met anderen in gemeen overleg te treden." 4 it

Pijnappel propageert rechtsvergelijking bij de vaststelling van wenselijk recht. Al die buitenlandse wetten leveren 'voor het ius constituendum niet onbelangrijke bijdragen, en zoo het nog lang eene onmogelijkheid zal blijven een Europeesch regt te verkrijgen, zal het toch altijd zaak zijn, om bij de herziening van eigen regt op dat van naburige staten het oog te houden." 448 Er is echter geen reden om voor spoorwegondernemingen een van artikel $1401 \mathrm{ew}$. afwijkende regeling te vervaardigen. De meeste deelnemers (onder wie Philips) aan de vergadering ondersteunen dit standpunt ${ }^{449}$. Zo niet Levy:

'Een conducteur bij de Rijnspoorwegmaatschappij, eene maatschappij die niet gewoon is de kaartjes onder het rijden te doen ophalen, kreeg bevel een enkelen keer die kaartjes onder het rijden op te halen en ten gevolge daarvan verongelukte hij. Ik stelde de gewone actie tot schadeloosstelling in en in twee instanties ben ik met die actie afgewezen, omdat ik niet kon bewijzen

444. Handelingen $(1874)$, p. $178 \mathrm{ev}$.

445. Art. 1. De ondernemers eener spoorwegdiensk zijn verantwoordelijk voor de schade, door personen of goederen bij de uitoefening der dienst geleden, ten ware de schade buiten hunne schuld of die hunner beambten of bedienden zij ontstaan.

446. Zo bijvoortbeeld in HR 3 april 1890 (Weekblad van het Recht. 5856); Handelingen (1874), p. 183; zie voor de Spoorwegwet 1859; Staatsblad 98, 1859; de Spoonwegwet 1875 in: Srb 67, 1875. Bruins vermeld in 1906 dat een constante jurisprudentie van de Hoge Raad uitgaat van deze beperking tot vervoedde personen en goederen. Bruins, G.W.J., Een onderzoek naar den rechtsgrond der schadevergoeding (1906), p. 89; Van Maanen, G.E. (1985), p. 416; Valkhoff, J., De invloed wan de spoorwegen op enkele gebieden wan het Nederlandse priwatrecht, Rechtsgeleerd Magazijn Themis 1939, p. 414 ev.

447. Handelingen (1874), p. 182 .

448. Handelingen (1874), p. 182 .

449. Handelingen (3ie zitting) (1874), p. 156. 
schuld an de zijde der magtschappij. Dat is recht in Nederland en het werd verkregen na tegenspraak mijner wordering door mijn hooggeachten Amsterdamschen anbigenoor Mr. Phi. lips. 490

Nederland zou een woorbeeld moeten nemen aan wetgeving in Duitsland, volgens Levy * waar omkering van bewijslast de benadeelde tegemoetkomt. Daar is de spoorwegonderneming aansprakelijk, tenzij sprake is van overmacht of eigen schuld van de benadeelde. De betreffende paragraaf luidt als volgt:

\begin{abstract}
\$1. Wenn bei dem Betriebe einer Eisenbahn ein Mensch getötet oder körperlich verlezt wird, so haftet der Berriebs-Unternehmer für den dadurch zntstandenen Schaden, sofem er wicht beweist, dass der Unfall durch böhere Gewalt oder durch eigenes Verschulden des Gerödteden oder Verletzten verursacht ist. ${ }^{451}$
\end{abstract}

Deze wet verving een oudere wet uit 1838 , waarin eveneens als in de Nederlandse spoorwegwet uitgegaan werd van een beperking tot vervoerde personen en goederen. Met 27 tegen 14 stemmen stemt de NJV tegen een van de algemene artikelen afwijkende regeling. Wetssystematiek en eenheid van recht zijn de belangrijkste redenen ${ }^{452}$. Tot nog toe gingen er stemmen op voor een aanpassing van de wetgeving. De mogelijkheid om in de rechtspraak gebruik te maken van een ruime uitleg van artikel 1403 lid I BW wordt nog niet bepleit. Dat zou kort nadien wel gebeuren.

\title{
C. DE VOORTZETTING VAN DE RUIME UITLEG DOOR EEN VRIJE RECHTSVINDING
}

\section{De spoorwegen}

Tichelaar brengt een ruime titleg van de bestaande wetgeving ter sprake. Hij stelt voor om de Spoorwegwet uit te leggen overeenkomstig de wijze waarop in Duitsland, Oostenrijk, Hongarije en Rusland de aansprakelijkheid van spoorwegondernemingen geregeld is:

"Niet uit zucht tot nawolging wan wreemde wetgevinger, maar op grond van een billijke vendesling van den bewijslast, zoodat in too veel mogelijk gevallen de rechter in staat zij de watheid to ontdekken, ancht ik het wenselijk, dat ook onze wer dit vermoeden bevat, en nu des woorden der wet het uitdrukkelijk zeggen, meen ik het voor eene onjuiste wijze van interpretatie to moeten houden, op grond van uitspraken van eenige kamerleden bij de behandeling der wet tot eene andere conclusie te geraken. ${ }^{453}$

450. Handelinger (3e zituing) (1874), p. 196-197.

451. Wet van 7 juni 1871 , Reichsgesetzblatt 1871 (14 juni), nr. 25.

452. Handelingen (3e zitting) (1874) p. 219. Voor stemden onder anderen Levy en, opvallend, Diephuis. In 1913 zal de vergadering wan de NIV over een vergetijkbaar onderwerp heel anders besluiten: zit hoofdstuk 7 \& $2 . \mathrm{C} .1$.

453. Tichelaar, P.A., Artikel 1 der wet van 9 april 1875 (S.67), tot tegeling van de dienst en her gebruik der spoorwegen, Rechisgeleerd Magazïn 1891, p. 32. 
Ook door middel van artikel 1403 lid 1 zou de aansprakelijkheid van spoorwegondernemingen op een wenselijke manier geregeld kunnen worden. Een voorbeeld van de ruime uitleg van $\llbracket 403$ is een uitspraak van de Rechtbank Amsterdam uit 1883: 'Men [is] aansprakelijk woor alle schade, veroorzaakt door zaken, welke men onder zijn opzicht

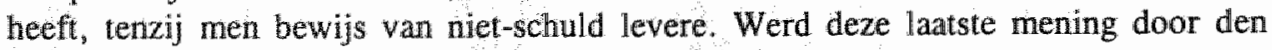
H.R. gedeeld, de spoorwegondernemingen zouden voor schade, veroorzaakt door hare locomotieven enz., toch aansprakelijk zijn, tenzij zij hare onschuld bewezen." ${ }^{534} \mathrm{De}$ uitleg wan wetsbepalingen kan een wenselijk recht tot stand brengen zonder tussenkomst van de wetgever.

\section{Een ruime uitleg door een andere grondslag van aansprakelijkheid}

Ook Scholten interpreteert artikel 1403 op ruime wijze. Hij breekt in zijn proefschrift een lans voor een andere grondslag van aansprakelijkheid ${ }^{45}$. De grondslag van aansprakelijkheid wordt volgens Scholten ten onrechte in schuld gezien. Waarom? In veel gevallen, constateert Scholten, is sprake van een verplichting om schadevergoeding te betalen, maar is schuld niet vereist. Jhering's uitgangspunt 'nicht der Schaden verpflichtet zum Ersatz, sondern die Schuld' heeft afgedaan ${ }^{456}$. Duitse en Oostenrijkse theorieën op economische grondslag (Mataja en Steinbach) bieden meer houvast. De schade moet door diegene gedragen worden waarmee 'het maatschappelijk belang' het beste is gediend. Dat is diegene die het voordeel van de schadeveroorzakende handeling heeft gehad ${ }^{457}$. Artikel 1403 lid 1 noemt Scholten als voorbeeld van aansprakelijkheid buiten schuld. De maatschappelijke wenselijkheid is Scholtens belangrijkste argument voor ruime interpretatie ${ }^{458}$. Daarnaast gebruikt Scholten grammaticale, systematische, historische en rechtsvergelijkende wijze van uitleg. In navolging van Opzoomer meent hij de aansprakelijkheid voor zaken uit het eerste lid van 1403, net als in het Franse recht waaraan de bepaling is ontleend, een zelfstandige betekenis heeft ${ }^{459}$. Door 'opzigt' wordt geen schuld geïmpliceerd ${ }^{460}$. Ook aan de wetshistorie, met name aan de geschiedenis van de overeenkomstige Franse artikelen ontleent Scholten argumenten voor een rume uitleg van artikel 1403 lid $1^{\text {t5t. }}$. Dat kon hij in 1899 ook goed doen. Sinds 1896

454. Tichelaar, P.A., (1891), p. 34 .

455. Zie 3.1. Scholten, P. Schadevergoeding buiten overeenkomsin onrechmatige daad (1899), p. 5. Zie over het belang van Scholtens proefschrift: Van Oven, J C., Nederlandss Juristenblad 1926, p. 109.

456. Scholten, P., (1899), p. 7.

457. Scholten, P., (1899), p. 22. Wie de voordelen dragt, moet ook de nadelen woor zijn rekening nemen, zo verwoordt Heijmans deze grondslag in de NJV in 1913. Steinbach wordt door Kantorowicz genoemd als een wan de juristen die als eerste eem vrije rechtsvinding in Duitsland en Oostenrijk woorstonden. Kantorowicz. H., (1925), p. 4.

458. Scholten, P., (1899), p. 20.

459. Scholten, P., (1899), p. 49. Zie ook hootdstuk 5 \& $2 . C .2$.

460. Scholtea, P., (1899), p. 50. Toullier en Diephuis stelden schuld wel als vereiste voor aansprakelijkheid, zie hoofdstuk 3 \& 4.A en hoofdsouk 5 \& 2.C.1.

461. Scholten, P., (1899), p. 52. 
hing het Franse Cour de Cassation een ruime opvatting aan van artikel $1384 \mathrm{Cc}^{462}$. Naar die uitspraak verwijst hij. Bovendien verwijst hij naar Toullier, Marcadé, Saleilles en Laurent ${ }^{467}$.

Ook Bruins verwijderd zich van "schuld" als dogmatisch uitgangspunt. De matschappelijke wenselijkheid is ook voor hem de reden een ruime uitleg voor te staan. Dat doet hij na vergelijking met het Franse recht. Tevens vermeldt Bruins Engelse en Amerikaanse rechtspraak, waarin bewijs van schuld werd vereenvoudigd door deze in de feiten beslloten te achten: "res ipsa loquitur." 464 De Nederlandse regeling is "geheel en al onvoldoende'. Daar 'zullen wij moeten komen tot eene zoo ruim mogelijke aansprakelijkheid voor alle zaken zonder uitzondering.' Dat zou, zo stelt Bruins voor, bewerkstelligd kunnen worden door een ruime uitleg van artikel 1403 lid 1 BW (een 'eisch des tijds'), in het voetspoor van de uitleg van artikel $1384 \mathrm{Cc}$ door de Franse rechtsprak ${ }^{465}$.

\section{De ruime Franse uitleg}

De ruime opvatting over $1384 \mathrm{Cc}$ wordt aangehangen door Toullier, Marcadé, Laurent en Saleilles, zo vermeldt Scholten. De vermelding van de eerste twee auteurs als voorstander van een ruime uitleg is twijfelachtig. De Franse auteurs interpreteren in het algemeen de bepaling ruimer. Bij Toullier was nog sprake van een schuldvereiste dat besloten lag in het opzicht. In de uitleg van Marcade is sprake van een schuldvermoeden, maar alleen van de expliciet genoemde zaken ${ }^{466}$. Bij Laurent is sprake van een vermoeden van schuld bij zaken in het algemeen:

'Il faut entendre dans le même sens l'article 1384: sil l'on est responsable des choses que l'on a sous sa garde, c'est parce qu'on commet une négligence ou une imprudence dáns la garde de la chose. Il n'y a pas de responsabilité sans faute. Reste à savoir sil celui qui a une chose sous sa garde est présumé en faufe. La loi tranclre la difficulté quand il sagit d"un bâtiment, puisqu'elle détemine les cas dans lesquells le propriétaire est responsable du donmage cause par sa ruine: c'est au demandeur a prouwer que la ruine est arrivée par le défaut d"entretien, ou par le vice de construction, sauf au défendeur à faire la preuve contraire.

Que faut-ill décider s'il s'agit d'une autre chose, par exemple, d'une noachine? Ce cas ne rentre pas dans le texte de J'article 1386 , qui ne parle que des bâtiments. Il faut donc appliquer la règle gênérate de l'article 1384 . Or cette disposition établit une présomption de faute à charge

462. Mazeaud, H., et Mazeaud, L., Traité théonique ê pratique de la responsabilité civilte, deel 2 (2e druk. 1934), nr. 1140-1141, Esmein, P. in: Planiol, M., et Ripent. G., Traite pratique de droit civil Franfais, deel 6 (2e druk, 1952), nr. 612; Planiol, M., Trainé étementaire de droil civil deel 2 (1921), nur. 931.

463. Scholten, P., (1899), p. 52.

464. Bruins, G.W.J., Een onderzoek naar den rechsgrond der schadewergoeding (1906), p. 89.

465. Bruins, G.W.J., (1906), p. 86 en p. 181. Anders dan Scholten, die de grondslag meer in economische verhoudingen legt, ziet Brains de grondslag in 'risicoverhoging', zie Bruirxs, G. W.J. (1906), p. 176.

466. Zie hoofdstuk 3 \& 3 . A en hoofdstuk $5 \& 2 . B$. 
de celui qui est déclaré responsable. De là suit que le propriétaire de la machine est présumét en faute, sauf a lui de fiaite la preuve contraire." ${ }^{467}$

Laurent verwoordt expliciet een schuldvermoeden voor schade door zaken veroorzaakt. De in artikel $1384 \mathrm{Cc}$ neergelegde allgemene regel vindt zijn grondslag in schuld: "(.) si nous sommes responsables, c'est que nous commettons une négligence ou une imprudence dans la garde de la chose. C'est l'application du principe qu'il n'y a pas de responsabilité sans faute." Maar waarom kan, een stap verder, een vermoeden van schuld worden aangenomen? Laurent vergelijkt met de aansprakelijkheid voor schade die door de instorting van gebouwen is teweeggebracht. In een dergelijk geval (art. 1386 $\mathrm{Cc}, 1405 \mathrm{BW}$ ) zal door de benadeelde aangetoond moeten worden 'vice de construction' of 'défaute d'entretien". Welnu, deze in bijzonder woor gebouwen geschreven regel mag niet gebruikt worden voor de uitleg van artikel $1384 \mathrm{Cc}$, de aansprakelijkheid voor schade veroorzaakt door andere zaken. Schade veroorzaakt door andere zaken zal. nauwelijks ergens anders uit voortgekomen kunnen zijn dan uit een gebrek aan de zaak zelf, of een nalatigheid in de bediening: 'donc le législateur a pu présumer la faute.' Toch verwijdert Laurent zich enigszins van schuld als grondslag. Een gebrek in de zaak zou namelijk kunnen voortvloeien uit een te weinig gevorderde stand van wetenschap of techniek. Dat zal niet aan de eigenaar van de zaak te verwijten zijn. En ook dan concludeert Laurent tot een aansprakelijkheid, echter om redenen van billijkheid: ' $($. .) mais alors il y a une considération d'équité: n'est-il pas juste que le propriétaire de la machine supporte le dommage plutôt que celui qui en est la victime?' ${ }^{468}$ Laurent wordt gezien als de eerste die een ruimere uitleg van het artikel $1384 \mathrm{Cc}$ voorstond ${ }^{469}$. In 1896 volgt het Franse Cour de cassation.

De aan die uitspraak ten grondslag liggende casus handelt over de stoomsleepboot Marie, eigendom van de heren Guissez. Op de Loire, onder de rook van Chantenay ontploft de stoommachine wan de Marie, de mecanicien Teffaine wordt zodanig verwond, dat deze nog dezelfde avond overlijdt. Zijn weduwe vordert van Guissez schadevergoeding. Nadat haar vordering in eerste instantie is afgewezen, in hoger beroep toegewezen, belandt de zaak voor het Cour de cassation (16 juni 1896) dat owerweegt:

\footnotetext{
'Altendu que l'arrêt attakgué constate souverainement que l'explosion de la machine du remorqueur à vapeur Marie, qui à causê la mont de Teffaine, est due à un vice de construction; qu'aux termes de l'art. $1384 \mathrm{c}$. civ., cette constatation, qui exclut le cas fortuit et la force majeure, établit, vis-ă-vis de la victime de l'accident, la responsabilité du propriétaire du remorqueur sans quil puisse s"y soustraire en prouvant soit la faute du constructeur de la machine, soit le charactère occulte du vice incriminé:? 470
}

467. Laurent, F., Cours élểmentraive de droit civil, deel 3 (1878), p. 221-222; dezelfde, Principes de droit civil, deel 20 (1878), nr. 639

468. Latirent, F., deel 20 (1887), nr. 639.

469. Zie Mazeaud. H., et L. Mazeaud, deel 2 (1934), nr. 1140.1141.

470. Dalloz 1897, 1, 433. 
Saleilles annoteert het arrest en concludeerde tot een "responsabilité purement objective" een toepassing van "la théorie du risque professionnel": "(..) même que le vice de construction n'eut pas été prouvé, si la machine eût fait explosion, sans qu'on pût en attribuer la cause à l'une de ces forces étrangères irrésistibles contre lesquelles les prévisions humaines sont impuissantes, la responsabilité du propriétaire n'en aurait pas moins été engagé, parce que, d'après l'art. 1384, il s"agirait d'une responsabilité provenant de la garde des choses ou de la direction d'une entreprise et que cela suffit à faire supporter les risques.' Ook Saleilles verwijst naar Laurent.

In latere Franse commentaren wordt deze ruime uitleg als de heersende uitleg geschetst. Zo bij Demogue: artikel 1384 vestigt 'au regard de du gardien de la chose, une présomption de faute qui ne peut être détruite que si celui-ci fait la preuve que l'accident a eu pour cause un cas fortuit ou de force majeure ou la faute de la victime (..) Enfin elle est accepté par la doctrine la plus récente." ${ }^{471}$ Waarom is dit volgens Demogue de heersende leer geworden? Dat komt doordat in plaats van de geschiedenis, tekst en systeem van de wet, thans 'les considérations sociales' de doorslag geven bij de uit$\operatorname{leg}{ }^{472}$.

\section{De automobiel}

De opkomst van de auto zorgt voor een hernieuwde belangstelling, eerst voor een regeling van de aansprakelijkheid voor ongevallen met auto's, later voor een ruime uitleg van artikel 1403 lid $1 \mathrm{BW}$. In hoofdzaak geschiedt die opleving onder invloed van de Franse uitleg van artikel $1384 \mathrm{Cc}$. Dat artikel wordt juist voor de door auto's teweeggebrachte schade gebruikt, en daarvan wordt in Nederlandse tijdschriften, met name in het Weekblad van het recht uitgebreid verslag gedaan. Die belangstelling wordt ook met name daardoor ingegeven dat de wetgever in de ogen van juristen achter was gebleven met de vervaardiging van een goede wetgeving: 'wie zich op den wetgever verlaat, bouwt op een zandgrond", zo had Van Oven Star-Busman geciteerd, die zich reeds in 1908 had uitgesproken woor een regeling ${ }^{473}$.

De omkering van de bewijslast van het Cour de Cassation uit 1896 kon de gelaedeerde vooralsnog niet veel heipen, omdat een ander onderscheid werd aangebracht in de toepassing van het Franse artikel 1384. Indien de zaak schade toebrengt als gevolg van cen handeling van de gebruiker wan de zaak, dan komt niet artikel 1384 voor toepassing in aanmerking, maar moet artikel $1382 \mathrm{Cc}$ toegepast worden. Deze weergave van het Franse recht wordt door Star Busman gegeven omdat ook de Franse wetgever sinds

41. Demogue, R., Traité des obligations en gënéral, deel 5 (1925), nr. 1119, p. 362 .

472. Demogue, R., (1925), p. 1121.

473. Van Oven, J.C., Aansprakelijkheid bij auto-ongelukken (art.25 Motor- en Rijwielwet), Nederiands Juristenblad 12 maart 1932, nr 11. Zie ook Star Busmann, C. W. De aansprakel ijkheid der automabiel in het verkeersrecht, Rechtsgeleerd magazijn 1908. 
$1906 \mathrm{er}$ niet in is geslaagd om een wet tot stand te brengen over de aansprakelijkheid van de automobilist:

\begin{abstract}
'En wal moge de wetgever indertijd slechts met een meer beperkte toepasselijkheid van het artikel rekening hebben gehouden, dai betekent niet, zooals Ballot-Beaupré zeide in zijn rede bij het eeuwfeest van den Code, dat het den rechters geoorloofd is, "lorsqu'ils ont à appliquer les règles de ce Code a des situations qu'elles n'ont pu préwoir, de les assouplir de façon à les adapter aux besoins nouveaux d'un état social transformé, tout en les respectant dams leur texte et dans lleur esprit." 474
\end{abstract}

Variaf 1924 wordt een ruime uitleg in Frankrijk aangehangen: 'Mocht deze nieuwe leer door een volgend arrest worden bevestigd, dan zal het schadevergoedingsrecht bij automobielongevallen in Frankrijk zonder eene wetswijziging als te onzent is ondernomen practisch van het onze niet veel verschillen: volgens het nieuwe artikel 25 bis de Motor- en Rijwielwet is de eigenaar van het motorrijtuig aansprakelijk, tenzij de schade is te wijten aan overmacht." ${ }^{475}$ Deze bevestiging wordt in 1927 door het Cour de Cassation gegeven, en van dit arrest wordt verslag gedaan onder het kopje: 'Een evolutie in de leer der aansprakelijkheid". Alle gevaarlijke zaken behoren onder opzicht te staan, en indien bij gebruik van zo een zaak schade wordt veroorzaakt, dan is artikel $1384 \mathrm{Cc}$ van toepassing, en behoeft schuld niet te worden aangetoond. Voor het afwenden van de aansprakelijkheid moet overmacht worden aangetoond ${ }^{476}$. Lagere Franse rechtspraak geeft soms een beperkte uitleg ${ }^{47}$. De ruime Franse uitleg van artikel $1384 \mathrm{Cc}$ wordt als voorbeeld voor 1403 gepropageerd door de advocaten Janssens en Pit. Beide verwijzen naar het Franse recht in verband met de wetsgeschiedenis en naar eigentijds Frans recht, onder meer naar Demogue en Capitant ${ }^{478}$. Demogue: 'L'art. 1384 (nouvelle interprétation) est déjà une limitation très sérieuse à la nécessité d'une faute prouvée.'

474. Star Busmann, C. W. Weekblad van het Rech 10864 (1922). Zie ook dezelide in Vragen des Tids 1922 deel 2, p. 170. Zie ook: Weekblad van het Rech 10903 (1922), p. 4. waarin een reactie op Star Busnann en enige lagere Franse rechtspraak met een beperkte uitleg van 1384.

475. Weekblad wan her Rech 11270 (1924), p. 4. Zie wok Asser-Hartkamp III (1994), nr. 161.

476. Weekblad von her Recht 1 1768, p. 7. Zie ook Nederlands Juristenblad 1929, p. 233, "Opmerkingen en mededeelingen." Enkele andere wermeldingen van Franse rechtspraak: Aansprakelijkheid voor au tomobiel-ongelukken. Weekblad wat het Rech 11728 , p. 4; Nog eens de aansprakelijkheid woor autorongelukken, Weekblad van her Rech 11974 (1929); Weekblad van her Rech 12196 (1930), p. 4, waar Franse literatuur over deze jurisprudentie wondt besproken; Weekblad van het Rectr 12758 (1934): enige Franse jurisprudentie wordt woorts besproken in het Nederlands Jursitenblad 1931, p. 485.

477. Zoals het Cour d"Appel d'Angers uit 1926, met een fundamentele motivering van een enge uitleg van artikel $1384 \mathrm{Cc}$ : '(.) c'est uniquement au législateur qu'il appartient de suppléer à l'insuffisance des textes existants et d'édicter une păreille disposition dérogatoire au droit commun.' 20 aprill 1926 , Dalloz 1926, 386, als geciteerd bij Janssens, L., De burgerrechtelijke aansprakelijkheid bij autoongelukken, Rechtsgeleerd Magazim 1929, p. 265.

478. Janssens, L.. (1929), p. 285. Demogue, deel 5(1925) nr. 1136. Pit, S.J., De aansprakelijkheid voor zaken, toegebracht door ondergeschikien, kinderen, dieren en door zaken, die men onder zijn opzicht heeft, Rechsseleerd Magazijm Thernis 1931, p. 66-68; 


\section{DE HEERSENDE MENING EN DE RECHTSPRAAK}

\section{De heersende mening in handboeken..}

In tegenstelling tot de stemmen die in de rechtswetenschap opgaan voor een ruime uitleg van artikel 1403 lid 1 (of van artikel 1 Spoorwegwet), wordt in rechtspraak en handboeken meestal, in navolging van Diephuis, een enge opvatting aangehangen ${ }^{479}$. Zo bijvoorbeeld in het door Teixeira de Mattos bewerkte handboek van De Pinto. Daarin wordt de beperkte uitleg weergegeven. Toch was de mening van Diephuis op één punt door anderen niet overgenomen. Diephuis sprak over artikel 1403 lid 1 als een inleiding op de artikelen 1404 en $1405 \mathrm{BW}^{480}$. Land kent artikel 1403 lid 1 wel betekenis toe $^{481}$. Daarbij kan op grond van artikel 1403 lid $1 \mathrm{BW}$ aansprakelijkheid voor schade, veroorzaakt door zaken volgen. Schuld zal dan wel aangetoond moeten worden ${ }^{482}$. Eenzelfde uitleg wordt door Oppenheim in 1914 weergegeven. De zinsnede van artikel 1403 lid $1 \mathrm{BW}$ waarin gesproken wordt over zaken is niet slechts een aanloop naar de volgende artikelen, zoals Diephuis voorstelde. De genoemde personen en zaken in de volgende leden en artikelen zijn een aantal uitwerkingen van 1403 lid 1 . Suijling neemt een positie in tussen een vrije interpretatie en een aan tekst en systeem van de wet gebonden uitleg ${ }^{483}$.

\section{2. ...en in rechispraak}

De betekenis van artikel 1403 lid 1 voor de aansprakelijkheid voor zaken was sinds 1870 een geringe ${ }^{484}$. Lagere uitspraken vertonen enige variatie, soms is sprake van een vergelijkbaar ruime uitleg als in 1859. Zo in een uitspraak van de Rechtbank Amsterdam in 1883. Door een gasexplosie wordt schade toegebracht. De vordering van de eiser berust op artikel 1403 lid $1 \mathrm{BW}$. De rechtbank stelt 'dat degeen, die het opzicht heeft over een zaak, geacht wordt gefaald te hebben in het houden van behoorlijk opzicht, indien die zaak aan een ander schade berokkent.' De benadeelde hoeft slechts aan te tonen dat schade is toegebracht door een zaak en dat degene die hij aanspreekt over de zaak het opzicht uitoefende ${ }^{485}$. In andere uitspraken waarbij een beroep op

479. Zie hoofdstuk $5 \$ 2$. Teixeira de Mattos. A., (1886), p. 573-575.

480. Zie hoofdstuk $5 \$ 2 . C .1$.

481. Land, N.K.F., deel 3 (1892), p. 259.

482. Land, N.K.F., deel 3 (1892)* p. 263 en n. 4.

483. Veegens, I.D., Schets wan her Nederlandsch burgerlijk rech, voortgezet door Mr. A.S. Oppentheim, derde deel (1914), p. 125-126. Zie over Sujjling verder hoofdstuk 7 \&.B.1.b.

484. Zie hoofdstuk 5 2.B. HR 4 maart 1870 , Van den Honert, Verzameling wan arresten von der Hoogen Raad der Nederlanden, burgerlijk regt, regt wan koophandel en burgerlijke regtrwordering, deel 34. 1871 , nr. 1162.

485. Weekblad van het Recht 4945 (1883). p. 1-2. De Rechtbank Leewwarden hanteert in 1894 eveneens een rume betekenis. Niet schudd doet het recht op schadevergoeding ontstatan, maar het opzicht over de zaak zelf. Weekblad wan het Recht $6517(1894)$, p. 3-4. 
artikel 1403 lid 1 wordt gedaan, wordt minder snel aansprakelijkheid aangenomen. Zo wordt in 1889 door de rechtbank Amsterdam overwogen dat schuld, nalatigheid of verzuim de enige gronden zijn, waarop de verplichting tot schadevergoeding in de artikelen 1401-1405 BW steunt. De bewezen feiten echter wettigen het vermoeden van schuld ${ }^{486}$. De Rechtbank Amsterdam overweegt in 1895 dat: "eigendom eener zaak niet per se de aansprakelijkheid voor die zaak meebrengt;" ${ }^{487}$ In andere uitspraken wordt niet van een omkering van bewijslast uitgegaan ${ }^{488}$. Ook de Hoge Raad blijft bij zijn enge uitleg van 1403 lid $1^{449}$. De Nederlandse heersende leer, de enge uitleg van artikel 1403 lid 1 wordt bovendien ondersteund door vermelding van Belgische rechtspraak: Artikel $1384 \mathrm{Cc}$ veronderstelt 'het bestaan van schuld (faute), en hij, die een onbezield voorwerp, waardoor schade is ontstaan, onder zich heeft, is voor die schade dus niet aansprakelijk, indien niet blijkt, dat zij te wijten is aan zijne onvoorzichtigheid of nalatigheid." ${ }^{490}$

\section{E. CONCLUSIES AANSPRAKELIJKHEID VOOR ZAKEN}

De heersende leer over de uitleg van artikel 1403 blijft de enge uitleg; een verruiming van de aansprakelijkheid wordt wel vaker voorgestaan. Een aantal klemmende betogen voor een ruime aansprakelijkheid gebaseerd op artikel 1403 verschijnt in de Nederlandse literatuur. In de eerste aanzet in de NJV wordt een beroep op de wetgever gedaan door wenselijk recht te beredeneren; later (Tichelaar, Scholten, Bruins, Star Busmann, Janssens en Pit) wordt dit wenselijke recht door een ruime interpretatie direct als mogelijk geldend recht gezien. Afzonderlijke wetgeving behoort ook tot de mogelijkheden (Tichelar). De argumentatie voor de enge uitleg is in hoofdzaak gebaseerd op systematiek en de eenheid van het recht; die van de ruime in hoofdzaak op de maatschappelijke wenselijkheid.

Duitse en Oostenrijkse regelingen dienen als voorbeeld voor een voorgestane verandering van wetgeving (NJV); van diezelfde rechtsstelsels en Frankrijk maken Scholten en Bruins gebruik. Laurents ruime interpretatie, de Franse rechtspraak na 1896, en Franse literatuur wordt gebruikt door voorstanders van een verruiming wan aansprakelijkheid voor auto's. Het gebruik van Duitse en Oostenrijkse wetgeving dient voor een argumentatie voor thet wenselijke recht. Dat wordt anders in de argumentatie van Tichelaar in 1891: deze bronnen werken bij hem direct door in de argumentatie voor het geldende recht. Het Franse recht (en het Belgische) verschaft Scholten een historisch argument (Toullier, de Franse wetsgeschiedenis), maar eveneens verschaft het hem rechtsvergelij-

486. Weekblad van het Recht 5812 (1890), p. 3. Zie woor een vergelijkbaar geval van toepassing van artikel 1959 BW hooldstuk 5 2.A.

487. Weeklad wan het Rech 6716 (1895), p. 2 .

488. We khblad wan het Rech 6844, (1896), p. $2-3$.

489. Weekblad van her Rechr 6927 (1897). p. 1.

490. Weekblat wan het Recht 6084 (1891), p. 3-4. De uitsprak is van 31 december 1891. 
kende argumenten voor een ruime uitleg (Laurent, Saleilles). Evenzo kan Scholten in deze ruimere mogelijkheden van interpretatie gebruik maken van Duitse en Oostenrijkse economische theorieën voor een andere grondslag van aansprakelijklueid. Evenzo wordt als rechtsvergelijkend argument gebruik gemaakt van de Franse rechtspraak in de vele pleidooien voor een kwalitatieve aansprakelijkheid voor de eigenaar van de auto.

\section{$\$ 3$. Artikel 2014: het verkeersbelang en de legitimatieleer}

Diephuis' uitleg van artikel 2014 BW blijft de heersende leer. De Staatscommissie 'tot voortzetting der herziening' van het Burgerlijk Wetboek geeft de heersende leer in 1899 als volgt weer:

"Het stelsel van het Burgerlijk Wetboek ten alamzien wan de verkrijging van den eigendom van roerende zaken is niet zoo klaar als wenschelijk zijn zou; meestal neemt men aan, dal de bepaling van artikel 2014 al. 1 tot eigenaar verklaart den bezitter, onverschillig hoe of van wien hij het bezit verkregen hebbe. Wie de zaak bezit, is er eigenas r van: wie har niet bezit, is geen eigenaar, ook all heeft hij haar vroeger op rechtmatige wijze verkregen en er niet an gredacht zijn recht over te dragen of op te geven. Staat zoo iemand tegenover eet bezitter en toont hij atan, dat hij de zalk door aankoop, door toeëigening, door zaaksvorming of op welke andere der erkende wijzen van eigendonswerkrijging dan ook, werworven heef, het zal hem niet baten. De ander heeft de zaak en behoudt lyaar, ook al weet hij ter rechtvaardiging van zijn bezit miets aan te voeren. Slechts dan zal hij verplicht zijn de zaak af te geven als de eischer kan bewijzen dat de zaak hem ontstolen of door hem verloren is, of dat hij haar aan de detentie van gedaagde toevertrouwde tegen belofte van restitutie ${ }^{491}$

De argumentatie voor deze leer verandert. Voor het Franse recht is die verandering in argumentatie treffend in beeld gebracht door Geny, ower artikel $2279 \mathrm{Cc}$ :

'Quelle grande importance y a-t-il. par exemple, quand il s'agit de connaître la portée de fa règle: En fait de meubles, la possession waut titre, à déterminer exactement une conception précise, à laquelle se rattacherait l'art. $2279 \mathrm{C}$. civ. Franç, , ou, suivant la terminologie usuelle, \$se prononcer stur le fondement juridique de ce texte. Et, en wérité, qu "entendon signifier, atu juste, quand on fait reposer la règle, qu'il exprime, soit sur l'idée d"une préscription (préscription instantanéè, soit sur celle d"une acquisition lege, soit encore sur celle d"une présomption légale, plus ou moins intense? Comme si l'intervention d'une théorie préconçue était indispensable pour justifier une règle toute pratique! Et comme si cente règle ne pouvait avoir sa ratison d'être propre et indépendante!" 492

Een dergelijke juridische constructie heeft volgens Geny geen enkele praktische warde: 'Ce qui détermine exclusivement, en fait, l'application et les effets de la règle (...,) ce sont les motifs bien connus, tant d'intérêt public que d'équité (basée sur la comparaison des intérêts en présence), qui la justifient rationnellement.' Het is het maatschappelijke

491. Ontwerp tot herziening van het Burgerlijk Wetboek, tweede boek, toelichting (1899) op de derde titel: Van eigendom, p. 344.

Geny, F., (1899, 1954), nr. 72. 
doel, en de 'equité, ' de rechtvaardigheid, die de belangrijkste grond vormen voor witleg. Ook in Nederland is deze verandering van argumentatie in de discussie over 2014 duidelijk. Historische argumenten ontleend aan het Franse recht worden minder belangrijk. Rechtsvergelijkende argumenten krijgen een meer prominente positie.

\section{A. DE ONTWIKKELING VAN DE MODERNE LEER: DE LEGITIMATIE-THEORIE}

\section{De aanloop tot Scholtens legitimatieleer}

De legitimatieleer van Scholten uit 1905 heeft voorgangers. Het standpunt van Faber (1871) vertoont sterke overeenkomst ${ }^{493}$, net als de uitleg van Roelvink en Molengraaff $^{494}$. Het ontwerp 1899 geeft een regel die de verkrijger ook dan eigenaar maakt indien het bezit van een roerende zaak door een niet-eigenaar is overgedragen. In de toelichting wordt gelezen: 'Den eisch te stellen, dat de overdracht door den eigenaar moet geschied zijn, zoude eene te groote belemmering voor het verkeer te weeg brengen.' In dit standpunt is de uitkomst van de NJV-vergadering uit 1890 te herkemnen, ook een onbevoegde kan een zakelijk recht verschaffen, de eigendom overdragen ${ }^{495}$. In 1905 introduceert Scholten zijn legitimatieleer, die veel later, bij stukjes en beetjes bovendien, in de jurisprudentie zal worden aanvaard, maar zeer snel in de literatuur met kracht zal worden ondersteund.

\section{De legitimatieleer van Scholten}

'Een zo ver gaande uitlegging is historisch niet te rechtvaardigen en ook practisch onjuist,' luidt Scholtens oordeel over de Germaansrechtelijke leer. Scholten presenteert een uitvoerige historische uiteenzetting, en maakt daarbij gebruik van Heusler en Huber, voor het Germaanse recht, van Bourjon voor het oude Franse recht ${ }^{496}$. Bij die historische uiteenzetting over het Germaanse recht heeft Scholten zich door Van Bemmelen laten inspireren: Van Bemmelen had immers een afwijkende historische beschouwing gegeven over het Germaanse recht. "Geen spoor" kon hij ontdekken van een beperking wan de revindicatie ${ }^{497}$. Scholten, meer genuanceerd, ziet in het Germaanse recht soms

493. Zie hoofdstuk $4 \$ 3 . A .6$.

494. Zie hooldstuk 5 3.B.

495. Zie hoofdstuk $5 \& 3 . \mathrm{B} ;$ Ant. 105 Ontwerp 1899 . Eigendom van roerende zaken wordt verkregen door overdracht van het bezit, indien de vervreender den wil heeft den verkrijger tot eigenaar te maken en deze den wil om eigenaat te worden, ook al is den vervreemder geen eigenaar.

Artikel 32 voegt toe een vermoeden van eigendom voor de bezitter. Indien de zaak is verloren of gestollen, heeft de vroegere eigenaar het recht tot terugvordering (artikel 42).

496. Scholten, P., Mr. C. Asser's Handleiding tot de beoefening van het Nederlandsch burgerlijk recht, deel 2 (4e druk, 1905), p. 61-68, met name p. 66; Huber, E. Die Bedeutung der Gewere im Deutschen Sachenrecht (1894), en Heuster, A., Institutionen des Deatscher Privatrechis, deel 2 (1886).

497. Zie hoofdstuk 5 \&.B. 
een onderscheid tussen bezit en eigendom. Zo heeft Scholten ook een historische onderbouwing in het Germaanse recht:

\begin{abstract}
'Historisch is de beteekenis van den regel van art. 2014 dus deze: het bezih legitimeert den bezitter als eigenaar; wie door zijn bezit eigenaar schijnt te zijn, words voor eigenaar gehouden. en jeder die daarop voontbouwt is veilig. De well geeft echter aan dit beginsel een te ruime uitdrukking door te werklaren, dat bezit volkomen titel is. Daardoor wordt ook hij, die de ziak werkreeg van iemand, dien hij wist dat geen eigenaar was, beschermo. M. a.w. er bestaat geen verschil tusschen bezit te goeder trouw en te kwader trouw. " 498
\end{abstract}

Met het idee van de legitimatie door bezit bouwt Scholten voort op de ideeën van Molengraaff die voor het handelsrecht een gelijke uitleg had voorgestaan: eigendomsoverdracht (waarvoor levering en een titel gelden als vereiste (artikel 639)) door een beschikkingsonbevoegde was mogelijk want (Molengraaff) 'de bloote houder kan feitelijk over de zaak beschikken, al mag hij het rechtens niet doen; het houden legitimeert hem tegenover derden tot beschikking over de zaak.' ${ }^{499}$ Scholten lijkt artikel 2014 lid 1 als een manier van eigendomsverkrijging te beschouwen ${ }^{560}$. Zo ver als de Germaansrechtelijke uitleg gaat Scholtens interpretatie echter niet. De verkrijger wordt niet beschermd als een geldige titel ontbreekt: 'wel [is] elke revindicatie uitgesloten tegen een ieder die, die het goed krachtens levering verkregen heeft hetzij van den eigenaar, hetzij van den niet-eigenaar, tegen ieder dus die den schijn van het recht voor het recht zelf aanzag, maar dan blijft toch de mogelijkheid van een revindicatie (...) van den vervreemder bij een nietige overdracht zoolang het goed nog onder den verkrijger berust (...)." sol

Over de goede trouw bestaat ook verschil van opvatting. Scholten verwijst naar Laurent en Dalloz. Laurent: 'Le possesseur doit être de bonne foi. Cette condition résulte encore de l'essence de la maxime. La loi veut favoriser les transactions mobilières qui sont l'âme du commerce; or la bonne foi est aussi une caractère essentiel des opérations commerciales; et le législateur n'a certes pas voulu donner son appuí à la mauvaise foi." ${ }^{502}$ Ook andere Franse auteurs hadden dit vereiste reeds gesteld, zoals Merlin ${ }^{503}$. Molengraaff stelt de goede trouw als vereiste en vermeldt dat. Franse en Belgische wetenschap en rechtspraak eenstemmig waren in het aannemen van de goede

498. Scholten, P., (1905), p. 65.

499. Molengraff, W.L.P.A., (1899), p. 126-129, als aangelvald door Salomons, A.F., (1990), p. 81.

500. Van Oven, J.C.., Art. 2014 B.W. en de bezitsbescherming van roerend goed, WPNR 2016-2019 (1908); zo ook Salomons, A.F., (1990), p. $113 \mathrm{ev.}$

501. Scholten, P., (1905), p. 66. Scholten heeft woorts wee systematische argumenten tegen de Germaansrechielijke opvatting. In de eerste plaats zouden de bepalingen over eigendomsverkrijging van roerende zaken bij dat standpunt geen enkele functie hebben; in de tweede plaats zijn de beide leden van 2014 minder goed met elkat in overeenstemming te brengen.

502. Laurent, F. deel 4 , (1878), nr. 713 .

503. Zie hoofdstuk 4 \& 3.A.2, Merlin, M., deel 29 (Se druk, 1828), p. 411. 
trouw 504 . Scholten neemt het niet aan. Hij baseert zich op de wettekst, maar: "Jure constituendo is zeker anders te oordeelen.' Een aan het legisme herinnerende argumentatie die bij Scholten niet lang standhoudt. In 1913 accepteert hij het vereiste in navolging van Van Oven. Van Oven had, om te spreken met de woorden van Wiarda, een "beslissend aandeel in de vestiging van de leer, dat "bezit" in art. 2014, lid 1 B.W. is "bezir te goeder trouw, "

\begin{abstract}
'Ja, die goede trouw, daarover moeten wij nog eens een woordje spreken; dat is nog een moeiljik punt bij de mieuwe leer, voor ons geldend recht atthans. Scholten durft het niet aan, voor anze wet goede trouw als vereiste woor eigendomswerkrijging krachtens 2014 te stellen. Hij wil er wel wan weten dal ze er bij hoort maar acht het een te stoute interpretatie, haar daar te vereisen, war de wet er niet met zoveel wootden over spreekt.

Ik zou echter meenen dlat degeen die de moderne leer voor onze wet annvaardt, ook gerust de goede trouw mee in den koop kan nemen, ja, dat hij dat eigenlijk moet doen. Werd de regel van 2014 niet ingevoerd voor de zekerheid wart her werkeer? Was het niet de bedoeling, den kooper of anderen verkrijger van roerend goed het onderzoek te besparen, of het goed soms eenmaal op werkeerde wijze vatn de eene hand in de andere was gekomen? Welnu wanneer men dan maar in het oog houdt dat een wetsbepalling niet zoo geïnterpreteerd mag worden dat zij aan haar doel voorbij streeft, dan zal men tot de slotsom moeten komen, dat art. 2014 hern gến eigenaar makakt, woor wien dat onderzoek nier noodig zou zijn, omdat hij wist dat er iets met de zaak niet pluis was, ma.w. men zal goede troluw eisen." sok
\end{abstract}

De zekerheid in het verkeer is het dwingend argument. 'Ik erken gedwaald te hebben..' schrijft Scholten in 1912. Vanaf dat moment stelt ook hij voor een geslaagd beroep op artikel 2014 de goede trouw ${ }^{507}$ : 'Wij meenden, in tegenstelling tot de Fransche jurisprudentie en doctrine (Planiol I, nr. 2479, Tissier bij Baudry deel 28, nr. 871 vlg., Hof van Cassatie 1 febr. 1893, Dalloz 1894, I, 278) die in het algemeen goede trouw verlangt, dezen eisch niet te mogen stellen, omdat zij nergens in het Burgerlijk Wetboek steun vindt." 50 "Waarom deze ommezwaai? Het is het doel van de bepaling waaraan getoetst moet worden: artikel 2014 beoogt de zekerheid in het verkeer. Voorkomen moet worden dat een werkrijger van een roerende zaak altijd zal moeten onderzoeken of hij het goed wellicht van een niet-eigenaar heeft verkregen. Indien de verkrijger dat al weet (of had behoren te weten) dan zou een dergelijk onderzoek toch niet nodig geweest zijn ${ }^{\text {sos }}$.

504. Molengraaff, W.L.P.A., bespreking wan: Thiel, J.H., De goede trou wan derden en ware bescherming tegenover de handelingen wan partijen (1903), in: Rechtsgeleerd magazinn (1905), p. 604-605. Thiel (p. 244) verklaart dat de Nederlandse wet de eigendom wan roerend goed heeft geregeld "zonder daarbij aan de goede trouw van den vermeenden eigenaar ook maar het geringste gevolg te verbinden.'

505. Wharda, J., J.C. Van Oven's beslissent aandeel in de vestiging wan de leer, dat "bezit" in art. 2014, lid $\mathbb{1}$ B.W. is "thezit te goeder trouw", WPNR 4548 (1958).

506. Van Oven, J.C., (1908), p. 434. Zie ook Salomons, A.F. (1990), p. 102.

507. Scholten, P.. (5e druk, 1913), p. 77.

508. Scholten, P., (5e druk, 1913), p. 77. Kont daarvoor reeds in een noot onder Hof Den Haag 19 december 1912, W. 9323. WPNR 2203 (1912).

509. Van Oren, J.C., (1908), p. 434. 
Van Oven meent ook dat Scholtens uitleg de meest gewenste uitleg is omdat ze in $\$ 932$ BGB als de heersende leer is verwoord.

(1) Durch eine nach \$ 929 erfolgte Veräusserung wird der Erwerber auch dann Eigenthümer. wenn der Sache nicht dem Veräusserer gehön, es sei denn, daß er zu der Zeit, zu der er nach diesen Vorschriften das Eigenthum erwerben würde, nicht in gutem Glauben ist. In dem Falle des $\$ 929$ Saiz 2 gilt dies jedoch nur dann, wenn der Enwerber den Besitz von dem Verausserer erlangt hatte. (2) Der Erwerber ist nicht in gutem Glauben. wenn ihm bekannt oder in Folge grober Fahrlầssigkeit unbekannt ist, dał die Sache nicht dem Veräusserer gehört.

De bepaling beschermt tegen beschikkingsonbevoegdheid van de vervreemder, indien het bezit is verkregen. De reden is dat de verkrijger "keinen Schaden davon haben [soll], daß er den Besitzer für den Eigentümer gehalten hat." ${ }^{510}$ Deze bescherming lijdt in $\$ 935$ BGB echter uitzondering wanneer het bezit van de zaak de eigenaar door diefstal, verlies, 'oder sonst abhanden gekommen war." ${ }^{511}$ Scholtens legitimatieleer vertoont veel overeenkomst met het Duitse stelsel. Belangrijk verschil is dat de uitleg van Schoiten alleen beschermt tegen beschikkingsonbevoegdheid, terwijl de derdeverkrijger in het Duitse recht eveneens bescherming verkrijgt wanneer de onderliggende titel mankeert. Die titel is voor eigendomsovergang in het Duitse recht niet noodzakelijk, zo volgt uit het in $\$ 929$ gelezen abstracte stelsel van eigendomsoverdracht ${ }^{512}$. Aan Scholtens leer zijn twee aspecten verbonden, die hij ontleent aan Saleilles: de processuele functie van 2014 (de bezitter wordt 'voor eigenaar gehouden' met andere worden, kan volstaan met het bewijs van zijn bezit); en de materiële functie van 2014 (wie op de legitimatie van het bezit afgaat is (mits te goeder trouw) veilig, wordt eigenaar). Saleilles: 'Il a ramassé en une seule règle la question de fond et la question de forme. L'une a pour objet le fait de l'acquisition du droit sur le fondement et du chef de bonne foi: c'est la question même du transfert. L'autre a trait aux questions de

510. Das Bürgerliche Gesetzbuch mit besonderer Beriaksichigung der Rechtsprechung des Reichsgerichts (1910), 932, p. 894, onder 1.

511. $\$ 935$. Der Erwerb des Eigentums auf Grund der $\$ 932$ bis 934 tritu nicht ein, wenn die Sache den Eigenüner gestoblen worden, verloren gegangen oder sonst ablhanden gekommen war. (...). Toelichting: "Unter Abwägung der Schutabedürnisse einerseits des Eigentümers, anderseits des gutglăubigen Erwerbers schränkt das Gesetz den Schutz des letzteren auf die Falle ein, in denen der Eigentümer selbst die Sache ablanden gegeben und so die Gelegenheit zur Veräusserung durch einen dritten geschaffen, die Täuschung des gutgliabigen Erwerbers über das Recht des Veräusserers mit verursachu hat. Sind die Sachen dem Eigentimer ohne seinen Willen "abhanden gekommen" so soll er durch den gutgläubigen Erwerb nicht gefährdet sein.' Das Bägerlichen Gesersbuch mi besonderer Beräcksichti" gung der rechrsprechusig des reichsgerichts (1910), \$935, p. 895, atantekening 1.

512. \$29. Zur Übertragung des Eigentums an einer beweglichen Sache ist erforderlich, dafl der Eigentümer die sache dem Erwerber übergibt und beide darüber einig sind, daß das Eigentum übergehen soll (...). Zie ook Zwalwe, W.J., (1993), p. $205 \mathrm{ev}$. en p. 109-110, die ten onrechte aanneemt (p. 207) dat de goede trouw niet als vereiste voor de eigendomsoverdracht wordt gesteld. 932 leert anders. 
preuve, c'est-à-dire à la présomption de titre'. ${ }^{513}$ Het wereiste van een bezwarende titel wordt later door Scholten toegevoegd, onder verwijzing naar de Engelse Sale of Goods Act uit $1893^{\text {514 }}$. Van Ovent onderschrijft met kracht deze door Scholten gepropageerde 'moderne leer." Ondersteuning voor deze nieuwe leer wordt ook geboden door Goudeket, in zijn bewerking van Opzoomers commentaar ${ }^{515}$.

\section{B. DE HEERSENDE LEER EN DE VERANDERDE ONDERBOUWING}

Scholten erkent: de leer van Diephuis, later uitgedragen door Meijers, Hofmann en anderen, is de heersende leer. Ook Levy hangt de heersende leer aan, met het vereiste van de goede trouw. Hij geeft een interpretatie van artikel 2014 die lijkt op de uitleg van Opzoomer ('afweren van de revindicatie'). De belangrijkste reden die hij daarvoor aandraagt is gelegen in het doel van de bepaling (een goed lopend economisch verkeer) ${ }^{516}$. Zijn onderbouwing is fundamenteel anders dan die van Opzoomer. Want waar Opzoomer tekst en systematiek bovenaan stelde, zijn voor Levy de eisen van het economische verkeer het belangrijkst. Hij verwerpt de opvattingen van Toullier en Marcadé. Veel heeft Levy ontleend aan de Duitse en de Zwitserse codificatie. Ook die Zwitserse codificatie stelt de goede trouw als vereiste. Tevens wordt de eigendom toegekend.

\footnotetext{
Art. 714. 1. Zur Übertragung des Fahrniseigentums bedarf es des Überganges des Besitzes auf den Erwerber.

2. Wer in gutem Glauben eine bewegliche Sache zu Eigentum übertragen erhält, wird, auch wenn der Veräusseter zur Eigentumsübentragung nicht befugt ist, deren Eigentümer, sobald er nach den Besitregeln im Besitze der Sache geschützt ist.
}

Daarnaast parafraseert Levy Gierke, die spreekt over "de legitimatie door het bezit". Tussen de heersende uitleg (Levy) en de nieuwe uitleg bestaat een punt van verschil: Scholtens uilleg beschermt alleen bij overdracht door een beschikkingsonbevoegde. De bescherming van de heersende leer is omvangrijker. Ook wanneer de titel mankeert wordt de bezitter te goeder trouw beschermd ${ }^{517}$.

513. Scholten, P., (7e druk, 1933), p. 97. Zie ook, eerder: Scholten, P., Bezit en bewijs bij revindicatie, WPNR 2897-2900 (1925), p. 498; Saleilles, R., De la possession des meubles (1907), p. 75. Een onderscheid owerigens dat in het ontwerp boek 2 BW van de commissie Meerbeke erkend zou worden (zie boven), en in het nievwe BW niet in strtikel 3. 86 zou worden opgenomen; de processuele functie is thans afzonderlijk te winden in artikel 3: 119 lid 1: De bezitter van een goed wordt vermoed rechrhebbende te zijn.

514. Scholten. P. (7e druk, 1933), p. 98-99. Het 'on bat' vereiste is door de Hoge Raad pas in 1994 aanward. Ziedaarower Salomons, A.F. De late axnwarding van het om baatvereiste bij art. 2014 oudBW. HR 2-12-1994, RvdW 1994, 264, WPNR 6174 (1995), p. $212-214$.

515. Zie Goudeket, J. Het burgerlijk wetboek verklaard door Mr. C.W. Opzooner deel 3 (1911), p. 442.

516. Levy, J.A. Het burgerlijk werboek verklaard door Mr. C.W. Opzoomer, deel 16 (1911), p. 243-246. Zie hoofistuk 4 \& 3.A.2.

517. Levy, J.A., (1911), p. 338-339. 
Het verkeersbelang, de belangrijkste reden voor deze of gene argumentatie, wordt ook in de rechtspraak gehoord. Zo bijvoorbeeld het Hof 's-Gravenhage van 12 januari 1912, besproken door Scholten die zich met de uitkomst kan verenigen: 'dat (...) uit verkeersbelang tegenover den vroegeren eigenaar rechtsbescherming is verleend geworden aan hem die te goeder trouw eene roerende zaak had verkregen; $O$. clat die rechtsopvatting van de bezitsbescherming van roerend goed recht geeft slechts dan een volkomen titel voor roerend goed tegenover den vroegeren eigenaar aan te nemen als de bezitter zich kan beroepen op goede trouw; ${ }^{518}$ Een deel van Scholtens leer, de processuele functie

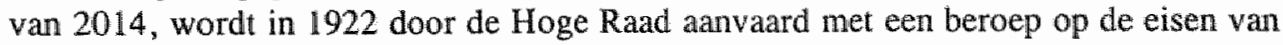
het verkeer: namelijk dat 'geheel overeenkomstig de algemeene woorden der wet, die geen beperking toelaten, de nuttige, door het verkeer geëischte wijde strekking wan den regel deze is: dat de bezitter van roerend goed tegenover elk en een iegelijk als eigenaar wordt beschouwd, zoolang een ander niet een beter recht bewijst." 519

\section{IN HeT NIEUWE BURGerLIJK WetBoek}

Ondanks flinke tegenstand in de literatuur (en rechtspraak, zie hoofdstuk 7) wordt de legitimatieleer in de Nederlandse wetgeving verwoord. Meijers neemt Scholtens interpretatie over. De rechtspraak is niet consistent. Meijers doel bij de uitleg van 2014 is een duidelijke lijn in de uitspraken te krijgen. Slechts twee constanten kan hij in de uitspraken onderscheiden: de woorden 'geldt als volkomen titel' worden opgevat als 'geeft eigendom' 520 , en bezit betekent bezit als eigenaar ${ }^{521}$. Vanaf 1950 wordt Scholtens leer door de Hoge Raad voor het grootste deel aanvaard ${ }^{522}$. Gezien het belang dat Meijers bovenal hechtte aan een duidelijke rechtspraak betekende dit een bijzondere ondersteuning voor de in zijn ontwerp verwoordde legitimatieleer. In afdeling 3.4.2 luidt artikel 3 , voor zover voor ons van belang, als volgt:

1. De onbevoegdheid yan de vervreemder kan ook aan denden-verkrijgers worden tegengeworpen, tenzij het tweede of het derde lid van toepassing is.

3. Is een toerende zak, die geen registergoed is, of een recht aan toonder verveemd, dan is ondanks de onbevoegdheid van de vervreemder een overdracht geldig, wanneer de verkrigger te goeder trouw is en on bat krachtens geldige titel verkrijgt.

Meijers' toelichting: 'Het derde lid van het artikel formuleert hetgeen de jongste rechtspraak in artikel 2014 lid 1 meent te moeten lezen. De regel wenst voor roerende zaken en rechten aan toonder geen verdere inbreuk op de wijzen van eigendomswerkrijging te

518. Scholten, P., An. 2014 B.W., - Beteekenis van het daarin genoende "bezit". WPMR 2203 (1912), p. $134-135$.

519. HR 3 februari 1922, NJ 1922 , p. 388 .

520. Ondanks een afwijkendie uitspraak in 1895, HR 14 jamuari 1895. Weekblad wam hat Recht 6616.

521. Mejjers, E.M. De rechtspraak van den Hoogen Raad omtrent "bezil geldt als wolkomen titel", in: Verzamelde Priwatrechtelijke Opstellen II, p. 146-147.

522. Zie hoofdstuk 2 \& 3. 
maken, dan dat degene, die van een onbevoegde vervreemder geleverd krijgt, beschermd wordt.' Meijers verwijst kort naar Saleilles, naar Scholten en naar de Engelse Sale of Goods Act $1893^{523}$.

\section{CONCLUSIES ARTIKEL 2014}

De legitimatieleer van Scholten komt sterk opzetten. In de argumentatie is verschil te ontdekken: terwijl de Germaansrechtelijke uitleg meer gebruik maakt wan vooral grammaticale, systematische en historische argumenten, moet de legitimatieleer het voor alles hebben van het met de regeling gediende doel. Een aantal zaken zijn belangrijk voor de toenemende acceptatie van Scholtens leer. In de jurisprudentie was geen duidelijke lijn te ontdekken; tekst en geschiedenis van 2014 hadden tot vele discussies geleid, maar niet tot enige consensus. Onder deze omstandigheden is veel plaats voor het teleologisch argument, met name voor Scholtens leer, maar ook voor de heersende. De Duitse wetgeving wordt gebruikt voor de interpretatie van 2014. De eigendom kan ook door een beschikkingsonbevoegde worden verschaft. De goede trouw wordt niet door de tekst van 2014 vereist, maar wel in de Franse en Belgische doctrine en in de Duitse wetgeving. Daarbij sluit de Nederlandse doctrine zich aan. Het onderscheid dat Scholten maakt tussen de procesrechtelijke en de materieelrechtelijke functie, ontleent hij aan Saleilles; het vereiste van de bezwarende titel vindt hij in Engelse wetgeving uitgedrukt.

\section{§4. Publiek domein, een privaatrechtelijke benadering}

\section{A. DE EERSTE OMSLAG NAAR EEN UNIFORM PRIVAATRECHTELUKE BENADERING}

De twijfel waarvan Opzoomer en Diephuis blijk gaven slaat door naar een geheel op het privaatrechtelijk eigendomsbegrip gebaseerde benadering van publiek domein. Sprake is van een omslag: Von Reeken publiceert in 1893 een artikel waarmee die omslag zeer scherp wordt aangeduid. Hij bouwt voort op eerdere kritiek op 'domaine public'. Met name Diephuis biedt hem aanknopingspunten voor zijn op het privaatrecht geschoeide overheidseigendom ${ }^{524}$. Voorts is in het administratiefrecht in de jaren tachtig van de negentiende eeuw een strijd ontstaan tussen voor- en tegenstanders van 'domaine public". De redactie van De Gemeentestem kiest eerst stellig partij voor Thorbecke's leer, maar kiest later (1882) voor een privaatrechtelijke benadering. Waarom meende de redactie om te moeten gaan?

In de artikelen 230 en 231 Gemeentewet wordt gesproken van 'aan de gemeente behoorende', voor openbare dienst bestemde zaken. In het vorige hoofdstuk is verklaard dat

523. Mejers, E.M., Onwerp woor en nieuw Burgerlikk Wetboek (1954), Tekst, p. 124 en Toelichting. p. 215. Ook in Frankrijk worden de processuele en de materieelrechtelijke functie onderscheiden. Marty. G., al P. Raynaud, Droit civil, les biens (1980), p. 491.

524. Hoofdstuk 5 \&.D.2. 
de artikelen 229 en 230 door Thorbecke waren bedoeld om zijn onderscheid tussen domaine public en domaine privé uit te drukken. Ook administratiefrechtelijke auteurs stonden deze mening voor, waaronder Van Oosterwijk. De redactie van de Gemeentestem over Van Oosterwijks standpunt: '(...) de door $\mathrm{Mr}$. v. O. verdedigde uitlegging van art.230 rust op de stelling dat publiekregtelijk goed geen voorwerp kan zijn van privaat eigendom." ${ }^{225}$ Daarmee was de redactie het niet (meer) eens: nergens is immers bepaald dat zaken die bestemd zijn voor de openbare dienst geen voorwerp van eigendom kunnen zijn, steit de redactie, waarbij zij verwijst naar Diephuis; tevens is het criterium 'openbare bestemming' onvoldoende om een zaak als buiten de handel te bestempelen; in de derde plaats zegt de Gemeentewet niets over een dergelijk onderscheid in het Burgerlijk Wetboek. Het privaatrechtelijke standpunt wordt aldus grotendeels gebaseerd op de argumenten die Diephuis had geleverd ${ }^{526}$. Daarnaast wordt gesteld dat het onderscheid in Frankrijk tussen domaine public en domaine privé niet zó stellig wordt gemaakt ${ }^{527}$.

\section{B. VON REEKEN EN ONMIDDELLUKE NAYOLGING}

\section{Von Reekens omslag}

Von Reekens mening in vogelvlucht: in het Nederlandse recht bestaat niet zoiets als domaine public, in tegenstelling tot het Franse recht; zaken met een openbare bestemming zijn niet als buiten de handel aan te merken; ten slotte is de staat gewoon privaatrechtelijk eigenaar van de in artikel $577 \mathrm{BW}$ genoemde zaken, terwijl hetzelfde geldt voor de gemeente met betrekking tot de zaken, genoemd in artikel 230 Gemeentewet ${ }^{528}$. Von Reekens argumenten voor deze stellige standpunten zijn deels ontleend aan een vergelijkende weergave van het Franse recht.

Voor acceptatie van domaine public in het Franse recht, zo laat Von Reeken zien aan de hand van de Code civil, Proudhon, het Répertoire van Dalloz, Maleville en Laferrière, zijn goede argumenten aan te voeren. Voor het Nederlandse recht gaat de Franse argumentatie echter nier op: tekst en geschiedenis van de Nederlandse wetsbepalingen laten een dergelijke uitleg niet toe. Von Reekens onderbouwing is verder volledig op het Nederlandse recht gebaseerd. In de Nederlandse wet wordt een onderscheid tussen privaatrechtelijke- en publiekrechtelijke eigendom niet gemaakt. Maar, zo vraagt Von Reeken, zou het onderscheid misschien gemaakt behoren te worden? Een vraag die Opzoomer nog bevestigend beantwoordde ${ }^{529}$. Nee, luidt Von Reekens antwoord, want

525. Art. 230 der gemeentewet, De Gevneentestem 1597,1598 en 1602 (1882).

526. Zie hoofdstuk $5 \& 4 . D .2$.

527. HR 25 oktober 1870, W. 3262, De Gemeentestem 1598, p. 1 . Arresten van 3 mei 1875 en 24 april 1868, genoemd in De Gemeentestem 1242.

528. Von Reeken, G.C., Uitoefening van private rechten op zaken met eene publieke bestemming. Themis 1893, p. 64.

529. Zie hoofdstuk 5 \& 4.D.2. 
door te spreken over 'publiekrechrelijke eigendom' wordt het onderscheid tussen publiekrecht en privaatrecht veronachtzaamd ${ }^{530}$. Von Reeken verwijst naar Diephuis en de redactie van De Gemeentestem. Voorts is 'openbare bestemming' onvoldoende om een zaak als buiten de handel aan te merken: 'Er kunnen redenen bestaan om sommige zaken hieraan te onttrekken, maar daardoor zijn zij er nog niet aan onttrokken; het is weder de Wet alleen, welke ze daaraan onttrokken kan doen zijn.(...) Tot die onttrekking is eene bepaling der wet noodig, slechts waar en voorzover ten aanzien van eenige zaak zoodanige onttrekking heeft plaats gehad, is die zaak buiten den handel.' 531 De argumenten van Von Reeken zijn in hoofdzaak grammaticaal en systematisch: artikel 230 Gemeentewet zou overbodig zijn, en de laatste zinsnede van artikel 577 heeft betrekking op alle in dat artikel genoemde zaken, en geeft aan dat eigendom van de genoemde zaken mogelijk is ${ }^{532}$.

Toch is ook in Von Reekens theorie plaats voor uitoefening van publieke dienst, en voor beperking van het eigendomsrecht: niemand kan 'eenig recht, strijdende met bedoelde bestemming, op deze zaken uitoefenen. (..) Bedoelde zaken zijn, voorzoover zij voor het publiek gebruik bestemd zijn, onttrokken aan het privaatrecht, aan het verkeer, en zijn dus gedeeltelijk buiten den handel'. Von Reeken maakt hier een stap die Diephuis nimmer had kunnen maken: door deze niet aan tekst of systeem van de wet ontleende constructie te gebruiken kan de staat zijn eigendomsrecht van de in $577 \mathrm{BW}$ genoemde zaken zelf houden, of aan anderen toestaan, onder de voorwaarde dat de publieke bestemming niet wordt belemmerd. Von Reeken noemt dit het 'gedeeltelijk buiten den handel zijn,' en daarvoor ziet Von Reeken ondersteuning bij Land, Diephuis, en de reeds door Diephuis vermeldde Wappäus. De laatste spreekt over 'den partiell dem Verkehr entzogenen Sachen. ${ }^{533}$

\section{Onwiddellijke ondersteuning}

'Von Reeken toont ons inziens overtuigend aan, dat ons recht niet kent het onderscheid tussen 'domaine public' en 'domaine privé, de onderscheiding gemaakt in den Code Civil', aldus twee jaar later Schepel in zijn dissertatie ${ }^{534}$. Von Reekens mening wordt

530. Von Recken, C.G., (1893), p. 7-13. Een argument dat vaker herhaald zal worden, en hierop neerkomt dai het Burgenlijk Wetboek slechts privaatrecht bevat: publiek-en privatrecht als twee (ook formeel) gescheiden rechtssferen. Zie Van Masnen, G.E., De wonderbaarlijke geschiedenis van de onrechmatige overhedsdaad in de 19e en 20 eenw (1996), \& 8.5, p. 69-70.

531. Von Reeken, C.G. (1893), p. 16-17.

532. Von Reeken, C.G., (1893), p. 18-20.

533. Von Reeken. C.G. (1893), p. 21. Daarbij gebruikt Von Reeken ook het artikel uit 1876 van die niet met name genoemde Diephuis. Dat artikel wordt door Van Gelein Virringa en Schepel gebruikt, en in het algemeen vaker angehaald dan Diephuis' commentaar. Wappäus, $\mathrm{H}$., Zur Lehre von den dem Rechssverkehr entzogenen Sachen nach römischem und heutigem Recht (Göttingen, 1867), p. 73. Zie hoofdsuk 5 4.D.2. De rechtspraak biedt Von Reeken een aantal uitspraken die van een uniform priwatrechtelijke benadering uitgingen. Von Reeken, C.G., (1893), p. 23-25.

534. Schepel, C.M.H., Wegenrecht in Nederland (1895), p. 60. 
eveneens onderschreven in een aantal kort nadien verschenen artikelen van De Hartog en Van Gelein Vitringa. In 1903 verklaart Van Gelein Vitringa:

\begin{abstract}
"Dat naar Nederlandsch recht ook de zaken, die deel witmaken van het publiek domein, vatbar zijn voor eigendom, kan thans moeil ijk meer eene stelling heeten. We rd vroeger door ieecr welu onder den invloed van Fransche rechtsbeschouwingen de leet voorgestaan. dat evenals het Fransche recht ook het Nederlandsche eigendom van zulke zaken niet toeltet, thars mag dat standpunt wel als overwonnen worden beschouwd. "Wetenschap en rechtspraak hebben doze men kan zeggen Fransche - opvatting den ng toegekeerd" , sis
\end{abstract}

De Hartog ${ }^{536}$, Van Gelein Vitringa en Schepel gebruiken, naast de argumenten van Von Reeken, rechtshistorische en rechtsvergelijkende argumenten. Ten tijde van de heersende publiekrechtelijke leer was de argumentatie in hoofdzaak gebaseerd op de recente wetsgeschiedenis (de herkomst van de bepalingen uit de Franse Code civil), en de rechtswergelijking met Frankrijk, Duitsland en Oostenrijk. De rechtshistorische argumenten gaan terug tot De Groot en Van Leeuwen. Beide schrijvers spreken over "eigendom' of "proprietas. " Dat betekent privaatrechtelijke eigendom. Een publiekrechtelijke eigendom mag daarom niet zomaar worden aangenomen: 'En zoo zouden dus wel afdoende argumenten noodig zijn om aan te nemen, dat ons Burg. Wetb. een leer heeft aangenomen, die met de oude gewoonten in zoo vierkanten strijd blijkt te zijn" 537 . De Hartog baseert zich ook op Duits rechtshistorisch onderzoek van Heusler. Deze grondvest de eigendom van zaken met een openbare bestemming in de 'Regalität', maar het blijft desondanks privatrechtelijke eigendom: 'Die Flüsse und die Strassen sind schliesslich in immer fortschreitenden Steigerung der Regalität geradezu als Eigenthum. des Königs bez. des Staats erklärt worden, sodass das Regal selbst sich als Eigenthumsrecht äussert, und daher auch in den Gesetzgebungen neuerer Zeit, z.B. in dem Preuss. Landr. unbedenklich gesagt ist, die Flüsse seien Eigenthum des Staates" ${ }^{* 38}$. Schepel voert recentere historische argumenten aan. Bij de totstandkoming van het BW is bij de redactie van artikel 577 afgeweken van $538 \mathrm{Cc}$. De zinsnede 'et généralement toutes les portions du territoire, qui ne sont pas susceptibles d'une propriété privée' is in het Nederlandse artikel niet teruggekeerd en juist hierdoor is uitgedrukt dat privaatrechtelijke eigendom van publiek domein mogelijk is ${ }^{539}$. In tegenstelling tot hel Franse recht, kent "ons Burgerlijk Wetboek geen publiek domein van den Staat meer $(. . .$, ) len

535. Van Gelein Vitringa, $₫$. Onteigening van publiek domein, Themis 1903 , p. 3.

536. De Hartog. L.. Nog iets over den Eigendom van de Res publicae, Themis 1894, p. 394.

537. De Hartog, L., (1894), p. 397. Dergelijk slechts op de enkele tekst gebaseerd historisch onderzoek is met name door Hardenberg sterk bekritiseerd. Zie booldsuk 3 \&.C.1; zie ook de dissertatie van Teunissen, J.H.F.M., Het Burgerlijk kleed van de Strat (1996), met name hoofdstuk 3.

538. De Hartog. L., (1894), p. 398. Een ander argument wan De Hartog (p. 400), dat Van Gelein Vitringa ook gebruikt (zie \& 4.C.4) is het volgende: "...de tot hel pubirek domein behoorende zaken eerst den menschen woorkomen in het karakter wan res communes, tot dat zich een publieke persoonlijkheid heeft ontwikkeld in voldoende mate om aan dezen den eigendom ervan toe te kennen (...)": Van Gelein Vitringa: 'naar men genst mag vertrouwen' zal de Staat de publieke bestemming respecteren.

539. Schepel, C.J.H., (1895), p. 62 
kan] er van publiek domein der provincie of der gemeente evenmin sprake (..) zijn' ${ }^{440}$. De eigendom zal ook bij een zaak behorend tot het publiek domein altijd aanwezig zijn, concludeert Schepel. Hij citeert Windscheid: de eigendom 'tritt heryor, sobald die öffentliche Bestimmung der Sache wegfällt', maar oók: 'während ihrer Dauer, soweit sie nicht entgegensteht." ${ }^{541}$

Vergeleken wordt bovendien met het eigentijdse Franse, Belgische, Duitse en Oostenrijkse recht. De Hartog vindt ondersteuning voor de privaatrechtelijke benadering bij de Franse schrijvers Barckhausen en Hauriou. Beiden hebben kritiek op 'domaine public'. Hauriou zou, in navolging van Barckhausen voor een uniform privaatrechtelijk eigendomsbegrip hebben gepleit. Van Gelein Vitringa plaatst hierbij kanttekeningen. Naar mijn mening terecht. Hij wijst op Hauriou's 'droit de propriếté publique' waarmee een tegenstelling met het gewone eigendomsrecht is bedoeld. In Frankrijk en Duitsland worden meer vormen van domaine public onderscheiden: 'domaine public' (er is in het geheel geen eigendom mogelijk op zaken met een openbare bestemming, Proudhon), 'propriété publique' (waarbij wel sprake is van een eigendomsrecht, maar dit wordt geheel ondergeschikt geacht aan, en ingevuld door publiekrecht, Hauriou). Hauriou over 'propriété publique': 'qui doit être rattachée à la puissance publique et qui est caractérisée dans ses effets par la destination d'utilité publique de la chose' ${ }^{542}$. Van Gelein Vitringa ondersteunt de privaatrechtelijke benadering van Von Reeken en De Hartog. Daarbij besteedt hij aandacht aan Frans en Duits recht, met name aan de Franse juristen Berthélémy, Barckhausen en Hauriou, en de Duitse jurist Otto Mayer. Voorstanders van publiekrechtelijke eigendom in Nederland ontleenden veel aan het Franse recht. Aan de bestrijding van deze standpunten uit Frankrijk en Duitsland moest daarom wel aandacht worden besteed.

\section{Twee Franse schriJvers, eEn DutTSE, EN VAN Gelein VITRINGA's kritiek}

\section{Berthélémy}

Berthélémy verwoordt de heersende Franse mening. Publiek domein is niet vatbaar voor eigendom, omdat eigendom het recht is "...de jouir et de disposer d'une chose de la manière la plus absolue.' En daarvan kan bij publiek domein geen sprake zijn. Tevens: 'Il ne paraît pas possible d'appeller propriêté un droit qui ne procure ni l'usus, ni le fructus, ni l'abusus." ${ }^{443}$ De karakteristieken van domaine public zijn: onvervreemdbaarheid (inaliénabilitê), onvatbaarheid voor verjaring (imprescriptabilité) en beslag (insais-

540. Schepel, C.J.H... (1895), p. 63

541. Schepel, C.J.H., (1895), p. 73. Windscheid, B., Lehrbuch des Pandectenrechts deel 1, 6e druk, p. 472; verder hoofdstuk 7 4.B.

542. De Hartog, L. (1893), p. 399, en Van Gelein Vitringa, J., (1903), p. 5-6.

543. Benthélémy, H., Traité élémentaire de droì administratif (1. le druk. 1926), p. 483-484. 
sabilité), de onmogelijkheid van onteigening, geen vestiging van zakelijke rechten en de afwezigheid van bezitsacties.

\section{Barckhausen en Hauriou}

Onomstreden is de heersende publiekrechtelijke mening niet meer. Aan de fundamenten in de Code civil wordt getornd. Barckhausen, hoogleraar in Bordeaux, neemt daarin het voortouw. Een van de argumenten om in het Franse recht domaine public als aparte rechtsfiguur te onderscheiden, was een onderscheid in de Code civil. Daarmee maakt Barckhausen korte metten. De woorden 'domaine public' in de artikelen 538 en $540 \mathrm{Cc}$ zijn door de Franse wetgever niet bedoeld in de bijzondere betekenis die de voorstanders van de theorie van domaine public er aan plegen te geveri: (...) les législateurs français n'ont pas attribué à l'expression de domaine public le sens spécial, précis et rigoureux, que les juristes modernes lui donnent." ${ }^{544}$ Hauriou onderschrijft deze stellingname van Barckhausen. Maar betekent dat ook dat hij geen onderscheid makt tussen publiek en privaat domein? Nee.

Hauriou: "Les dependances du domaine public sont des propriétés administratives affectées formellement à l'utilité publique (..) et qui, par suite de cette affectation, sont inaliénables, impréscriptibles et protégées par les règles pénales de la voirie.' Hauriou spreekt over propriété, eigendom wan de overheid (door De Hartog gelezen als privaatrechtelijke eigendom), maar Hauriou vult dit begrip 'propriété administrative' in op een wijze die het tot een publiekrechtelijk concept maakt. Hauriou ziet wel degelijk een verschil met de opvatting van Proudhon. Deze, en zijn navolgers hadden de opvatting dat de zaken die tot het publiek domein behoren niet vatbaar konden zijn woor privaatrechtelijke eigendom ('Ce domaine (...) ne peut être la propriété de personne') ${ }^{545}$, deze zaken waren 'res nullius', 'laissées à la garde et surintendance de l'Etat" "546'. Deze opvatting wordt door Hauriou niet gedeeld, want hij ziet enkele karakteristieken bij publiek domein die doen denken aan privaatrechtelijke eigendom. Hij noemt - onder meer - een van de bestemming (affectation) afhankelijke onvervreemdbaarheid, de mogelijkheid tot het instellen door een overheid van de revindicatie, en jurisprudentie waarbij gesproken wordt over eigendom. Wat is het gevolg: '. un jour vient où l'on s'aperçoit que la doctrine de la propriété est à la fois plus exacte et plus pleine d'effects; pour notre droit Français actuel, ce jour est venu. ${ }^{547}$ De dag van de privaatrechtelij-

544. Barckhausen, H. Remarques sur la théorie des domaines, Revue crivique dé légistation ar de jurisprudence, deel $13(1884)$, p. $30-43$, p. 34 .

545. Zie hoofdstuk 5 \&.A

546. Zie de bij Hauriou genoende literatuut. Hauriou, M. Précis de droit administratif el de droit public (12e druk, 1933), p. 782. Dat het hier om een latere druk handelt is geen bezwaar: Haturiou: 'Depuis de trente ans nous soutenons que le domaine public est objet de propriété administrative ef à chacume des éditions de ce livre, les faits admimistratifs el la jurisprudence nous tournissent de nouvelles raisons de nous affermir dans cette opinion." 
ke eigendom is aangebroken, maar toch concludeert Hauriou niet tot een volledige gelijkstelling, door middel van de volgende vondst:

\footnotetext{
"äu point de la jourssance du droit, il n"y a qu"une seul forme de la propriétế dans les deux domaines; au point de vue de l'exercise du droit, il $y$ a deux formes parce que, tandis que le domaine priwe est administré par des procédés de la wie privée, le domaine public est administré par dess procédés de la yie publique. ${ }^{548}$
}

Aldus is alleen sprake van een onderscheid op het niveau van uitoefening van het recht. Wanneer sprake is van publiek domein, kan de overheid haar rechten slechts uitoefenen met in achtneming van de administratiefrechtelijke regels die gelden voor publiek domein zoals onvervreemdbaarheid en onvatbaarheid voor verjaring, beide afhankelijk van een bestemming (affectation) tot publiek domein ${ }^{549}$.

\section{Otro Mayer}

De staat is 'den natürlichen selbstverständlichen Eigentümer der öffentlichen Sachen. Sie gehören ihm als gemeines Eigentum des Staates, domaine public, öffentliches Gut, eigentliches Staatseigentum. Es ist ein Eigentum besonderer Art, ausgezeichnet namentlich durch Unveräusserlichkeit und Unersitzbarkeit.(...) Der usus publicus ist nur eine Form der Ausübung dieser Herrschaft oder eine Last und Beschränkung derselben, zugleich ein Merkmal, daß das Eigentum des Staates hier von der besonderen rechtlichen Natur ist, die es vor einfachem gewöhnlichem Eigentum auszeichnet." ${ }^{550}$ Ook Mayer gebruikt een afzonderlijk eigendomsbegrip voor publiek domein. Wat houdt Mayers begrip 'öffentliche Eigentum' in? Anders dan Hauriou onderscheidt Mayer wel twee principieel verschillende vormen van eigendom. De öffentliche Eigentum is van toepassing op öffentliche Sachen: "die Sache müsse einem öffentlichen Zwecke unmittelbar dienen'; in de woorden van Van Gelein Vitringa: 'de zaak is voor de overheid niet meer hulpmiddel bij het volbrengen van hare taak, maar reeds door het bestaan van de zaak wordt die taak volbracht. Het belangrijkste en zekerste kenmerk wan zulke zaken is, dat ze openstaan voor het publiek gebruik'. ${ }^{55 s}$ Hoe wordt een zaak een openbare Zakk? Dat geschied door de "Widmung": "die öffentliche Sache ist immer erst in dem Augenblicke da, wo feststeht, daß die öfentliche Gewalt sie von nun an für ihren Zweck verwenden wird.' 552 Voldoende is dit nog niet. Pas als de staat (of een andere overheid) tevens de (privaatrechtelijke) eigendom verwerft, ontstaat de öffentliche Eigentum $^{553}$, inhoudende een bescherming tegen inbreuk ${ }^{554}$, en de mogelijkheid

548. Hauriou, M., (1933), p. 787-788, in noot 11

549. Hauriou, M., (1933), p. $791 \mathrm{ev.}$

550, Mayer, O., Deutsches Verwaltungstecht deel 2 (1896), p. 65.

551. Mayer, 0., (1896), p. 72-74; Van Gelein Vitringa, J., (1903), p. 23.

552. Mayer, 0., (1896), p. 90.

553. Mayer, 0.. (1896), p. 92

554. Mayer, O., (1896), p. 94. 
van beschikking, éen en ander vormgegeven door publiekrechtelijke regels. Er is sprake van publiekrechtelijke regels omdat de zaken aan het privaatrecht onttrokken zijn ('die Sache ist außer Verkehr') en omdat de staat bestuurt door middel van die zaken. "Die Sache ist die Anwendbarkeit des Civilrechts entzogen. Die rechtliche Herrschaft, in welcher die Staat sie hat, ist offentlichrechtlicher Art, weil er offentliche Verwaltung durch sie führt" 5.55 .

\section{Van Gelein Vitringa's kritiek}

Van Gelein Vitringa verwerpt alle besproken opvattingen, zowel de opvattingen van Berthélémy en die van Mayer, waarin de oorspronkelijke leer van Proudhon benaderd wordt, als de op het eerste gezicht wat gematigde opvatting van Hauriou. Van Gelein Vitringa's kritiek komt in hoofdzaak hierop neer dat de theorieën die uitgaan van een publiekrechtelijk eigendomsconcept weinig licht bieden op de constructie van domaine public ${ }^{556}$. Mayers theorie heeft als zwakke zijde dat de bepaling welke zaak als publiek domein wordt beschouwd, welke zaak 'dem öffentlichen Zwecke unmittelbar dient $^{2}$, aan een subjectief inzicht ${ }^{557}$. Van Gelein Vitringa's belangrijkste bezwaar is dat Mayer achterwege laat aan te tonen dat het privaatrecht principieel niet van toepassing is. De hierboven behandelde Franse schrijvers gingen tevens in op de bepalingen betreffende zaken buiten de handel, bepalingen die publiek domein aan het privaatrecht zou onttrekken. Ten onrechte, aldus Van Gelein Vitringa, de bepalingen over zaken buiten de handel zijn 'zuiver privaatrechtelijk', zij onttrekken de zaak juist niet aan het privaatrecht, maar stellen een 'gewijzigd burgerlijk recht' vast. Verder zijn de bepalingen volgens Van Gelein Vitringa niet interessant, want eigenlijk overbodig: 'De Staat, die een openbare weg heeft aangelegd, zal, naar men genst mag vertrouwen, dien weg niet aan een particulier verkopen, zoolang hij dien weg voor den openbaren dienst noodig acht." ${ }^{588} \mathrm{Hij}$ concludeert stellig: '..onze beschouwingen, waarvan de slotsom is, dat aan den publieken weg geen greintje publiekrecht te bekennen is..., 559

\section{DOCTRINE EN REChTSPRAAK NA VON REEKENS ARTIKEL}

De doctrine richt zich naar Von Reekens interpretatie: het privaatrecht is het uitgangspunt. In de rechtspraak is minder eenwoudig dan in de literatuur een omslag te bekennen. In 1918 , in het Hofvijverarrest, wordt door de Hoge Raad uitgemaakt dat voor 1838, toen de Code civil in Nederland gold, de overheid met de overdracht van het

555. Mayer, O., (1896), p. 95; zie wok: Mayer, O., Eisenbahn und Wegerecht, Archiv fur offentiches Recht 1901 , 38-87 en 209-243. Zie over Mayer: Planit, ${ }_{H}$. (ed), Die Rechtswissenschoff der Gegenwart in Setbstdarstellunger: (1924), p. 153 175 .

556. Van Gelein Vitringa, J., (1903), p. 18.

557. Van Gelein Vitringa, J., (1903), p. 23.

558. Van Gelein Vitringa, J., (1903), p. 35.

559. Van Gelein Vitringa, J., Publiekrechtelijk karakter van den openbaran weg?, Rechisgeleerd Magazijn 1907, p. 38. 
beheer van de hofvijver (publiekrechtelijk) tevens het recht van eigendom had overgedragen ${ }^{560}$. Deze uitspraak is als volgt uitgelegd: Meijers stelt dat daarmee door de Hoge Raad werd erkend dat voór 1838 de overheid tevens een recht van eigendom had op publiek domein, maar tevens dat dit eigendomsrecht door het publieke recht werd beheerst: een geheel aan Barckhausen herinnerende argumentatie zal hij opmerken ${ }^{561}$. Vraag blijft, of deze opvatting ook voor het geldende recht van 1918 zou gelden. Scheltema meent wan niet, de uitspraak had immers slechts betrekking op het in 1812 in Nederland geldende Franse recht. Duidelijkheid komt in 1941. Vanaf het parlevinkerarrest werd duidellijk van het primaat van het privaatrecht uitgegaan ${ }^{562}$.

\section{E. CONCLUSIES PUBLIEK DOMEIN}

Von Reekens privaatrechtelijk uitgangspunt vindt vrijwel meteen bijval in het privaatrecht: het Burgerlijk Wetboek kent geen onderscheid tussen publiek en privaat domein; de artikelen over zaken buiten de handel zijn niet direct van toepassing, of zelfs overbodig. In de rechtspraak bestaat minder eenstemmigheid. Tekst en systeem van het Burgerlijk Wetboek kunnen domaine public en toepasselijkheid van 'zaken buiten de handel' niet meer schragen. Zij dienen nu om het primaat van het privaatrecht te onderbouwen. Ook de rechtshistorie dient om de ommezwaai te beargumenteren. De argumentatie voor de privaatrechtelijke benadering laat zien dat een sterk op tekst en systeem gerichte uitleg bepaald niet verdwenen is. Een vrijere interpretatie diende om 'zaken buiten de handel" op analoge wijze te kunnen toepassen.

Opvallend is dat de omslag naar een privaatrechtelijke benadering plaats vindt in afwijking van de heersende meningen in Frankrijk en Duitsland. Aan de rechtsstelsels van die landen worden rechtsvergelijkende en rechtshistorische argumenten ontleend. Met het onderscheid dat in de Code civil te vinden is in de artikelen 538-540 werd in 1838 gebroken, zo wijzen tekst en systeem van het Burgerlijk Wetboek uit. Duits rechtshistorisch onderzoek wijst op gebruik van het woord 'Eigenthum' en dus op priwaatrechtelijke eigendom. In Frankrijk wordt een omslag gesignaleerd naar privaatrechtelijke eigendom. Het blijkt echter geen drastische omslag zoals in Nederland te zijn. Het onderscheid tussen domaine public en domaine privé wordt alleen ontkend, voor zover het in de Code civil weergegeven zou zijn. Elke (historische) grond ontbreekt om dit onderscheid in de Code civil an te nemen, zo maakt Barckhausen duidelijk. Barckhausens mening wordt gebruikt voor de ondersteuning van Von Reekens leer in literatuur en rechtspraak. De andere, meer publiekrechtelijke meningen in het Franse en Duitse recht worden uitgebreid in de Nederlandse literatuur behandeld en verworpen.

560. HR 7 juni 1918 . WPNR 2544 (1918).

561. Meijers, E.M., Publiek domein en zaken buiten de handel, WPNR 2543; zie ook: Scheltema, F.G., De zaken der openbare lichamen, in: Verspreide geschriften (1953), p. 654.

562. HR 17 januari 1941, N 1941,644, m.n. Paul Scholten. 


\section{\$5. De relativiteit der onrechtmatige daad}

Het vereiste van de relatieve onrechtmatige daad vindt pas na de eeuwwisseling een plaats in de Nederlandse rechtswetenschap. Er is immers sprake van een toevoeging aan artikel $1401 \mathrm{BW}$ zonder dat de wettekst aanknopingspunten biedt. Van Gelein Vitringa heeft (in 1919) dit vereiste, in navolging van $\$ 823$ van het Duitse BGB, geintroduceerd. Vanaf een tiental jaren na Van Gelein Vitringa"s artikel wordt het nieuwe vereiste onafgebroken in de rechtspraak toegepast, eerst bij het onrechtmatigheidscriterium 'strijd met een wettelijke plicht', later, vanaf $₫ 937$ evenzeer bij de ongeschreven zorgvuldigheidsnormen ${ }^{563}$.

\section{A. DE DUITSE RELATIVITEIT}

In het Duitse BGB wordt in 1900 een relatieve schending van een rechtsplicht weergegeven:

8 823. Wer vorsätzlich oder fahrlässig das Leben, den Körper, die Gesund heit, die Freilheit, das Eigentum, oder ein sonstiges Recht eines anderen widerrechtlich verteczt, ist dem andern zum Ersatze des daraus entstehenden Schadens werpflichtet.

Die Gleiche Verpflichtung trifft denjenigen, welchergegen ein den Schutz eines andern bezweckendes Giesetz verstößt. Ist nach dem Inhalte des Gesetzes ein Verstolngegen dieses auch ohne Verschulden möglich, so tritt die Ersatzptlicht nur im Falle des Verschuldens ein.

In het tweede lid is de eis van de relativiteit duidelijk verwoord. Een verplichting tot het vergoeden van schade wordt gelegd op diegene die handelt in strijd met een bijzondere wettelijke plicht. Alleen indien het een wettelijke plicht betreft die de bescherming van de gelaedeerde beoogt, ontstaat een schadevergoedingsverplichting. Deze Duitse relativiteit heeft een andere betekenis dan de Nederlandse relativiteit. Lankhorst merkt terecht op dat er sprake is van een uitbreiding van aansprakelijkheid in de Duitse constructie ${ }^{564}$. Deze opmerking is echter alleen juist als zij wordt gezien tegen de achtergrond van de toevoeging van de relativiteit in het Nederlandse recht: hier betreft de eis van de aansprakelijkheid een beperking, omdat niet elke schending van een wettelijke norm een schadevergoedingsplicht met zich mee behoort te brengen.

Een verplichting tot schadevergoeding ontstaat indien één (of meer) van de in $\$ 823$ lid 1 genoemde rechten wordt geschonden, maar tevens indien een bijzondere wet (Schutzgesetz) zoals in algemene bewoordingen in lid 2 van $\$ 823 \mathrm{BGB}$ omschreven, wordt overtreden. Er is in de Duitse wetgeving geen sprake van een algemeen geformuleerde abstracte norm, zoals in ons artikel 1401 oud BW of 6: 162 BW, maar van een opsomming van min of meer concrete gevallen van onrechtmatigheid. Naast de opsomming van de rechten waarvan schending een schadevergoedingsplicht oplevert, biedt ook een

563. Zie hoofdstuk $2 \& 5 . A$.

564. Lankhiorst, G.H., (1992), p. 10 en p. 47. 
schending van een 'Schutzgesetz', grond voor schadevergoeding ${ }^{565}$. Tijdens de parlementaire behandeling werd over de redactie gesproken en onder meer voorgesteld om 'den Schuiz eines Anderen bezweckendes' niet op te nemen, omdat 'daß Gesetzliche absolute Verbot einem Jeden zum Schutze dient." Een dergelijke wijziging werd echter afgewezen, omdat niet de schending van iedere wettelijke bepaling aanleiding kon zijn voor een vergoedingsplicht. Zo werd gewezen op wettelijke plichten die in het belang van de gemeenschap als geheel zijn gesteld, die 'auch jedem irgendwie Betheiligten zugute kämen". Alleen die wettelijke bepalingen die tevens gericht waren 'die Interessen des Einen vor der Beeinträchtigung durch den Anderen zu bewahren' werden gedacht bij schending een vergoedingsplicht op te leveren ${ }^{566}$. 'Es muß also zum mindesten neben dem Schutze der Gesamtheit unmittelbar auch den Schutz des einzelnen im Auge haben, woruber die Inhalt des Gesetzes meist klare Auskunft gibt." 567 Volstrekt duidelijk bleek de bepaling echter toch niet te zijn, zo blijkt uit een tweetal reacties op $\$ 823$. Gesproken wordt over: 'Rätseln, die das Gesetz aufgebe. (...) Andere bezeichneten den Sinn der Vorschrift als völlig Dunkel" 568. Oertmann: "Die Gesetzliche Bezeichnung. hat in ihrer alles und nichts besagenden Unbestimmtheit lebhaftes Mißbehagen und große Meinungsverschiedenheiten hervorgerufen.' 569

In de eerste jaren na de inwerkingtreding van het BGB heeft de Schutzzwecklehre bij (de interpretatie van) geschreven normen zich in drie richtingen als een begrenzing, een relativering van de aansprakelijkheid laten zien: naar de personen die door de overtreden regel worden beschermd ('personalen Komponente'); naar de aard van de getroffen schade ('sachlichen Komponente'), en naar het soort gevaar dat zich verwezenlijkt ('Gefahrenkomponente"). 'Der Verstoß gegen das Schutzgesetz verpflichtet den Handelnden zum Schadensersatze, wenn dadurch die Gefahr verwirklicht worden ist, die die Schutzvorschrift verhüten wollte, wenn das Rechtsgut oder Interesse verletzt ist, zu dessen Schutze sie erlassen wurde, und wenn die Person durch den Verstoß geschädigt worden ist, die sie Schützen wollte." 570 Aldus is eigenlijk sprake van twee toetsen, eerst moet worden bepaald of een bepaalde wettelijke norm een Schutznorm is, vervol-

565. Zie onder meer Drucker, W.H., Onrechmatige doad, p. 6: 'Het is de bedoeling van de regelling zodts die is neergelegd in het $\mathrm{BGB}$, on niet ann het rechtsgevoel van den rechter ower te faten de beslissing der vraag, of een of andere handeling alls rechtmatig of onrechtmatig is te beschouwen, matr om deze beslissing watt te leggen in de wet."Zie ook Smits, P.H., Iets, over de vraag der relatiwiteit wan de onrechtmatigheid bij onrechtmatige daad in verband met de door den Hoogen Raad onderscheiden onrechumatigheidswomen, WPNR 3586-3590 (1938). p. 446; ook: Lankhorst, G.H. (1992), p. 47.

566. Mugdan, B. Die gesawien Materialien zum Bürgerlichen Gesetzbuch fiir das Deutsche Reich, band 2, Recht der Schuldverhalthisse (1899. 1979), ad 704, p. 1073.

567. Das Burgerliche Gesetzbuch mit besonderer Berücksichtigung der Rechtsprechung des Reichsgerichts (1910), \&823, nr. 14, p. 651.

568. Lang, R.. Normz'weck und Dury of Care. Eine Untersuchung wher die Grenzen der Zurechnung im deutschen und anglo-amerikanischen Delikstecht (1983), p. 12-14.

569. Oermann, P.. Recht der Schuldverhälnnisse (5e druk, 1929), onder \$ 823, nr. 4, p. 1388.

570. Das Bürgerliche Geseszbuch mit Besonderer Berücksichtigung der Rechtsprechung des Reichsgerichts. (1910), \$823, nr. 15, p. 652 . 
gens moet worden bepaald of de betreffende norm in eén van de genoemde richtingen bescherming verleent. Een verdeling tussen 'Schutzzweck', en 'Schutzumfang'. Telders verdedigt deze indeling voor het Nederlandse recht.

\title{
B. DE KENNISNAME VAN $\$ 823$ LID 2 IN NEDERLAND
}

W.H. Drucker zet in 1912 het Duitse onrechtmatige daadsrecht uitgebreid uiteen. Daarin constateert hij over $\$ 823 \mathrm{BGB}$ het volgende:

\begin{abstract}
"Tot aanwulling der aansprakelijkheid gaat het B.G.B. in 823 (lid 2) op dergelijke wijze te werk als onze Hoge Rad bij de toepassing van artikel $1401 \mathrm{~B}$. W. In verband met $\$ 823$ (lid 2) kan de onrechmatige daad bestaan zoowel in de aantasting van eenig bijzonder rechtsgoed. als van het vermogen in het algemeen. Tot vergoeding is verplicht, wie door de overtreding eener wettelijke bepaling, die bescherming van den ander ten doel heeft, dezen benadeelt. Wettelijke bepaling is in den ruimsten zin te nemen (..); men is geneigd hierbij in de eerste platats aan de strafwer te denken, maar ook priwatrechelijke bepalingen vallen daaronder. Of een wer de bescherming van individueele belangen beoogt, moet uit de strekking worden afgeleid, wat veele noeilijkheden meebrengt, daar toch bij de meeste stratbepalingen zoowel individueele als algemeene belangen betrokken zijn. Alleen die schade komt voor vergoeding in aanmerking, welke de betrokken wet beoogt te voorkomen. ${ }^{57 n}$
\end{abstract}

Drucker gaat uit van een grote mate wan overeenkomst tussen regelingen in Duitsland en Nederland: naast onrechtmatigheid die voortvloeit uit de schending van subjectieve rechten staat de onrechtmatigheid die voortkomt uit het handelen in strijd met een wettelijke bepaling. De Duitse 'relativiteit' is reeds bekend voor de introductie van Van Gelein Vitringa. Op het moment van Druckers proefschrift ontbreekt de expliciet uitgesproken opvatting van absolute onrechtmatigheid $(1917)^{572}$ waartegen Van Gelein Vitringa zijn relativering af kan zetten. Voorts valt op dat Drucker de Duitse onrechtmatigheidscategorie 'strijd met een wettelijke bepaling' niet als een van Nederland afwijkende schetst. Een relativering lijkt naar de mening van Drucker reeds in Nederland te worden gebruikt. Want, zegt hij: 'Of een wet de bescherming van individueele belangen beoogt, moet uit de strekking worden afgeleid'. Drucker verpakt een relativerende benadering van de onrechtmatige daad in een interpretatievraag. Drucker spreekt over een aanvulling van de aansprakelijkheid maar kwalificeert dit niet als een andere benadering dan de Nederlandse ${ }^{573}$.

571. Drucker, W.H., (1912), p. 29-30.

572. HR 30 maart 1917, NJ 1917, 502 (Slegten/Westenerk).

573. Zie Lankhorst, G.H., (1992), p. 49; Smits P.H., (1938), p. 445 ev.; zie over Smits" stand punt hierna hoofdstuk $7 \$ 5$ 


\section{ABSOLUTE ONRECHTMATIGHEID EN VAN GELEIN VITRINGA'S RELATIVERING}

\section{Slegten-Westertenk}

Op 30 maart 1917 wijst de Hoge Raad een arrest waarin een absolute opvatting verdedigd wordt met betrekking tot de onrechtmatigheid: iedereen die schade lijdt heeft een recht op schadevergoeding. In casu was door Slegten een openbare weg versperd zonder (benodigd) voorafgaand verlof van het openbaar gezag. Westenenk leed daardoor schade en vorderde vergoeding. De vordering werd door rechtbank en hof toegewezen. Volgens het hof is "ieder bijzonder persoon (...) bevoegd (..) een vordering tot schadevergoeding in te stellen wegens een jegens hem gepleegde onrechtmatige daad." Daartegen is het cassatiemiddel gericht. Slegten gaat in cassatie en stelt dat de onrechtmatige daad niet 'jegens de eiser' (Westenenk) geschied is en gebruikte dus een vereiste van relativiteit. Besier stelt in zijn conclusie dat voor beoordeling of een daad onrechtmatig is, een schending van het objectieve recht 'als kenmerk op de voorgrond [staat] en behoeft dus in het algemeen niet te worden onderzocht, of een bepaalde persoon, en in het bijzonder de benadeelde, die schadevergoeding vraagt, in zijn rechten gekrenkt is.' De Hoge Raad stelt het door Slegten aangevoerdle terzijde. Het recht op schadevergoeding wordt door de artikelen 1401 en 1402 BW niet beperkt tot die benadeelde tegen wie op enige wijze een onrechtmatige daad gepleegd is. De overwegingen van de Hoge Raad, voor zover van belang, luiden als volgt:

'Dat waar nu het plegen wan dit strafbaar feit buiten twijfell is eene onrechtmatige daad, ieder, die door deze handeling schade lijdt gerechtigd is om op grond van art, $1401 \mathrm{BW}$ tegen dengene door wiens schuld de schade is veroorzaakt de vergoeding daarvan te vorderen (...)

Dat pleiter voor den eischer wel heeft betoogd dat er meer moet zijn dan de bovengenoemde factoren on eene vordering uit onrechtmatige daad te rechtvaardigen; dat het immers onaannemelijk zoude zijn, dat een ieder, die, door welke onstandigheden dart ook, madeel ondervindt van de door een ander begane wetsovertreding, dien ander tot schadevergoeding zou kunnen verplichten, en een juiste foepassing van art. 1401 dan ook medebrengt dit recht op schadevergoweding alléén toe te kennen an den benadeelde tegen wien op eenigerlei wijze de onrechtmatige daad is verricht, doch dat bij dit betoog uit het oog is verloren, dat uit art. $1402 \mathrm{BW}$ blijkt. dat de onrechtmatige dad. waturuit de atansprakelljkheid ontstaat, in vele gevallen niet als tegen een bepasalde persoon gericht, kan worden beschouwd:" 574

574. HR 30 maart 1917, NJ 1917, p. 502. Een verklaring voor deze absolute onrechmatigheid is dar juist deze opwatting wan onrechmatigheid binmen de grenzen van het in 1910 gewezen Zutphense waterleiding-arrest een billije schadevergoeding kan bewerkstelligen. HR 10 juni 1910, W. 9038 ; Ned. Rechrspraak deel 215, \$27, p. 235-242. Zie ook Lankhorst, G.H. (1992), p. 14-15, met een verklaw ring die in de geringe regeldichtheid de oorzak legt. Daarnaast kan de relativiteitseis worden gezien als een inwulling van de onrechtmatigheidscriteria na Lindenbaum-Cohen uit 1919 (NJ 1919, 161). De betekenis van schuld als bepaling van de verwijtbaarheid nam af, en haar plaats werd deels ingenomen door de zorgvuidigheid. Bij daze verruiming behoort niet elke onrechtmatigheid een schadevergoedingsplicht op te leveren. Van Maanen, G.E., (1986), p. 196 ev.; Hartlief. T., Van Maanen, G. E. Hoe werkt de onrechtmatige daad (1995), p. 61; Van Maanen, G. E., De Zutphense juffrouw en de ontrouwe bediende wan Linderbaun (1995), p. 50-51; zie ook: Van Maanen, G.E., (1986), p. 198. 
In deze passage komt de absolute onrechtmatigheid, door gebruik te maken van artikel 1402, duidelijk tot uitdrukking. Met een beroep op de wetssystematiek (artikel 1401 en 1402 in onderling verband) stelt de Hoge Raad het in het cassatiemiddel aangevoerde terzijde. De stellige uitspraak leidt tot kritiek van Van Gelein Vitringa in een artikel met een verder andere strekking.

\section{De introductie door Van Gelein Vitringa (1919)}

Juist naar aanleiding van deze absolute onrechtmatigheid (onrechtmatig jegens een ieder) bepleit Van Gelein Vitringa een vereiste van relativiteit als element van de onrechtmatige daad. Maar dacht hij dat als een nieuw element? Dat lijkt niet zo te zijn. Van Gelein Vitringa stelt:

\footnotetext{
'Daarmede is niet gezegd en zeker ook niet bedoeld, dat als grondslag voor de vordering tot schadevergoeding onder alle omstandighedem voldoende is, dat én zelfde daad èn straftuan is èn aan een ander schade veroorzakk. Stellig moet dit voorbehoud worten gemaakt, dat het belang. waaraan de schade is toegebracht, tevens is het belang, tot bescherming waatwan het overtreden wetswoorschrift strekt." $57 \%$
}

Van Gelein Vitringa lijkt de uitspraak van de Hoge Raad te interpreteren alsof de relatieve opvatting daarin al besloten ligt: 'Daarmee is niet gezegd en zeker ook niet bedoeld (..) Stellig moet dit voorbehoud worden gemaakt(..).. Hij verwijst naar de Duitse bepaling: wat de Hoge Raad onder schending van rechtsplicht verstaat, wordt in $\$ 823$ lid 2 BGB genoend: 'verstossen gegen ein den Schutz eines Anderen bezweckendes Gesetz'. Slechts aan diegene wiens bescherming de wet beoogt komt een vordering tot schadevergoeding toe. Het is juist dit aspect van het Duitse artikel, dat ook bij artikel 1401 gebruikt zou moeten worden om de consequenties van de absolute opvatting van de onrechtmatigheid te ontgaan. Zo noemt hij als voorbeeld, onder verwijzing naar het Franse recht, de onbevoegde uitoefening van de geneeskunst: dat geeft aan bevoegde artsen nog geen recht op schadevergoeding, omdat de Nederlandse wettelijke regeling alleen waakt voor een algemeen gezondheidsbelang ${ }^{576}$. In het Franse recht wordt door de regeling ook de concurrerende arts beschermd, zodat daar een schadevergoeding wel kans van slagen heeft ${ }^{577}$. De door Van Gelein Vitringa gebruikte bewoordingen zijn niet altijd even makkelijk te plaatsen. Bedacht moet worden dat het relativiteitsvereiste nog moest worden vormgegeven. Zo kan het standpunt van Van Gelein Vitringa soms doen denken aan een constructie zoals van Besier of Demogue, waarbij het causaal verband meer centraal wordt gesteld; soms gebruikt Van Gelein Vitringa het schuldver-

575. Van Gelein Vitringa, I., Openbaarheid wan den weg en burgerlijk recht, Rechtsgeleetd Magazijn 1919 , p. 29.

576. Zie ook HR 17 jantari 1958 , NJ 1961,568 .

577. Van Gelein Vitringa, J., (1919) p. 30 , 
eiste om tot een relativering van een onrechtmatige daad te komen ${ }^{578}$. Waar het om gaat is dat Van Gelein Vitringa tracht te voorkomen dat elke schending van een wettelijke norm tot schadevergoeding dwingt. Dit lijkt in de woorden van Van Gelein Vitringa iets wat vanzelf spreekt: 'Daarmee is niet gezegd en zeker ook niet bedoeld (..). Stellig moet dit voorbehoud worden gemaakt..' Het artikel van Van Gelein Vitringa is slechts een voorbode: een tiental jaren nadien zou de Hoge Raad het relativiteitsvereiste gaan toepassen; Van Gelein Vitringa is inmiddels raadsheer geworden in de Hoge Raad.

\section{Een geheel nieuwe toevoeging?}

Het idee dat niet elke onrechtmatige daad tot schadevergoeding behoort te leiden is geen nieuw idee. Een aantal vroege uitspraken, die dateren van vóór de introductie van de relativiteit als afzonderlijk vereiste, doet sterk denken aan een relativiteitsvereiste ${ }^{579}$. Zelfs Van Gelein Vitringa westigt de aandacht daarop ${ }^{580}$. Zo werd in 1870 door de rechtbank Maastricht het volgende vonnis gewezen. Sprake was van een onbevoegd uitgeoefende 'wagendienst tot vervoer van personen'. Een concurrent, wel in het bezit van de vereiste vergunning, werd in deze uitspraak de mogelijkheid ontzegd om schadevergoeding te vorderen. Want, aldus de rechtbank, de concessionaris kan aan zijn concessie

\footnotetext{
'hoegenatamd geen exclusief recht (..) ontleenem; dat derhalve, wanneer iemand, zonder door thet openbaar gezag eene vergunning tot oprigting eener dienst van openbare middelen van verwoer te hebben verkregen, door het aanleggen var eene regelmatige dienst van vervoer, eene overtreding pleege van meergemeld reglement, hij wel daardoor strafregtelijk verantwoordelijk is, maar niet kan gezegd worden eene onregtmatige daad te hebben gepleegd jegens dengene, die eene roodanige wettelijke concessie had bekomen; 581
}

Waarom kon de concessionaris geen exclusief recht aan zijn concessie ontlenen? Omdat "concessiën als die, waarvan de rede, niet zozeer in bet particulier dan wel in het algemeen belang worden gegeven', en verder doordat de concessiën 'voor herroeping vatbaar zijn, zonder dat hij, die dezelve had bekomen, zich deswege kan beklagen.' In deze uitspraak wordt in ieder geval precies weergegeven wat Van Gelein Vitringa later, in 1919, voor ogen stond. Wettelijke voorschriften beogen de bescherming van 'zekere belangen'. Noodzakelijk is nu te kijken of het geschonden belang in kwestie door de geschonden norm wordt beschermd. In de vroege uitspraak van 1870 is van een derge-

578. Asser-Harkikamp III (1994), nr. 107. Enkele voorbeelden: 'tusschen het onrechtmatig en het schadelijk karakter der daad elk verband te ontbreken'; of: 'ook de woorden van art. $1401 \mathrm{BW}$ staan hier aan de vordering tot vergoeding in den weg. Het artikel spreekt van schade veroorzaakt door schuld. Den dader moet werwijt treffen, dat hiji schade toebrengt." Van Gelein Vitringa, J., (1919), p. 31.

579. Zie Lankhorst, G.H., $(1992)$, p. 13.

580. Van Gelein Vitringa, J., (1919), p. 30.

581. Rechibank Maastricht, 13 oktober 1870, W. 3285. 
lijke toets sprake. Onderscheiden wordt in die kwestie tussen de beoogde bescherming van het algemeen belang, en de particuliere belangen van de uitbater der wagendienst.

De introductie uit het Duitse recht in 1919 moet vooral worden gezien als de creatie van een afzonderlijk vereiste uit een reeds bekende juridische redenering; ze werd gestoken in de jas van een 'nieuw' vereiste. Waarom? Wanneer we trachten een reden te vinden voor het ontstaan van een relativering als afzonderlijk vereiste, dan lijkt het vooral de in 1917 uitgesproken absolute onrechtmatigheid te zijn. Daarbij biedt het Duitse recht een passende formulering, en later, bij de ontwikkeling en uitwerking van de relativiteit, passende invullingen. Vanaf 1928 wordt het vereiste in de rechtspraak gesteld.

\section{De zaAk Marchant et d'Ansembourg; Besier en Demogue}

In 1928 past de Hoge Raad het relativiteitsvereiste voor het eerst (op onduidelijke wijze) toe ${ }^{582}$. Van Gelein Vitringa heeft dit arrest mede gewezen. Telders is de grootste voorstander van het nieuwe vereiste. Voor het gebruik van dit nieuwe vereiste ontleent hij veel aan het Duitse recht. Zijn betoog zet Telders af tegen de conclusie van de advocaat-generaal Besier voor het arrest Marchant. Tevens brengt hij de mening van Besier in verband met een standpunt van Demogue.

\section{Marchant in het kort}

In $\S 2.5$ is de uitspraak reeds uitvoerig aan de orde geweest. Een stuk grond van Marchant is aangewezen ter onteigening, maar een voorschrift uit de Onteigeningswet blijkt geschonden (er had geen ter inzagelegging plaatsgevonden). Marchant lijdt schade door de aanwijzing tot onteigening. Kan de enkele schending van het voorschrift uit de Onteigeningswet grond opleveren voor schadevergoeding? Nee, dat kan niet volgens de Hoge Raad, omdat de strekking van het geschonden artikel niet is om de eigenaar te beschermen tegen nadelen die uit de aanwijzing tot onteigening voortvloeien.

\section{Demogue (1924) en Besier (1928)}

Demogue ziet de oplossing in de causaliteit:

II ne peut ếne question die cause que out autant qu' ill y une relation nécessaire entre la fait incrimine ef le dommage. Il faut qu"il soit certain que, sang ce fait, le dommage n'aurait pas eu lieu. Ansi, il ne suffit pas qu'une personne ait contrevenu à certang ag glements. il faut que sans cette contravention le dommage n'eut pas eu lieu. Ámsi, un entrepôt de bois ayant êt ouvert sans autorisation, le proprietaire n'est pas de plein droit responsable de l'incendie qui s'est communiqué à un immeuble voisin. allors cependant qu' on peut se demandier si l'autorisation sollicìée eut été obtenu. Ici, la relation n'est plus absolument nécessaire en le juge en est 
réduit à dire que mêne si l'on šétail conformé a la loi, le dommage eut sans doute eu lieu. $\$ 83$

Uit het citaat wordt duidelijk dat Demogue dezelfde situatie op het oog heeft als in Nederland bij de relativiteitsleer wordt gedacht: het ontbreken van een vergunning bij een houtopslag maakt de eigenaar niet reeds op grond van die reden aansprakelijk voor een naar een nabuur overslaande brand. Een ander voorbeeld van Demogue wordt ook door Telders gebruikt:

"Cêlui qui conduit une automobile sans permis, n'est pas nécessairement responsable s'il écrase un passant. Nous estimons cependant, que l'absence de permis, peut constituer une présomption de fait d"ignorance et d'inhabilite." sod

In Demogue's standpunt, het eerste citaat, komt het causaal verband goed tot uitdrukking: 'une relation nếcessaire entre le fait incriminé et le dommage'. Maar de door hem gekozen bewoordingen geven aanleiding te veronderstellen dat hij zich nòg een verband dacht: tussen "contravention" en 'dommage', het onrechtmatige element en de schade. Het is dit dubbele causale verband dat ook Besier zou huldigen ${ }^{585}$.

Besier neemt voor het arrest Marchant et d"Ansembourg de betreffende conclusie die verwantschap vertoont met het standpunt van Demogue ${ }^{586}$. Besier kwam niet tot een verplichting tot schadevergoeding op grond van een onrechtmatige daad, want:

\footnotetext{
'Art. 1401 B.W eischt dan aok een dubbel causaal verband. Het eischt, dat door de daad schade zij toegebracht, doch daarnevens, dat de schade veroorzaakt zij door schuld.(..) De onrechtmatige schadetoebrengende daad legt derhalve ook volgens den Hoogen Raad alleen them, door de onrechtmatigheid van wiens handelen de schade is veroorzaakt (..) de verplichting op die te vergoeden. (...) In het onderhavige geval ontbrak dus het voor de toepassing van artikel 1401 B.W. noodzakelijk verband russen de onrechtmatigheid van het Kon. Besiuir en de daardoor veroorzakie schade. De schade toch zou ewengoed zijn ingetreden, indien dit besluit niet op cen onvoldoenden grondslagag thad berust, doch de neerlegging der plannen van het werk behoorlijk had plaats gehad. " 587
}

Besier gebruikt expliciet een dubbel causaal verband: tussen de daad en de schade en tussen de schuld (onrechtmatigheid) en de schade ${ }^{588}$

583. Demogue, $\mathbb{R}$., deel $4(1924)$, nr. 366 .

584. Demogue, R., (1924), nr. 366, p. 2, noot 3 .

585. Zie Asser-Hartkamp III (1994), nr. 107

586. Zie hoofdstuk 2 \& 5.8; Asser-Harkamp IIT, nr. 107.

587. HR 25 mei 1928 , NJ 1928, 1688, p. 1690.

588. Zo merkte ook Telders op: Telders, B.M., (1929), p. 170. 


\section{E. TELDERS: ONDERSTEUNING EN INVULLING AAN DE HAND VAN HET DUITSE RECHT} (1929)

Telders is de grootste pleitbezorger van het nieuwe vereiste. Hiervoor is Telders, zo blijkt uit een noot bij zijn artikel, niet door Van Gelein Vitringa in 1919 geïnspireerd. Volgens Telders zijn de drie vereisten, onrechtmatigheid, schade en causaal verband, ontoereikend ${ }^{589}$. De relativiteit is een onmisbaar vervolg op deze vereisten, omdat in een aantal gevallen well tot een schadevergoedingsplicht geconcludeerd kan worden, terwijl daarvan geen sprake behoort te zijn. De door Besier, Meijers en Demogue voorgestane dogmatische oplossingen die in tekst en het systeem van de wet passen, zijn volgens Telders onjuist. Waarom? Het is voomamelijk het door Besier en Demogue geconstrueerde oorzakelijk verband, waartegen Telders in het geweer komt. Door beiden wordt een causaal verband gelegd tussen de onrechtmatigheid van de daad, en de schade. Dit verband is echter een geheel ander verband, volgens Telders een normatief verband en zeker geen causaal verband ${ }^{590}$. $\$ 823,2$ e lid BGB geeft dit verband goed weer. Telders vertaalt de in dit Duitse artikel neergelegde regel als volgt: 'Niet iedere onrechtmatigheid brengt schadevergoedingsplicht mee, maar slechts die onrechtmatigheid, waardoor een rechtsnorm wordt overtreden, die ten doel heeft eens anders belangen te beschermen.' De invulling die het Duitse Reichsgericht aan deze regel geeft, en die boven reeds aan de orde kwam, wordt door Telders als toepassing in Nederland gesuggereerd, en door hem als volgt samengevat:

\footnotetext{
"Vere ischt is dat de geschonden norm le. het belang beschermt, dar door de onrechtmatige daad is gelaedeerd; $2 \mathrm{e}$. dit belang beschermt tegen het gevaar, dat door de onrechtmatige daad is verwerkelijkt; $3 \mathrm{e}$. de persoon betreft wiens belang door de onrechtmatige daad is gelaedeerd. 591
}

Duitse rechtspraak is volgens Telders van belang omdat het resultaat ook hier te lande vrij algemeen aanvaard wordt ${ }^{592}$. Zo bijwoorbeeld een uitspraak uit 1906: iemand had aandelen van een vennootschap aangeschaft, afgaande op valse balansen en ongemotiveerde dividenduitkeringen. De commissarissen hadden het bestuur onvoldoende gecontroleerd, en gehandeld tegen een wettelijke bepaling uit het Handelsgesetzbuch. Vraag was nu of deze normschending ook een normschending was in de zin van $\$ 823$ lid 2 . Het criterium daarvoor was of de norm in het HGB tevens geschreven was ter bescherming van de belangen van personen zoals gelaedeerde, die als toekomstig aandeelhouder op het verkeerde been was gezet. Nee, concludeerde het Reichsgericht, de bepalingen waren slechts bedoeld ter bescherming van de belangen van aandeelhouders of schuld-

589. Telders laat het begrip schuld wegens onduidelijkheid beiten beschouwing.

590. Met deze argumentatie van Telders wordt voor het eerst Besier in verband gebracht met Demogue. Wertheim zal in 1930 in zijn proefschrift spreken ovar de "theorie Denogue-(Hof Den Bosch)-Besier" Wertheim, W.F., Aansprakelijkseid woor schade buiten overeenkomst, Leiden 1930, p. 108 en 130.

591. Telders, B.M., (1929), p. 170-171.

592. Telders, B.M., (1929), p. 171. 
eisers van de wennootschap. Ook AG Berger maakt in 1931 gebruik van Telders' aan de Duitse jurisprudentie ontleende criteria. 'Dat deze norm rechtstreeks gericht is op bescherming van dien ander en tevens strekt tot beveiliging van het belang, waarin verweerder in het onderwerpelijke geval is geschaad, behoeft uitteraard, dunkt mij, geen betoog. " ${ }^{93}$ Telders' standpunt leidt tot een polemiek met Wolfsbergen, en ook anderen zullen zich tegen dit nieuwe, en niet in de wettekst verankerde vereiste, keren. Ondanks grote tegenstand zal het vereiste toch in het Nederlandse recht worden aanvaard: in de jurisprudentie, maar ook in de literatuur.

\section{F. DE ONGESCHREVEN NORMEN VAN LANGEMEUER (1934)}

Telders laat de toepassing van de relativiteit bij zorgvuldigheidsnormen buiten beschouwing. Dat is voor Wolfsbergen aanleiding om op te merken: 'met het sinds 1919 bestaande recht houdt Mr.T daarbij geen rekening" ${ }^{594}$. De relativiteit kan sterk de nadruk leggen op de geschreven norm, waardoor de vraag of wellicht ongeschreven normen zijn geschonden, wat veronachtzaamd kan raken. In kort geding * rechtspraak treft Langemeijer deze nalatigheid aan: 'niet overwogen is, of niet de gedaagde naast een wetsbepaling ook een dier elementaire regels van maatschappelijke moraal schond, die de H.R. in 1919 als regels van ongeschreven recht heeft erkend.'595 Hij onderschrijft weliswaar het nieuwe vereiste, maar stelt zijn 'correctie Langemeijer' als noodzakelijke toevoeging. Wanneer relativiteit tussen geschonden wettelijke norm en schade ontbreekt en overtreding van deze wettelijke norm dus geen aanleiding geven kan tot een schadevergoedingsplicht, kan het daarnaast zijn dat ook een ongeschreven norm is geschonden, dat aldus sprake was van een jegens de gelaedeerde onbehoorlijke wetsschending. Op grond daarvan kan dan toch een aansprakelijkheid ontstaan, waarbij de wetsovertreding meegewogen wordt ${ }^{\mathrm{s} 96}$.

\section{G. ACCEPTATIE IN RECHTSPRAAK, HANDBOEKEN, EN IN HET NIEUWE BW}

In een aantal arresten wordt de relativiteit van de onrechtmatige daad toegepast ${ }^{597}$. In 1937 volgt een uitbreiding en wordt het vereiste van de relativiteit ook bij de zorgvul-

593. Zie W. 12321

594. Wolf shergen, A., Nonnatieve onrechtmatigheid of causale onrechmatige daad, WPNR 3115-3116 (1929), p. 523 . Telders repliceert, en merkt op dat hij will afzien van de wraag 'of daarnaast wellicht ook reeds een norm wan ongeschreven recht de handeling verbiedt". Telders, B.M., Nog eens: het verband tusschen onrechtmatigheid en schade bij art. 1401 B.W. WPNR 3126 (1929), p. 667.

595. Langemeijer, G.E., Onrechmatige daad en concurrentiestrijd, Nederlands Juristenblad 1934, p. 617. De door Langemejer genvende uitspraken hebben alle betrekking op gestelde oneerligke concurrentie: NJ 1934, 231; NJ 1934, 285; NJ 1934, 414; NJ 1934, 925.

596. Zie daarover ook Van Maanen, G.E., (1986), p. 1984199.

597. HR 24 januari 1930, NJ 1930, 299; in zijn noot onder het arrest gaat Meijers ook in op die zorgwuldigheidsnormen, en vemeldt expliciet dat in Duitsland in \$ 826 het vereiste riet wordt gesteld. HR 19 juni 1931 W. 1232丩 (1931) en in NJ 1931, 1303 ; HR 17 juni 1932, NJ 1932, 1464; HR 23 november 1939, NI 1940, 242. 
digheid toegepast. Wat was in die rechtszaak het geval? Een zekere Van der Werff, werkzaam aan de beurs te Rotterdam, verstrekt aan de directeur van de Nederlandsche Beleggingstrust veel te gunstige inlichtingen over de zaken van de Hollandsche Disconteeringsbank NV (Holdisco). Op grond van deze inlichtingen koopt de Beleggingstrust voor een kleine vierduizend gulden aandelen van Holdisco. Van der Werff is tevens commissaris van Holdisco. De Hoge Raad overweegt:

\footnotetext{
"dat het aan een commissaris eener vennootschap niet vrij stat omtrent den gang van zaken bij die vennootschap aan derden bewust ongerechnaardigde inlichtingen te geven, welke niet anders konden worden opgevat dan als een aansporing om de aandelen dier vennooschap te koopen: dat een dergelijke norm strekt ter bescherming niet alleen van den derde, asan wien de inlichtingen zijn verstrekt, doch ook van den ruimer kring van personen, wa ronder zeker begrepen zijn lichamen, welke door middel wan dien derde als hum vertegenwoordiger aan het verkeer deelnemen:' $\$ 98$
}

Een toepassing van de relativiteitseis, 'Germaanser dan Germaans', aldus Wolfsbergen ${ }^{599}$. Het Duitse recht kende inderdaad geen toepassing met betrekking tot ongeschreven normen (zie $\$ 826 \mathrm{BGB}$ ). Ook Molengraaff signaleert dat de Hoge Raad de relativiteit heeft aanvaard: "De gegeven beslissing is een leerzaam voorbeeld van de betrekkelijkheid van het begrip onrechtmatige daad ${ }^{600}$. Van der Grinten accepteert de nieuwe eis eveneens: 'Voor een actie uit onrechtmatige daad zal derhalve de eisch gesteld moeten worden, dat de handeling onrechtmatig is tegenover de benadeelde ${ }^{601}$. Na tien jaren wordt de relativiteit van de onrechtmatigheid van de Hoge Raad door enkele schrijvers verdedigd: Van Gelein Vitringa, Telders, en Van Der Grinten. In de diverse handboeken worden de uitspraken van de Hoge Raad steeds stelliger als de heersende mening onderschreven. Polak is in zijn bewerking van het handboek van Veegens nog enigszins aarzelend. Deze leer, zegt hij, vindt niet onverdeeld bijval ${ }^{602}$. Hofmann daarentegen onderschrijft onomwonden de mening van de Hoge Raad ${ }^{603}$. Suijling maakt melding van de toets der relativiteit als heersende leer ${ }^{62}$. In de literatuur is het nieuwe vereiste echter niet zonder slag of stoot geaccepteerd. In het volgende hoofdstuk zullen we op die kritiek ingaan: alle commentaar op het vereiste heeft als gemeenschappelijke noemer, dat het relativiteitsvereiste een te grote afwijking met zich meebrengt van de wettekst en systematiek, terwijl ook op andere wijzen wel een billijke aansprakelijkheid bewerkstelligd kan worden.

598. HR 11 mant 1937, NJ 1937, 899.

599. Wolfsbergen, A., Onrechtmatige daad, (1946), p. 94.

600. Molengraff, W.L.P.A., in zijn noot onder HR 24 jaruari 1930, W. 12091 (1930), p. 2.

601. Van der Grinten, W.C.L., Onrechtmatige daad en schade, Nederlands Juristenblad 1939, p. 159.

602. Veegens, J.D. en A.S. Oppenheim, Schets wan het Nederlandsch burgerlijk recht, deel 3 (4e druk, 1934), bewerkt door C.H.F. Pollak, p. 150-151.

603. Hofmann, L.C., Het Nederlandsch verbintemissenreckt, deel 1 (4e druk, 1935), p. 273-274.

604. Suijling. J.Ph., Inleiding tor het burgerlijk recht, 2e stuk, 2e gedealte (2e druk 1936), p. 217.218. 


\section{H. CONCLUSIES RELATIVITEIT}

Een relativering van de aansprakelijkheid uit onrechtmatige daad is als juridische bewerking geen nieuwe toevoeging. Dat blijkt uit uitspraken vóór 1917, en uit de nogal geruisloze presentatie door Drucker en dito eerste introductie door Van Gelein Vitringa. De introductie van de relativiteit vindt plaats als reactie op de absolute onrechtmatigheid. Niet elke overtreding van een wettelijke bepaling behoort tot schadevergoeding aanleiding te geven. Het voornaamste argument is gelegen in eisen van de praktijk: alleen op deze wijze zou een billijke aansprakelijkheid bewerkstelligd kunnen worden. Met tekst en systeem alleen zou geen sluitende argumentatie te verkrijgen zijn.

Voordat het nieuwe vereiste wordt ingevoerd moet met de in de tekst besloten criteria worden geargumenteerd. Besier doet zulks en gebruikt het causaal verband als mogelijke oplossing. In het Franse recht wordt dezelfde constructie door Demogue voorgestaan. Duitsland heeft een precies in de Nederlandse situatie passende toepasbare formule in het $B G B$, en het is dan ook deze formule die door Van Gelein Vitringa wordt gebruikt: 'verstossen gegen ein den Schuizeines Anderen bezweckendes Gesetz'. Telders, de grootste voorstander van het nieuwe vereiste, formuleert aan de hand van het Duitse recht een aantal criteria: naast de vraag of een geschreven norm behalve een algemeen belang, tevens een individueel belang beschermt, formuleert hij een drietal criteria die bij de invulling van de relativiteit wan cle geschreven norm behulpzaam kunnen zijn. Twee daarvan keren terug in de uitwerking van het rellativiteitsvereiste: de geschonden norm moet juist het geschade belang beschermen, en moet juist de persoon beschermen wiens belang is geschaad. Deze zijn rechtstreeks uit de Duitse jurisprudentie en rechtswetenschap afkomstig. De uitbreiding van de relatieve onrechtmatigheid bij schending van ongeschreven normen vindt plaats zonder enig aanknopingspunt in het Duitse recht.

\section{§ 6. Conclusies over de periode van de vrije rechtsvinding (1880-1910)}

\section{A. DE HEERSENDE MENINGEN}

De door Diephuis voorgestane beperkte uitleg blijft voor een groot deel de heersende vitleg van artikel 1403 eerste lid. Toch gaan er stemmen op voor een ruime uitleg, toordat sprake is van een toename van schade door spoorwegen en door auto's. De ruime uitleg hangt samen met het uitblijven van wetgeving. De rechtspraak blijft een beperkte uitleg voorstaan, maar weet door bewijstechnische kwesties de bewijslast van schuld te verlichten. In afzonderlijke wetgeving wordt een veel ruimere aansprakelijkheid vastgelegd. Artikel 2014 kent twee richtingen van uitleg. In de eerste plaats de voortzetting van Diephuis' uitleg, de heersende leer die ook in de jurisprudentie wordt voorgestaan. Deze leer kent voor roerend goed geen onderscheid tussen eigendom en bezit. In de tweede plaats is prominent aanwezig de op Faber en Molengraaff voortbouwende nieuwe uitleg van Scholten. Zij houdt in dat de overdracht van eigendom door een beschikkingsonbevoegde kan geschieden. De feitelijke toestand, het bezitten, legiti- 
meert de vervreemder als rechrhebbende, als eigenaar, en de verkrijger mag daarop afgaan. Een geldige titel is noodzakelijk. De goede trouw, aanvankelijk door Scholten niet vereist, wordt ingebracht op aangeven van Van Oven. De vrijwel unaniem aangehangen mening dat publiek domein aan een eigendom 'iure publico' onderworpen is, wordt abrupt verlaten tegen het einde van de negentiende eeuw. Vanaf dat moment wordt ook publiek domein onderworpen geacht aan privaatrechtelijke eigendom, als weergegeven in het Burgerlijk Wetboek. De eis van de relativiteit ten slotte, wordit vanaf 1928 geïncorporeerd in het Nederlandse onrechtmatige daadsrecht. Voor een dergelijke eis biedt de wet geen directe aanknopingspunten. Toch wordt de relativiteit aanvaard in de rechtspraak van de Hoge Raad en door een aantal schrijvers. Vanaf 1937 wordt de relativiteit ook toegepast op ongeschreven normen.

\section{B. KWANTITATIEVE ANALYSE}

Vergeleken met de voorgaande perioden wordt meer naar Nederlandse bronnen verwezen (van $\pm 50 \%$ naar $70 \%$ ). Naar Belgisch recht wordt iets meer verwezen dan in de voorgaande periode. Iets minder dan de voorgaande periode wordt naar Duits (van $10 \%$ naar $7 \%$ ) en Frans (van $20 \%$ naar $16 \%$ ) recht verwezen. Er is sprake van een flinke afname in het gebruik van het Romeins recht (van $19 \%$ naar $6 \%$ ). Het verschil in gerichtheid op andere rechtsstelsels tussen Themis en het Rechtsgeleerd Magazijn is opmerkelijk. Het Rechtsgeleerd Magazijn laat een grote oriëntatie zien op een verscheidenheid aan rechtsstelsels. In Themis ontbreekt die oriëntatie vrijwel geheel.

\section{ONTLEENDE ASPECTEN}

Duitse en Oostenrijkse economische theorieën bieden de Nederlandse rechtswetenschap een andere grondslag voor aansprakelijkheid. Aan de hand van de uiteenzettingen van de Franse jurist Saleilles en de Belgische jurist Laurent wordt een ruime uitleg van artikel 1403 voorgestaan. In de discussie over artikel 2014 wordt aan het Duitse recht de mogelijkheid ontleend dat 2014 een overdracht kan betekenen door een beschikkingsonbevoegde. De eis van de goede trouw wordt in navolging van het Duitse BGB en de Franse doctrine geaccepteerd. Het onderscheid tussen de beide functies van artikel 2014 wordt ontleend aari de Franse jurist Saleilles. In de discussie over publiek domein wordt aan het Duitse en het Franse recht een nieuwe historische interpretatie ontleend. Het Duitse recht toont dat oude bronnen spreken over 'Eigenthum'; het Franse recht laat zien dat in de Code civil geen onderscheid werd beoogd tussen publiek en privaat domein. Beide visies op de historie boden steun aan de voorstanders van de privaatrechtelijke benadering. Het vereiste van de relativiteit van de onrechtmatige daad wordt voorafgegaan door een aan Demogue ontleende extensieve interpretatie van de causaliteit. De bewoordingen van het relativiteitsvereiste zijn aan de Duitse wetgeving ontleend. Ook de invulling van het vereiste geschiedde aan de hand van het Duitse recht: aansprakelijkheid wordt beperkt naar persoon, en naar het geschade belang. 


\section{RECHTSVINDING}

De belangrijkste wijzen van interpretatie zijn in de eerste plaats de teleologische, in de tweede plaats de historische. Bij elke uitleg staat het maatschappelijk nut, het te bereiken doel voorop; de historische uitleg wordt belangrijker. Beide manieren van uitleg vergemakkelijken het gebruik van andere rechtsstelsels bij de interpretatie van Nederlandse bepalingen. Bij de teleologische uitleg wordt minder aan tekst en systeem van de wet: redelijke oplossingen die voor dezelfde kwestie in een ander rechtsstelsel worden gevonden laten zich makkelijker in de argumentatie gebruiken. Het rechtsvergelijkend argument, dat in de voorgaande periode van het legisme slechts in het verlengde lag van de historische interpretatie, heeft nu een veel zelfstandiger positie ingenomen.

Het gebruik van andere rechtsstelsels was in de periode van het legisme op een aantal manieren mogelijk: als historische interpretatie, als beredenering van het wenselijke recht, als rechtsvergelijkende interpretatie en door de invloed van andere Nederlandse disciplines op het privaatrecht. In de periode van de vrije rechtsvinding zijn vooral van belang de rechtswergelijkende en de historische interpretatie. De rechtsvergelijkende methode wordt bij alle onderwerpen gebruikt. Bij de ontwikkeling van een aansprakelijkheid voor zaken worden Duitse en Oostenrijkse wetgeving gebruikt. De voorgestane ruime interpretatie zou conform die wetgeving zijn. De Franse jurisprudentie en de Franse en Belgische doctrine worden als rechtsvergelijkend argument gebruikt voor een ruime interpretatie van artikel 1403. In de interpretatie van artikel 2014 wordt het Duitse BGB (en een voorgaand ontwerp) gebruikt voor de onderbouwing van de legitimatieleer: overdracht van eigendom door een beschikkingsonbevoegde. De Franse doctrine en jurisprudentie, de Belgische doctrine en de Duitse en Zwitserse wetgeving kennen de goede trouw als vereiste omwille van de billijkheid. De verwijzingen naar deze stelsels dienen als rechtsvergelijkend argument voor de acceptatie van de goede trouw in artikel 2014. Saleilles onderscheid tussen de processuele en de materiële functie wordt sinds Scholten in de Nederlandse doctrine gebruikt. Het Engelse recht biedt een rechtsvergelijkend argument voor het 'om baat'- vereiste. De voorstanders van de privaatrechtelijke benadering van publiek domein gebruiken rechtsvergelijkende argumenten uit Frankrijk en Duitsland ter ondersteuning van hun standpunt. Enerzijds. worden de weinige privaatrechtelijke standpunten aangehaald (Barckhausen, Hauriou), anderzijds worden de Franse en Duitse publiekrechtelijke standpunten besproken en verworpen. Ook aan de rechtshistorische interpretatie komt in deze periode betekenis toe voor gebruik van andere stelsels. De ruime uitleg van een aansprakelijkheid voor zaken gebruikt de interpretatie van het Franse artikel 1384 uit de wat oudere Franse literatuur: de bepaling heeft in ieder geval een 'zelfstandige" betekenis (Toullier), wellicht werd zelfs een vermoeden van schuld aangenomen (Marcadé). Duits rechtshistorisch onderzoek biedt aan de legitimatieleer ondersteuning. In dat onderzoek wordt tot een minder vergaande gelijkstelling van bezit en eigendom geconcludeerd. Voorstanders van de privaatrechtelijke benadering ontleenden aan Frans rechtshistorisch onderzoek 
het ontbreken van een onderscheid tussen publiek en privaat domein in de Franse Code civil.

Andere (rechts)gebieden dienen komen nog steeds naar voren in de beoefening van het privaatrecht. Zo bieden economische theorieën uit Duitsland en Oostenrijk (Steinbach, Mataja) een andere grondslag voor aansprakelijkheid; de rechtstheoretische opvattingen van Geny en Saleilles over de vrije rechtsvinding krijgen ruime aandacht in het Nederlandse privaatrecht.

\section{E. RECHTSVERGELUKING}

Veel explicieter dan in de vorige periode laten civilisten zich uit over het gebruik van andere rechtsstelsels. Rechtsvergelijking komt nadrukkelijk op de voorgrond bij de verantwoording van methoden: voor Molengraaff is het een onmisbare factor bij de uitleg van Nederlandse bepalingen. Ook Drucker spreekt zich uit voor gebruik van andere rechtsstelsels. De Savornin Lohman maakt gebruik van het onlangs afgekondigde Duitse BGB, en commentaren daarop, ondat het 'klaarder inzicht' bieden kan in de eigen Nederlandse wetgeving. Van dit gebruik van andere rechtsstelsels bij de beoefening van het privaatrecht blijkt in de onderwerpen. Aldus is behalve van een toename in 'afzonderlijke' rechtsvergelijking tevens sprake van rechtsvergelijking binnen het Nederlandse privaatrecht zelf. De redenen daarvoor zijn terug te voeren op de toename van het (handels)verkeer, maar ook in de opmars van de rechtsvergelijking als afzonderlijke discipline en in de opkomst van het international privaatrecht. 



\section{Terugtocht van vrije interpretatie,}

\section{bestendiging van de rechtsvergelijking (1910-1940)}

\section{$\S 1$. Inleiding}

\section{A. INLEIDING}

Fockema Andreae vraagt kort na de eeuwwisseling aandacht voor de vraag hoe "het recht op de hoogte van zijn tijd te houden.' Twee wijzen van benadering steli hij zich als oplossing yoor: 'hetzij door gestadige wetsherzieningen, hetzij door vrije hanteering van de wettelijke voorschriften door den rechter $(. .)^{\prime 605}$. In beide richtingen wordt een mogelijke oplossing geboden de kloof tussen recht en volk te overbruggen. In de periode van het legisme ligt de nadruk op wetgeving als wijze van aanpassing van het recht. In de volgende periode van de vrije rechtsvinding ligt de nadruk op de recht. spraak door een vrijheid in interpretatie. Geen van beide benaderingen krijgt de overhand. In deze laatste te onderzoeken periode zijn zowel elementen aanwezig van het legisme als van de vrije rechtsvinding. Het gebruik van andere rechtsstelsels wordt bestendigd. Aan de orde komt: de kritiek op de vrijheid in de rechtsvinding ( $1 . \mathrm{B}$ ); de herziening van de codificatie, en de wet als uitgangspunt voor rechtsvinding ( $8 \mathbb{1}, \mathrm{C})$; het recht als open systeem, en de rechter als uitgangspunt voor rechtsvinding (\$ $1 . D)$; de reactie in Frankrijk en Duitsland op de grotere vrijheid in de rechtsvinding ( $\$ 1 . \mathrm{E})$; en, ten slotte, de kennisname van andere rechtsstelsels in de Nederlandse privaatrechtswetenschap $(\$ 1 . F)$. 


\title{
B. KRITIEK OP DE VRUE RECHTSVINDING: TWEE MOGELIJKHEDEN
}

De vrije rechtsvinding legt het primaat in de rechtsvinding bij de rechter. De rechtspraak neemt die taak niet op zich ${ }^{60 \%}$. De vrijheid zou ook tot rechtsonzekerheid aanleiding kunnen geven. Suijling:

\begin{abstract}
'Slechts in het woorbijgan stip ik aan, dat de school van de wrije rechtsworming ons weer voert natr eene ongewisheid, niet minder groot dan die, waruit bloedige revoluties ons hebben moeten verlossen. Als zij vasten woet kreeg, zouden wij dus indertijd de uitsluitende heerschappij der wet slechts gevestigd hebben on ten slotte, na een tusschenpoos, de willekeur van den vorst door het believen van den rechter of de administratie te vervangen." $60 \%$
\end{abstract}

Volgens Suijling kent de vrije rechtsvinding aan de gerechtigheid ('een menschelijke deugd') een eigenschap toe die zij niet bezit: namelijk dat het tevens een bron van recht is.

\footnotetext{
"Van een menschelijke deugd maken zij een bron van recht; wan een opweiling van het menschelijk gemoed eene openbaring van het staatsgezag. Dat is hunne eerste groote vergissing. "60is
}

De wet en uit de wet afgeleide begrippen (de geest van de wet) zijn voor Suijling de bronnen van het recht. Alleen als er een leemte bestaat beslist de uitlegger naar beginselen die niet uit het recht zijn geput: het geweten, de behoeften van het verkeer of de historische ontwikkeling van het recht: 'Hoe gebrekkig de afzonderlijke artikelen der wetten al geredigeerd mogen wezen, zij bergen in hun schoot, zij het ook nog zo verscholen, de grote beginselen, die het gehele rechtssysteem schragen. ${ }^{609}$

Scholtens kritiek staat hooguit naast zijn waardering. Over Hamaker merkt Scholten op dat hij 'in het wat duffe huis der rechtswetenschap van zijn tijd - waar de wetenschap tot wetgeleerdheid was verschrompeld, een raam openwierp, nieuwe gezichten deed zien, waarvan men geen voorstelling had. ${ }^{960}$ De eenzijdige gerichtheid op vorming wan recht buiten de wet om past niet goed in Scholtens visie. Hij stelt rechtsvinding voor als een vrijheid in gebondenheid aan het rechtssysteem. Alleen in dit systeem kan nieuw recht kan worden gevonden, want 'het nieuwe, het eigene, is door al de gegevens wan dit systeem beperkt. Het nieuwe kan slechts aarzelend worden uitgesproken - er moet plaats voor zijn.' "W11 Het systeem is een open systeem, omdat het 'uit zijn aard

606. Zie daarover Handelingen II (1912); Florijn, E. O.H.P., (1994), p. 67 ev; Fockema Andreae, J.P. Tien jaren rechtspraak wan den Hoogest Radd. Bijtrage tot de leer der wetsuitlegging (1904).

607. Suijling, J. Plh. Het wereldverkeer in het privatrecht (1911), p. 7; zie ook Inleiding tot het burgerlijk recht deel 1 (2e druk 1927) p. 33-34

608. Süjling, J. Ph., (1911), p. 10.

609. Suijling, J. Ph., Inteiding tot het burgerlijk recht, deel i (3e druk, 1948), p. 51-52.

610. Scholten, P., Algemeen Deel (1931). p. 241. Zie over Hamaker hoofdstuk $6 \$ 1$.

611. Scholten, P., (1931), p. 173 
niet af is en niet af zijn kan, omdat het grondslag is van beslissingen, die aan het systeern iets nieuws toevoegen." ${ }^{12}$ Het recht kan dan worden gevonden door gebruik te maken van een veelheid aan interpretatiemethoden. Zo zijn er twee richtingen te ontwaren: de ene richting legt het zwaartepunt meer op de mogelijkheden die een vrijheid in rechtswinding biedt voor de rechtspraak (Scholten); de andere op een grotere gebondenheid aan de wet en herziening van wetgeving (Meijers, Sujling).

\title{
C. HERZIENING VAN DE CODIFICATIE, EN EEN STERKERE BINDING AAN DE WET
}

In 1912 is de overheersende mening in de vergadering van de Nederlandse JuristenVereniging dat de wetgever te traag werkt om een gehele of gedeeltelijke herziening van het BW aan te kunnen. Een vrije rol van de rechter is daarom noodzakelijk ${ }^{613}$. Ook Meijers is in 1910 nog hiervoor geporteerd: 'in vele gevallen dwingt de wet zelf tot deze wijze van rechtspreken, doordat zij voor een bepaald geval geen voldoende regeling geeft, of doordat zij uitdrukkelijk den rechter vrij laat naar eigen zelfstandig oordeel te bepalen, wat als recht gelden zal. ${ }^{, 614}$ Het Duitse, Franse en Zwitserse recht erkennen deze vrijheid van de rechter ten opzichte van de wet, en gaan verder dan het Nederlandse recht. Meijers:

\begin{abstract}
"Weinig blijft er meer over van de trotsche almacht van de allesregelende codificatie, watr de wer erkennen moet, dat op eern zoo uitgebreid gebied als dat der door haar werleende rechten en bevoegdhedien zij niet op strenge handhaving harer eigen regelen mag andringen, maar ook daar de billghkheid of het werkelijke Recht richtsnoer moet blijven. "615
\end{abstract}

Later richt hij zich meer op herziening van wetgeving, in 1922 als voorzitter van de vergadering van de NJV ${ }^{616}$. In 1927 waarschuwt hij tegen een te grote rol van de rechtspraak en tegen te grote verwachtingen van de rechtspraak in de vorming van recht: "slechts binnen enge grenzen, en hoogst fragmentarisch voltrekt zich de hervorming van het recht door de rechtspraak." wit

Het accent ligt bij Meijers later meer op wet. "Aldus blijken van alle kanten de krachten, die in den mensch en in de moderne maatschappij werkzaam zijn, steeds meer de wet tot het hoofdbestanddeel van het burgerlijk recht te maken. Dit echter maakt het voor den staat tot een duren plicht te zorgen dat het wettelijk recht op de hoogte van

612. Scholten, P., (1931), \& 17,

613. Florijn, E.O.H.P., (1994), p. 67 ew.

614. Meijers, E.M., De taak der rechtswetenschap ten aanzien der vrije rechtspratak (1910), in: Verzametde Privaatrechtelijke Opstellen I (1954) , p. 3.

615. Meijers, E.M., Verzamelde Privaatrechtelijke Opstellen I (1910, 1954), p. 8. Bij wijze wan voorbeeld verwijst Meijers naar de Franse rechtspraak inzake 'abus du droit', naar $\$ 226 \mathrm{BGB}$ en de Zwitserse codificatie.

616. Handelingen II (1922), p. 2 ev.; Meijers, E. M., Ontwerp voor een niedw Burgerlijk Wetboek, Toelichting, deel 1, p. 6; Florijn, E.O.H.P., (1994), p. 83.

617. Zie Hondelingen II (1912), p. 143; Florijn. E.O.H.P. (1994), p. 67-70. 
zijn tijd blijft." 618 In 1938 pleit Meijers voor een herziening van het BW. De vele gedeeltelijke herzieningen en aanvullingen die het wetboek heeft ondergaan, hebben veroorzaakt dat er vele vormelijke tekortkomingen zijn ontstaan; het verband van het herziene onderwerp met de overige artikelen gaat teloor; de partiële herzieningen bergen het gevalar in zich dat er ad hoc wordt besloten: 'In het burgerlijk recht en in het bijzonder in het vermogensrecht hangen vele onderwerpen zoo nauw samen, dat het gevaarlijk is de herziening ter hand te nemen alls een toerist, die naar zijn tijd het toelaat nu eens dit, dan weer dat land bezoekt. De vraag dringt zich steeds krachtiger op, of het stelsel zelf, dat wij bij de herzieningen volgen, wel het juiste is.' ${ }^{619}$ Aldus blijft voor Meijers over de algehele herziening van het Burgerlijk wetboek, en hij besluit zijn opstel:

'Laat hetr rechtsgeleerd Nederland een zoodanig voorstel niet te vlug als onbereikbaar ter zijde stellen, laten wij om een koninklijk woord te gebruiken, er eene eerezaak wan maken om datgene aan te vatten, waarin ook een klein volk groot kan zijn. "620.

Ook Scheltema is voorstander van herziening van wetgeving maar meende dat het politiek niet haalbaar zou zijn. 'Laat ons dan vooropstellen, dat het o.i. voor de gemeenschap van het hoogste belang is, een rechtsstelsel te hebben, waarin het geldend recht zo volledig mogelijk in wet of wetboek is "geschreven"' 621, aldus Scheltema in 1938. De waarde van het ongeschreven (rechters) recht naast de wet is geaccepteerd. Toch gaat voor Scheltema de voorkeur uit naar geschreven recht, omdat daarmee duidelijkheid en voorspelbaarheid gediend zijn. Een algehele herziening van het BW schijnt hem onbereikbaar, maar duidelijk is wel dat een uitleg dicht bij het geschreven recht dient te liggen. Zo kiest ook Suijling voor een benadering die op tekst en systeem van de wet is gegrondvest ${ }^{622}$.

618. Mejpers, EM., De beteekenis der burgerlike wet in de huidige samenteving (1927), p. 24 en 26, en in: Verannelde Privaatrechtelijke Opsstellen I (1954), p. 43.

619. Als voorbeeld noent Meijers hier de in artikel 25 Motor - en Rijwielwet, later 31 Wegenwerkeerswet opgenomen aansprakelijkheid wor auto-ongellukken, terwijl artikel 1403 lid 1 eendergelijke aansprakelijkheid had kunnen omvatten. Meijers, E.M., Gedenkboek Burgerlijk Wetboek 1838-1938 (1938), p. 58 en p. 60 . Zie voorts zijn mening over het relativiteitsvereiste: hij is om wetssystematische redenen tegen een dergelijke vergaande interpretatie, maar zal in zijn ontwerp voor een nieuw BW voor het vereiste wel een plats inrumen. Zie $\$ 5$.

620. Meijers, E.M., Onwerp voor een Nienw Burgertijk Werboek (1954), p. 21; zie ook Lokin, J.H.A., Waarin ook een klein volk groot kan zijn, Tekst en witleg (1994), p. 138 (oorspronkelijk in: Nederlands Tyjdschrift voor Burgerlijk Rech 1992, p. 2-12).

621. Seheltema, F,G., De toekomst van her burgerlijk wetboek, Rechtsgeleerd magazijn 1938, p. 569.

622. Van Diewot constateert dat deze theoretische verantwoording van methode niet zeer owereenkont met Sujjlings inhoudelijke behandeling: daar gebruikt hij eveneens rechtspraak en doctrine. Van Dievoet, E. (1943), p. 194. Eenzelfde conclusie volgt op grond van dit onderzoek. Suijling blijkt tot werrassende standpunten in staat. 


\section{RECHT ALS OPEN SYSTEEM: SCHOLTENS METHODE}

De tegenstelling tussen Meijers en Scholten in het Gedenkboek BW 1838-1938 is bekend: terwijl Meijers herziening voorstaat, karakteriseert Scholten het honderd jaar oude Burgerlijk Wetboek als een 'rustig bezit' en een 'oud, groot huis", waarin de jurist vertrouwd is en zich thuis voelt. Deze tegenstelling is nogal sterk benadrukt maar later terecht gerelativeerd ${ }^{623}$. Ook Scholten onderkent de gebreken van het Burgerlijk Wetboek, maar gaat ervan uit dat de gebreken inherent zijn aan een codificatie: "Het logische element in het recht maakt, dat wij kunnen systematiseren en moeten - het irrationele, historische, dat dit systematiseren nooit volledig slaagt. Het systeem ligt in den aard van het recht. Maar het omvat het recht niet." ${ }^{224}$ Het is Scholtens open systeem van het recht, dat zijn milde houding tegenover het oude Burgerlijk Wetboek kan verklaren. Ondanks alle gebreken bevat het Burgerlijk Wetboek 'het gemeen recht, de beginselen van rechtsverkeer: huwelijk, ouderlijke macht - eigendom - contract schadevergoeding bij onrecht - vererving. Daarin zit veel sterker blijvend element, dan in de details.' Zonder politieke drang is herziening bovendien onwaarschijnlijk.

Scholten presenteert in zijn Algemeen Deel een methode van rechtsvinding die zorgvuldig het midden houdt tussen de vrije rechtsvinding en het legisme. Enerzijds geeft hij aandacht aan de 'klassieke' methoden van uitleg zoals de grammaticale, de systematische, de (twee) historische, vervolgens de 'sociologische of teleologische' interpretatie (uitlegging naar het doel van het voorschrift, naar het werband met de maatschappelijke toestanden), de analogie en rechtsverfijning door gebruik van rechtsbeginselen. Scholtens systeem van het recht wordt door hem als een open systeem betiteld: niet alleen door een logische redenering wordt het recht gevonden. Er bestaat 'altijd het oordeel van hem, die beslist, dat mede de toepassing bepaalt'. Wetgever en rechter, de twee machten die de legisten zo gescheiden zagen, vertonen in Scholtens theorie meer overeenkomst, zo 'dat bij den eerste de vrijheid primair is, bij den tweede de gebondenheid, de eerste in de schepping van het nieuw toch altijd gebonden blijft aan che handhaving van het oude, de tweede in de handhaving toch altijd weer iets nieuws aan het bestaande toevoegd." ${ }^{25} \mathrm{Het}$ is door de waardering ('in de beslissing zit ten slotte altijd een sprong') dat de rechter dat nieuwe aan het recht toevoegt. De erkenning van de aanwezigheid van deze 'sprong' is een erfenis van de vrije rechtsvinding. Met behulp van deze methoden moet de beslissing, het nieuwe worden verantwoord. Bij Scholten ligt het accent bij de rechtsvinding meer op de interpretatievrijheid van de rechter. Die vrijheid

623. Scholten, P., Gedenkboek Burgertijk Wetboek 1838-1938, (1938), p. 30-31; daartegen: Meijers, E.M. (1938), p. 61. Zie Lokin, J.H.A., en W.I. Zwalve, (1992), p. 287; Florijn, E. O.H.P., (1994) p. 87.

624. Scholten, P., De codificatie-gedachte voor honderd jaar en thans, Gederikboek Burgerlijk wertboek 1838 1938 (1938), p. 24.

625. Scholten, P.x (1931), p. 102-103. Zie ower Scholten, het legisme en de wrije rechtsvinding ook: Corjo Jansen en Mea de Ruiter; Het Algemeen Deel; Asser-Scholten en Asser-Vranken in rechtshistorisch perspectief, Recht en Kritiek 22 (1996), p. 5-26; Van Dievoet, E., (1943), p. 195-202. 
bij de interpretatie wordt in het nieuwe Burgerlijk Wetboek opgenomen ${ }^{626}$. Het nieuwe BW kent een groot aantal vage begrippen en open normen, die aan de rechter een grote mate van vrijheid laten; een vrijheid binnen het systeem van de wet ${ }^{627}$.

\title{
E. DE REACTIE OP VRIJE INTERPRETATIE IN DUITSLAND EN FRANKRUK
}

\section{Ontwikkelingen in Frankrijk}

In de Franse privaatrechtsgeschiedenis wordt de strijd tussen voorstanders van herziening van het burgerlijk recht door de wetgever en voorstanders van een grotere vrijheid van interpretatie door de rechter (Geny en Saleilles) duidelijk in het voordeel van de tweede groep beslist. Een nieuwe Code civil is er, ondanks enige voorbereidende werkzaamheden door enkele commissies, niet gekomen ${ }^{628}$. Ballot-Beaupré verwoordde de heersende mening, de 'libre recherche scientifique', zoals die door Geny en Saleilles werd voorgestaan, tijdens het eeuwfeest van de Code civil:

\begin{abstract}
'(...) j'estime que le juge, alors, a les pouvoirs d'interprétation les plus étendues; il ne doit pas s"attarder à rechercher obstinément quelle à êté, il y a cent ans, la pensée des auteurs du Code en rédigeant têl ou tel article, il doit se demander ce qu'elle serait si le mëme article était aujourd hui rédigé par eux; il doit se dire qu'en présence de tous les changements, qui, depuis un siècle, se sont opérés dans les idées "dans les moers, dans les institutions, dans l'état économique et social de la France, la justice et la raison commandent d' adapter liberalement, humainement, le texte aux réalinés et aux exigences de la vie moderne." 229
\end{abstract}

Planiol, Demogue en Capitant kennen allen in hun conmentaren op de Code civil, de rechtspraak en een grotere vrijheid in de rechtsvinding, een belangrijke plaats toe ${ }^{630}$. Zo stelt Planiol: 'A la longue, il s'est formé ainsi une tradition doctrinale qui, malgré son originalité, n'avait pas de valeur pratique. J'ai jugé qu'il était inutile de maintenir ce divorce. A quoi bon enseigner encore, comme étant la formule du droit français actuel, des théories qui ne sont ni écrites dans les lois, ni admises en jurisprudence?' ${ }^{631}$ De rechtswetenschap moet aandacht schenken aan de jurisprudentie. De rechtsprak is wrij in haar interpretatie, maar deze vrijheid is niet zo groot als die van de rechtswetenschap: die laatste is immers geheel theoretisch, de eerste heeft een oplossing te vinden 'la plus juste et la meilleure' in het voorliggende geval. De rechtsvinding

626. Meijers, E.M., Ontwerp voor een Nieuw Burgerlijk Wetboek, Toelichting, (1954), p. 9.

627. Zie daarover Harkamp, A.S., Wetsuhleg en rechtstoepassing na de invoering van het niewwe Burgerlijk Werboek (1992), met name hoofdstuk 7 .

628. Zie Lokin, U.H.A. en W.J. Zwalve (1992), p. 183; Colin, A. en H. Capitant, Cours élementaire de droil civil Fronçais (4e dnuk 1923), p. 20-24, warin een zekere voorkeur voor een gehele herziening uitgesproken wordr; Ghestin, J., en Goubeaux, G., (1990), nr. 153.

629. Als gecteerd in: Wan Dievoer, E., (1943), p. 126.

630. Van Dievoet, E. (1943), p. 124; Coing, H., (1989), p. 37.

631. Ook omdat de rechtenstudie bij de praktijk aan zow moeten sluiten dient zij veel meer aandacht aan de jurisprudentie te schenken. Planiol. M., Traité élémentaire de droit ciwil deel 1 (8e druk, 1920), p. ix. 
door de rechtswetenschap ' $n$ 'a d"autre utilité que la conviction qu' elle peut faire pénétrer dans l'esprit du juge.' Welke wijzen van rechtsvinding zijn er in Planiols beschrijving? De wijze varieert naarmate de wet onduidelijker is, zwijgt, of tegenspraak vertoont. Vrijheid is er met name in het geval de wet zwijgt. Dan kan de uitlegger de grootste vrijheid nemen en interpreteren naar analogie of a-contrario. 'l'Esprit général des lois' en 'les principes généraux du droit' moeten in acht genomen worden. Geenszins verdwijnt de logische methode geheel naar de achtergrond, maar ' (...) elle doit être tempérée par des considérations d'utilité et d'équité. "Er moet altijd voor worden gewakt dat een strikt logisch uitgelegde wet zich niet van zijn eigen doel verwijderd, een doel 'qui est le bien social ${ }^{\prime}{ }^{632}$. Capitant wijst op de nadelen die kunnen kleven aan een grotere rechterlijke vrijheid van interpretatie. Hij wijst op het gevaar van deze vrijheid. De rechtspraak kan het geschreven recht aanpassen maar dat moet met voorzichtigheid gepaard gaan: 'Elle ne révolutionne pas; elle adapte. Et par elle, en conséquence, le progrès juridique se développe d'une manière moins brusque, dans une rythme plus naturel (..) et suivant la ligne de la tradition." ${ }^{633}$ De interpretatievrijheid bestaat voor elk van de genoemde schrijvers, het is niet meer de vraag of er vrijheid is, maar hoe groot deze vrijheid mag zijn. Soms was zij zeer groot. De toepassing die de rechtspraak heeft gegeven aan artikel $1384 \mathrm{Cc}$ wordt door Ghestin genoemd als het meest sprekende voorbeeld ${ }^{634}$.

De rechtsvergelijking komt in deze periode sterk op. De Parijse hoogleraar Saleilles, veelvuldig in de Nederlandse rechtswetenschap aangehaald, bezet vanaf 1892 de eerste leerstoel voor rechtsvergelijking, "de droit civil approfondi et comparé." Een gemeenschappelijk recht, of een unificatie van verscheidene rechtsstelsels wordt (door onder meer Saleilles en Lambert) als doel gezien op het rechtsvergelijkende congres dat in 1900 te Parijs wordt gehouden ${ }^{635}$. Rechtsvergelijking houdt zich bovendien met meer bezig dan met wetsvergelijking:

"I en est tout naturellement arrive a considérer que le droit comparé nee pouvait pass se limiter - la simple correspondance dune règle de droit national aves une règle de droit étranger. Derrière la règle de droji formulée par la loi, il s"est efforcé de rétrouver l'espril de la législation toute entiere dans laquelle cette règle de droit doit prendre place. Conscient de lavolution d'une doctrine qui se dégageait, à la fin du XXXène siécle, de la simple exégèse pour s's sppliquer à la critique des textes et à la prise en considerration des solutions jurisprudentielles, ill a voulu, dans le domaine du droit comparé, $s^{\circ}$ attacher également aux solutions de la jurisprudence

632. Planiol. M., (1920), p. 86.

633. Colñ. A. en H. Capitant. Cours élëmentaire de üroir civil Franlcais (4te druk, 1923), p. 36.

634. Ghestin, J. en Goubeaux, G., (1990), nr. 151; zie over de aandacht die de Franse rechtspraak over artikel 1384 in de Nederlandse literatuur ontving: hoofdsuk 6 \& 2.C.

635. Zie daarover Marc Ancel $\mathrm{La}$ tendance universaliste dans la doctrine comparative Françase au debut du xxême siecle, Fessischrift fü Ermst Rabel, deel 1 (1954), p. 17. De volgende jaren wordlen door Sauveplanne gekarakteriseerd door toename en verdieping van de rechtsvergelijking. Sauveplanne, J.G., in: Kokkini-datridou, D. Een inleiding tot het rechsvergelijkend onderzoek, (1988), p. 46-47 
comme aux besouns de la pratique, et rechercher, derière cette pratique et eette jurisprudence, les fraisons profondes des solutions légisilatives." 636

Deze verandering in de wijze warop het recht wordt vergeleken loopt parallel aan de wijze van beoefening van het privaatrecht: van een op tekst en systeem van de wet gerichte uitleg naar een uitleg waarbij de maatschappij wordt betrokken. Ook civilisten ruimen een plaats in voor rechtsvergelijking in de beoefening van het privaatrecht:

\begin{abstract}
'Notons, en passant, une nouvalle fonction assignée à la science juridique par des écrivains, plus audacieux encore. Cette fonction consisterait à tirer de l'étude des législations êtrangères, et de leur rapprochement avec la nôtre, les grandes liggnes d'un Droit commun législatif qui, en attendant la formation de groupements nouveaux de peuples, plus êtendus que nos patries actuelles, écláirerait l'interprétation des diverses liois nationales de manière à leur faire produire ensemble des solutions aussi conformes que possible à la moyenne des aspirations communes au monde civilisé. Il est évident que, si la Doctrine du XXe siècle pouwait jamais jouer un rôte aussi élevế, sà mission acquerait une ümportance et une grandeur qui ne lui laisseraient rien à envier à nos grands jurisconsultes d'auirefois. ${ }^{637}$
\end{abstract}

\title{
2. Ontwikkelingen in Duitsland
}

De Freirechtschule kent een grote aanhang rond de eeuwwisseling. Een grote nadruk wordt op de rechtsvorming door de rechter gelegd ${ }^{638}$. In diezelfde tijd, waarin eerst de Interessenjurisprudenz, wat later de Freirechtschule opkomen, wordt het BGB tot stand gebracht. De combinatie van een privaatrechtelijke codificatie met een rechtswetenschap die een weinig starre dogmatische houding heeft is een illustratieve combinatie. Zij laat zien dat een zeer op de wettekst gerichte wetenschap niet het noodzakelijk gevolg behoeft te zijn van die codificatie. Niets was minder waar: het bleek reeds uit de houding van de juristen uit de Freirechtschule zoals Erlich, die, we zagen het in het vorige hoofdstuk, bepaald niet tegen een codificatie waren, maar tegen een starre dogmatische rechtswetenschap ${ }^{639}$. Schlosser ziet een eerste periode die nog zeer door het positivisme wordt ingekleurd, en een sinds 1920 toenemende invloed van Interessenjurisprudenz en Freirechtschule ${ }^{(4)}$. De combinatie van een nieuwe codificatie en een ruime uitleg komt het meest fraai tot uiting in het in 1912 totstand gebrachte Zwitserse Zivilgesetzbuch. Daarin wordt aan de rechter een expliciete vrijheid gegeven in de uitleg: de rechter mag in geval van leemten die regel toepassen die hij als wetgever zou opstellen. Artikel $1 \mathrm{ZGB}$ :

636. Ancel, M., (1954), p. 20.

637. Colin, A. en H. Capitant (1923), p. 34. Iets minder optimistisch is Boulanger: Ripert G., en Boulanger, J., Traité ékmentaine de droir civil de Planiol, deel 1 (5e druk, 1950), nr. 176.

638. Zie Köbler, G., Deutsche Rechrgeschichte (5e druk, 1996), p. 189.

639. Zie hoofdstuk 6 \& 1.D.2.

640. Schlosser, H., (1985), p. 136-137; Wieacker, F., (1967), p. 514-515. 


\begin{abstract}
Das Gesetz tindet auf alle Rechtsfragen Anwendung, fur die es nach Wortaut oder Auslegung eine Bestimmung enthält.

Kann dem Gesetze keine Worschrift entnommen werden, so soll der Richter nach Gewolmheitstecht und, wo auch ein solches fehlt, nach der Regel entscheiden, die er als Gesetzgeber aufstelllen würde.

Er folgt dabei bewahrter Lehre und Überlieferung.
\end{abstract}

Een van de redenen voor de opname van deze bepaling is de ervaring uit het verleden, die leerde dat overschatting van de wet tot merkwaardige interpretaties aanleiding geven kon: "jene Gesetzesgläubigkeit, die dem Gesetz eine unbegrenzte Leistungsfähigkeit zumutet und die deshalb "alles und jedes und wäre es mit dem bedenklichsten Interpretationskünsten aus dem Gesetze abzuleiten" unternimmt." ${ }^{411}$ Vanaf 1933 wordt de mogelijkheid van een ruime interpretatie door de nationaal-socialistische dictatuur misbruikt ${ }^{642}$. Beschouwingen in algemene zin over de Duitse rechtswetenschap in die periode kunnen hier verder achterwege blijven. Ook in Duitsland komt de rechtsvergelijking na $1900 \mathrm{op}$. Een buitengewoon grote invloed wordt op dat gebied uitgeoefend door Rabel, de grondlegger van de moderne Duitse rechtsvergelijking ${ }^{643}$.

\title{
F. ANDERE RECHTSSTELSELS EN KENNISNAME IN NEDERLAND
}

In Themis maken de verwijzingen naar Nederlandse bronnen het leeuwedeel uit: $71 \%$. Naar Franse bronnen wordt in $11 \%$ verwezen, naar Duitse in $9 \%$, naar Romeins recht in $4 \%$ en naar andere stelsels, te weten België en Oostenrijk, incidenteel, respectievelijk 3 en 6 keren $^{644}$. In een deel van Suijlings Inleiding wordt in $69 \%$ verwezen naar een Nederlandse bron. Naar Frans recht verwijst hij in $16 \%$ van de gevallen; naar Duits recht in $10 \%$, en naar Zwitsers recht in $5 \%$. In twee jaargangen (1929 en 1930) geeft Themis 24 artikelen, waarvan er 1 gericht is op het Duitse recht. Van de 57 aankondigingen en besprekingen in hetzelfde tijdschrift zijn er vijf die betrekking hebben op Duits recht. Het Rechtsgeleerd Magazijn geeft de volgende aantallen: 20 artikelen, waarvan 1 betrekking heeft op een ander rechtsstelsel; 107 besprekingen en aankondigingen, waarvan 13 betrekking hebben op boeken die op het Duitse recht zijn gericht; 5 op het Franse en 1 op het Belgische recht.

\section{Rechtsvergelijking als afzonderlijke discipline}

De rechtsvergelijking ontstaat, na een aarzelend, en hoofdzakelijk wetsvergelijkend begin, eerst echt na 1900 als een afzonderlijke discipline. Dat geschiedde in Frankrijk,

641. Egger, A., Komnentar zum Schweizerischen Zivilgesetzbuch. Einleitung und Personenrecht (1930. 1978), p. 45; Schlosser, H., (1985), p. 147.

642. De zogenaamde 'unbegrenzten Auslegung'. Zie Köbler, G. (1996), p. 229, Schlosser, H. . (1985), p. 138-139; Wieacker, F., (1967), p. 514-515.

643. Max Rheinstein in: Festschriff fur Ernst Rabel, deel 1 (1954), p. 1.

644. Zie bijlage. 
in Belgiè, in mindere mate in Duitsland, maar ook in Nederland. Opvallend is de parallel tussen de verandering in de methoden van rechtsvinding en de verandering van de rechtsvergelijking. Beide richten zich meer op het recht in de praktijk ${ }^{64}$. Over de methoden van de rechtsvergelijking laten Hoetink, Winkel en Kisch zich uit ${ }^{646}$. Uit hun geschriften spreken dezelfde kwesties die sinds de eeuwwisseling rechisvergelijkers had beziggehouden: de wending wan de rechtswetenschap naar de maatschappij komt aan de orde, maar ook een mogelijk gemeenschappelijk recht. Zo bij Hoetink: 'Maar alleen de diepere, werkelijk begrijpende kennis wan vreemde rechten kan ons de oogen openen voor de meest algemeene grondlijnen en de overal aanwezige beginselen die aan alle menschelijke rechtsvorming ten grondslag liggen.' Hoetink spreekt over 'gemeenschappelijke boventijdelijke grondstructuren van alle recht.' Een van Winkels doelen van de rechtsvergelijking is een 'unificatie aller rechtsstelsels' en bovendien moet de beoefening geschieden in samenhang met sociale verschijnselen. Winkel heeft oog voor de aanwezigheid van rechtsvergelijking in het gehele recht: de wetgever maakt ervan gebruik en in de doctrine wordt naar buitenlandse ontwikkelingen verwezen. Kisch is wat genuanceerder over die unificatie van rechtsstelsels:

\footnotetext{
"Een goed is zij daar, waar de diversiteit des rechts als een euvel wordt gevoeld, en her recht niet sterk national is gebonden. Een kwaad is zij daar, waar het recht sterk nationaal is gebonden. en de diversiteit des rechts als euvel niet worit gevoeld.
}

Aan rechtsvergelijking als afzonderlijke discipline wordt aldus ook in Nederland gedaan. Maar, anders dan bijvoorbeeld in Frankrijk, vooralsnog niet in georganiseerd verband: een Nederlandse vereniging voor rechtsvergelijking wordt eerst in 1968 opgericht. Leerstoelen voor internationaal privaatrecht worden onder meer door Meijers en door Suijling bezer ${ }^{647}$.

\section{Rechtsvergelijkende argumenten}

Maar er is meer dan een afzonderlijke discipline van rechtsvergelijking, Winkel constateerde de aanwezigheid van rechtsvergelijking in het privaatrecht. De opkomende beoefening van de rechtsvergelijking gaat gepaard met een toename van gebruik van rechtsvergelijking binnen de privaatrechuelijke discussie. Het afzonderlijke rechtsvergelijkende argument krijgt vaste woet in het Nederlandse privaatrecht. Af en toe stuit het nog op grote weerstand, zoals bij Wtewaal in de discussie over artikel 2014. Voor hem

645. He gehele recht lijkt in deze verandering betrokken, waaronder de rechtsvergelijking. Deze constatering biedt meer inzicht dan de beschrijwing alsof de rechtsvergelijking zich geïsoleerd veranderde onder invloed van die sociologische notie. Zie Sauveplanne in: Kokkini-Iatridou, D., (1988), p. 46-47.

646. Hoetink, H.R., Over het werstaan wan wreend wecht (1929), in: Ankum, J.A., e.a. (ed), Rechtsgeleerde opstellen (1982), p. 21-61, met name p. 50; Winkel, H., De methode der rechiswergelijking (1936); Kisch, I., Rechtsvergetijking en handelsrecht (1935). p. 5.

647. Zie Steenhoff, GJ W. De wetenschap van her internationaal priwaatrecht tussen 1862 en 1962 (1994), p. 190 . 
was een beroep op het andere, moderne recht 'waardeloos' 648 . Veel vaker wordt het beroep op ander recht aanvaard, en geaccepteerd of ten minste serieus besireden. Die uiteindelijke acceptatie blijkt fraai uit het gebruik dat werd gemaakt van rechtsvergelijking bij de totstandkoming van het nieuwe Burgerlijk Wetboek. Bij de beslissing over vrijwel ieder punt heeft rechtsvergelijking een rol gespeeld ${ }^{649}$. Ook in dit onderzoek wordt veel van andere stelsels gebruik gemaakt. Door Suijling bijvoorbeeld wordt Planiols onderscheid tussen gevaarlijke en niet-gevaarlijke zaken in artikel 1403 gelezen. De ruime uitleg van artikel 1384 in de Franse rechtspraak wordt als mogelijkheid aangereikt voor een ruime uitleg van artikel 1403. In het Franse recht worden door Meijers medestanders gevonden voor zijn uitgangspunt dat bezit van roerend goed gelijk is aan eigendom. Scholten vindt in het Franse recht ondersteuning voor aspecten van de legitimatieleer. Het privaatrechtelijk eigendomsbegrip vindt onderbouwing door gebruik van het Franse en Duitse recht. Meijers over Planiols handboek: 'Planiols werk getuigt op bijna iedere bladzijde van een oorspronkelijken, historischen of critischen kijk op de rechtsinstellingen. Oorspronkelijkheid heb ik in het werk van Colin et Capitant tot op heden weinig kunnen ontdekken. " 550 Van beide commentaren wordt door Meijers (en anderen) ruim gebruik gemaakt. De oriëntatie van de Nederlandse civilist op de buitenlandse rechtsstelsels is groot. Volgens Kisch ligt daarin juist de reden dat pas zo laat een Nederlandse vereniging voor rechtsvergelijking is opgericht. 'Thus, the Netherlands lawyer, for five-score years, has been a comparatist sans le savoir.' ${ }^{651}$ Het gebruik van andere rechtsstelsels in de privaatrechtelijke doctrine krijgt steun door de bestendiging van de rechtswergelijking.

\section{$\S$ 2. Aansprakelijkheid voor zaken}

\section{A. SCHULD ALS DOGMATISCH UTTGANGSPUNT?}

De grondslag van de aansprakelijkheid, door Scholten en Bruins gezien in het economische voordeel van de schadeveroorzakende handeling, of in het veroorzaakte gevaar, wordt door het wetsontwerp Regout expliciet in schuld gelegd. In het wetsontwerp voor de onrechtmatige daad (1911) wordt ook voor de aansprakelijkheid voor zaken een aparte bepaling opgenomen, die geldt voor alle zaken ${ }^{652}$. In de MvT wordt dit schuldbe-

648. Zie \$ 3.B.

649. Meijers, E.M., Ontwerp voor een nieww Burgerlijk Wetboek, Toelichting (1954), p. 8: Florijn. E.O.H.P., (1994), p. 112-113.

650. Meijers, E.M., Nieuwere burgerrechtelijke literatuur. WPNR 2737 (1922), p. 265.

651. Kisch. I., By way of introduction, in: Netherlands reports to the whith international congress of comparative law, Pescara 1970.

652. Weekblad van het Recht. 9099 (1911), p. 1. Artikell 1406 wan dat ontwerp luidde; Indien schade wordt toegebragt door een dier of door eenige andere zaak, dan berokkent degene, aari wiens schuid te wijten is, dat de schade toegebragt wordt, zelf die schade door eene onregtmatige daad. De eigenaar wordt, behoudens bewijs van het tegendeel, geacht de schade door zijne schuld te hebben be rokkend. Met den 
ginsel uitdrukkelijk verwoord en wordt overwogen dat "(..) die aansprakelijkheid behoort te drukken op hem, dan wiens schuld te wijten is, dat het bepaalde rechtsobject de schade veroorzaakt heeft (..)' Daarbij is sprake van een bewijsvermoeden. In het parlement wordt dit voorstel met veel kritiek onthaald: gewezen wordt op Scholten en Bruins, die beiden wijzen op de mogelijkheid van een schadevergoedingsplicht buiten schuld. De regering voelt niets voor een aansprakelijkheid buiten schuld: 'eene dergelijke bepaling (komt), voor zoover bekend, nergens ter wereld in eenige wetgeving van een beschaafd land voor.' Een uitzondering maken voor bijzondere gevallen, zoals schade veroorzaakt door auto"s komt de regering niet noodzakelijk voor, "wanneer de wetgever het oog gevestigd houdt veeleer op de gebleken behoeften van het eigen land dan op de vruchten van buitenlandsche legislatieve werkzaamheid. ${ }^{653}$ Eyssell keert zich eveneens op felle wijze tegen een andere grondslag voor aansprakelijkheid. Daarbij zet hij zich zeer sterk af tegen de Franse uitleg in de rechtspraak van artikel 1382 (en $1384 \mathrm{Cc})$ :

'Zoo wak uit cen zamenloop van onstandigheden, waarin doodrustige voorbiggangers betrokken raken, schade geboren wordt, is niet meer de vraag of zoo'n woorbigganger eenige schuld aan die schade heeft, maar wordt in de doctrine en jurisprudentie slechts leukjes gevraagd: a-t-il créé un risque? en gelukt het eenen handigen eischer den regter te beduiden dat 's mans aanwezigheid op den weg een "risico" woor den beschadigde heeft opgeleverd, dan wordt die bloote aanwezigheid, als ware de man een woeste paardrijder of een niets ontziende chauffeur, onder het bereik van art 1382 gebrachi; wonnissen waarvoor ik geene andere bestempeling dan die van juridische uitspattingen weet, komen tegenwoordig steeds vaker in de Fransche verzamelingen van regtspraak voor." 694

In de Franse doctrine vindt Eyssell steun bij Planiol: een andere grondslag dan schuld "est incompatible avec les textes actuels du Code." ${ }^{655}$ Ook de Duitse jurisprudentie 'maakt kromme sprongen..' volgens Eyssell. 'Zonder schuld is eene onregtmatige daad onbestaanbaar." 556

Een omkering van bewijslast wordt steeds meer voorgestaan, hetzij vervat in een algemene bepaling, zoals in het ontwerp Regout, hetzij in afzonderlijke wetgeving, toegesneden op bijzondere zaken. Deze ontwikkeling is vergemakkelijkt door de voorbeelden van verlichting van het schuldvereiste door wetgevingen van omringende landen, door de ruime uitleg van Laurent en in de Franse jurisprudentie, en door de pogingen een

$652, \rightarrow$

behoudens bewijs van het tegendeel, geacht de schade door wijne schuld te hebben berokkend. Met den eigenaar wordt te dezen opzigte gelijk gesteld de laatste eigenaar van eenige zaak, die ten tijde, dat de schade toegebragt werd, ast niemand toebehoorde.

653. Weekblad wan het Recht 9459 (1913) „p. 1 .

654. Eyssetl. A.Ph.T. Het wetsvoorstel ontrent de onregtmatige daad en de regtszekerheid, Themis 1911 . p. $601-602$.

655. Planiol, M., Thatététémentaire de droit ciwil, deel 2 (5e druk, 1909), p. 315.

656. Eyssell, A.P.Th., (1911) p. 568-617. p. 601-604. 
andere grondslag voor de onrechtmatige daad te vinden. Behalve deze oplossing stelt Suijling een andere weg voor. Een weg die eveneens het midden houdt tussen een enge uitleg waarin schuld door de gelaedeerde bewezen zal moeten worden, en een ruime uitleg, zoals in de Franse jurisprudentie wordt aangehangen. In Suijlings oplossing, waarin artikel 1403 een centrale rol speelt, vallen niet alle zaken onder de omkering van de bewijslast, maar alleen de gevaarlijke zaken.

\section{B. DE BESTAANDE WETGEVING RUTM UTTGELEGD?}

\section{In het Nederlandse recht}

a. De terughoudendheid in de ruime uitleg

Voor alles wordt in Nederland gepleit voor een zekere terughoudendheid in de ruime uitleg.

\footnotetext{
'Men zal eerder tot de conclusie moeten komen, dat, indien men, voor de aansprakelijkheid woor auto-ongelukken den bewijslast wenscht om te keeren, het beter is dit ais een uitzonderingsgeval uirdrukkelijk te bepalen, zooals dit bij ons is geschied, dan de oplossing te zoeken in een voor vele gevallen gewrongen toepassing van art. $1403 .^{\cdot 657}$
}

De leer waarbij de eigenaar van een zaak ongeacht schuld aansprakelijk zou zijn is "niets minder willekeurig dan het eenvoudig laten van de schade voor rekening van hem, dien zij heeft getroffen," zo wordt in navolging van Esmein opgemerkt ${ }^{658}$. Van Oven meent dat een algemene aansprakelijkheid zonder schuldvereiste ten koste gaat van de rechtvaardigheid ${ }^{659}$. Er zijn echter wel bepaalde zaken die gevaarlijk zijn, en daarvoor mag afgeweken worden van het schuldbeginsel in afzonderlijke wetgeving. Daar moet het beginsel van gevaarzetting uitgangspunt zijn voor ansprakelijkheid ${ }^{(6, t)}$. De reserve ten aanzien van een vrije toepassing van artikel 1403 is algemeen ${ }^{661}$. Deze terughoudende uitleg reflecteert de wijze waarop in de rechtspraak artikel 1403 werd uitgelegd: in de overgrote meerderheid wan de uitspraken wordt voor het aannemen van aansprakelijkheid op grond van 1403 gewoon schuld vereist. Maar in vele gevallen

657. Nog cens de aansprakelijkheid bij automobiel-ongelluken, Weekblad wan het Recht 11732 (1927), p. 8. Zie ook: Rechter of wetgever, Weekblad wan het Recht 11910 (1929), p. 1 .

658. Nieuwe Fransche rechtsprak over aansprakelijkheid voor zaken, die men onder zijn opzicht heeft, Nederlands Juristenblad 1929, p. 233.

659. Van Oven, J.C., Schade veroorzaakt door dieren, gebouwen en andere zaken, Nederlands Juristenblad 1926, p. 109. Zie hoofdstuk 6 8. 7.D; HR 6 maart 1924, NJ 1924, p. 507.

660. Van Oven, J.C., (1926), p. 115-117

661. Oppenheim, A.S., in een bewerking van Veegens, J.D., Schets vam het Nederlandsch Burgerlijk Recht, deel 3 (2e druk, 1917) p. 126. Zo Polak, C.H.F, in een bewerking wan Weegens, I.D., en A.S. Oppenheim, Schers wan het Nederlandsch Burgerlijk Recht, deel 3 (4e druk, 1934); Anten, J.H.A.M.. Rondom artikel 1403 BW, WPNR 3206 (1931): zo ook De Savornin Lohman. W.H., Verklaring wan het Burgerlijk Wetboek, deel 4 (2e druk, 1907), p. 325 . 
wordt het bewijs van die schuld gemakkelijk geleverd: uit de gestelde feiten volgt vaak de schuld ${ }^{662}$ ?

\title{
b. Suijlings middenweg
}

Van een terughoudendheid blijkt ook bij Suijling: de ruime Franse uitleg gaat hem te ver: '(. ) zoo wordt men echter onrechtvaardig tegenover den gebruiker". Hij laat zien dat een middenweg mogelijk is tussen de heersende Nederlandse uitleg, watabij schuld aangetoond zal moeten worden door de benadeelde, en de Franse jurisprudentie, waarbij een omkering van de bewijslast het uitgangspunt is. Suijling maakt een onderscheid tussen van nature gevaarlike zaken of zaken die alleen in gevaarlijke toestand gebruikt kunnen worden aan de ene kant, en zaken die alleen gevaarlijk worden door onoordeelkundig gebruik. Wanneer sprake is van cen zatk van de eerste categorie, is het yoor de eiser makkelijker de vordering te staven. Hij hoeft slechts te bewijzen dal schade is geleden door de 'gemeengevaarlijke zaak' en dat de aangesproken persoon het toezicht over de zaak had. De vordering

\begin{abstract}
"Zal dus worden toegewezen, tenzij de gedaggde asntoont, dat hem bij witzondering geen aansprakelijkheid treft. Dat doet hij door te bewijzen dat hij onder de omstandigheden wan het gewal niet behoefde te rekenen met het bestabn van het getroffen belang, of dat de schade in een overmachtsfeit hare oorzadk vindt $(. .)^{663}$
\end{abstract}

Wanneer schade is veroorzaakt door een zaak uit de tweede categorie, is de bewijslast zwaarder. Dan zall tevens bewezen moeten worden dat de zaak niet zorgvuldig is gebruikt. Aldus bewerkstelligt Suijling een nime toepassing van artikel 1403 lid 1 op gevaarlijke zaken. "Het verkeer brengt de gebreken van het gebezigd instrument ten laste van den handelenden mensch.' 6 ten oplossing, in het Franse recht uitgesproken in een arrest van het Cour de Cassation uit $1927^{665}$, in het bijzonder voorgesteld en verdedigd door Ripert, maar op weerstand gestuit in de literatuur ${ }^{66 \%}$, en reeds in

662. Rb. Amstendam, 25 mei 1904 in: Weekblat wan het Recht 8239 (1905); HR 15 februari 1907, in Weekblad van het Redt? 8500 . Gerechtshof Annsterdatm, 7 mei 1917. Weekblad wan het Recht 10151 ; in HR 6 maart 1924, Wevkblad wan het Recht 11192 wordt de schuld verondersteld aanwezig te xijn. Aansprakelijkheid op grond van 1403 werd aangenomen in een utspraak van de Rechbank Rotterdam, wharbij bij het lossen van een schip een käbel brak. Uit dit breken nu volgde schuld van gedaagde. Rb Rotterdam 9 maar 1925, NJ 1926, p. 35; en in: Weekblad van het Recht 11356. In een uitspraak wan de Rechtbank Den Bosch word artikel 1403 ten grondslag gelegd wan een vordering tot schadevergoeding en roegewezen. In die zaak was sprake wan een van een rijdende auto afgelopen wiel, waardoor een passant werd getrofien. In die feiten nu werd door de rechtbank schuld wan de automobilist anwwezig geacht. Rb. "s-Hertogenbosch, 8 tebruari 1929, Weekblad van het Recht 12042.

663. Suijling. 1. Ph., Inleiding toi het burgerljk recht, 2e stuk, 2e gedeelte (2e druk, 1936), nr. 563, p. 268269 .

664. Suijling. I.Ph., (1936), nr. 563, p. 270.

665. 21 febnari 1927, D. 1927.1.97.

666. Mazeaud. H. et L. Mazeaud, Traite theorique et pratique de la responsabilité civile délichuelle et contrachelle, deel 2 (2e editie, 1934), wr. $1227 \mathrm{ev}$, p. $173 \mathrm{ev}$. 
1930 weer verworpen door de hoogste Franse rechter 667 . De scheidslijn tussen beide soorten zaken is in Suijlings visie echter niet heel duidelijk: zo kunnen sommige zaken soms 'gemeengevaarlijk" zijn, soms ook niet. Een stilstaande, of een 'goed" gereden auto is geen 'gemeengevaarlijk' voorwerp, echter

\begin{abstract}
"onder bepaalde omstandigheden kan een auto tot een gemeengevaarlijk voonwerp worden. De sneiheidsmaniak, die zijn $150 \mathrm{~km}$. per uur haalt, bedient zich wan een woorwerp, dat drager is van niet meer naar willekeur te beheerschen krachten. En gemeengevar rijk is zelfs iedere auto, die op de plaats waar en onder de omstandigheden, waarin de wagen zich bevindt, zóó gereden wordt, dat de bestuurder niet langer bij machte is de bewegingen wan bet voertuig te regelen overeenkomstig de eischen van een veilig en geordend verkeer. Door an te toonen, dat de auto gereden werd op zulk een manier, dat de bestunirder niet ten wolle met de bellangen van andere weggebruikers kon rekenen, bewijst de benadeelde, dat de wagen door de schuld van den chauffeerenden knecht - schuld die woor rekening van den meester komt - tot een gemeengewata lijk voorwerp was geworden." 668
\end{abstract}

In deze opvatting is schuld eenvoudiger aan te tonen naarmate de zaak gevaarlijker is. Het onderscheid in de gevaarlijke zaken, zoals dat door Suijling geillustreerd wordt aan de hand van de auto, is met name van belang, omdat het sterk contrasteert (en Suijling presenteert het ook op die wijze) met de Franse rechtspraak, waarin een auto steeds als een gevaarlijk voorwerp wordt gezien ${ }^{6 * 2}$.

\title{
2. In het Franse recht
}

Een zeer uitgebreide leer van de aansprakelijkheid voor zaken heeft zich in het Franse recht op grondslag van $1384 \mathrm{Cc}$ gevormd, in de doctrine en in de jurisprudentie. Daarvoor verschafte Laurent de basis. In de Franse rechtspraak wordt door het Cour de cassation sinds 1896 een ruime uitleg gegeven ${ }^{670}$. Scholten schetst de uitspraak als een voorbeeld van risico-aansprakelijkheid. Maar was dat ook zo? De vraag naar de grondslag van aansprakelijkheid heeft de discussie in Frankrijk jarenlang beheerst. Is sprake van een risico-aansprakelijkheid, een responsabilité purement objective, zoals Saleilles beweert, of moet in de schuld, faute, de grondslag worden gevonden, zoals Planiol verdedigt ${ }^{671}$ ? Het is de wetgever die met een tweede lid tussengevoegd in artikel $1384 \mathrm{Cc}$ de grondslag in de schuld heeft gelegd: in één bijzonder geval (het ontstaan van brand) wordt expliciet uitgemaakt dat de benadeelde dient te bewijzen dat

667. Reeds drie jaren later: 13 februari 1930, D.P. 1930.1.157; Esmein, P., Traté pratique de droit civil Francais par Marcel Planiol et Ceorges Ripert. deel 6 (2e druk, 1952), nr. 615, p. 863-864.

668. Suijling, J.Ph., (1936). p. 271 .

669. Suijling. J.Ph., (1936), p. 273. Zie ook Nieuwe Fransche rechtspratk over aansprakelijkheid woor zaken, die men onder zijn opzicht heeft, Nederhands Juristenbiad 1929, p. 233 .

670. Zie hoofdstuk $6 \$ 2 . C .3$.

671. Planiol, M., Traité étémentaire de droit civil, deel 2 (5e druk, 1909), p. 317. Ripert heefteveneens forse kritiek op de grondslag. Eenheid in het aansprakelijklieidsrecht is daarvoor Riperts belangrijkste reden. Een omkering wan de bewijstast is woldioende. Ripert "G., in: Ripert, $G$. en J. Boulanger, Troithe étémentaire de droit ciwil de Planiol, deell 2 (4e dnk, 1952), nr. 1049-1050, p. 372-373. 
de opzichter schuld treft. Daaruit wordt de conclusie getrokken dat dit bewijs van schuld in andere zaken niet vereist is. 'Le légisiateur admet donc que, dans tous les autres cas, la victime est dispensée de cette preuve; l'article 1382 ne s'applique pas aux dommages causés par les choses inanimées hors l'hypothèse d'incendie; l"article 1384, §1 a une portêe absolue." ${ }^{672}$ Zo oordeelt ook de Cour de cassation in 1930. De schuld werd besloten geacht in het begrip 'garde': 'l'art. 1384 rattache la responsabilité à la garde de la chose, non à la chose elle-même. 'De aansprakelijkheid bestaat alleen in het geval de opzichter 'a commis une faute dans la garde'; een verwijt gemaakt kan worden in het opzicht houden. Deze schuld wordt vermoed aanwezig te zijn, maar kan alleen worden weerlegd door 'la preuve d'un cas fortuit ou de force majeure ou d'une cause étrangère qui ne lui soit pas imputable." ${ }^{673}$

Het arrest uit 1930 maakt aan een eerdere onderscheiding, dezelfde die door Suijling wordt toegepast, een einde. Artikel $1384 \mathrm{Cc}$ is van toepassing op alle zaken ${ }^{674}$ en geen onderscheid moet worden gemaakt tussen gevaarlijke en ongevaarlijke zaken. Het is niet nodig 'qu'ell ait une vice inhérent à sa nature et susceptible de causer le dommage. ${ }^{675}$ Ripert introduceert dat onderscheid in $1924^{676}$. Mazeaud:

\begin{abstract}
'L'art. 1384, \$1, ne wend en effet responsable que "du fait des choses que l'on a sous sa garde"; or, toutes les choses n'ont pas besoin d"être gardées; seules les choses dangereuses nécessitent une garde. Chaque fois, par conséquent, qu'un dommage sera causé par une chose non dangereuse, la victime devra prouvé la faute (art. 1382); claque fois qu "elle sera atteinte par the chose dangereuse (telle une automobile), elle pourra se prévaloir de la présomption de responsabilité ếdictée par l'art. $1384, \& 1 .{ }^{6} 677$
\end{abstract}

In 1927 wordt dit onderscheid door de Cour de Cassation onderschreven. Overwogen wordt dat het voor de toepassing van artikel 1384 voldoende is 'qu'il s'agisse d'une chose soumise à la nécessité d'une "garde" en raison des dangers qu'elle peut faire courir à autrui." Een bezwaar tegen deze indeling is dat niet op voorhand uitgemaakt kan worden welke zaak gevaarlijk is: 'La classification générale de $M$. Ripert ne peut suffire, car, ainsi que l'a justement observé $M$. Savatier, toutes les choses peuvent y

672. Mazeaud, H. en I Mazeaud, Traité hesorique et pratique de la responsabilité civile dếlictuelle er contrachuelke, deel 2 (2e druk, 1934), nr. 1145, p. 105.

673. Cour de cassation 13 februari 1930, D.H. 1930. 129; Mazeaud H. en L. Mazeaud, (1934), nr. 1149. p. $106 \div 107$.

674. Uitgezonderd de genoende in artikel $1386 \mathrm{Cc}$ (gebouwen), die in artikell 1384 lid 2 " en wiegtuigen (wett van 31 mei 1924).

675. D.H. 1930. 129.

676. In zijn noot onder Cour de cassation 29 juli 1924, D.P. 1925.1.5.: "Aussi nous parait-il préférable de fonder la distinction nécessaire sur le charactère dangereux de la chose qui est sous la garde de l'homme." Alleen gevaarlijke zaken zouden zo onder het vermoeden van schuld worden gebracht van artikel 1384.

677. Mazeaud, H., Mazeaud, L., Trate théorique et pratique de la responsabilite civile delictuelle er contractuelle, deel 2 (2e druk 1934), p. 173-174 (nr. 1227). 
rentrer.' Afhankelijk van de omstandigheden zal een zaak nu eens meer gevaarlijk, dan weer minder gevaarlijk zijn ${ }^{678}$. Al in 1930 maakt de Cour de Cassation aan dit onderscheid een einde. Uit hetzelfde arrest wordt meer afgeleid. Niet meer van een présomption de faute wordt sinds 1930 gesproken, maar van een vermoeden van aansprakelijkheid, een présomption de responsabilité ${ }^{67 \%}$. Waartoe dient deze verandering? Om uit te drukken dat het tegenbewijs van niet-schuld onvoldoende is: 'Ce changement de vocabulaire s'explique sans doute par le souci d'affirmer le charactère irréfragable de la présomption." 680

\section{EEN AFZONDERLUKE WETGEVING MET EEN YERLICHTING VAN HET SCHULDBEGINSEL}

De opkomst van de auto maakt ook voor deze zaken een verruiming van aansprakelijkheid nodig. In 1908 wijst Star Busmann op bewijsmoeilijkheden van schuld bij autoongelukken in verschillende landen ${ }^{681}$.

"Sedert de opkomst der automobielnijwerheid, dagreekenend wan de laatste tien jaren, heeft het verkeer op de wegen eene groote verandering ondergaan, grooter dan dhe, welke reeds v roeger door de verschijining der rijwielen was teweeggebracht.(.) Geen wonder, dat zij de belangstelling ook van rechrgeleerden en wergevers in toenemende mate op zich heeft gevestigd."

In Frankrijk, Oostenrijk, Duitsland en Zwitserland moet de gelaedeerde wegens ontbreken van wetgeving gebruik maken van het gemene recht, waarbij het bewijs van schuld lastig is. Wel, zo vermeldt Star Busmann, zijn er wetsontwerpen in behandeling in de drie laatstgenoemde landen, die de grondslag van de aansprakelijkheid niet in schuld zien, maar in gevaarzetting. Voor Nederland verdienen deze ontwerpen navolging ${ }^{682}$. Zo oordeelt ook de NJV in 1913.

\section{De Nederlandse Juristen-Vereniging in 1913}

In 1874 beantwoord de NJV de vraag of van het schuldbeginsel afgeweken moet worden ontkennend ${ }^{633}$. In 1913 is het tij gekeerd. De vereniging stelt zich de volgende vragen:

678. Cour de cassation 21 februari 1927, D. 1927,1.97. met noot Ripert; Mazeaud, H. en L. Mazeatud, (1934) p. 181, nr. 1234. Zie ook Mazeaud-Tunc, Traitế therorique et prafique de la responsabilité civile délicuelle er contractuelle. deel 2 (5e drak, 1961), nr. 1238 .

679. 13 februari 1930 (Jeandheur) D.P. 1930.1.57.

680. Ripert, G. en J. Boulanger, in hun bewerking wan Traité élémemtaire de droit civil de Planiol, weel 2 (4e druk, 1952). p. 372.

681. Star Busmann, C.W., De aansprakelijkheid der atumobiel in het verkeersirech, Rechisgeleerd Magazijn 1908 , p. 393.

682. Star Busmann, C.W., (1908) p. 412.

683. Zie hoofdstuk 6 \& $2 . B$. 
1. Is het gewenscht hem, die door zijn niet onreentmatig handeten gevaar woor schade doet ontstan, aansprakelijk te stellen, indien de schade werkelijk intreed?

2. Zoo ja, welke beginselen behooren daarbij richtsnoer te zijn; moet de regeling zijn algemeen, of is het verkieslijk hat ke beperken tot bepaalde onderwerpen?

Van Leeuwen en Hijmans behandelen deze vragen. Daaruit blijkt dat beide meer zijn geinteresseerd in praktische oplossingen voor verschillende afzonderlijke soorten zaken, dan in discussies die zich slechts op de grondslagen van de aansprakelijkheid richten. Van de rechtspraak werd niets verwacht ${ }^{684}$. In wetgeving moet deze aansprakelijkheid worden geregeld ${ }^{685}$. De eigenaar of houder van een auto zou in die kwaliteit van houder aansprakelijk moeten $\boldsymbol{z} i j n$, onafhankelijk van de vraag of de automobilist een verwijt gemaakt kan worden: "Moeten wij (...) dagelijks op straten en wegen blootgesteld worden aan de willekeur der razende Rolands en Kilometer-maniacs.' Van Leeuwen stelt voor in de Motor - en rijwielwet 1905 bepalingen over de aansprakelijkheid van de eigenaar of houder van de auto op te nemen. Deze bepalingen ontleent hij met enige kleine wijzigingen aan de Duitse en Oostenrijkse wetgeving ${ }^{686}$.

'Nog is de schuld een machtig vorst. Maar zijn troon wankelt', vangt Hijmans zijn betoog krachtig aan. Vooral in Nederland, dat 'slechts een paar oude voorschriften kent', terwijl andere landen het zij door rechtspraak, het zij door wetgeving aansprakelijkheid buiten schuld hebben bewerkstelligd ${ }^{687}$. Hijmans stelt gevaarzetting voor als grondslag voor aansprakelijkheid ${ }^{688}$. Deze theorie zou voor toepassing in aanmerking komen op een aantal zaken: dieren, spoorwegen, fabrieken, auto's, electrische leidingen, "luchtscheepvaart'. Een algemene bepaling waarin een risico-aansprakelijkheid wordt gevestigd of een omkering van de bewijslast van schuld wordt met grote meerderheid verworpen. Voor bijzondere genoemde gevallen mag. zo blijkt na stemming, afgeweken worden van het schuldbeginsel ${ }^{689}$. In 1924 komt, na jaren van aarze-

684. Zie 1.C.

685. Bij de 'beschaafde staten' mag Nederland niet achterblijven, aldus Van Leeuwen, verwijzend naar het commentuar van Regout tijdens de behandeling van zijn wetsvoorstel. Het was immers Regout die zich zo tegen een afwijking van het schuldbeginsel in een algemene bepaling toonde, niet was geporteerd voor een regeling van aansprakelijkheid voor auto-ongelukken, en meende dat beschafde staten juist geen algemene afwijking van het schuldbeginsel kenden. Zie $\$ 2$.A.

686. Van Leeuwen, H.J., In: Handelingen I (1913), p. 179. In Duitsland is voor auto's 3 mei 1909 een wet verwaardigd; Oostenrijk 9 augustus 1908; Denenarken, dat Van Leeuwen ook nog terloops noemt, 9 maart 1906 :

687. Hijmans, I.H., in Handelingen I (1913), p. 203-204.

688. Hijmans, L.H., Handelingen $\(1913)$, p. 229 ev.

689. Handelingen II (1913), p. 80-81. 
ling ${ }^{69 x}$, een aansprakelijkheid voor auto"s in de Motor-en Rijwielwet (art. 25) tot stand. Maar was deze regeling bevredigend?

\section{De Motor-en Rijwielwet en kritiek}

In de literatuur is de overheersende opvatting dat dit artikel, met name doordat een beroep op overmacht wordt toegestaan (waarmee zowel risico als schuld als grondslag van de aansprakelijkheid in de regeling waren verwerkt) en verder door de door de ingewikkelde redactie tekort schoot ${ }^{69:}$. De wet is niet op schade aan vervoerde goederen en personen van toepassing; er wordt een beperking ingebracht door de artikelen 1406 en 1407 wan toepassing te verklaren; de hoogte van de schadevergoeding wordt onredelijk beperkt; de vordering moet binnen korte tijd worden ingesteld ${ }^{592}$. De wet-

690. Star Busmann laakte de tragheid van de wetgever. "(...) weing zal hij toen vermoed hebben dat reeds twee jagr later diezelfde, door hem zo gedenigreerde wetgever, zou overgan tol hel opnemen van ean artikel wan eene strekking als door hem bepleit in de "Motor-en Rijwielwet" . Binnerts, C... Aanspra kelijkheid woor automobielen "uit de hand", WPNR 307 1 (1928). In 1905 kwam de Motor-en Rijwielwet gereed. Bepalingen betreffende aansprakelijkheid kwamen daarin niet voor. Zie Sifarsblad 1905 , 69. Staarsiad $1924,492$.

691. Zie Van Oven, J.C., Aansprakelijkheid bij atuto-ongelukken (art.25 Motor - en Rijwietwet). Nederlandsch Juristenblad, 12 matt 1925, p. $145 \mathrm{ev}$. en (deel 2) p. $169 \mathrm{ev}$. en de allaar genoemde litera nutit.

692. Janssens, L., De bungerrechtelijke ansprakelijkheid bij autorongelukken. Rechsgeleerd Magazijh 1929, p. 294 ev. Artikel 25 lid 1. Ingeval van botsing, an- of overrijding net een motorrijtuig op de wegen of rijwielpaden is de eigenar van het motorrijuig of - indien het bij art. 9 bedoelde atn het nijuig aangebrachte nummer met letter door het bevoegde gezag is opgegeven anden houder wle houder ansprakelijk voor de schade, toegebracht aan, niet door dat motorrijuig vervoerde, personern en goederen, tenzij aanumemelijk is, dat de schade is te wijten aan overmacht, daaronder begrepen sclwold van iemand, voor wien de eigenaar of houder niet aansprakelijk is. De overige leden wan het artikel luden als volgt: 2 . De eigenar of houder, die het motorrijuig niet zelf besturt, is annsprake-

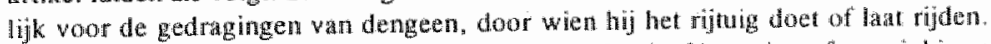

3. Wrnneer het ongeval iemands dood ten gewolge heeft of kwetsing of werrinking van ewig doel des lichaans, vinden de arti. 1406 en 1407 van thet Burgerlijk Wethoek overewnomsthe toepassing mat betrekking tor de personen, die ene rechtswordering tot schadevergoeding hebben, en de wijze, waarop de schade wordt gewardeerd.

4. Terzake van en zalfde ongeval is het total bedrag ther ingevolge het eerste lid verschuldigdi vergoed ing voor an goederen toegebrachte schade beperkt tot de warde van het motorrijuig op liet ogenblik van het ongeval, tenzij wordt angetoond schuld wan den eigernath of houder zeff of wan iemand, woor wien de eigenar of houder ansprakelijk is. Ingeval van geschil heefi de engonat of houder an te tonen tot well bedrag zijne atusprakelijkhe id is beperkt.

5. Het bepalde bij de worige leden windt geene toepassing ten adzien van schade, door een molorrij tuig toegebractht aan lositoopende dieren, aan een ander notorrijtug in beweging of an personen of goederen, welke daamede worden verwoerd.

6. Do rechterkan het bedrag dar schadevergoeding beperken. wanneer annemelijk is, dat het ongeval mede is te wijten aan de schuld varn hemand, voor when de eigenar of houdet niet aansprakelijk is. 7. De rechtswordering tot schadevergoed ing vervalf door tijdsverloop van zess maanden, te rekenen van den dag. warop het ongeval heeft plaatsgehad.

8. De bij dit artikel gegewer voorschriften laten onverkort de uit hef gemene recht voorvioeiende aansprakelijkheid. 
tekst verklaren uit de wetsgeschiedenis is onbegonnen werk, aldus van Oven: ' $(. .$.$) het$ voorschrift is voortgekomen uit een amendement en een lange reeks van subamendementen, wier geestelijke vaders elkander vaak slecht begrepen hebben, en geenszins allen op hetzelfde principe stoelden." ${ }^{693} \mathrm{De}$ in artikel 1403 verscholen ruime uitleg komt door deze onduidelijkheden weer in de belangstelling te staan. De rechtspraak is er in geslaagd een goed gebruik van dit artikel te maken, zo vermeldt Van Oven ${ }^{694}$.

\section{Het nieuwe Burgerlijk Wetboek}

"In Frankrijk is men aansprakelijk voor een bloempot op dezelfde wijze als hier voor een auto in gebruik. (...) juist wegens die algemeenheid van die regeling is het Franse stelsel niet gekozen', verklaart Meijers in het parlement ${ }^{695}$. In het ontwerp nieuw Burgerlijk Wetboek worden daarom een aantal bijzondere aansprakelijkheden voor zaken geregeld waaronder een risico-aansprakelijkheid van de bezitter van een auto. Tevens wordt een algemene bepaling opgenomen voor schade, veroorzaakt door gebrekkige zaken ${ }^{6 \%}$. De vraag wordt gesteld of er een algemene aansprakelijkheid voor gevaarlijke zaken moet komen. Een ontkennend antwoord volgt omdat "ervaring in Frankrijk en Engeland heeft geleerd dat deze omschrijving onvoldoende houvast biedt aan de rechtspraktijk, mede omdat in vele gevallen alleen van de begeleidende omstandigheden afhangt of een zaak al dan niet "gevaarlijk" kan worden genoemd. ${ }^{697}$ Suijlings onderscheid wordt verworpen. Verwezen wordt naar de behandeling en de verwerping van dat onderscheid in Mazeaud-Tunc ${ }^{698}$. Van aansprakelijkheid zal sprake zijn indien van een gebrek sprake is, wanneer een zaak niet voldoet aan de eisen die aan die zaak gesteld mogen worden. Aangesloten wordt bij de opvatting van het Belgische Hof van Cassatie over artikel 1384 (Belgisch) BW, en de door Dekkers gegeven uitleg: 'La Cour de Cassation, s'inspirant de l'article $1386(\ldots)$, décide quel'article 1384 aussi suppose la vice de la chose, et la relation de cause à effet entre le vice et le dommage.' Dekkers

693. Zie Van Nispen tot Sewenaer, C.M.O. Het begrip "schuld" volgens ant. 25 Motor- en Rijwielwet en volgens art. $536 \mathrm{~K}$, in W. 12042; verder Van Oven, J.C., (1932), p. 147-149; Van Oven, J.C., (1932), p. 169; Binnerts, C., Aansprakelijkheid voor automobielen "uit de hand". WPNR 3071 (1928).

694. Yan Oven, J.C. Aansprakelijkheid bij auto-ongelukken, Nederlandsch Juristenblad (1932), p. 146 en p. 174. Over de gestage uitbreiding van aansprakelijkheid Valkhoff, J., Een eeuw rechtsontwikkeling, (2e druk, 1949), p. 172 en 174.

695. Van Zeben., C.I., e.a., Partenentaire geschiedenis van het nieuwe Burgerhijk Wetboek, boek 6. (1981), p. 740 .

696. Art. 6: 173 BW, Mazeaud-Tunc, deel 2 (1961), nr. 1238; Zie hierboven \$ 2.B.2.

697. Drion, $\mathrm{J}, \mathrm{G}$. de Grooth. F.J. de Jong, Onwwerp yoor een nieuw Burgerlijk Wetboek van E.M. Meijers (1961), Tollichning boek 6, op ant. 6.3.15, p. 700; zie ook Van Zeben, C.J., e.a., Parlemenraire geschiedenis wan her nieuwe Burgerlijk Wetboek, boek 6, (1981), p. 732-749.

698. Zie 2.B.2. 
vermeldt dit standpunt als een sinds 1904 aangehamgen interpretatie van het Hof van
Cassatie ${ }^{699}$.

\section{CONCLUSIES AANSPRAKELIJKHEID WOOR ZAKEN}

Op twee manieren kan vereenvoudiging van aansprakelijkheid voor zaken worden bewerkstelligd: door middel vam een algemene bepaling (artikel $1403 \mathrm{BW}$ ) of een op specifieke zaken toegesneden wetgeving. De laatste weg vertegenwoordigde de heersende leer, voor de mogelijkheid van een nime uitleg wan 1403 wordt af en toe in de literatuur gekozen. In het nieuwe Burgerlijk Wetboek wordt een algemene bepaling opgenomen voor gebrekkige zaken. Ook voor bijzondere zaken (spoorwegen, auto's, later vliegtuigen) wordt wetgeving vervaandigd. De argumenten die worden aangedragen voor de beperkte uitleg zijn eerst nog op tekst en systeen gebaseerd (Eyssell). Later worden vooral aan het maatschappelijk belang ontleende argumenten gebruikt voor vereenvoudigde aansprakelijkheid. Het matschappelijk belang wordt ook gebruikt tegen een ruime algemene aansprakelijkheid maar voor een op speciale zaken toegesneden regeling (Hijmans, Van Leewwen, Van Oven, Meijers). Daarnaast spreken aan tekst en systeem ontleende argumenten voor afzonderlijke regelgeving: alleen zo kan het systeem van het aansprakelijkheidsrecht in het Burgerlijk Wetboek in stand blijven.

Zowel Frans, Duits, Oostenrijks, Zwitsers en later Belgisch recht worden gebruikt in de argumentatie. Door de voorstanders van een strikt vasthouden aan het schuldbeginsel worden de afwijkingen van het schuldbeginsel in de Franse en Duitse rechtspraak met kracht verworpen. Later verdwijnt deze vorm van tegenspraak, die zich nog buitengewoon sterk laat leiden door teksi en systeem van de wet. De volgende tegenstanders van een ruime uitleg van 1403, of een nieuwe algemene bepaling voor aansprakelijkheid voor zaken buiten schuld, kiezen billijkheidsargumenten. Eyssell ontleent systematische argumenten voor het schuldbeginsel aan Planiol. Door voorstanders van een ruime uitleg wordt ook het Franse recht gebruikt, omdat daar juist een billijke oplossing met een ruime uitleg bewerkstelligd is. Voorstanders van een ruime aunsprakelijkheid menen dat. een algemene (risico) aansprakelijkheid voor zaken onbillijk kan zijn voor de "opzigter" en verwerpen de Franse uitleg. Zo niet Suijling, die an de Franse rechspraak (Ripert) een beperkte algemene aansprakelijkheid ontleent, maar alleen voor gevaarlijke zaken. Uiteindelijk wordt gekozen voor een oplossing, aan het Belgische recht ontleend: een algemene aansprakelijkheid voor gebrekkige zaken. Die wordt ook in het nieuwe BW opgenomen.

699. Van Zeben, C.I., e.a., (1981), p. 744. Genoemd wordt de uirspratk Hof van Cassatie 21 december 1956, Journal des Tribuneaux 1957. p. 205, en nutar de bij Dekkers, R., Handboek van Burgerlijk Recht, nr. 269, vermelde eerdere rechtspraak. Het cital is afkomstig wit de Franse editie: Pricis de alroit civil Belge, deel 2 (1955), nr. 269. 


\section{\$ 3. Artikel 2014, de legitimatieleer en de kritiek}

\section{A. DE ONZEKERHEID OVER DE AANGEHANGEN LEER: MEITERS EN HOFMANN}

Meijers ziet over artikel 2014 slechts twee vaste lijnen in de rechtspraak: "geldt als volkomen titel' moeten worden opgevat als: "geeft eigendom" en "bezit' is bedoeld in de zin van artikel $585 \mathrm{BW}{ }^{700}$. Over het al dan niet vereist zijn van de goede trouw bestaat darentegen geen duidelijkheid. De historische betekenis van de zinsnede is onduidelijk. Meijers echter: "Het is voor mij niet twijfelachtig, dat bij Bourjon de regel niets anders wil zeggen dan dat bij roerend goed bezit hetzelfde recht aan den bezitter geeft als bij onroerend goed de levering van den eigendom, zoodat tegen een bezitter geen revindicatie is toegelaten." ${ }^{701}$ Behalve de historische uitleg is ook van belang "de overige artikelen van het wetboek en in geval van twijfel, gronden van billijkheid.' Het systeem van de wet laat de uitlegger wat in de steek. Bij ellke uitleg kunnen een of meerdere artikelen worden aangeduid die met de uitleg in overeenstemming te brengen zijn. Zo is het dan noodzakelijk dat eindelijk eens in de rechtspraak een duidelijke uitleg wordt gegeven ${ }^{302}$. Die noodzaak wordt te meer duidelijk na het arrest uit 1922 waarin de processuele betekenis van artikel 2014 uit Scholtens leer werd aanvaard: de bezitter wordt als eigenaar beschouwd, zolang een ander niet een beter recht bewijst ${ }^{303}$. Daarmee is in ieder geval niet Meijers' verderstrekkende uitleg 'bezit van roerend goed geeft eigendom' geaccepteerd. Maar eveneens is niet duidelijk of de Hoge Raad met deze uitspraak nu ook de rest van Scholtens legitimatietheorie heeft onderschreven, waarbij tevens wordt vereist dat het bezit krachtens geldige titel is verkregen. Wanneer artikel 2014 lid 1 niet meer zeggen zou dan dat de bezitter vermoed wordt eigenaar te zijn, dan is de bepaling overbodig, omdat artikel 604 lid $1 \mathrm{BW}$ hetzelfde doet ${ }^{704}$. Er moet dus nog meer in het artikel verborgen zitten, en dat meerdere zou ofwel geboden kunnen worden door de leer van Meijers of wel door die van Scholten. Behalve de noodzaak van een eenduidige rechtspraak heeft Meijers de volgende argumenten voor zijn uitleg van 2014 .

700. Meijers, E.M., De rechtspraak van den Hoogen Raad ontrent "bezit geldt als wolkomen titel" "WPNR 3026-3027 (1927); ook in VPO II (1954).

701. Meijers, E.M., (1927, 1954), P. 139.

702. Zoats in Firankrijk is gebeurd, vermeldr Meijers, en geeft als reden voor het verschil dat in Nederland de literatuur een grotere invloed heeft gehad op de rechtspraak dan in Frankrijk: 'Dientengevolge hebben wij bij art. 2014 thans arresten à la Land, à la Diephuis, à la Scholten. 'Meijers, E.M., (1927. $1954 \%, \mathrm{p} .151$.

703. Zie hoofdstuk $6 \$ 3.8$.

704. Art. 604. Het bezit te goeder trouw geeft, ten opzichte der zaak, aan den bezitter hel regt: 1e. Dat hij bij voorrad, en tot het tijdstip der geregtelijke terugvordering, als eigenaar wordt aangemerkt; 
Artikel 2014 betekent dat bezit dezelfde uitwerking heeft "als iedere andere wijze van eigendomsverkrijging." 2014 lid 1 is bedoeld als complement van artikel $2000 \mathrm{BW}^{705}$. Daarin wordt de eigendom toegekend na verjaring van de miet in 2014 genoemde goederen. 2014 sluit verjaring voor genoemde goederen uit, maar dat kan alleen dan als 2014 lid 1 de eigendom toekent. In 2014 wordt geen onderscheid gemaakt tussen soorten bezitters: tussen diegenen die van de eigenaar het bezit hebben gekregen en derden (in Scholtens leer, waarin nog een geldige titel wordt vereist, is dat wel het geval). In het Franse recht zijn jurisprudentie en doctrine eenduidig en wijzen beide voor het Franse recht in de richting van Meijers' uitleg. Meijers maakt gebruik van Planiol en Colin/Capitant. Colin/Capitant komt via een verwerping van twee andere theorieën, de 'préscription instantanée' en 'présomption de propriěté' tot aanvaarding van een voornamelijk op historische argumenten gebaseerde eigendomsverkrijging op grond van de wet:

'La véritable solution nous est fournie par l'histoire. Elle consiste à dire que, en considétation des avantages pratiques présentés par cette solution, la loi attache au fait de la possession de bonne foi un effet transiatif de proprieté et supprime, au profit du possesseur, le droit de révendication du propriétaire, lors"que celui-ci s"est volontairement dessaisi. Il y a dans l"article 2279 , nous l'avions par avance indique, un cas d'acquisition lege. " $0 \%$

Vervolgens beschouwen we de uitleg van Planiol, wiens mening door Colin/Capitant volstrekt wordt verworpen. Volgens Meijers zeggen beiden eigenlijk hetzelfde:

"Dans la théorie la plus répandue, et que je crois wrai, l'art. 2279 crée au profit du possessent" une présomption de propriété et cetre présomption ne souffre pas la preuve contraire, puisque, sur son fondement, la loi dénie l'action en justice. La révendication mobilière est écartée, et par suite la disposition générale de l"art. 1352 doin s'appliquer: "nulle preuve n'est admise contre la présomption de la loi....". 707

Beide schrijvers geven volgens Meijers: "bezit van roerend goed geeft eigendom." Planiol spreekt weliswaar van een onweerlegbaar vermoeden van eigendom ${ }^{708}$, maar omdat het een onweerlegbaar vermoeden betreft, heeft diegene die zich daarop kan beroepen eigeniijk 'hetzelfde recht als degene, die door de wet zonder meer tot eigenaar

705. Art. 2000. Die te goeder trouw, en uit kracht var eenen wettigen titel, een onroerend goed, eene rente of eenige andere, aan toonder niet betalbare, inschuld verkriggt, bekom daarvan den eigendom, bij wege van verjaring, door een bezit van twintig jarem.

706. Colin, $A_{n}$ en H. Capitant, Cours élémentaire de droit civil Francais, deel 1 (4e druk, 1923), p. 918.

707. Planiol, M., Traité élémentaire de droit ciwil, deel 1 (Be druk, 1920), nr 2496, p. 768.

708. Zie Aubry en Rau over "une présomption de propriété absolue et irréfragable", hoofdstuk 5 \& $3 . A .1$ 
verklaard wordt ${ }^{70 \%}$. Bezit en goede trouw als vereisten voor een geslaagd beroep op artikell 2014 worden ook in het Franse recht gesteld ${ }^{710}$.

Er zijn meer voorstanders van Meijers' interpretatie. Zo Wttewaal in 1916 die met historische argumenten voomamelijk deze uitleg tracht te verdedigen: 'Het artikel is (...) overgenomen uit den Code. Uit dit wetboek derhalve dient het verklaard te worden, nu van den wil daarvan af te wijken niet blijkt." 711 Tevens is de tekst van 2014 belangrijk: 'hoe kan men dan naast het bezit nog een titel eisen!' In de onderbouwing van de legitimatieleer wordt veel van Duits recht gebruik gemaakt. Die interpretatie kan voor Wttewaal niet door de beugel: "voor de uitlegging van ons tegenwoordige wetboek is dit moderne waardeloos" ${ }^{* 12}$. Andere rechtsstelsels spelen slechts een rol wanneer dit als historische interpretatie gebruikt kan worden. Evenzo principieel, nog meer gegrondvest in de historie dan Wttewaal, stelt zich Hofmann op. Hij onderschrijft het betoog van Meijers, en voegt daar nog een uitvoerige historische uiteenzetting aan de hand van een groot aantal Franse (onder wie Bourjon, Pothier) en Duitse bronnen (oude land- en stadsrechten, onder veel meer Heusler en Huber) aan toe. Het is de historie van het adagium 'en fait de meubles, possession vaut titre' die wijst op de leer van Meijers, en spreekt tegen de uitleg van Scholten ${ }^{713}$. Scholten reageert in een naschrift op Hofmanns betoog: ook indien Bourjon aan een andere betekenis gaf aan de woorden "possession vaut titre', aan een wetshistorische uitleg mag volgens Scholten in het algemeen nooit beslissende betekenis toekomen ${ }^{714}$ : "Historische interpretatie is bij Dr. Hofmann - en de vellen die daarbij te werk gaan als hij - de uitlegging van een wetstekst door beroep op de parafrase, die de makers der wet of een auteur aan wien zij hun tekst ontleenden hebben gegeven. Voor mij zijn zulke oordeelen niet bindend.' ${ }^{715}$ Dat is zeker het geval bij artikel 2014 waarbij die historie zelf onduidelijk is.

709. Meijers, E.M., (1922), p. 286. Met de anname van een onweerlegbalar vermoeden van eigendorn wordt, zo vermeldt Meijers, de rweedeling in een processuele, en een materiële functie, door Saleilles gepropageerd, eveneens afgewezen. Meijers, E.M., (1927, 1954), p. 148.

710. Tot an de duidelijke uitspraak van de Hoge Raad in Stat-Damhoff kon deze vitleg ook aan het Nederlandse recht worden gegeven. Pas daarna gingen Nederlands en Frans recht uit elkaar lopen. Zie Zwalwe, W.J., (1993), p. 192.

711. Wttewal, G. Artike 2014 BW, Rechtsgeleerd Magazijn 1916, p. 175-209; Ook de leer van Meijers zijn toegedaan: De Lange, C.I. Een vergelijkende beschouwing der "oude en nieuwe" leer omtrent artikel 2014 BW, WPNR 3466 (1936), P. 277-281; Veegens, J., Schets van het Nederlandsch burgerilik rech" deel $2(1909)$, p. 22.

712. Wttewal, G., (1916), p. 195. Zie hoofelstuk 6 3.A.2.

713. Hofmann, L.C. Eenige opmerkingen over de beteekenis wan artikel 2014 BW, WPNR 3059-3060 (1928); Hofmann, L.C. Nog eens: Ant. 2014 B.W.,WPNR 3074-3075 (1928); Hofman, L.C., Het Nederlandsch zakenrecht (1933), p. 81 ev.

714. Schotten, P., naschrift, WPNR 3060 (1928), p. 519.

715. Scholten, P., naschrift onder: L.C. Hofmann, Nog eens: Art 2014 BW (II), WPNR 3075. (1928). 


\section{B. DE ACCEPTATIE VAN DE LEGITIMATIELEER}

Langzaam maar zeker wordt Scholtens legitimatieleer geaccepteerd. In Scholten en Van Oven heeft deze legitimatieleer voorstanders van formaat, die bovendien nog kunnen bogen op een voorganger als Molengraaff. De acceptatic wordt verder vergemakkelijkt doordat Meijers de hoogste prioriteit toekent aan eenduidige rechtspraak. De Lange betoogt in zijn artikel in 1936 dat de verschillen tussen beide theorieèn groter worden voorgesteld dan ze in werkelijkheid zijn: waar de 'oude leer' (Diephuis, Meijers) alle 'feilen, die de levering mochten aankleven' (titel, beschikkingsbevoegdheid) herstelt, doet de 'nieuwe leer' (Scholten, Van Oven) dat alleen met de onbevoegdheid van de vervreemder ${ }^{716}$. Suijling maakt ook al onderscheid tussen de procesrechtelijke (weergegeven in het eerste lid) en de materieelrechtelijke betekenis (weergegeven in het tweede lid) van artikel $2014^{7 / 7}$. Die materieelrechtelijke betekenis die Suijling aan artikel 2014 geeft is dezelfde die Scholten weergeeft in de legitimatieleer ${ }^{718}$. Het standpunt van Eggens is iets afwijkend. Wel accepteert hij de dubbele betekenis en verwerpt de gelijkstelling 'bezit is eigendom', de bescherming die artikel 2014 aan de bezitter geeft zou hij echter ook aan de houder willen laten toekomen ${ }^{7 / 9}$. Ook in de rechtspraak lijkt de balans steeds meer door te slaan naar de leer van Scholten ${ }^{720}$. Het processuele deel van de legitimatietheorie was reeds in 1922 expliciet aanvaard ${ }^{721}$. Over het materiële deel van Scholtens legitimatieleer kwam eerst duidelijkheid in 1951, DanhofStaat ${ }^{722}$. Tot die tijd werden telkens afzonderlijke elementen van de legitimatieleer uitgesproken: dat sprake moet zijn van civiel bezit (conform artikel $585 \mathrm{BW}$, een oud discussiepunt ${ }^{733}$, dat de goede trouw vereiste was ${ }^{724}$; tevens werden twee arresten gewezen die zich niet lieten verenigen met de materiële betekenis van artikel 2014 in Meijers' uitleg: ontbinding liet de eigendom terugkeren in het vermogen van de verkoper, terwijl in het bezit geen verandering was gebracht ${ }^{725}$. Eerst onlangs, in 1994, is het 'om baat' vereiste door de Hoge Raad in het oude artikel 2014 gelezen ${ }^{726}$.

716. De Lange, C.J., Een vergelijkende beschouwing der "oude en nieuwe" leer omtrent antikel 2014 B. W., WPNR 3466 (1936), p. $277-281$.

717. Suijling. J.Ph., Inleiding rot het burgerlijk rech. Se stuk (1940), nr. 294.

718. Suijling J.Ph. (1940), met name nrs. 298 en 303.

719. Eggens, J., Het jongste arrest van den H.R. inzake art. 2014. Nederlonds Juristenblad 1926, p. 87-92.

720. Zie hierover ook Sallomons, A.F. (1990), p. 122-128.

721 . HR 3 februari $1922, N J 1922,388$.

722. Zie hoofdstuk 2 \& 3 en hoofdstuk 6 \&3.C.

723. HR 4 juni 1920, NJ 1920,712 .

724. HR 19 april 1928, NJ 1928, 1504; HR 10 mei 1929, NJ 1929, 1615.

725. HR 25 februari 1916, NI 1916, 501; HR 20 december 1924, N/ 1925, 153; zie hierover ook Meijers. E.M., (1927, 1954), p. 149.

726. HR 2 december 1994, RrdW 1994, 264; daarover: Salomons, A.F., De late aanvalarding van het ombaatvereiste bij art. 2014 oud-BW, WPNR 6174 (1995), p. 212. 


\section{CONCLUSIES 2014}

De balans slaat langzaam door in de richting naar de legitimatieleer van Scholten. De uitleg van Meijers verliest terrein. Meijers, Hofmann en andere voorstanders baseren zich voorall op de historie en op tekst en systeem. Toch geven teleologische argumenten van Scholten en Van Oven de doorslag, en wordt hun uitleg langzaam maar zeker geaccepteerd in doctrine en rechtspraak. Van andere rechtsstelsels wordt gebruik gemaakt, ook door de voorstanders van de Germaansrechtelijke leer: verwezen wordt naar het oude Franse en het Duitse recht. Dat geschiedt op twee wijzen: in de eerste plaats valt op het zware gewicht dat aan de historie van de bepaling wordt toegekend. In dat verband komt het oude Franse en Duitse recht uitvoerig aan de orde, met name bij Hofmann. Meijers bedient zich minder van de historie, maar ook van eigentijdse bronnen in het Franse recht. Daar dan vindt hij ondersteuning bij zowell Planiol als bij Capitant. Wttewaal lijkt met zijn expliciete verwerping van gebruik van ander recht bij de uitleg van Nederlands recht een uitzondering te zijn.

\section{\$ 4. Publiek domein}

\section{A. DE VERANKERING VAN HET PUBLIEK DOMEIN IN HET PRIVAATRECHT}

Von Reeken zet de toon; alleen op detailniveau zijn er nog afwijkende meningen, met name met betrekking tot het begrip 'zaken buiten de handel.' Aan het fundament in het privaatrecht wordt nauwelijks meer getornd. De argumentatie voor de uniform privaatrechtelijke eigendom is in het administratiefrecht en in het privaatrecht in grote lijnen gelijk $^{727}$.

\section{Goudekets uiteenzetting}

Goudeket geeft de privaatrechtelijke benadering vorm in zijn bewerking van Opzoomers handboek 'Het Burgerlijk Wetboek verklaard,' met behulp van een groot aantal standpunten die in de ons omringende stelsels werden aangehangen. Hij bouwt voort op de door Barckhausen, Hauriou, Baudry-Lacantinerie, Planiol, en Mayer verkondigde meningen. Verder komen bij hem kort aan de orde Franse jurisprudentie, en een enkele Duitse schrijver (Dernburg), de Zwitserse en de Duitse privaatrechtelijke wetgeving ${ }^{728}$. Goudeket zet Opzoomers visie deels voort: het regelen en handhaven van de bestemming van publiek domein heeft met het eigendomsrecht niets te maken, het gaat

727. Geheel verschillend waren argumentaties in de beide rechtsgebieden tijdens de periode dat "domaine puly.ic" als heersende leer in de nederlandse rechtswetenschap gold. Zie daarover met name \$ 5.4.4.1, en Milo, I.M., (1995), passim.

728. Meijers, die later zelf een zeer genuanceend standpunt zou imnemen, verklaarde dat Goudekets uiteen" zetting "tot het beste behoort, wat in ons land over dit onderwerp is geschreven." Meijers, E.M., Publiek domein en zaken buiten de handel, WPNR 2543-2547 (1918), p. 430. 
dan om de uitoefening van publiekrechtelijke bevoegdheden die de staat als staat toekomen ${ }^{729}$; maar, zo voegt Goudeket toe, naast deze bevoegdheden is de staat tevens privaatrechtelijk eigenaar van publiek domein. Maar het is eerst Gondekets laatste stap die het standpunt zeer naar de privaatrechtelijke benadering trekt. Want, zo vraagt Goudeket zich af, kan het eigendomsrecht misschien beperkt worden door toepassing van de bepalingen over 'zaken buiten de handel'? Daarvan kan in geen geval sprake zijn. Waarom niet? Het is het algemeen belang dat zich hiertegen verzet.

\begin{abstract}
(..) wordert het algemeen belang, dat de Staat in zijne beschikkingsbevoegdheid door civielrech telijke voorschriften wordt beperkt, en dat door soortgelijke voorschriften bijzonderen personen belet wordt rechten op die zaken te verkrijgen? Beantwoordt men die vraga bevestigend, dan zou dit alleen op dezen grond kunnen geschieden, dat anders de publieke bestemming dier zaken gevaar zou kunnen loopen. Wie echter schept die publieke bestemming? De Staar. En wie kan ze er weder aan ontnemen? De Staat. Maar kan men dienzelfden Staat het dan ook niet gerustelijk overlaten te beslissen, in hoeverre rechten wan bijzonderen personen met de publieke bestemming vereenigbaar zijn, en zal hij, die het meerdere kan, nl. de bestenming tery publieken dienste opheffen, niet ook tot het mindere bevoegd zijn, nl. tot de beperking er wan, of zelfs om met instandhouding dier bestemming over zijn eigendom te beschikken?" 730
\end{abstract}

De eerst voorzichtig naast publiekrechtelijke bevoegdheden toegekende eigenaarsbevoegdheden krijgen door de afwezigheid van beperkingen alle ruimte. Maar niet alleen ontbreekt de noodzaak van beperking voor Goudeket, het algemeen belang maakt een onbeperkte uitoefening van private rechten door de overheid zelfs noodzakelijk. En zo dan komt de privaatrechtelijke eigendom tot volle wasdom:

${ }^{2}$ Doch niet alleen is het niet in strijd met het algemeen belang, dat de Staat de vrije beschikking over de ten algemeenen nutte bestemde zaken heeft, het algemeen belang kan eir nog meer doon bevorderd worden. Inmers het is zeer well mogelijk, dat die zaken tegelijk direct en indirect het algemeen belang ten goede komen, doordien de Stat die zaken, zonder de publieke bestemming in het minst te kort te doen, productief maakt en dus tegelijk als priwate domeinen behandelt, zooals door verpachtingen van grasgewas, vestiging van servinuten tegen betaling, werhuring van schoolgebouwen buiten schooltijd, verhuring van muurwakken voor reclames enz." 731

De teleologische interpretatie speelt bij Goudeket een rol van betekenis bij de toekenning van de privaatrechtelijke eigendom. Op grond van het algemeen belang kiest hij voor een onbelemmerde uitoefening. Tekst, systeem en geschiedenis van de wet zijn onduidelijk over de toepasselijkheid van 'zaken buiten de handel.' In de rechtspraak wordt de

729. Zie hoofdstuk 5 \&.D.2, waar Opzoomer in het cital spreekt ower hoogheidsrechten, die scherp onderscheiden zijn wan de rechten die de staat ais eigenaar zouden toekomen. Het handelde hier om een onderscheid dat woor Opzoomer niet in de wetgewing was uitgedrukt, maar er in uitgedrukt had behoren we worden: "ius constituendum.." Zie hoofdstuk 5 \& 1.C. 3.

730. Goudeket, J. Het Burgerlijk Wetboek werklaard door Mr. C.W. Opzoomer, deel 3 (3e druk, 1911), p. 153.

731. Goudeket, Y., (1911), p. 154. Het enige beperkende voorschrift is gelegen in artikel 14 AB. Goudeket. J.. (1911), p. 156, 159. Art. 14 AB: Door geene handelingen kan aan de wetten, die op de publieke orde of goede zeden betrekking hebben, hare kracht worden ontnomen. 
laatste zinsnede ("onverminderd de door titel of bezit verkregen regten van bijzondere personen of gemeenschappen') van de artikelen 577 en 579 ruim uitgelegd. Ook private personen kunnen rechten verkrijgen op de genoemde zaken. Er bestaat geen bezwaar "diezelfde beginselen ook op andere ten algemeenen nutte bestemde zaken toe te passen. Voor zover ze den staat toebehoren, is er geen enkele reden hem in zijne beschikkingsbevoegdheid te beperken, nu de wet dit ook niet doet.' Andere schrijvers hadden een mening van vergelijkbare stelligheid, doch vaak minder onderbouwd ${ }^{732}$. Met name Scheltema heeft zich in een groot aantal artikelen uitgesproken woor een privaatrechtelijke benadering als door Goudeket werd voorgesteld. Daarbij brengt hij wel wat nuanceringen aan, maar op hoofdzaken blijft de argumentatie in stand ${ }^{733}$.

\section{Scholtens gemene rechisleer}

Scholten ontkent de aanwezigheid van een onderscheid tussen publiek en privaat domein in het Burgerlijk Wetboek, en acht net als Goudeket de bepalingen over zaken buiten de handel niet van toepassing wegens een gebrek aan een in de wet gegeven criterium. Tot beide standpunten komt hij met behulp van het Franse (Planiol) en het Duitse recht (Windscheid) ${ }^{334}$. Maar meer van belang dan Scholtens stellingname in het debat over publiek domein is zijn gemene rechisleer:

"Geen scheiding van publiekrecht in ruimen zin en privaatrecht die geldt woor alle tijden en alle platsen. Geen meerderwaardigheid woor het publiek recht boven het privaat. Geen principieel ander karakter der normen in het een en het ander gebied. Doch evenmin een volstrekte ontkenning van het verschil, voor zover het nier de rechtsnorm in het algemeen, maar het positieve rechl wan het heden betreft. Nog altijd schajnt mij, dat de kijk, die Hamaker op het vraagstuk had, het juiste inzicht geeft. Het privaatrecht wijst de algemene rechtsregelen aan, het gemeene recht is dararvor de juiste term. In het publiekrecht worden (...) ewenzeer gedragsregelen

732. Veegens, J.D., Schets van het Nederlandsch burgerlijk rech, deel 2 (1909), p. 10-12; Kronemberg. H.G., Rechsgeschiedenis van den aanwas (1911), p. 92 107; Laman Trip. H., boekbespreking van Kronenlserg, H.G., Rechssgeschiedenir wan den anwas (1911), ir: Rechisgeleerd Magazinn 1912, p. 182-184. A dH. Kamerlingh Onnes: 'Het denkbeeld, dat er zaken zouden zijn, die wegens haren aard of bestemming onvatbatar zouden zijn voor gewonen burgerrechelijken eigendom, is aan ons oudHollandsche recht ten eenenmale vreemd. in: Openbare wegen overparticulieren grond (1915), p. 82. Harzfeldt, Over vertegenwoordiging en har rechtsgevolgen, naar privat- en publiekrecht. Themis 1900, p. 501: Bool, J., De geneentewer (1930), p. 566-569.

733. F.G. Schettena, Zaken buiten den handel, WPNR 2533-2534 (1918), met name p. 335: 'O.i. is het civiele recht op ten publieken dienste bestemde objecten van toepassing niet "behoudens de vereischten van den publieken dienst", maar in onbeperkten mate, zij het dan, dat bij de uitoefening wan de aan dat civiele recht ontleende bevoegdheden uitteraard zal zijn rekening te houden met de positieve bepalingen van verordenenden aard, welke door de verschillende corporatiën in verband met de handhaving van den publieken dienst zijn gesteld." Dezelfde: De openbare weg en de beperking van den eigendom, Rechtsgeleerd magazijn 1920, p. 264-286, met name p. 265; Nederlandsch Bestuursrech (1932), hoofdsnk 2. De zaken der openbare lichamen, p. 115-134.

73. Scholten. P., Handleiding tot de beoefening wan het Nederlandsch butgerlijk recht door Mr. C. Asser, deel 2 (4e druk, 1905). p. 16-20; dezelfde (5e druk, 1913), p. 23-27. 
gegeven, bevelen der overheid, rechtsregels, als die van het gemeene recht, die dat wechi terwille van de staatstakak aanvullen en er wan af wijken. 735

Het privaatrechtelijk standpunt past uitstekend in deze gemene rechtsleer: het privaatrecht is van toepassing op publiek domein, andere regelgeving kan op de toepassing van privaatrechtelijke voorschriften inbreuk maken. Scheltema incorporeerde Scholtens gemene rechtsleer in zijn argumentatie ${ }^{736}$.

\title{
B. Publiek domein in Frankruk en DutTsland
}

\section{Frankrijk}

Berthélémy verkondigt de heersende leer van het domaine public. Hauriou heeft een iets afwijkende opvatting. Benadrukt moet worden dat zij tot hun opwattingen komen met een argumentatie die niet of nauwelijks aan de Code civil was ontleend. Civilisten onderbouwen domaine public met een aan de Code civil ontleende argumentatie ${ }^{737}$. De onderbouwing met behulp van de Code civil verandert. Barckhausen toont aan dat het in de Code civil gelezen onderscheid tussen domaine public en domaine privé niet aanwezig is ${ }^{738}$. Op een duidelijke wijze knoopt Baudry-Lacantinerie hierbij aan, waarbij hij eerst eigendom als uitgangspunt voor publiek domein construeert:

\begin{abstract}
'Parmi les biens du domaine national, il y en a qui sont affectées à un usage ou à un service public (...). On les designe dans la dinctrine sous le nom de biens du domaine public (national ou de l'Etat). Leur charactère est d'être inaljénables et imprescriptibles. On soutient à tort. croyons-nous, que l'Etat n'est pas propriétaire de ces biens, et qu'il en a seulement la garde et la. surintendance. (...) En deux mots les biens du domaine national se divisent en biens du domaine public et biens du donaine de l'Etat. Les premiers sont inaliénables et impréscriptibles; il en est autrement des derniers' "7x9
\end{abstract}

terwijl hij vervolgens Barckhausens uiteenzetting gebruikt om aan te tonen dat de Franse wetgever geen onderscheid voor ogen stond tussen domaine public en domaine privé:

735. Scholten, P., Algemeen deel (1931). p. 40.

736. Scheltema vergelijkt terloops deze gemene rechssleer met de in Frankrijk en Duitsland aangehangen standpunten in het administratiefrecht. In Duitsland (Fleiner), 20 vermeldt Schellena, wordt aok een vergelijkbare 'gemene rechtsleer' gehuldigd, terwijl in Frankrijk (Jèze) uitgangspunt is dat handelingen van de owerheid beoordeeld behoren te worden naar een eigen objectief rechi, vormgegeven door rechtspraak van de Conseil d"Etat. Scheltema, F.G. Het grensterrein van publiek en privast rechr. Rechtsgeleerd magazim 1927 , p. 233-265, met name p. 240.243 .

737. Zie hoofdstuk $5 \$ 4 . D .2$.

738. Barckhausen, H., Remarques sur la théorie des domaines, Revue critique de législation et de jurisprudence deel 13 (1884), p. $30-43$. Zie hoofdstuk 6 \% 4 .C.

739. Baudry-Lacantinerie, $\mathrm{G}$, en M. Chauwean, Traité théorique et pratigue de droit civit, des biens (3E druk, 1905), nr 133, p. 139. 
"Tous les anteurs reprochent au législateur du code civil d"avoir foulé aux pleds cete distinction fondamentale dans les articles de ce chapitre. (...) Dans un article fort intéressant publié par la Revuè critique de législation ef de jurisprudence, notre savant collègue $M$. Barckhausen, a dếmontrế, péremptoirement a notre awis, l'inanité de cette critique. Le législateur de code civil dit indifferemment: domaine public (art. 538 ef 540 ), domaine de l'Etat (art. 541 ) ou domaine de la nation $(. .),.{ }^{740}$

De Code civil geeft geen historische grondslag om onderscheid aan te nemen. Toch bestaat er tussen de zaken die worden genoemd in de artikelen 538-541 een onderscheid: "il y en a qui, étant affectées a un usage ou un service public, sont inaliénables et impréscriptibles (...).' De bepalingen met betrekking tot de zaken buiten de handel brengen beperkingen aan. Andere civilisten slaagden er wel degelijk in een onderscheid aan te brengen dat verder strekte dan alleen de toepasselijkheid van de bepalingen over zaken buiten de handel. Zo Planiol, die inderdaad van mening was dat de Code een 'confusion complète' voorschotelde, zodat uit de tekst zelf niets kon worden afgeleid. Van een privaatrechtelijk eigendomsrecht op publiek domein kan bij de staat echter geen sprake zijn aldus Planiol:

'Non seulement des particuliers ne peuvent pas acquểir sur (..) eux (...) un droit de proprieté (...), mais les autorités publiqques elle-mêmes ${ }_{i}$ chargées de la garcie et de la gestion du domaine. n"en peuvent disposer sous aucune forme. Toutefois l'inaliénabilité et l'impréscriptabilité ne sont que des conséquences de l"affectation à l'usage du public des biens quä composent le domaine public (...). l'Etat n'a pas un véritable domaine de propriété; qu'ill n'excerce sur eux qu'une sorte de surintendance, c'est à dire une fonction de garde et de surveillance. " 741

Opvallend is dat Planiol zijn argumentatie aan het Franse administratiefrecht ontleent. De staat heeft geen eigendomsrecht maar een 'droit de surintendance.'

Planiols stellige voorspraak voor een publiekrechtelijke benadering wordt overtroffen door de administratiefrechtelijk jurist Duguit ${ }^{742}$. Zijn afwijkende standpunt wordt ook in Nederland gebruikt door Scheltema en Meijers. Publiek domein is niet aan privaatrechtelijke regels onderworpen: 'Précisement parce qu'elles sont affectées à une service public, toutes les clépendances du domaine public sont soustraites au régime normal de la propriété privée. " 743 Maar daarnaast beschouwt Duguit ook de zaken van de overheid waaraan die publieke bestemming ontbreekt als zaken waarop het privaatrecht niet van toepassing is: '(...) je maintiens l'expression domaine privé pour désigner les choses

740. Baudry-Lacantinerie, G., en M. Chauveau, (1905), p. 139-140; zie voor Barckhausens mening hoofdstuk 6 \& 4.C.

741. Planiol, M., Traité élémentaire de droit civil, deel 1 (8e dnuk, 1920), nr. 3062, 3065, p. 964, 966-967.

742. Deze beschrijft op fraaie wijze de ontwikkeling wan de theorie van het domaine public in Frankrijk, en de aandelen daarin van Proudhon en Barckhausen. Duguit, L.. Traire de droit constinutionnel, deel 3 (3e druk, 1930), 74, p. $3.44 \mathrm{ev}$.

743. Duguii, L., (1930), p. 352. 
qui, bien qu'appartenant à l'Etat, sont soumises à un régime analogue à celui de la propriété privée et j'oppose le domaine privé au domaine public." ${ }^{744}$

De noodzaak van een bijzondere juridische positie is, in tegenstelling tot in het Nederlandse privaatrecht, altijd in Frankrijk beklemtoond. In Aubry en Rau, 1935: de zaken behorende tot het publiek domein, 'ne forment pas l'objet d"un vêritable droit de propriété. Elle ne sont, à vrai dire,dans le patrimoine de personne et restent exclues du commerce." ${ }^{745}$ Picard (1952) verwijdert zich meer van de publiekrechtelijke constructie: de theorie dat het recht van de overheid op publiek domein van een andere aard is dan de privaatrechtelijke eigendom "est plus en plus abandonnée. Sans doute, les biens du domaine public échappent aux règles du droit civil concernant la propriété: l'Etat n'excerce pas sur eux l'usus, puisque l"usage en appartient à tous; il n'en tire pas en principe des révenus; il ne peut enfin en disposer. Mais cela n'exclut pas l'idée que les dépendances du domaine public sont des objets de propriêté, d'une propriêté d'affectation, soumise à de nombreuses limites, mais donnant à son titulaire des droits plus étendus que ceux qui dérivent de la garde et de la surveillance." ${ }^{746}$ Ook thans nog wordt het onderscheid aangehouden ${ }^{747}$. Van een verwijdering van Proudhons theorie is zonder twijfel sprake in de Franse rechtswetenschap, maar dat geschiedt in elk geval langzamer en genuanceerder dan in Nederland.

\section{Duitsland}

Het onderscheid tussen domaine public en domaine privé is in de Duitse rechtswetenschap ook bekend. Daar wordt gesproken over het 'Finanzvermëgen' en het "Verwaltungsvermögen', of 'öffentliche Güter' en 'Staatsvermögen' ${ }^{748}$. Dernburg merkt over de öffentliche Sachen op ${ }^{749}$ : 'Sie unterstehen einem besonderen Recht, durch welches sie außerhalb des Privatverkehrs gestellt sind.' Zij zijn aldus 'buiten de handel' geplaatst. Welk recht heeft de overheid op deze zaken? Dernburg:

744. Duguit, L. (1930), p. 350.

745. Bartin, E., in diens bewerking van Aubry, C., en C. Rau, Cours de droit civil Français, deel 2 (6e druk. 1935), \& 169, p. 54.

746. Picard, M., in: Planiol M., en Ripert, G., Traitế pratique de droit civil Francals, deel 3 (2e druk, 1952), \&120, p. 130-131

747. Zie bijwoorbeeld Malaurie, Ph. en Aynds, L., Cours de droit civil, deel 4 (3e dnuk, 1994), 5. p. 56 ev: 'Les biens sont, en principe, privếs; it en est un cenain nombre qui ont un charactere public, d'une maniere qui, selon les cas, est plus ou moins accusěe.(...) Le Code distingue les biens qui appartiennent à l'Eat et aux collecrivités publiques. (...) Les secondes relèwent d'un régime jurădique particulíer surtout quand ils font partie du domaine public "par opposition au domaine privé. Les biens du domaine public sont affectés au public et par conséquent échappent à la compétence des tribuneaux judiciaires, et sont inaliénables et imprescriptibles."

748. Zie hoofdstuk 5 \& 4.D.2.

749. Een categorie die vrijwel overeenkomt met publiek domein, behalve dan dat er bij Dernburg en vereiste wan 'onmiddellijkheid' aan is toegevoegd: 'welche unmittelbar den offentlichen Zwecken dienen. Dernburg, H., Pandekten deel 1 (3e drik, 1892), 81 , p. 165. 


\begin{abstract}
"Der Rechtscharacter der offentlichen Sachen ist bestritten. Manche betrachten sie als Niemandem gehörig, auch nicht dem State selbst. Nach dieser Ansicht stehen sie nur unter einem publicistischen Hoheitsrechie des Staates (...). Dals Richíge ist, das auch die ôffendiche Sachen des Staates und der Gemeinde in deren Eigenthum stehen. Deshalb gehören itnen đie pekuniaren Nutzungen, welche solche Sachen neben ihrer offentlichen Bestimumung abwerfen $(\ldots),+750$
\end{abstract}

Ook de openbare zaken van staat of gemeente '[stehen] in deren Eigenthum;' ze behoren in eigendom aan de staat. Maar de openbare bestemming blijft bestaan en dat heeft de volgende consequentie: 'Indeß unterliegt das Eigenthum an öffentlichen Sachen einem Sonderrechte, vermöge dessen Akte privatrechtlicher Natur nicht im Stande sind sie ihrem Zweck zu entfremden. (...) Durch rechtsgültige publicistische Akte dagegen kann die öffentliche sache ilhres besonderen Characters entkleidet werden. Damit tritt sie unmittelbar in das gewöhnliche Eigenthum des Staates oder der Gemeinde und wird verkehrsfähig." ${ }^{791}$ De eigendom treedt aan het daglicht, zodra de openbare bestemming ontnomen wordt. Bij Windscheid vinden we dezelfde constructie. De privaatrechtelijke eigendom 'tritt hervor, sobald die öffentiliche Bestimmung der Sache wegfällt, und auch während ihrer Dauer, soweit sie nicht entgegensteht." ${ }^{752}$ In het Duitse BGB is in let geheel niets geregeld over het bijzondere aan publiek domein. De voorschriften die betrekking hebben op publiek domein zijn publiekrechtelijke voorschriften, en horen aldus niet thuis in een burgerlijk wetboek. In de "Motive" voor het ontwerp BGB wordt overwogen dat de juridische kwalificatie van publiek domein weliswaar omstreden is, maar dat de leer dat de staat (privaatrechtelijk) eigenaar is, de heersende is: 'Im allgemeinen scheint die Ansicht zu überwiegen, das das Eigenthum (...) an den res publicae dem Staate oder ebenfalls einem Gemeindeverbande zusteht.' Verwezen wordt naar de hierboven aangestipte bespreking van Windscheid: 'Sie können insoweit Gegenstand von Privatrechten sein, als nicht die in der Rechtsordnung gegründete Bestimmung der Sache hindernd entgegentritt. De regeling van de openbare bestemming wordt aan de afzonderlijke staten overgelaten ${ }^{75 \%}$. Dat heeft tot gevolg dat er verschillende regelingen tot stand zijn gekomen. De Franse leer van het domaine public is in een tweetal regelingen opgenomen: in het wegenrecht van Hamburg, en in de Waterwegenrecht van Baden-

750. Dernburg, H., (1892), \& 71, p. 166.

751. Dernburg. H., (1892), p. 167.

752. Kipp. Th.. in diens bewerking van Windscheid, B. Lehrbuch des Pandekpenrechts, deel 1 19e druk, 1906). 146. p. 725; zo ook Crome, C. System des Deutschen Burgerlichen Rechts, deel 1 (1900), 867, p. 302 .

753. Mugdan, B., Die gesanten Materialien zum Bürgeritchen Gesetzbuch fur das Deutsche Reich, band 3. Sachenrecht $(1899,1979)$, p. 15 . 
Württemberg ${ }^{754}$. In de Zwitserse privaatrechtelijke wetgeving krijgı publiek domein wel een plaats toebedeeld ${ }^{755}$.

\title{
C. Een terugtred VAN DE PRIVAATRECHTELUKe WEG
}

\section{Suijlings waarschuwing}

Suijling neemt in 1916 een genuanceerd standpunt in. Wel is Proudhons leer verlaten, maar: "Art. 577 BW laat kwalijk een andere opvatting toe. Alle in beginsel volkomen heerschappij over zaken, door het Burgerlijk Wetboek gegeven, is eenerlei eigendomsrecht, onverschillig of het aan een particulier of aan een openbaar lichaam toekomt." Heeft de overheid net als een particulier alle bevoegdheden uit het eigendomsrecht? Nee, dat gaat te ver:

\begin{abstract}
"Gelijk het hervormers echter meer wergati, kemen de bestrijders wan het "domane public" in hunnen ijver geen grenzen. Nauwelijks hebben zij den afgod van den publiekrechtelijken eigendom van zijon woetstuk gestort, of op de ledig gekomen plaats richten zij uit de bevoegdheden, aan de administratie met betrekking tot opentbare wegen verleend, een beeld wan het "domaine privé" op. Daarmee overschrijden zij de schreef. Aan het overheidsgezag, d.t. het gezag, dat met volstrekte uitsluiting van particulieren enkel aan openbare lichamen toekomt, wijolt het Burgerlijk Wetboek immers geen woord. 756
\end{abstract}

Suijling treft deze te ver doorschietende privaatrechtelijke benadering aan bij Kamerlingh Onnes, in zijn bij Van Gelein Vitringa geschreven proefschrift. Kamerlingh Onnes construeert de openbaarheid van een weg als een (privaatrechtelijk) zakelijk recht ${ }^{757}$. Geheel ten onrechte aldus Suijling: 'Private en publieke macht komen zoo op een hoop te liggen. (...) Het algemeen belang dreigt hier in de knel te geraken. Aan het publiek gezag wenst men zijn gerechte portie te onthouden en juist daarom plaatst men het, zijnen eigen aard ten spijt, onder de autoriteit van een recht, dat voor zulk gezag niet is geschreven. ${ }^{758}$ De publiekrechtelijke beheersmacht stelt Suijling op de voorgrond. Daarnaast heeft de overheid de privatrechtelijke eigendom van publiek domein. Uit beide "bronnen' kan de overheid in het algemeen naar keuze bevoegdheden ontlenen, maar grenzen aan het gebruik van privaatrechtelijke bevoegdheden worden gesteld door gebruik van de constructie 'misbruik van recht': 'privaatrechtelijke bevoegdheden

754. Salzwedel, 3., Anstaltsnutzung und nutzung öffenticher Sachen, in: Allgemeihes Verwathungsrecht (8e druk, 1988\%, p. 480-481. Zie ook Frauke Wernecke, Die offentliche Sache im Widerstreit privater und allgemeiner Belange, AcP 195 (1995), p. 449 .

755. Artikel 664 ZGB: Die herrenlosen und die offentichen Sachen stehen unter der Hoheit des States. in dessen Gebiet sie sich befinden.

756. Suiling.J.Ph., De openbare weg in publiek - en privaatrecht, Themis 1916, p. 153-186, met name p. 184.

757. Kamerlingh Onnes. A.H., Openbare wegen over particulieren grond (1916), mer name p. 82-90, en p. 107.

758. Subjling, J.Ph, (1916), p, 186. 
mogen nooit worden uitgeoefend ter verwezenlijking van doeleinden [volgens] welke het aan de overheid verboden is anders dan door de uitoefening van overheidsmacht na te streven." 759

\section{Publiekrechtelijke beperkingen in het Burgerlijk Wetboek}

Scheltema, Goudeket, en Scholten ontkennen de toepasselijkheid van de bepalingen over zaken buiten de handel. Op dat standpunt heeft Meijers kritiek. Indien sprake is van publiek domein, dan zijn de bepalingen over "zaken buiten de handel" wel toepasselijk. Het Nederlandse recht heeft de bepalingen verwaarloosd: 'Het Fransche recht onderscheidt zich hier van het Nederlandsche, op een wijze, die niet ten gunste van het laatste spreekt. ${ }^{760}$ Het is met name het eigentijdse Franse recht waarmee Meijers zijn behandeling onderbouwt, naast het Romeinse en thet oude Franse recht. In die beschouwingen passeren de reeds behandelde Franse schrijvers de revue. Hij gebruikt het (door Diephuis verworpen) criterium "openbare bestemming" en kan op die wijze de bepalingen over zaken buiten de handel weer een betekenis geven. Dat doet Meijers voornamelijk aan de hand van Franse administratiefrechtelijke literatuur. Welke zaken worden door de bepalingen bestreken? In navolging van Hauriou begrijpt Meijers ook roerende zaken (bijvoorbeeld kunstvoorwerpen) en zaken waarvan het publiek geen vrij gebruik kan maken $^{76 !}$.

De consequenties van het buiten de handel zijn komt neer op onvervreemdbaarheid (inaliénabilité) en de onvatbaarheid voor verjaring (impréscriptabillité). Deze begrippen worden door Meijers uitgewerkt, waarin hij wordt bijgevallen door Hofmann ${ }^{762}$. De mogelijkheid van verkrijging van beperkte rechten ${ }^{763}$ door verjaring wordt in de wet geboden door (een ruime uitleg van) de slotwoorden van artikel $577 \mathrm{BW}$. Aan het administratiefrechtelijke commentaar van De Récy ontleent Meijers een drietal kwesties waarin de onvervreemdbaarheid wordt geconcretiseerd. In de eerste plaats de vraag of een overllyeidsorgaan in de wet tot vervreemding bevoegd is verklaard ${ }^{764}$. In de tweede plaats speelt de vraag of aan de vervreending een verklaring vooraf moet gaan dat de openbare bestemming is gewijzigd. In het Nederlandse recht impliceert de vervreemding reeds een besltuit tot bestemmingswijziging. De derde kwestie ten slotte behelst de vraag of beperkte rechten gevestigd kunnen worden. Dat is mogelijk omdlat private

759. Suijling, I.Ph., Inleiding tot het burgerlifk recht, 5e stuk (zakenrecht), 1940, \$14., p. 154 .

760. Meijers, E.M. Publiek donein en zaken buiten den handel "WPNR 2543-2547 (1918), p. 441.

761. Zie Hauriou, M., (1933), p. 804: '(.. ) son dépendances du domaine public toutes les chose qui, etant propriétés auministratives, ont étés l'object d'une affectation formelle à l'urilaté public."

762. Hofmann, L.C., Het Nedertondsch zakenrecht (1933), p. 33-35.

763. De werkriging wan de eigendom door verjaring wordt verhinderd door de artikelen $593 \mathrm{en} 1990 \mathrm{BW}$.

764. Meijers, E.M., (1918), p. 454. Nog steeds geldt dan in Nederland de Franse wet wan 1 december 1790 , die verklaart dat vervreendingen op een wet dienen te berusten. Artikel 8 van de wet van 22 nowember/l decenber 1790 verklaart dat de domaines nationaux "peuvent être vendus et aliẻnés ( en wertu d'un dẻcret formel du corps lègislatif (...). 
rechten op publiek domein onafhankelijk van de bestermming kunnen worden uitgeoefend.

De eigen rechtspositie van publiek domein komt door erkenning van de bepalingen over zaken buiten de handel duidelijker naar voren. De toepasselijkheid van deze bepalingen heeft een belangrijke functie:

\begin{abstract}
'Zelfs echter, indien thans practisch de betekenis der wettelijke voorschriften van zaken buiten den handel geheel ontbrakk, dan nog zouden zij een theoretisch bestansmsecht hebben; zij zijn wen uitdrukking der waarde, die aan het ten algemeenen nute bestemde gemeenschappelijk eigendom van het volk wordt toegekend; wat eenmal ten nutte wan het algemeen strekt, kan niet zonder goedvinden van het wolk of zujin organen in privatbezht overgaan, het moet volkseigendom bligven. ${ }^{*}$ t6s
\end{abstract}

Het is dit theoretisch bestaansrecht dat Meijers ertoe brengt om in zijn ontwerp voor Boek 5 wel een bepaling over publiek domein op te nemen, een bepaling die door de hem na 1954 opgevolgde codificatoren niet wordt opgenomen, omdat juist het praktische element er aan zou ontbreken ${ }^{76 .}$. Alleen voor veralgemening vatbaar werd geacht de (eerst in de Wegenwet geregelde) bewijslast met betrekking tot de eigendom (artikel 5:28 BW). De bepalingen over zaken buiten de handel zijn niet teruggekeerd. Hun plaats is ingenomen door een enkele zeer algemene bepaling die publiekrechtelijke regels in het algemeen van toepassing verklaart ${ }^{767}$.

\title{
3. Domaine public
}

In het Weekblad voor gemeentebelangen wordt in het begin van de jaren dertig krachtig stelling genomen tegen een bepaald gebruik van eigenaarsbevoegdheden van de staat: het verlangen van een vergoeding voor gebruik, in combinatie met publiekrechtelijke bevoegdheden (het verlenen of intrekken wan een vergunning) ${ }^{768}$. Kort nadien zal door Vos de leer van domaine public weer met kracht worden verdedigd:

"Het is in de eerste plats de overweging, dat alle schrijwers die de stelling werdedigen dat ons reche "slechts één soor wan eigendom" kent, in hoofdzaalk, en, gelijk wij zeiden, zonder veel

765. Meijers, E.M., (1918), p. 471; met instemming aangehaald door Van Maanen, G.E., Publiek domein en het betang var de overhaid bij bodemsanering: een ongewasschen warken (1990).

766. 'Zowel de vaag of de zaken die aats particulieren in eigendom toebehoren, kunnery behoren tot de ten algemenen nutte bestende zaken, als de vraag, hoe de publieke bestemming ontstaat en tenietgaat, en wat de rechisgewolgen van deze bestemming zijn, kunnen nier op gelijke wijze worden beancwoord( . . ) Van Zeben, C.J. e.a., Partementaire geschiedenis van het Nieuwe Burgerlijk Werboek, boek 5, p. 141. op artikel 5.3 .8 .

767. 3:14. Eer bevoegdheid die iemand krachtens het burgerl ijk recht toekomt, mag niet worden uitgeoefend in strijd met geschreven of ongeschreven regels van publiekrecht. Ook Meijers had deze bepaling opgenomen, maar dan in de Injeictende Titel, artikel 9.

768. Vos, H., Intrekking vant wergunningen, Weekblad woor gemeentebelangen 19 sept.1930, p. 327-328; Vink, I., Geen knevelarij. Weekblad voor gemeentebelargen 21 nov. 1930. p. 399-401 
wariatie, zich ertoe bepalen, hiervoor in te roepen de bedoelingen van ons Burgerlijk Wetboek con den tekst wan enkele zijner artikelen (...). In de tweede en voornaamste platas sterkt ons voor ons betoog de overwiging, dat men het rechtskatakter van publieke zaken in het algemeen en van publieke wegen in het bijzonder, niet opbouwt uit regelen yan privaturecht, gelijk die in ons burgerlijk wetboek zijn neergelegd, maar uit het wezen en de beginselen van het publieke recht zelf.' 769

Daarbij sluit hij zich aan bij de Franse en Duitse voorstanders van die constructie: Hauriou, Duguit en Mayer. De publiekrechtelijke eigendom stalat naast de privaatrechtelijke eigendom. Wanneer sprake is van publiek domein en de zaak aan de overheid zelf in privaatrechtelijke eigendom toebehoort, lost deze privaatrechtelijke eigendom zich op in de publiekrechtelijke. Hierin is bij uitstek Mayers constructie te herkennen, die immers het offentliches Eigentum liet ontstaan nadat de overheid een aan haar toebehorende zaak door 'Widmung" een openbare bestemming heeft gegeven. Vos had weinig succes met zijn standpunt, dat vooral rustte op een argumentatie ontleend aan het publiekrecht; tekst, systeem en bedoeling van de betreffende artikelen uit het Burgerlijk Wetboek hebben voor hem weinig waarde. Hoewel hij aangaf het idee: ' $(\ldots)$ dat ooit de Hooge Raad zou meegaan met een leer, die het den Staat mogelijk maakt, de beginselen, die hem met betrekking tot een zaak als overheid krachtens publiekrecht binden, als eigenaar van die zaak krachtens privaatrecht weder opzij te zetten $(. .)^{\prime}$ niet goed denkbaar te achten, zal in 1941 de Hoge Raad in het parlevinker-arrest de door Vos verworpen stelling betrekken, in navolging van procureur-generaal Berger ${ }^{70}$. De privaatrechtelijke eigendom zal voor de overheid in latere jaren onderschreven worden als uitgangspunt ${ }^{77 !}$.

\section{CONCLUSIES PUBLIEK DOMEIN}

De privaatrechtelijke leer is de heersende, maar blijkt bij nadere beschouwing toch aan kritiek onderhevig te zijn. Door Goudeket, Scholten en Scheltema wordt de heersende leer stevig verankerd. Kritieken komen van Suijling, van Meijers en van Vos. De heersende leer gebruikt aan tekst en systeem van het BW ontleende argumenten, maar schraagt deze tevens met het algemeen belang, de maatschappelijke noodzaak. Zo

769. Vos, H. Publiek domein, Weekblad woor gemeentebelangen 20 februari 1931, p. 61-63.

770. IRR 17 januari 1941, NJ 1941, 644. Zie ook: Teunissen, J.M.H.F, (1996), hoofdstuk 3, met name p. 133 .

771. De meeste schrijwers blijven deze privaatrechtelijke benadering voorstaan. De rechtspraak van de Hoge Ratd is eveneens eenduidig: met de publiekrechtelijke benadering alls door het Hof Amsterdam in de kwestie wan de lozingen op het IJsselmeer door de gemeente Huizen werd door de Hoge Raad korte metten gemaaki. Zie HR 19 jamuari 1962, NJ 1962, 151; zie ook Eindhoven-Staals, HR 19 januari 1968, NJ 1968, 166, Asser/Beekhuis II (1990), or. 123; uitzonderingen zijn: Reehuis/Heisterkamp nr. 550-552; Tak, A.Q.C., en J.M.H.F. Teunissen, "Een ieder neemt voldoende zorg woor het milieu in acht". Wie zorgt er voor de rechtsstaat? Een voorgezet debat. Recht en Kritiek 20 (1994) 4, 340-354; Teunissen J.M.H.F, en A.Q.C. Tak (1994), Recht ist was der Umwelt nütat? Nederlands Juristenblad 1994,18, p. $605-617$. 
geschiedt met de toekenning van de eigendom: wie het meerdere kan (bestemming opheffen) mag ook het mindere (gebruikmaken van eigenaarsbevoegdheden), aan de staat kan men gerustelijk de eigendom overlaten (Goudeket); met de niet-toepasselijkheid van de zaken buiten de handel (tekst en systeem). Zo ook Scholten die met zijn gemene rechtsleer de privaatrechtelijke eigendom wel als uitgangspunt moet nemen.

Degenen die kritiek leveren hebben grammaticale en systematische (het Burgerlijk Wetboek zegt niets over overheidsgezag) argumenten, maar ook aan het algemeen belang ontleende (Suijling). Meijers wijst op de aanwezigheid van de bepalingen over zaken buiten de handel en acht ze van toepassing om redenen van algemeen belang, maar wettekst en systematiek spelen bij hem evenzeer een rol. Vos is tenslotte vanwege het onderscheid tussen publiekrecht en privaatrecht voor toepasselijkheid van alleen publiekrecht op publiek domein.

Van het Franse en het Duitse recht wordt een uitvoerige vergelijkende weergave gegeven, door beide partijen. De gebruikte bronnen zijn voor een klein deel als rechtshistorisch te kwalificeren, voor een veel groter deel als rechtsvergelijkend. Scholten (Planiol en Windscheid) en Goudeket wijzen op de Franse en Duitse theorieën met betrekking tot overheidseigendom. De belangrijkste Franse en Duitse meningen worden weergegeven en vervolgens geaccepteerd of verworpen. Met name de Franse omslag als door Barckhausen bewerkstelligd en door vele Franse auteurs overgenomen, wordt gebruikt: ook in Frankrijk heeft een omslag naar een uniform privaatrechtelijke benadering plaatsgevonden (Hauriou en Baudry-Lacantinerie). Die omslag is bepaald minder stellig dan in Nederland; alleen de onderbouwing in de Code civil wordt van het onderscheid publiek en privaat domein wordt ondergraven. De visie van Mayer wordt, net als eerder Van Gelein Vitringa deed, ook door Goudeket bestreden.

Ook de tegenstanders van de (extreme) privaatrechtelijke benadering gebruiken eveneens Frans en Duits recht. Meijers ontleent veel aan Hauriou, en acht in navolging van het Franse recht de bepalingen over zaken buiten de handel toepasselijk. Vos sluit zich vooral aan bij Mayers leer van de öffentlichrechtliche Eigenthum en maakt ook van Hauriou en Duguit gebruik.

\section{\$. De relativiteit der onrechtmatige daad}

\section{A. DE ABSOLUTE ONRECHTMATIGHEID}

Elke onregtmatige daad, waardoor aan een ander schade wordt toegebragt, stelt dengenen, door wiens schuld die schade veroorzaakt is in de verpligting om dezelve te vergoeden. Wanneer de nadruk bij lezing van artikel 1401 zo op het eerste woord wordt gelegd., is sprake van een absolute opvatting van onrechtmatigheid. In het arrest Slegten- 
Westenenk uit 1917 wordt deze opvatting vertolkt ${ }^{72}$. Deze uitleg biedt de mogelijkheid tot een wat ruimere aansprakelijkheid te komen in de beperkte opvatting van onrechtmatigheid uit het Zutphense waterleiding-arrest ${ }^{77}$. Tegelijk kan deze absolute visie de poorten wijd openen voor een te ruime aansprakelijkheid. Deze verwachting brengt Van Gelein Vitringa tot de, aan het Duitse recht ontleende formulering van het relativiteitsvereiste. Meijers en Scholten nemen stelling tegen dit nieuwe vereiste.

\section{Meijers" argumentatie}

In een noot onder het brandstichtingsarrest ${ }^{774}$ stelt Meijers dat de eis van de relativiteit een overbodige is: 'Het is zeer de vraag, of in deze bepaling een vooruitgang der wetenschap is te zien' zegt Meijers, want de meeste rechtsregels zijn als absolute regels overgeleverd. Sommige niet, maar die nu kennen wij in een andere juridische constructie: verbintenissen. Het is juist door het element van relativiteit waarin zich de wanprestatie van de onrechtmatige daad onderscheid. Dat onderscheid kent een lange historie. In het Romeinse recht vond, zo vermeldt Meijers, een ontwikkeling plaais van een relatieve onrechtmatige daad (slechts de gelaedeerde eigenaar heeft een actie) naar een meer absolute (een ieder die het aangaat heeft een actie) benadering ${ }^{775}$. Beide benaderingen, een absolute, en een meer relatieve, treft Meijers aan in de negentiende-eeuwse beoefening van het Duitse recht ${ }^{776}$. In Nederland wordt echter sinds Hugo de Groot de absolute benadering aangehangen. Op grond van rechtshistorische en rechtssystematische argumenten heeft Meijers een voorkeur voor de absolute onrechtmatigheid.

Daarnaast vergelijkt Meijers met het Duitse recht. De eis van de relativiteit wordt niet gesteld bij $\& 826 \mathrm{BGB}$, bij de overtreding van ongeschreven normen ${ }^{m 7}$. In een uitspraak van het Reichsgericht, $\mathbb{1 1}$ maart 1912 wordt een absolute interpretatie gegeven. Eveneens verwijst hij naar Oertmann:

'Diese Haftung erfordert: a) Scladenszufügung, im weitesnen Sinn gemail $\$ \$ 249 \mathrm{ff}$, also irgendwie nachteilige Beeinflussung der Interessenlage in inrer Gesatrotheit, wie nach \& 823

772. Zie hoofdstuk $6 \$ 5 . C .1$.

773. HR 10 juni 1910, W. 9038; zie 8.5.3.1; Van Maanen, G.E., Onrechmatige daad (1986), p. 198; Wan Maanen, G. E. "De Zutphense juffroww en de ontrow we bediende van Lindenbaum (1995), passim.

774. HR 24 jamari 1930 ; NJ 1930, p. 299.

775. De ontwikkeling van het Romeinse recht vindt Mejers beschreven in Fadda, Rapporti del condortore coi terzi in fema di danni (1891) en bij thering, R., Rechtsschutz gegen injuriöse Rechtsverletzungen, in: Jahrbuicher für Dognatik 23 , p. 287.

776. Windscheid, B.. Lehrbwch des Pandektentechts, deel 2, \$455, n. 17; Dernburg, H., Pandekten deel 2. § 131: Gluck, Ausfihrliche Erlauterung der Pandekten, deel 10, \$704, p. 375.

777. \$826. Wer in einer gegen die guten Sitten verstoßenden Weise einem andern vorsâtzlich Schaden zufügr, ist dem andern zum Ersatze des Schadens verpflichtet. 
Abs.2, nicht nur Verletzung eines besonderen Rechts oder Rechtsgutes im Sinne von 823 Abs.1, so auch RG. VII $v$. 11 März 1912."778.

Vanaf 1937 wordt het relativiteitsvereiste door de Hoge Raad ook op ongeschreven normen toegepast ${ }^{79}$. Scholten is, hoewel minder uitgesproken dan Meijers, eveneens tegen de toevoeging van dit vereiste. In een noot onder het Intercueros-arrest, in 1929, laat hij blijken het begrip 'wèl rechtmatig tegenover den een en niet rechtmatig tegenover den ander' niet zo helder te vinden ${ }^{780}$. In hun kritiek wordt nauwelijks aandacht besteed aan de vraag, hoe het dogmatisch mogelijk is om niet tot een aansprakelijkheid te komen. Alleen door een korte mededeling in een noot wordt duidelijk dat Meijers de oplossing in 'schuld' ziet ${ }^{784}$. Anderen waren van aanvang af explicieter in hun uitwerking van hun oplossing: die zagen zij ofwel in causaliteit, ofwel in schuld gelegen ${ }^{782}$.

\section{B. Causal verband}

\section{Het dubbele causale verband van Besier}

In zijn conclusie voor het arrest Marchant maakt Besier gebruik van een dubbell causaal verband. Het ene verband is de causale relatie tussen daad en schade, het andere verband bestaat tussen de onrechtmatigheid en de schade. Dat laatste verband ontbreekt in het geval Marchant. Tussen de onrechtmatigheid van de onteigening en de door Marchant geleden schade ontbreekt causaal verband. Die schade zou ook veroorzaakt zijn. wanneer de onteigening geheel volgens de regels (dus met een ter inzagelegging) zou hebben plaatsgevonden. Op deze wijze kan een absolute onrechtmatigheid gematigd worden ${ }^{783}$. Anderen zouden het causale verband eveneens aangrijpen om een alterna-

778. Oermann, P. Recht der Schuldverhalhnisse, Se druk, p. 1407 onder 2 a. Vit het genownde arest: 'Es wäre auch kein innerer Grund dafür erkenmbar, warum ein Verhalten sofern es überthanpo gegen die guten Sitten verstöszt, mur gewissen Personen gegenuber eine Schadenersatzpflicht begrididen sollte, anderen gegenüber dagegen nicht."

779. HR 11 maan 1937; N/ 1937, 899. Hofmann wordn door dit arrest duidelijker gekant tegen de eis van de relativiteit. Als argumenten noemt hij de onbillijke uitkomst (wan bijvoorbeeld het brandstichtingsarrest); het gebruik dat de Hoge Raad maakt wan de relativiteitse is bij schending van ongeschreven normen, warbij Hofmann vermeldt dat in het Duitse rechtsstelsel die theorie alleen bij de overireding wan wettelijke bepalingen gebruikt wordt. Daarmaast noernt hij de mogelijkhe to ofwel via de beantwoording van de vraag of er sprake is wan een causaal verband tussen onrechtratige daad en schade hetzelfide resultaat te bereiken, ofwel door te beaordelen of wellicht schuld ontbreekt. Het is de argumentatie van Meijers die zich na lezing wan Hofmann opdringt. Hofmann, L.C., Het Nederlandsch verbintenissenrecht, deell 1 (6e druk 1941), p. 314-315.

780. Scholten, P., noot onder HR 28 februari 1929. NJ 1929, 905. Zo ook Scholtevn onder HR 19 jumi 1931, NJ1931, 1303.

781. HR 11 maart 1937, NJ 1937, 899.

782. Lankhorst, G.H., (1992), p. 49-74. 
tief voor te staan. Telders leverde kritiek op dit in zijn ogen onmogelijke causale verband ${ }^{7 \% 4}$.

\section{Andere voorstanders van het causale verband}

De belangrijkste verdediger van het causaal verband als criterium om de aansprakelijkheid te beperken is Wolfsbergen, die zijn bezwaren uiteenzet in een bekende polemiek met Telders: 'Is er echter, om in de praktijk tot redelijke resultaten te geraken, eenig nut te verwachten van een gewrongen constructie als blijkbaar de Duitsche jurisprudentie te zien geeft?" ${ }^{855}$ "Wolfsbergen meent van niet: het is de causaliteit waarin de oplossing ligt verscholen. Hoe werkt Wolfsbergens oplossing van het causaliteitsvereiste? Daarbij moet niet, zoals Wolfsbergen vermeldt, de 'conditio sine qua non' benadering van Telders worden gebruikt maar de adaequatietheorie. Er moet dan een antwoord gegeven worden op de vraag of er een causaal verband aanwezig is tussen de onrechtmatige daad en de schade ${ }^{786}$. In een concreet geval moet onderzocht worden of de schade zou zijn ingetreden, indien de onrechtmatigheid aan de daad had ontbroken. In die analyse moet dan uitgegaan worden van een fictie in plats van het concrete te beoordelen geval ${ }^{787}$. Uit het Duitse recht voert Wolfsbergen meningen aan die zijn opvatting zouden ondersteunen ${ }^{788}$. Dit illustreert hoezeer in Duitsland zelf onduidelijkheid bestaat over de betekenis van $\$ 823 \mathrm{BGB}$.

Naast Wolfsbergen wordt de weg der relatieve causaliteit ook in meer of mindere mate bewandeld door Wertheim, Fruin ${ }^{789}$, Van Nispen tot Sevenaer en De Haan ${ }^{790}$. Door Wertheim wordt in 1930 het nieuwe vereiste en de andere oplossing middels de causaliteit vergeleken met de in Frankrijk, Duitsland en Zwitserland aangehangen meningen ${ }^{791}$. In de Franse rechtswetenschap wordt een absolute benadering van de onrechtmatigheid voorgestaan. Demogue is een uitzondering ${ }^{792}$. Planiol geeft de absolute benadering weer: "Toute personne lésée par la faute a le droit d'être indernni-

784. Zie hootdstuk 6 5.F.

785. Wolfsbergen, A. Normatieve onrechmatigheid of causale onrechtmatige daad, WPNR 3115-3116 $(1929)$, p. 474 .

786. Zie hooldsnik 31 .

787. Lankhorst, G.H., (1992) p. 56; zie ook Hartkamp in Asser/Hartkamp III (1994), nr 107.

788. Bij Planck, Greiff en Dernburg vindt hij zinsneden die op de causaliteit zouden wijzen. Wolfsbergen, A., (1929), p. 474 in noot 3 .

789. Fruin, H.M., De tegenwooritge stand der jurispradentie betreffende de onrechtmatigheid in art. 1401 BW, in: Rechisgeleerd Magazin (1932), p. 28 ev, met name p. 42. Fruin gebruikt dezelfde Duitse bromen als Van Gelein Vitringa en Telders.

790. Van Nispen tot Sevenaer, De beteekenis van het algemeen welzijn ten aanzien van privaatrechtelijke werhoudingen, Rechssgeleerd magazijn 1937, p. 300; De Haan, C.J., Asnsprakelijkheid uit onrechtnuatige daad, WPNR 3704-3705 (1940), p. 601. Zie ook: De Haan, C.J., Eenige beschouwingen over het leerstuk der onrechtmatige daad, Rechtsgeleerd magazinn 1938, p. 351-372.

791. Werthein, W.F., Aansprakelijkheid wor schade buten overeenkomst (1930), p. $102 \mathrm{ev}$.

792. Wertheim, W.F., (1930), p. 105; zie hoofdstuk 6 \& 5.D.2. 
sêe. " 793 In het Franse en Belgische recht heeft het in Nederland gewortelde vereiste van de relativiteit niet kunnen inburgeren. Wertheim sluit zich aan bij de woorden van Von Thur:

\begin{abstract}
'Aus der Verletzung gesetzlicher Vorschriften entsteht Schadenersatz nur dam, wenn diese Vorschriften den Schutz des Geschädigten bezwecken; dienen die Vorschriften einem anderen Zweck, so ist der Kausalzusammenhang zwischen der widerreclutlichen Handung und dem Schaden nicht adäquat." 794
\end{abstract}

De causaliteitsvraag beperkt de aansprakelijkheid. Schade die niet is geleden in het door de overtreden norm beschermde belang, is eveneens niet een 'redelijkerwijs te verwachten gevolg ${ }^{x}$ van de onrechtmatige handeling.

\title{
C. SCHULD OF DE LEER VAN SMITS
}

Vigelius (1935), Smits (1938) en Kist (1941) ${ }^{705}$ gebruiken het begrip schuld voor matiging van de aansprakelijkheid. Vigelius' typeert de relativiteit als een 'wanstaltige overwoekering." ${ }^{7 \%}$ Het nieuwe vereiste maakt het leerstuk van de onrechtmatige daad nodeloos ingewikkeld.

'En zoo kwam men ertoe er maar een nieuwe theorie bij te verzinnen, krachtens welke de schade moest zijn geleden in het belang, dat de overtreden morm wil beschermen. Men zou nooit de leer uit Duitsland hebben hoeven te importeeren, als nen het woord ontecthimatig eens eindelijk geheet had durven uitbannen en art. 1401 lezen in het licht der historie: "Wie schade door schuld weroorzakt, moet deze vergoeden". Maar in plaats van deze eenvoudige en aller soepelste formule dankbaar te benutten, trachate men "soepellheid" te brengen met de plompe Schutzuormerei? 797

Daarbij kan zich volgens Vigelius, in navolging van Langemeijer, voordoen dat de aansprakelijkheid te zeer wordt beperkt doordat de aandacht wordt gericht op geschreven normen ${ }^{798}$. Smits onderschrijft de argumenten van Vigelius en gebruikt bovendien het Duitse recht. De Nederlandse jurist legt de Duitse relativiteit geheel verkeerd uit; met de toepassing door Telders en de Hoge Raad van het relativiteitsvereiste wordt de Duitse 'Schutznormleer' misvormd tot 'iets wat noch de Duitse wetgever daarmede

793. Planiol, M., II (1921), nr. 892, p. 293. Opvallend is dat Wertheim onderseuning vindt bij Planiol. Planiol stond ooit een relatieve benadering voor in een annotatie. Zie CC 7 augustus $1895, D P 1896$, 1.81. Zie ook Lankhorst, G.H. (1992), p. 13.

794. Wertheim, W.F.. (1930), p. 114-115.

795. Kist, J. De leer der relatieve onrechtmatigheid, WPNR 3734-3736 (1941), p. 302

796. Vigelius, C.C., De elementen wan art. $1401 \mathrm{BW}$, uit: Rechrskandige opstellen Meijers (1935), p. 824

Vigetius, C.C.. De elementen wan ant $1401 \mathrm{BW}$, in: Rechiskuncige opstelten Meijers (1935), p. 839.

Vigelius gebruikt alls eerste de term 'Schutznorm'.

798. Vigelius, C.C.. $(1935)$. p. 843 ; zie hoofdsmok 6 \& $5 . \mathrm{F}$ 
heeft bedoeld, noch de Duitse rechtspraak of doctrine er wan hebben gemaakt' ${ }^{299}$. Wat wordt volgens Smits in het Duitse recht verstaan onder de eis van de relativiteit? In de eerste plaats is de Duitse bepaling niet gedacht als een relativering wan een absiolute onrechtmatigheid, doch als een hulpmiddel van wetsuitleg. In de tweede plaats wordt in Duitsland de relativering niet op ongeschreven regels toegepast, want:

'Gehed buiten de schutzno mileer staan ook de ongeschreven normen, voorzoverre daaraan het BGB in 826 woor het onrechtmatigheidsoordeel bij toebrenging wan wermogensschade in het algemeen betekenis toekent". 800

Ongeschreven normen kunnen bovendien moeilijk precies geformuleerd worden, terwijl dit nu juist een vereiste is om te komen tot een vaststelling van de omvang van de beschermende werking ${ }^{801}$. Smits' oplossing ligt in een toetsing aan 'ongeschreven normen van behooren:"

'Zonder dat men de bestenmingstheorie noodig heeft, kan men aan ongerechtwaardigde aansprakelijkheidl op grond der gegeven wetsovertreding ontkomen door de aansprakelijkheid wan den wetsovertreder afhankelijk te maken van het antwoord op de vragg of hij, onder de gegeven omstandigheden, met het oog op de voorzienbare gevolgen (rechtsinbreuk, schade voor anderen) daze wetsovertreding had behooren na te laten." 802

Het is aldus de toetsing aan ongeschreven zorgvuldigheidsnormen, de later als "leer van Smits' bekend geworden constructie, die niet alleen de andere onrechtmatigheidscriteria, maar ook de relativiteit overbodig zou kunnen maken ${ }^{803}$ "Ondanks alle kritiek krijgt het relativiteitsvereiste een plaats in de nieuwe Nederlandse privaatrechtelijke wetgeving ${ }^{804}$.

799. Smits, P.H. Iets over de vrag der relativiteit der onrechtmatigheid bij onrechtmatige daad in verband met de doot den Hoogen Rad onderscheiden onrechtmatigheidsvormen, WPNR 3586-3589 (1938). Deze kritiek tegen het vereiste van de relativiteit wordt vaker, en in later jaren gehoord: zie Van Dumbe, J.M. . Aansprakelijkheid en verweren bij bodemverontreinigingen uit het verleden, Tijdschrift woor Milienansprakelijheid (1992), p. 98-104.

800. Voor $823 \mathrm{BGB}$ : zie bowen, hoofdstuk 6 \$ 5.A. \$826. Wer in einer gegen die guten Sitten verstoßenden Weise einem anderen vorsärslich Schaden zufügt, ist dem anderen zum Ersatze des Schadens verphichtet.

801. Voor zijn bespreking van de Duitse leer maakt Smits gebruik wan een uitgebreide hoeveetheid Duitse literatuur. De revue passeren: de Morive zu dem Ennwafe eimes $B G B$, en de diverse commentaren Stauthinger en Planck. Oertmann en verder Demold (Der Begriff des Schwtzgesetzes) en Leonhand (Besonderes Schuddrecht).

802. Smits, P.H., (1938), p. 491 .

803. Daarover: Asser-Harthamp III, (1994), nr, 54 en 106.

804. Zo lijk ook Wolfsbergen iets van zijn tegenstand tegen de relativiteit van de onrechtmatigheid tengg te nemen. Het lijkt hem dat de Hoge Raad 'de consequenties van die leer binken enge grenzen houdt'; zie ook: De toepassing der nomenleer bij BW 1401 door de HR, WPNR 3442 (1935), p. 555. 


\section{CONCLUSIES RELATIVITEIT}

$\mathrm{Er}$ is sprake van een principiële stellingname tegen het relativiteitsvereiste. Absolute onrechtmatigheid is voor deze tegenstanders het systematisch uitgangspunt voor aansprakelijkheid uit onrechtmatige daad. Bovendien zijn meer voor de hand liggende manieren denkbaar om aansprakelijkheid te beperken. Dat zijn de in de wet te vinden vereisten van causaal verband en schuld. Deze principiële tegenstand tegen de relativiteit baseert zich sterk op grammaticale, systematische en historische argumentatie.

In de rechtshistorische argumentatie wordt gebruik gemaakt van buitenlandse rechtsstelsels. Zo grijpt Meijers terug op de Franse wetgeving, het Romeinse recht en het geleerde recht ter illustratie van een ontwikkeling van een relatief naar een absoluut stelsel. Bovendien proberen tegenstanders van de relativiteit op drie wijzen het vereiste van de relativiteit te ondergraven aan de hand van het Duitse recht: in de eerste plaats zou de Duitse constructie een minder juiste, overbodige, soms zelfs een gewrongen constructie zijn. In de tweede plaats wordt aangevoerd dat er ook in Duitsland andere standpunten worden gehuldigd. Dit standpunt kan dienen als illustratie van de moeilijkheden die in de Duitse rechtswetenschap zelf werd ondervonden bij de uitwerking van de relativiteit. In de derde plaats wordt gesteld dat de Duitse leer in Nederland door de voorstanders van de relativiteit verkeerd begrepen is.

\section{$\S 6$. Conclusies over de periode 1910-1940}

\section{A. DE HEERSENDE MENINGEN}

Afzonderlijke wetgeving met een verlichting van de stelplicht en bewijslast wordt vanaf 1925 bewerkstelligd voor auto's. Toepassing van een algemeen artikel met een vereenvoudiging van aansprakelijkheid voor zaken wordt slechts incidenteel voorgestaan. Beide oplossingen, afzonderlijke wetgeving en een algemene aansprakelijkheid voor zaken worden uiteindelijk in het nieuwe Burgerlijk Wetboek en in afzonderlijke wetgeving opgenomen.

De balans van de discussie over artikel 2014 slaat langzaam door in de richting van de legitimatieleer. In de rechtspraak worden verschillende vereisten telkens afzonderlijk aangenomen. Eerst in 1951 wordt het belangrijkste deel van de leer door de Hoge Raad uitgesproken: alleen in geval van beschikkingsonbevoegdheid biedt 2014 soulaas voor de derde-verkrijger; deze werkrijgt in dat geval de eigendom; het bezit van de zaak alleen is onvoldoende om de eigendom te verkrijgen. De tegenstand tegen de legitimatieleer in de doctrine neemt af.

De uniform privaatrechtelijke benadering van publiek domein blijft bij uitstek de heersende leer. Enkele kanttekeningen worden bij dit privaatrechtelijk uitgangspunt geplaatst. Deze kanttekeningen zijn gebaseerd op de bijzondere positie van publiek do- 
mein: het privaatrecht is niet geschreven voor deze rechtsbetrekking: ten onrechte worden publiekrechtelijke bepalingen (over zaken buiten de handel) die in het burgerlijk wetboek staan, buiten toepassing gelaten; geheel volgens publiekrecht moest publiek domein worden bestuurd. Het relativiteitsvereiste ontstaat dank zij een grote vrijheid in de uitleg wan een wettelijke bepaling. De kritiek richt zich daarop. De meest fundamentelle kritiek baseert zich op het onderscheid tussen de absolute onrechtmatige daad en de relatieve verbintenis. De criteria zoalls die in artikel 1401 zijn opgenomen, zijn voldoende om aansprakelijkheid te begrenzen.

\section{B. ONTLEENDE ASPECTEN}

In de discussie over aansprakelijkheid voor zaken zijn een drietal aspecten ontleend aan andere stelsels. Dat is in de eerste plaats het onderscheid dat Suijling aanbrengt tussen gevaarlijke en niet-gevaarlijke zaken. Dat ontleent hij aan de Franse jurisprudentie tussen 1927 en 1930, en aan Ripert. De wetgeving voor auto's wordt ontleend aan de eerder in Duitsland en Oostenrijk tot stand gekomen wetgeving. In de derde plaats wordt in het nieuwe Burgerlijk Wetboek een bepaling voor gebrekkige zaken opgenomen, ontleend aan de Belgische jurisprudentie en doctrine sinds 1900. De toepasselijkheid van de bepalingen over zaken buiten de handel ontleent Meijers (deels) aan de Franse rechtswetenschap. De publiekrechtelijke constructie van Vos heeft veel gemeen met de 'öffentlliche Eigenthum' van de Duitse jurist Mayer.

\section{KWANTITATIEVE ANALYSE}

In Themis blijft het percentage verwijzingen naar Nederlands recht rond de $70 \%$; het percentage verwijzingen naar Frans recht neemt af (van 16 naar $11 \%$ ); het percentage naar Duits recht is iets toegenomen (van 7 naar $9 \%$ ) terwijl het percentage verwijzingen naar Romeins recht weer verder is afgenomen (van 6 naar $4 \%$ ). De verwijzingen bij Suijling geven een ander beeld. Terwijl verwijzingen naar Nederlandse bronnen vrijwel op gelijk niveau zijn als bij Themis, wordt door Suijling meer naar Frans (16\%), Duits $(10 \%)$ en Zwitsers recht ( $5 \%$ ) verwezen. Het Duitse recht valt ook op in de inhoudsopgave van de beide onderzochte tijdschriften: alle artikelen en boekbesprekingen die bij Themis betrekking hebben op een ander stelsel, betreffen het Duitse, en bij het Rechtsgeleerd Magazijn is sprake van een aanmerkelijke aanwezigheid van op het Duitse recht gerichte boeken.

\section{RECHTSVINDING}

Bij de discussie over aansprakelijkheid voor zaken spelen aan de praktijk ontleende argumenten in de eerste plaats, aan tekst en systeem ontleende in de tweede plaats een rol. Beide interpretatiemethoden worden zowel voor de ruime, als de beperkte uitleg worden gebruikt, en in alle methoden van interpretatie wordt tevens van andere rechtsstelsels gebruik gemaakt. De ruime uitleg is in het vorige hoofdstuk aan de orde geko- 
men (zie hoofdstuk $6 \$ 6$ ), en maakt bij uitstek gebruik van teleologische argumenten. De beperkte uitleg van 1403 wordt eerst wóral op tekst en systeem gebaseerd, maar in deze periode wordt tevens gewezen op de onbillijke aspecten van een ruime uitleg van 1403 voor de gebruiker, of eigenaar van een zaak. Ook in Frankrijk wordt deze kritiek (Esmein) gehoord, en deze word! in de Nederlandse discussie gebruikt. Suijling is na Opzoomer de eerste van de bekende civilisten die aan tekst en systeem argumenten ontlenen om aan artikel 1403 enige betekenis toe te kennen: alleen voor gevaarlijke zaken is de opzichter aansprakelijk. Dit onderscheid ontleent Suijling aan Ripert en de Franse rechtspraak. In Frankrijk wordt dit onderscheid verworpen, en ook in Nederland zal het niet worden geaccepteerd, met argumenten die ook in Frankrijk worden gebruikt: het onderscheid is niet bruikbaar zijn in de praktijk (Mazeaud). Wel wordt een voordien onbekend onderscheid aan het Belgische recht ontleend (gebrekkige zaken). Billijkheidsargumenten maken dat een beperkte uitleg van 1403 gepaard gat met een voorkeur voor wetgeving toegesneden op bijzondere zaken, die afwijkt van het gemene onrechtmatige daadsrecht. In de discussie wordt veel ontleend aan Duitse en Oostenrijkse wetgeving.

Artikel 2014 wordt op twee wijzen uitgelegd. De opkomende legitimatieleer van Scholten werd uiteengezet in het vorige hoofdstuk (zie hoofdstuk $6 \$ 6$ ), de Germaansrechtelijke uitleg verliest gaandeweg terrein. Met name Meijers en Hofmann maken zich sterk voor deze uitleg en gebruikten daarvoor hoofdzakelijk aan tekst, systeem en historie ontleende argumenten. In dat verband wordt gebruik gemaakt van Franse en Duitse bronnen voor de historie van 'bezit geldt als volkomen titel.' Voor aan tekst en systeem gebaseerde argumenten worden door Meijers eigentijdse Franse bronnen gebruikt (Planiol, Colin/Capitant).

De heersende privaatrechtelijke leer bouwt voort op met een op tekst en systeem van de wet gebaseerde argumentatie. Ook een teleologisch argument wordt gebruikt. Het 'algemeen belang' zou het beste zijn gediend met een onbelemmerde uitoefening van eigenaarsbevoegdheden door de overheid. Het Franse recht biedt ondersteuning voor dit standpunt. Ook daar heeft een omslag plaatsgewonden naar het privaatrechtelijk concept van overheidseigendom (Barckhausen, Hauriou). Het is slechts een deel van de leer van Proudhon die met vrucht is bestreden, namelijk het op de Code civil gebaseerde deel van de argumentatie (Barckhausen). In Frankrijk blijft een onderscheid aanwezig. Juist rond de eeuwwisseling vindt de Franse leer van het domaine public ingang in de Duitse rechtswetenschap, in de 'öffentliche Eigenthum' van Otto Mayer. Zowel deze Duitse theorie, als Franse uiteenzettingen worden in de Nederlandse literatuur verworpen. Er dienen zich een drietal critici van de privaatrechtelijke benadering aan in de Nederlandse discussie: Suijling. Meijers en Vos. Zij zullen zich in oplopende intensiteit verzetten tegen een benadering die al te zeer de eigendomsbevoegdheden aan de overheid zal toekennen, en gebruiken daarvoor argumenten die vooral aan het publiekrecht en algemeen belang zijn ontleend. Daaruit concluderen zij wel tot een onderscheid. Meijers vindt in tekst en systeem van het Burgerlijk Wetboek een argument voor de toepasselijk- 
held van bepalingen over zaken buiten de handel. Meijers en Vos ondersteunen hun argumentatie met behulp van Hauriou en Mayer.

De legitimatieleer wordt geaccepteerd in het Nederlandse recht, maar kent in de beginjaren een aanzienlijke tegenstand. De tegenstand is met name gebaseerd op geschiedenis, tekst en systeem van het Burgerlijk Wetboek. Ondersteuning voor deze (twee: ofwel causaliteit ofwel schuld als oplossing) standpunten wordt uit het Franse recht geput. Daar wordt uitgegaan van een absolute onrechtmatigheid (Demogue, Planiol). Ook het Duitse recht wordt gebruikt: door de voorstanders van de relatieve onrechtmatige daad is het Duitse recht niet begrepen, het is voorts minder juist en ook overbodig, en ook in het Duitse recht, zo wordt vermeldt, worden andere standpunten gehuldigd, en in ieder geval bij ongeschreven normen wordt geen gebruik gemaakt van een relatieve benadering.

\section{E. RECHTSVERGELIKING}

Nog steeds wordt bij de bespreking van methoden door civilisten niet algemeen ingegaan op vergelijking met andere rechtsstelsels. Maar wel in opkomst is de rechtsvergelijking als afzonderlijke discipline, waarmee ook civilisten als Meijers, Molengraaff, Hoetink, Kisch en Scholten zich bezig houden. Dat heeft op het gebruik van andere stelsels bij de beoefening van het privaatrecht een positief effect. Zelfs in deze periode, waarin het accent in de rechtsvinding meer op tekst en systeem van de wet of op herziening van wetgeving komt te liggen wordt in de argumentatie telkens met oplossingen uit andere stelsels vergeleken. Dat geschiedt in verband met de rechtshistorie, in verband met een ruimere uitleg, gebaseerd op de 'praktische noodzakelijkheid' van de uitleg, maar zelfs in geval van een op tekst en systeem gebaseerde uitleg. De stellingname van Wttewaal lijkt meer een uitzondering te zijn wanneer we in het merendeel van de standpuriten het gebruik van andere stelsels zo duidelijk zien geillustreerd. Wel is in de tijd het percentage verwijzingen naar andere stelsels afgenomen, maar dat is een noodzakelijk gevolg van de toename in Nederlandse literatuur. Het inhoudelijk gebruik is (zeker in vergelijking met de periode van het legisme) toegenomen. 
Hoofdstuk 8

\section{Conclusies}

\section{$\$ 1$. Inleiding}

De vraagsteilling van dit onderzoek is de volgende. 'In welke mate en op welke wijze was er in de periode van 1838 tot in recente tijd in de Nederlandse privaatrechtswetenschap sprake van een internationale oriëntatie?' Deze vraag is in een viertal concrete deelvragen werkbaar gemaakt. Deze zijn achtereenvolgens: in welke mate werd naar andere stelsels verwezen in de Nederlandse privaatrechtswetenschap (1); welke (aspecten uit de) behandelde onderwerpen zijn ontleend aan andere rechtsstelsels (2); op welke wijze past het aan een ander rechtsstelsel ontleende argument in de methoden van rechtsvinding (3); op welke wijze past het aan een ander rechtsstelsel ontleende argument in de ideeën over rechtsvergelijking (4). In dat laatste verband wordt tevens de visie op de historische ontwikkeling van rechtsvergelijking aan de orde gesteld. Deze volgorde wordt in de afsluitende conclusie aangehouden ( $\$ \$ 2-5)$. In een laatste paragraaf $(\S 6)$ wordt kort ingegaan op de betekenis van dit onderzoek voor een Europees privaatrecht.

\section{§. De mate van verwijzingen}

Bekeken is hoe de mate van oriëntatie op elk land afzonderlijk zich heeft ontwikkeld. Voorts worden enkele opmerkelijke aspecten gesignaleerd. Verwijzingen naar Neder landse bronnen zijn over de gehele onderzochte periode het meest talrijk. Er is een opwaartse trend van $40-50 \%$ in de eerste periode $(1838-1850)$, naar een $70 \%$ in de laatste periode (1910-1940). Dat betekent niet dat de beoefening van het privaatrecht meer een nationale beoefening werd. Het verwijzen naar andere Nederlandse bronnen is gebruikelijk. De Nederlandse bronnen nemen in de loop van de tijd in aantal toe en zijn bovendien toegankelijker dan bronnen uit een ander stelsel.

De mate van verwijzingen naar Romeins recht nam af. Van 15-20\% in de eerste periode naar $5 \%$ in de laatste periode. Eerst werd het belang van het Romeinse recht nog bena- 
drukt, waarbij het (rationis auctoritate) bij de uitleg van de nieuwe wetgeving het hoogste gezag toekwam (Den Tex). Bij Diephuis was dat belang van het Romeinse recht vrijwel afwezig. Dat had te maken met zijn eigen kijk op rechtsvinding en de plaats van het Romeinse recht daarin: het Romeinse recht was afgeschaft en het kwam daarom geen gezag meer toe.

Verwijzingen naar Frans recht kwamen veel voor in de eerste periode (40\% (in Themis) - $60 \%$ (bij Diephuis)). Dat neemt af tot $11 \%$ (Themis) - $16 \%$ (Suijling). Assers verwachting in 1838 werd meer dan bewaarheid: "...ja, dat er wel eene halve eeuw en meer zal verloopen, eer dezelve hare kracht zullen verloren hebben.' Naar Belgisch recht werd incidenteel verwezen, met uitzondering van de jaren 1880-1900, na Laurents commentaar op de Code civil. Diephuis maakte veel gebruik van Laurent (11\%). Er werd steeds van Duits recht gebruik gemaakt. In de gehele periode nam de frequentie wat toe. Van rond de $5 \%$ (1838-1850) naar ongeveer $10 \%$ vanaf 1880 . Er zijn flinke verschillen tussen dle onderzochte schrijvers. In de tweede druk van Diephuis' commentaar was sprake van $4 \%$ aan verwijzingen naar Duitse bronnen. In zijn latere systeem was nog slechts een enkele incidentele verwijzing aan te treffen. De Savornin Lohman gaf aan (1907) juist gebruik te maken van het BGB: 'ik meende mij intusschen niet te kunnen beperken tot de Nederlandsche auteurs, maar met name gebruikte moeten maken van het met den aanvang dezer eeuw ingevoerde Duitse burgerlijk wetboek (...)' Ook van andere stelsels werd gebruik gemaakt. Suijling maakte veel gebruik van het Zwitserse recht $(5 \%)$. Anderen maakten incidenteel van het Zwitserse recht gebruik. Van het Oostenrijkse recht werd incidenteel gebruik gemaakt in de tweede (1850-1880) en de laatste periode (1910-1940).

\section{$\S 3$. Van buitenlandse rechtsstelsels overgenomen aspecten}

In elk onderzocht onderwerp zijn aspecten aangetroffen die afkomstig zijn uit een ander rechtsstelsel of sterke gelijkenis wertonen met een ander rechtsstelsel. Soms zijn dat gehele leerstukken, of een interpretatie van een artikel. Een dergelijke overname was de relativiteit van de onrechtmatige daad. Deze was afkomstig uit de Duitse rechtswetenschap. Een andere ontlening betrof Proudhons domaine public. Deze ontleningen zijn bekend. De Bieberstein, leerling van Thorbecke, over artikel 577 BW: "Geheel kunnen wij ons vereenigen met Proudhon, Traité du domaine public.' Van Gelein Vitringa verwees naar $\$ 823$ lid $2 \mathrm{BGB}$ en verklaarde '... stellig moet dit voorbehoud worden gemaakt, dat het belang (...) tevens is het belang tot bescherming waarvan het overtreden wetsvoorschrift strekt."

Vaker dan deze overdracht van gehele onderwerpen was sprake van aspecten van een onderwerp die aan andere stelsels werden ontleend, of een sterke gelijkenis vertonen met een uitleg in een ander rechtsstelsel. Soms werd een aspect geaccepteerd in het Nederlandse privaatrecht. Vaker was sprake van een door een enkele schrijver aanvaard aspect uit een ander stelsel. In de eerste twee perioden (1838-1880) werd veelal in 
verband met een historische uitleg ontleend. Dat gebeurde bijvoorbeeld bij artikel 1403 en artikel $2014 \mathrm{BW}$, artikelen die letterlijk overgenomen waren uit de Franse Code civil. Zo maakten bijvoorbeeld Diephuis en De Pinto beiden gebruik van het Franse recht in hun verzet tegen een analogische toepassing van artikel $1403 \mathrm{BW}$ op andere zaken dan de genoemde in de arikelen 1403-1405 BW.

In latere perioden (1880-1940) werd vooral aan andere stelsels ontleend in verband met een wenselijke uitleg. Zo werd gepleit voor een Nederlandse regeling van aansprakelijkheid van spoorwegondernemingen conform regelingen in een groot aantal andere Europese staten (onder meer Duitsland en Oostenrijk): 'Niet uit zucht tot navolging van vreemde wetgevingen, maar op grond wan een billijke verdeeling van den bewijslast (...).' Ook in de uitleg van artikel 2014 BW werd op vergelijkbare wijze van ander recht gebruik gemaakt. Molengraaff en Roelvink gebruikten uit Duitse ontwerpen voor het $\mathrm{BGB}$ de voorganger van $\$ 932 \mathrm{BGB}$ : 'Onze conclusie kan geen andere zijn dan, dat een onbeperkt vindicatierecht voor roerend goed. [zoals Van Bemmelen voorstond], in strijd met de behoeften van onzen tijd, inderdaad onrecht is (...).' Opvallend is dat in de gehele onderzochte periode aan andere stelsels werd ontleend. Enkele voorbeelden: domaine public werd uit het Franse recht rond 1850 geaccepteerd; de invulling van het relativiteitsvereiste uit het Duitse recht werd in de jaren 20 en 30 geaccepteerd; de 'gevaarlijke zaak' van Suijling uit het Franse recht in de jaren dertig van deze eeuw; het verzet tegen de analoge uitleg van artikel $1403 \mathrm{BW}$ sinds 1850; de goede trouw in 2014 werd rond 1890-1910 naar voren gebracht uit het Duitse en Engelse recht; Opzoomers aan Marcadé ontleende uitleg van 2014 in de jaren 50 van de negentiende eeuw. Rond de eeuwwisseling werd in het algemeen veel aan de Duitse rechtswetenschap ontleend.

\section{\$4. Buitenlandse rechtsstelsels en rechtsvinding}

Vaker dan aspecten werden ontleend, was sprake van gebruik van andere stelsels in de argumentatie. De heersende rechtsvindingsmethoden veranderden in de onderzochte periode. Het gebruik van het andere recht in de argumentatie veranderde mee. Dat geschiedde op de volgende wijze.

In de eerste behandelde periode (1838-1850) werd een onderscheid gevonden tussen de eerste literatuur over het Burgerlijk Wetboek en de latere commentaren. De eerste duiding van de nieuwe codificatie gebeurde op een eenvoudige wijze. Uitleg van een Nederlandse bepaling was alleen noodzakelijk wanneer deze grammaticaal afweek van de Franse voorganger. Gewezen zij op de eerste becommentarieerde tekstedities van het Burgerlijk Wetboek zoals de werken van Asser, Lipman, De Martini, en Opzoomers eerste commentaar. Opzoomer: 'De meeste bepalingen onzer wet zijn reeds toegelicht; ik zou eenvoudig moeten overnemen wat door onze uitleggers reeds ontwikkeld is en zich in ieders handen bevindt.' Goudsmit en Opzoomer: ' (...) ons eigen wetboek heeft beslist en kan uit zich zelve worden verklaard.' Bij de totstandkoming van het Burgerlijk 
Wetboek 1838 en de eerste commentaren werden de werschillen die er in de Franse rechtswetenschap aanwezig waren niet geëxpliciteerd. De kennis van het Franse recht werd voorondersteld bij de Nederlandse juristen, terwijl bovendien sterk geleund werd op de reeds geschreven commentaren op de Franse Code civil. Ook het Romeinse recht viel (hoewel in geringere mate dan het Franse recht) een dergelijke benadering ten deel: de keuze voor een oplossing uit het Romeinse recht werd eveneens niet geëxpliciteerd. Ik wijs hier op de bepalingen over zaken buiten de handel. Pas na verloop van tijd werd gebruik gemaakt van het Franse recht als noodzakelijke rechtshistorische uitleg. Dezelfde standpunten en onderbouwingen als in de Franse rechtswetenschap waren ingenomen, werden in de Nederlandse rechtswetenschap gebruikt. Opzoomer verzuchtte over artikel 1403 dat de wetgever zich maar weer eens aan het vertalen gezet had. De verschillen in uitleg van artikel 2014 kunnen alle worden teruggevoerd op de verscheidenheid aan interpretaties in het Franse recht. Naar deze Franse meningen werd telkens verwezen.

Dit rechtshistorische gebruik van het Franse en Romeinse recht werd voortgezet. Aan de rechtshistorie als middel tot uitleg werd echter steeds minder belang gehecht, en van meer belang werden tekst en systeem van de wetgeving als wijzen van interpretatie. Diephuis: 'Ik heb mij vooral eene exegetische en dogmatische behandeling van het burgerlijk wetboek voorgesteld, en mij daartoe, in de eerste plaats toegelegd op een naauwgezet onderzoek der wet zelve (...)." Andere mogelijkheden voor gebruik van buitenlandse rechtsstelsels werden gevormd. Zo was het administratiefrecht minder gebonden aan de rechtswinding van civilisten, die tekst en systeem van het Burgerlijk Wetboek op de voorgrond plaatsten. Andere rechtsstelsels konden makkelijker in de argumentatie worden gebruikt. Zo gebruikten Thorbecke en zijn administratiefrechtelijke navolgers het Franse, Duitse en Oostenrijkse recht voor de onderbouwing van domaine public. Naarmate de gelding van het Romeinse recht en het Franse recht verder in het verleden kwam te liggen, veranderde het gebruikelijke beroep op het Franse recht door rechtshistorische interpretatie in een beroep op een vergelijkende interpretatie met het eigentijdse Franse recht. Zo besteedde Diephuis zeer veel aandacht aan eigentijdse Franse auteurs bij de interpretatie van artikel $2014 \mathrm{BW}$. Ook van andere stelsels werd gebruik gemaakt, zoals de Belgische rechtswetenschap (Laurent), en de Duitse rechtswetenschap (met name in de discussie over publiek domein). De belangrijkste mogelijkheid om van andere rechtsstelsels gebruik te maken werd in de periode van het legisme geboden door de argumentatie naar het ius constituendum, het recht, zoals dat zou behoren te luiden. Binnen dit deel van de privaatrechtswetenschap was de wetenschap vrij. Daar bestond de mogelijkheid om een keur aan buitenlandse regelingen de revue te laten passeren. Op deze wijze werd door Opzoomer de Franse theorie van het domaine public voorgestaan. Met de onderbouwing van deze theorie voor het geldende recht had hij problemen. Tekst en systeem van het Burgerlijk Wetboek waren daar de belangrijkste methoden van uitleg en voor de acceptatie van domaine public schoot dat te kort. In de vergadering van de Nederlandse Juristen-Vereniging werden allerhande buitenlandse regelingen (zoals Duitse en Oostenrijkse wetgeving over aansprakelijkheid voor zaken) aan de orde gesteld. Zo werd overwogen dat wetgeving uit andere landen 
'voor het ius constituendum niet onbelangrijke bijdragen [biedt], en zoo het nog lang eene onmogelijkheid zal blijven een Europeesch regt te verkrijgen, zal het toch altijd zaak zijn, om bij de herziening van eigen regt op dat van naburige staten het oog te houden.'

Onder invloed van grote maatschappelijke veranderingen kwam in de wetenschap van het privaatrecht verzet tegen de op tekst en systeem gebouwde dogmatiek. Twee kampen werden gesignaleerd. Aan de ene kant diegenen die vasthielden aan tekst en systeem van het Burgerlijk Wetboek en verandering in het geldende recht aan de wetgever wilden overlaten. Deze groep ging tegelijk meer aandacht besteden aan het wenselijke recht (zoals Land). Aan de andere kant diegenen die meer waren geporteerd voor vrijere opstelling ten opzichte van de wet en aldus de rechter de vrijheid toekenden om wenselijk recht direct te kunnen lezen in de wetgeving. Molengraaff: ". . het werkelijk leven, der menschen handel en wandel, [moet] de basis zijn, waarop de jurist zijne wetenschappelijke stelsels doet rusten.' Het bleek dat in cleze periode het belang van de verschillende interpretatiemethoden veranderd is. Het is de vrijere vitleg, naar de maat schappelijke behoeften, naar de redelijkheid, die het belangrijkst werd gevonden. Het is de vrijheid die de jurist zich eerst alleen bij de beredenering van het wenselijke recht kon permitteren, die zich steeds meer manifesteerde bij de beredenering van het geldend recht. In die vrijheid werd van andere rechtsstelsels gebruik gemaakt, en aldus kreeg het rechtsvergelijkende argument een meer prominente rol. Drucker: '...de wetgever behoort zich te beperken: de wetgever kan nu eenmaal niet alles regelen; sommige onderwerpen zijn nog niet rijp voor wettelijke ordening, andere zijn over het geheel te ingewikkeld of te weinig belangrijk; tal van bijzondere gevallen ontsnappen aan wettelijke formuleering. Daarom slechts de beginselen in de wet neergelegd, de vrije toepassing aan den rechter overgelaten.'

Ook werd rond de eeuwwisseling aan rechtshistorie meer gewicht toegekend, met name door Land: 'De richting, waarin het recht zich voortbewoog, verder te volgen, wijst ons in den regel den meest betrouwbaren weg; die weg is meestal langer dan wij wenschen, doch de ervaring van eeuwen dwingt ons tot een bedachtzamen tred.' Ook als onderdeel van de rechtshistorische methode bleef van andere stelsels gebruik gemaakt worden (Van Bemmelen, Land). In de laatste besproken periode stond de terugtred van de vrije rechtsvinding centraal. De meest vergaande standpunten uit de vrije rechtsvinding (zoals die van Hamaker, waarbij de wet slechts een richtsnoer was maar niet meer) werden door weinigen verkondigd. Altijd werden aan tekst en systeem gebonden of aan de historie ontleende argumentaties gebruikt, naast de uitleg aan de hand van de maatschappelijke noodzakelijkheid of de redelijkheid. Ook in deze laatste onderzochte periode werden twee richtingen in de rechtswetenschap onderscheiden: In de eerste plaats die richting die meer vasthield aan de traditie van het legisme en meer de nadruk legde op tekst, systeem en historie (Meijers, Suijling). Suijling: "Als de school der vrije rechtsvorming vasten voet kreeg, zouden wij dus indertijd de uitsluitende heerschappij der wet slechts gevestigd hebben om ten slotte, na een tusschenpoos, de willekeur vant den vorst. 
door het believen van den rechter of de administratie te vervangen.' In de tweede plaats die groep die meer belang hecht aan de redelijke uitleg, het maatschappelijke doel van de wetgeving. Zo is Scholten in deze laatste groep onder te brengen. De rechter is in Scholtens theorie weliswaar gebonden aan de wet, maar voegt "in de handhaving toch altijd weer iets nieuws' toe. Ook Meijers erkent dit: 'Weinig meer blijft er over van de trotsche almacht van de allesregelende codificatie, waar de wet erkennen moet, dat op een zoo uitgebreid gebied als dat der door haar verleende rechten en bevoegdheden zij niet op strenge handhaving harer eigen regelen mag aandringen, maar ook daar de billijkheid of het werkelijke Recht richtsnoer moet blijven." In deze laatste periode is in de rechtsvinding op een aantal manieren ruimte voor het aan een buitenlands stelsel ontleend argument. Het werd aangetroffen alls rechtshistorisch argument. Het meest belangrijke was echter in beide onderscheiden richtingen geworden het gebruik van buitenlands recht als zelfstandig rechtsvergelijking binnen het privaatrecht.

\section{\$. De buitenlandse bron en rechtsvergelijking}

In de eerste plaats ( $\$ 5 . \mathrm{A})$ wordt rechtsvergelijking besproken in ruime zin als 'het gebruik van een buitenlands rechtsstelsel", en in dat verband komen meningen over gebruik van andere rechtsstelsels in de beoefening van het privaatrecht aan de orde. In de tweede plaats wordt gesproken over rechtsvergelijking als de afzonderlijke discipline die sinds het einde van de negentiende eeuw is ontstaan $(\$ 5 . B)$.

\section{A. HET GEBRUIK VAN EEN ANDER RECHTSSTELSEL ALS RECHTSVERGELIJKING}

Kort na de codificatie van 1838 werd de kennisname van met name Frans en Romeins recht hogelijk aangeprezen. Kennis van die rechtsstelsels was onmisbaar om tot een zinvolle uitleg te komen van een Nederlandse bepaling, het Franse recht meer dan het Romeinse. De eerste (noodzakelijke) rechtshistorische interpretatie verscheen. Zowel Frans als Romeins recht werden in dit verband gebruikt. Het gebruik van andere rechtsstelsels dan de genoemde was niet noodzakelijk. Het recht werd gezien als de vrucht van een nationale rechtsovertuiging, een karakteristiek onderdeel van het gedachtengoed van de Duitse Historische School. Toch werd, zo bleek, in de privaatrechtelijke literatuur op verschillende manieren gebruik gemaakt van andere rechtsstelsels.

Tegen het einde van de negentiende eeuw werd gewezen op de noodzakelijke kennisname van andere rechtsstelsels bij de interpretatie van de nationale regels. Eerst gebeurde dit in verband met de beredenering vain het wenselijke recht. Zo kon een internationale regeling als wenselijke regeling noodzaken tot rechtsvergelijking. Een uitleg waarbij rekening wordt gehouden met de belangen van het handelsverkeer noodzaakte tot kennisname van andere rechtsstelsels omdat die handel internationaler is geworden. Wel werd er gewezen op 'eene onmogelijkheid (...) een Europeesch regt te verkrijgen', maar dat maakte rechtsvergelijking niet overbodig. Molengraaff verwoordde het gebruik van het andere rechtsstelsel als 'een onmisbaren factor.' Andere civilisten oordeelden vergelijk- 
baar. Zo werd het in 1900 van kracht geworden BGB zonder meer gebruikt bij de uitleg van Nederlandse bepalingen omdat het "klaarder inzicht' bood in de Nederlandse bepalingen (De Savornin Lohman). Dat zo werd gewezen op noodzakelijke kennisname van andere rechtsstelsels is een opmerkelijk verschil met de voorgaande perioden (18381850-1880). Naast deze vermeldingen door civilisten springt het ontstaan van rechtswergelijking als afzonderlijke discipline sinds 1900 in het oog. Dit heeft het gebruik van andere rechtsstelsels bij de beoefening van het Nederlandse recht gestimuleerd. Het gebruik van andere stelsels werd een gewoon onderdeel van de rechtsvinding, ook voor hen, die een groot belang hechtten aan tekst, systeem en geschiedenis van het Nederlandse Burgerlijk Wetboek.

\section{B. RECHTSVERGELIJKING: EEN BUSTELLING}

Rechtsvergelijking is een onderdeel geworden van de nationale privaatrechtsbeoefening. In de inleiding werd een korte blik geworpen op de verscheidenheid aan beschrijvingen van rechtsvergelijking als afzonderlijke discipline. Steeds weer wordt er gewezen op het nationale karakter van de wetgevingen, op het incidentele karakter van rechtsvergelijking als afzonderlijke discipline in de vorige eeuw en op het ontstaan van afzonderlijke rechtsvergelijking sinds 1900 . Tegelijk wordt met deze constateringen veel over het hoofd gezien. Op inhoudelijk niveau werd in de wetenschap van het privaatrecht in de periode 1838-1850 niet gedacht aan een nationale beoefening. Telkens werd op de noodzaak van kennisname van Frans (en Romeins) recht gewezen. Later (1850-1880) werd op allerlei manieren bepaald wel van ander recht gebruik gemaakt. Dat gebruik zette zich op een veranderende wijze voort tot het einde van de onderzochte periode. Het andere rechtsstelsel is binnen de wetenschap wan het privatrecht een gewone methode van rechtsvinding geworden. Zo was de Nederlandse privaatrechtswetenschap minder nationaal dan wordt afgeschilderd. In de privaatrechtswetenschap werd meer gebruik gemaakt van andere rechtsstelsels, meer aan rechtsvergelijking gedaan dan uit de gangbare beschrijvingen van rechtsvergelijking volgt.

\section{$\$ 6$. Betekenis van dit onderzoek voor een Europees privaatrecht}

In de inleiding is dit onderzoek geplaatst in de huidige trend van de privaatrechtswetenschap naar een Europees privaatrecht. De aandacht is in dit onderzoek gericht op de verwijzing naar buitenlandse rechtsstelsels. Op een aantal manieren is dit verwijzen geanalyseerd. Op welke wijze kunnen de bevindingen dienstbaar zijn aan de totstandkoming van een Europese privaatrechtswetenschap? Twee richtingen in het Europees privaatrecht kwamen in de inleiding aan de orde. Aan de ene kant een wetgeving op Europees niveau; aan de andere kant een Europees privaatrecht door een meer Europees gerichte rechtswetenschap. Een codificatie van het gehele privaatrecht is nog ver werwijderd en alleen op een aantal deelgebieden is wetgeving totstandgebracht. Naast deze wetgeving op onderdelen zal het de rechtswetenschap zijn warvan veel mag worden verwacht bij het totstandbrengen van een Europese rechtswetenschap. Enerzijds kan dat 
gebeuren door de rechtswetenschap te richten op deze Europese regelgeving, anderzijds door aandacht te besteden aan de 'gemeinsamen Gegebenheiten' (Coing) van de verschillende nationale stelsels. Een belangrijk deel van die gemeenschappelijke punten betreft de gemeenschappelijke oorsprong van de verschillende nationale stelsels uit het Europese gemene recht. Een ander gemeenschappelijk aspect tussen de verschillende nationale stelsels betreft de overeenkomsten in rechtsvindingsmethoden en in de aandacht voor rechtsvergelijking. Deze overeenkomsten vereenvoudigden de oriëntatie op andere stelsels, en deze oriëntatie op andere stelsels is op een aantal concrete manieren onderzocht. In het Nederlandse privaatrecht werd veel gebruik gemaakt van buitenlandse rechtsstelsels. Het refereren aan aspecten van het privaatrecht die uit een ander stelsel afkomstig zijn, het wijzen op het regelmatig gebruik van een aan een ander stelsel ontleend argument, het wijzen op een getalsmatig grote oriëntatie op een bepaald stelsel zal ondersteuning kunnen betekenen voor een standpunt in een exercitie op het gebied van het nieuwe Europese gemene recht. 
Bijlage

\section{\$1. Inleidende opmerkingen}

Het navolgende biedt de getalsmatige weergave van de verwijzingen naar andere rechtsstelsels in de privaatrechtelijke literatuur. Daartoe is de volgende methode gehanteerd.

\section{A. DE SELECTIE VAN HET TE ONDERZOEKEN MATERIAAL}

Een selectie is gemaakt van representatieve لiteratuur uit het vermogensrecht. Gebruikt worden handboeken (De Pinto), commentaren (Diephuis, Suijling), en tijdschriften (Themis, Rechtsgeleerd Magaziin). Werken van enkele belangrijke civilisten zijn geselecteerd (Diephuis, Suijling); van de tijdschriften is gekozen voor Themis en voor het Rechtsgeleerd Magazijn. De continue verschijning gedurende de onderzochte periode biedt een ononderbroken beeld van de mate waarin naar andere rechtsstelsels wordt verwezen.

In Themis en Rechtsgeleerd Magazijn is op twee wijzen de mate van gebruik van buitenlandse bronnen gemeten. In de eerste plaats is de inhoudsopgave gebruikt. Die biedt op iwee wijzen inzicht: door middel van het aantal artikelen met een rechtsvergelijkende titel; door middel van het aantal besproken en aangekondigde boeken van buitenlandse origine. In de tweede plaats is het percentage verwijzingen naar andere rechtsstelsels in privaatrechtelijke artikelen bepaald.

\section{B. DE VERWUZING}

Een verwijzing naar een ander rechtsstelsel moet eenduidig en herkenbaar zijn om vergelijkingen in de tijd te kunnen maken en om praktische redenen. Dat betekent dat een belangrijke categorie verwijzingen op voorhand afvalt: die waarbij op meer impliciete of op een in de tekst vervlochten wijze, aan de hand van de inhoud van de tekst naar dat andere stelsel verwezen wordt. Deze zijn belangrijk, maar ze komen aan de orde in de inhoudelijke behandelingen. Van een telbare verwijzing is sprake wanneer ze naar buitenlands recht (literatuur, jurisprudentie, soms wetgeving) verwijst, en daarbij de precieze herkomst vermeldt. Voor de literatuurverwijzingen is naam en 
vindplaats noodzaak (Toullier, deel 13, nr. 47). Dat kan ook op indirecte wijze, wanneer eerder een schrijver werd aangehaald en naar die plaats wordt terugverwezen (Windscheid, t.a.p.). Niet eronder vallen dus verwijzingen als: 'zoals Mayer van mening is'. Verwijzingen naar eigen, maar ander werk worden meegeteld, terwijl verwijzingen naar hetzelfde werk niet worden meegenomen. Ook verwijzingen naar jurisprudentie wordt geteld. Ook daarvoor geldt dat de verwijzing met vindplaats moet zijn, waarbij een uitspraak, met twee vermelde vindplaatsen als één verwijzing wordt geregistreerd. Verwijzingen naar wetsartikelen worden ook geteld, met uitzondering wan verwijzingen naar Nederlandse en Franse artikelen. Om praktische redenen (de enorme hoeveelheid) zijn deze verwijzingen buiten beschouwing gelaten.

\section{DE HERKOMST VAN DE VERWIJZING}

Bij deze telling is onderscheid gemaakt naar nationale herkomst: Frankrijk, Duitsland, België en andere landen, waarnaar in mindere mate is verwezen; daarnaast wordt ook het Romeinse recht als afzonderlijke categorie onderscheiden. Deze afbakening naar nationale herkomst is niet sluitend. Juist de afbakening van Duitsland alls herkomst is voor de negentiende eeuw een lastige kwestie. Voor de meest lastige kwestie is een knoop doorgehakt: de Duitse jurist Zachariae wordt met zijn commentaar op de Code civil geschaard onder de bronnen van Franse herkomst. Verwijzingen naar het Obligationenrecht van Von Thur zijn als verwijzingen naar $Z$ witsers recht geregistreerd.

\section{$\S 2$. De getalsmatige weergave naar behandelde periode}

\section{A. TOELICHTING}

De resultaten zijn weergegeven in de volgorde: totaal aantal verwijzingen, verwijzingen naar Nederlands recht, naar Romeins recht, naar Frans recht, naar Duits recht, naar andere stelsels. Tevens wordt de absolute aantallen in een percentage van het totaal uitgedrukt. Bij de aantallen verwijzingen in de tijdschriften is het totaal aantal gevonden verwijzingen de som van de in de afzonderlijke jaargangen gevonden aantallen. Die jaargangen worden genoemd.

B. DE EERSTE PERIODE $1838-1850$

\section{Venwijzingen}

De Pinto, A., Handleiding tot het Burgerlijk Wetboek deel 2 (1837/8).

$\begin{array}{lrr}\text { Totali } & 1503 ; & 100 \% \\ \text { Nederland: } & 631 ; & 42 \% \\ \text { Romeins: } & 225 ; & 15 \% \\ \text { Frankrijk: } & 610 ; & 41 \%\end{array}$


$\begin{array}{lrr}\text { Duitsland: } & 35 ; \quad 2 \% \\ \text { Belgiê: } & 2 ; \quad<<1 \%\end{array}$

Themis $(39,41,43,47,49,50)$

Totaal:

Nederland:

Romeins:

$566 ; 100 \%$

Frankrijk:

Duitsland:

$275 ; \quad 49 \%$

$124 ; \quad 22 \%$

Diversen:

$118 ; \quad 21 \%$

$33 ; \quad 6 \%$

16

2. Inhoudsopgave Themis

Thernis 1845

Artikelen: $\quad$ Nederland $\quad 16$

Duitsland 1

Boekbespreking: Nederland 13

Themis 1846

Artikelen: Nederland $\quad 15$

Boekbespreking: Nederland 13

Frankrijk 3

Spanje $\quad 1$

C. DE TWEEDE PERIODE (1850-1880)

1. Verwijzingen

Diephuis, G., Het Nederlandsch Burgerlijk Regt naar de volgorde van her Burgerlijk Werboek deel 6 (1856-1859)

Total: $\quad 3789 ; \quad 100 \%$

Nederland: $\quad 1352 ; 36 \%$

Romeins: $\quad 31 ;<1 \%$

Frankrijk: $\quad 2271 ; 60 \%$

Duitsland: $\quad 135 ; \quad 4 \%$

Diephuis, G., Het Nederlandsch burgerlijk recht, $11 \mathrm{e}$ deel (1888) 
Totad:

1818; $\quad 100 \%$

Nederland:

$691 ; \quad 38 \%$

Romeins:

$23 ;>1 \%$

Frankrijk:

894; $\quad 49 \%$

Duitsland:

$10 ;<<1 \%$

België:

195; $\quad 11 \%$

Oostenrijk:

$2 ;<<1 \%$

Zwitserland:

$3 ;<<1 \%$

Themis $(51,52,53,55,56,57,59,61,63,65,67,69,71,73,75,77,79)$

Totaal:

Nederland:

Romeins:

$2331 ; \quad 100 \%$

Frankrijk:

$1116 ; \quad 48 \%$

Duitsland:

$443 ; \quad 19 \%$

508; $\quad 22 \%$

Belgiè:

$223 ; \quad 10 \%$

Oostenrijk:

diversen:

$1 ;<<1 \%$

$3 ; \quad<<1 \%$

$37 ; \quad 2 \%$

2. Inhoudsopgave Themis en Rechtsgeleerd Magazijn

Themis 1879

Artikelen: $\quad$ Nederland $\quad 9$

Boekbespreking: Nederland 3

Duitsland 1

Themis 1880

Artikelen: Nederland $\quad 6$

Romeins $\quad 1$

Boekbespreking: Nederland $\quad 13$

Frankrijk 3

Spanje 1

Thenis 1882

Artikelen: $\quad$ Nederland $\quad 10$ 
Boekbespreking: Nederland

\section{Themis 1883}

Artikelen:

Nederland

10

Boekbespreking: Nederland 7

Frankrijk 3

Duitsland

Rechtsgeleerd Magazijn 1882

Artikelen:

Nederland

Anders

Boekbespreking: Nederland

Frankrijk

Duitsland

Engeland

Rechtsgeleerd Magazijn 1883

$\begin{array}{llr}\text { Artikelen: } & \text { Nederland } & 13 \\ & \text { Anders } & 8 \\ \text { Boekbespreking: } & \\ & \text { Nederland } & 18 \\ & \text { Romeins recht } & 1 \\ & \text { Frankrijk } & 1 \\ & \text { Duitsland } & 9 \\ & \text { Italië } & 5\end{array}$

D. DE DERDE PERIODE (1880-1910)

1. Verwijzingen

Themis $(83,86,90,93,96,1900,04,07,10)$

Totaal:

Nederland:

Romeins:

$942 ; 100 \%$

Frankrijk:

$647 ; \quad 69 \%$

$57 ; \quad 6 \%$

$150 ; \quad 16 \%$


Duitsland:

64; $\quad 7 \%$

Belgiti:

13; $\quad 1 \%$

diversen:

11 ;

2. Inhoudsopgave Themis en Rechtsgeleerd Magazijn

Themis 1904

Artikelen: Nederland 8

Boekbespreking: Nederland $\quad 9$

Themis 905

Artikelen: $\quad$ Nederland $\quad 12$

Boekbespreking: Nederland 9

Duitsland 2

Rechisgeleerd Magazijn 1904

Artikelen: $\quad$ Nederland $\quad 12$

Anders $\quad 3$

Boekbespreking: Nederland 27

Duitsland 4

Italië 1

Engeland 1

Rechsgeleerd Magazijn 1905

$\begin{array}{lll}\text { Artikelen: } & \text { Nederland } & 9 \\ & \text { Anders } & 4\end{array}$

Boekbespreking: Nederland 41

Duitsland 3

Frankrijk 2

E. DE VIERDE PERIODE (1910-1940)

1. Verwijzingen

Suijling. J.Ph., Inleiding tot het burgerlik recht, 2e stuk, 2e gedeelte (2e druk, 1936) 


$\begin{array}{lrr}\text { Totaal: } & 1808 ; & 100 \% \\ \text { Nederland: } & 1244 ; & 69 \% \\ \text { Frankrijk: } & 290 ; & 16 \% \\ \text { Duitsland: } & 189 ; & 10 \% \\ \text { Zwitserland: } & 85 ; & 5 \%\end{array}$

Thermis $(12,14,17,20,23,26,29,31,33,39)$

Totaal:

Nederland:

$2341 ; \quad 100 \%$

Romeins:

Frankrijk:

$1665 ; \quad 71 \%$

Duitsland:

$87 ; \quad 4 \%$

$257 ; \quad 11 \%$

België:

211; $9 \%$

Oostenrijk:

$3 ;<<1 \%$

$6 ;<<1 \%$

2. Inhoudsopgave Themis en Rechtsgeleerd Magazijn

Themis 1929

$\begin{array}{llr}\text { Artikelen: } & \text { Nederland } & 12 \\ & \text { Duitsiand } & 1\end{array}$

Boekbespreking: Nederland 25

Duitsland 5

Themis 1930

Artikelen: $\quad$ Nederland $\quad 12$

Boekbespreking: Nederland 27

Rechtsgeleerd Magazijn 1929

Artikelen: Nederland 11

Boekbespreking: Nederland 38

Frankrijk 2

Duitsland 5

België 1 
Rechtsgeleerd Magazijn 1930

Artikelen:

Nederland

8

Anders

1

Boekbespreking: Nederland 50

Frankrijk

3

Duitsland

8 


\section{Samenvatting}

Door de invoering van de nationale codificaties sinds het begin van de negentiende eeuw is de beofening van de privaatrechiswetenschap een nationale aangelegenheid geworden. Dat is het uitgangspunt van veel schrijvers (zoals Coing en Zimmermann). In de huidige tijd is er een streven in de privaatrechtswetenschap om die nationale grenzen te overschrijden. In de woorden van Zimmermann: " . a comprehensive 'Europeanization' of legal science has to be brought about.' Maar was de privaatrechtswetenschap werkelijk zo nationaal? Dit onderzoek geeft een antwoord op de vraag in welke mate en op welke wijze sprake was van oriëntatie op andere rechtsstelsels in de Nederlandse wetenschap van het privaatrecht. Deze vraag is op de volgende manier geconcretiseerd. Als object van onderzoek dient het gebruik van het aan een ander rechtsstelsel ontleend argument in de Nederlandse discussie over vier verschillende onderwerpen uit het vermogensprivaatrecht. De volgende onderwerpen worden onderzocht: de in artikel 1403 lid $1 \mathrm{BW}$ (oud) weergegeven aansprakelijkheid voor zaken, publiek domein, artikel $2014 \mathrm{BW}$ (oud) en de relativiteit van de onrechtmatige daad. Bij de analyse van de discussie ligt de nadruk op de vorming van standpunten in de privaatrechtelijke literatuur: commentaren op het Burgerlijk Wetboek, boeken, publikaties in (vak)tijdschriften, en annotaties. De onderzochte periode strekt zich uit over een ruime eeuw: vanaf de codificatie van 1838 tot aan 1940. Bij de analyse van de literatuur worden de standpunten en argumenten opgespoord. Verwijzingen tonen de herkomst van een standpunt of argument uit een ander rechtsstelsel. Op een viertal manieren kan uit deze verwijzingen de oriëntatie op andere rechtsstelsels volgen. De eerste manier is een kwantitatieve benadering. Een relatieve verandering in het aantal gebruikte verwijzingen illustreert de gerichtheid van de rechtswetenschap op een bepaald rechtsstelsel. Daartoe worden verwijzingen onderscheiden naar herkomst en vervolgens geteld in geselecteerde literatuur. In een bijlage zijn deze bevindingen weergegeven.

Een kwalitatief onderzoek naar de oriëntatie op andere rechtsstelsels vindt plaats op drie manieren. In de eerste plaats wordt de inhoudelijke ontwikkeling van het leerstuk geanalyseerd: duidelijk wordt welke (delen van de) onderwerpen ontieend zijn aan andere rechtsstelsels. In de tweede plaats wordt het gebruikte argument gewaardeerd als methode van rechtsvinding. Door het argument als methode van rechtsvinding te kwalificeren wordt de oriëntatie op het andere stelsel duidelijker in een bekende historische ontwikkeling van het privaatrecht geplaatst (van legisme naar vrije rechtsvinding). Dit 
criterium is de belangrijkste grond geweest voor de verdeling van de onderzochte periode in vier deelperioden die telkens in afzonderlijke hoofdstukken worden behandeld. In de derde plaats word het onfleende argument nader beschouwd door visies van civilisten op rechtsvergelijking erbij te betrekken. Na twee inleidende hoofdstukken (hoofdstuk. 1 met een inleiding en vraagstelling, hoofdstuk 2 met een introductie van de onderwerpen) wordt in hoofdstuk 3 de privaatrechtswetenschap voorafgaande aan 1838 belicht en wordt de betekenis vastgesteld van de onderzochte onderwerpen in 1838 . Ingegaan wordt op het Romeinse recht en het Franse recht, en de betekenis van beide stelsels voor het BW van 1838. Parlementaire geschiedenis en de voorgaande ontwerpen van wetgeving blijken onwoldoende om de bepalingen in het Burgerlijk Wetboek te interpreteren. Frans en Romeins recht zijn noodzakelijk bij de uitleg. Soms blijkt zelfs met behulp van deze rechtsstelsels een duidelijke uitleg onmogelijk. Door de letterlijke vertaling van artikel $2279 \mathrm{Cc}$ in artikel 2014 worden onduidelijkheden uit het Franse recht overgenomen in het Nederlandse recht.

In hoofdstuk 4 wordt deze onvolkomenheid van de Nederlandse bronnen duidelijk geillustreerd. Dit hoofdstuk behandelt de eerste periode (1838-1850) na de codificatie van 1838 . We zien dat bij de uitleg van alle behandelde onderwerpen steeds het Franse recht wordt betrokken. Kort na de codificatie is nog getracht door een beknopte tekstuele vergelijking tussen de Nederlandse en de corresponderende Franse bepalingen tot een uitleg van de Nederlandse bepaling te komen. Dat blijkt onvoldoende. Vrij snel verschijnen meer uitgebreide behandelingen van het Nederlandse recht waarin met het Franse wordt vergeleken. Dat Franse recht is voor een uitleg van de Nederlandse bepalingen onontbeerlijk. Het Romeinse recht wordt ook bij de uitleg betrokken, maar in mindere mate dan het Franse. Aan de hand van het Franse recht is een beperkte uitleg van de aansprakelijkheid in artikel 1403 lid 1 het meest waarschijnlijk. De uitleg van artikel 2014 vindt plaats op vele verschillende wijzen, alle aan de hand van het Franse recht. Het Romeinse recht makt een interpretatie van het begrip "zaken buiten de handel' mogelijk. Vooral is in deze periode sprake van een historische uillegmethode van de bepalingen in het Burgerlijk Wetboek. Daarbij vervullen Frans en Romeins recht een onmisbare rol.

Hoofdstuk 5 behandelt de periode wan het legisme ( $1850-1880$ ). Kenmerkend voor die periode is een gerichtheid op tekst en systeem van het Nederlandse Burgerlijk Wetboek. Toch wordt ook in die periode ruim gebruik gemaakt van andere rechtsstelsels. De oriẻntatic op het Franse recht blijft aanwezig. Andere rechtsstelsels worden eveneens gebruiki. Duitse wetgeving en wetsontwerpen met een aansprakelijkheid buiten schuld worden betrokken bij aansprakelijkheid voor zaken. Uit het Belgische recht wordt Laurent aangehaald bij de uitleg van artikel 2014 (Diephuis' interpretatie van artikel 2014 vertoont veel overeenkomsten met Laurents interpretatie van artikel $2279 \mathrm{Cc}$ ). Het Duitse ontwerp voor een Bürgerliches Gesetzbuch dient als onderbouwing voor een nieuwe uitleg van artikel 2014 (een voorloper van Scholtens legitimatieleer). Het Franse 
recht staat aan de basis van de acceptatie van publiekrechtelijke eigendom in het Nederlandse (administratief- en privaat)recht.

Wanneer we kijken naar het gebruik van het buitenlandse argument in de wijzen van rechtsvinding dan valt het volgende op. Kenmerkend voor de rechtsbeoefening in de legistische periode is de scheiding die wordt aangetroffen tussen de beredenering van het geldende recht (ius constitutum) en de beredenering van het wenselijke recht (ius constituendum). De beredenering van het geldende recht is gebonden aan tekst en systeem van het Nederlandse Burgerlijk Wetboek. In de beredenering van het wenselijke recht kan veel meer gebruik gemaakt worden van andere rechtsstelsels. In dat verband wordt een nieuwe uitleg van artikel 2014 voorgestaan en een invulling gegeven aan het begrip 'zaken buiten de handel.' Maar ook zien we dat in de beredenering van het geldende recht van andere stelsels gebruik gemaakt wordt. Zo dienen het Franse en (in mindere mate) het Romeinse recht als historische interpretatie. Maar evenzeer wordt (in geringe mate) naar eigentijdse uiteenzettingen met betrekking tot corresponderende artikelen in het Franse recht verwezen. Bovendien wordt in andere rechtsgebieden, zoals het administratiefrecht, met meer vrijheid van andere rechtsstelsels gebruik gemaakt. Via het (nieuw ontwikkelde) administratiefrecht wordt de (Franse) publiekrechtelijke eigendom van publiek domein als heersende leer ook in het privaatrecht geaccepteerd. Aldus is ook op indirecte wijze (door middel van het administratiefrecht) sprake van een oriëntatie op andere rechtsstelsels. De rechtsvergelijking verwerft zich aldus langzamerhand in de uitlegmethoden een zelfstandige positie. Er is in de periode van het legisme meer dan alleen rechtsvergelijking als historische interpretatie met behulp van het Franse of het Romeinse recht.

Hoofdstuk 6 behandelt de periode van de vrije rechtsvinding (1880-1910). De reactie tegen de strikte uitlegmethoden van het legisme treedt sterk op de voorgrond. De maatschappelijke wenselijkheid van een bepaalde uitleg geeft niet alleen het wenselijke recht aan, zoals tijdens het legisme voornamelijk het geval was, maar vormt tevens een (veleologisch) argument in de beredenering van het geldende recht. In deze "vrije rechtsvinding' komt een ruime plaats toe aan het buitenlandse recht. Zo dient Duitse en Oostenrijkse wetgeving als onderbouwing voor een ruime aansprakelijkheid voor zaken in artikel 1403 lid 1. Ook de ruime uitleg in de Franse literaturur en jurisprudentie van het corresponderende Franse artikel $1386 \mathrm{Cc}$ wordt hiervoor gebruikt. De twee belangrijkste interpretaties van artikel 2014 worden beide onderbouwd met behulp van het Franse en het Duitse recht. Ook het Engelse recht (Sale of Goods Act) en het Zwitserse worden bij de uitleg betrokken. Publiek domein wordt sinds 1890 algemeen onderworpen geacht aan het privaatrecht en de onderbouwing van dat standpunt vind plaats aan de hand van (minderheidsstandpunten in) het Duitse en het Franse recht. De relativering van de onrechtmatige daad uit het Duitse Bürgerliches Gesetzbuch wordt uitgebreid in de Nederlandse literatuur behandeld. 
In de methoden wan rechtsvinding neemt het maatschappelijk wenselijke doel de meest belangrijke plaats in. In verband met deze teleologische interpretatie komt alan genoemde andere rechtsstelsels een ruime plaats toe. Het Franse recht blijft als historische interpretatiemethode in gebruik. Gebruik van andere rechtsstelsels in het algemeen wordt bij de beredenering van her geldende recht van groter belang. Civilisten onderkennen dat belang van rechtsvergelijking. In deze periode spreken een aantal zich expliciet uit voor een grotere rol van rechtsvergelijking in het Nederlandse privaatrecht.

Hoofdstuk 7 behandelt de laatste periode (1910-1940) waarin twee richtingen te onderkennen zijn. Enerzijds zet zich de vrije rechtsvinding voort met een grote rol voor de teleologische interpretatie. Anderzijds zijn er anderen die een grotere rol voor tekst, systematiek en historie van het Burgerlijk Wetboek voorstaan. Beide richtingen gebruiken rechtsvergelijking. Dat gebeurt bij alle onderzochte onderwerpen. Zowel het Franse als het Duitse recht komen aan de orde. Kritiek komt op tegen de ruime aansprakelijkheid die in artikel $1403 \mathrm{kan}$ worden gelezen. In dat verband worden (Franse) tegenstanders van de heersende ruime uitleg van artikel $1386 \mathrm{Cc}$ in het Franse recht aangehaald. De argumenten zijn aan tekst en systeem van de wet ontleend. Tevens wordt echter gewezen op de onbillijke gevolgen van een ruime aansprakelijkheid voor de (aansprakelijke) gebruiker van een zaak. Een voorgesteld onderscheid tussen gevaarlijke (of gebrekkige) en ongevaarlijke zaken (Suijling) wordt ontleend aan het eigentijdse Franse en het Belgische recht. In de discussie over artikel 2014 maken voorstanders van de Germaansrechtelijke uitleg ('bezit is eigendom,' Meijers) gebruik van het Franse en Duitse recht. De nieuwe legitimatieleer (Scholten) wordt onderbouwd met Frans, Duits, Engels en Zwitsers recht. In de discussie over de rechtstoestand van publiek domein worden Frans en Duits recht ingebracht. De Nederlandse heersende leer van privaatrechtelijke eigendom wordt onderbouwd met een uitvoerige bespreking en verwerping van de Franse heersende publiekrechtelijke leer, en de op het Franse recht gestoelde theorie van Mayer uit het Duitse recht. Het nieuwe vereiste van de relativiteit van de onrechtmatige daad wordt geaccepteerd in de rechtspraak en deels in de literatuur. Het Duitse recht levert een invulling van de relativiteit in het Nederlandse recht. De tegenstand tegen het nieuwe relativiteitsvereiste is echter aanzienlijk, en ook daarin wordt van het Duitse recht, en het Franse (in mindere mate) gebruik gemaakt.

In deze periode zijn twee richtingen in de methoden van rechtsvinding in het privaatrecht te onderkennen. Aan de ene kant de richting die de grootste waarde toekent aan de vrijheid in de uitleg, waarbij de teleologische uitleg het meest belangrijk is. Aan de andere kant de richting die meer waarde hecht aan tekst, systeem en geschiedenis van het Burgerlijk Wetboek. Die waarde is niet zo groot dat aan een maatschappelijk wenselijke uitleg geen ruimte meer zou toekomen. Aan rechtsvergelijking kan (veel meer dan in het legisme) een ruime plaats toekomen. In beide richtingen wordt van rechtsvergelijking gebruik gemaakt: hetzij als rechtshistorisch argument, maar veel belangrijker is geworden de verwijzing naar het eigentijdse recht van een ander rechtsstelsel. 
Hoofdstuk 8 besluit het onderzoek met een algemene conclusie over de gehele besproken periode. Ingegaan wordt op de betekenis van dit onderzoek voor een Europees privaatrecht. Tussen de nationale privaatrechtsstelsels van Europa bestaan overeenkomsten. In dit onderzoek vallen er twee vooral op. In de eerste plaats is er de overeenkomst tussen de methoden van rechtsvinding in een bepaalde periode: het legisme (l'école de l'exégèse, Begriffsjurisprudenz) in de tweede helft van de negentiende eeuw en de vrije rechtsvinding (Interessenjurisprudenz en Freirechtschule, la libre récherche scientifique) rond 1900 . In de tweede plaats is er sinds 1900 sprake van een toenemende expliciete aandacht van civilisten voor rechtsvergelijking. Door deze uitwendige overeenkomsten tussen de privaatrechtsstelsels wordt kennisname van andere stelsels in het Nederlandse privaatrecht vereenvoudigd. In toenemende mate wordt in de beredenering van het geldende recht gebruik gemaakt van andere rechtsstelsels. Dat gebruik komt tot uiting op een aantal manieren. In de eerste plaats is sprake van een getalsmatig grote oriëntatie op andere rechisstelsels. In de tweede plaats is vaak sprake van overname van standpunten uit andere stelsels. In de derde plaats worden argumenten uit andere stelsels regelmatig geaccepteerd of verworpen. Kennisname van dergelijk gebruik van ander recht kan dienstbaar zijn bij harmonisatie of unificatie van onderwerpen uit de verschillende nationale stelsels van privaatrecht. 



\section{Summary}

The introduction of national codifications from the early nineteenth century onwards has made the study of private law into a national affair. This is the view of many scholars, including Coing and Zimmermann. Nowadays, when studying private law, there is a movement to transgress national borders. As Zimmermann has put it: ". . a comprehensive "Europeanization" of legal study has to be brought about". However, how national was the study of private law in former times? This dissertation examines the extent to which and the manner in which scholars were guided by knowledge of foreign legal systems when studying Dutch private law. The object of this study is the use of arguments from foreign legal systems in the Dutch legal debate on four different private law subjects in the field of Dutch property law and the law of obligations. The subjects are: liability for corporeal objects as laid down in Article 1403, section 1, of the Dutch Civil Code of 1838 (DCC); public ownership; Article 2014 DCC; and the relevance requirement in relation to wrongful acts (onrechtmatige daad). In analysing the literature, the author focuses on viewpoints developed in scholarly writing on private law, i.e. commentaries on the 1838 Dutch Civil Code, books, publications in legal reviews and annotations. The period under investigation spans more than a century: from the 1838 codification of Dutch private law (DCC) until the year 1940.

Through the literature analysis the different views and arguments were collected. References to foreign law revealed that these views or arguments pertain to foreign legal systems. There are four ways in which the influence of a foreign legal system can be established. The first is a quantitative approach. A relative change in the number of references used reveals the reliance of legal scholars on a particular foreign legal system. For this purpose, references are distinguished as to provenance and subsequently counted throughout the selected materials. The outcome is featured in the annex.

There are three ways in which qualitative research into the reliance on other legal systems can be conducted. First, the substantive development of the above subjects is analyzed. This reveals which (elements of the) subjects under study have been derived from other legal systems. Second, the argument used is evaluated as a method of lawfinding. By qualifying "argument" as a method of law-finding, reliance on knowledge of a foreign legal system is placed more discernably in a familiar historical development, from formalism (legisme) to "sociological jurisprudence". This criterion has been 
the principal reason for subdividing the period under study into four sub-periods. Each of the sub-periods are treated in a separate chapter. Third, the argument derived from a foreign legal system is further examined by looking at private lawyers ${ }^{*}$ attitudes to comparative law.

By way of introduction, Chapter 1 contains a general introduction and the thesis, whereas Chapter 2 introduces the subjects. Chapter 3 deals with the study of private law of before 1838 and the relevance and scope in 1838 of the subjects under study. Roman and French law is examined and the relevance for the 1838 Dutch Civil Code is discussed. The legislative history and the preceding relevant bills yielded insufficient information for a proper interpretation of the provisions of the 1838 Civil Code. French and Roman law needed to be recruited to assist in the interpretation. Even with the assistance of these foreign systems, at times a proper and clear interpretation could not be achieved. Because of the literal translation of Article 2279 of the French Code civil (Cc), the ambiguities of the French law were transferred to Article 2014 of the 1838 Dutch Civill Code.

In Chapter 4 , examples clearly demonstrate these imperfections of the Dutch legal sources. The author discusses the first period (1838-1850) following the codification of 1838. On every occasion in which subjects needed interpretation, French law was invoked. Not long after codification, there was an attempt at interpreting the Dutch provisions by comparing the literal text of the Dutch provisions with that of the French provisions. This proved to be inadequate. A more profound scholarly debate on Dutch law developed, in which Dutch law was compared with French law. French law was indispensable in the interpretation of Dutch legal provisions. Roman law was also used in interpreting Dutch law, but to a lesser extent. When comparing Article 1403, section 1, of the 1838 Dutch Civil Code with French law, a restrictive interpretation of the liability laid down in section 1 of the Dutch article emerged as the most convincing. Article 2014 DCC could be interpreted in many ways, but they all involved French law. Roman law offered the foundation for the interpretation of the term "zaken buiten de handel" (res extra commercium). Particularly in this period, an historical interpretation method was applied to the provisions of the 1838 Dutch Civil Code. For this purpose, French and Roman law were indispensable.

Chapter 5 treats the period of formalism (legisme) which was between 1850 and 1880 . Characteristic of this period is the emphasis on the text and systematic organization of the Dutch Civil Code. Nevertheless, other systems were employed for the purpose of law-finding. The reliance upon French law continued and other legal systems were examined as well. German statutes and bills relating to strict liability were consulted to define tortious liability for corporeal objects under Dutch law. From Belgian law, Laurent is quoted for the purpose of interpreting Article 2014 DCC, and Diephuis' interpretation of this article shows many similarities with Laurent's interpretation of Article 2279 Code civil. The German Draft for a Civil Code (Bürgerliches Gesetzbuch) 
served as the basis for a new interpretation of Article $2014 \mathrm{DCC}$ (the precursor of Scholten's theory of "legitimatie". French law lies at the root of the reception of public ownership into Dutch administrative and private law.

If we examine the use of foreign argument in law-finding, we notice the following: characteristic for practising the study of law in the formalistic period is the separation between the reasoning applied with respect to operative law, the jus consritutum, and the arguments in advocating future law, the jus constituendum. The reasoning for the jus constitutum of the Dutch Civil Code was restricted to text and system. In reasoning which was directed towards future law it was possible to rely on foreign legal systems. Thus, a new interpretation of Article 2014 DCC was adwocated, and the term "zaken buiten de handel" was defined. However, in reasoning relating to operative law foreign legal systems were used as well. For instance, French law and, to a lesser extent, Roman law, served as elements of an historical interpretation. There are also references, albeit few, to contemporary exposés on corresponding articles in French law. In addition, foreign legal systems were drawn upon; however, this practice was more common in other legal areas, such as administrative law. As a result of (newly developed) Dutch administrative law, the French concept of public ownership was received as the prevailing doctrine in Dutch private law. Thus, indirectly, through administrative law, we see an interpretation based on a foreign legal system. Step by step, comparative law is gaining an independent place among interpretation methods. In the formalistic, or "legistic", period, there was more than just comparative law as an historical interpretation with the assistance of French or Roman law.

Chapter 6 discusses the period of [vrije rechstvinding] between 1880 and 1910. There was a reaction against the formalistic interpretation methods of the "legistic" period. The sociall desirability of a particular interpretation not only indicated the law as it should be, as was primarily the case during the "legistic" period, it also constituted an argument in the reasoning about operative law. In this free method of law-finding, ample room was afforded to foreign law. German and Austrian legislation, for instance, served as the foundation for a broad tortious liability for objects as laid down in Article 1403 , section 1, of the 1838 Dutch Civil Code. To this end, also the broad interpretation by French scholarly writers and in the French case law relating to Article $1386 \mathrm{CC}$ was deployed. The two major interpretations of Article 2014 DCC were both supported by French and German law. Also English law (the Sale of Goods Act 1893) and Swiss law were taken into account. Since 1890 , public ownership of reall property is deemed to be governed by private law and the underpinning for this view is derived from (the minority view within) German and French law. The requirement of relativity ( $c f$ the statutory duty of care) as laid down in the German Bürgerliches Gesetzbuch was taken into account by Dutch scholars. In the law-finding method of this period, the socially desirable objective of law was the main issue. In connection with this teleological interpretation, there was ample space for the earlier-mentioned legal systems. French law was preserved as an historical interpretation method. The use of foreign legal 
systems in general gained more prominence in arguments about operative law. Private lawyers acknowledged the relevance of comparative law; a number of them advocated more influence for comparative law in Dutch private law.

Chapter 7 treats the final period (1910-1940), in which two directions can be distinguished. The one containing the sociological method of law-finding allowing a large role for teleological interpretation. The other advocates a larger role for the text, the systematic organization and legislative history of the 1838 Dutch Civil Code. Both directions apply comparative law. This holds true for all subjects under investigation. Both French and German law were taken into account. The broad interpretation of the tortious liability laid down in Article 1403 of the Dutch Civil Code was criticised. To this end, French opponents of the prevailing broad interpretation of Article $1386 \mathrm{Cc}$ were quoted. The arguments were derived from the text and the systematic organization of the Dutch Civil Code. However, at the same time, it was pointed out that a broad interpretation of liability for wrongful acts would lead to outcomes that were unfair on the user of the object responsible for the wrongful act. The distinction, as proposed by Suijling, between dangerous (or defective) objects and harmless ones, is derived from contemporary French and Belgian law. In the discourse on Article 2014 DCC, proponents of Germanic legal interpretation (Meijers' "possession equals ownership") made use of French and German law. Scholten's newly developed doctrine of "legitimatie" is based on French, German, English and Swiss law. The discourse on the legal status of public ownership of real estate featured French and German law. The Dutch prevailing theory of private law ownership drew on a comprehensive study and rejection of the prevailing public law theory in French law, and Mayer's theory in German law, which was derived from French law. The new element of "relativity" was accepted in case law and to some degree among academics. German law provided the components of the relativity concept under Dutch law. Opposition to the new relativity theory was considerable and the opponents atso employed German, and to a lesser degree, French law to underpin their views.

During this period, two approaches can be distinguished in law-finding in private law. The first placed most value on free/contextual interpretation, whereby the teleological interpretation method is the most important. The other relied on the text, systernatic organization and legislative history of the Dutch Civil Code; however, not to the extent that there was no room for an interpretation based on social desirability. In contradistinction to the formalistic period, comparative law could play an important role. Comparative law was applied in both approaches: either as a legal-historical argument, or, more importantly, to refer to the contemporary law of a foreign legal system.

Chapter 8 concludes the study and offers a general conclusion for the entire period under investigation. The author discusses the relevance of the study for a European private law. There are similarities between the national private law systems of Europe. This study reveals two conspicuous similarities. First, there are similarities between the 
methods of law-finding in a particular period: legisme/l'école de l'exégèse, Begriffsjurisprudenz, in the latter half of the nineteenth century and sociological jurisprudence: Interessenjurisprudenz, Freirechischule, la libre recherche scientifique, of around 1900. Second, from 1900 onwards, private lawyers show an increasing interest in comparative لaw. These external similarities between private law systems facilitate understanding foreign legal systems. Increasingly, in the reasoning about operative law use is made of other systems. Such use manifested itself in several ways. First, there is the quantatively large reliance on foreign systems. Second, there are numerous cases in which views were adopted from other systems. Third, arguments brought forward in foreign systems were regularly accepted or rejected. Awareness of such deployment of foreign law may be conducive to harmonizing or unifying elements from the various national private law systems.

Translated by Louise Rayar, B. tr 



\section{Literatuur}

Ancel, M., La tendance universaliste dans la doctrine comparative Française au debut du xxène siecle, Festschriff fiur Ernst Rabel, deel 1 (1954), p. 17-38

Anten, J.H.A.M., Rondom artikel 1403 BW, WPNR 3205-3207 (1931), p. 285-287, 293-294, 305-306

Apeldoorn, L.J. van, boekbespreking van het Gedlenkboek Burgerlijk Wetboek 1838-1938, in: Rechrsgeteerd Magazijn Themis (1939): p. 69-84

Art. 230 der gemeentewet, De Gemeentestem 1597, 1598 en 1602 (1882)

Asser, C., Het Nederlandsch Burgerlijk Wetbotk, vergeleken met het Wetboek Napoleon (2ue druk, "s-Gravenbage. Amsterdam 1838)

Asser, $\mathrm{C}$. Handleiding tot de beofening wan het Nederlandsch birgerlijk recht. deet 2 (2e druk, Zwolle 1890)

Aubry, C., en Rau, C., Cours de droit ciwil Français, deel 2 (4e druk, Paris 1869)

Barckhausen, H., Remarques sur la théorie des domaines, Revue critique de lëgislation et de jurisprudence, deel $13(1884)$, p. $30-43$

Bartin, E., Cours de droir civil Francais (...) par C. Aubry et C. Rau, deel 2 (6e druk, Paris 1935)

Bassecour Caan, J.J. de la, Handleiding rot de kennis wan her administratieve regr in Nederland, deal 1 (2e druk, "s-Gravenhage 1865 )

Baudry-Lacantinerie, G., en M. Chauveau, Trathe theorigue et pratique de droit civil Des biens.s. (3e druk, Paris 1905)

Baudry-Lacantinerie, G., en Tissier. A., Traite theorique et pratique de droil civil. De fa prescription (3e druk. Paris 1905)

Beekhuis, J.H., Mr. C. Asser's Handleiding tot de beoefening van het Nederlands burgerligk recht. Zakenrech! I (10e druk, Zwolle 1975)

Benedity, $N$ de, Proeve tot verzoening van de dogmatische en sociologische riclatingen in de rechtswetert. schap, Rechtsgeleerd Magazijn Themis (1939), p. 128-142.

Bergh, G.C.J.J. vanden, Eigendom. Grepen uit de geschiedenis van een omstreden begrip (2e druk "Deventer 1988) 
Bergh, G.C.J.J van den, Geleerd recht (3e druk, Deventer 1994)

Berthêlëmy, $\mathrm{H}$., Traité élémentaire de droit administralff (1 le druk, Paris 1926)

Bieberstein, P.G.E.H. de, Proeve over zaken büten den handel (Leiden 1849)

Binnerts, C., Aansprakelijkheid voor automobielen "uit de hand", WPNR 3071 (1928), p. 689-693

Boer, Th.M. de, Vitgangspunten van een rechtsvergelijkendle theorie: een paradigma voor de lage landen, Ars Aequi 43 (1994) 5. p. $303-310$

Bool, J., De gemeentewet (Zwolle 1930)

Hosel Kemper, I. de, Handleiding tof de kennis van het Nederlandse staatsregr en staatsbestuur (Amsterdam 1865)

Bouckaert, B., De exegetische school. Een kritiscke studie wan de rechrsbronnem en interprefatieleer bij de 19e eeuwse commentatoren van de Code Civill (Antwerpen 1981)

Braams, W. Th, Buiten-contractuele aansprakelijkeid voor gevaarlijke stoffert (Deventer 1989)

Brahn, O.K., De ontwikkeling wan twee zakentechtelijke wetsbepalingen tussen 1842 en 1988, in: Luijten, E. A.A. (e.a.), 146 jaar Burgerijk Weiboek. Het jubilewn wan het 550 -jarig Wetboek en zijn invoering in her Herrogdom Limburg op 1 januari 1842 (Deventer 1989), p. 49-60

Brahn, O.K., Levering. Beschikkingsonbevoegdheid (Deventer 1992)

Bruins, G.W.J., Een onderzoek naar den rechtsgrond der schadevergoeding ("s-Gravenhage 1906)

Brunner, C.J.H., Was Diephuis een legist? Een herwardering na 100 jaat, in: G. Diephuis, C. W. Opzoamer 1892-1992 (Groningen 1992), p. 1-23

Catenegen, R.C. wan, Geschiedkandige inleding tot het privadrecht (Gent 1981)

Code Napoléon, suivi de l'exposé des motifs, sur chaque loi (..), deel 4 (Paris 1808)

Coing. H., Europaisches Privatrech Band 2 (München 1989)

Coing. H.. Europäisierung der Rechtswissenschaft, Neue Jurisilsche Wochenschrift 1990, p. 937-941

Colin, A, en H. Capitant, Cours êtementaire de droir civil Frangais, deel 1 (4e druk, Paris 1923)

Coninck Liefsting, F. B., De algemeene beginselen van het bezitrecht en de Nederlandsche bezitactiën (Leiden 1869)

Constantinesco, L.J., Rechrsvergleichung, Band $\llbracket(K o ̈ \ln \llbracket 97 \rrbracket)$

Cort van der Linden, P.W.A., Beschomwingen over het strand (Leiden 1869)

Crome, C., System des Deutschen Bürgerlichen Rechts, deel 1 (Tubingen 1900) 
Das Bürgerliche Gesetzbuch mit besonderer Berücksichigung der Rechtsprechung des Reichsgerichts (Nürnberg, Leipzig 1910)

Dekkers, R., Hondboek wan Burgerlijk Recht, deel 2 (Bussel 1972)

Dekkers, R. Précis de droit civil Belge, deel 2 (Bnuxeltes: 1955)

Delvincourt, M. "Cours de Code civil, deel 8 (Bnuxelles 1825)

Demogue, R., Traité des obligations en général, deel 4 (Paris 1924 en deel 5 (Paris 1925)

Dennolombe, C., Cours de Cade Napoléon. Traité des engagements qui se forment sans convention, deel 8. (Paris, 1882)

Den Tex, C.A., Encyclopedia Jurisprudentiae (Ansterdam 1839)

Den Tex, C.A., J. van Hall, Nederlandsche Jaarboeken woor Regtsgeleerdheid en Wetgewing (1839)

Dernburg, H., Pandekten, deel 1 en 2 (3e druk, Berlin 1892)

Diephuis, G., Het Nederlandsch Burgerlijk Regt naar de volgorde van het burgerijk wetboek 1-9 (le druk. Groningen $1844-1855$, 2e druk, 1856-18.59)

Diephuis, $\mathrm{G}_{n}$ Het Nederlandsch Burgerlijk Regt 1-13 (Groningen 1869-1890)

Diewoet, E. van, Het burgerlijk recht in België en Nederland 1800-1940, (Antwerpen 1943)

Drion, J., G. de Grooth, F.J. de Jong, Ontwerp voor een mieuw Burgerlijk Werboek wan E.M. Mejijers. Toelichting boek 6 (1961)

Drucker, H.L., Rechtswetenschap en wetgeving (1882), in: Rechtsgeteerd Magazijn 1882, P. 517-5.47

Drucker, W.H., Onrechtmatige daad ("s-Gravenhage 1912)

Duguit, L., Traité de droit constitutionnel, deel 3 (3e druk, Paris 1930)

Dunné. I.M. van, Aansprakelijkheid en werweren bij bodemwerontreinigingen uit het verleden, Tijdschriff woor Miliewaansprakelijkheid (1992), p. 98-104

Ehrlich, E., Freie Rechtsfindung und freie Rechtswissenschaft (Aaten 1906, 1987)

Eggens, J.. Het jongste arrest van den H.R. inzake art. 2014. Nederlands Juristenblad 1926, p. 87-92.

Egger. A. Kommentar zum Schweizerischen Zuvitgeserzbuch. Einteitung and Personenrechn (Zü rich 1930. 1978)

Esmein. P., Traité pratique de droit civil Français par Marcel Planial et Georges Ripert, deel 6 (2e druk. Paris 1952)

Eyssell, A.Ph.T. Het wetswoorstel omtrent de onregmatige daad en de regtszekerheid, Themis 1911 , p. 568 617 
Faber, J.G.A., Ver opmerkingen over bezit. Natraanteiding van Mr. Coninck Liefsting"s Bezitreche, Themis 11871 , p. $1-14$

Feenstra, R., Romeinsrechtelijke grondslagen wan het Nederlands privaatrechi (Leiden 1990)

Feith, P.R., bespreking van Land, N.K.F., Verklaring van het Burgerlijk Wetboek, deel 2 en 3 (2e druk, 1901, 1902), Land, N.K.F., Rechren op Zaken, naar het Ontwerp Tweede Boek B.W. 1901, in: Thernis 1904, pin $168-184$

Florijn, E.O.H.P., Ontstaan en onmukkeling wan her nieuwe Burgerlijk wetboek (Maastricht 1994)

Fockema Andreat, J.P. Tien jaren rechtspraak van den Hoogen Raad. Bijdrage tot de leer der wetsuitlegging (Leiden 1904)

Fockema Andreae. J.P., Moderne Praetuur? Beschouwingen over het jongste werleden en de naaste roekomst van wetsroepassing en rechishenorming (Haarlem 1907)

Frain, H.M., De tegenwoordige stand der jurisprudentie betreffende de onrechtmatigheid in art. $1401 \mathrm{BW}$, in: Rechtsgeleerd Magazijn 1932, p. $1-65$

Gaius, Instituten, vertaling van A.C. Oltmans (3e druk, Groningen 1967)

Gelein Vitrunga, J. van, Onteigening van publiek domein, Themis 1903, p. 1-39 en 171-190

Gelein Vitringa, J, van, Publiekrechtelijk karakter wan den openbaren weg?. Rechtsgeleerd Magazijn 1907 , p. $1-44$

Gelein Vitringa, J. van, Openbaarheid van den weg en burgerlijk recht, Rechtsgeleerd Magazin 1919, p. 2350

Geny, F., Méthode d'interpresarion et sources en droit privé positif, deel 1 (Paris 1899, herdruk 1954)

Van Gessel-De Roo, M.J.E.G. (red), Bronnen wan de Nederlandse codificotie sinds 1798 . Zakenrecht 17981820 (Urecht 1991)

Ghestin, J., en Coubeaux, G. Traité de droit civil. Introduction générale (3e druk, Paris 1990)

Gilissen, I., Historische intedding rot het recht (Antwerpen 1981)

Gluck, C.F. von, Alsführliche Erläarerung der Pandekten, deel 10 (Erlangen, 1867)

Goudeket, I., Het Burgerlik Wetboek werkiaard door Mr. C.W. Opzoomer, deel 3 ("s-Graventhage 1911)

Goudsmit, J.E. Bespreking van: Van Boneval Faure, Specimen inaugurate continens observationum ad ait. WI, Lib. IV Codicis Civilis Capita IV. Groningae 1848, in: Themis 1848, p. 675-690

Goudsmit, J, E., Over de werking en den aard van het bezit van roerende goederen, naar aanleiding van art. 2014 B.W, Themis 1854, p. 473-496

Goudsmit, J.E., Pandecten-Systeen (Leiden 1866)

Goudsmit, J.E., en C.W. Opzoomer, Beschouwing wan artikel 881 en 619 B.W., Themis 1844, p. 249-262 
Grinten, W.C.L. van der, Onrechtmatige daad en schade, Nedertands Jisistenblad 1939, p. 159-168 en 179. 189

Groot, G.R. de, Vergelijk alles en behoudt wet goede (Deventer 1989)

Groot, H. de, Inteidinge tor de Hollandsche rechrs geleerdheid, door F. Dowring, H.F.W.D. Fischer en E.M. Meijers (Leiden 1952)

Gutteridge, H.C., Comparative law (Cambridge 1971)

Haan, C.J. de, Aansprakelijkheid uit onrechtmatige daad, WPNR 3704-3705 (1940)

Haan, C.J. de, Eenige beschouwingen over het leerstuk der onrechtmatige daad, Rechtsgeleerd magazijn 1938 , p. $275-311$ en $345-380$

Hamaker, H.J., Burgerlijk Recht, (1888-1889) (collegedictaat van F.J. Vlamingh Kiebêrt) Bibliotheek For, UU, B $1 \mathrm{~d}-1$.

Handelingen der Nederlandse Juristen-Vereniging 1874, 1890, 1912, 1913

Hardenberg, L., De "eigendom" van de staat, in: Ter recognitie. Opstellen aangebaden can prof. m*. H. van der Linden bij zim afscheid als thoogleraar in de Nedertanase nechtsgeschiedenis aan de Vrije Universiteir (1987). p. $341-371$

Hartamp, A.S., Wetsuitleg en rechtstoepassing na de inwoering van het nieww Burgerlik Wetboek (Devemter 1992)

Harkamp, A.S. e.a. (red.), Towards a European Ciwi Cade (Deventer 1994)

Hartkamp, A.S., Mr. C. Asser's Handleiding tot de beoefening van het Nederlands Burgerlijk Recht. Verbinstenissenrecht, deel 3 (9e druk, Z wolle 1994)

Hartlief, T. en G.E. van Maanen, Hoe werkr de ontrechmatige daad of het paard van de professor en andere aangrijpende verhalen (Nijmegen 1995)

Hartog. L. de, Nog iets over den Eigendom van de Res publicae, Themis 1894, p. 394-401

Harzfeldt, Over vertegenwoordiging en haar rechtsgevolgen, naar privata en publiekrecht, Themis 1900, p. $473-510$

Hasselt, W.J.C. van, De Nederlandsche wetboeken met aanteekeningen ("S-Graventiage, Amsterdam 1843)

Hauriou, M., Précis de droit administratif et de droit public (12e dnik, Paris 1933)

Heijnsbergen, P. van, Geschiedenis der rechtswetenschap in Nederland (Amsterdam 1925)

Hengst C.J.W.N. van, Eenige opmerkingen over het eigendomsregt der gemeenten (Utrecht 1863)

Heusde, P.W. van, Mr. C. Asser's Handleiding tot de beofening van het Nederlandsch burgerlijk rech. Zakenrecht (Zwolle 1890)

Heusler, A., Institutionen des Deutschen Privatrechts" deel 2 (Leipzig 1886) 
Hoetink, H.R., Over het verstacan wan wreend recht (1929), in: Ankum, J.A., e.a. (red), Rechtsgeteerde opketlen (Alphen aan den Rijn 1982), p. 21-61

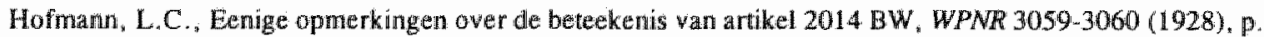
$505-507,517-519$

Hofmann, L.C., Nog eens: Art 2014 B.W., WPNR 3074-3075 (1928), p. 732-734, 751

Hofmann, L.C., Het Neterlandsch zakenrecht (Groningen, Den Haag. Batavia 1933)

Hofmann, L.C. Het Nederlandsch verbintenissenrech, deel 1 (4e druk, Groningen 1935. 6e druk 1941)

Hondius, E.H, Het Burgerlijk wethoek in rechtsvergelijkend perspectief, in: Recht vooruit. Opstellen verza meld ter gelegentheid wan 150 jaar BW (Deventer 1988), p. 59-71.

Hondius, E.H., Naar een Europees burgerlijk recht, preadwies woor de Vereniging voor Burgerlijk Recht (1993)

Huber, E., Die Bedeutung der Cewere im Deutschen sachenrecht (Bern 1894)

Hufeland, G., Verhandeling over den eigenadrdigen geest wan het Romeinsche regt in het algemeen, en met betrelking tot de hedendaggse welgeving en regtsgeleerdheid, door C.C.C. Warmolts (Leeuwarden, 1827)

Hug. W. The history of comparative law, Harvard law review 1932, p. 1027-1070

Jansen, C.J.H., Natuurrecht of Romeins recht; een studie over leven en werk wan F.A. van der Marck (17191800) in het licht van de opvattingen van zijn tijd (Leiden 1987)

Jansen, C.J.H., Der Briefwechsel zwischen H.W. Tydeman (1778-1863) und F.C. Von Savigny (1779-1861): Streiflichter au f die niederländische Rechtswissenschaft am Anfang des 19. Jahrhunderts, in: Die Rechtswissenschaftichen Beziehungen zwischen den Niederlanden und Deutschland in historischer Sichn (Nijmegen 1991), p. $71-89$

Jallse n, C.J.H., Popularisering wan het recht in Nederland. Enige beschouwingem over de kloof tussen recht en volk in het laatste kwart wan de $19 \mathrm{e}$ en het begin wan de $20 \mathrm{e}$ eeuw, Tijdschrifo voor rechtsgeschiedenis 63 (1995) 119

Jansen C.J.H. en M. de Ruiter, Het Algemeen Deel: Asser-Scholten en Asser-Vranken in rechtshistorisch perspectief, Ritch en Krittek 22 (1996), p. 5-26

Janssens, L.. De burgerrechtelijke aansprakelijkheid bij auto-ongelnkken, Rechtsgeleerd Magazijn 1929, p. $265-304$

Jaspers, T., Rechtspretien in de maatschappij (Zwolle 1980)

Jhering, R. von, Das Schuldmoment in römischen Privatrech, Vermischte Schrifien jwristischen Imhalts (Leipzig 1879)

Jonge, J.A. de, De industrialisatie in Nederland tussen 1850 en 1914 (Njimegen 1968, reprint 1976)

Jordens, H.G., Beschowwingen over zaken buiten den handet (Leiden 1869) 
Kamerlingh Onnes, A.H., Openbare wegen over parriculleren grond (Leaden 1915)

Kantorowice, H., Aus der Vorgeschichte der Freirechrslehre (Mannheim 1925)

Kappeyne van de Coppeilo, J., bespreking van Opzoomer, C.W., Het Burgerijk Werboek. Aanterekwing op de artikelen die thans nog verklaring behoeven, deel 1 (1849), Themis 1849, p. 607-629 en (deel 2), Themis 1850, p. $595-629$

Kappeyne van de Coppello, J., bespreking van Larombière M.L., Theorie et pratique des abligations on commentaire des Tirres III ef IV. liwre IIT du Code Napoléon in: Themis 1859 p. 312-315

Kappeyne van de Coppello, bespreking van Goudsmit, J.E. Pandekten-Systeem (1866), Themis 1867, p. 466473

Kaser, M. Romeins privatrecht, bewerkt door F.B.J. Wubbe (2e druk, Zwolle 1971)

Kelly, J.M., A Short History of Western Legal Theory (Oxford 1992)

Kipp. Th., in: Windscheid, B., Lehrbuch des Pandektenrechts, deel 1 (9e druk, Frankfurt am Main 1906)

Kisch, I., Rechtsvergelijking en handelsrecht (Alphen aan den $\mathbb{R}$ in 1935)

Kisch, I., By way of introduction, in: Netherlands reports to the VIrth internationat congress of comparative law (Deventer 1970)

Kist, J. De leer der relatieve onrechtmatigheid, WPNR 3734-3736 (1941), p. 301-304, 309-311, 313-316

Kleinheyer, G. en Schröder, Deussche juristen aus füff Jahrhunderten (Karlswhe, Haidelberg 1989)

Kuniff, D., Gebrekkige zaken (Deventer 1973)

Köbler, G., Dewtsche Rechtsgeschichre (Se druk, München 1996)

Kokkini-latridou, D., Een inleiding tor dret rechswergelijkende onderzoek (Deventer 1988)

Konijnenbelt. W. Publiek domein en privaatrecht, in: Qui bene distinguit bene docet, privatrechtelike opstellen man S. Gerbrandy (Amhem 1991), p. $67-89$

Kooiker, H., De overlevingskanalen wan het romeinse recht na de codificatie, in: Jansen, C.J.H. . E, Poortinga , T.J. Veen (red). Twalf bijdragen tot de studie wan de rechtsgeschiedenis wan de negentiende eenw (Ansterdam 1993)

Kooiker, H., Lex scripta abrogata. De derde reviassance wan her Romeinse recht (Nijmegen 1996)

Kop, P.C.. Savigny en de wetenschap wan het privaatrecht in Nederland in de negentiende eeuw, Tijdschriff voar Rechtsgeschiedenis 57 (1989) 1.17

Kop, P.C., Bencerkungenzum Einfluß der Deutschen Rechtswissenschaft auf die Niederlandische Privatrechtswissenschaft des neunzehnten Jahrhunderts, in: Die Rechiswisserschafficheri. Beziehungen zwischert den Niederlanden wand Deutschland in historischer Sicht (Nijmegen 1991) p. 91-107

Kop, P.C., Legisme en privaatrechtswetenschap (2e druk, Deventer 1992) 
Koschaker, P., Europa und das Römische rech (München, Berlin 1966)

Kossmann, E.H., De lage landen 1780-1940 (1984)

Kronenberg. H.G., Rechtsgesschiedenis van den aonwas (Leiden 1911)

Laman Trip, H., boeksespreking van Kronenberg, H.G., Rechtsgeschiedenis van den aanwas (1911), in: Rechisgeleerd Magazijn 1912, p. 182-184

Land, N.K.F., Burgerlijk regt en regtswordering - Aantekeningen op artikelen van het burgerlijk wetboek, V, Themis 1873, p. 480-505

Land, N.K.F., Ons reclit op roerend goed, Rechtsgeleerd magazijn 1889, p. 238-284

Land, N.K.F., Verklaring wan het burgerlikk wetboek, deel I en deel 2 (Haarlem 1889)

Land, N.K.F., Beschowwingen over de verbintenis wit onrechtmatige dadd (Haarlem 1896)

Land, N. K.F., lnteiding tot de verklaring wan het burgerlijk wetboek (2e druk, Harlem 1910)

Lang, R. Normzweck und Duty of Care. Eine Unterswchung uber die Grenzen der Zurechwang im deurschen und anglo-Gmerikanischen Deliktsrechr (München 1983)

Lange, C.J. de, Een vergelikende beschouwing der "oudle en nieuwe" leer omtrent artikel 2014 B. W., WPNR $3466(1936)$, p. $277-281$.

Langemeijer, G.E., Onrechtmatige daad en concurrentiestrijd, Nevierlands Juristenblad 1934, p. 617.622

Lankhorst, G.H., De relatiwiteit van de onrechtmatige daad (1992)

Laurent, F., Principes de droit civil, deel 20 (1878), deel 32 (Bruxelles, Paris 1887)

Laurent. F., Cours élémentaire de droir civil, deel 3 (Bruxelles. Paris 1878)

Lem, P.D.M., Netow rechr (Nijmegen 1945).

Levy. J.A., Het Burgerlijk Wetboek werkiaard door Mr. C.W. Opzoomer, deel 16 ('s-Gravenhage 1911)

Lipman. S.P. Het Burgerlijk Wetboek woorafgegaan door de wet, houdende algemeene bepalingen der wetgeting wan het kaningrijk. vergeleken met het Romeinsche ent het fransche regt (Amsterdam 1839)

Lokin, J.H.A. De nationale codiffcatie in haar verhouding tot het geschreven en ongeschreven subsidiaire recht, Nederlawds Juristenblad 1988. p. 660-668

Lokin, I.HA. A. De invoering van het BW in het Hertogdom Limburg op 1 januari 1842 , im: Luijten, E.A.A. (e. a.), 146 jaar Bargerlijk Wetboek. Her jubilesm van het 150-jarig Wetboek en zim inwoering in het Herrogdow Listburg op I jantari 1842 (Deventer 1989), p. 15-28

Lokin, J.H.A., en W.J. Zwalve, Haofdstukken uit de Europese codificatiegeschiedenis (Groningen 1992)

Lokin, J.H.A., De takk van de rechtswetenschap volgens Diephuis en Opzoomer, in: G. Diephuis, C.W. Opzoomer 1892-1992 (Groningen 1992), p. 24-44 
Lokin, M.H.A., Waarin ook een klein volk groot kan zijn, Nederlands Tijdschrift woor Burgerlijk Recht 1992. p. 2-12, ook in Tekst en witleg (Groningen 1994)

Lokin, J.H.A., De invloed van de pandektistiek op het werk van Diephis en Opzoomer. in: R. Pieternan e.a. (red.). Bijdragen tor de rechtsgeschiedenis van de negentiende eatw (Arnhem 1994), p. 2942

Lokin, J.H.A., Tekst en uttleg (Groningen 1994)

Lokin, J.H.A., De plaats van Mejers in de legistische traditie, in: Telin en uirleg (Groningen 1994 ). p. 143. 170

Luijten, E.A.A. (e.a.), 146jaar Burgerlijk Wetboek. Het jubileum wan her 150 jarig Werboek en ziph invoering in het Hertogulom Limburg op I jamuari 1842 (Deventer 1989)

Maanen, G.E. van, Stoomtreinen en aansprakelijkheid, WPNR $5742-5743$ (1985), p. 389-393, 412-417

Maanen, G.E. wan, Onrechmatige daad. Aspecten wan de onmikkeling en structuar wan een omstreden leerstuk (Deventer 1986)

Maanen, G.E. van, Eigendomsschinnbewegingen. Juridische, historische en politiek-filosofische opmerkingen over eigendam (Nijmegen 1987)

Maanen, G.E. van, Publiek domein en twee-wegenleer, Recht en kritek 16 (1990) 3. p. 198.209

Maanen, G.E. van. Publiek domein en her belang wan de overheid bij bodemsanering: een ongewasschen warken (Deventer $\llbracket 990)$

Maanen, G.E. van, Van de wogeten des hemels en de stranden der zee, WPNR 6074 (1992). p. 970-977

Maanen, G.E. van, '...om te doen ophouden de meniguldige twistgedingen.. Opmerkingen omtrent de historische achtergrond van de onrechtmatige daod (Nijmegen 1995)

Maanen. G.E. vam, De Zutphense juffrow en de ontrouwe bediende van Lindenbaum (Nijmegen 1995)

Maanen, G. E. van, De wonderbaarlijke geschiedenis wath de onrechtmatige overheidsdaad in de $19 \mathrm{e} \mathrm{th} 20 \mathrm{e}$ eerw (Nijmegen 1996)

Maanen, G.E. van, Onrechtmatige daad 1 , artikel 6: 163, aantekening 8 ev. (juni 1996)

Malaurie, Plh. en Aynès. L., Cours de droit civil, deel 4 (3e druk. Paris 1994)

Marcádé, V.. Explication théonique ef pratique du Code Napoléan, deel 2 (5e druk, Paris 1852)

Marcadé, V., Explication du vit.x, liv.ui da Code Napoléon (...) de la préscription (Paris 1854)

Martini, G.J. de, De Nederlandsche wetgeving (Amsterdam 1840)

Marty, G., et P. Raynaud, Droit ciwil. Les biens (Patis 1980)

Mayer, O., Dewtsches Verwaltungsrecht, deel 2 (Berlin 1896)

Mayer, O., Eisenbahn und Wegerechi, Archiv für öfentliches Recht (1901). p. 38-87 en 203-243 
Mazeaud, H. et L. Mazeatud, Traité théariqué et pratique de la responsabilité civile délictuelle el contractuelle, deel 2 (2e druk, Paris 1934)

Mazeaud, H. en L. Mazeaud, Traité théorique et pratique de la responsabilitế civile délichuelle et contractwelle, deel 2 (2e druk, Paris 1934)

Mazeaud-Tunc, Troité théorique er pratique de la responsabilité civile délictuelle et contractuelle, deel 2 (5e druk, Paris 1961)

Merlin, M., Répenoire universel et misonné de jurisprudence, deel 29 (5e druk, Bruxelles 1828)

Meijers, E.M., De takk der rechtswetenschap ten anzien der vrije rechtspraak (1910), in: Verzamelde Privatrechtelijk Opstellen I (1954)

Meijers, E.M., Publiek domein en zaken buiten den handel, WPNR 2543-2547 (1918), p. 429-432, 441-443, $453-456,461-463,469-472$

Meijers, E.M., Nieuwere burgerrechtelijke literatuur, WPNR 2737 (1922), p. 263-265

Meijers, E.M., De rechtspraak van den Hoogen Raad ontrent "bezir geldt als wolkomen titel" , WPNR 3026$3027(1927)$, p. $895-898,915-919$

Meijers, E.M., De beteekenis der burgerijke wet in de huidige samenleving (1927), in: Verzanelde Privaatrechyelijke Opstellen I (1954)

Meijers, E.M., noot onder HR 25 mei 1928 , NJ 1928,1688

Meijers, E.M., Wijzigingen en aanvullingen wam het Burgerlijk Wetboek na 1838 , in: Scholten, P. en E.M. Meijers (red) Gedenkboek Burgerlijk Wetboek 1838-1938 (Zwolle 1938), p. 33-63

Meijers, E.M. Ontwerp woor een nieuw Burgerlijk Wetboek (boek 1-4) ('s-Gravenhage 1954)

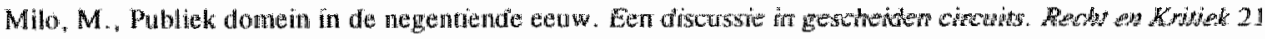
(1995) 2. p. 166-187

Modderman, W. De recepte van het Romeinsche regr (Groningen 1874)

Molengraaff W.L.P.A. Hei verkeersrecht in wotgeving en wetenschap (Haartem 1885) in: Molengraaff bundel. Kenze wit de geschriften wan Mr. W.L.P.A. Molengradf met levensbeschrijuing en biografie (1978). p. $48-51$.

Molengrafafi. W.L.P.A., De "oneerlijke concurrentie" voor het forum van den Nederlandschen rechter, Rechtsgeleend Magazijn 1887, p. 373-435

Molengraaff, W.L.P.A. bespreking van: Thiel, J.H., De goede trouw wan derden en hare bescherming tegenover de handetinger: wam partijen (1003), Rechtsgeleerd magazin 1905. p. 604-605

Motengraaff, W.L.P.A., noot onder HR 24 jamari 1930, Weekblad wan her Rechl 12091 (1930)

Mom Visch. D.I., bespreking van Levy. J.A., Het ideëele in recht en staat, in: Themis 1877 , p. 108-132 
Mugdan, B., Die gesamren Materialien zum Bürgerichen Gerewbuch fü das Deutsche Reich, band 2, Recht der Schuldverhältnisse; idem band 3, Sachenurecht (1899. Nendruck, Aalen 1979)

Muscheler, K., Relativismus und Freirecht (Heidelberg 1984)

Nieuwe Fransche rechtspraak over aansprakelijkheid voor zaken, die men onder zijn opzicht heeft, Nederlands Juristerblad 1929 , p. 233

Nispen tot Sevenaer, C.M.O. van, Het begrip "schuld" volgens ant. 25 Motor- en Rijwielwet en wolgens art. 536 Kooph., in Weekblad van het Recht 12042 (1929)

Nispen tot Sevenaer, C.M.O. van, De beteekenis wan het algemeen welzijn ten aanzien wan privaatrechtelijke verhoudingen, Rechtrgeleerd magazin 1937, p. 288-310

Nog eens de aansprakelijkheid bij automobiet-ongelukken, Weekblad wan her Recht 11732 (1927)

Oermamn, P., Recht der Schuldverhältnisse (Se dnuk, Berlin 1929)

Olivier, $\mathbb{N}$, boekbespreking wan Diephuis" Het Nederlandsch burgerlijk regt naar de wolgorde wan het Burgerlijk Wetboek, deel 1 (1844), in: Themis 1844, p. 355-360

Olivier, W.C.D., Proeve over de beperkingen van den eigendom door het politieregt. (Leiden 1847)

Olivier, W.C.D., Herinneringen aan Mr. J.R. Thorbecke (Arnhem 1872)

Onbekend auteur, Nog iets over zaken buiten den handel, Tijdschrift voor her Nederlandsche regt 1876, p. $305-316$

Onderhoudsplicht, art. 231 en 239 gem.wet, De Gemeentestem $1242(1875)$

Ontwerp van het Burgerlijk Werboek woor hel Koningrijk der Nederlanden ('s-Gravenhage. Amsterdam. Dordrecht, Breda 1820)

Onnerp tor herziening van het Burgerlijk Werbokk. Tweede boek (" $\mathrm{s}$-Gravenhage 1899)

Oosterwijk, G. van, Boissevain. J.H.G., De Gemeentewet, opgehtelderal door ene auntekening, angevidd met eene geschiedenis haver toepassing door G. Von Oostemwjik. (Arthem 1864)

Oppentheim. A.S., Schers wan het Nederlandsch Bargerlijk Recht door Mr. J.D. Veegens, deel 1 (Haariem 1914), deel 2 (3e druk, 1925), deel 3 (2e druk, 1917)

Opzoomer, C.W. Het Burgerlijke Wetboek. Aanteckening op de artikelen, die thans nog verklaring behoewen, deel 3 (Ansterdam 1852)

Opzoomer, $C$. W. Over den aard en de werking van her bezit van roerende goederen, naar aanleiding van art. 2014 BW, Themis 1856, p. 92-117

Opzoomer, C.W., Het Burgerlijk Werboek werklaard, deel 1-11 ('s-Graventrage 1865-1887)

Opzoomer, C.W., Aanteekening op de wet, houdende algemeene bepalingen der wetgeving van her koningrijk (4e druk.'s-Gravenhage 1884) 
Oven, 1.C. yan, Artikel 2014 en de bezitsbescheming van roerend goed, WPNR 2016-2019(1908), p. 417$420 ; 433-435 ; 449-451 ; 461-463$

Oven, J.C. van, Schade veroorzakt door dieren, gebouwen en andere Záken, Nederlands Jusristenblad 1926. p. $109-117$

Oven, J.C. wan, Aansprakelijkheid bij auto-ongelukken (art.25 Motor- en Rijwielwet), Nederlands Juristenblad 1932, p. $145-151$ en $169-175$

Pekelharing, 0. Opmerkingen aver den onderhoudsplicht wan bijzondere personen ten opzichfe van wegen en andere ten apembaren dienste bestende werken (Leiden 1880)

Picard, M., Traité pratigue de droì civil Français par M. Planiol, G. Ripent, deel 3 (les biens) (2e druk, Paris 1952)

Pinto, A. de, Handleiding lat het Burgerlijk Wetboek ("s-Gravenhage 1837-1838, 4e druk 1860)

Pinto, A. de, bespreking van Diephuis, G., Het Nederlandsch Burgerlijk Regt, naar de volgorde van het Burgerlijk Wetboek, deel 1 (2e druk 1856). Themis 1857, p. 471-479

Pink, A. de, Art. 577 BW - Openbar staals-domein, Weekblad van bet Regt 3404 (1872)

Pit, S.J., De ansprakelijkheid voor zaken, toegebrachtdoor ondergeschikten, kinderen, dieren en door zaken, die men onder zijn opzicht heeft Rechisgeleerd Magazijn Themis 1931, p. 33-72

Pitlo, A., Het systeen van het Nederlandse privautrecht (Haarlem 1958)

Pitlo-Brahu, Het Nederlands Burgerlijk Wetboek. Dee! 2. Het Zakenrecht (Amhem 1987)

Planiol, M., Traité élémentaire de drait civil, deel 1 (8e druk, Paris 1920), deel 2 (5e druk, 1909 en $8 \mathrm{e}$ druk 1921)

Planitz. H. (ed), Die Rechtswissenschafi ver Gegenwart in Selbstdar:stellangen (Leipzig 1924)

Polsk. C.H.P., Mr. J.D. Veegens en A.S, Oppenteim. Schers van het Nederlandsch Burgerlijk Recht, deel 3 (4e druk, Hatllem 1934)

Poortinga, E., De scheiding thusen publiek- en privadrechi bij Johan Rudolph Thorbecke (Nijmegen 1987)

Proudhon, J.B.V., Traté̉ dis domaine de propriété (Bruxelles 1842)

Rechter of wetgever, Weekblad van her Recht 11910 (1929)

Reehuis, W.H.M. (e.a), Goederenrecht (Arnhem, 1994)

Reeken, C.G. van, Uitoefening van private rechten op zaken met eene publieke bestemming. Themis 1893 , p. $1-66$.

Rheinstein, M., Enst Rabel, in: Festschriff für Ernst Rabel, deel 1 (1954), p. 1-4

Ripert $\mathrm{G}$., en I. Boulanger, Thaté élementaire de droir civil de Planiol, deel 1 (5e druk, Paris 1950 ), deel 2 (4e dnuk, Paris 1952) 
Riperi, G. Traitét pratique de droit cinil Frangais de Planiol, deel 6 (2e druk, Paris 1952) Rogron, Code Ciwil expliqué par ses motifs et par des exemples, avec la solution, sons chaque article (6e
druk. Bruxelles 18.33 )

Roos, N.H.M., De Nederlandse privaatrechtsleer in dramatisch perspectief (Groningen 1987)

Saleilles, R. De la possession des meubles (Paris 1907)

Salomons, A.F., De interpretatiegeschiedenis waw artikel 2014 BW (1838-1945) (1990)

Salomons, A.F., De late aanvaarding van het om-baatyereiste bij art. 2014 oud-BW. HR 2-12-1994, RvdW 1994,264, WPNR $6174(1995)$, p. 212-214.

Salzwedel, J., Anstaltsnutzung und nutzung offenthcher Sachen, in: Altgemeines Venwathungsrecht (8e druk, Berlin 1988)

Sauweplanne, J.G. Rechtsstelsels in vogelwhoh (Devanter 1981)

Sauveplanne, J.G., Van buitenlands recht tot rechtswergelijking, in: Kokkini-latridou, D. ,Een inleiding tot het rechtsvergelijkende anderzoek (Deventer 1988)

Savonin Lohman, W.H. de, Verklaring van het burgerlijk wetboek door Mr. N.K.F. Land, deel 4 (2e druk, Haarlem 1907)

Scheltema, F.G., Zaken buiten den handel, WPNR 2533-2534 (1918), p. 321-323, 333-335

Scheltema, F.G. De openbare weg en de beperking wan den eigendom, Rechtsgeteerd magazijn 1920, p. 264286

Scheltema, F.G., Het grensterrein van publiek en privaat recht, Rechtsgeleerd magazijn 1927, p. 233-265

Scheltema, F.G. . De zaken der openbare lichamen, hoofdstuk 2 van Nederlands Bestutrstecht, deel 1 (1932), Verspreide geschriften (Grouingen en Djakarta 1953), p. 647-670

Scheltema, F.G., De toekomst wan her burgerlijk wetboek, Rechtsgelect magrazijn 1938. p. 569-575

Schepel, C.I.H., Wegenrech in Nederland (Groningen 1895)

Schlosser, H., Grundzäge der neueren Priwatrechtsgeschichte (Heidelberg 1985)

Scholten, P. Schadevergoeding buiten overeenkomst on ontechtmatige daad (Amsterdam 1899)

Scholten, P., Mr. C. Asser'\$ Handleiding tot de beoefening wan het Nederlandsch Burgertijk Recht. Tweede deet. Zakenrecht (4e druk, Zwolle 1905; idem Se druk, 1913)

Scholten, P., An. 2014 B.W. - Beteekenis van het daarin genoemde "bexit". WPNR 2203 (1912), p. 134-135.

Scholten, P. Bezit en bewijs bij revindicatie, WPNR 2897-2900 (1925), p. 481-484, 497-500, 513-515, 521. 523

Schoiten, P., Naschrift bij L.C. Hofmann, Eenige opmerkingen (...) WPNR 3060 (1928), p. $519-520$ 
Scholten, P. Naschrift bij L. C. Hofmann, Nog ens: Art.2014 BW, WPNR 3075 (1928), p. $751-753$

Scholten, $\mathbb{P}^{x}$, noor onder HR 28 februari 1929. NJ 1929, 905

Scholten, P., noot onder HR 19 juni 1931, NJ 1931,1303

Scholten, $\mathbb{P}_{n \rightarrow}$ Mr. C. Asser's Handleiding tot de beaefening van het Nederlands Burgerlijk Recht. Aigemeen Deel (Zwolle 1931, 2e druk 1934)

Scholten, P. en E.M. Meijers (red) Gedenkboek Burgerlijk Wetboek 1838-1938 (Zwolle 1938)

Scholten, P., De codificatie-gedachte voor honderd jaar en thans, in: Scholten, P. en E.M. Mejers (red), Gedenkboek Burgerlijk Wetboek 1838-1938 (Zwolle 1938), p. 1-31

Schulze, R. Le droit priqế commun Europẻen, Revue lnternationale de Droit Comparé 1-1995, p. 7-32

Schwitters, R.J.S., Riskante aansprakelijkheid, Recht en Kritiek 17 (1991) 1, p. 5-39

Schwitters, R.J.S., De risico's van de arbeid. Het onstaan van de ongevallenwet in sociologisch perspecrief (Groningen 1991)

Smits, J.M., De noodzaak en de mogelijkheid van rechtsvergelijking in het civiele recht, WPNR 6154 (1994). p. $728-730$

Sinits $s_{n}$ J.M., 'A brooding ommipresence in the sky': over rechtsontwikkeling en butenlandse rechtsliteratuur, WPNR $6207(1996)$, P. 44-47

Smits, P.H., lets over de vrag der relativiteit der onrechtmatigheid bij onrechtmatige daad in verband met de door den Hoogen Raad onderscheiden onrechtmatigheidswormen, WPNR 3586-35911 (1938), p. 433-437, $445-448,469-472,477-479,489-492$

Snijders, H.J., Rechtswinding door de burgerlijke rechter (Deventer 1978)

Snijders, H.J., Rank-Berenschot, E.B., Goederentrecht (Dewenter 1994)

Spruit, J.E., en K.E.M. Bongengar, Corpus Juris Civitis. Tekst en vertaling, deel 1, Instituten (Zurphen, "sGrawenthage 1993)

Star Busmann, C.W. De asansprakelijkheid der automobiel in het werkeersrecht, Rechtsgeleerd magazijn 1908. p. 393-413

Steenhof, G.J.W. . De Wetenschap wan het Internationaal Privatrecht in Nederland in de periode tussen 1862 en 1962 (Zwolle 1994)

Strikwerda, L. en 1 , R. de Jong, Rechtsvergelijking en rechtsvinding in burgerijike zaken, Ars Aequi 43 (1994) 5. p. 284-289

Suijling, J.Ph. Het wereldwerker in hef privatrecht (Haarlem 1911)

Sujiling, I.Ph., De openbare weg in publiek - en privaatrecht, Themis 1916, p. 153-186

Suijhing, J.Ph., Inleiding tot het bargerlijk rechr, deel t (2e druk, Haarlem 1927 en 3 e druk 1948) 
Suijling, J.Ph., Inteiding fot het burgerlijk recht, 2e stuk, 2e gedeelte (2e druk, Haarlem 1936)

Suiling, J.Ph., Inleiding wor het burgerijk recht, zakenrecht, se stuk (Haarlem 1940)

Tak, Publiek domein, overheidscontract en rechterlijke wetshandhawing. Nederlands Tijdschrifi voor Bestuursrecht 1990, p. $265-271$

Tak, A.Q.C., en J.M.H.F. Teunissen, "Een ieder neemt voldoende zorg voor het milieu in acht'. Wie zorgt er voor de rechtsstaat? Een voortgezet debat. Recht en Kritiek 20 (1994) 4, p. 340-354.

Teixeira de Mattos, A., bewerking van A. de Pinto, Handleiding rot het Burgerlijk Werboek (6e dnuk, "s" Gravenhage 1886)

Telders, B.M., Het verband tussen onrechtmatigheid en schade bij art. 1401 B.W., WPNR 3091-3093 (1929). p. $169-171,185-187,201-203$

Telders, B.M. Nog eens: het verband usselhen onrechtmatigheid en schade bij art. 1401 B.W., WPNR 3126 (1929), p. 667-668

Teunissen, I.M.H.F., en A.Q.C. Tak, Recht ist was der Unwelt nützt, Nederlands Juristenblad 1994, p. 605617

Teunissen, J.M.H.F., Het burgerlijk Mleed van de Staat (Zwolle 1996)

Thorbecke, J.R., Aanteekening op de Grondwet, deel 2 (Amsterdam 1843)

Thorbecke, J.R., Collegedictaat administratief regt (1846-1847) (UB Maastricht, nr MU EAG 661)

Thorbecke, J.R., Over plaatselijke begrooting (Leyden 1847)

Tichelaar, P.A., Artikell 1 der wet van 9 april 1875 (S.67), tot regeling van de dienst en het gebruik der spoorwegen, Rechtsgeleerd Magazijn 1891, p. 1-35

Toullier, C.B.M. Le droit ciwil Français, whivan l'ordre dw code, deel 1-20 (Bruxelles 1820-1838)

Valkhof, I., De invloed van de Spoorwegen op enkale gebieden van het Nederlandse privatutrecht. Rechrsgeleerd Magazin Themis 1939 , p. 399443

Valkhoff, $\mathrm{J}$., Een eetw rechtsonnvikkeling. De vermaarschappetijking van het Nederlandse privaatrecht sinds de codificatie (2e druk. Amsterdam 1949)

Veegens, J.D., Schets van het Nederlandsch burgerlijk recht, deel 2 (Haarlem 1909)

Veen, G. van der, reactie op Tak en Teunissen Nederlands Jaristenblod (1994), p. 1008 1010

Veen, T.J.en P.C. Kop, Zestig juristen (Zwolle 1987)

Vegting. W.G., Publiek domein en zaken buiten de handel (Alphen aan den Rijn 1946)

Vigelius, C.C., De elementen van art. 1401 BW, uit: Rechtskundige opstellen Meijers (1935), p. 824-866 
Vijver, I. D. van de, The Etatisation of public property, in: D.P. Visser (ed.), Essays on the history of law (Cape Town, Wetton, Johannesburg 1989), p. 261-299

Vink, J., Geen knevellarij. Weekblad wour gemeentebelangen (1930), p. 399-40i

Woorduin, J.C., Geschiedenis en beginselen der Nederlandsche wetboeken (Utrecht 1837-1838)

Vos, H., Intrekking van vergunningen, Weekblad voor gemeentebelangen (1930), p. 327-328

Vos, H. Publiek domein, Weekblad woor gemeentebelangen 1931, p. 61-63

Vranken, J.B.M., Mr. C. Asser's Handleiding tot de beoefening van het Nederlands Burgerlijk Recht. Algemeen Deed (Zwolle 1995)

Wappäus, H., Zur Lehre von den dem Rechtswerkehr entogenen Sachen nach römischem und heurigem Recht (Götingen, 1867)

Watson, A. Legal transplants. An approach to comparative law (Athens and London 1993)

Wernecke, F., Die öfentliche Sache im Widerstreit priwater und allgemeiner Belange, Archiv für die civilistische Praxis 195 (1995), p. 445-467

Wertheim, W.F., Aansprakelijkheid woor schode buiten overeenkomst (Leiden 1930)

Wiarda, J., J.C. Van Oven's beslissend aandeel in de vestiging wan de leer, dat 'bezit' in art. 2014, lid 1 B.W. is "bezit te goeder trouw", WPNR 4548 (1958), p. 345-351

Wieacker, $F_{.}$, Priwatrechtsgeschichte der Nenzeit (Göttingen 1967)

Winkel. H., De methode der rechtsvergeliyking ("s-Gravenhage 1936)

Wolfsbergen, A., Normatieve onrechtmatigheid of causale onrechtmatige daad, WPNR 3115-3116 (1929), p. $473-476,523-525$

Wolfsbergen, A., De loepassing der normenleer bij BW 1401 door de HR, WPNR 3442 (1935), p. 555-556

Wolfsbergen, A., Onrechimatige doad (Leiden 1946)

Wttewaal, G., Artikel 2014 BW, Rechrgeleerd Magazinn (1916), p. 175-209

Zimmernatna, R. Law of Obligarions. Roman foundations of the civilian tradition (Deventer 1990)

Zimmermann, R., Roman Law and European Legal Unity, in: Harkamp. A.S. et al (ed.), Towards a European Civil Code (Nijmegen 1994), p. 65-81

ZWalwe, W.J., Over oorzaak en titel bij Diephuis en Opzoomer, in: G. Diephuis, C.W. Opzoomer 1892-1992 (Gromingen 1992), p. 45-59

Zwalve, W.J., Hoofdsukken uir de geschiedenis van het Europese privaatrecht. Deel A. Inleiding en zakenrecht (Groningen 1993)

Zeben, C.J. van, e.a., Parlententaire geschiedenis van het niewwe Burgerlijk Wetboek (boek 6) (1981) 


\section{Rechtspraakregister}

\section{Hoge Raad}

HR 3 april 1846, W707 (1846)

H4, 3B

HR 7 november $1850, W 1218$ (1851)

H4, 2B/H5, 2D

HR 6 januari 1854 , W 1510 (1854)

H5, \$ 4DI

HR 29 juni 1855, Van den Honert.

Verzameling van arresten wan den Hoogen

Raad der Nederlanden, burgerlijk regt.

regt wan koophandel en burgerlijke.

regrswordering, deel $19(1856)$, p. 337.

$\mathrm{H}_{4} \& 3 \mathrm{~B}$

HR 30 oktober $1857, W 1908$ (1857)

I5. \& 2D

HR 11 juni $1858, W 1967$ (1858)

H5, \& $2 \mathrm{~A}$

HR 28 januari 1859 ,W 2031; NR, deel 61, p. 92-105

$\mathrm{H} 2, \S 2 \mathrm{~B} / \mathrm{H} 4, \S 2 \mathrm{~A} / \mathrm{HS}, \S 2 \mathrm{D}$

HR 22 mei 1863, W2499 (1863)

HS, \& 4DI

HR 26 juni 1863,W 2499 (1863)

H5. $4 \mathrm{DI}$

HR 1 februari 1867, NR deel 85

H5. 4D:

HR 26 juni 1867 , W 2929 (1867)

HS. 4DI

HR 24 april 1868, W 3004 (1868)

H5, 4DI

HR 22 januari 1869, W 3084 (1869)

HR 4 maart 1870, Van den Honer.

Verzameling yan arresten wan den

Hoogen Raad der Nederlanden, burgerlijk

regt, regr wan koophandel en burgerlijke

regtswordering, deel 34 (1871), nr. 1162 .

H5, $2 \mathrm{~B}$

HR 25 oktober $1870, W 3262(1870)$

H6, $4 \mathrm{~A}$ 
HR 29 juni 1871, W 3399 (1871)

H5, § 4D2/H6, § $2 \mathrm{D} 2$

HR 30 juni 1879. W 4406 (1879)

H5. \&4D1

HR 30 mei $1881, N R$ deel 128, p. 163

H5, 4DI

HR 29 juni 1883,W 4929 (1883)

$\mathrm{H} 5,8 \mathrm{~A} 3$

HR 17 december 1883, W 5000 (1884)

H5. 4DI

HR 6 oktober 1885, W 5086 (1885)

H5, \& 4D1

HR 4 aprill 1890, W $5856(1890)$

$\mathrm{H} 5, \S 2 \mathrm{~A} / \mathrm{H} 6, \S 2 \mathrm{~B}$

HR 17 november 1892, W 6271 (1892)

$\mathrm{H} 5, \S 4 \mathrm{D} 1$

HR 14 januari 1895,W6616 (1895)

H5, $\$ 3 \mathrm{~A} 3 / \mathrm{H} 6, \S 3 \mathrm{C}$

HR 31 oktober 1895, W6732(1895)

$\mathrm{H} 5, \S 4 \mathrm{D} 1$

UR 5 februani 1897,W 6927 (1897)

H6, \&2D2

HR 11 december 1899, W 7374 (1900)

H5, \& 4DI

HR 14 december 1900, W7536 (1901)

H5, $3 \mathrm{~A} 3$

H5, $\& 3$ A3

HR 12 juni $1906, W 8390$ (1906)

$\mathrm{H} 7, \S 2 \mathrm{Bla}$

HR 15 februari 1907 , in $W 8500$ (1900)

$\mathrm{H} 6, \& 5 \mathrm{Cl}$

deel 215, p. $235-242$

H7. \& $3 \mathrm{~B}$

HR 25 februari 1916, NJ 1916,501

H6, \& $5 \mathrm{~B}$ en $\mathrm{C}$

URR 30 matart $1917, N / 1917,502$

HR 7 jun 1918, WPNR 2544 (1918)

$\mathrm{H} 6, \S 4 \mathrm{D}$

HR 31 jomuari 1919, N. 1919, 161

146. $\$ \mathrm{Cl}$

HR 4 juni 1920 "NJ 1920.712

H7. $3 \mathrm{~B}$

HR 3 februari 1922 , NJ 1922,388

H6, $3 \mathrm{~B} / \mathrm{H} 7, \S 3 \mathrm{~B}$

HR 6 maart 1924, W11192 (1924)

H7. $\$ 2 \mathrm{~B} 1 \mathrm{a}$

HR 20 december 1924, NJ 1925, 153

H7, $3 B$

HIR 19 aprill 1928, NJ 1928, 1504

H7. $\$ 3 B$

HR 25 mei $1928, N J 1928,1688$ m.n. E.M.M.

H2, $\$$ A $/ \mathrm{H} 6, \S 5 \mathrm{D} 1$ 
HR 10 mei 1929, NJ 1929, 1615

H7, 38

HR 24 januari 1930, NJ 1930, 299

$H 6 . \$ 5 \mathrm{G}$

HR 19 juni $1931 W 12321(1931)$, NJ 1931,1303

$H 6, \S 5 F$ en $G$

HR 17 juni $1932, N J 1932,1464$

$116, \$ 5 \mathrm{G}$

HR I1 maart 1937, NJ 1937, 899

146, 5发, G

HR 23 november 1939, NJ 1940,242

H6. 89

HR 17 januari 1941, NJ 1941, 644, m. n. Paul Scholten

H6. $4 \mathrm{D} / \mathrm{H} 7, \S 4 \mathrm{C} 3$

HR 5 mei 1950, NJ 1951, 1 (Damhoff-Staat)

$\mathrm{H}_{2}, 3$

HR 17 januari $1958, N J 1961,568$

H6. $\$ 5 \mathrm{C} 2$

HR. 26 januari 1990, $A B$ 1990, nr. 408; RwdW 1990, 36;

NJ 1991, 393 (Windmill)

H2, \$4

HR 9 februari $1990, N J 1991,462$

112, \$ $5 \mathrm{~A}$

HR 24 april 1992, NJ 1993, 643 (Stat/Van Wijngaarden)

H2, $\$ 5 A$

HR 19 februari 1993, NJ 1996, 318

$\mathrm{H}_{2} \approx 2 \mathrm{~B}$

HR 24 decenber 1993, NJ 1994, 214 (Leebeek/Vrumona)

H2, $2 \mathrm{~A}$

HR 2 december 1994, RudW 1994, 264

H6, 3A2/H7, \& 3B

\section{Gerechtshovert}

Hof Amsterdam 7 nei 1917, W 10151 (1917)

H7, $281 a$

Provincial Geregtshof Noord-Holland,

1 oktober 1857, Rechtsgeleerd Bibblad,

behoorende vot de Nieuwe Bijdragen woor

Regtsgeleerdheid en Wetgeving (1858), p. 151-156

H5. $2 \mathrm{~A}$

Provinciaal Geregtshof Noord-Holland,

8 februari 1858, Rechtsgeleerd Bijblad.

behoorende tot de Nieuwe Bijaragen voor

Regtrgeleerdheid en Wetgeving (1858), p. 438-440

H.S. $2 \mathrm{~A}$

Provinciaal Geregtshof Geldertand 23 december 1874 ,

W $3882(1875)$

H5. $84 \mathrm{DI}$

Hof Amsterdam 22 mei 1896, W 6844, (1896)

$1 \mathrm{H6}, 2 \mathrm{D} 2$ 


\section{Rechrbanken}

Rb Mastricht, 13 oktober 1870, W 3285 (1870)

H6, $5 \mathrm{C} 3$

Rb Amsterdam 17 april 1883, W 4945 (1883)

H6, $2 \mathrm{D} 2$

Ro "s-Gravenhage 21 november 1883, W 5006 (1884)

H5. $\$$ DI

$\mathrm{Rb}$ Amsterdam 5 november 1889, W 5812 (1890)

H6. $2 \mathrm{D} 2$

Rb Leeuwarden 18 januari 1894, W 6517 (1894)

H6. $2 \mathrm{D} 2$

Rb Amsterdam 8 januari 1895, W 6716 (1895)

H6, $\$ 2 \mathrm{D} 2$

Rb Arnsterdam 25 mei 1904, W 8239 (1905)

H7, 2Bla

Rb Rotterdam 9 maart 1925, NJ 1926, 35, W 11356 (1926)

$\mathrm{H} 7, \S 2 \mathrm{Bla}$

Rb "s-Hertogenbosch, 8 februari 1929, W 12042 (1.929)

$\mathrm{H} 7,2 \mathrm{Bla}$

\section{Franse rechtspraak}

Cour de Cassation 16 juni 1896, Dalloz 1897, 1, 433

H6. $\$ 2 \mathrm{C} 3$

Cour de Cassation 21 februari 1927, Dalloz 1927, 1, 97

$\mathbb{H} 7, \S 2 \mathrm{~B} \perp \mathrm{b} / \mathrm{HI}, \$ 2 \mathrm{~B} 2$

Cour de Cassation 13 februari 1930, Dalloz 1930, 1, 157

$\mathrm{H} 7, \S 2 \mathrm{~B} 1 \mathrm{~b} / \mathrm{H} T, \& 2 \mathrm{~B} 2$

Cour d Appel d'Angers 20 april 1926, Dalloz 1926, 386

$\mathrm{H} 6, \S 2 \mathrm{C} 3$ 
John Michael Milo (1961) behaalde in 1979 het diploma gymnasium ß3. Hij studeerde kortstondig, behaalde zijn propaedeutisch examen biologie, werkte enige jaren, was instructeur tijdens zijn militaire dienstplicht en voltooide in 1991 een studie Nederlands recht aan de Rijksuniversiteit Groningen. Hij was tot 1995 werkzaam aan de Rijksuniversiteit Limburg te Maastricht bij de vakgroep privaatrecht. Sindsdien werkt hij als universitair docent aan het Molengraaff Instituut voor Privaatrecht, Universiteit Utrecht. 